Kształtowanie się nauki o niebie w teologii patrystycznej I-III wieku 



\title{
Kształtowanie się nauki o niebie w teologii patrystycznej I-III wieku
}

\author{
Dariusz Kasprzak OFMCAP
}




\section{Recenzenci}

Ks. dr hab. Jan Żelazny, prof. UPJPII, Kraków

O. dr hab. Wiesław Block, prof. PUA, Rzym

Redakcja językowa, indeks biblijny, indeks rzeczowy

Katarzyna Kastelik

Redakcja techniczna, indeks osobowy

Jadwiga Malik

Publikacja finansowana z dotacji na utrzymanie potencjału badawczego Uniwersytetu Papieskiego Jana Pawła II w Krakowie przyznanej przez Ministra Nauki i Szkolnictwa Wyższego w roku 2017.

Copyright (C) 2017 by Uniwersytet Papieski Jana Pawła II w Krakowie

ISBN 978-83-7438-617-3 (wersja drukowana)

ISBN 978-83-7438-618-0 (wersja online)

DOI: http://dx.doi.org/10.15633/9788374386180

Uniwersytet Papieski Jana Pawła II w Krakowie

Wydawnictwo Naukowe

30-348 Kraków, ul. Bobrzyńskiego 10

tel./faks 124226040

e-mail: wydawnictwo@upjp2.edu.pl 


\section{Wstęp}

Współczesna teologia katolicka w swojej refleksji nad Objawieniem odwołuje się metodologicznie między innymi do dziedzictwa ojców i pisarzy Kościoła. Teologowie okresu patrystycznego są obecnie wzorcem słuchania Słowa Bożego, trwania w komunii kościelnej oraz ukazywania prawdy Bożej. Sama tradycja patrystyczna stanowi natomiast jedną z istotnych norm określających w teologii to, co katolickie ${ }^{1}$. W niniejszej monografii przedstawiam krytyczną refleksję nad pierwotną nauką patrystyczną odnoszącą się do jednej z pierwszorzędnych prawd wiary zawartych w chrześcijańskim credo, którą jest wiara w eschatologiczne niebo i życie wieczne.

Temat niniejszego studium Ksztattowanie się nauki o niebie $w$ teologii patrystycznej I-III wieku określa główny cel badawczy pracy, który jest moją próbą racjonalnego uporządkowania przekazu patrystycznego pierwszych trzech wieków dotyczącego nadziei na eschatologiczne niebo - życie wieczne i jego teologicznego wyjaśnienia oraz wykazania rozwoju nauki o eschatologicznym niebie w teologii patrystycznej I-III wieku. Pierwszy problem

1 Por. Międzynarodowa Komisja Teologiczna, Teologia dzisiaj: perspektywy, zasady i kryteria 4-100, tłum. K. Stopa, Kraków 2012, s. 13-106; D. Kasprzak, Wykorzystanie myśli patrystycznej $w$ dokumencie Międzynarodowej Komisji Teologicznej „Teologia dzisiaj: perspektywy, zasady i kryteria", w: Koncepcje teologii katolickiej, red. M. Chojnacki, J. Morawa, A. A. Napiórkowski, Kraków 2013, s. 253-269. 
Kształtowanie się nauki o niebie w teologii patrystycznej I-III wieku

badawczy, na jaki zwróciłem uwagę w trakcie poszukiwań, to odnalezienie i opisanie źródeł analizowanej myśli patrystycznej oraz wskazanie na ciągłość zastosowania w teologii patrystycznej przekazu biblijnego, zarówno na etapie narracji teologicznej, jak i w warstwie przekazu symbolicznego. Kolejnymi zagadnieniami badawczymi napotkanymi w trakcie moich poszukowań okazały się: rekonstrukcja nauki o eschatologicznym niebie w teologii autorów patrystycznych pierwszych trzech wieków, w tym kontekstualizacja tej nauki w dziełach poszczególnych ojców i pisarzy Kościoła, wskazanie na zgodność ich przekazu teologicznego z przekazem biblijnym oraz na możliwe powiązania z klasyczną filozofią grecką. Nie mniej istotne było odnalezienie w badanych tekstach patrystycznych zbieżności i różnic występujących pomiędzy tezami eschatologicznymi o niebie poszczególnych teologów. Przedmiotem niniejszych analiz są teksty reprezentatywnych teologów omawianego okresu, będących przedstawicielami tradycji azjatyckiej i aleksandryjskiej.

Rozdziały pracy są odpowiedzią na cele szczegółowe. Opracowanie biblijnego nazewnictwa, koncepcji i obrazowości języków hebrajskiego i greckiego odnoszących się do tematyki nieba miało na celu wykazanie spójności tego przekazu oraz określenia podstawowych motywów biblijnej eschatologii nieba. Eschatologiczna myśl zawarta w Piśmie Świętym stanowiła bazę źródłową dla rozważań pisarzy chrześcijańskich, dlatego należało ją zestawić z eschatologicznymi koncepcjami filozofii klasycznej, aby wskazać dla teologii wczesnochrześcijańskiej zarówno ideowe różnice, jak i możliwe zapożyczenia. Przedstawienie kształtowania się nauki o eschatologicznym niebie w teologii ojców i pisarzy okresu poapostolskiego I-II wieku (ojców apostolskich i apologetów greckich) miało na celu wykazanie rozwoju wczesnochrześcijańskiej eschatologii końcowej dotyczącej nieba. Podobnie ukazanie kształtowania się nauki o niebie w teologii patrystycznej w wieku III miało wskazać progresywną charakterystykę spekulacji teologicznej w analizowanym okresie.

Dokonując wyboru takiego tematu, zauważyłem, że podejmowana przez mnie tematyka nie doczekała się jeszcze systematycznego opracowania monograficznego z zakresu patrologii. Istniejące obcojęzyczne prace przekrojowe dotyczące teologicznego wątku nieba w historii chrześcijaństwa, zazwyczaj po wstępnym wprowadzeniu do semickiego tła chrześcijańskiej 
nauki o niebie i konsekwentnym opisie tematycznej teologii biblijnej, odnoszą się zazwyczaj do omówienia eschatologii końcowej wybranych arbitralnie nielicznych autorów patrystycznych, zazwyczaj Ireneusza i Augustyna², albo omawiają ją skrótowo na zakończenie artykułów tematycznych poświęconych eschatologii wybranego autora ${ }^{3}$ lub rozważają tematy i modele wspólne dla teologii judaizmu, hellenizmu i chrześcijaństwa ${ }^{4}$, czasem też koncentrują się na opisie tylko wybranych wątków eschatologii końcowej: raju ${ }^{5}$, raju i nieba ${ }^{6}$, wizji uszczęśliwiającej ${ }^{7}$, Królestwa Bożego $^{8}$ lub też cech zbawionych w niebie (wolnossć, bezgrzeszność, szczęśliwość) ${ }^{9}$. Istnieją wreszcie wybory tekstów patrystycznych dotyczących wiary w niebo, nie są to jednak opracowania krytyczne ${ }^{10}$.

Polskie opracowania przekrojowe eschatologii patrystycznej są nieliczne: praca Henryka Pietrasa odnosi się w kwestii eschatologii końcowej jedynie

2 Por. C. McDannell, B. Lang, Heaven. A History, New Haven-London 1988.

3 Por. Studi sull'escatologia. VI Incontro di studiosi dell'antichità cristiana, Roma 1977, (Studia Ephemeridis Augustinianum 15, Roma 1978).

4 Por. Visioni dell'Aldilà in Occidente. Fonti, modelli, testi, ed. M. P. Ciccarese, Firenze 1987 (Biblioteca Patristica 8); G. Filoramo, L'escatologia e la retribuzione negli scritti dei Padri (dai Padri Apostolici ad Agostino), w: Dizionario di Spiritualità-Biblico-Patristica, vol. 16. Escatologia, Roma 1997, s. 195-316; J. E. Wright, The Early History of Heaven, New York-Oxford 2000; B. E. Daley, The Hope of the Early Church. A Handbook of Patristic Eschatology, Peabody (Massachusetts) 2003.

5 Por. M. Schmaus, Das Paradies, München 1965 (Münchener Universitätsreden. Neue Folge, Heft 38); J. Delumeau, Une histoire du Paradis. Le Jardin des délices, Paris 1992; Paradise interpreted: representations of biblical paradise in Judaism and Christianity, ed. G. P. Luttikhuizen, Leiden-Boston-Köln 1999 (Themes in Biblical Narrative 2); F. Giardini, Il desiderio del paradiso nella vita cristiana, Roma 2003; J. Delumeau, Alla ricerca del paradiso, Cinisello Balsamo (Milano) 2012.

6 Por. H. Vorgrimler, Geschichte des Paradieses und des Himmels. Mit einem Exkurs über Utopie, München-Paderborn 2008.

7 Por. Ch. Trottmann, La vision béatifique des disputes scolastiques à sa définition par Benoît XII, Roma 1995 (Bibliothèque des Écoles Françaises d'Athènes et de Rome, 229).

8 Por. W. Weisse, Reich Gottes. Hoffnung gegen Hoffnungslosigkeit, Göttingen 1997 (Ökumenische Studienhefte 6).

9 Por. S. F. Gaine, "Will there be Free will in Heaven?" Freedom, Impeccability and Beatitude, London-New York 2003.

10 Por. I novissimi negli scritti dei Padri della Chiesa, ed. V. Brosco, Napoli 2008; Ancient Christian Doctrine, vol. 5. We Beleve in One Holy Catholic and Apostolic Church, ed. A. Di Berardino, T. C. Oden, Downers Grove (Illinois) 2010. 
Kształtowanie się nauki o niebie w teologii patrystycznej I-III wieku

do wybranych wątków tej myśli jak: wieczny szabat ojców apostolskich (tamże, s. 37-41), życie po śmierci a dualizm antropologiczny (tamże, s. 5262); drugi millenaryzm (tamże, s. 63-82); tematy Orygenesowskie (tamże, s. 83-108) ${ }^{11}$. Ta cenna pozycja wnosi wiele do studium myśli eschatologicznej w patrystyce, nie jest jednak systematycznym studium tematyki eschatologii końcowej w pierwszych czterech wiekach. Drugim polskim opracowaniem tej tematyki jest książka Marcina Wysockiego, w której autor skupia się na odtworzeniu eschatologii końcowej jedynie w pismach wybranych autorów łacińskich III wieku (Tertulian, Cyprian) ${ }^{12}$.

Inną grupą studiów patrystycznych dotyczących eschatologii patrystycznej są monografie i opracowania poświęcone poszczególnym autorom późnego antyku. Do tych prac odnoszę się w niniejszej pracy przy omawianiu eschatologii kolejnych pisarzy i ojców Kościoła. Wymienione opracowania patrystyczne ujmują najczęściej jeden z aspektów tematyki eschatologii końcowej w sposób pośredni albo sygnalizują pewne zagadnienia szczegółowe w tekstach omawianych autorów wczesnochrześcijańskich. Studia te nie rozważają jednak całościowo problematyki eschatologicznego nieba i życia wiecznego w ujęciu reprezentatywnych teologów chrześcijańskich I-III wieku. Natomiast pozostałe opracowania naukowe, do których odwołuję się w trakcie pracy, poruszają wybrane zagadnienia eschatologiczne związane $\mathrm{z}$ analizowaną problematyką eschatologii końcowej.

Istnieje też sporo współczesnych opracowań historii dogmatu, które zawierają przekrojowe syntezy myśli patrystycznej dotyczącej eschatologicznego nieba lub są studium szczegółowych aspektów tejże eschatologii. Te pierwsze najczęściej pobieżnie referują tematykę eschatologicznej szczęśliwej wieczności w teologii patrystycznej na przykładzie myśli jednego dwóch antycznych autorów, najczęściej Ireneusza z Lyonu i Augustyna z Hippony ${ }^{13}$. Częściowym wyjątkiem od tej reguły jest opracowanie Briana

11 Por. H. Pietras, Eschatologia Kościota pierwszych czterech wieków, Kraków 2007 (Myśl Teologiczna [dalej: MT] 55).

12 Por. M. Wysocki, Eschatologia okresu prześladowań na podstawie pism Tertuliana i Cypriana, Lublin 2010, s. 153-182.

13 Por. G. Ancona, Escatologia cristiana, w: Nuovo Corso di Teologia Sistematica, vol. 13, Brescia 2003, s. 169-173; Z. J. Kijas, Niebo w domu Ojca, czyśsiec dla kogo, piekto 
Daley’a, gdzie autor przedstawia systematycznie zarys eschatologii patrystycznej od I do III wieku, nie skupia się on jednak ani na analizie tekstu patrystycznego, ani na zagadnieniach samej eschatologii końcowej, ale podaje całościowe omówienie wszystkich wątków eschatologicznych u poszczególnych teologów antycznych ${ }^{14}$. Inne opracowania dogmatyczne najczęściej skupiają się na jednym wątku teologii końcowej w przekazie patrystycznym, np. na paruzji ${ }^{15}$, lub, tworząc encyklopedyczne uogólnienie, redukują myśl pierwszych wieków do kilku stron rudymentarnej syntezy ${ }^{16}$. Przytoczone prace dogmatyczne nie stosują metodologii nauk patrystycznych przy formułowaniu tez badawczych i ich konsekwentnym rozwiązywaniu, zasadniczo nie odnoszą się w rozwijanej refleksji do chrześcijańskich autorów pierwszych trzech wieków, formułowane przez ich autorów wnioski nie wynikają z własnych analiz tekstów starożytnych, ale są najczęściej encyklopedycznym powtórzeniem i uogólnieniem. Prace te nie są zatem właściwym dla patrologii (bo nie opartym na autorskiej analizie źródłowej) systematycznym uporząadkowaniu myśli chrześcijańskich autorów I-III wieku o eschatologicznym niebie.

Osobnym działem w literaturze są opracowania kulturoznawczo-religioznawcze poświęcone tematyce raju bądź eschatologicznego nieba. Odnotowuję te prace jako istotne dla ogólnokulturowej dyskusji nad ludzkim wyobrażeniem eschatologicznego nieba. Nie są one jednak krytycznymi studiami teologicznymi nad przekazem Objawienia biblijnego i Tradycji chrześcijańskiej, a w związku z brakiem zastosowania metodologii

w oddaleniu, Kraków 2010, s. 95-120; J. Taubes, Zachodnia eschatologia, tłum. A. Serafin, Warszawa 2016, s. 96-98.

14 Por. B. Daley, Drittes Kapitel: Patristische Eschatologie, w: Handbuch der Dogmengeschichte, Hrsg. M. Schmaus, A. Grillmeier, L. Scheffczyk, M. Seybold, Bd. 4. Faszikel 7a: Eschatologie. In der Schrift und Patristik, Hrsg. B. Daley, J. Schreiner, H. E. Loina, Freiburg-Basel-Wien 1986, s. 84-140.

15 Por. A. Nitrola, Trattato di escatologia, vol. 2. Pensare la venuta del Signore, Cinisello Balsamo (Milano) 2010, s. 408-504.

16 Por. M. Bordoni, N. Ciola, Gesù nostra speranza. Saggio di escatologia i prospettiva trinitaria, Bologna 1988, s. 96-101; T. D. Łukaszuk, Ostateczny los czlowieka i świata wświetle wiary katolickiej, Kraków 2006, s. 222-225; G. Fedalto, Verso la Gerusalemme nuova. Considerazioni sulla vita eterna, Verona 2013; W. Hryniewicz, Oczekuje życia w przysztym świecie, Poznań 2013. 
Kształtowanie się nauki o niebie w teologii patrystycznej I-III wieku

właściwej naukom teologicznym nie wnoszą one wiążących refleksji dla dziedziny patrologii, dlatego pomijam je w moim opracowaniu ${ }^{17}$.

Niniejsza praca byłaby zatem analitycznym studium tekstów chrześcijańskich pisarzy antycznych I-III wieku, tekstów poświęconych zagadnieniom eschatologii końcowej oraz związanych z tematyką eschatologicznego nieba i życia wiecznego zbawionych. Takie ujęcie problematyki w moim studium stanowi pewnego rodzaju próbę uzupełnienia luki w dotychczasowych badaniach patrystycznych. Podejmowany przeze mnie problem badawczy, jako główny cel pracy, został określony przez temat niniejszego opracowania. Kolejne rozdziały pracy są odpowiedzią na cele szczegółowe. Gruntownego uściślenia badawczego domagały się zatem tematyki, jakie omawiam w poszczególnych rozdziałach i podrozdziałach.

Tekstami źródłowymi, które analizuję, są współczesne edycje krytyczne pism autorów wczesnochrześcijańskich I-III wieku. W pracy przywołuję, kiedy to konieczne, zarówno tekst źródłowy, jak i jego współczesne przekłady. Te ostatnie podaję w tłumaczeniach z uznanych serii polskich przekładów patrystycznych, daję też własne tłumaczenia niektórych tekstów patrystycznych, co zaznaczam przy danym cytowaniu.

Czynności podejmowane na poszczególnych etapach pracy są zależne od kolejnych rodzajów prowadzonych przeze mnie badań. Jako że pisana praca należy do dziedziny patrologii, sama metoda będzie właściwa naukom patrystycznym, czyli związana z pluralizmem trzech metod badawczych: filologicznej, historycznej i teologicznej, których zwieńczeniem będzie wnioskowanie teologiczne. W pismach pisarzy i ojców Kościoła IIII wieku napotkałem problematykę historyczną, filologiczną i teologiczną, dlatego, aby dotrzeć do oryginalnej myśli eschatologicznej badanych autorów, wykorzystałem pluralizm metod badawczych, który jest obecnie paradygmatem współczesnej metodologii nauk. W zależności od analizowanej

17 Por. S. Kobielus, Cztowiek i ogród rajski w kulturze religijnej średniowiecza, Warszawa 1997; G. Beri, I mondi ultraterreni, Milano 1998; S. Kobielus, Niebiańska Jerozolima. Od sacrum miejsca do sacrum modelu, Ząbki 2004; A. Scafi, Il paradiso in terra. Mappe del giardino dell'Eden, Bologna 2007; L. Majdecki, Historia ogrodów, t. 1. Od starożytności po barok, Warszawa 2010; Czas apokalipsy. Wizje dni ostatecznych w kulturze europejskiej od starożytności do wieku XVII, red. K. Zalewska-Lorkiewicz, Warszawa 2013; G. Looser, Dokąd podąża dusza? Wizje i wyobrażenia w różnych religiach świata, tłum. E. Łukaszyk, Kraków 2015. 
tematyki zastosowana metoda jest interdyscyplinarna i podporządkowana zasadzie wnioskowania do najlepszego wyjaśnienia ${ }^{18}$. Wkład poszczególnych dyscyplin zachował swoją oryginalność ze względu na własny aspekt badań i własną metodę, jednak synteza myśli eschatologicznej analizowanych autorów ostatecznie przyjęła charakter teologiczny.

W pierwszym rozdziale dotyczącym biblijnych terminów, koncepcji i obrazów eschatologicznego nieba posługiwałem się metodą filologiczną. Leksykalna interpretacja tekstów biblijnych pozwoliła mi na określenie struktur syntaktycznych, podkreślenie znaczenia i odniesień przedmiotowych, ukazanie sensów i odniesień podmiotowych, umożliwiła przedstawienie oddziaływania badanych źródeł w czasach patrystycznych oraz ich ówczesną interpretację i recepcję ${ }^{19}$. W kolejnych rozdziałach także przy pomocy metody leksykalnej odczytywałem, tłumaczyłem i analizowałem teksty kolejnych autorów chrześcijańskich I-III wieku jako źródła myśli teologicznej opisujące społeczność kościelną pierwszych trzech wieków, dające zatem obraz Kościoła w tamtych czasach oraz poruszające zagadnienia związane z ówczesną eschatologią i antropologią teologiczną. Zastosowanie metody filologicznej pozwoliło mi również na ustalenie terminów z analizowanego okresu I-III wieku przez nadanie słowom i wyrazom występującym w źródłach znaczenia takiego, jakie miały one w czasach, w których były zapisane ${ }^{20}$.

Równocześnie przy użyciu metody teologicznej omawiałem powyższe teksty w ich znaczeniu historyczno-teologicznym ${ }^{21}$. W ciągłym odniesieniu do źródeł pisanych starałem się odkryć orędzie eschatologii końcowej dotyczącej nieba i życia wiecznego, wynikające z badanych tekstów, wyjaśnić znaczenie omawianych świadectw dla wierzących w I-III wieku oraz dla wierzących dzisiaj. Jako że doktryna chrześcijańska porządkuje się w układ hierarchiczny, dlatego starałem się systematyzować myśl eschatologiczną omawianych autorów według kryterium hierarchii prawd wiary, czyli prawd

18 Por. A. Grobler, Metodologia nauk, Kraków 2006, s. 236.

19 Por. T. Buksiński, Zasady i metody interpretacji tekstów źródtowych, Poznań 1991, s. $49-52$.

20 Por. B. Miśkiewicz, Wstęp do badań historycznych, Warszawa-Poznań 1988, s. 243-244.

21 Por. J. Wicks, Wprowadzenie do metody teologicznej, tłum. J. Ożóg, Kraków 1995, s. 32-38 (MT 3). 
Kształtowanie się nauki o niebie w teologii patrystycznej I-III wieku

pierwszorzędnych i drugorzędnych. Te pierwsze, określane czasami jako odwieczne, dotyczą porządku celu, czyli Boga Trójjedynego, Wcielenia, przepowiadania o śmierci i zmartwychwstaniu Jezusa, historii zbawienia, odkupienia i życia wiecznego. Badane w niniejszym studium zagadnienie przynależy do prawd pierwszorzędnych. Odwoływałem się też we właściwej kolejności do prawd drugorzędnych, zwanych czasami prawdami pochodnymi, gdyż dotyczącymi porządku środków zbawienia. W niniejszej pracy chodziło głównie o tzw. zwyczajne środki zbawienia ${ }^{22}$.

Praca składa się z Wstępu, trzech rozdziałów: 1. Biblijne terminy, koncepcje i obrazy dotyczace nieba, 2. Ksztattowanie się nauki o niebie $w$ teologii patrystycznej-wiek I-II, 3. Ksztattowanie się nauki o niebie w teologii patrystycznej-wiek III, Zakończenia i Bibliografii. Sam układ jak i poszczególne tematyki są uwarunkowane materiałem źródłowym zawartym w analizowanych tekstach źródłowych ojców i pisarzy Kościoła I-III wieku. W rozdziale pierwszym opracowuję odnoszącą się do idei eschatologicznego nieba podstawową terminologię oraz koncepcje hebrajskie $(\$ 1.1$.) i greckie $(\$ 1.2$.), następnie przechodzę do teologicznej charakterystyki głównych linii rozwoju biblijnej koncepcji nieba (\$1.3.), opisu symboliki biblijnych obrazów nieba $(\$ 1.4$.) i zestawienia biblijnej teologii nieba z koncepcjami antycznej filozofii greckiej (\$ 1.5.). Rozdział kończy się zwięzłym podsumowaniem (\$1.6.). Opisana teologia biblijna stanowi podstawową bazę źródłową dla eschatologicznych rozważań teologów wczesnochrześcijańskich I-III wieku na temat nieba i życia wiecznego. W rozdziale drugim analizuję rozwój nauki o eschatologicznym niebie i życiu wiecznym zbawionych w tekstach ojców i pisarzy okresu poapostolskiego I-II wieku (\$ 2.1.) oraz w teologii apologetów greckich II wieku (\$2.2.). Rozdział trzeci ukazuje rozwój teologicznej nauki o eschatologicznym niebie u reprezentatywnych teologów III wieku: Ireneusza z Lyonu (\$ 3.1.), Klemensa Aleksandryjskiego (\$ 3.2.), Orygenesa $(\$$ 3.3.) oraz przedstawicieli teologii łacińskiej tego okresu Tertuliana, Cypriana z Kartaginy, Laktancjusza, Wiktoryna z Poetovium oraz w Męczeństwie świętych Perpetui i Felicyty (\$ 3.4.). Po koniecznym zaprezentowaniu podstawowych wątków biblijnych oraz klasycznej myśli

22 Por. S. Pawłowski, Hierarchia prawd wiary, w: Leksykon teologii fundamentalnej, red. R. Rusecki, Lublin-Kraków 2002, s. 488-490. 
filozoficznej na temat eschatologicznego nieba, aby lepiej przybliżyć omawiane treści patrystyczne, w schemacie opisu podaję najpierw krótki opis postaci autora, teologiczną charakterystykę jego utworów oraz omawiam teologiczny kontekst nauki o niebie. Następnie charakteryzuję terminologię dotyczącą rzeczywistości niebiańskich oraz teologię eschatologicznego nieba. Rozdziały i podrozdziały kończą się podsumowaniami. Zachowując, na tyle na ile było to możliwe, porządek chronologiczny w prezentacji myśli eschatologicznej poszczególnych autorów starożytnych, realizuję zatem pracę badawczą z zakresu patrologii i historii teologii chrześcijańskiej. 



\section{Biblijne terminy, koncepcje i obrazy dotyczące nieba}

W niniejszym rozdziale omawiam nazewnictwo, koncepcje i obrazowość języka hebrajskiego i greckiego odnoszące się do tematyki nieba, która występuje w Piśmie Świętym. W dwóch pierwszych paragrafach najpierw precyzuję biblijną terminologię specjalistyczną, podaję etymologię poszczególnych pojęć, rozróżnienia dotyczące zakresu znaczeniowego omawianych słów, możliwe zapożyczenia i specyficzne zwroty oraz związane z tymi terminami tematyczne koncepcje teologii biblijnej. Po opracowaniu terminologii i koncepcji hebrajskich $(\$ 1.1$.) i greckich $(\$ 1.2$.) przechodzę następnie do teologicznej charakterystyki głównych linii rozwoju biblijnej koncepcji nieba ( $\$$ 1.3.), opisu symboliki biblijnych obrazów nieba $(\$ 1.4$.) oraz zestawienia biblijnej teologii nieba z koncepcjami antycznej filozofii greckiej (\$1.5.), rozdział kończy się zwięzłym podsumowaniem (\$ 1.6.).

\subsection{Biblijne terminy i koncepcje hebrajskie dotyczące nieba}

Człowiek starożytny najczęściej nazywał niebem to, co znajdowało się ponad nim, odróżniając je w ten sposób od tego, co go otaczało i od ziemi, 
Kształtowanie się nauki o niebie w teologii patrystycznej I-III wieku

na której żył. Tej fizycznej koncepcji odpowiadała inna - metafizyczna, powstała także w antycznej przeszłości: obok wskazania na miejsce, niebo oznacza w niej całościowo wszystko to, co ma moc nad człowiekiem, tj. na bogów i na duchy. W ST podstawowymi terminami hebrajskimi

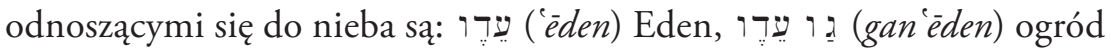

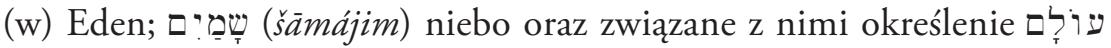
('ôlām) długi czas, trwanie, wieczność. Przytoczone biblijne pojęcia hebrajskie stały się z czasem terminami technicznymi nieba jako nadprzyrodzonego miejsca szczęśliwości. Dla bliższego określenia ich znaczeń konieczne jest omówienie zagadnień literacko-historycznych i przesłania teologicznego.

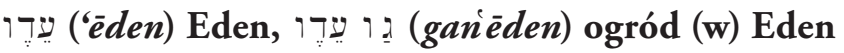

Motyw ogrodu Eden występuje w ST 14 razy: po sześć razy w Księdze Rodzaju (Rdz 2, 8. 10. 15. 23; 3, 24; 4, 16) i w Księdze Ezechiela (Ez 28, 13; 31, 9. 16.18 (2x); 36, 35), raz jako „ogród Pana” u Iz 51, 3 i raz jako „ogród Eden” u Jl 2, 3¹. Pochodzenie hebrajskiej nazwy Eden jest wciąż dyskutowane. Najczęściej wywodzi się dwie etymologie: Eden jako step, obficie nawodniona ziemia oraz Eden jako przyjemność, rozkosz, obfitość ${ }^{2}$. Jedna grupa badaczy uważa znaczenie hebrajskiego rzeczownika éden za bezpośrednie zapożyczenie z sumeryjskiego edin albo z sumeryjskiego edin za pośrednictwem akadyjskiego edinu. Starszy termin edin pojawia się często w tekstach sumeryjskich, co zdaniem badaczy świadczy, że odnośne tradycje biblijne są bardzo dawne i odzwierciedlają najstarsze warstwy kulturowe Mezopotamii. Akadyjskie edinu jest bardzo rzadkie. W tym znaczeniu etymologicznie Eden oznacza zatem ziemię obficie nawodnioną, podatną

1 Por. H. N. Wallace, Eden, Garden of, w: The Anchor Bible Dictionary, ed. D. N. Freedman, vol. 2, New York 1992, s. 282.

2 Por. J. D. Price, שדו, w: New International Dictionary of Old Testamment Teology \& Exegesis, ed. W. A. VanGemeren, vol. 3, Grand Rapids (Michigan) 1997, s. 329-330; I. Cornelius, ערד, we New International Dictionary of Old..., dz. cyt., vol. 3, s. 331332; I. Cornelius, Eden, w: New International Dictionary of Old Testamment Teology \& Exegesis, ed. W. A. VanGemeren, vol. 4, Grand Rapids (Michigan) 1997, s. 555. 
na nawadnianie, potencjalnie żyzną, co zgadza się z sensem $\operatorname{Rdz} 2,10$ $14 ; 13,10^{3}$.

Według drugiej grupy uczonych termin eeden w świadomości Hebrajczyków wywoływał skojarzenie nawołujące do drugorzędnego sensu rdzenia עדו, stąd hebrajski rzeczownik עִדרו oznacza: rozkosz, obfitość, nadmiar, przyjemność wyszukanej potrawy - Rdz 49, $20^{4}$ (por. Jr 51, 34; Ps 36, 8; Lm 4, 5). Takie znaczenie hebrajskie odpowiada np. arabskiemu (ǵadan). Tłumacze LXX, a za nimi np. Filon Aleksandryjski czy Orygenes, poszli właśnie za tym drugim znaczeniem Eden - jako przyjemność, rozkosz ${ }^{5}$. Janusz Lemański, analizując powyższe teorie, jakie pojawiły się w historii egzegezy na temat pochodzenia nazwy Eden, podsumowuje, że w obecnym kontekście Rdz 2, 8 chodzi o rodzaj oazy, która obfitowała w wodę, gdzie Bóg sam zasadził ogród i umieścił w nim człowieka ${ }^{6}$.

W Księdze Rodzaju spotykamy też dwojaki sposób posługiwania się nazwą „Eden”: odnosi się ona do krainy geograficznej na wschodzie, gdzie znajduje się ogród $(\mathrm{Rdz} 2,8 ; 2,10 ; 4,16)$, albo oznacza nazwę ogrodu $(\mathrm{Rdz} 2,15 ; 3,23 ; 3,24)^{7}$. Claus Westermann w latach 70. XX wieku dowodził, że owo podwójne nazewnictwo świadczy, że istniało wiele tradycji, być może nawet jakiś cykl tradycji wykorzystany w biblijnym opowiadaniu o Edenie (por. Genesis, w: Biblischer Kommentar: Altes Testament, Bd. 1, Darmstadt 1972, s. 285-287). Tezę Westermanna dopełnia wyjaśnienie Waldemara Chrostowskiego, że autorzy biblijnego opowiadania o przyjaźni pierwszych ludzi z Bogiem i ich upadku dokonali prawdopodobnie

3 Hebrajsko-polski Stary Testament. Ksiegga Rodzaju. Wydanie interlinearne z kodami gramatycznymi, transkrypcja oraz indeksem rdzeni, tłum. i oprac. A. Kuśmirek, Warszawa 2000 (Prymasowska Seria Biblijna [dalej: PSB] 14), Rdz 2, 10: „I strumień wypływa z Eden, aby nawadniać ogród”, s. 8; Hebrajsko-polski Stary Testament. Ksiega Rodzaju..., dz. cyt., Rdz 13, 10: „I podniósł Lot oczy swe i widział całą okolicę Jordanu, że cała (była) ona nawodniona, zanim zniszczył Jahwe Sodomę i Gomorę, jak ogród Jhwh, jak ziemia Egiptu biegnąca (do) Soar”, s. 43.

4 Hebrajsko-polski Stary Testament. Ksiegga Rodzaju..., dz. cyt., Rdz 49, 20: „Od Aszera (będzie) tłusty pokarm jego, i on da przysmaki królewskie", s. 203.

5 Por. W. Chrostowski, Ogród Eden. Zapoznane świadectwo asyryjskiej diaspory, Warszawa 1996, s. 75-79 (Rozprawy i Studia Biblijne [dalej: RSB] 1).

6 Por. J. Lemański, Księga Rodzaju, rozdziaty 1-11. Wstęp, przektad z oryginatu, komentarz, t. 1, cz. 1, Częstochowa 2013, s. 222 (Nowy Komentarz Biblijny - Stary Testament).

7 Por. H. N. Wallace, Eden, Garden of, w: The Anchor Bible..., dz. cyt., vol. 2, s. 283. 
Kształtowanie się nauki o niebie w teologii patrystycznej I-III wieku

demitologizacji: przejęto nazwę Eden, mającą podłoże mityczne, ale nadano jej nowe, symboliczne znaczenie. Ogród został umieszczony w Eden, czyli w krainie położonej na wschodzie $(\mathrm{Rdz} 3,8)$. Lokalizację podano nie po to, aby ogrodu szukać, lecz aby podkreślić, że stanowi on element składowy świata stworzonego przez Boga. Nawet jeśli wschód był dla antycznego Izraelity kierunkiem podstawowym, według którego ustalano pozostałe strony świata, to dwukrotne nawiązanie do wschodu w $\operatorname{Rdz} 3,24$ na początku i na końcu tego opowiadania sugeruje, że region Eden stale pozostawał poza zasięgiem ekspansji Izraelitów, w dalekiej nieznanej krainie. Poprzez wprowadzenie przyimka „w” sugerowano, że chodzi o konkretną krainę, która kojarzyła się hebrajskim słuchaczom z położoną nad środkowym Eufratem krainą Bit-Adini (2 Krl 19, 12; Iz 37, 12; Am 1, 5). Jednak wspomnianej zmiany autorzy biblijni nie przeprowadzili konsekwentnie, dlatego Eden trzykrotnie pozostał w Rdz jako nazwa ogrodu, a trzykrotnie jako nazwa krainy geograficznej ${ }^{8}$.

Rzeczownik 1 g gan) - ogród występuje po raz pierwszy w $\operatorname{Rdz} 2,8$, a w samym opowiadaniu o przyjaźni z Bogiem i grzechu pierwszych ludzi pojawia się jeszcze 8 razy $\left(\mathrm{Rdz} 2,9.10 .16\right.$; 3, 1-3. 8. 10) ${ }^{9}$. Ogród ten jest dziełem Boga, zaistniał po stworzeniu człowieka i ze względu na człowieka. Wegetacja w ogrodzie zależała od deszczu zsyłanego przez Boga, nurtu wody wypływającego z ziemi oraz od mężczyzny, który miał uprawiać ziemię ( $\mathrm{Rdz}$ 2, 5-6. 10). Umieszczając w ogrodzie pierwszego mężczyznę, a następnie kobietę, Bóg uczynił z ogrodu dar ( $\mathrm{Rdz} 2,8)$. Na ogród złożyły się elementy tego, co Bóg stworzył wcześniej. Dorodne i piękne okazy roślinności, „miłe w wyglądzie i dobre do spożywania, a także drzewo życia w środku tego ogrodu oraz drzewo znajomości dobra i zła” ( $\operatorname{Rdz} 2,9)$.

8 Por. W. Chrostowski, Ogród Eden..., dz. cyt., s. 75-80. Natomiast Wielki stownik hebrajsko-polski i aramejsko-polski Starego Testamentu, t. 1, red. L. Koehler, W. Baumgartner, J. J. Stamm, [red. nauk. wyd. pol. P. Dec], Warszawa 2008, s. 741 (PSB 30), podając opracowanie hasła עִ - idzie jedynie za interpretacją C. Westermana z BK 1/1, s. 286 i postuluje, że pierwsze znacznie עִדֶו jako terminu homofonicznego z I עִד to rozkosz, a z powodu niezgodności fonetycznej (za wspomnianym opracowaniem C. Westermanna),,sugeruje się, że עִדֶו pochodzi od sumeryjskiego edinu step (AHw. 187b; CAD E:27; też w KBL), ale mniej prawd".

9 Por. B. Jacobs-Horning, 1 (gan), w: Theologisches Wörterbuch zum Alten Testament, Hrsg. G. J. Botterweck, H. Ringgren, H.-J. Fabry, vol. 2, Stuttgart 1977, s. 35-41. 
1. Biblijne terminy, koncepcje i obrazy dotyczące nieba

„Drzewo znajomości dobra i zła” posiada bardzo wiele interpretacji, ale we współczesnej dyskusji egzegetycznej upowszechnia się pogląd, który uznaje w tym drzewie aluzję do możliwości podejmowania przez człowieka autonomicznych decyzji o tym, co słuszne i właściwe ${ }^{10}$.

Natomiast wzmianka o „drzewie życia” sugeruje roślinę o nadzwyczajnych właściwościach, która dzięki spożywaniu jej owoców jest zdolna zapewnić człowiekowi trwałe życie. Jednak współczesna egzegeza zwraca uwagę, że Rdz $1-2$ nie sugeruje nigdzie nieśmiertelności pierwszych ludzi. Także w ogrodzie w Eden byli oni poddani zjawisku przemijania, ukierunkowanemu ku starzeniu się i śmierci. Ta ostatnia w pierwotnym porządku stworzenia była jednak przyjmowana przez ludzi z pełnym zaufaniem do Boga, co otwierało człowieka na wieczność ${ }^{11}$. Opowiadanie o pierwotnym

10 Por. W. Chrostowski, Ogród Eden..., dz. cyt., s. 32-41.

11 Por. W. Chrostowski, Czy Adam i Ewa mieli się nie starzeć i nie umierać? Egzegetyczny przyczynek do nauczania o nieśmiertelności pierwszych ludzi, w: Verbum caro factum est. Księga pamiątkowa dla ks. prof. Tomasza Jelonka w 70. Rocznicę urodzin, red. R. Bogacz, W. Chrostowski, Warszawa 2007, s. 170-173. Jak zaznacza W. Chrostowski na s. 171172, wnioski współczesnej egzegezy Rdz $1-2$ nie pokrywają się z doktrynalnymi wypowiedziami Kościoła: np. tą z KKK 375-376 (pierwsi ludzie zostali ukonstytuowani w stanie świętości i sprawiedliwości pierwotnej; było nią uczestnictwo w życiu Bożym). Zatem według nauczania katechizmu, dopóki człowiek pozostawał z zażyłości z Bogiem - nie miał ani umierać (tu powołanie na Rdz 2, 17; 3, 19), ani cierpieć (tu odwołanie do Rdz 3, 16). Jednak nie ma w KKK żadnego konkretnego argumentu z NT czy Tradycji, który dotyczyłby ludzkiej nieśmiertelności w Edenie. Natomiast odwołania do Rdz 2, 17 i 3, 19 bynajmniej nie wskazują, aby Biblia nauczała o ludzkiej nieśmiertelności w Edenie. W związku z tym, iż przedstawiona egzegeza jest spójna, a wyprowadzone wnioski wiernie rozwijają oryginalny sens tekstów biblijnych, W. Chrostowski sugeruje, aby dokonać przemyśleń i reinterpretacji doktrynalnych orzeczeń Kościoła oraz ich relacji do wyników egzegezy biblijnej. Wobec powyższego postulatu zostają przytoczone rozważania J. Salija, Przekleństwo śmierci i śmierć w Chrystusie, „Zeszyty formacji duchowej” 24 (2004), s. 12-14, który przypomina, że w historii teologii katolickiej ukształtowały się cztery dopuszczalne interpretacje problematyki nieśmiertelności pierwszych ludzi: (1) człowiek był raczej wezwany do nieśmiertelności, niż nią obdarzony - (przedstawiciel: Teofil z Antiochii, List do Autolika 2, 27, POK 18, s. 76); (2) pierwsi ludzie mogli nie umierać (posse non mori), podczas gdy w życiu wiecznym zbawieni „nie będą mogli umrzeć” (non posse mori) (przedstawiciel: Augustyn z Hippony, O państwie Bożym 22,30,3, PAX 18/2, s. 615); (3) człowiek zgodnie z naturą zarówno nie podlega śmierci, jak i jej podlega. Dla człowieka w raju nieśmiertelność ducha ogarniała ciało, gdyż był blisko Boga. Po grzechu słaba dusza nie ogarniała już nieśmiertelnością ciała. Stąd ludzkie podleganie śmierci jest zarówno naturalne (naturalne dla ciała; w raju, dzięki stanowi sprawiedliwości, 
Kształtowanie się nauki o niebie w teologii patrystycznej I-III wieku

ogrodzie z Rdz 2, 4b - 3, 24 jest narracją o ogrodzie w Eden jako symbolu szczęśliwości, piękna i harmonii, co odzwierciedla piękno samego Boga.

Biblijne opowiadanie o ogrodzie w Eden z Księgi Rodzaju ma cechy swoistości, pomimo podobieństwa do ogrodów znanych z mitycznych opowiadań tradycji mezopotamskiej: krainy Dilmum (sumeryjski mit o Eneki i Ninhursag), lasu cedrowego Irinini i ogródu Siduri (babiloński mit o Gilgameszu) oraz do greckiego mitu o ogrodzie Hesperidion ${ }^{12}$. Oryginalność biblijnej narracji o Edenie w stosunku do mitycznych przekazów o wymienionych ogrodach wykazuje Chrostowski. W biblijnym Edenie odmienny jest zatem od opowiadań antycznych mitologii motyw pracy: w $\mathrm{Rdz} 2$, 15 Bóg powierza człowiekowi troskę o ziemię, czyniąc go swoim partnerem; natomiast w mitach bogowie powołują człowieka do istnienia po to, aby im służył, z zamiarem wykorzystania go do najcięższych prac. Odmiennym jest motyw drzewa życia: Adam i Ewa są umieszczeni w ogrodzie, w którym rośnie drzewo życia (drzewo życia staje się dla nich niedostępne dopiero po grzechu), ale nacisk w opowiadaniu biblijnym nie jest położony na osiągnięcie życia wiecznego, lecz na wymóg posłuszeństwa wobec Bożego przykazania; natomiast w mitach mezopotamskich drzewo życia jest rośliną niedostępną dla ludzi, a sama nieśmiertelność jest dla człowieka nieosiągalna. Odmienny jest także motyw rzeki: „Wśród badaczy powszechny jest pogląd, że Rdz 2, 10-14 wykorzystuje znane w mitach mezopotamskich wątki rzeki. Jednak w opowiadaniu biblijnym widać partykularność. Po piewsze, w opisie Edenu położono nacisk na opis położenia ogrodu i występowania rzeki, aby uczynić go integralnym elementem stworzonego świata. W mitach podkreślano zaś niedostępność ogrodu. Po drugie, w ogrodzie Eden jedynie Bóg, jako suwerenny władca świata, jest także dawcą deszczu, On sprawia, że rzeki

ta właściwość ciała byłaby zawieszona), jak i jest konsekwencją grzechu (gdyby nie grzech, dusza nadal udzielałaby swej nieśmiertelności ciału) - (przedstawiciel: Tomasz z Akwinu, Summa theologiae 1q. 97 a. 1; 1-2 q. 85 a. 5; 2-2 q. 104 a. 1); (4) człowiek nawet w sprawiedliwości pierwotnej podlegałby umieraniu, które byłoby jednak spokojnym, wolnym od lęku i bólu przejściem do życia wiecznego. Wskutek grzechu pojawiła się śmierć, czyli wszystko to, co jest w ludzkim umieraniu drapieżne, okrutne, straszne, budzące lęk - (przedstawiciel: Jacek Bolewski SI, Początek i śmierć człowieka w Starym Testamencie, „Horyzonty wiary” 5 (1990), s. 19-33).

12 Por. T. Jelonek, Biblia a mity. O Raju i ztotym wieku, Kraków 2010, s. 7-96. 
mają swoje źródła, sprawuje nadzór nad ich biegiem i umożliwia wykorzystanie tej wody przez człowieka (por. Rdz. 2, 5; 8, 2). Natomiast w mitach mezopotamskich występuje wierzenie, że osobne bóstwa są odpowiedzialne za poszczególne zjawiska przyrody (w poszczególnych mitologiach za fenomeny wody, deszczu i morza były odpowiedzialne np. w Babilonie Marduk, w Ebla - bóstwa Hadda lub Adda, w języku akadyjskim znane jako Adad lub Addu, a w języku ugaryjskim Hadad, Haddu lub Baal). Biblijny opis rzeki w Eden stanowi zatem ukrytą polemikę z wierzeniami mezopotamskimi. Nie znaleziono natomiast pozabiblijnych paraleli z motywem „drzewa znajomości dobra i zła”. Motyw cherubów i błyszczącego miecza z Rdz 3, 22-24 to dwa odrębne wątki literackie, sugerujące dwie pierwotnie autonomiczne tradycje o cherubach pełniących funkcję strażników (motyw bóstw wstawienniczych kâribu przejęty z mitologii mezopotamskiej) oraz o błyszczącym mieczu (symbolika zaczerpnięta z mitologii sumeryjskiej). Cherubowie w Rdz 3, 24 (por. Ez 28, 14. 16) pełnią rolę strażników drogi do drzewa życia. Natomiast wzmianka o mieczu błyszczącym to aluzja do Boga, który panuje nad ogniem i błyskawicami, a pośrednio jest to również polemika biblijna z bóstwami pogańskimi: bóstwom tym w Rdz 3, 24 odbiera się ich mityczne przymioty i sprowadza do roli wykonawców woli Boga. Wymowa samego motywu o cherubach i mieczu ognistym wskazuje, że nieśmiertelność jest poza zasięgiem człowieka ${ }^{13}$.

W Księdze Ezechiela (napisanej przez proroka w Tell-Abib w Babilonii, w latach 592-570 przed Chr.) spotykamy 6 fragmentów z motywem Edenu: „Eden w ogrodzie Boga” (Ez 28, 13), „wszystkie drzewa Edenu, które były w ogrodzie Boga” (Ez 31, 9), „wszystkie drzewa Edenu” (Ez 31, 16), „drzewa Edenu" (Ez 31, 18 - 2 razy) oraz ,jak ogród Edenu” (Ez 36, 35). Porównując Ezechielowe wzmianki o Edenie w „ogrodzie Boga” (gañ élōhim) z fragmentami o Edenie z Rdz 2, 4b - 3, 24 oraz z wyrażeniami „ogród Jahwe” (gan jhwh z Rdz 13, 10 i z Iz 51, 3), dochodzi się do wniosku, że w obu przypadkach chodzi o tę samą lub podobną rzeczywistośćc ${ }^{14}$. Pięć aluzji do Edenu znajdujemy w wypowiedziach przeciw królowi Tyru $($ Ez 28,13$)$ i przeciw

13 Por. W. Chrostowski, Ogród Eden..., dz. cyt., s. 80-114; zob. także H. N. Wallace, Eden, Garden of, w: The Anchor Bible..., dz. cyt., vol. 2, s. 283-284; J. Lemański, Ksiegga Rodzaju, rozdziaty 1-11..., dz. cyt., s. 223-227.

14 Por. H. N. Wallace, Eden, Garden of, w: The Anchor Bible..., dz. cyt., vol. 2, s. 906-907. 
Kształtowanie się nauki o niebie w teologii patrystycznej I-III wieku

władcy Egiptu (Ez 31, 9. 16. 18), zaś ostatnia aluzja do Edenu w Księdze Ezechiela jest w zapowiedzi oczyszczenia Izraelitów, związanego z powrotem do ich ziemi (Ez 36, 35). Wątek ogrodu Eden jest zatem odczytywany jako symbol płodności, bujnego rozkwitu i życia ${ }^{15}$.

Fragment z Jl 2, 3: „ziemia ta jest przed nim jak ogród Eden” (Biblia Tysiąclecia, dalej $\mathrm{BT}^{5}$ ) to odwołanie do ogrodu Eden z Rdz 2, 8 jako obrazu wegetacji i urodzaju (prorok Joel napisał swą księgę w Jerozolimie, pod koniec $\mathrm{V}$ wieku przed Chr.). Podobnie wyrażenie „ogród Jahwe” z Iz 51, 3 („zlituje się Pan nad Syjonem, zlituje się nad całym jego zniszczeniem. W Eden przemieni jego pustynię, a jego stepy w ogród (Jahwe) Pana”, BT ${ }^{5}$ ) jest paralelą do ogrodu Boga w Eden z Ez 28, 13 („mieszkałeś w Edenie, ogrodzie Bożym”) i stanowi ostatnie biblijne odniesienie opisujące odnowę Syjonu, kiedy pustynia stanie się jak Eden (przyjmuje się, iż Deutero-Izajasz pisał tę część Księgi Izajasza (tj. Iz 40 - 55) podczas niewoli babilońskiej około roku 550) ${ }^{16}$.

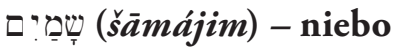

Rzeczownik šamāj - niebo istnieje w wielu językach semickich. W przeciwieństwie do semickiego południowego (arabski samåa; samāj) w semickim północnym i wschodnim (šam $\hat{u}<\check{s} a m a \hat{u} \hat{u}$, w antycznym babilońskim pojawiał się także w formie liczby pojedynczej šamûm i oznaczał „deszcz”; w znaczeniu pochodnym desygnował „baldachim”) występował on pod względem formalnym jedynie w liczbie mnogiej - mimo znaczenia liczby pojedynczej (plurale tantum). Forma liczby podwójnej dla rzeczownika šāmájim w antycznym hebrajskim jest w rzeczywistości, zdaniem badaczy Paula Joüona, Eduarda Meyera, rzadką formą liczby mnogiej. Wydaje się prawdopodobną etymologia ludowa bazująca na zjawisku asonansu, a wywodząca znaczenie šămájim od rzeczownika májim (woda), gdyż oba wyrazy posiadają

15 Por. W. Chrostowski, Ogród Eden..., dz. cyt., s. 123.

16 Por. I. Cornelius, Eden, w: New International Dictionary of Old..., dz. cyt., vol. 4, s. 555; H. N. Wallace, Eden, Garden of, w: The Anchor Bible..., dz. cyt., vol. 2, s. 282 (por. też $\mathrm{w}$ niniejszej pracy $\$ 1.2$. Terminy greckie, hasło $\pi \alpha \rho \alpha \dot{\delta} \in\llcorner\sigma o \varsigma$ (parádeisos) ogród, park, raj). 
to samo zakończenie. W interesującym nas złożeniu šàmájim: $\check{s}^{a} \bar{a}-$ byłoby zaimkiem względnym, a dodane do rdzenia májû oznacza „miejsce wody”. Dlatego zdaniem niektórych semitologów (np. Pelia Fronzaroliego) termin šămájim w znaczeniu niebo był w antycznym hebrajskim utożsamiany pojęciowo z rzeczownikiem raqia (firmament), który oznaczał zbiornik wód kosmicznych ${ }^{17}$.

Rzeczownik šāmájim pojawia się w ST 420 razy: 74 razy w Psalmach, 44 razy w Pwt, 41 razy w Rdz, 33 razy u Iz, 33 razy u Jr, 28 razy w 2 Krn, 23 razy u Hi, 20 razy $1 \mathrm{Krl}, 16$ razy w $2 \mathrm{Krl}$, po 14 razy w Wj i u Ne, 9 razy u Ez, po 6 razy w 2 Sm, Prz i 1 Krn, po 5 razy w Za, Syr, Lm, Dn, po $4 \mathrm{u} \mathrm{Joz}, \mathrm{Jdt}, 1 \mathrm{Sm}, \mathrm{Oz}$, po 3 razy u Jl i Ag, po 2 razy u Am, So, Ezd i $1 \mathrm{raz}$ w Kpł, Jon, $\mathrm{Na}$, Ab i Ml. Natomiast aramejski termin $s^{e}$ majjā występuje w ST 38 razy: 28 razy u Dn, 8 razy u Ez i 2 razy u Jr ${ }^{18}$.

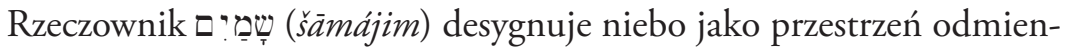
ną od ziemi i od morza, zgodnie z dwudzielną (niebo-ziemia) i trójdzielną (niebo-ziemia-morze) wizją świata rozpowszechnioną na antycznym Bliskim Wschodzie: niebo powyżej, pośrodku ziemia, a dookoła i pod spodem woda. Obie kosmologie, charakterystyczne dla starożytnej Babilonii, występują w opisach ST ${ }^{19}$. Nie zostały zanotowane prawdziwe synonimy dla šámájim. Najbardziej zbliżonym do šāmájim wydaje się rzeczownik rāgi $\bar{\imath}^{a}$ (firmament). Ten ostatni występuje w ST 17 razy, z czego 9 razy w Rdz 1, 6-20; 5 razy u Ez 1, 22-26 i 10, 1 oraz u Iz 42, 5 - 44, 24; Ps $136,6^{20}$. Zbliżonym znaczeniem wydaje się także 'aguddā (sklepienie) u Am 9, 6. W niektórych tekstach šámájim jest powiązane z rzeczownikiem šehāqim (chmury): Pwt 33, 26; Iz 45, 8; Jr 51, 9; Ps 36, 6; 57, 11; 108, 5; Hi 35, 5, będąc w opozycji do 'ároes (ziemia), do še 'ól (świat podziemny) i do $t^{e} h \bar{m} m$ (masa wód) / ewentualnie mabbūl (ocean niebiański). Wymienne powiedzenia „niebo-ziemia” lub „ziemia-niebo” oznaczają w ST uniwersum.

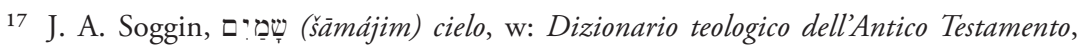
ed. E. Jenni, C. Westermann, vol. 2, Casale Monferrato 1982, s. 871.

18 Por. J. A. Soggin, שָׁמִ (sámájim) cielo, w: Dizionario teologico..., dz. cyt., vol. 2, s. 872.

19 Por. D. T. Tsumura, The Earth and the Waters in Genesis 1 and 2: A Linguistic Analysis, Journal for the Study of the Old Testament, Sheffield 1989, s. 66-77 (Journal for the Study of the Old Testament, Supplement Series 83).

20 Por. P. H. Seely, The Firmament and the Water above, „The Westminster Theological Journal" 53 (1991), s. 227-240. 
Kształtowanie się nauki o niebie w teologii patrystycznej I-III wieku

Natomiast nie jest do końca jasne sformułowanie šemē haššämájim („niebiosa niebios" - Pwt 10, 14; 1 Krl 8, 27; Ps 148, 4; Ne 9, 6; 2 Krn 2, 5; 6, 18; Syr 16, 18). Wyrażenie „niebiosa niebios” pojawia się zawsze w ST podczas stosowania podniosłego stylu (hymny, modlitwy, powiedzenia mądrościowe). Mamy tutaj do czynienia najprawdopodobniej z parafrazą stopnia najwyższego, w oparciu o wzorzec „pieśń nad pieśniami” (Pnp 1, 1) czy „marność nad marnościami” (Koh 1, 2). Wyrażenie šemē hǎšāmájim wydaje się zatem wskazywać na niebo w jego całości w sensie absolutnym, a nie tylko na jakiś jego wybrany, najwyższy poziom ${ }^{21}$.

Według ST - niebo, podobnie jak ziemia, ma wyznaczone, stabilne granice. Niebo jest rozciągnięte (nțh jako „rozciągnąć” występuje 136 razy w ST, przy czym łącznie z rzeczownikiem niebo - 9 razy: Iz 40, 22; 42, 5; 44, 24; 45, 12; 51, 13; Jr 10, 12; 51, 15; Za 12, 1; Ps 104, 2; Hi 9, 8) lub jest rozwinięte (Iz 34, 4), posiada okna ('arubbōt- $\operatorname{Rdz} 7.11 ; 8,2 ; 2 \operatorname{Krl} 7,2.19$; $\mathrm{Ml}$ 3, 10; Iz 24, 18), wspiera się o słupy niebieskie ('ammūdìm - Hi 26, 11) lub o posady $\left(m \overline{o s}{ }^{e} d \bar{o} t\right.$ haššàmájim - 2 Sm 22, 8), może być przez Boga rozdarte $(g r$ - Iz 63, 19). W powyższych tekstach zachodzi pełna ekwiwalencja šămájim (niebo) z rāgīa (firmament). W antycznym hebrajskim nie istnieje wyrażenie rzeczownikowe wskazujące na powietrze czy atmosferę (występuje ono natomiast w średniohebrajskim ' awèr l' awirr < greckie

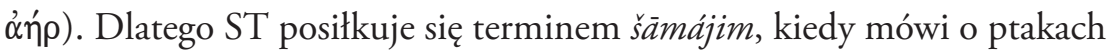
niebieskich (Pwt 4, 17; Jr 8, 7; Ps 8, 9; Lm 4, 19), kiedy opisuje wypadek Absaloma, który zawisł „między niebem a ziemią” (2 Sm 18, 9) oraz kiedy naturalne fenomeny dokonują się "między ziemią a niebem” (Ez 8, 3; Za 5, 9; 1 Krn 21, 16). Niebo pojawia się w ST szczególnie wtedy, gdy mowa jest o zjawiskach związanych z wszelkimi opadami wody (Jr 10, 13; 51, 16; Ps 148, 4), deszczu ( $\operatorname{Rdz} 2$, 5; 8, 2; Pwt 11, 11; Jr 14, 22), rosy, lodu i szronu (Hi 38, 28-29) czy śniegu (Iz 55, 10). Z nieba mogą także padać: ogień (Rdz 19, 24), kurz (Pwt 28, 24) czy ogromne kamienie (Joz 10, 11).

21 Por. B. Alfrink, L'expression šamaim ou šemei haššamaim dans l'AT, w: P. Hennequin, Mélanges Eugène Tisserant, vol. 1, Città del Vaticano 1964, s. 231-237 (Studi e Testi

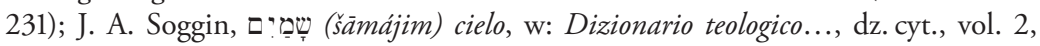
s. 872-873; D. T. Tsumura, שָׁמי (sāmájim), heaven, sky, firmament, air, w: New International Dictionary of Old..., dz. cyt., vol. 4, s. 161. 
W ST spotykamy też ideę nieba jako domu Boga z pokojami-skarbcami (Pwt 28, 12; 32, 34), w których są przechowywane wiatry (Jr 10, 13; 51, 13; Ps 135,7$)$ oraz śnieg i grad (Hi 38, 22; Ps 33, 7). Do tak pojmowanego nieba w kosmografii starosemickiej przynależą też gwiazdy: słońce (šcemoeś) i księżyc $(j a \bar{a} r \bar{e} a b)-27$ razy w ST, czy gwiazda $(k \bar{o} k \bar{a} b)-37$ razy. Z nieba pochodzi także manna (mān - 14 razy w ST: Wj 16, 15. 31. 33. 35; Lb 11, 6. 7. 9; Pwt 8, 3. 16; Joz 5, 12; Ps 78, 24; Ne 9, 20; „chleb z nieba” Wj 16, 4; Ps 105, 40) ${ }^{22}$.

Od momentu stworzenia przez Boga nieba i ziemi $(\operatorname{Rdz} 1,1)$ oraz sklepienia nazwanego niebem $(\operatorname{Rdz} 1,6-8)$ niebo nie istnieje autonomicznie, lecz przynależy do kategorii dzieł Bożych. Tę myśl ST powtarza wielokrotnie (Rdz 2, 4b; 14, 19. 22; Iz 42, 5; 45, 18; Ps 8, 4; 33, 6; Prz 3, 19; $8,27)$. Choć niebo jako dzieło stworzone wyraża swym istnieniem długą trwałość (Pwt 11, 21; Ps 89, 30; 45, 15), to także dla niego przewidziany jest koniec (Iz 51, 6; Hi 14, 12). Powyższa idea końca przeniknęła następnie do pism międzytestamentalych oraz do NT. Niebo ma być zwinięte (Iz 34, 4) i zastąpione stworzeniem nowego nieba, które w przeciwieństwie do obecnego nie będzie miało końca (Iz 65, 17; 66, 22). Późniejsze wyobrażenia nieba, które pojawiają się pod koniec ST, opisują niebo za pomocą obrazu dwóch gór, pomiędzy którymi rozpięte są niebo i ziemia (por. Za 1, 8; 6, 1). Taka koncepcja prowadzi, zdaniem Gerharda von Rada, do swoistej remitologizacji nieba, które staje się miejscem, gdzie Bóg ma już przygotowane swoje królestwo i czeka na jego rychłe wypełnienie dla ziemi (por. Dn 7, 13 i apokaliptyczne wyobrażenie człowieka nadchodzącego na obłokach niebieskich) ${ }^{23}$.

W ST niebo jest często opisywane jako mieszkanie Jahwe i jego wojska (șäba $)-P \mathrm{wt}$ 4, 39; 10, 14; 26, 15; $1 \mathrm{Krl}$ 8, 23; Iz 63, 15; 66, 1; Ps 2, 4; 11, 4; 20, 7; 89, 12;102, 20;115, 3. 16; Lm 3, 41). Niebo nie może jednak objąć

22 Por. J. A. Soggin, שִָׁ (sámájim) cielo, w: Dizionario teologico..., dz. cyt., vol. 2, s. 873-874.

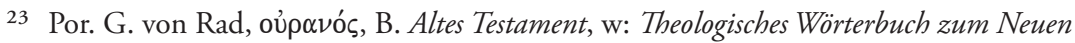
Testament, Hrsg. G. Kittel, G. Friedrich, Bd. V, Stuttgart-Berlin-Köln 1990, s. 508;

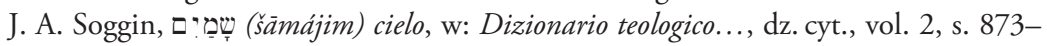

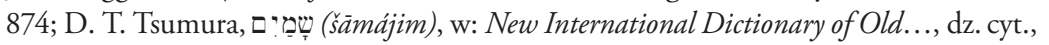
vol. 4, s. 161-162. 
Kształtowanie się nauki o niebie w teologii patrystycznej I-III wieku

Boga, gdyż nie obejmują go jakiekolwiek granice kosmiczne $(1 \mathrm{Krl}$ 8, 27; 2 Krn 2, 5; 6, 18; Jr 23, 24). Niebo nigdy nie jest w ST deifikowane, zawsze pozostając jednym z dzieł Bożego stworzenia ${ }^{24}$. Tylko raz w ST, w Pwt 33, 26, występuje starożytne wyrażenie mityczne „cwałuje po niebie” (rōkēb šămájim), które zostaje odniesione do Jahwe. Niebo jako miejsce przebywania Boga przynależy także do sfery kultycznej (Ez 24, 10). Według ST człowiek jedynie teoretycznie może wstąpić ( lh) do Boga ( $\operatorname{Rdz} 11,4$; 28, 12; 2 Krl 2, 11; Ps 139, 8; Hi 20, 6; Prz 30, 4). Bóg zstępuje (jrd) z nieba (Rdz 11, 5; 2 Sm 22, 10; Ps 18, 10; 144, 5), Bóg z nieba spogląda w dół (šqp-Pwt 26, 15), z nieba przemawia albo Bóg, albo Jego posłaniec (mal 'àk) - (Rdz 21, 17; 22, 11. 15; Wj 20, 22; Ne 9, 13). Od okresu perskiego panowania w Babilonie (lata 30. VI wieku przed Chr.) w tytulaturze Jahwe pojawia się określenie „Bóg nieba” (Ps 136, 26; Jon 1, 9; Ezd 1, 2; 2 Krn 36, 23; Ne 1, 4; analogiczne wyrażenia aramejskie u Dn 2, 18 czy w papirusach z Elefantyny). Jednak na podstawie $\operatorname{Rdz} 24$, 3.7 nie wyklucza się, że powyższy tytuł mógł być używany, chociaż rzadko, także w czasach przed wygnaniem babilońskim. Co więcej, tytuł „Bóg nieba” lub „Pan / Pani nieba” był znany w antycznych religiach Bliskiego Wschodu ${ }^{25}$ : np. dla bóstwa Ba' alšamèm tytuł ten jest poświadczony na inskrypcji fenickiej z Biblo (X wiek. przed Chr.) ${ }^{26}$; „Panią nieba” była nazywana sumeryjska bogini „Inanna”, w mitologii babilońskiej znana jako Isztar ${ }^{27}$; w Egipcie „Panią nieba” nazywano boginię Hathor ${ }^{28}$, a „królową nieba” - kananejską

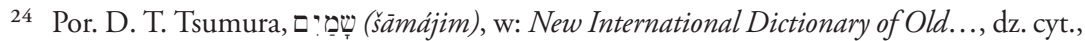
vol. 4, s. 163-164.

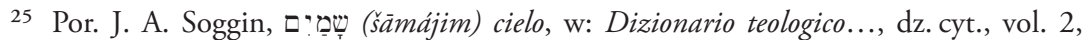
s. 875; D. T. Tsumura, שָׁמי (sámájim), w: New International Dictionary of Old..., dz. cyt., vol. 4, s. 163-165. O odmienności kultu Jahwe od kultów religii ościennych, zob. T. Stanek, Jahwe a bogowie ludów. Religia Izraela na tle religii ludów Egiptu, Kanaanu i Mezopotamii, Poznań 2002; M. Münnich, Ł. Niesiołowski-Spanò, P. Muchowski, Zachować tożsamość. Starożytny Izrael w obliczu obcych religii i kultur, Warszawa 2008 (RSB 31).

26 Por. O. Eissfeldt, Ba 'alšamēm und Yahweh, „Zeitschrift für die Alttestamentliche Wissenschaft" 57 (1939), s. 1-31.

27 Por. D. Wolkstein, S. N. Kramer, Inanna, Queen of Heaven and Earth, Her Stories \& Hymns from Sumer, New York 1983, s. 91-113, 136-174.

28 Por. W. Bator, Hathor, w: Bogowie, demony, herosi. Leksykon, red. Z. Pasek, Kraków 1997, s. 164. 
1. Biblijne terminy, koncepcje i obrazy dotyczące nieba

boginię Szapasz, którą często utożsamiano z fenicko-kananejską boginią Asztarte (por. Jr 7, 18; 44, 17) ${ }^{29}$.

\section{עוֹלָם ('ôlām) - długi czas, trwanie}

Najczęściej w języku hebrajskim oznacza: długi czas, trwanie na wieki, wieczność. Dalsze znaczenia to: czasy nadchodzące, dawno temu, wiekuisty Bóg, trwały stan odnośnie przeszłości i przyszłości ${ }^{30}$. Pochodzenie rzeczownika 'ôlām jest niepewne, etymologię najczęściej wywodzi się od rdzenia 'Im (ukryty), stąd podstawowe znaczenie rzeczownika można oddać jako „nieokreślony czas”. Temat “lm jest dobrze udokumentowany w języku ugaryckim, gdzie oznacza wieczność, w analogicznym znaczeniu jest stosowany w języku hebrajskim (“d'lm, l'lm - „zawsze”, „na zawsze”). Temat 'lm pojawia się w wielu dialektach języka aramejskiego, jako 'àlmā' desygnuje: wieczność, wiek, świat ${ }^{31}$.

Podstawowe znacznie rzeczownika ערזָ ('ôlām) to najdalszy czas, odległy czas. Nie oznacza on wieczności w rozumieniu filozoficznym, czy jakiegoś czasu bezgranicznego lub wiecznej bezczasowości. W zdecydowanej większości przypadków znaczenie hebrajskiego 'ôlām jest ściśle związane z występowaniem jakichś konkretnych wydarzeń, gdzie 'ôlām jest zwykle stosowane do opisania wydarzeń rozciągających się w ramach odległej przeszłości lub przyszłości ${ }^{32}$. Przy czym ów odległy czas może być relatywny: może go wyznaczać długość własnego życia (Ps 77, 5), życia jako niewolnik „na zawsze” (Wj 21, 6) czy królowania Boga nad Izraelem „na zawsze” (Wj 15, 18). Kiedy pojęcie ‘ôlām odnoszono do przeszłości,

29 Por. A. Naumczyk, Ważniejsze bóstwa panteonu kananeńskiego w świetle tekstów z Ugarit, „Rocznik Teologiczny Chrześcijańskiej Akademii Teologicznej 1960”, Warszawa 1961, s. 133-177; T. Binger, Asherah: goddesses in Ugarit, Israel and the Old Testament, Sheffield 1997.

30 עוֹרָ, w: Wielki stownik hebrajsko-polski i aramejsko-polski Starego Testamentu..., dz. cyt., t. 1 , s. $747-748$.

31 A. Tomasino, עולָָ ('ôlām), w: New International Dictionary of Old..., dz. cyt., vol. 3, s. $345-346$.

32 Por. H. D. Preuß, עָלָ ('älam), w: Theologisches Wörterbuch zum Alten Testament, Hrsg. G. J. Botterweck, H. Ringgren, H.-J. Fabry, vol. 5, Stuttgart 1986, s. 1144-1146. 
Kształtowanie się nauki o niebie w teologii patrystycznej I-III wieku

najczęściej występowało ono w związkach frazeologicznych z innymi określeniami i zasadniczo określało starożytność: „starożytne bramy” (pîthêe “ôlàm - Ps 24, 7. 9), „antyczną miedzę” (Prz 22, 28; 23, 10), „prastare zwaliska” (Iz 58, 12; 61, 4), „starożytny naród” (Jr 5, 15), „dawne dni” (Pwt 32, 7; Mi 7, 14; Ps 77, 6). Podczas gdy wyrażenie „odwieczne pagórki” (gib ‘ôt ‘ôlàm - Rdz 49, 26; Pwt 33, 15; Ha 3, 6) oznaczało źródło błogosławieństwa i dobroci, to określenie „dawna / starożytna droga / ścieżka” wskazywało na bałwochwalczy sposób postepowania (por. Hi 22, 15; Jr 18, 15). Termin 'èl 'ôlām („Pan wiekuisty” - Rdz 21, 33; Iz 40, 28) może także wskazywać na starożytność Boga. Przymioty Boga są opisywane jako trwające „od wieków” łaska / miłosierdzie (Ps 25, 6) czy mądrość (Prz 8, 23). Nadchodzącemu Dniowi Pana „równego nie było od wieków” (Jl 2, 2),

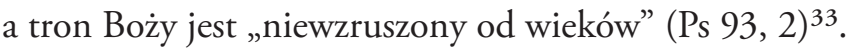

Częściej rzeczownik עוך ער ( ôlàm) odnosi się w ST do przyszłości. Może być stosowany do opisu przyszłości o określonym czasie trwania ${ }^{34}$. I tak niewolnik, który odmówił wyzwolenia i zdecydował się na życie w służbie swego pana, jest nazywany „niewolnikiem jego na zawsze” (Wj 21, 6; Pwt 15, 17; 1 Sm 27, 12). Według Prz 10, 25 „podstawy sprawiedliwego są wieczne ( $y^{e}$ sôd 'ôlām)", tzn. trwają przez całe jego życie. Podobną konstrukcję myślową znajdujemy u Jr 20, 11, gdzie prześladowcy człowieka Bożego są okryci ciąłłą, czyli - „wieczną hańbą”, a łono kobiety, która straciła dziecko, jest nazywane „wiecznie brzemiennym” (Jr 20, 17). Lud po słowach Mojżesza ma mu uwierzyć „na zawsze” - le 'ôlàm, czyli do końca jego życia (Wj 19, 9); Samuel, syn Anny ma zostać w sanktuarium Bożym w Szilo „na zawsze” - 'ad 'ôlām, czyli przez resztę swego życia (1 Sm 1, 22). Jonatan prosi Dawida, aby jego życzliwość wobec potomków Jonatana nie była odebrana „na wieki” - 'ad 'ôlàm (1 Sm 20, 15), czyli aby Dawid był zawsze życzliwy wobec potomków Jonatana. Błogosławieństwo, którym Bóg obdarzył króla „długimi dniami na wieki i na zawsze” (Ps 21, 5; por. Ps 61, 8; $1 \mathrm{Krl} 1,31$; Ne 2, 3) nie oznacza życia wiecznego, ale okres długiego życia. Analogiczny sens posiada wyrażane w wielu psalmach życzenie „na

33 Por. A. Tomasino, שוֹ ('ôlàm), w: New International Dictionary of Old..., dz. cyt., vol. 3, s. 346-347.

34 Por. H. D. Preuß, עִדָ ('älam), w: Theologisches Wörterbuch zum Alten..., dz. cyt., vol. 5, s. 1148-1149. 
wieki / na zawsze" ( $a d$ 'ôlàm, le 'ôlām), czyli na długość życia wypowiadającego dane słowa: wysławianie Boga (Ps 30, 13; 52, 11; 79, 13), chwalenie imienia Boga (Ps 86, 12; 145, 2), błogosławienie imienia Pańskiego (Ps 145, 1), śpiewanie pieśni (Ps 89, 2), radość (Ps 75, 10), zaufanie łaskawości Boga (Ps 52,10), pozostawanie przez Bożym obliczem-mieszkanie w Bożym przybytku (Ps 41, 13; 61, 5), brak chwiejności u sprawiedliwego (Ps 15, 15; 30, 7; 55, 23; Prz 10, 30) ${ }^{35}$.

W innych przypadkach rzeczownik עוֹ ('ôläm) służy w ST do wskazania długiego przedziału czasu, który implikuje nieustanność bądź stałość ${ }^{36}$. W takim znaczeniu 'ôlām jest użyte, aby opisać aspekty Bożej kreacji: pierwsze dzieło stworzenia to „mądrość, rozum roztropności od wieków” (Syr 1, 4), ziemia zostaje opisana jako "ugruntowana / umocniona na wieki” (Ps 78, 69; 104, 5), niebiosa również Bóg „utwierdził na zawsze, na wieki” (Ps 148, 6), Syjon jako Boża góra jest umacniana przez Niego „na wieki” (Ps 48, 9). Podobnie do dzieł Boga opisane są też w ST dzieła Jego świętych: po przejściu przez Jordan Jozue ustawił 12 kamieni, które są „pamiątką na zawsze dla Izraelitów" (Joz 4, 7); Izajasz swój duchowy testament ma polecone spisać jako „wieczyste świadectwo”, czyli stałe świadectwo przeciwko zatwardziałości ludu Izraela (Iz 30, 8). Analogicznie jest w ST opisywana stałość stanów czy sytuacji: autor natchniony stawia pytanie, czy Bóg będzie się ,gniewał na wieki” przeciw Izraelowi jako odstępcy (Jr 3, 5), czy przeciwko grzechowi Judy (Jr 17, 4), gdyż Filistyni, jako bezprawnie przetrzymujący Arkę Przymierza, są okryci wstydem „na wieki” (Ps 85, 6). W odnowionej Jerozolimie „Pan będzie ci światłością wieczną” (Iz 60, 19). Także „słowo Boga naszego trwa na wieki (Iz 40, 8; Ps 111, 8; 119, 89. 152). Świątynia jest opisana jako stałe / „na wieki” miejsce Bożego przebywania $(1 \mathrm{Krl} 8,13)$; Dawid i jego ród stale / „na wieki” nie czuje się przed Panem winny za śmierć Abnera (2 Sm 3, 28); Gechazi, po niegodnym przyjęciu darów od Naamana i okłamaniu Elizeusza, zostaje ukarany trądem „na zawsze” / stale $(2 \mathrm{Krl} 5$, 27). Jako stała / „na wieki” jest opisana wrogość pomiędzy Izraelem a niektórymi z narodów ościennych - Ammonitami

35 Por. A. Tomasino, עוֹ ('ôläm), w: New International Dictionary of Old..., dz. cyt., vol. 3, s. 347.

36 Por. H. D. Preuß, עִ ('âlam), w: Theologisches Wörterbuch zum Alten..., dz. cyt., vol. 5, s. 1149-1156. 
Kształtowanie się nauki o niebie w teologii patrystycznej I-III wieku

i Moabitami (Pwt 23, 4), Kananejczykami, Chetytami, Peryzzytami, Jebusytami, Ammonitami, Moabitami, Egipcjanami i Amorytami (Ezd 9, 1. 12), Filistynami i Keretytami (Ez 25, 12; 35) ${ }^{37}$.

Ukreślenie עוֹלְ ('ôlàm) jest też często używane w powiązaniu z ideą przymierza pomiędzy Bogiem a ludźmi. Boże obietnice dla ludzi są opisane jako stałe czy też wieczne. I tak przymierze noahickie z $\mathrm{Rdz}$ 9, 12 . 16 jest określone jako berît 'ôlām - „przymierze na wieczne czasy”. Podobnie jako „przymierze wieczne” / „na zawsze” jest nazwane przymierze z Abrahamem (Rdz 17, 7. 13. 19; Sdz 2, 1; 2 Sm 7, 24; 1 Krn 16, 15; Ps 105, 10). Także z Pinchasem, dzięki jego „zazdrości” / gorliwości wobec Boga i dokonanemu aktowi przebłagania, Bóg zawiera „przymierze, które mu zapewni kapłaństwo na wieki” (Lb 25, 13). Analogicznie przymierze zawarte przez Boga z Dawidem jest opisywane jako „stałe” / „na wieki” (2 Sm 7, 13. 16. 25. 29; 22, 51; 23, 5; 1 Krl 2, 33. 45; 9, 5; 2 Krn 13, 5; Ps 18, 51; $89,5)$. Podobnie warunki wymagane dla poszczególnych przymierzy są określane w ST jako „stałe” / "na wieki” przymierze (berît 'ôlàm): obrzezanie ( $\mathrm{Rdz} 17,3)$, zachowywanie szabatu (Wj 31, 16-17), przygotowanie chlebów pokładanych w szabat (Kpł 24, 8). Natomiast szereg przepisów z Pięcioksięgu, jakie należy wypełniać regularnie, zostaje nazwanych jako „stałe rozporządzenia” (huqqat 'ôlām): obchód Paschy i innych świąt (Wj 12, 14. 17. 24; Kpł 23, 14. 21. 41), palenie światła przed Arką Przymierza (Wj 27, 21; 28, 43), trąbienie na zwołanie modlitewne (Lb 10, 8) czy rozmaite przepisy dotyczące przygotowania i składania ofiar (Wj 29, 9. 28; 30, 21; Kpł 3, 17; 6, 18; 7, 34. 36; 10, 9. 15; 16, 29. 34; Lb 15, 15; 18, 8. 11. 19. 23; Ez 46, 14). Sformułowanie mè 'ôlàm 'ad 'ôlàm - „od wieku, aż po wiek” oznacza cały czas (Ps 41, 14; 90, 2; 103, 17). Wyrażenie z Koh 3, 11 „wieczność ( hā 'ôlàm) włożył w ich serca” (tłumaczenie Biblii Poznańskiej ${ }^{38}$ ) jest jedynym miejscem w ST, gdzie rzeczownik 'ôlām jest użyty jako podmiot

37 Por. A. Tomasino, עוֹ עוֹ ('ôläm), w: New International Dictionary of Old..., dz. cyt., vol. 3, s. 348 .

38 Księga Koheleta 3, 11: „Także wieczność włożył w ich serce”, Pismo Święte Starego i Nowego Testamentu w przektadzie z języków oryginalnych ze wstępami i komentarzami, red. M. Peter i M. Wolniewicz, t. 2, Poznań 1997, s. 509. Tłumaczenie tego fragmentu Księgi Koheleta w przekładzie ks. Konrada Marklowskiego w Biblii Tysiąclecia w wydaniu 5 stanowi niestety swoistą parafrazę tekstu: „Dał im nawet wyobrażenie o dziejach świata”... Jedynie w przypisie znajdujemy nieprecyzyjne wyjaśnienie, iż 
lub dopełnienie dla czasownika, a prawdopodobny sens tego wyrażenia to omowne wyrażenie idei wieczności. Termin 'ôlām jest często używany w późniejszym, pozabiblijnym języku hebrajskim, w którym są powtarzane znaczenia biblijne. Słowo to, częściej niż w ST, występuje tam w formie liczby mnogiej ${ }^{39}$. W LXX termin 'ôlām jest zwykle przekładany jako

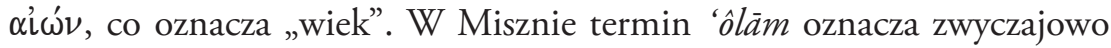
„wiek” i „świat”, natomiast w złożeniu 'ôlām hazzeh wskazuje na obecny wiek (świat), a w złożeniu 'ôlām habbā desygnuje wiek (świat), który nadejdzie, erę mesjańską ${ }^{40}$.

Podsumowując przegląd starotestamentalnych terminów i związanych z nimi koncepcji, opisujących ideę nieba, należy stwierdzić, że teologia biblijna tego okresu stosowała dwa zasadnicze motywy przestrzenne („ogród (w) Eden”; „niebo”) oraz jeden motyw jakościowy - trwanie. W obrębie każdego z nich można zaobserwować swoisty rozwój danej koncepcji. Biblijny ogród Eden jest symbolem szczęścia, harmonii i przyjaźni Boga z człowiekiem. To opis pierwotnej sytuacji, jaką Bóg zamierzył dla człowieka. „Ogród w Eden” z Rdz 2, 8 to rodzaj oazy, obfitującej w wodę, gdzie Pan Bóg sam zasadził ogród i umieścił w nim człowieka. W greckim tłumaczeniu LXX ogród ten zostaje nazwany „ogrodem rozkoszy”. Natomiast od Ez 28, 13; Jl 2, 3 i Iz 51, 3 „ogród w Eden”, nazwany „ogrodem Boga", nadal symbolizuje płodność, rozkwit i życie. Ważnym przesłaniem tego motywu jest, iż po grzechu pierwszych ludzi i wygnaniu ich z ogrodu Eden on sam zostaje dla ludzi zamknięty, a nieśmiertelność jest poza zasięgiem człowieka.

Także w obrębie motywu „nieba” obserwujemy jego stopniowe przechodzenie w koncepcję „nowego nieba” i „królestwa Boga”. Od wyobrażenia

"wyraz hebrajski może oznaczać także "wieczność» w popularnym znaczeniu długiego trwania", s. 745.

39 Por. H. D. Preuß, עָ ('älam), w: Theologisches Wörterbuch zum Alten ..., dz. cyt., vol. 5, s. $1156-1159$.

40 Por. A. Tomasino, עוֹלָם ('ôlām), w: New International Dictionary of Old..., dz. cyt., vol. 3, s. 349-350. 
Kształtowanie się nauki o niebie w teologii patrystycznej I-III wieku

miejsca wody, utożsamianego często ze zbiornikiem wód kosmicznych, niebo zaczyna być też opisywane jako mieszkanie Boga, które jednak nie może Go objąć. Według przesłania ST człowiek po śmierci nie znajduje się w niebie, ale w szeolu. Niebo swym istnieniem wyraża długą trwałość, lecz jest dla niego przewidziany nie tylko koniec, ale także jego zastąpienie nowym niebem. Ta ostatnia myśl jest szczególnie obecna w późniejszych księgach ST (Iz 65 - 66; Za 1, 8; Dn 7, 13), gdzie niebo staje się miejscem przyszłego królestwa Boga.

Natomiast motyw „trwania” pierwotnie wskazuje na czas nieokreślony, najdalszy lub przyszłość o określonym czasie trwania, długi-stały okresu czasu, nie posiada jednak w biblijnym języku hebrajskim filozoficznego znaczenia wieczności. Terminem ôlām są w ST opisywane przymierza Boga z ludźmi, warunki przymierzy oraz wypełnianie szeregu przepisów z Pięcioksięgu.

\subsection{Biblijne terminy i koncepcje greckie dotyczące nieba}

Podobnie jak w ST, tak i NT stosuje pojęcia i związane z nimi koncepcje dotyczące nieba w znaczeniach fizycznych i metafizycznych. Termin grecki oủ $\alpha \nu o ́ \varsigma$ zawiera oba wspomniane powyżej znaczenia, wskazując zarówno na niebo fizyczne, jak i na firmament jako miejsce Boga; czasami ten rzeczownik jest zastępowany czysto formalnie przysłówkiem $\alpha$ $\nu \omega$,

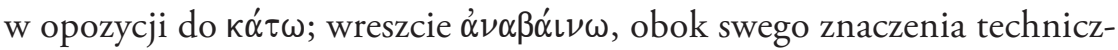
nego (często jako wchodzenie na święta górę, do sanktuarium) bywa używane szczególnie na określenie podniesienia (na wysokość) lub wstąpienia Jezusa ${ }^{41}$. Od tłumaczenia LXX po raz pierwszy pojawiają się w grece biblijnej pojęcia mocno obciążone znaczeniami kultur innych narodów:

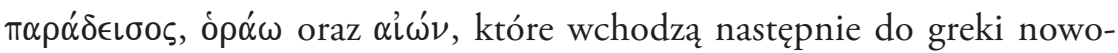
testamentalnej.

41 Por. Cielo, w: Dizionario dei concetti biblici del Nuovo Testamento, ed. L. Coenen, E. Beyreuther, H. Bietenhard, Bologna 1980, s. 280-281. 
1. Biblijne terminy, koncepcje i obrazy dotyczące nieba

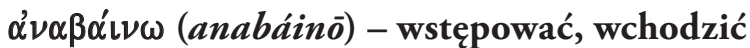

Termin ten pojawia się w tekstach greckich od czasów Homera. Podstawo-

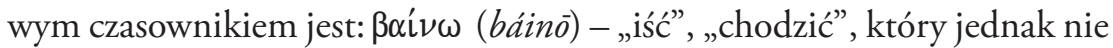
występuje w tekstach NT, gdzie spotykamy natomiast "€ $\rho \chi 0 \mu \alpha \iota$ (érchomai) „przybyć”. Złożenie $\alpha \nu \alpha \beta \alpha ́, \nu \omega$ wyraża „bezpośredni ruch do celu”, „wstę-

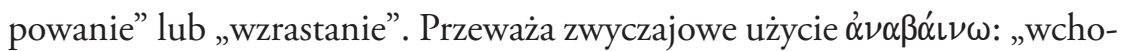
dzi się na górę”, „na trybunę”, „na wyższe piętro mieszkania”. Jeśli celem jest jakieś miejsce święte, to wchodzenie do niego staje się akcją kultyczną. I tak modlący się „wstępuje do świątyni znajdującej się powyżej”, wtajemniczanemu w misteria zostaje obiecane „wstąpienie do świata bogów do nieba” / „względnie na Olimpie” (por. Mithras Liturgie 10, 22 (Papyrus 574, Bibliotheque Nationale, Paris).

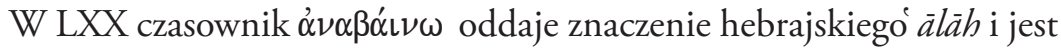
używany jako sformułowanie wskazujące: „wstępowanie na górę Bożą”, „wstępowanie na drogę w kierunku Jerozolimy”, „wchodzenie do sanktuarium" (Wj 34, 4; $2 \mathrm{Krl} \mathrm{19,} \mathrm{14;} 1$ Sm 1, 3). W Rdz 28, 12 Jakub we śnie ma wizję, w której objawia się mu drabina, która zgodnie z antyczną kosmologią, prowadzi powyżej, aż do bram nieba. Posłańcy Boga wchodzą i schodzą, aby wypełniać rozkazy Boga lub aby czuwać nad ziemią. U Jon 2, 7 zstępowanie do świata podziemnego oznacza potępienie i śmierć, natomiast wstępowanie określa łaskę i życie. NT powtarza podstawowe znaczenie $\alpha \nu \alpha \beta \alpha ́ \alpha \nu \omega$ jako ruchu: „wstępowania na górę”, „wstępowania do Jerozolimy na święto Paschy" (Łk 2, 4; 18, 10; J 7, 8; Dz 3, 1; Ga 2, 1).

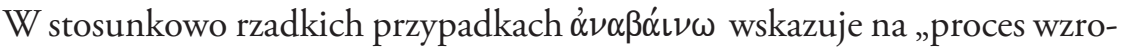
stu roślin" (Mt 13, 7; por. Rdz 41, 5), natomiast metaforycznie może wyrażać „powstawanie myśli” (Łk 24, 38; 1 Kor 2, 9) lub „wznoszenie modlitw ku Bogu”. U synoptyków pojawia się nowy odcień semantyczny czasownika $\alpha \nu \alpha \beta \alpha ́ \iota \nu \omega$, kiedy termin ten posiada znaczenie ogólnie duchowe: kiedy Jezus wynurza się z wody Jordanu lub kiedy wstępuje na górę, wtedy oznajmia bliską interwencję Boga. Jezus otrzymuje Ducha Świętego, modli się, wygłasza naukę, uzdrawia, wzywa do siebie (Mt 3, 16 paral.; 5, 1; 14, 23;

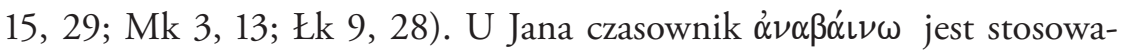
ny jako wyrażenie wskazujące na „wstępowanie Syna człowieczego” (podobnie w Dz 2, 34; Rz 10, 6; Ef 4, 8). Terminem doń przeciwstawnym 
Kształtowanie się nauki o niebie w teologii patrystycznej I-III wieku

jest $\kappa \alpha \tau \alpha \beta \alpha i ́ \nu \omega$ (katabáinō) - „zstępować”. Te dwa pojęcia („wstępowanie” i „zstępowanie”) wskazują na ruch, który w niebie ma swój punkt wyjścia, a na ziemi punkt dojścia i przeciwnie. Nie chodzi tutaj o dowolny ruch niebiański, ale o działanie Jezusa do i w kierunku Boga, wyrażone w kategoriach przestrzennych antycznej kosmologii. Chrystus jako Logos preegzystujący przebywa przestrzeń pośrednią pomiędzy niebem a ziemią i staje się człowiekiem (J 3, 13; 6, 33. 38. 41 $)^{42}$.

Z wywyższeniem na krzyżu wstępuje On tam, gdzie był wcześniej (J 6, 62). Jego zstępowanie objawia miłość Ojca, Jego wstępowanie objawia pełnię mocy Bożej. W zstąpieniu Jezus jest objawicielem, a we wstąpieniu tym, który niesie wszystko - celem wypełnienia, przez co Jego naśladowcy otrzymują możność stania się dziećmi Bożymi i braćmi Syna (J 20, 17). Zstępując i wstępując, Jezus przebywa przestrzeń, która dzieli Boga od świata, jasność od ciemności. W tej koncepcji jawi się oczywistym tło gnostyckie, jednak katecheza Jana oddala się od gnozy poprzez głoszenie przesłania o Wcieleniu Boga w osobie Jezusa. Syn Boży jest w stałym kontakcie z Ojcem, co zostaje oddane przez obraz anioła, który zstępuje i wstępuje (J 1, 51; por. $\mathrm{Rdz} 28,12$ ). W ten sposób obecność Syna człowieczego na ziemi jest ciągłym zstępowaniem i wstępowaniem. Jezus bierze swoje myśli od Ojca i działa w funkcji Ojca. Natomiast termin $\mu \epsilon \tau \alpha \beta \alpha i \nu \omega$ (metabáinō) wskazuje w teologii Janowej na „przejście od śmierci do życia”. Jak Jezus w wywyższeniu na krzyżu, tak człowiek w posłuszeństwie wiary przechodzi granicę pomiędzy śmiercią a życiem. Wierzący przenosi się w przestrzeń życiową Zmartwychwstałego (J 5, 24; $13,1 ; 1 \mathrm{~J} 3,14)$.

U Pawła, szczególnie w Ef 4, 7-13, sformułowanie $\alpha \nu \alpha \beta \alpha ́ \iota \nu \omega ~ \kappa \alpha \iota ~$ $\kappa \alpha \tau \alpha \beta \alpha i \nu \omega$ - „wstępowanie i zstępowanie”, poszerza się i nabiera nowych znaczeń teologicznych. Chrystus, który „ «wstąpił» cóż oznacza, jeśli nie to, że również zstąpił do niższych części ziemi? Ten, który zstąpił, jest i Tym, który wstąpił ponad wszystkie niebiosa, aby wszystko napełnić” (Ef 4, 9-10). Chrystus jako Wcielony Bóg dokonał zatem tego, co dla człowieka jest niemożliwe. Przebył On wszystkie przestrzenie / wymiary, także śmierć. Nie istnieje zatem jakikolwiek wymiar, przestrzeń czy stan,

42 Por. B. Siede, $\alpha \dot{\alpha} \alpha \beta \alpha \dot{\alpha} \iota \nu \omega$, w: Dizionario dei concetti biblici..., dz. cyt., s. 281-282. 
którego On nie może objąć i uspokoić (np. zstąpieniu Chrystusa do otchłani przed zmartwychwstaniem, por. Rz 10, 6n; 1 P 3, 18nn; 1 P 4, 5; Ap 1, 18). Termin $\kappa \alpha \tau \alpha \beta \alpha i \nu \omega$ oznacza wreszcie w teologii Pawłowej i Janowej „przyjście Kyriosa” i „zstąpienie niebieskiej Jerozolimy” w czasach ostatecznych (1 Tes 4, 16; Ap 3, 12; 21, 2. 10). Do tego momentu ożywiające dary Boga zstępują z nieba na chrześcijan, zstępuje / przybywa Jego słowo pełne wierności, które pozwala na nadzieję przyszłej chwały $(\mathrm{Jk} 1,17 \mathrm{n})$; w ten sam sposób nowe i zbawcze życie pochodzące od Boga przybywa do wierzących i realizuje się w Jezusie jako chleb życia (J 6, 50n. 60) ${ }^{43}$.

\section{$\alpha^{\prime} \nu \omega($ anō $)$ - powyżej, na wysokości, ponad}

Termin ten oznacza dosłownie „coś powyżej”, a w znaczeniu czasowym „coś pierwszego”. W odniesieniu do morza پِ $\nu \omega$ może wskazywać na „stały ląd" lub na "góry”; w odniesieniu do ziemi « $\alpha \omega$ może oznaczać „powietrze” lub „niebo wraz z bogami”; wreszcie w odniesieniu do świata podziemnego $\alpha \nu \omega$ może oznaczać „ziemię”. Judaizm międzytestamentalny mocno akcentował opozycję pomiędzy „tym, co powyżej” a „tym, co poniżej”, czyli pomiędzy niebem pojmowanym jako świat Boga a ziemią. $Z$ drugiej strony w wyrażeniach językowych judaizmu tego okresu odnotowujemy paralelizm pomiędzy „tym, co istnieje w niebie" $\mathrm{i}$ „tym, co istnieje i dokonuje się na ziemi”. Np. jak niebo nie może utrzymać się bez dwunastu konstelacji niebieskich, tak ziemia nie może istnieć bez dwunastu pokoleń. To, co jest ponad, pochodzi także sprzed czasu. Pod wpływem idei gnostyckich i helleńskich Filon z Aleksandrii dał własną interpretację dotyczącą „tego, co ponad i pod”. Dla Filona świat powyżej i ten poniżej są ułożone według stopni. Stopniem najniższym byłaby ziemia, podczas gdy na stopniu najwyższym znajduje się Bóg. Powietrze oraz materia duchowa reprezentowałyby stan pośredni pomiędzy „światem powyżej” a tym „poniżej”. Jednak dywagacje kosmologiczne Filona nie wpłynęły zasadniczo zarówno na ówczesny judaizm, jak i na Nowy Testament ${ }^{44}$.

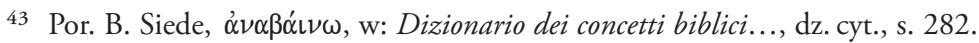

44 Por. H. Bietenhard, ¿ֵvo, w: Dizionario dei concetti biblici..., dz. cyt., s. 282-283.
} 
Kształtowanie się nauki o niebie w teologii patrystycznej I-III wieku

W NT nie występują spekulacje kosmologiczne, które dzieliłyby świat na kolejne sekcje. Bóg jest Stworzycielem i Panem całego świata. Natomiast opozycja występuje, kiedy NT dokonuje rozróżnienia pomiędzy Bogiem świętym a światem grzesznym. W opisach NT Jezus podnosi oczy ku górze (’’ $\propto \omega)$, czyli ku niebu, gdzie według antycznych przekonań mieszka Bóg (np. J 11, 41; Dz 2, 19). Podczas gdy Jego nieprzyjaciele mają „niskie” pochodzenie, tj. z tego grzesznego świata, Jezus wywodzi swe pochodzenie z „wysoka” (« $\propto \omega)$, czyli od Boga, do którego ma wrócić (J 8, 23; 12, 1). W Ga 4, 26 wyrażenie „górne Jeruzalem” oznacza miasto wolności i uwolnionych z niewoli grzechu i śmierci chrześcijan. Jest ono przeciwstawione obecnej Jerozolimie, która trwa w niewoli przymierza Prawa Mojżeszowego zawartego pod górą Synaj (por. Ga 4, 24-25). Pojęcia „wezwanie w górę” czy „meta, nagroda (...) w górę” z Flp 3, 14, do których zmierza Paweł, to odwołanie do Boga w Jezusie Chrystusie. Paweł zachęca do aspirowania do „tego, co w górze”, gdyż zaraz potem dopowiada: „gdzie przebywa Chrystus, zasiadając po prawicy Boga” (Kol 3, 1; por. Ps 110(109), 1; Mk 16, 19) ${ }^{45}$.

\section{oúpavós (ouranós) - niebo}

To termin wywodzący się prawdopodobnie z tematu indoeuropejskiego oznaczającego „deszcz”, „wodę”, desygnującego dokładnie „tego” lub „to,

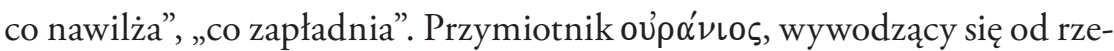

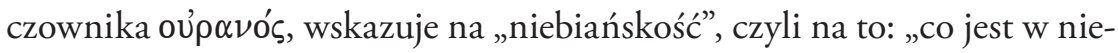
bie”, „co z nieba pochodzi”, „,o w niebie się dokonuje”. Oznacza także to, „co odnosi się do Boga”, a zatem „coś boskiego”, a czasami samą „boskość”. Może także wskazywać na to, „co stanowi część firmamentu” czy też „część

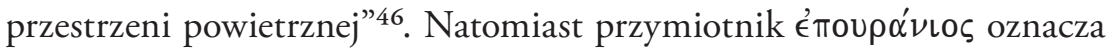
stan niebiański: będący „w niebie”, „przynależący do boskiego nieba” ${ }^{47}$. Podobne znaczenie posiada też przymiotnik oúp $\alpha \nu o^{\prime} \theta \epsilon \nu$ - „z nieba” 48 .

45 Por. H. Bietenhard, ״ै $\nu$ o, w: Dizionario dei concetti biblici..., dz. cyt., s. 283.

46 Por. H. Bietenhard, oủpavós, w: Dizionario dei concetti biblici..., dz. cyt., s. 283.

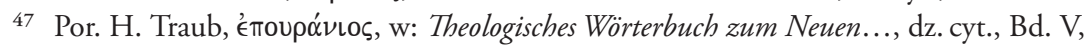
s. $538-542$.

48 Por. H. Traub, oủpavó $\theta \in v$, w: Theologisches Wörterbuch zum Neuen..., dz. cyt., Bd. V, s. $542-543$. 
W klasycznym języku greckim rzeczownik oủpavós był używany wyłącznie w formie liczby pojedynczej. W liczbie mnogiej występował bardzo

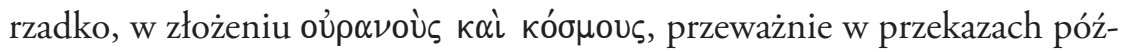
nej tradycji filozoficznej o Anaksymandrze (Pseudo-Plutarch, Stromateis 2; Hippolit, Ref. I, 6, 2; Aetius, De placitis philosophorum 1, 17, 12) ${ }^{49}$. Termin

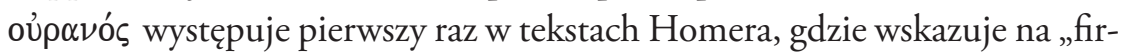
mament" rozumiany jako sfera niebiańska. Ponieważ obejmuje on wszystko, oủpavós był uznawany za coś boskiego. W greckiej mitologii religijnej okresu przedhomeryckiego oủpavós był pojmowany jako boski byt przybyły spoza ziemi, który zapłodnił ją w „świętych nocach”. Lecz Uranos został wykastrowany przez Kronosa, dlatego utracił władzę nad ziemią. Prawdopodobnie wydarzenie to symbolizuje w mitologii oddzielenie sfery nieba od sfery ziemi. W mitologii orfickiej niebo wywodzi swe pochodzenie z wyższych części kosmicznego jaja. Dla Homera niebo (z brązu, $\mathrm{z}$ żelaza) wspiera się o kolumny postawione przez Atlasa ${ }^{50}$. W tym niebie zamieszkują niebianie (oủpóvıo - przede wszystkim Zeus oraz nieśmier-

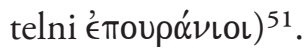

W epoce sofistyki (V wiek przed Chr.) wcześniejsze wyobrażenia mitologiczne zmieniły swe znaczenie i tak oủp $\alpha$ vó $\varsigma$ zaczął od tego czasu wskazywać na niebieski firmament i procesy, jakie na nim się dokonują. W warstwie pojęciowej zmiana ta jest widoczna w terminologii filozoficznej. Niebo wypełnione gwiazdami stało się początkiem filozoficznej wizji bytu i absolutnego poznania. Według Platona niebo może być porównane

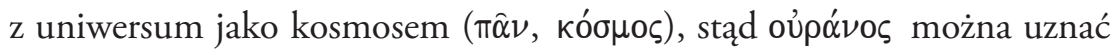
za realny, rzeczywiście istniejący byt, posiadający własności bytu inteligibilnego, podobnego do bytu absolutnego i doskonałego. Także Arystoteles przyznawał oủpóvos, oprócz znaczenia kosmologicznego, znaczenie czegoś boskiego ( $\theta \in \hat{\imath} \mathrm{\nu} \nu)$. Szkoła stoicka mianem nieba określała najwyższe warstwy eteryczne, czyli sprawcze pryncypium świata, w tym sensie oznaczało ono coś boskiego. Natomiast według niektórych systemów gnostyckich

49 Por. H. Traub, oủp $\alpha \nu$ ó, A. Griechischer Sprachgebrauch, w: Theologisches Wörterbuch zum Neuen..., dz. cyt., Bd. V, s. 496.

50 Por. Homer, Odyseja 1,62, tłum. i oprac. J. Parandowski, Warszawa 1998, s. 34 (Biblioteka Antyczna [dalej: BA] 1).

51 Por. H. Bietenhard, oủpavós, w: Dizionario dei concetti biblici..., dz. cyt., s. 283-284. 
Kształtowanie się nauki o niebie w teologii patrystycznej I-III wieku

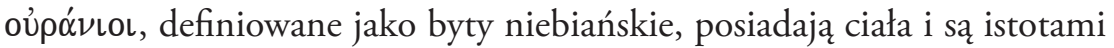
pośrednimi o nadludzkiej naturze ${ }^{52}$.

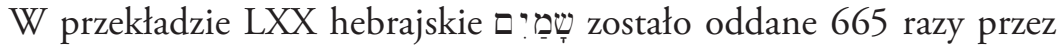
rzeczownik oủpavós. Termin grecki wskazuje na „sferę niebiańską”, często wyobrażaną w helleńskiej kosmologii jako jedna z dwóch (niebo i ziemia) lub trzech (niebo, ziemia, morze) części uniwersum, o ile można określić granice kosmosu. W helleńskim ujęciu mitologicznym niebo było „miejscem bogów”, „siedzibą na Olimpie” skrytą w chmurach. W ujęciu filozofii greckiej od V wieku prz. Chr. niebo było przyrównywane do „bytu absolutnego”. Należy przypomnieć, że w LXX hebrajskie šāmájim występuje w formie liczby podwójnej. Natomiast w tłumaczeniu LXX aż 51 razy prze-

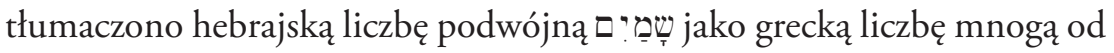
oủpavós czyli oúpavoí (por. LXX Iz 44, 23; 49, 13). Ten rodzaj przekładu sprawił, że w niektórych tekstach (LXX Mdr 9, 10; LXX Tb 8, 5; LXX $\mathrm{Sdz} 9,12 ; 13,18)$ termin oủpavoí zaczął propagować orientalną koncepcję wielości sfer niebiańskich oraz pośrednio odsyłać do spekulacji z tym związanych ${ }^{53}$.

W NT rzeczownik oủpavós w liczbie pojedynczej występuje 190 razy, a w liczbie mnogiej (oủpavoí) spotykamy go 94 razy. We wszystkich przypadkach występowania tego terminu krzyżują się znaczenia kosmologiczne i teologiczne znane z ST ${ }^{54}$. Stąd, zwracając się do nieba, nakierowuje się na Boga (Mk 6, 41; 7, 34; Łk 18, 13; J 17, 1; Dz 7, 55), lecz znaczenie teologiczne tego terminu w NT jest szersze. NT nadal posługuje się schematami świata starożytnego, stosując język metaforyczny. Niebo jest zatem mieszkaniem Boga (Mk 11, 25; Mt 5, 16; Łk 11, 13), jest tronem Boga (Mt 5, 34; 23, 22), a ziemia jest Jego podnóżkiem (Mt 5, 35). Być w niebie oznacza być u Boga (Mt 16, 19; 18, 18). Otwarte niebo oznacza bliskość Boga (Mk 1, 10 paral.). Z otwierającego się nieba przychodzi „głos Boży” (Mk 1, 1 paral.). Niebo, podobnie jak w ST, tak i w NT jest mieszkaniem

52 Por. H. Traub, oủpavós, A. Griechischer Sprachgebrauch, w: Theologisches Wörterbuch zum Neuen..., dz. cyt., Bd. V, s. 498-499.

53 Por. H. Traub, oujpavós, C. Septuaginta und Judentum, w: Theologisches Wörterbuch zum Neuen..., dz. cyt., Bd. V, s. 509-512.

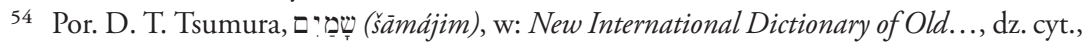
vol. 4, s. 165-166. 
aniołów (Mk 12, 25; 13, 32; Mt 18, 10; 22, 30), którzy oglądają Boga w niebiańskiej wizji (Mt 18, 10). Aniołowie zstępują z nieba na ziemię (Mt 28, 2; Łk 22, 43), z nieba Chrystus strącił też szatana (Łk 10, 18). Niebo jest mieszkaniem Chrystusa, gdzie wraca po zakończeniu ziemskiej działalności (Mk 16, 19; Dz 1, 9-11), gdzie zasiada po prawicy Boga (Mk 16, 19). $\mathrm{Z}$ nieba Chrystus przyjdzie na końcu czasów (Mk 8, 33 paral.; 13, 36 paral.; 14, 62; Mt 26, 64). Z nieba przychodzi także Duch Święty (Mk 1, 10; J 14, 16. 26;15, 26;16, 7; Dz 1,8 $)^{55}$. Chrześcijanie mają swa ojczyznę w niebie (Flp 3, 20; 2 Kor 5, 1; Hbr 12, 22-24). W niebie uczniowie Chrystusa mają gromadzić swe skarby (Mk 10, 21 paral.; Mt 6, 20; Łk 12, 33), w niebie oczekuje na nich zapłata za trudy poniesione na ziemi (Mt 5, 12; Łk 6, 23). Już teraz imiona uczniów są zapisane w niebie $\left(Ł k\right.$ 10, 20) ${ }^{56}$. Niebo Nowego Testamentu to końcowy etap Królestwa Bożego, to bycie z Chrystusem (Łk 23, 43; Flp 1, 23; 2 Kor 5, 8), to miejsce wiekuistej liturgii (Hbr 4, 14; 8, 1-6; 9, 11; Ap 4, 8-11; 15, 2) ${ }^{57}$.

\section{$\pi \alpha \rho \alpha^{\prime} \delta \epsilon \iota \sigma \varsigma$ (parádeisos) - ogród, park, raj}

Grecki termin $\pi \alpha \rho \alpha ́ \delta \epsilon \iota \sigma o \varsigma$ wywodzi się z języka awestyjskiego (język klasyczny starożytnej Persji) - od słowo pairidaēza (pari). W języku średnioirańskim termin ten brzmiał paradez i oznaczał „mur graniczny prywatnej posiadłości” oraz „ogród otoczony murem”. W antycznych mitologiach bliskowschodnich termin ten był używany najczęściej tam, gdzie jest mowa o „kraju lub miejscu uprzedniej szczęśliwości” lub też dla czasów bieżących o „miejscach znajdujących się na obrzeżach znanego świata, gdzie żyją bogowie, bohaterowie oraz ci spośród śmiertelników, którzy są do życia w tej szczęśliwości specjalnie predestynowani” (specjalnie przywiedzeni za życia lub po śmierci). Termin hebrajski pardēs (aramejski paradês $\bar{a}$ )

\footnotetext{
55 H. Traub, oủpavóc, D. Neues Testament, w: Theologisches Wörterbuch zum Neuen..., dz. cyt., Bd. V, s. 512-535.

56 Por. H. Langkammer, Życie po śmierci. Eschatologia Starego i Nowego Testamentu, Lublin 2004, s. 188-190.

57 Por. A. Jankowski, Eschatologia Nowego Testamentu, Kraków 2007, s. 143-145.
} 
Kształtowanie się nauki o niebie w teologii patrystycznej I-III wieku

jest zapożyczeniem z perskiego i oznacza „zwyczajny ogród” (Pnp 4, 13; Koh 2, 5; Ne 2, 8) ${ }^{58}$. W ST znajdujemy pewne odniesienia do mitów rajskich kultury mezopotamskiej czy irańskiej, także fenickiej (np. Ez 28, 13), ale formalnie ST nie używa terminu par des. Na opisanie miejsca utraconej szczęśliwości pierwszych ludzi stosuje terminy: „ogród”, „ogród Eden” lub „ogród Boży” (Rdz 2, 8. 15; 13, 10). W tym ogrodzie przed popełnieniem pierwszego grzechu (n.b. grzechu rajskiego ...) człowiek żył we wspólnocie z Bogiem. Prorocy ST przenoszą wyobrażenie rajskości ogrodu Eden na życie przyszłe, stąd Kanaan (Ez 36, 35) i Syjon (Iz 51, 3) mają na końcu czasów wyglądać jak ogród Eden. Na wzór raju jest też przedstawiany kraj Izraela na końcu czasów (Iz 2, 2; 35, 1-10; 41, 18; Ez 47, 1-12; Oz 2, 24; Am 9, 13; Mi 4, 1. 2; Za 14, 8). Nigdzie jednak Kanaan końca czasów nie jest utożsamiany przez proroków z Bożym ogrodem Eden ${ }^{59}$.

W literaturze targumicznej spotykamy tylko raz przenośne użycie terminu pardēs celem ukazania gnostyckich spekulacji metafizycznych o znaczeniu kosmogonicznym (por. T. Hag. 2, 3 paral. Hag. j. 2, I (77b); Hag. b 14 b; Midr. Cant. a I, 4). Zdaniem Joachima Jeremiasa ten wyjątek może być wytłumaczony wpływem j. greckiego na pojęciowanie późnego judaizmu. Aby wskazać pierwotny ogród rajski ( $\mathrm{Rdz} 2,15$; 3, 23), ale także raj obecny i eschatologiczny, rabini okresu międzytestamentalnego posługiwali się nadal hebrajskim zwrotem gan èden („ogród Eden”) czy analogicznym aramejskim ginn ${ }^{e} t \bar{a} d^{e c} \bar{e} d e n$. Z języka perskiego słowo $\pi \alpha \rho \alpha ́ \delta \epsilon \iota \sigma o \varsigma$ przeszło także jako kalka semantyczna do języka greckiego, gdzie oznaczało „ogród” lub „park”. Pierwsze potwierdzone historycznie użycie terminu $\pi \alpha \rho \alpha ́ \delta \epsilon\llcorner\sigma o \varsigma \mathrm{w}$ jezyku greckim znajdujemy u Ksenofonta, który go stosował, aby wskazać na „ogrody władców” i „ogrody wielkich możnowładców perskich”. W LXX termin $\pi \alpha \rho \alpha ́ \delta \epsilon \iota \sigma o \varsigma$ pojawia się 47 razy, w przeważającej części jako przekład hebrajskiego gan (gannah) - „ogród”; 13 razy znajdujemy użycie tego terminu w Rdz 2 - 3, a 4 razy u Ez i 3 u Iz ${ }^{60}$. Także antyczna kultura grecka znała

58 Por. J. Jeremias, $\pi \alpha \rho \alpha ́ \delta \epsilon \iota \sigma o \varsigma$, w: Theologisches Wörterbuch zum Neuen..., dz. cyt., Bd. V, s. $763-764$.

59 Por. Raj, w: F. Rienecker, G. Maier, Leksykon biblijny, tłum. D. Irmińska, J. Kruczyńska, Warszawa 2001, s. 685 (PSB 18).

60 Por. J. Jeremias, $\pi \alpha \rho \alpha \dot{\delta} \epsilon\llcorner\sigma o \varsigma$, w: Theologisches Wörterbuch zum Neuen..., dz.cyt., Bd. V s. 764-766. 
1. Biblijne terminy, koncepcje i obrazy dotyczące nieba

mitologiczny przekaz o Wyspach Błogosławionych (por. Hezjod, Prace i dni 166-173; Pindar, Ody olimpijskie II, 61-76) / szczęśliwych Polach elizejskich (por. Homer, Odyseja 4, 1996) ${ }^{61}$.

Tłumacze LXX, aby odróżnić ogród Eden od innych ogrodów, określali go przymiotnikowo jako:

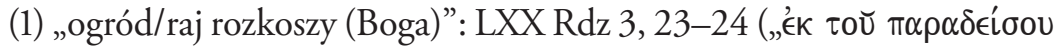

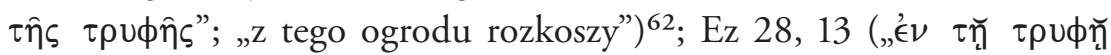

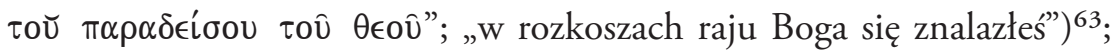

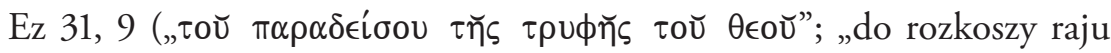

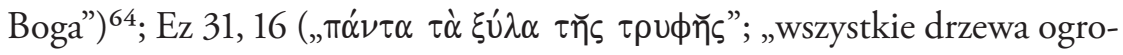

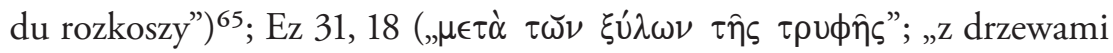

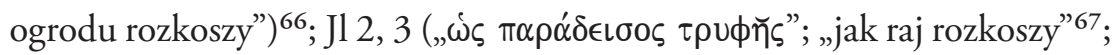

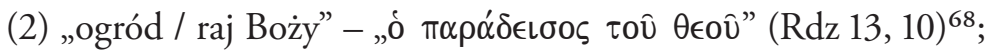

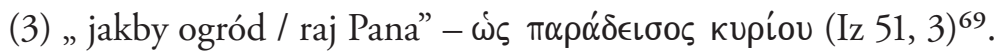

61 Por. Homer, Odyseja 4,1996: „Nieśmiertelni wyślą cię na Pola Elizejskie”, BA 1, s. 72. Zdaniem Z. Kubiaka, Mitologia Greków i Rzymian, t. 1, Warszawa 1998, s. 208, termin „Pola Elizejskie” (podawane, ale wątpliwe etymologie: „miejsce przyjścia”, „miejsce dotknięte piorunem" - i przez to uświęcone) został wprowadzony przez Homera i stanowi najprawdopodobniej inną nazwę „Wysp Błogosławionych”, gdzie istoty uprzywilejowane są przenoszone wprost z życia, bez przejścia przez bramę śmierci.

62 Septuaginta. Id est Vetus Testamentum graece iuxta LXX interpretes edidit Alfred Rahlfs. Duo volumina in uno, vol. 1 Leges et historiae, Stuttgart 1979, s. 5; przekład polski Septuaginta, czyli Biblia Starego Testamentu wraz z ksiegami deuterokanonicznymi i apokryfami, tłum. i oprac. R. Popowski, Warszawa 2014, s. 9.

63 Septuaginta. Id est Vetus Testamentum graece iuxta LXX interpretes edidit Alfred Rahlfs. Duo volumina in uno, vol. 2 Libri poetici et prophetici, Stuttgart 1979, s. 820; thumaczenie własne Autora; R. Popowski, Septuaginta..., dz. cyt., s. 1555 przetłumaczył: „W rajskich dostatkach się znalazłes".

${ }^{64}$ LXX, vol. 2, edidit A. Rahlfs..., dz. cyt., s. 824; tłumaczenie własne Autora; R. Popowski, Septuaginta..., dz. cyt., s. 1558 tłumaczy zaś „do przepychu ogrodu Boga”.

65 LXX, vol. 2, edidit A. Rahlfs..., dz. cyt., s. 826; tłum. R. Popowski, Septuaginta..., dz. cyt., s. 1559.

66 LXX, vol. 2, edidit A. Rahlfs..., dz. cyt., s. 826; tłum. R. Popowski, Septuaginta..., dz. cyt., s. 1559.

${ }^{67}$ LXX, vol. 2, edidit A. Rahlfs..., dz. cyt., s. 520; tłumaczenie własne Autora; R. Popowski, Septuaginta..., dz. cyt., s. 1325 tłumaczy: ,jak rozkoszny ogród”.

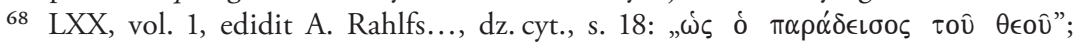
tłum. R. Popowski, Septuaginta..., dz. cyt., s. 20: ,jak ogrody Boga”.

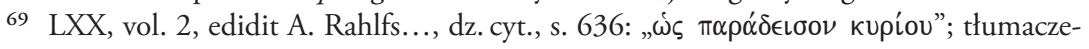
nie własne Autora; R. Popowski, Septuaginta..., dz. cyt., s. 1426: „jakby raj Pana”. 
Kształtowanie się nauki o niebie w teologii patrystycznej I-III wieku

W Rdz 2, 8. 10; 4, 16 tłumacze LXX dokonali też transliteracji hebraj-

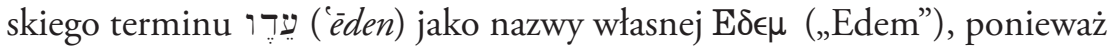
język hebrajski przez użycie przyimków wskazuje w tych przypadkach Eden jako nazwę geograficzną ${ }^{70}$.

Ogród, o którym myślą tłumacze LXX, jest ogrodem Bożym w takim znaczeniu, w jakim opisuje go autor jahwistyczny lub też w znaczeniu, w jakim żywi się nadzieję, że takim właśnie będzie. W LXX jedynie u Ne 2, 8; Koh 2, 5; Pnp 4, 13 grecki $\pi \alpha \rho \alpha ́ \delta \epsilon \iota \sigma o \varsigma$ oddaje znaczenie irańskiego paradez, czyli ogrodu otoczonego murem. Jak odnotowuje Jeremias w LXX, termin $\pi \alpha \rho \alpha ́ \delta \epsilon \iota \sigma o \varsigma$ przeszedł zatem zasadniczą zmianę semantyczną: tłumacze LXX przenieśli $\pi \alpha \rho \alpha ́ \delta \epsilon \iota \sigma o \varsigma$ ze sfery świeckiego rozumienia (jakikolwiek ogród) do znaczenia ściśle religijnego (ogród Eden).

Poza LXX po raz pierwszy w apokryficznym Testamencie Lewiego 18, 10 rzeczownik ò $\pi \alpha \rho \alpha ́ \delta \epsilon\llcorner\sigma o \varsigma$ posiada już, bez dodatkowych określeń przymiotnikowych, znaczenie techniczne raju. Co więcej, właśnie w przedchrześcijańskiej apokaliptyce żydowskiej zaczyna się utożsamiać raj pierwotny z rajem ostatecznym, już otwartym dla ludzi (Testament Lewiego 18, 10; por. Testament Dana 5, 12; Ksiegga Henocha wersja etiopska 25, 4; Ksiega Henocha wersja stowiańska 65, 9; 4 Księga Ezdrasza 7, 36. 123; 8, 52; Apokalipsa Mojżesza 13). W większości tych tekstów (za wyjątkiem Ksieggi Barucha wersja syryjska i Księgi Henocha wersja stowiańska) miejscem raju otwartego dla ludzi (Testament Lewiego 18, 10; 4 Ksiega Ezdrasza 8, 52; por. też Wyrocznie Sybilli 3, 769) jest ziemia, a konkretnie nowa Jerozolima (Księga Henocha wersja etiopska 24, 4; 25, 4. 7; 4 Księga Ezdrasza 7, 36. 123; 8, 52; Apokalipsa Mojżesza 28, 4; Testament Lewiego 18, 10). Według autorów rabinackich cechami tej eschatologicznej rajskości są dla zmartwychwstałych sprawiedliwych: spożywanie owoców z drzewa życia, woda i chleb życia, udział w uczcie eschatologicznej. W języku greckim okresu późnojudaistycznego termin $\pi \alpha \rho \alpha ́ \delta \in \iota \sigma o \varsigma$ stał się zatem terminem technicznym

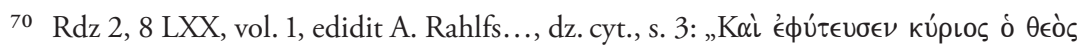

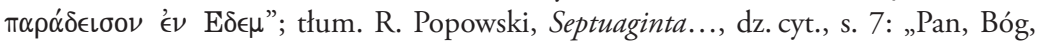
założył ogród w Edemie"; Rdz 2, 10 LXX, vol.1, edidit A. Rahlfs..., dz. cyt., s. 3: „, $\xi \xi$ E $\delta \in \mu$ ”; tłum. R. Popowski, Septuaginta..., dz. cyt., s. 7: „z Edemu”; Rdz 4, 16

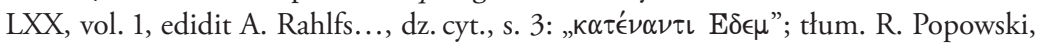
Septuaginta..., dz. cyt., s. 10: „poza Edemem”; 
oznaczającym biblijny ogród Eden, w odróżnieniu od wszystkich innych ogrodów, do których opisu stosowano termin $\kappa \hat{\eta} \pi о \varsigma^{71}$.

Według pism apokaliptyki żydowskiej raj obecnie jest ukryty, a znajdują się w nim dusze patriarchów (Księga Henocha wersja etiopska 70, 4; Apokalipsa Mojżesza 37, 5; Testament Abrahama 10B-11B, 20 A), dusze wybranych i sprawiedliwych (Ksiega Henocha wersja etiopska 60, 7; 61, 12; 70, 4; Księga Henocha wersja stowiańska 9, 1; 42, 3; Apokalipsa Abrahama 21, 6; Testament Beniamina 16a). Widać też różnicę w pojmowaniu Szeolu i raju pomiędzy eschatologią ST a tą z apokalips żydowskich: podczas gdy koncepcja starotestamentalna zakłada, iż dusze wszystkich zmarłych idą do Szeolu, to koncepcje apokaliptyczne dowodzą, iż Szeol jest tylko dla bezbożnych, a sprawiedliwi idą właśnie do raju. W czasach NT obie powyższe koncepcje współistniały w nauczaniu rabinackim obok siebie: i tak według nauczania jednych ostatecznym schronieniem dusz po śmierci na ziemi jest Szeol (utożsamiany z Hadesem), a według nauczania innych rabinów I wieku jest nim raj. Zdaniem Jeremiasa w tekstach apokaliptyki żydowskiej okresu międzytestamentalnego cały czas chodzi o jeden i ten sam raj-gan èden, a nie o trzy odrębne miejsca rajskie (pierwotny, międzyczasowy, eschatologiczny). O ich identyczności świadczy obecność pośrodku nich - drzewa życia ${ }^{72}$.

W NT rzeczownik $\pi \alpha \rho \alpha ́ \delta \epsilon \iota \sigma o \varsigma$ oznacza raj - jako przyszłe miejsce szczęśliwości. Mówi o nim jednak stosunkowo rzadko, bo tylko 3 razy: Łk 23, 43; 2 Kor 12, 4; Ap 2, $7^{73}$. Tak incydentalne odniesienia do raju w NT tłumaczy się tym, że dla Jezusa ogród rajski nie był tematem pierwszoplanowym, ważniejsza w Jego przepowiadaniu była odbudowa wspól-

71 Por. J. Jeremias, $\pi \alpha \rho \alpha \dot{\delta} \epsilon\llcorner\sigma 0 \varsigma$, w: Theologisches Wörterbuch zum Neuen..., dz. cyt., Bd. V, s. $763-765$.

72 Por. J. Jeremias, $\pi \alpha \rho \alpha \dot{\delta} \in\llcorner\sigma o \varsigma$, w: Theologisches Wörterbuch zum Neuen..., dz. cyt., Bd. V, s. 765-766 (por. też Kommentar zum Neuen Testament aus Talmud und Midrasch, Hrsg. H. L. Strack, P. Billerbeck, vol. 4. Exkurse zu einzelnen Stellen des Neuen Testaments: Abhandlungen zur Neutestamentlichen Theologie und Archäologie, München 1961, s. 1118-1120, 1132-1143).

73 Por. J. Jeremias, $\pi \alpha \rho \alpha \dot{\delta} \epsilon\llcorner\sigma o \varsigma$, w: Theologisches Wörterbuch zum Neuen ..., dz. cyt., Bd. V, s. 767; zob. też. $\pi \alpha \rho \alpha \dot{\delta} \epsilon \iota \sigma o \varsigma$, ó, -ov, w: R. Popowicz, Wielki Stownik Grecko-Polski Nowego Testamentu. Wydanie z petna lokalizacja greckich haset, kluczem polsko-greckim oraz indeksem form czasownikowych, Warszawa 1995, s. 462 (PSB 3). 
Kształtowanie się nauki o niebie w teologii patrystycznej I-III wieku

noty Boga z człowiekiem, która została zniszczona przez grzech Adama. Podobnie dla pierwotnego Kościoła istotne było skupienie się na kwestii przepowiadania Jezusa i Jego nauki, a nie koncentrowanie się na aspektach wyglądu raju czy cechach ludzi w raju (co było natomiast typowe dla apokaliptyki żydowskiej) ${ }^{74}$.

Pozostałymi określeniami nowotestamentalnymi wskazującymi na stan zbawionych po śmierci są: „łono Abrahama” (Łk 16, 23), „stać w obliczu Pana” (2 Kor 5, 8), „być z Chrystusem” (Flp 1, 23; por. Dz 7, 59; J 12, 26), „królestwo niebieskie” (2 Tm 4, 18), „niebieskie Jeruzalem” (Hbr 12, 22), zamieszkanie „w domu Ojca mego” (J 14, 2) ${ }^{75}$.

We fragmentach z Łk 23, 43 i 2 Kor 12, 4 stosowany jest rzeczownik $\pi \alpha \rho \alpha \dot{\delta} \epsilon \sigma o \varsigma$ na opisanie miejsca pobytu dusz sprawiedliwych w okresie między śmiercią i zmartwychwstaniem ${ }^{76}$ (to tzw. raj międzyczasowy / raj

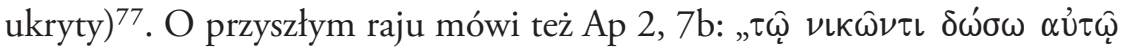

74 Por. J. Jeremias, $\pi \alpha \rho \alpha ́ \delta \in\llcorner\sigma o \varsigma$, w: Theologisches Wörterbuch zum Neuen..., dz. cyt., Bd. V, s. $770-771$.

75 Por. J. Jeremias, $\pi \alpha \rho \alpha \dot{\delta} \epsilon \iota \sigma o \varsigma$, w: Theologisches Wörterbuch zum Neuen ..., dz. cyt., Bd. V, s. 767; zob. też Testament Abrahama 20; Kommentar zum Neuen Testament aus Talmud und Midrasch, Hrsg. H. L. Strack, P. Billerbeck, vol. 2. Das Evangelium nach Markus, Lukas und Johannes und die Apostelgeschichte, München 1961, s. 228; Kommentar zum Neuen Testament aus Talmud..., dz. cyt., vol. 4, s. 1040. Jak odnotowuje J. Kudasiewicz, Ewangelie synoptyczne dzisiaj, Ząbki 1999, s. 277-278, u synoptyków napotykamy na dwie formuły, którymi określali oni ideę panowania Boga: Królestwo Boże (basileia tou Theou) i królestwo niebios / niebieskie (basileia ton ouranon). Formuła „królestwo niebios” wydaje się późniejsza od formuły „królestwo Boże”, była znana w okresie redakcji Ewangelii św. Mateusza, stąd ewangelista, pisząc głównie dla judeochrześcijan, używa określenia „królestwo niebios”, a tylko pięciokrotnie stosuje określenie „Królestwo Boże”. Zakładając zjawisko rzadkiego występowania wyrażenia „Królestwo Boże" w środowisku judaistycznym w I wieku, przypuszcza się, że Jezus używał właśnie tego sformułowania. Formuła „królestwo niebios” pojawiła się w literaturze judaistycznej 50 lat po działalności Jezusa, tj. około 80 roku, a wprowadził ją rabbi Johanan ben Zakai.

76 Por. J. Jeremias, $\pi \alpha \rho \alpha \dot{\delta \epsilon \iota \sigma o \varsigma, ~ w: ~ T h e o l o g i s c h e s ~ W o ̈ r t e r b u c h ~ z u m ~ N e u e n . . ., ~ d z . c y t ., ~}$ Bd. V, s. 767, 768-769; zob. też Kommentar zum Neuen Testament aus Talmud..., dz. cyt., vol. 2, s. 227; Kommentar zum Neuen Testament aus Talmud und Midrasch, Hrsg. H. L. Strack, P. Billerbeck, vol. 3. Die Briefe des Neuen Testaments und die Offenbarung Johannis, München 1961, s. 534; Ksiegga Henocha wersja etiopska 39, 4; $70,1-4$.

77 Por. Kommentar zum Neuen Testament aus Talmud..., dz. cyt., vol. 2, s. 264-269, podaje szereg wyrażeń hebrajskich tego okresu, analogicznych do „raju ukrytego”: „świat 


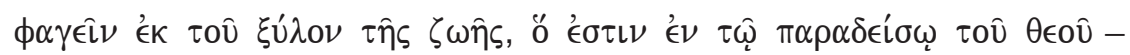
"Zwyciężającemu dam mu zjeść z drzewa życia, które jest w raju Boga"78. Apokalipsa wg św. Jana, stosując starotestamentalne i późnojudaistyczne wyobrażenia pierwotnego raju oraz prorockie obrazy chwały raju po zakończeniu świata, wprowadza natomiast nowe wyobrażenie rajskości zbawionych - niebiańskie Jeruzalem. Przyjmie ono zbawionych jako nowa ziemia, gdzie będą oni karmieni z drzewa życia i pojeni wodą życia (Ap 21, 10-27; $22,1-10)$. W nowym Jeruzalem diabeł zostanie unicestwiony (Ap 20, 10), nie będzie tam śmierci, bólu, krzyku, cierpienia i łez (Ap 21, 4). Zbawieni dostąpią wiecznej wspólnoty życia z Bogiem ${ }^{79}$ (Ap 21, 3: „Oto namiot Boga z ludźmi i rozbije namiot z nimi i oni ludami jego będą, i on Bóg z nimi będzie [ich Bóg]”; Ap 22, 3-5: „I wszelkie wyklęte nie będzie już. A tron Boga i baranka w niej będzie i niewolnicy jego służyć będą mu, i widzieć będą twarz jego, a imię jego na czołach ich. I nocy nie będzie już i nie mają potrzeby światła lampki i światła słońca, bo Pan Bóg świecić będzie na nich, i królować będą na wieki wieków”) ${ }^{80}$. Choć w przytoczonych fragmentach Janowej Apokalipsy nie pojawia się termin $\pi \alpha \rho \alpha ́ \delta \epsilon \iota \sigma o \zeta$, to jednak nowa niebiańska Jerozolima - jest opisywana jako eschatologiczny raj: znajduje się tam rzeka wody życia (Ap 22, 1), aleja drzew życia (Ap 22, 2), starożytny wąż zostaje unicestwiony (Ap 20, 2), zbawieni są wolni od łez, śmierci, żałoby, krzyku i trudu (Ap 21, 4$)^{81}$.

Nowością, w stosunku do orędzia ST i myśli okresu późnego judaizmu, jest przepowiadanie NT, że powrót ludzi do raju rozpoczął się wraz z przyjściem Jezusa. On sam ogłasza to orędzie (Mt 11, 5; Łk 7, 22; Mk 10, 2-12) jako aktualizację raju opisanego w Iz 35, 5; kiedy oznajmia swym uczniom jako obowiązującą tę wolę Ojca, która była na początku - w pierwotnym raju (nierozwiązywalne małżeństwo - Mt 19, 8; por. też wątki: chwała, jaką posiadał Adam - Rz 3, 23; stan bez grzechu i bez śmierci - Rz 5, 12; 8, 20).

podziemny”, „niebo”, „Królestwo Boga”, „akademia niebiańska”, „tron Boga”, „skarbiec”, „przymierze żyjących”, „ziemia żyjących”, „u aniołów”, „, na kolanach Abrahama”.

78 Por. Grecko-polski Nowy Testament. Wydanie interlinearne z kodami gramatycznymi, tłum. R. Popowski, M. Wojciechowski, Warszawa 1995, s. 1163 (PSB 1).

79 Por. Raj, w: F. Rienecker, G. Maier, Leksykon biblijny..., dz. cyt., s. 686.

80 Por. Grecko-polski Nowy Testament..., dz. cyt., s. 1229, 1233-1234.

81 Por. J. Jeremias, $\pi \alpha \rho \alpha ́ \delta \in \iota \sigma o \varsigma$, w: Theologisches Wörterbuch zum Neuen..., dz. cyt., Bd. V, s. 767. 
Kształtowanie się nauki o niebie w teologii patrystycznej I-III wieku

Jezus w swej osobie zaofiarował ludziom - chleb życia (J 6; por. Mk 8, 14) i wodę życia (J 4, 10-14; por. Mk 7, 27-29), czyli antyczne symbole raju, którego On jest odnowicielem ${ }^{82}$.

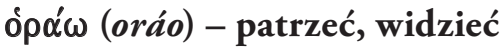

Termin używany w języku greckim od czasów Homera oznacza w sensie podstawowym: „patrzeć”, „spoglądać”; „posiadać wzrok”; „baczyć”, „zważać”, „zwracać uwagę”; „mieć widzenia”, „mieć jasnowidzenia”; „rozpoznać”, „zrozumieć”. W formie z użyciem biernika ó $\rho \alpha \omega$ oznacza: „widzieć”, „spostrzec”, „zobaczyć”, „zauważyć”, „ujrzeć”, „dostrzec”83. Stąd ó $\rho \alpha ́ \omega$ rozumiane jako „widzieć” posiada w języku greckim znaczenie „być żywym”, „mieć udział w życiu” (np. Homer, Odyseja 4,2269 - „żyć i widzieć ( $\zeta \omega \in \iota \nu$

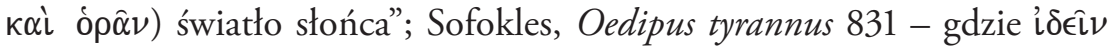
oznacza „doświadczać”). W przypadkach form znaczeniowych, których brakuje czasownikowi ó $\alpha \alpha \omega$, są one dopełnione albo od rdzenia óm- (np. czas

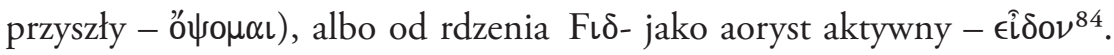

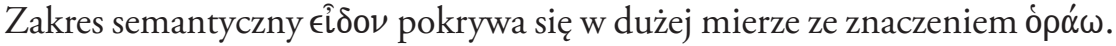
Termin $\hat{\imath} \delta \in \hat{\imath} \nu \mathrm{w}$ formie aorystu $\epsilon \hat{\imath} \delta o \nu$ - oznacza „widzieć”, „oglądać”, „dostrzegać”, „zobaczyć się z kimś”, „doznać, „zaznać, „doświadczyć”, „zobaczyć”, „patrzeć”, „spoglądać na coš”. W znaczeniu poetyckim, w formie medium єîઈov oznacza „być widzialnym”, „widnieć”, „ukazywać się”, „wydawać się”, „zdawać się”; z celownikiem „upodobnić się”85. W NT oprócz

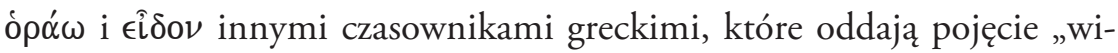

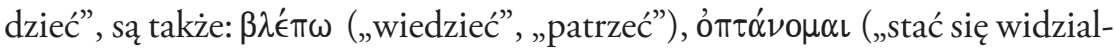
nym”, „objawić się”), $\theta \epsilon \alpha ́ \alpha \mu \alpha \iota$ („widzieć”, „kontemplować”, „obserwować”,

82 Por. J. Jeremias, $\pi \alpha \rho \alpha \dot{\delta} \epsilon\llcorner\sigma o \varsigma$, w: Theologisches Wörterbuch zum Neuen..., dz. cyt., Bd. V, s. 770.

83 Por. ó $\alpha \dot{\omega} \omega$, w: Stownik grecko-polski, red. Z. Abramowiczówna, t. 3, Warszawa 1962, s. 307-308.

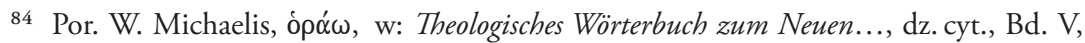
s. 316.

85 Por. €€ઈ̋, w: Stownik grecko-polski, red. Z. Abramowiczówna, t. 2, Warszawa 1960, s. $28-29$. 
„doświadczać”, „widzieć w wizji”), $\theta \epsilon \omega \rho \in ́ \omega$ („patrzeć”, „pójść, aby coś zobaczyć") ${ }^{86}$.

„Wizja Boga” nazywana też wizją błogosławioną lub uszczęśliwiającą to przenośnia bliska antycznej obrazowości greckiej, gdzie postrzeganie świata i jego opis dokonywał się w sposób szczególny za pomocą zmysłu widzenia. Dla greckiej filozofii i religii to, co boskie, nie było czymś „do wierzenia” czy „do słuchania”, ale „do ujrzenia”. W języku greckim dosyć szybko terminy opisujące „widzenie” nabrały także dodatkowego znaczenia i zaczęły wskazywać poznanie intelektualne, co wskazuje, iż aspekt zmysłowy i intelektualny nie były jeszcze rozdzielone i że opracowanie przez voûs danych przekazywanych przez zmysły nie wprowadzało jeszcze przeciwstawienia pomiędzy zmysłami a intelektem. Często filozofowie greccy podkreślali niewystarczający i ograniczony zakres poznania zmysłowego (np. Herakilt, Fragment 12), stąd pojawił się problem: do jakiego stopnia można widzieć to, co boskie. Dla Homera bogowie z reguły objawiali się w ubraniach ludzkich, aby później zupełnie zniknąć (np. Odyseja 1,96-105; 2,267; 22,205), czy pod postacią ptaka (Odyseja 1,319; 3,371; $22,239)$, były to objawienia zarezerwowane tylko dla wybranych ludzi, nie dla wszystkich jednoznaczne, a ludzie, którym objawiały się poszczególne bóstwa, byli przejęci strachem. U Homera nie istnieje jednak idea, że ten, kto zobaczył boskość, musi umrzeć. W opisach homeryckich przeważa aspekt wizyjności. Natomiast Empedokles był przekonany, że bóstwo jest niewidzialne dla człowieka (Fragment 133). Podobnie zdaniem Platona jest niemożliwym widzieć zmysłami świat idei, ten ostatni może być pojmowalny jedynie intelektualnie. Także w greckich kultach misteryjnych akcentowany jest moment wizyjności: błogosławiony jest zatem ten, kto może dostrzec (Pindar, Fragment 137). W misteriach eleuzyjskich chodzi prawdopodobnie o widzenie świętych rytów (np. Apulejusz, Metamorfozy 11, 23), w misteriach Izydy - o widzenie i adorowanie z bliska bogów podziemnych i bóstwa wyższe, a w liturgii Mitry - o wizje ekstatyczne dla tzw. odrodzonych w duchu. Religijne analogie do eleuzyńskiego „widzenia Boga” można znaleźć w religijności starożytnego Egiptu - w czasach

86 Por. W. Michaelis, ò ${ }^{\alpha} \omega$, w: Theologisches Wörterbuch zum Neuen..., dz. cyt., Bd. V, s. 317-320. 
Kształtowanie się nauki o niebie w teologii patrystycznej I-III wieku

tzw. Nowego Państwa (XVI-XI wiek przed Chr.), kiedy mówiono o kultycznym „zobaczeniu boga" ${ }^{87}$. Natomiast gnoza okresu hellenistycznego potwierdza wcześniejszą opinię, iż bóstwo pozostaje niewidzialne dla natury człowieka ${ }^{88}$.

Samo utożsamianie „widzieć” i „wiedzieć” jest przed-greckie, co można odnieść do indoeuropejskiego rdzenia: „wid-”, np. w języku polskim jest obecne w słowach: widzieć i wiedzieć. Jak wskazują językoznawca Émile Benveniste $^{89}$ czy biblista Wilhelm Michaelis ${ }^{90}$, grecki temat $\left(_{F}\right)$ id- $\left(_{F}\right)$ oid-,

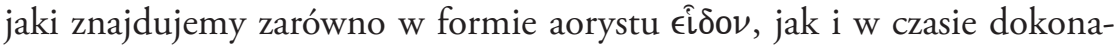
nym (perfectum) oí $\alpha$, jest używany w wyrazie złożonym ó $\rho \alpha \omega$, gdzie perfectum oi $\delta \alpha$ („zobaczyłem”, „doświadczyłem świata w życiu”) oznacza czas teraźniejszy „ja jestem”1. Z tego samego indoeuropejskiego rdzenia „wid-” pochodzi także łaciński temat vid-zarówno w videre, jak i w visio. Jak zauważył Juan Luis Ruiz de la Peňa, w refleksji teologicznej Zachodu bardziej podkreślano w wizji Boga element poznawczo-intelektualny (np. theoria, kontemplacja) ${ }^{92}$. Tezę tę od czasu XIII-wiecznej scholastyki głosi dziś np. współczesny tomizm ${ }^{93}$. Dlatego Karl Rahner postulował przy

87 Por. A. Niwiński, Egiptu starożytnego religia, w: Religia. Encyklopedia PWN, t. 3, red. T. Gadacz, B. Milerski, Warszawa 2001, s. 372, zaznacza, iż w trakcie modlitwy Egipcjanin stał lub klęczał z rękami uniesionymi w geście adoracji bądź padał na twarz, co określano jako „całowanie ziemi przed bogiem”. W czasie świąt kontakt z bóstwem nabierał bardziej uroczystego charakteru i był określany jako „zobaczenie boga”, czyli barki procesjonalnej niesionej na ramionach kapłanów, w której znajdował się zakryty naos (przenośne sanktuarium) z posążkiem boga. Więcej na ten temat, zob. A. Niwiński, Bóstwa, kulty i rytuaty starożytnego Egiptu, Warszawa 1993.

88 Por. W. Michaelis, ópáw, w: Theologisches Wörterbuch zum Neuen..., dz. cyt., Bd. V, s. 318-324.

89 Por. E. Benveniste, Il vocabolario delle istituzioni inodoeuropee, vol. 2. Potere, diritto, religione, Torino 1981, s. 414-415.

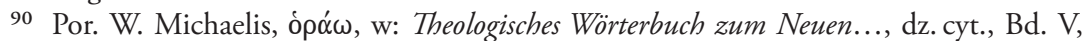
s. 316, szczególnie przypis 7.

91 Por. A. Nitrola, Trattato di escatologia, vol. 2. Pensare la venuta del Signore, Cinisello Balsamo (Milano) 2010, s. 415-416.

92 Por. J. L. Ruiz de la Peňa, L'altra dimensione, Roma 1981, s. 237.

93 „Najdoskonalszym zatem poznawczym aktem nadprzyrodzonym jest tzw. «visio beatifica», stanowiąca najwyższy typ zjednoczenia człowieka z Bogiem”, w: Z. J. Zdybicka, Religia $i$ religioznawstwo, Lublin 1988, s. 427 (por. M. A. Krąpiec, Z. J. Zdybicka, Świętość spetnieniem osoby, w: M. A. Krąpiec, Cztowiek - kultura-uniwersytet, Lublin 1982, s. 73-74). 
stosowaniu tego terminu łączenie elementu intelektualno-poznawczego $\mathrm{z}$ aspektem relacyjnym ${ }^{94}$.

W LXX ó $\alpha ́ \omega$ oznacza w większości przypadków akt widzenia, i wy-

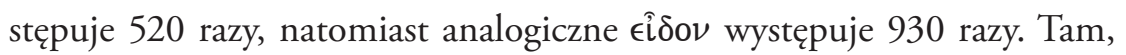
gdzie LXX idzie za tekstem masoreckim, greckie ó $\alpha \dot{\alpha} \omega$ oddaje treść hebrajskiego $r \bar{a} \hat{a}^{95}$ (około 350 razy), hebrajskiego hāzâ (27 razy) i aramej-

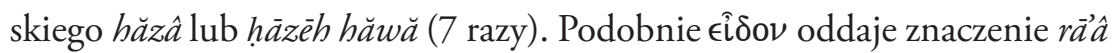
(670 razy), hāzâa (17 razy) i hăzâ (19 razy). We frazie „widzieć chwałę Bożą” (np. Ps 96, 6; Iz 26, 10; 35, 2; 66, 18) chodzi o szczególny dar objawienia się Boga w swej chwale, doświadczany intelektualnie, a nie fizycznie. W LXX termin $\beta \lambda \epsilon ́ \pi \omega$ pojawia się 130 razy i najczęściej odpowiada hebraj-

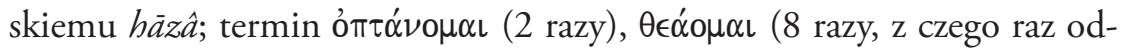

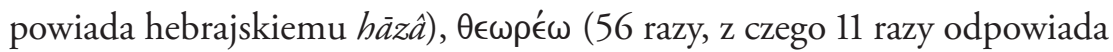
hebrajskiemu $h \bar{a} z \hat{a})$. W Septuagincie ó $\rho \alpha$ i $\omega$ i $€ \hat{\delta} \delta o \nu$ są typowymi terminami, które wskazują akt widzenia w sensie wizjonersko-ekstatyczno-prorockim i metaforycznym. Nawet jeśli jest stosowane słowo „widzieć”, to oznacza ono nie tyle widzenie, co doświadczanie Boga, słyszenie Go. Takie rozumienie ó $\rho \alpha ́ \omega, \epsilon i ̂ \delta o \nu$ czy pokrewnych terminów w przekładzie LXX wynika, tak jak w Biblii hebrajskiej, z zachowania zasady z Wj 33, 20b, że „żaden człowiek nie może oglądać mojego oblicza i pozostać przy życiu”. Stąd patriarchowie Abraham, Izaak i Jakub, podczas Bożych teofanii, doświadczają Bożej obecności, ale nie widzą Boga na własne oczy. Podobnie prorocy w swych wizjach nie widzą Boga, lecz w tych sytuacjach Bóg, przemawiając do nich, w tym także do Mojżesza, daje im jedynie poznać swą wolę. Mojżesz i siedemdziesięciu starców Izraela widzieli Boga z daleka, w Jego majestacie, i nie umarli (Wj 24, 9-11). Jedynie Mojżesz mógł się zbliżyć bardziej do tronu Bożego (Wj 24, 12). Zasadniczo, według ST, człowiek nie może jednak zobaczyć Boga. Ten sam Mojżesz zakrywa twarz wobec wizji

94 Por. K. Rahner, Considerazioni dogmatiche sulla scienza e autocoscienza di Cristo, w: K. Rahner, Saggi di cristologia e mariologia, Roma 1965, s. 225-230; K. Rahner, Visio beatifica, w: K. Rahner, Enciclopedia teologica. Sacramentum mundi, vol. 8, Brescia 1977, s. 637.

95 Por. H. F. Fuhs, räâ, w: Theological Dictionary of the Old Testament, vol. 13, Hrsg. G. J. Botterweck, H. Ringgren, H.-J. Fabry, Grand Rapids (Michigan) 2004, s. 208-242. 
Kształtowanie się nauki o niebie w teologii patrystycznej I-III wieku

krzaku gorejącego (Wj 3, 6); Mojżesz może zobaczyć jedynie Boże plecy (Wj 33, 20). Przekonanie o niemożliwości zobaczenia Boga przez człowieka (Wj 19, 21; Kpł 16, 2; Lb 4, 20; Sdz 13, 22) jest jednak zestawiane w ST z tymi wydarzeniami, kiedy to Bóg sam ze swej inicjatywy objawia się człowiekowi i mówi z $\operatorname{nim}(\operatorname{Rdz} 12$, 7; 17, 1; 26, 2. 24; 35, 9-10; $2 \operatorname{Krn} 1$, 7; 7, 12; Hi 19, 26; 23, 9; 34, 29; 42, 5). Niemożność widzenia Boga przez człowieka to prawdopodobnie skutek grzechu rajskiego $(\mathrm{Iz} 6,5)^{96}$. ST, szczególnie w Psalmach, podkreśla jednak ciągłe pragnienie widzenia Boga przez człowieka (Ps 11, 7; 16, 11; 17, 15; 21, 7; 27, 13; 36, 10; 42, 3; 63, 3; 140, 14) ${ }^{97}$.

W późnym judaizmie użycie terminów związanych $\mathrm{z}$,widzeniem” nie jest homogeniczne. W pismach apokaliptycznych podkreśla się sam moment wizji (np. Księga Henocha wersja etiopska 14, 15; 18, 14; Księga Jubileuszów 32, 17; 44, 3). Jednak apokaliptyka żydowska tego okresu w żaden sposób nie opisuje wizji Boga jako celu, do którego się dąży i jaki osta-

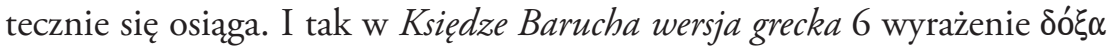
$\theta \in o v ̂$ wskazuje jedynie na oglądanie niebiańskich wspaniałości jak słońce czy feniks. Księga Henocha wersja etiopska 89, 30 omija problem wizji Boga przez odwołanie się do wymyślonych imion („owca”, „pan owiec”, ect.), jednak sama wizja Boga jest uznana za możliwą rzeczywistość eschatologiczną. W 4 Księdze Ezdrasza 7, 87 opisany jest stan grzeszników, którzy po śmierci najpierw - przez 7 dni - przebywają w stanie pośrednim, a w ostatnim dniu tej wstępnej, siedmiokrotnej kary mają oglądać oblicze Najwyższego, przeciwko któremu grzeszyli i przez którego zostaną

96 Por. W. Michaelis, óó́ $\omega$, w: Theologisches Wörterbuch zum Neuen..., dz. cyt., Bd. V, s. 324-334.

97 Jak odnotowuje T. Tułodziecki, Widzenie Boga w świetle ksiegi Psalmów, „Verbum Vitae” 16 (2009), s. 209, M. Dahood w swoim studium Psalms I, 1-50, AB 16, Garden City 1966, XLIX, starał się dowieść, iż zacytowane powyżej fragmenty Psalmów mają charakter eschatologiczny i wskazują na nagrodę dla sprawiedliwego, którą będzie oglądanie oblicza Bożego w niebie (tzw. „visio beatifica”). Jednak koncepcja ta została jednoznacznie skrytykowana i odrzucona przez: L. Dorna, The Beatific Vision in Certain Psalms: An Investigation of Mitchell Dahood's Hypothesis, Chicago 1980 i J. F. Healey'a, The Immortality of the King: Ugarit and the Psalms, „Orientalia” 53 (1984), s. 245-255. Badacze ci wykazali, iż żaden z wymienionych Psalmów nie zawiera w swojej treści problematyki eschatologicznej. Dlatego także w Psalmach sformułowanie „ujrzeć / widzieć oblicze Boga" oznacza jedynie tyle, co wierzyć w Boga, którego nie można zobaczyć (por. T. Tułodziecki, Widzenie Boga..., dz. cyt., s. 120-121). 
osądzeniu w dzień sądu. Analogicznie sprawiedliwi zobaczą dzień chwały, czyli oblicze Pana (4 Księga Ezdrasza 7, 91; 7, 98; Apokalipsa Mojżesza 31). Według 4 Ksiegri Ezdrasza 6, 25; 9, 8 człowiek nie dochodzi do wizji samego Boga, lecz do wizji swego zbawienia. W Psalmach Salomona 17, 31. 44;

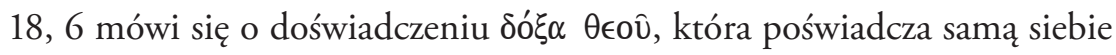
w łasce okazanej Izraelowi. Natomiast w Księdze Jubileuszów 1, 28 można przeczytać o obietnicy, że na końcu czasów Bóg objawi się naocznie każdemu (por. Wyrocznie Sybilli 5, 426; 4 Ksiega Ezdrasza 13, 52; Testament Zabulona 9,3). Przeciwnie do przekazów literatury apokaliptycznej rabini okresu późnego judaizmu podkreślali moment słuchania Boga, natomiast byli bardzo ostrożni, jeśli chodzi o wszystko, co jest związane z wizjami i stanami ekstatycznymi. Charakterystycznymi wyrażeniami omownymi dla frazeologii rabinackiej były: „zachować oblicze szekinah”, „zachować oblicze króla wszystkich królów”, „widzieć oblicze szekinah”. Jedynie w bezpośrednich cytowaniach ST można znaleźć sformułowania: „widzieć Boga”, „widzieć oblicze Boga”, „widzieć chwałę Boga”. Wizja Boga była częścią ówczesnej eschatologii rabinackiej: w stanie pośrednim gañe èden pobożni będą widzieć oblicze szekinah, podczas gdy bezbożni zostaną tego pozbawieni. Jedynie po zmartwychwstaniu w świecie, który nastąpi - błogosławieństwo będzie polegało na wizji Boga (np. Księga Liczb 20; Miszna: Berachot, Talmud babiliński 17a). Późniejsze teksty rabinackie podkreślały natomiast okres „dni Mesjasza”, dlatego przenosiły na ten etap wizję Boga, która miała następować natychmiast po śmierci ${ }^{98}$.

98 Por. W. Michaelis, ópá $\omega$, w: Theologisches Wörterbuch zum Neuen..., dz. cyt., Bd. V, s. 335-339; M. Parchem, Zmartwychwstanie, odptata po śmierci i życie wieczne w literaturze międzytestamentalnej, „Verbum Vitae” 15 (2009), s. 99-142, w swym studium stwierdza, iż wiara w zmartwychwstanie, sąd nad umarłymi i życie wieczne (dla sprawiedliwych - szczęście, dla bezbożnych - potępienie) pojawia się w literaturze międzytestamentalnej (II wiek przed Chr. - I wiek po Chr.) w kontekście apokaliptycznym (por. Dn 12, 1-3; literatura henochiczna: Księga Strażników: 1 Hen 22, 24-27; Apokalipsa zwierzat: 1 Hen 90, 33; List Henocha: 1 Hen 91, 10. $92,3.104,2-6)$. Różne aspekty tej wiary podlegały rozwojowi, zwłaszcza jako interpretacja i ubogacenie motywów obecnych w Dn 12, 1-3. Teksty z Qumran uwypuklały szczególnie wiarę w życie wieczne (1 QS; 1 Q34; 4 Q181). Odpłata po śmierci miała stanowić konsekwencję życia na ziemi. Ta wiara była szeroko akceptowana w judaizmie I wieku po Chr. (4 Ezd 4, 35-42. 7, 32-37. 14, 35; 2 Ba 49-51. Ksiegga 
Kształtowanie się nauki o niebie w teologii patrystycznej I-III wieku

W NT najczęściej używanymi terminami odnoszącymi się do „widzieć”

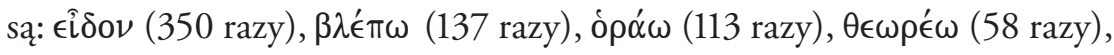

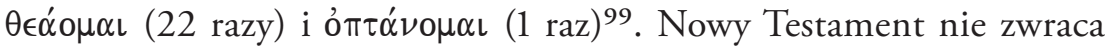
szczególnej uwagi na aspekt fizjologiczno-psychologiczny postrzegania przez widzenie i rzadko opisuje spotkanie Bogiem w kategorii wizji wyobrażeniowej. W NT nie istnieje też typowe dla filozofii greckiej rozróżnienie pomiędzy światem zmysłowym a inteligibilnym. Co więcej, ewangelie nie podają opisu twarzy Jezusa czy innych osób (za wyjątkiem Łk 19, 3), nie opisują kolorów, nie podają charakterystyki topografii terenu, gdyż tym, co miało być przekazane w katechezie ewangelicznej, są przede wszystkim czyny i słowa Jezusa ${ }^{100}$. W NT, w przeciwieństwie do ST, występują bardzo nieliczne opisy objawień onirycznych (Mt 1, 20; 2, 13. 19) czy teofanii (za wyjątkiem Dz 7, 2) ${ }^{101}$. Bóg dalej pozostaje

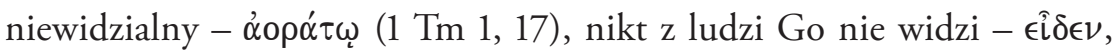

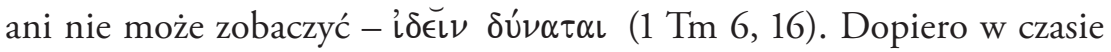
ostatecznym, według Mt 5, 8, ludzie czystego serca będą Boga „widzieli” (”४ $\nu \nu \tau \alpha$ ); według 1 Kor 13, 12, w wieczności będziemy widzieli Boga „twa-

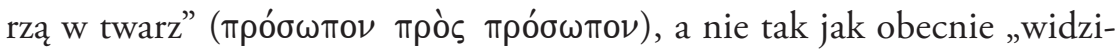

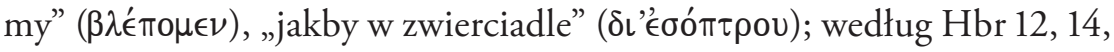
„widzenie” (ő $\psi \in \tau \alpha \iota)$ Pana będzie możliwe dzięki jeszcze doczesnemu szukaniu pokoju ze wszystkimi i dzięki uświęceniu; według Ap 22, 4, słudzy Pana będą Go „widzieli” (’ł czwarta ewangelia kanoniczna. Dla Jana Ewangelisty Bóg jest niepojmowalny i niewidzialny, lecz właśnie tego Boga objawia Syn (J 6, 46; 14, 9). Widzieć Boga w i przez Chrystusa jest tym samym, co wierzyć (J 12, 4445). To postrzeganie Boga przez wiarę / wizję zostanie dopełnione na końcu świata przez zmartwychwstanie ciał dzięki wierze w Jezusa Chrystusa

Przypowieści: 1 Hen 46, 6. 48, 10. 51, 1-2. 62, 15-16; Ps Sal 2, 30-31. 3, 11-12. 4 Syb 179-182).

99 Por. W. Michaelis, ó $\alpha$ $\omega$, w: Theologisches Wörterbuch zum Neuen..., dz. cyt., Bd. V, s. 340-346.

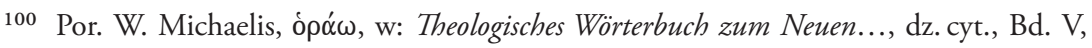
s. 346-348.

101 Por. vedere, visione, w: Dizionario dei concetti biblici..., dz. cyt., s. 1930. 
1. Biblijne terminy, koncepcje i obrazy dotyczące nieba

$(\mathrm{J} 6,40)^{102}$. W teologii Janowej wizja Boga wynika także z wzajemnej miłości $(1 \mathrm{~J} 4,12 ; 1 \mathrm{~J} \mathrm{3,2})^{103}$.

\section{$\alpha i \omega^{\prime} \nu$ - trwanie, przyszłość, wiek; $\alpha i \omega \nu i ́ \varsigma$ - trwałość, wieczność}

Hebrajskie 'ôlām (czas bardzo odległy, zarówno w przeszłości, jak i w przy-

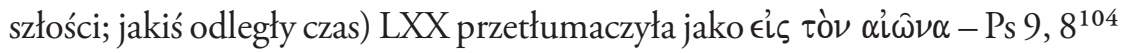
(por. Ps 89(90), 2 ${ }^{105}$; Ps 91(92), 9 ${ }^{106}$; Ps 101(102), 13 ${ }^{107}$; Ps 144(145), $1^{108}$; Syr 18,1$)^{109}$. Jednak przekład „wieczność” nie odpowiada dokładnie znaczeniu w wielu fragmentach ST i grozi niebezpieczeństwem narzucenia tekstom ST greckiego czy chrześcijańskiego rozumienia wieczności. W okresie hellenistycznym hebrajskie 'ôlàm prawdopodobnie uległo semantycznym wpływom greckiego $\alpha \iota \omega \nu$. Stąd znajdujemy w literaturze apokaliptycznej okresu międzytestamentalnego wyrażenia „ten czas” / „czas historii” ('ôlàm

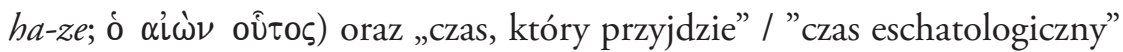

102 Por. €î́ov, w: W. Bauer, A Greek English Lexicon of the New Testament, Chicago 1957, s. 220; C. R. Koester, Hearing, Seeing, and Believing in The Gospel of John, „Biblica” 70 (1989), s. 327-348; óów, w: Manual Greek Lexicon of the New Testament, ed. G. Abbott-Smith, Edinburgh 1999, s. 322.

103 Por. W. Michaelis, ópá $\omega$, w: Theologisches Wörterbuch zum Neuen..., dz. cyt., Bd. V, s. 351-368.

104 LXX, vol. 2, edidit A. Rahlfs..., dz. cyt., s. 7; tłum. R. Popowski, Septuaginta..., dz. cyt., s. 838: „na wieki”.

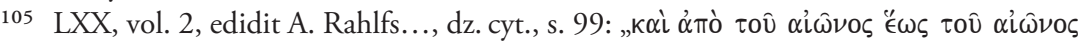
où $\epsilon$ '”; tłum. R. Popowski, Septuaginta..., dz. cyt., s. 923: „od zawsze i na zawsze Ty jestes".

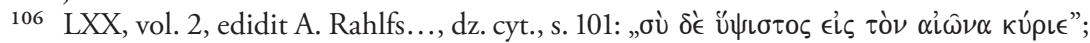
tłum. R. Popowski, Septuaginta..., dz. cyt., s. 925: „Ty, o Panie, jesteś najwyższy na wieki".

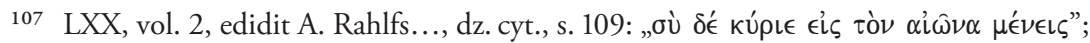
tłum. R. Popowski, Septuaginta..., dz. cyt., s. 932: „Ty natomiast, Panie, jesteś zawsze".

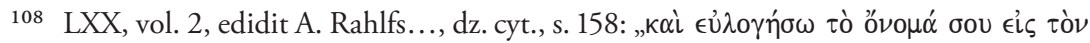

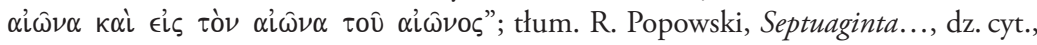
s. 978: „chcę błogosławić Twe imię zawsze i na wieki wieków”.

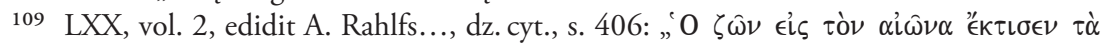

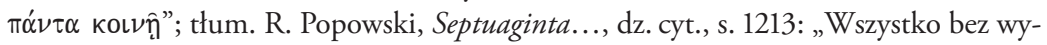
jątku stworzył wiecznie Żyjący”. 
Kształtowanie się nauki o niebie w teologii patrystycznej I-III wieku

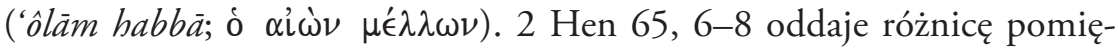
dzy tymi dwoma czasami, choć nie jest to jeszcze koncepcja teologiczna, jaka zrodzi się w chrześcijaństwie (Por. 2 Księga Barucha 54, 21; 4 Księga Ezdrasza 6, 25). Należy też zaznaczyć, że w okresie hellenistycznym i rzymskim istniało w judaizmie napięcie pomiędzy ideą zmartwychwstania a ideą nieśmiertelnej duszy. Zwolennicy zmartwychwstania utrzymywali, iż u końca czasów dusza połączy się na nowo ze zmartwychwstałym ciałem i tak odrodzony człowiek otrzyma dopiero nagrodę lub karę. Odzwierciedleniem tej koncepcji w Biblii hebrajskiej jest jedynie zapis z Dn 12, 2, a modyfikacją tej idei jest przekonanie rabinackie, że tylko sprawiedliwi zmarli zmartwychwstaną, aby mieć udział w eonie mesjańskim. Natomiast zwolennicy idei o nieśmiertelnej duszy po śmierci twierdzili, iż dusza nadal żyje po śmierci ciała i od razu otrzymuje nagrodę lub karę. W Testamencie Abrahama 12-13 (około 100 roku po Chr.) można zatem przeczytać, że po śmierci ciała każda dusza staje na sąd z uczynków przed Ablem synem Adama. Sprawiedliwi dostępują zbawienia, a niegodziwi idą na ogniste męki. Napięcie między tymi dwoma ideami judaistycznymi utrzymywało się także w judeochrześcijaństwie I wieku ${ }^{110}$.

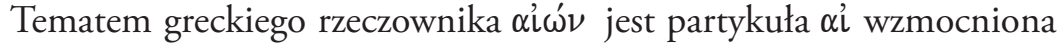
sufiksem $\omega$, która wskazuje na siłę życiową, siłę, która tworzy i czyni rodzaj ludzki. Termin $\alpha \iota \omega ́ v$ oznacza zatem najpierw ludzki wymiar siły życiowej, siłę życiową konkretnej osoby. Dlatego u Homera w Odysei ${ }^{111}$ połączenie

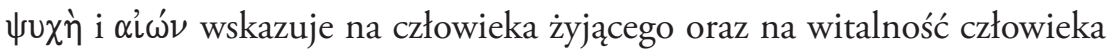
żyjącego. Stąd też $\alpha \imath \omega ́ \nu$ wziął ludzką konotację oraz swój wymiar czasowej ograniczoności. Toteż tak długo, jak w człowieku nienaruszenie trwa jego $\alpha \imath \omega ́ v$, tak długo żyje sam człowiek ${ }^{112}$.

110 Por. S. A. White, Życie pośmiertne i nieśmiertelność - Judaizm drugiej świątyni i wczesne chrześcijanstwo, w: Stownik wiedzy biblijnej, red. B. M. Metzger, M. D. Coogan, [konsult. wyd. pol. W. Chrostowski], Warszawa 1996, s. 835-836 (PSB 5).

111 Odyseusz, pozbawiwszy wzroku Polifema, mówił do niego, w: Homer, Odyseja 9,

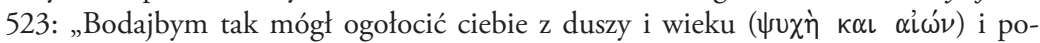
słać cię do domu Hadesa”, BA 1, s. 124; podobnie: Homer, Iliada 5, s. 684-690, tłum. i oprac. I. Wieniewski, Kraków-Wrocław 1984, s. 111; Iliada 22, s. 55, 58-467; Odyseja 7, s. 224.

112 E. Benveniste, Expresion indo-européene de l'éternité, Paris 1937, s. 109. 
1. Biblijne terminy, koncepcje i obrazy dotyczące nieba

Według Platona istnieje radykalny rozdział pomiędzy światem spostrzeganym zmysłowo, a światem idei, stąd też wynika nieprzekraczalna grani-

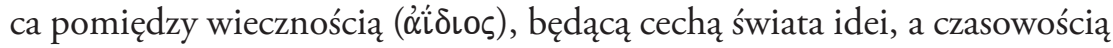

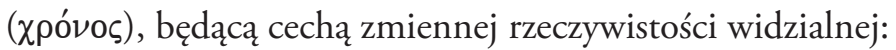

„Czas zrodził się jednocześnie z niebem, aby zrodzone razem, razem się także rozpadły, gdyby kiedyś miały się rozpaść. Utworzony został według modelu substancji wiecznej, aby był możliwie najpodobniejszy do

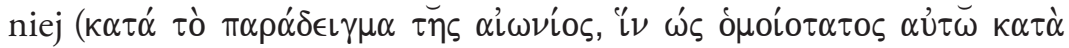
$\delta$ $v \alpha \mu \iota \nu \eta)$. Model bowiem jest bytem wiecznym, a czas od samego początku istniał, istnieje i istnieć będzie"113.

Stąd przeszłość, teraźniejszość czy przyszłość to atrybuty przynależące do odbicia wieczności, którą jest czas. Obraz, który jest pierwowzorem, trwa poza wszelkim czasem ${ }^{114}$. Dla Platona $\alpha i \omega$ ' i $\alpha i \omega \nu$ íos stanowią treść idei wieczności, którą porównuje on z czasem. Tak pojmowana wieczność nie jest nieskończonym astronomicznym czasem, lecz formą życia Bożego / idei. Wieczność jest niezmienna, bez przeszłości, teraźniejszości i przyszłości, jej obrazem jest stworzony czas, w którym są dni, noce, miesiące i lata. Pomiędzy wiecznością a czasem istnieje, według Platona, różnica jakościowa, jak pomiędzy doskonałym wzorem a zwykłą odbitką. Dla Platona wieczność jest zatem całkowicie a-czasowa ${ }^{115}$. Tak radyklanego

113 Platon, Timajos 38b, tłum. P. Siwek, Warszawa 1986, s. 46 (Biblioteka Klasyków Filozofii [dalej: BKF] 153).

114 Platon, Timajos 37d-38a: „Niestety, nie można było dostosować całkowicie do świata zrodzonego tej wieczności, która, jak widzieliśmy, cechuje substancję Żyjącego modelu. Toteż [Bóg] postanowił utworzyć pewien obraz ruchów wiecznych i zajęty tworzeniem nieba, utworzył wieczny obraz bytu wiecznego, nieruchomego, jedynego, i sprawił, że postępuje on według praw matematycznych - nazywamy go Czasem. Dnie i noce, miesiące i lata nie istniały, zanim się zrodziło niebo: ich urodziny dokonały się w tym czasie, w którym niebo było budowane. Wszystkie one to część Czasu. Przeszłość i przyszłość są normami zrodzonymi z czasu. A gdy nieświadomie odnosimy je do substancji wiecznej, to dlatego, że nie znamy jej natury", s. 45 (BKF 153).

115 Por. R. D. Mohr, Plato on Time and Eternity, „Ancient Philosophy” 6 (1986), s. 3646; S. Łojek, O tryumfie (platońsko-chrześcijańskiej) wieczności nad (presokratejska) nieśmiertelnością, „Edukacja filozoficzna” 45 (2008), s. 135-152. 
Kształtowanie się nauki o niebie w teologii patrystycznej I-III wieku

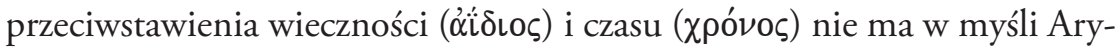
stotelesa, dla którego jedna i druga są cechą materii, która przejawia się jako wieczna. Pierwsza przyczyna ma atrybut trwania ( $\alpha \iota \omega ́ \nu)$, w którym w spo-

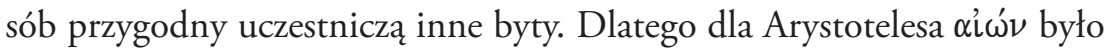

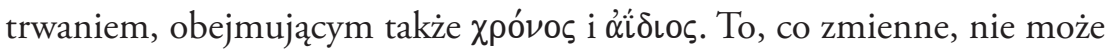
według Stagiryty, udoskonalić się w niezmienne i wieczne ${ }^{116}$. Dla stoików materia stanowiła jedyny rodzaj istnienia, w którym można wyróżnić dwa czynniki - bierny i czynny, przy czym ten ostatni był przez nich utożsamiany z pneumą $(\pi \nu \in \breve{u} \mu \alpha)$. Pneuma była określana negatywnymi przymiotnikami - nieśmiertelny ( $\propto \phi \theta \alpha \rho \tau o \varsigma)$ i niezrodzony ( $\alpha \gamma \in \mathcal{\prime}\langle\nu \eta \tau o \varsigma)$. Te przymioty określały, według stoików, wieczność. Filon z Aleksandrii, przejmując od Platona naukę o ideach, utożsamił ją z myślami Bożymi, a wieczność

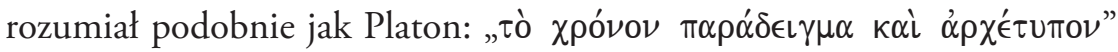
(Filon Aleksandryjski, Quod Deus sit immort. 32) ${ }^{117}$.

W łacińskim aeuus (aevus), aeuum (aevum) znajdujemy ten sam rdzeń

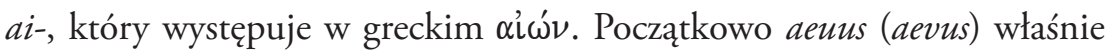

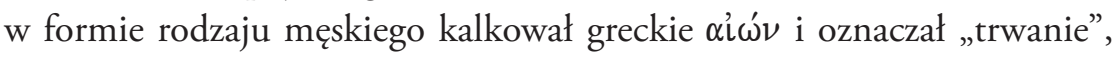
„coś ożywionego”. Do formy męskiej aevus została przypisana forma neutrum: aevum, powiązana z czasem. Ostatecznie właśnie ta druga forma wyparła pierwszą. Od aevus pochodzi rzeczownik aevitas oraz aetas, wskazujące wiek lub czas całego życia, oraz formy przymiotnikowe: aeuiternus, a następnie aeternus. Od rzeczownika detas został też urobiony rzeczownik nieokreślony aeternitas, który oznacza nieskończony okres trwania. Po raz pierwszy terminu aeternitas użył Cyceron (lata 106 - 43 przed Chr.) w swoim De inventione (około roku 84 lub 83 przed Chr.), w którym określił, że czas („tempus”) jest częścią aeternitas („pars quaedam aeternitatis”) ${ }^{118}$. Odwrotnie zatem niż w języku greckim, gdzie wieczność ( $\alpha \grave{i} \omega \nu)$ miesza się znaczeniowo i wielu aspektach z czasem konkretnym, w języku łacińskim

116 Por. W. von Leyden, Time, Number, and Eternity in Plato and Aristotle, „The Philosophical Quarterly"14/54 (1964), s. 35-52.

117 A. S. Jasiński, Wedtug postanowienia wiecznego Boga. Aionios w Nowym Testamencie, Opole 1991, s. 25-33.

118 Por. M. T. Cyceron, De inventione 1,34. 
1. Biblijne terminy, koncepcje i obrazy dotyczące nieba

terminy tempus i aeternitas, w wymiarze praktycznym dla rzymskiego retora, wskazują na czas jako na część (pars) wieczności ${ }^{119}$.

W NT pojęcie wieczności nigdy nie jest opisywane jednym greckim słowem, lecz zawsze stosowane są wyrażenia, w których pojawia się, wska-

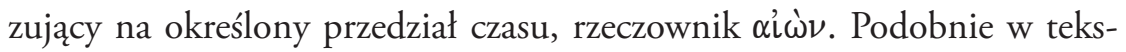
tach NT jest stosowany przymiotnik $\alpha i \omega \nu$ íos, którego zakres semantyczny wskazuje, iż przynależy on ewidentnie do słownictwa greckiej filozofii. Nowy Testament, stosując określenie $\alpha i \omega ̀ \nu$, wskazuje długość trwania tego czasu w formie negatywnej, tzn. jest on przeciwstawiony światu Bożemu (Mk 4, 19; Mt 13, 39. 40. 49; Łk 16, 8; Rz 12, 2; 1 Kor 1, 20; 2, 6; 10, 11; por. 2 Ksiega Barucha 54, 21; 4 Ksiega Ezdrasza 6, 25). Termin $\alpha i \omega ̀ \nu$ jest również rozumiany apokaliptycznie jako przyszłość (Mk 10, 30; Ef 1, 21; Hbr 6, 5), odnoszony do Boga jest stosowany często w formie superla-

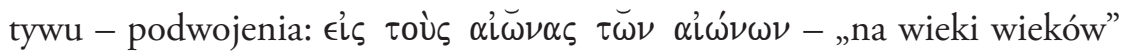
(Ga 1, 5; Ef 3, 21; Flp 4, 20; 1 Tm 1, 17; 2 Tm 4, 18; Hbr 1, 8; 1 P 4, 11; 12 razy w Ap) ${ }^{120}$. Wszyscy synoptycy $\left(\right.$ Mk 10, 17. 30 ${ }^{121}$; Mt 19, 16. 29 ${ }^{122}$;

119 Por. E. Benveniste, Expresion indo-européenne de l'éternité..., dz. cyt., s. 104; A. Arnout, Morphologie historique du latin, Paris 1914, s. 3; A. Meillet, Morphologie historique du latin..., 3.

120 Por. A. S. Jasiński, Wedtug postanowienia wiecznego Boga..., dz. cyt., s. 403-406.

121 Por. K. Stock, Il cammino di Gesù verso Gerusalemme. Marco 8, 27-10, 52, Roma 2002 (Pontificio Instituto Biblico) na s. 148.152-154 wykazuje, iż Mk 10, 27-31 jest perykopą zdominowaną przez tematykę życia eschatologicznego („życie wieczne”, „wejść do królestwa Bożego”, „być zbawionymi”). Sam dialog Jezusa z bogatym młodzieńcem rozgrywa się w jednym miejscu, a opowiadanie o tym jest uwypuklone przez

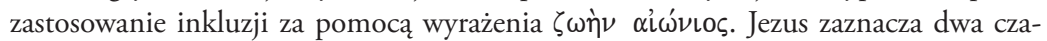
sy i wskazuje na efekty pójścia za Nim: w czasie obecnym uczniowie otrzymają w zamian stokrotność w rzeczach i osobach, a w wieku przyszłym - życie wieczne. Zatem na pytanie młodego bogacza co zrobić, aby osiągnąć życie wieczne $(\mathrm{Mk} 10,17)$ zostaje udzielona odpowiedź: zostawić wszystko i naśladować Jezusa (Mk 10, 30).

122 A. Paciorek, Ewangelia wedtug świętego Mateusza rozdziaty 14-28. Wstęp, przektad z oryginatu, komentarz, cz. 2, Częstochowa 2008, s. 265 (Nowy Komentarz Biblijny Nowy Testament I/2), w komentarzu egzegetycznym do Mt 19, 16 odnotowuje, iż pytanie o życie wieczne odznacza się tutaj silnie judaistyczno-apokaliptycznym kolorytem (por. Dn 12, 1). Życie wieczne według tradycji judaistycznej jest rozumiane jako określenie przyszłego wieku oraz ustanowienie Królestwa Bożego. W komentarzu do Mt 19, 29 A. Paciorek na, s. 277 podkreśla, iż jeśli Marek w swej wersji tej perykopy kładzie nacisk na nagrodę w tym życiu, to Mateusz - na nagrodę życia wiecznego, która jest obecna już teraz, ponieważ pewność przyszłej nagrody stanowi źródło obecnej radości. 
Kształtowanie się nauki o niebie w teologii patrystycznej I-III wieku

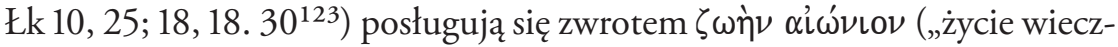
ne"), lecz nie stanowi on rdzenia ich katechezy o zbawieniu, ale nawiązują oni bardziej do tradycji apokaliptyczno-judaistycznej ${ }^{124}$.

Natomiast w Ewangelii wg św. Jana idea życia wiecznego stanowi novum treściowe, ścisłe związane z Wcieleniem się Syna Bożego. U Jana przymiotnik aîvíos nie określa wieczności Boga, lecz trwałość Jego daru życia: poznanie Boga i zjednoczenie z Nim $(\mathrm{J} 17,3)^{125}$. Bóg przez Syna obdarowuje

123 Analogiczne rozważania o apokaliptyczno-judaistycznym wydźwięku Łk 10, 25 znajdujemy u: F. Mickiewicz, Ewangelia wedtug św. Eukasza rozdziaty 1-11. Wstęp, przektad z oryginatu, komentarz, Częstochowa 2011, s. 559-560 (Nowy Komentarz Biblijny Nowy Testament III/1).

124 E. P. Gould, Critical and Exegetical Commentary on the Gospel according to St. Mark, odnotowuje: „Eternal life was the term in common use among the Jews to denote the blessings of the Messianic kingdom, both here and hereafter", The International Critical Commentary on the Holy Scriptures of the Old and New Testament, Edinburgh 1982, s. 190; podobnie C. A. Evans, Word Biblical Commentary, vol. 34B. Mark 8:2716:20, Nashville 2001, s. 95, który, odnotowując judaistyczny kontekst pytania i odpowiedzi o życie wieczne (np. Tg. Onq. Lev 18:5), podkreśla, iż Jezusowa odpowiedź wskazuje, że posłuszeństwo Prawu, jeśli łączy się z miłością bliźniego, w rezultacie daje życie wieczne.

125 G. R. Beasley-Murray, Word Biblical Commentary 36. John, Waco (Texas) 1987, s. $296-$ 297, podkreśla, że definicją życia wiecznego, o której mówi ewangelia Janowa to: znajomość Boga i Jego Syna Jezusa, czyli Chrystusa, którego posłał Bóg. Myśl ta ma swoje zaplecze kulturowe w tradycji judaistycznej, zarówno tej palestyńskiej (np. Bar Qappara, Ber. 63a, widział esencję Prawa w Prz 3, 6: „Poznawaj [tj. znaj-kursywa i uwaga G. R. Beasley-Murray] Go na każdej swej drodze, a On twe ścieżki wyrówna”, BT55), jak i hellenistycznej (np. Filon Aleksandryjski, Deus 143, końcem ścieżki mądrości jest „znajomość i rozumienie Boga”). W teologii Janowej poznanie Boga, oprócz elementu intelektualno-poznawczego zawiera także osobową relację i komunię z Bogiem, to wejście we wspólnotę (koinonia) Ojca i Syna. R. Schnackenburg, The Gospel according to St John. Vol. 3. Introduction and Commentary on Chapters 13-21, transl. by D. Smith, A. G. Kon, New York 1982, s. 172-173, dowodzi, iż tekst J 17, 3 wskazuje, że „życie wieczne” osiąga się dzięki wspólnocie z Ojcem i Jego Synem Jezusem lub poprzez Jezusa Chrystusa, który prowadzi człowieka do wspólnoty z Bogiem Ojcem. Sentencja J 17, 3 nie mówi nic więcej, co potwierdza także 1 J 2, 25. Natomiast w historii egzegezy dla ojców greckich ten tekst stanowił punkt teologicznego odrzucenia wszelkich form pogańskiego politeizmu (np. Jan Chryzostom, Homilia 80, 2, PG 59, k. 435). Natomiast dla niektórych ojców łacińskich fragment J 17, 3 stanowił punkt odniesienia dla tezy o wizji uszczęśliwiającej w niebie, którą najpełniej z czasem rozwinął Tomasz z Akwinu, Komentarz do Ewangelii Jana 17, lect. I,3. Dlatego Rudolf Schnackenburg wskazuje, iż J 17, 3 nie stanowi jakiejkolwiek definicji o poznawczym widzeniu Boga, natomiast zarówno komentowany fragment, jak i cała teologia Janowa odnoszą się do obecnej-aktualnej wspólnoty wierzącego z Bogiem jako wypełnienia 
1. Biblijne terminy, koncepcje i obrazy dotyczące nieba

wierzących życiem wiecznym $(\mathrm{J} 3,16)^{126}$, Jezus jest dawcą życia wieczne-

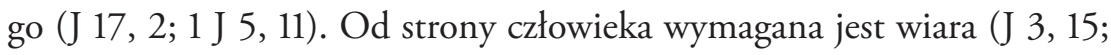
$1 \mathrm{~J} 5,13)$, dzięki której może on spożywać pokarm, który „trwa na życie wieczne" (J 6, 27) ${ }^{127}$, Ciało i Krew Pana (J 6, 54) na życie wieczne ${ }^{128}$, będące sferą, do której nie ma dostępu śmierć $(\mathrm{J} 12,25)^{129}$, gdyż jest ono związkiem z Bogiem Ojcem i Synem (J 17, 3; 1 J 5, 10) ${ }^{130}$.

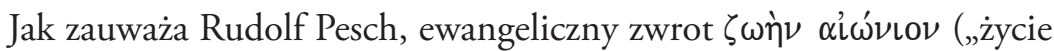
wieczne”) jest życiem wiecznym w przyszłym eonie. Życiem które wypływa i pochodzi z oczekiwanego zmartwychwstania umarłych. Esencjalna treść

ludzkich oczekiwań na zbawienie, co osiąga się w wierze i unii miłości z Jezusem Chrystusem.

126 R. Schnackenburg, The Gospel according to St John. Vol. 1. Introduction and Commentary on Chapters 1-4, transl. by K. Smyth, New York 1967, s. 400 (Herder's Theological Commentary on the New Testament), zaznacza, iż Janowe sformułowanie „aby każdy, kto w Niego wierzy, nie zginął, ale miał życie wieczne” wskazuje, że wieczna „destrukcja”-,,potępienie”-,,sąd” dokonują się w niewierze w Jezusa, tak jak „życie”-,życie wieczne" dokonuje się w wierze w Jezusa. Miejscem zatracenia duszy i ciała, czyli całego człowieka była według wierzeń żydowskich Gehenna, co znajduje swój oddźwięk u synoptyków np. Mt 10,28), natomiast u Jana spotykamy właśnie korelatywną koncepcję potępienia lub życia wiecznego. Według Jana człowiek może uciec od katastrofalnego zatracenia, czyli mieć „życie wieczne” jedynie przez wiarę w Jezusa (J 3, 36).

127 R. Schnackenburg, The Gospel according to St John. Vol. 2. Introduction and Commentary on Chapters 5-12, transl. by C. Hastings, M. McDonagh, D. Smith, R. Foley, New York 1980, s. 37-38 (Herder's Theological Commentary on the New Testament), wskazuje, iż J 6, 27 mówi o „życiu wiecznym” jako o darze zbawienia. Dlatego niezależnie od symbolicznych konotacji z midraszem o chlebie życia czy ogólnoreligijną symboliką „pokarmu” odnoszoną do życia (także życia wiecznego), J 6, 27 jest przede wszystkim odniesieniem do Eucharystii.

128 R. Schnackenburg, The Gospel according to St John. Vol. 2..., dz. cyt., wykazuje, że J 6, 54 przez podkreślenie realistycznego rozumienia sakramentalnego posiłku (tj. spożywanie ciała, picie krwi) odrzuca tym samym jakiekolwiek rozumienie magiczne czy gnostyckie. Sakramentalne spożywanie Ciała i picie Krwi Jezusa Chrystusa są bowiem dla wierzącego sposobem uzyskania osobistej komunii z Jezusem.

129 L. Morris, The Gospel according to John. Revised Edition, The New International Commentary on the New Testament, Grand Rapids (Michigan) 1995, wskazując na

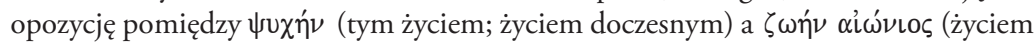
w wieku, który przyjdzie), zaznacza, iż pierwsze ( $\psi$ $\chi \eta \dot{\eta} \nu)$ oznacza naturalne życie człowieka, podążanie za pragnieniami i afektami, bez respektowania woli Boga. Drugie

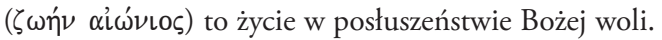

130 Por. A. S. Jasiński, Wedtug postanowienia wiecznego Boga..., dz. cyt., s. 403-409; S. Mędala, Tradycja o wieczności Mesjasza i redakcja J 12, 34, „Ruch Biblijny i Liturgiczny" 28 (1975) nr 4-5, s. 199-216. 
Kształtowanie się nauki o niebie w teologii patrystycznej I-III wieku

eschatologicznej nadziei na zbawienie rozwinęła się w chrześcijaństwie od II wieku, kiedy to autorzy chrześcijańscy zaczęli ją wiązać właśnie z wyrażeniami: „życie wieczne” lub „życie”. Natomiast samo sformułowanie $\zeta \omega \eta \nu$ $\alpha \iota \omega ́ \nu ı \nu$ w tradycji judaistycznej jest powiązane ze wskazaniem określonego zachowania, w zamian za którego stosowanie wierzący otrzyma wynagrodzenie czy też dziedzictwo. Stąd zwrot „odziedziczyć życie wieczne” stanowi formułę związaną z eschatologią zbawienia ${ }^{131}$. Joachim Gnilka zwraca uwagę, że w judaizmie międzytestamentalnym pytanie o życie wieczne było związane z wyborem konkretnego postępowania moralnego. Jeśli świątynia w Jerozolimie była uznawana za miejsce życia, to życie wieczne zakładało wiarę w zmartwychwstanie umarłych. Wiara ta rozpowszechniła się w judaizmie wyłącznie w powiązaniu z apokaliptyką żydowską. Ta zaś głosiła, że zbawienie zapewnia nie tylko sama przynależność do narodu wybranego, ale każdy pojedynczy człowiek powinien być przynaglony do podjęcia decyzji moralnej i do dania własnym życiem dobrego przykładu innym. Sposób postępowania wyznaczała zaś Tora, interpretowana przez wielu rozmaicie. Jednak rygoryzm interpretacji Tory przez rabinów rozmaitych szkół, szczególnie tej z Qumran, sprawiał, że wielu nawet najbardziej pobożnych Żydów odczuwało zamieszanie w kwestii zbawienia ${ }^{132}$.

Koncepcja wieczności w NT jest zatem dosyć dwuznaczna, odnosi się bowiem do dwóch różnych schematów czasowych: jeden mówi o istnieniu czegoś przez cały czas, drugi o wiecznym istnieniu określonego odcinka czasu, rozumianego często w kategoriach okresu zaczynającego się od pewnego punktu. Czas w tym drugim znaczeniu jest szczególnie wykorzystywany

131 R. Pesch, Il vangelo di Maerco. Parte seconda. Testo e traduzione. Commento ai capp. 8,27-16,20, ed. italiana: ed. M. O. Soffritti, trad. Soffritti, Brescia 1982, s. 215 (Commentario teologico del Nuovo Testamento II/2).

132 J. Gnilka, Marco, trad. G. Poletti, Assisi 1987², s. 548 (Commenti e Studi Biblici). W tym kontekście charakterystyczne są uwagi, jakie poczynił w swoim komentarzu William L. Lane, The Gospel of Mark. The English Text with Introduction, Exposition, and Notes, The New International Commentary on the New Testament, Grand Rapids 1974, s. 365, kiedy, mówiąc o zdecydowanie judaistycznym kontekście pytania o życie wieczne z Mk 10, 17-30, przytacza z ówczesnego judaizmu szereg tekstów paralelnych z pytaniem o życie wieczne: Psalmy Salomona 14,6 (postępujący sprawiedliwie odziedziczą od Boga życie wieczne); analogicznie: Psalmy Salomona 3,16; 14,10; 1 Ksiega Henocha 38,4; 40,9; 48,3; 2 Ksiega Machabejska 7,9; 4 Ksiega Machabejska 15,3; Talmud Babiloński, Traktat Berachot 28b. 
w literaturze apokaliptycznej jako motyw przydatny do opisu przejścia od jednej epoki do drugiej ${ }^{133}$. W oparciu o analizy leksykalne i składniowe, dokonane przez Jamesa Barra, odrzucono we współczesnej biblistyce tezę, iż grecka wersja NT wyraża tylko jedno podejście do czasu - uwzględniające jego nieskończoność, które miałoby odzwierciedlać jedynie hebrajski sposób myślenia ${ }^{134}$. Można zatem dziś mówić, iż w nowotestamentalnej i wczesnochrześcijańskiej literaturze są obecne trzy koncepcje wieczności: (1) wieczność nieograniczona, (2) wieczność ograniczona i (3) życie wieczne:

(1) wieczność nieograniczona odnosi się do przypadków, w których jest ona postrzegana jako rzeczywistość pozbawiona końca i granic, nieograniczona parametrami miar czasowych. W NT takie ujęcie pojawia się rzadko: w kontekstach tych wspomina się o Bogu i Jego egzystencji (wieczny tron i królestwo Boga: Hbr 1, 8; Ap 4, 9. 10; 5, 13; o Chrystusie: Ap 7, 12; 2 P 1, 11; o wieczności Boga i Jego świata: 1 P 1, 25; Ap 10, 6; 15, 7; w doksologiach odnoszących się do Boga: Hbr 13, 21; 1 P 4, 11; 5, 11; w nawiązaniu do Ducha Świętego: Hbr 13, 20). W tekstach ojców apostolskich mamy do czynienia z takim rozumieniem wieczności, gdy jest mowa o wieczności Boga i Jego władzy (Klemens Rzymski, List do Koryntian 35, 3; 55, 6; 61, 2), gdy wspomina się o Chrystusie (Męczeństwo Polikarpa 14, 3), w doksologiach w odniesieniu do nieskończoności Boga (Klemens Rzymski, List do Koryntian 32, 4; 50, 7; 58, 2; 61, 3) i do Chrystusa (Didache 9, 2; 3; Klemens Rzymski, List do Koryntian 64; Homilia z II wieku 20, 5; List do Diogneta 12, 9);

(2) wieczność ograniczona to koncepcja dotycząca egzystencji, która rozpoczęła się w pewnym punkcie i może być rozciągnięta na nową epokę. W NT odzwierciedlają ją teksty Dz 3, 21 (Bóg obiecał wszystko odnowić, co przepowiedział przez swych świętych proroków „od wieków”. Termin „od wieków” dotyczy działalności proroków, posiada wydźwięk apokaliptycznej odnowy dokonywanej przez Boga; analogiczne znaczenia pozabiblijne, w tym u ojców apostolskich: Klemens Rzymski, List do Koryntian 32, 4; List Pseudo-Barnaby 18, 2; Didache 16, 4) i Dz 15, 18 (za pomocą

133 Por. S. E. Porter, wieczność, wieczny, w: R. P. Martin, P. H. Davids, Stownik późnych ksiag Nowego Testamentu i pism ojców apostolskich, [red. wyd. pol. J. Kręcidło], Warszawa 2014, s. 1064 (PSB 39).

134 Por. J. Barr, Biblical Words for Time, London $1962^{2}$ (Studies in Biblical Theology 33). 
Kształtowanie się nauki o niebie w teologii patrystycznej I-III wieku

określeń zaczerpniętych z Iz 45, 21 Jakub dodaje do cytatu z Am 9, 11-12 sformułowanie o „odwiecznych działaniach Pana”, czyli o działaniach znanych od czasu, od kiedy można było je znać). Innym sposobem użycia tej koncepcji wieczności jest odniesienie jej do określonego odcinka czasu, często $\mathrm{z}$ nawiązaniem do przyszłości, często w kontekście władzy Chrystusa (Hbr 13, 8; 2 P 3, 18; 2 J 2) lub pełnienia woli Boga (1 J 2, 17; Ap 22, 5; Hbr 9, 15; 1 P 5, 10). Analogiczne zastosowanie tej koncepcji spotykamy u ojców apostolskich (Hermas, Pasterz 2, 3, 3; List Pseudo-Barnaby 6, 3; 9, 2; 11, 10-11; Ignacy Antiocheński, List do Smyrneńczyków 1, 2; Homilia z II wieku 6, 7);

(3) życie wieczne pojawia się wtedy, kiedy występuje wyrażenie złożone

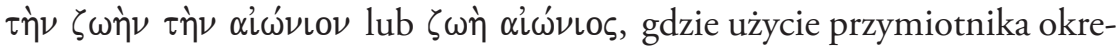
ślającego rzeczownik wskazuje, iż jest to wyrażenie typowo greckie, a nie hebrajskie (gdzie zastosowana byłaby raczej dopełniaczowa forma rzeczownika). Koncepcja ta opisuje warunki obecnej i przyszłej relacji z Bogiem opartej na zbawczym dziele Chrystusa (1 J 1, 2; 5, 20; por. $1 \mathrm{~J}$ 2, 25; 3, 15 ; 5, 11. 13. 20; Jud 21; Dz 13, 46. 48), Hbr 5, 9 mówi podobnie o wiecznym zbawieniu. Koncepcja ta pojawia się także u ojców apostolskich (Hermas, Pasterz Wizja 2, 3, 2; 3, 8, 4; Didache 10, 3; Ignacy Antiocheński, List do Efezjan 18, 1; Homilia z II wieku 5, 5; 8, 4, 6; Męczeństwo Polikarpa 14, 2; 2, 3) ${ }^{135}$.

Teologiczny przekaz Biblii wiąże wszelkie życie i jego jakość wyłącznie z Bogiem. Człowiek nie posiada życia sam z siebie, ale jako jedno ze stworzeń Bożych został obdarowany życiem przez Boga. NT, podobnie jak ST, przedstawia Boga jako Pana życia, który określa trwałość swego daru życia dla wszelkich stworzeń. Bóg w ST jest opisany jako Bóg żywy, obdarzający ludzi życiem i powołujący ich do życia. Obecne życie ludzkie jest kruche, ale święte. Bóg obiecuje swym stworzeniom ciągłość ich życia, bo to Bóg jest źródłem życia ${ }^{136}$. Według NT nowością jest

135 Por. S. E. Porter, wieczność, wieczny, w: R. P. Martin, P. H. Davids, Stownik późnych ksiag..., dz. cyt., s. 1065-1066.

136 ST stale podkreśla, iż Bóg jest życiem i nim obdarowuje. Wzywać „Boga żywego” (Joz 3, 10; Ps 42, 3), oznacza występować w charakterze „sługi Boga żywego” (Dn 6, 21; $3 \mathrm{Krl} \mathrm{18,} \mathrm{10.} \mathrm{15),} \mathrm{przysięgać} \mathrm{się} \mathrm{„na} \mathrm{Boga} \mathrm{żywego”} \mathrm{(Sdz} \mathrm{8,} \mathrm{19;} 1$ Sm 19, 6; Iz 40, 28; Jr 10, 10), to przypominać Jego niezwykłą żywotność. Życie pojawia się na ostatnim etapie dzieła stwarzania jako jego ukoronowanie. (Rdz 1, 21-22. 24. 28). Ludzkim ideałem ST jest to, by cieszyć się jak najdłużej obecnym istnieniem (Koh 11, 8; Ps 27, 13), 
natomiast wskazanie na Jezusa jako na Pana życia (Mt 6, 25; Mk 3, 4 paral.; Mk 12, 27 paral.; J 11, 15. 21; Mt 7, 14; 18, 8n paral.; 9, 6; 16, 25n; 19, 16 paral.; 19, 29 paral.) ${ }^{137}$. W Nim jest życie (J 1, 4; 1 J 1, 1; J 5, 26; $10,10 ; 17,2 ; 14,6 ; 11,25)$, bo Jezus jest życiem (J 10, 11. 15. 17n; $1 \mathrm{~J} 3,16$; 1 Kor 15, 45; Dz 3, 15; Dz 5, 20). Chrześcijaństwo to życie w Chrystusie (J 5, 24; Rz 6, 3; 6, 13; 6, 10n; J 17, 3; 10, 14; Kol 3, 3; 2 Kor 6, 16; Ef 4, 18; 2 P 1, 4; Rz 8, 10; Flp 1, 21). W Chrystusie dokonało się wchłonięcie śmierci przez życie (2 Kor 4, 10; 2 Kor 5, 4; 1 Kor 15, 35-55). Wieczność to bycie w niebie (Ap 6, 9), bycie z Chrystusem (Flp 1, 23; 2 Kor 5, 8), to być podobnym do Boga i oglądanie Go takim, jakim jest (1 J 3, 2), twarzą w twarz $(1$ Kor 13, 12), w ciele chwalebnym i zmartwychwstałym $(\mathrm{Kol} 3,4)$, w Jerozolimie niebieskiej (Ap 21,3), skąd wytryska źródło życia i gdzie rośnie drzewo życia (Ap 22, 1; 22, 14. 19); gdzie nie będzie już więcej śmierci (Ap 21, 4; 20, 14), gdzie wszystko zostanie w pełni poddane Bogu, który będzie wszystkim we wszystkich $(1 \text { Kor } 15,28)^{138}$.

umrzeć, jak Abraham, w szczęśliwej starości i sytości życia (Rdz 25, 8; 35, 29; Hi 42, 17). Dzieci są uważane za przedłużenie życia rodziców (Rdz 15, 1-6; 4 Krl 4, 12-17; Ps 127; 128; Za 8, 4n). Wszystkie istoty żywe podlegają prawu śmierci (Rdz 6, 3; Rdz 47, 8; Hi 14, 1; Ps 37, 36; Mdr 2, 2; Ps 39, 6; Ps 90, 10; Ps 144, 4; Syr 18, 9), a życie jako dar Boży jest zawsze zależne od Boga (Iz 42, 5; Ps 104, 28; Pwt 32, 39). Życie jest święte, bo pochodzi od Boga ( $\operatorname{Rdz} 2,7$; Mdr 15, 11) i do niego prowadzi, który odbiera w chwili śmierci (Hi 34, 14; Koh 3, 19; 12, 7). Dlatego Bóg zabrania wszelkich mordów (Rdz 4, 11-15; 9, 4-5; Wj 20, 13), także na zwierzętach (Kpł 17, 11). Bóg swoim stworzeniom obiecuje ciągłość ich życia (Rdz 3, 22; Ez 18, 32; Mdr 1, 13n; 2, 23); i wskazuje swym stworzeniom „drogi życia” (Wj 15, 26; Wj 23, 26; Kpł 18, 5; Pwt 4, 1. 40; Prz 2, 19; Prz 11, 19; Ps 16, 11; Pwt 30, 15; Jr 21, 8; Ha 2, 4; Ba 3, 14). Bo to Bóg jest źródłem życia (Jr 2, 13; 17, 13; Ps 36, 10; Prz 14, 27; Ps 63, 4; Ps 84, 11). Według proroków zaś istota życia sprowadza się do „szukania Jahwe” (Am 5, 4n; $\mathrm{Oz} 6, \ln$ ). Bóg jest nadzieją grzesznika na życie przyszłe (Ez 33, 11-14; 37, 11-14; Iz 53, 8; 53, 10; 2 Mch 7, 23. 36; Dn 12, 2n) (por. A.-M. Dubarle, Oczekiwanie nieśmiertelności w Starym Testamencie i w judaizmie, „Concilium” 6-7 (1970), s. 214-222).

137 Por. A. S. Jasiński, Chrześcijanin a życie wieczne (Mt 19, 16. 19), w: Szukajcie zawsze oblicza Jahwe. Personalistyczne perspektywy orędzia biblijnego, red. A. S. Jasiński, Opole 1999, s. 189-196; A. S. Jasiński, Osoba arcykaptana a zbawienie wieczne $w$ Liście do Hebrajczyków, w: Szukajcie zawsze oblicza Jahwe..., dz. cyt., s. 197-205.

138 A.-A. Viard, J. Guillet, życie, w: Stownik teologii biblijnej, red. X. L. Dufour, tłum. i oprac. K. Romaniuk, Poznań 1994, s. 1156-1161. 
Kształtowanie się nauki o niebie w teologii patrystycznej I-III wieku

W podsumowaniu rozważń dotyczących greckiej terminologii i koncepcji biblijnych dotyczących eschatologicznego nieba należy stwierdzić, iż podstawowymi motywami teologicznymi są: „wstępowanie” i „zstępowanie”, „powyżej - na wysokości - ponad”, „raj”, „widzenie” Boga, „trwanie - wieczność”. Pozostałymi określeniami NT na oznaczenie stanu zbawionych po śmierci są określenia: „łono Abrahama”, „stać w obliczu Pana”, „być z Chrystusem”, „królestwo niebieskie”, „niebieskie Jeruzalem”, zamieszkanie „w domu Ojca mego”. W NT przeważają motywy przestrzenne, których jest osiem: „wstępowanie” / „zstępowanie”; „powyżej” - „na wysokości - „ponad”; „niebo”, „raj”, „łono Abrahama”, „królestwo niebieskie”, „niebieskie Jeruzalem”, zamieszkanie „w domu Ojca mego”. Natomiast pozostałe cztery to motywy jakościowe: „widzenie” Boga, „trwanie - wieczność”, „stać w obliczu Pana”, „być z Chrystusem” — wskazujące już nie ziemskie, ale niebiańskie przebywanie człowieka z Bogiem.

Naczelnym motywem teologicznym NT dotyczącym życia pośmiertnego zbawionych jest niebo. W NT sformułowanie „raj” pojawia się jedynie 3 razy i oznacza przyszłe miejsce szczęśliwości. Nowością teologii NT jest trynitarne opisywanie nieba: oprócz mieszkania Boga Ojca niebo to mieszkanie Chrystusa, gdzie ostatecznie zasiada po prawicy Boga, skąd przyjdzie na końcu czasów. Z nieba przychodzi także Duch Święty. Motywy przestrzenne „wstępowania” i „zstępowania” oraz „powyżej” - „na wysokości - „ponad” są ewidentnie związane z naczelnym motywem nieba i Boga. Motyw widzenia Boga to metafora opisująca duchowe doświadczenie Boga, a motyw trwania wskazuje na długość istnienia osoby. Związane z tym ostatnim pojęcie „życia wiecznego” nie stanowi centrum orędzia o zbawieniu, przynależy do żydowskiego pojmowania czasu eschatologicznego. U Jana „życie wieczne” jest związane z Wcieleniem Syna Bożego i wskazuje na trwałość życia jako Bożego daru.

\subsection{Rozwój biblijnej koncepcji nieba}

Dla teologii ST i NT wspólny jest podstawowy przekaz teologiczny wszystkich wymienionych motywów dotyczących nieba. NT, powtarzając zasadniczą tematykę nieba znaną ze ST, dodaje nowe wątki teologiczne. 
Własnym dla ST jest motyw „ogrodu (w) Eden” / „ogrodu Boga” - jako obraz pierwotnej płodności, rozkwitu i życia. Własnym dla NT są motywy: „wstępowania-zstępowania” (obok znaczenia przestrzennego, działanie Jezusa, mające wymiar soteriologiczny), „powyżej - na wysokości - ponad” (motyw przestrzenny symbolizujący niebo), „raju” (miejsce szczęśliwości) oraz „widzenia Boga” (niemożliwe w doczesności, nastąpi w czasach ostatecznych - dla ludzi czystego serca). Przy podkreśleniu całej specyfiki językowej i kulturowej, właściwej dla obu przymierzy, zarówno w ST, jak i w NT powtarzają się motywy: „nieba” oraz „trwania” - „wieczności”. Motyw „nieba” w ST odnosi się do symboliki wody; ma wymiar kosmologiczny oraz teologiczny; niebo to mieszkanie Boga, miejsce przyszłego „królestwa Boga”. NT powtarza znaczenia kosmologiczne i teologiczne ST. Wątkami własnymi NT dla tematyki nieba są: niebo to mieszkanie Chrystusa, stamtąd przychodzi Duch Święty; to ojczyzna chrześcijan, zapłata za życie ziemskie, stąd "nowe niebo" to byciem z Chrystusem, miejsce wiekuistej liturgii, końcowy etap Królestwa Bożego. Motyw „trwania / wieczności” w ST odnosi się do wyrażenia najdalszego czasu, przyszłości o określonym okresie, długiego-stałego okresu czasu, czas przymierza Boga z ludźmi i czas stałego zachowywania warunków przymierza. W NT ai $\omega \nu$ wskazuje długość trwania lub trwałość (np. życia), a w ujęciu apokaliptycznym jest rozumiany jako przyszłość, czas eschatologiczny, który nadejdzie.

Wydaje się, że spośród analizowanych wątków tematycznych uprzywilejowanym w Biblii jest motyw nieba, który łączy wszystkie pozostałe. Poniżej zarysuję zatem rozwój teologii „nieba” w Piśmie Świętym.

\section{Znaczenia nieba w Starym Testamencie}

Bóg a niebo. W teologii ST dotyczącej nieba najważniejszą kwestią jest myśl, że to Bóg - Jahwe stworzył niebo i ziemię, czyli cały świat (Rdz 1, 1; Iz 42, 5; Ps 33, 6). Tak jak całe stworzenie, również i niebo, firmament (Ps 19, 2) oraz byty niebiańskie (Ps 29, 9) wychwalają Boga ${ }^{139}$. Według

139 D. T. Tsumura, שָׁמִ (šämájim), w: New International Dictionary of Old..., dz. cyt., vol. 4, s. 163-164. 
Kształtowanie się nauki o niebie w teologii patrystycznej I-III wieku

najstarszych przekonań żydowskich Bóg zamieszkuje na Synaju i stamtąd wkracza w historię (Pwt 33, 2; Sdz 5, 4; Ab 3, 3). Istniało również przekonanie, że Bóg zamieszkuje górę Syjon (Am 1, 2; Iz 8, 18). Obok tych koncepcji geograficznych, spotykamy w ST dosyć heterogeniczną ideę, że Bóg co prawda przebywa na ziemi w świątynnych ciemnościach „świętego świętych" (1 Krl 8, 13), ale nawet wszystkie niebiosa nie wystarczą, aby Go objąć $(1 \mathrm{Krl} 8,27)$. Prawdopodobnie pod wpływem wierzeń kananejskich dotyczących Baala, zostało przyjęte nazywanie Jahwe „Bogiem / Panem nieba” (Rdz 11, 5; 24, 3) lub „królem nieba” (Ps 29, 10). Stąd Jahwe jako król nieba zaczął być nazywany, podobnie jak bóstwa kananejskie, tym, który dosiada obłoków (Pwt 33, 26; Ps 68, 5; Iz 19, 1), będąc władcą nieba, Jahwe wybudował też pałac ponad oceanem niebieskim (Ps 104, 3). Jahwe, opisywany na wzór ugaryckiego bóstwa El, zasiada na tronie niebiańskim otoczony przez byty niebiańskie będące Jego doradcami (1 Krl 22, 19; Iz 6, 3; Hi 1, 6; Ps 82, 1; Dn 7, 9) ${ }^{140}$. Jahwe w otoczeniu swego dworu niebiańskiego jest jednak jedynym Bogiem na niebie i na ziemi (Pwt 4, 39; 10, 14) ${ }^{141}$.

Koncepcja Jahwe zasiadającego na niebiańskim tronie zaczyna przeważać nad wcześniejszymi poglądami na temat Jahwe zamieszkującego na Synaju: z miejsca panowania znajdującego się ponad firmamentem (Wj 24, 9) Jahwe zstąpił na Synaj (Wj 19, 18). Niebo staje się zatem sferą Bożą par excellence ${ }^{142}$. Wątki o zamieszkaniu Jahwe w niebie, skąd pozwala, aby było słyszane Jego słowo, są szczególnie widoczne w teologii Pwt 4, 36; 12, 5. 11. 21; 26, 15. Według tej koncepcji na ziemi, a konkretnie w świątyni jerozolimskiej zamieszkuje jedynie „imię” (shèm). W dalszym ciągu jest powtarzane stwierdzenie, że wszystkie niebiosa nie wystarczą, aby objąć Jahwe, ani świat widzialny, ani ten niewidzialny nie są w stanie objąć Jahwe, gdyż są one tylko Jego stworzeniem, a On zawsze jest wyższy od każdego stworzenia i nie pozwala się zamknąć w jakikolwiek sposób (1 Krl 8, 27; Ps 113, 5). Jak Jahwe jest w niebie, tak i jego słowo, które trwa na wieki ma w niebie swą siedzibę (Ps 89, 3; 119, 89). Człowiek pobożny

140 Por. G. von Rad, oủpavós, B. Altes Testament, w: Theologisches Wörterbuch zum Neuen..., dz. cyt., Bd. V, s. 503-507.

141 Por. H. Bietenhard, oủp $\alpha$ ós, w: Dizionario dei concetti biblici..., dz. cyt., s. 285.

142 Por. D. T. Tsumura, שָמֵַי (šämájim), w: New International Dictionary of Old..., dz. cyt., vol. 4, s. 164. 
lamentuje nocą, że Jahwe pozostaje w ukryciu (Lm 3, 44), dlatego Go wzywa, aby rozdarł niebo i zstąpił (Iz 63, 19). Bóg, który mieszka w niebie, jest wzywany (Pwt 26, 15; $1 \mathrm{Krl}$ 8, 30) poprzez wznoszone ku niebu ręce (Wj 9, 29.33), podobnie jest przyzywany w momencie przysięgania (Pwt 32, 40). Wybrańcy Jahwe mogą być przez Niego porwani do nieba ( $\operatorname{Rdz} 5,24 ; 2 \mathrm{Krl}$ 2, 11; Ps 73, 24). Stanowi to znak szczególnego wybrania, ponieważ dla ST niebo nie było miejscem przebywania zmarłych czy błogosławionych po śmierci, gdyż zstępowali oni do Szeolu. Niebo w wierze antycznego Izraela nie stanowiło zatem centralnego punktu odniesienia dla wierzeń dotyczących życia pośmiertnego; było ono wspominane okazjonalnie i uznawane za miejsce zbawienia przygotowywanego dla Izraela, lecz samo zbawienie zawsze miało dokonać się na ziemi ${ }^{143}$.

Opisy nieba. ST przekazuje wielość koncepcji starożytnego Wschodu dotyczących nieba. Niebo, ziemia i piekło tworzą razem budowlę świata (Wj 20, 4; Ps 115, 15-17). Powyżej płaskiego dysku ziemi, otoczonego oceanem, znajduje się niebo lub firmament wyobrażany jako powłoka lub kulista sfera ${ }^{144}$. Ponad tym niebem rozciąga się niebiański ocean (Rdz 1, 8; Ps 148, 4-6). Ponad widzialnym firmamentem ziemi znajdują się inne sfery niebiańskie. Echa podobnych wyobrażeń nieba można odnaleźć w wyrażeniach „niebiosa niebios” (Pwt 10, 14; 1 Krl 8, 27; Ps 148, 4). W ST brakuje natomiast wyobrażenia nieba i świata posiadającego wartość normatywną i sakralną, które byłoby osadzone w ramach precyzyjnie określonego modelu kosmologicznego ${ }^{145}$. Starotestamentalne opisy nieba są raczej racjonalne, nawet jeśli $\mathrm{w}$ dyskursie pobrzmiewają elementy mitologiczne ${ }^{146}$. I tak niebo ma okna $(\operatorname{Rdz} 7,11 ; 2 \mathrm{Krl} 7,2)$, przez które mogą staczać się w dół wody przetrzymywane w niebie; niebo opiera się

143 Por. G. von Rad, oủp $\alpha$ óc, B. Altes Testament, w: Theologisches Wörterbuch zum Neuen..., dz. cyt., Bd. V, s. 509; H. Bietenhard, oủpavós, w: Dizionario dei concetti biblici..., dz. cyt., s. 285; P. S. Johnston, Cienie Szeolu. Śmierć i zaświaty w biblijnej tradycji żydowskiej, tłum. P. Sajdek, Kraków 2010, s. 83-103.

144 Por. B. W. Matysiak, Niebo w hebrajskim obrazie świata, „Studia Theologica Varsaviensia" 38 (2000) nr 1, s. 295-304.

145 Por. G. von Rad, oủp $\alpha \nu$ ó, B. Altes Testament, w: Theologisches Wörterbuch zum Neuen..., dz. cyt., Bd. V, s. 502.

146 Por. D. T. Tsumura, שָָמִ (šämájim), w: New International Dictionary of Old..., dz. cyt., vol. 4, s. 160-163. 
Kształtowanie się nauki o niebie w teologii patrystycznej I-III wieku

na kolumnach (Hi 26, 11) albo na fundamentach (2 Sm 22, 8); jest ono rozciągnięte jak namiot (Iz 40, 22; 44, 24; Ps 104, 2) lub jak rozwinięty zwój księgi (Iz 34, 4); może ono być także rozdarte (Iz 63, 19). Kosmos jest porównywany do domu, gdzie niebo stanowiłoby strop (Ps 104, 3; Am 9, 6). Oprócz firmamentu także przestrzeń powietrzna ponad ziemią jest w ST określana jako niebo ( $\operatorname{Rdz} 1,26 ; 6,7)$. Ponad firmamentem znajdują się zbiorniki śniegu, gradu ( $\mathrm{Hi} 38,22)$, wiatrów (Jr 49, 36; Hi 37, 9; Ps 135, 7) i wody (Ps 33, 7; Hi 38, 37), która po nawodnieniu ziemi deszczem jest przeznaczona do powrotu do nieba (Hi 36, 27; Iz 55,10). W sensie przestrzennym można mówić o czterech krańcach nieba (Jr 49, 36; Za 2, 10; 6, 5; Dn 7, 2). Człowiek nie może wstąpić do nieba (Pwt 30, 12; Prz 30, 4). Próba zbudowania wieży sięgającej nieba była zarozumiałą głupotą, która została ukarana $(\mathrm{Rdz} 11,4)^{147}$.

Niebo w ST jest synonimem trwałości (Pwt 11, 21; Ps 89, 30). Jednak prorocy przepowiadają sąd nad niebem, który będzie kosmiczną katastrofą (Am 8, 9; Jr 4, 23-26; 13, 13; 34, 4; 50, 3; Iz 51, 6). Po tym sądzie nastąpi stworzenie nowego nieba (Iz 65, 17; 66, 22). Wyrażenie „wojska / zastępy niebieskie” odnosi się zarówno do gwiazd ( $\mathrm{Rdz} 2$, 1; Pwt 4, 19; Sdz 5, 20), jak i do nieziemskich bytów duchowych (1 Krl 22, 19; Hi 1, 6). Wojska niebieskie mają wojownika (Joz 5, 14), który dosiada rumaków z ognia (2 Krl 2, 11; 6, 17). Prawdopodobnie pod wpływem wierzeń asyryjskich rozprzestrzenił się kult wojsk niebieskich, przeciwko któremu protestowali prorocy (2 Krl 17, 16; 21, 3). Dlatego wyjątkową jest wzmianka Pwt 4, 19, że Izrael nie będzie oddawał czci ciałom niebieskim i wojskom niebieskim, gdyż „Pan Bóg twój przydzielił je wszystkim narodom pod niebem”148.

W ST niebo nie posiada jakichkolwiek funkcji władzy. Wskazuje na to $\mathrm{np}$. opis $\mathrm{z} \operatorname{Rdz} 1,14$, że gwiazdy na firmamencie są porównane do lamp, które służą do oddzielania dnia od nocy, co z kolei jest pomocne do wyznaczania pory roku czy dnia. Opis biblijny różni się zatem od

147 Por. G. von Rad, oủpavós, B. Altes Testament, w: Theologisches Wörterbuch zum Neuen..., dz. cyt., Bd. V, s. 502-503; H. Bietenhard, oủpavós, w: Dizionario dei concetti biblici..., dz. cyt., s. 284.

148 Por. G. von Rad, oủp $\alpha \nu$ ó , B. Altes Testament, w: Theologisches Wörterbuch zum Neuen..., dz. cyt., Bd. V, s. 503; H. Bietenhard, oủp $\alpha \nu$ ó, w: Dizionario dei concetti biblici..., dz. cyt., s. 284. 
1. Biblijne terminy, koncepcje i obrazy dotyczące nieba

mocno zmitologizowanych antycznych koncepcji religijnych Egiptu ${ }^{149}$ czy Bliskiego Wschodu ${ }^{150}$, gdzie spersonifikowane bóstwa czy ich wozy

149 A. Niwiński, Egiptu starożytnego religia, w: Religia. Encyklopedia..., dz. cyt., t. 3, s. 371, zaznacza, iż według wierzeń staroegipskich w życiu pośmiertnym miało nastąpić przekształcenie człowieka w świetlistą duchową formę Wielkiego Boga, zwaną „ach”, co następowało dopiero po pomyślnym przebyciu Sądu Zmarłych (kiedy życie doczesne człowieka było zgodne z normami „Maat”). Ocenieni pozytywnie łączyli się z Wielkim Bogiem, uczestnicząc przez całą wieczność w jego podróży wokół świata: „ba” („dusza słoneczna”) zmarłego towarzyszyła Słońcu, podczas gdy „ka” człowieka („dusza ozyriańska") zamieszkiwała w mumii. Oba elementy łączyły się okresowo w nocy podczas podróży Słońca przez Krainę Podziemną. Egipska koncepcja życia pozagrobowego zakładała też taką egzystencję wyobrażoną jako pozbawioną trosk kopię życia ziemskiego, co wiązało się z przygotowaniem odpowiedniego wyposażenia grobowego i zabezpieczeniem służby, ofiar pośmiertnych. Trwałość pośmiertnego istnienia zapewniało też, według egipskiej koncepcji, zachowanie imienia zmarłego, czemu służyły inskrypcje, a także nadawanie imion teoforycznych. Więcej na ten temat, zob. A. Niwiński Mity i symbole starożytnego Egiptu, Warszawa 1992.

150 Jak odnotowuje A. Sołtysiak, Mezopotamii starożytnej religie, w: Religia. Encyklopedia PWN, t. 6, red. T. Gadacz, B. Milerski, Warszawa 2002, s. 515, bogowie sumeryjscy czy akkadyjscy, z nielicznymi wyjątkami (sumeryjskie dingir - zapisywane tym samym znakiem co an "niebo", akadyjskie ilu), byli przedstawiani jako istoty antropomorficzne, zamieszkujące niebo i świat podziemny, na ziemi reprezentowane przez posągi ustawiane w świątyniach. Znane są sumeryjskie imiona ponad 2500 bogów, około 30 spośród nich to wielcy bogowie, których kult był rozpowszechniony w całej Mezopotamii. W III-II tysiącleciu przed Chr. zostali oni utożsamieni z semickimi (akadyjskimi i amoryckimi) odpowiednikami. Od III tysiąclecia przed Chr. sporządzane były klasyfikacje bogów, z których najbardziej rozbudowana jest lista An = Anum . Już w III tysiącleciu przed Chr. istniała koncepcja czwórki najwyższych bóstw-stwórców, do których zaliczano Ana, Enlila, Ninhursag i Enki. Często razem wymieniane były także 3 bóstwa planetarne: Nanna-Sin, Utu-Szamasz i Inanna-Isztar, do których w późniejszym okresie dołączano atmosferycznego Adada. Świat w wyobrażeniach sumeryjskich i babilońskich składa się z 3 stref: nieba, ziemi i świata podziemnego. Ziemia jest zamieszkiwana przez ludzi i zwierzęta, w niebie rezydują wielcy bogowie w swoich pałacach, światem podziemnym władają bóstwa świata podziemnego. Wszystkie 3 poziomy połączone są bramami na wschodzie i na zachodzie, przez które przechodzą bóstwa ciał niebieskich i posłańcy bogów, a także cienie zmarłych w drodze do świata podziemnego i demony wychodzące z zaświatów, by karać grzeszników. W babilońskiej tradycji ezoterycznej istniała koncepcja 3 poziomów nieba i 3 poziomów ziemi, zaś w tekstach magicznych przekazywano myśl o 7 niebach i ziemiach. Skojarzenie cyklicznej widoczności ciał niebieskich z koncepcją ustalania przeznaczania przez bogów w miejscu wschodu słońca $(d u k u)$ i następnie ogłaszania go przez bogów słońca, księżyca i bogów nocy doprowadziło do pojawienia się najpierw zainteresowania astromancją, a w okresie schyłkowym cywilizacji sumero-babilońskiej do powstania religii astralnej i astrologii. 
Kształtowanie się nauki o niebie w teologii patrystycznej I-III wieku

kierowały ruchem gwiazd i innych ciał niebieskich, np.: Anu („Władca niebios” - trzeciej najwyższej sfery niebios), Innana / Isztar („Pani niebios”, utożsamiana z planetą Wenus), Nanna(r) / Sin (bóg księżyca), Utu / Szamasz (bóg słońca) ${ }^{151}$. Do nieba, rozumianego tak jak w mitach mezopotamskich (tj. niebo jako siedziba bogów i utożsamiane z samymi bogami), ludzie nie mają dostępu ${ }^{152}$.

W ST stosunkowo rzadko pojawiają się idee astrologiczne (Pwt 18, 9; Iz 47, 13; Jr 10, 2), które występują natomiast często w mitach kosmologicznych starożytnego Bliskiego Wschodu. Pewne echo antycznych koncepcji kosmologicznych spotyka się w ST w tych fragmentach, które mówią o swoistej relacji pomiędzy światem niebiańskim a tym ziemskim, szczególnie kiedy jest mowa o przyodzianiu w godność sakralną. W opisach kapłańskich (Wj 25, 9. 40) przybytek ziemski zostaje zbudowany według modelu niebieskiego („według tego, co ci ukażę”; „według wzoru, jaki zobaczyłeś na górze”). Podobnie Ezechiel mówi o zwoju księgi, który preegzystuje w niebie (Ez 2, 1) czy kiedy Izajasz mówi o mieczu Pana, który upił się na niebiosach, ale i spadnie na Edom potępiony przez Boga (Iz 34, 5). Także przyszły porządek zbawczy jest już obecny w niebie (Za 2) - jego prefiguracją

151 Por. A. Sołtysiak, Bogowie nocy. Motywy astralne $w$ religiach starożytnej Mezopotamii, Kraków 2003; O. Drewnowska-Rymarz, Z. Wygnańska, Mitologie świata - Ludy Mezopotamii, Warszawa 2007, s. 34-61.

152 W religii Mezopotamii panowało przekonanie, że bogowie zarezerwowali nieśmiertelność wyłącznie dla siebie, natomiast po śmierci człowieka jego cień musi udać się do świata podziemnego („królestwa cieni”, w mitologii sumeryjskiej znanego jako „Kur” lub „Ki-Gal” - „Wielka Ziemia”, a w mitologii babilońskiej nazywanego Arallu „Ziemia bez powrotu”), gdzie będzie przebywał niezależnie od swej postawy na ziemi. W w Arallu rozpad ludzkiego istnienia jest porównany do starej szmaty toczonej przez robaki. Natomiast mitologiczna kraina szczęścia - Dilmun, którą władała para bóstw Enki i Ninhursanga, była zarezerwowana wyłącznie dla bóstw i wybranych bohaterów jak Utnapisztim. W religiach Sumerów czy Akadyjczyków brak jest koncepcji odpowiedzialności moralnej czy idei pośmiertnej nagrody za pobożne / dobre życie. Koncepcja osobistej relacji człowieka z bóstwem oraz koncepcja grzechu pojawiają się dopiero w religijności Babilończyków w II tysiącleciu przed Chr. (por. A. Sołtysiak, Mezopotamii starożytnej religie, w: Religia. Encyklopedia..., dz. cyt., t. 6, s. 516). Według mezopotamskich wierzeń eschatologicznych w podziemnym świecie przebywali także bogowie, ale ludzie nie mieli z nimi możliwości kontaktu. Dla zmarłych mieszkańców Mezopotamii nie istniała zatem perspektywa doskonałego i szczęśliwego życia pozagrobowego (por. N. Cohn, Kosmos, chaos i świat przyszty. Starożytne źródta wierzeń apokaliptycznych, tłum. A. Kurowska-Mitas, Kraków 2006, s. 56-57). 
1. Biblijne terminy, koncepcje i obrazy dotyczące nieba

jest będąca w niebie osoba „Syna Człowieczego”, który jest również personifikacją eschatologicznego ludu Bożego (Dn 7, 13) ${ }^{153}$.

\section{Znaczenia nieba w Septuagincie i w późnym judaizmie}

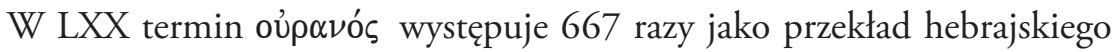
pojęcia shāmajim, poza kilkoma wyjątkami: 51 razy oủp $\alpha \nu$ ó zostaje użyty jako określenie w liczbie mnogiej (niebiosa), co było obce dla ówczesnego języka greckiego ${ }^{154}$, a zostało prawdopodobnie zastosowane w Septuagincie jako ekwiwalencja formalna terminu hebrajskiego shāmajim. Zabieg ten jest w LXX szczególnie widoczny w tłumaczeniu psalmów. Rzeczownik oủ $\alpha \nu$ ós,

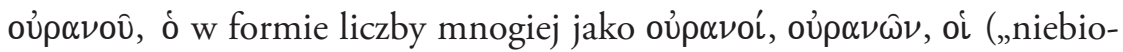
sa”) często występował w ówczesnych tekstach, wyrażając w ten sposób rozpowszechnioną w starożytności na Bliskim Wschodzie ideę wielu niebios (2 Mch 15, 23; 3 Mch 2, 2; Mdr 9, 10; Tb 8, 5). W judaizmie okresu międzytestamentalnego nasilała się tendencja do niewymieniania imienia Boga (por. Wj 20, 7), używając zamiast tego terminów zastępczych, z których jednym był rzeczownik „niebo” (1 Mch 3, 18; 4, 10; Pirkei Avot 1, 3. 11). W konsekwencji także termin „niebo” był zastępowany np. przez hebrajskie określenie māqōm (miejsce) ${ }^{155}$. Natomiast przymiotnik oủpóvıoৎ występuje

153 Por. G. von Rad, oủp $\alpha \nu o ́ \varsigma$, B. Altes Testament, w: Theologisches Wörterbuch zum Neuen..., dz. cyt., Bd. V, s. 502-503; H. Bietenhard, oủpavós, w: Dizionario dei concetti biblici..., dz. cyt., s. 284-285.

154 Por. D. T. Tsumura, שָׁמִ (šämájim), w: New International Dictionary of Old..., dz. cyt., vol. 4, s. 165.

155 Por. H. Traub, oủpavós, C. Septuaginta und Judentum, w: Theologisches Wörterbuch zum Neuen..., dz. cyt., Bd. V, s. 509-511; H. Bietenhard, oủp $\alpha \nu$ s, w: Dizionario dei concetti biblici..., dz. cyt., s. 286. Jak zauważa M. Parchem, Teologiczne znaczenie terminu „niebiosa” jako zastępczego określenia Boga $w$ tradycji biblijnej oraz $w$ literaturze rabinicznej, w: Gloriam praecedit humilitas (Prz 15, 33). Księga pamiątkowa dla księdza profesora Antoniego Troniny w 70. rocznice urodzin, red. M. Szmajdziński, Częstochowa 2015, s. 532, jedynym miejscem w Biblii hebrajskiej, gdzie określenie „niebiosa” staje się synonimem określenia „Bóg” jest tekst Dn 4, 23. Późniejsze świadectwa pochodzące z Ksiąg Machabejskich, Nowego Testamentu czy literatury rabinicznej odnoszące się do posługiwania się terminem „niebiosa” czy innymi terminami zastępczymi na określenie Boga, wynikają bardziej z ogólnej tendencji późnego judaizmu do używania 
Kształtowanie się nauki o niebie w teologii patrystycznej I-III wieku

w LXX tylko 9 razy: aby wskazać na Pana (кúpıoৎ) Izraela (1 Księga Ezdrasza 6, 14); aby opisać moc ('€̧́ovoí $\alpha$ ) Bożą (Dn 4, 26 B); aby określić aniołów jako „zastępy niebieskie” (4 Mch 4, 11; por. Łk 2, 13) oraz wskazać na synów Bożych (2 Mch 7, 34) ${ }^{156}$. Jeśli chodzi o wyrażenie przymiotnikowe

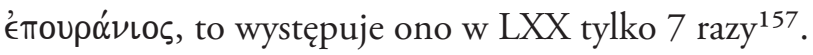

W apokryfach ST oraz w pismach rabinackich okresu międzytestamentalnego spotykamy rozmaite spekulacje duchowe i kosmologiczne. Apokaliptyczni podróżnicy czy rabini podejmują się zatem niebiańskich podróży, skąd przynoszą na ziemię objawienia dotyczące niebiańskich sfer. Opowiadania te nie doprowadziły jednak do powstania w ówczesnym judaizmie jakichś normatywnych doktryn eschatologicznych dotyczących nieba ${ }^{158}$. Dlatego w jednych apokryficznych apokalipsach ST spotykamy opowiadania o jednym niebie (Ksiega Henocha wersja etiopska; 4 Ksiega Ezdrasza, syryjska Apokalipsa Barucha), inne apokalipsy mówią o trzech niebach (Testament Lewiego 2), kolejne już o pięciu niebach (grecka Apokalipsa Barucha), czy wreszcie spotykamy opowiadania o siedmiu niebach (Apokalipsa Abrahama, Ksiega Henocha wersja stowiańska, tradycja rabinacka) ${ }^{159}$. Bliskowschodniego pochodzenia jest również doktryna, według której każda rzeczywistość ziemska ma swój archetypiczny odpowiednik w niebie, a każde ziemskie wydarzenie jest prefiguracją wydarzenia niebiańskiego (późnojudaistyczna koncepcja ’’ $\alpha \omega$ ). Stąd z jednej strony pod postacią objawień anielskich są przekazywane doktryny astronomiczne (Księga Henocha wersja etiopska 72-82; Księga Jubileuszy), z drugiej strony mówi się o fenomenach atmosferycznych typu deszcz czy grad, które swe źródło mają w niebie, gdzie są gromadzone w oddzielnych zbiornikach.

terminów zastępczych w odniesieniu do osoby Boga, niż z praktyki unikania używania imienia Boga z powodu szacunku dla Jego świętości ze względu na przykazanie z Wj 20, 7.

156 Por. H. Traub, oủpóvıos, w: Theologisches Wörterbuch zum Neuen..., dz. cyt., Bd. V, s. 537.

157 Por. H. Traub, '̇тoupóvııৎ, w: Theologisches Wörterbuch zum Neuen..., dz. cyt., Bd. V, s. 539.

158 Por. H. Traub, oủpavós, C. Septuaginta und Judentum, w: Theologisches Wörterbuch zum Neuen..., dz. cyt., Bd. V, s. 511-512.

159 Por. D. Iwański, Mieszkanie Boga w niebie wedtug Ksiegi Czuwajacych (1 Henoch 14, 8-23), „Collectanea Theologica” 79 (2009) nr 2, s. 101-112. 
W literaturze międzytestamentalnej aniołowie byliby postrzegani jako administratorzy zarządzający poszczególnymi procesami dokonującymi się na niebie lub w atmosferze ${ }^{160}$.

W opinii autorów tekstów apokryficznych ST raj niebiański byłby usytuowany w trzecim niebie (Księga Henocha wersja stowiańska 8, 1-8, Apokalipsa Mojżesza 37), natomiast według poglądów autorów tradycji rabinackiej, raj znajdowałby się w siódmym niebie. Według późnojudaistycznych przekonań również piekło pojmowane jako $\gamma^{\prime} \in \nu \nu \alpha$ miałoby znajdować się w niebie. Tak rozumiana Gehenna stanowiłaby miejsce, do którego po śmierci byłyby kierowane dusze, które oczekiwałyby na sąd na podstawie czynów, których człowiek dokonał za życia, nim przejdzie do 'ôlām habbā (hebrajskiego „świata, który nadejdzie”; por. Pirkei Avot 2, 21). W okresie międzytestamentalnym rozważano tematykę niebiańskiej Jerozolimy. Szczególnie zastanawiano się nad niebiańskim tronem Boga (w odniesieniu do tekstów Ez 1, 1; 24, 9-11; 1 Krl 22, 19; Iz 6, 1; Dn 7,9$)$, nad aniołami w niebie, ich imionami, nad ołtarzem niebiańskim, gdzie archanioł Michał składa ofiarę, a inne byty niebiańskie oddają Bogu chwałę. W tradycji późnojudaistycznej podkreślano również tematykę niebiańskiego skarbu ( $\theta \eta \sigma \alpha u \rho o ́ \varsigma)$, w którym byłyby przechowywane dobre ludzkie czyny. Nie mniej istotnym był przekaz o księgach i tablicach niebiańskich, gdzie byłyby zapisywane do dnia Sądu Ostatecznego ludzkie zasługi i przewiny. W niebie znajdowałby się również szatan, pojmowany albo jako oskarżyciel ludzi przed Bogiem (tradycja starotestamentalna, np. Hi 1, 1), albo jako moc wroga Bogu (tradycja późnojudaistyczna). Według Filona z Aleksandrii, który łączy idee greckie z późnojudaistycz-

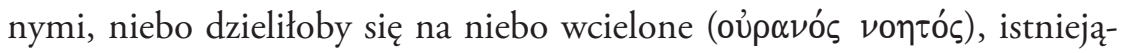
ce w idei wyobrażeń intelektualnych, oraz na niebo pojmowane zmysłami

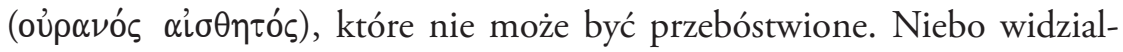
ne i rzeczy ziemskie zależą od nieba duchowego. Niebo stanowi realizację jedności całego kosmosu. Filon mówi o człowieku niebiańskim jako

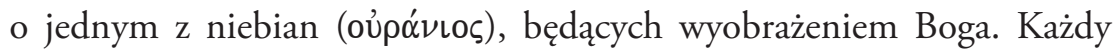
człowiek jest obywatelem nieba w mierze, w jakiej partycypuje w owym

160 Por. H. Bietenhard, oủp $\alpha$ ós, w: Dizionario dei concetti biblici..., dz. cyt., s. 286. 
Kształtowanie się nauki o niebie w teologii patrystycznej I-III wieku

człowieku bożym. W tym sensie Filon mówi też o cnocie niebiańskiej i cnocie ziemskiej ${ }^{161}$.

\section{Znaczenia nieba w Nowym Testamencie}

\section{Termin}

W NT termin oủpavó 94 razy. Pojęcie to najczęściej pojawia się u Mt - 84 razy (58 w l. mn.), gdzie

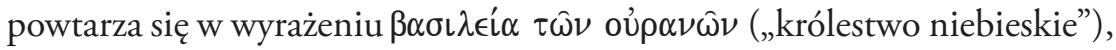
w Ap 54 razy (1 w l. mn.), następnie u Łk - 37 razy (5 w l. mn.), w Dz 26 razy ( 2 w l. mn.), u J - 19 razy (co ciekawe, nie występuje u J nigdy w l. mn.), w listach Pawła - 10 razy, 11 razy u Hebr (8 w l. mn.), 6 razy w 2 P. W NT, począwszy od Mt, przeważa użycie terminu niebo w liczbie pojedynczej. Natomiast w liczbie mnogiej, jako oủ ó́ $\nu \iota \varsigma$, termin pojawia się 6 razy u Mt, kiedy jest powtarzana formuła „wasz Ojciec niebieski” (Mt 5, 48; 6, 14. 16. 32; 23, 9) lub w zwrocie „mój Ojciec niebieski” (Mt 15, 13; 18, 35). Oba wymienione wyrażenia są grecką ekwiwalencją wyrażenia aramejskiego, którego sens w innych miejscach NT zostaje oddany jako „mój (twój, wasz)

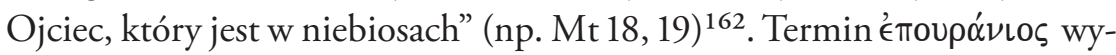
stępuje w NT 18 razy, z czego 10 razy w tekstach Pawłowych, 6 razy u Hbr i po jednym razie u J i w listach katolickich. Zważywszy na dosyć ograniczone użycie przymiotnika oủpó $\nu$ เo $\mathrm{w}$ NT, terminem preferowanym i sto-

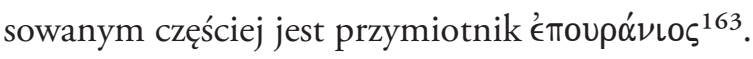

\section{Bóg a niebo}

Według NT w niebie są aniołowie, opisywani jako słudzy i posłańcy Boga (Mt 18, 10; Mk 12, 25; 13 paral.; Ef 3, 15; Ap 12, 7; 19, 1). Aniołowie zstępują i wstępują do nieba (Mt 28, 2 paral.; Łk 2, 15; 22, 43; Ga 1, 8),

161 Por. H. Traub, oủp $\alpha \nu$ ó , C. Septuaginta und Judentum, w: Theologisches Wörterbuch zum Neuen..., dz. cyt., Bd. V, s. 512; H. Bietenhard, oủpavós, w: Dizionario dei concetti biblici..., dz. cyt., s. 286.

162 Por. H. Traub, oủpavós, D. Neues Testament, w: Theologisches Wörterbuch zum Neuen..., dz. cyt., Bd. V, s. 512-513.

163 Por. H. Bietenhard, oủpavós, w: Dizionario dei concetti biblici..., dz. cyt., s. 286. 
tak podróżujących aniołów dostrzega posiadający apokaliptyczne wizje (Ap 10, 1; 18, 1). Szatan został wygnany z nieba i nie może wnosić oskarżenia przeciwko wspólnocie Jezusa (Łk 10, 18; J 12, 31; Ap 12, 12; por. LXX Iz 49, 13). Z tego faktu cieszą się niebo i święci, apostołowie, prorocy oraz męczennicy w niebie (Ap 18, 20;11, 12; 7, 14). Na tym ostatnim przykładzie widać rozwój koncepcji kosmologicznej nieba i głęboką różnicę pomiędzy wyobrażeniem nieba z okresu międzytestamentalnego (późny judaizm, apokaliptyka) a chrześcijańskim wyobrażeniem nieba. Wraz z wyrzuceniem szatana z nieba, co dokonało się w konsekwencji zbawczego dzieła Chrystusa, znika z nieba wszelki element związany z ciemnością i złem, a niebo staje się światem czystym i pełnym światła. Ten ostatni element podkreślają niektóre apokryfy NT, np. Wniebowstaqienie Izajasza 6-11. Kiedy natomiast autorzy NT mówią o potęgach zła przebywających w niebie, odnoszą się zawsze do przestrzeni powietrznej oraz do firmamentu (Ef 2, 2; 3, 10; 6, 12; Dz 7, 42). Oznacza to, że sfera tych duchów znajduje się poniżej świetlistego nieba Boga ${ }^{164}$.

W pełnej harmonii z teologią ST, także w NT, Bóg jest opisany jako stwórca nieba i ziemi (Dz 4, 24; 14, 15; 17, 24; Ap 10, 6; 14, 7) oraz jako Ten, który stworzy je na nowo (2 P 3, 13; Ap 21, 1). Dlatego obecne niebo, podobnie jak ziemia, jest przemijające (Mk 13, 31 paral.; Hbr 12, 26; 2 P 3, 7. 10. 12; Ap 20, 11). Natomiast słowo Jezusa jest nieprzemijające (Mk 13, 31 paral.). Bóg jest Panem nieba i ziemi (Mt 11, 25; Dz 7, 49; 17, 24; Mt 5, 34; por. Iz 66, 1). W NT, podobnie jak w ST, Bóg jest czasami określany jako „Bóg nieba” (Ap 11, 13; 16, 11). Niebo jest tronem Boga (Mt 5, 34) lub też spotykamy w NT określenie, iż Boży tron jest w niebie (Dz 7, 49; Hbr 8, 1; Ap 4). Stąd, zgodnie z późnojudaistycznym sposobem wyrażania, termin niebo może w NT pełnić także funkcję pojęcia zastępczego na określenie Boga (Mt 5, 10; 6, 20; Mk 11, 30; Łk 10, 20; 15, 18. 21; J 3, 27), szczególnie w wyrażeniu typowym dla Mt „królestwo niebieskie" (Mt 3, 2; 4, 17).

$\mathrm{Z}$ teologicznego punktu widzenia najważniejszym wyrażeniem nowotestamentalnym związanym z niebem jest: „Ojciec, który jest w niebie” (Mt 5, 16. 45; 6, 1. 9; 7, 11. 21; 10, 32; 12, 50), które wskazuje, że w osobie

164 Por. H. Bietenhard, oủp $\alpha$ ós, w: Dizionario dei concetti biblici..., dz. cyt., s. 287. 
Kształtowanie się nauki o niebie w teologii patrystycznej I-III wieku

Jezusa Chrystusa Bóg zwraca się do ludzi. Jeśli Bóg jest w niebie, to Jego objawienie zstępuje z nieba (Mt 11, 27). Podczas chrztu Jezusa lub w innych momentach Jego publicznej działalności, Bóg daje słyszeć z nieba swój głos (Mk 1, 11 paral.; J 12, 28; por. Hbr 12, 25). Obdarzony darem widzenia odbiera głosy z nieba (Ap 10, 4. 8; 11, 12; 14, 13; 18, 4; 21, 3). Zawsze z nieba zstępuje Duch Święty (Mk 1, 10 paral.; Dz 2, 2; 1 P 1, 12). Także z nieba gniew Boży zstępuje jak ogień na ludzką bezbożność i nieprawość (Łk 9, 54; 17, 29; Dz 20, 9; Rz 1, 18) ${ }^{165}$.

W NT mówi się o zbawczych dobrach, które są w niebie. I tak nagroda za życie błogosławieństwami znajduje się w niebie (Mt 5, 12; Łk 6, 23). Uczniowie Chrystusa winni gromadzić swe skarby w niebie (Mt 6, 20). W niebie są zapisane imiona uczniów Chrystusa (Łk 10, 20; Hbr 12, 23), gdyż dopiero w niebie uczniowie staną się uczestnikami Boskiej natury $(1 \mathrm{P} 1,4)^{166}$. Dla chrześcijan niebo jest wiecznie trwałym mieszkaniem danym przez Boga, domem nie ręką uczynionym (2 Kor 5, 1) i ojczyzną, skąd w czasie ostatecznym przyjdzie po chrześcijan Chrystus (Flp 3, 20) ${ }^{167}$. Prawdziwa ojczyzna chrześcijan jest określana jako: nowe niebo (2 P 3, 13), górne Jeruzalem (Ga 4, 26), Jerozolima niebieska (Hbr 12, 22), nowe Jeruzalem (Ap 3, 12; 21, 2. 10) albo jako Świątynia Boga w niebie (Ap 11, 19) ${ }^{168}$.

\section{Chrystus a niebo}

Nowotestamentalne określenia nieba nabierają znaczenia w odniesieniu do osoby Jezusa Chrystusa. Od momentu rozpoczęcia Jego misji podczas przyjęcia chrztu Janowego w wodach Jordanu niebo zostaje określone w kontekście trynitarnym: po wyjściu Jezusa z wody natychmiast otwierają się niebiosa, skąd zstępuje na Jezusa Duch Święty, a Bóg Ojciec zaświadcza o umiłowaniu i Bożym synostwie Jezusa (Mt 3, 16). Jezusowe powiedzenie:

165 Por. H. Traub, oủpavós, D. Neues Testament, w: Theologisches Wörterbuch zum Neuen..., dz. cyt., Bd. V, s. 519-522.

166 Por. H. Bietenhard, oủp $\alpha$ ós, w: Dizionario dei concetti biblici..., dz. cyt., s. 288.

167 Por. T. Söding, Mieszkanie Boga dla ludzi. Nowotestamentowa nowina, "Communio” 25 (2005) nr 3, s. 42-51.

168 Por. F. Mickiewicz, Wizja nowego nieba i nowej ziemi w Ap 21,1-22, 5, „Communio” $20(2000)$ nr 4, s. 20-39. 
„Ujrzycie niebiosa otwarte i aniołów Bożych wstępujących i zstępujących na Syna Człowieczego" przenośnie charakteryzuje całość ziemskiego życia Jezusa jako Mesjasza, który łączy ziemię z niebem (J 1, 51; por. Rdz 28, 12). Jezus naucza swoich uczniów modlić się, aby wola Boża wypełniła się na ziemi, tak jak w niebie (Mt 6, 10). Od momentu, kiedy Jezus przekazuje władzę Piotrowi i starszym Kościoła, ich ziemskie działanie nabiera ważności także w niebie (Mt 16, 19; 18, 18; por. J 20, 23). Szczególną opieką ze strony Boga są objęci „mali” ( $\mu$ крós), gdyż jak objaśnia Jezus, ich aniołowie kontemplują oblicze Boga (Mt 18, 10). Jezus z Nazaretu osądzony przez kolegium kapłańskie jest tym samym, który jako Syn Człowieczy

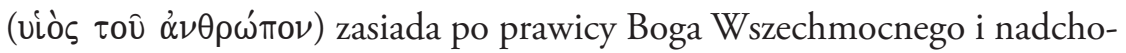
dzi z obłokami niebieskimi (Mk 14, 62; por. Ps 110, 1; Dn 7, 13). W chwili paruzji objawi się na niebie znak Syna Człowieczego (Mt 24, 30). Wtedy też zbierze On swoich wybranych zewsząa - od krańca ziemi aż do szczytu nieba (Mk 13, 27; Mt 24, 31; Łk 21, 27-28; por. Pwt 4, 32; Za 2, 10). Zmartwychwstałemu Jezusowi została dana wszelka władza w niebie i na ziemi, dlatego wszelkie istoty niebieskie, ziemskie i podziemne oddają Mu cześć (Flp 2, 10). Jezus, jako wywyższony Pan i Mesjasz, zsyła z nieba Ducha Świętego, który zbawczo działa w wierzących (Dz 2, 17-21; 32-36). Chrześcijanie oczekują powtórnego przyjścia Jezusa Mesjasza, który przebywa w niebie (Dz 1, 11) aż do czasu odnowienia wszystkich rzeczy (Dz 3, 21). Jezus Mesjasz ma moc, aby otworzyć księgę „zapisaną wewnątrz i na odwrocie, zapieczętowaną na siedem pieczęci”, która jest symbolem wyroków Bożych w sprawie losów świata (Ap 5, 1-5). Całe niebiańskie stworzenie oddaje Mu cześć (Ap 5, 11-14). Jezus wniebowzięty objawia się swoim

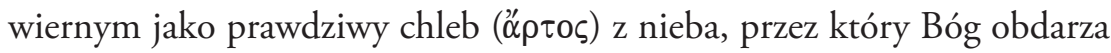
wierzących życiem wiecznym (J 6, 31-38. 41-50) ${ }^{169}$.

Świątynia ziemska jest jedynie cieniem i kopią świątyni Boga w niebie (Hbr 8, 5; 9, 23). Chrystus, który wstąpił do nieba, objawił się jako autentyczny najwyższy kapłan (Hbr 8, 5). Stąd chrześcijanie, jako uczestni-

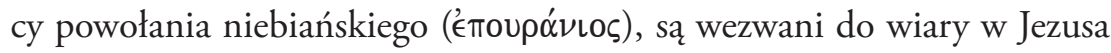

169 Por. H. Traub, oủpavó, D. Neues Testament, w: Theologisches Wörterbuch zum Neuen..., dz. cyt., Bd. V, s. 522-529; H. Bietenhard, oủpavós, w: Dizionario dei concetti biblici..., dz. cyt., s. 288-289. 
Kształtowanie się nauki o niebie w teologii patrystycznej I-III wieku

Arcykapłana i Apostoła chrześcijańskiego wyznania i zdążania do nieba jako do mety tej wiary (Hbr 3, 1; Flp 3, 14). Niebo, jako eschatologiczne zbawienie, jest darem, w którym chrześcijanie już częściowo uczestniczą (Hbr 6, 4; 9, 28). Dla chrześcijan w doczesności, jako ludu pielgrzymującego (Hbr 11, 16), niebo jest eschatologicznym celem: górą Syjon, miastem Boga żyjącego, niebiańskim Jeruzalem, Kościołem pierworodnych, któ-

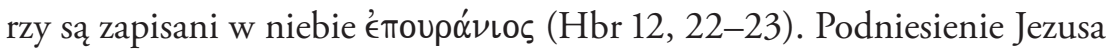
do nieba (Hbr 1, 3; 8, 1) oznacza wypełnienie Jego urzędu kapłańskiego przebył on niebiosa i został ponad nie wywyższony, gdyż dotarł do tronu Boga (Hbr 4, 14; 7, 26; 9, 11. 23) i zasiadł po prawicy tronu Majestatu w niebiosach (Hbr 8, 1). Zdaniem Hansa Bietenharda trudno określić zawartą w księdze koncepcję kosmologiczną. Natomiast wydaje się jasnym, że autor Hbr pojmuje Boga nie jako przebywającego w niebie, czyli wewnątrz swego stworzenia tylko poza. Dlatego Bóg jest ponad stworzeniem albo ponad wszystkimi niebiosami. Opisana idea wyższości Boga ponad stworzenia zostaje zatem wyrażona za pomocą kategorii przestrzennych ${ }^{170}$.

Pawłowe listy dodają kilka istotnych szczegółów do chrystologicznego opisu nieba w NT. Chrystus jest w nich określony jako pośrednik stworzenia (1 Kor 8, 6), bez Niego nic nie ma możliwości istnienia (Kol 1, 1523), a każde stworzenie znajduje swe dopełnienie w Chrystusie (Ef 1, 10; Kol 1, 16. 20). W teologii Pawłowej nie jest zatem dopuszczalne rozłączenie porządku stworzenia i odkupienia, co postulowały kierunki gnostyckie. Chrystus jest pierwszym ze stworzeń i zarazem jest niestworzony (Kol 1, 16), jest Panem wszystkich mocy i potęg (Kol 2, 20). Chrystus wywyższony w niebie jest tym samym, który przebył sfery niebiańskie i zstąpił na ziemię. Oznacza to, że Chrystus zniósł barierę pomiędzy Bogiem a człowiekiem, którą wytworzyły siły zła (Ef 1, 10; 4, 9; Rz 9, 5; por. LXX Ps 67, 9). W ten sposób zostaje odniesiona do Jezusa teza ST, że Bóg napełnia wszystko, niebo i ziemię (Ef 1, 23; 4, 10; por. Jr 23, 24). Wywyższenie Jezusa (Flp 2, 9) zostało zapisane w Ef 1, 10 za pomocą antycznego wyobrażenia gnostyckiego o człowieku pierworodnym, złożonym z głowy i korpusu. Jednak w opisie Pawła nie istnieje inny świat, oprócz świata Chrystusa. Natomiast wyrażenie z Ef 3, 15, gdzie niebo i ziemia są określone jako rody, które mają

170 Por. H. Bietenhard, oủp $\alpha \nu$ ós, w: Dizionario dei concetti biblici..., dz. cyt., s. 289. 
za ojca Boga, zostało prawdopodobnie zapożyczone z terminologii późnego judaizmu (por. Ksiega Henocha wersja etiopska 69, 4; 71, 1; 106, 5). W 1 Kor 15, 40 jest mowa o fizycznej formie ciał niebieskich, czyli prawdopodobnie gwiazd rozumianych jako moce anielskie. Chrystus preegzystujący i zmartwychwstały jest opisany jako człowiek niebieski, a zmartwychwstali w momencie paruzji przybiorą niezniszczalne, nieśmiertelne ciało duchowe na podobieństwo ciała Jezusa (1 Kor 15, 48-53). Sformułowanie,

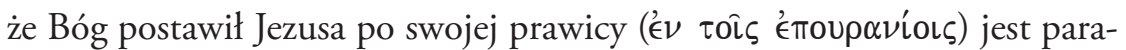
frazą wskazującą, że Jezus jest w niebie i obdarza chrześcijan swym błogosławieństwem duchowym (Ef 1, 3. 20), ponieważ jako Jego wierni są oni już duchowo zmartwychwstali z Chrystusem i jako tacy są uznani za obywateli nieba $(\mathrm{Ef} 2,6)^{171}$.

\section{Opisy nieba}

NT przedstawia obraz świata według antycznych wyobrażeń bliskowschodnich ${ }^{172}$. Spośród ksiąg NT najwięcej kosmologicznych odniesień do bytów i rzeczywistości niebiańskich znajdujemy w Apokalipsie wedtug św. Jana. Zasadniczą optyką tej księgi nie jest jednak kosmologia, ale teologia, a szczególnie soteriologia. Janowa Apokalipsa różni się zatem od apokalips żydowskich okresu międzytestamentalnego właśnie tym, iż jej narracja nie rozpoczyna się od jakichś enigmatycznych doktryn dotyczących nieba. Znaczące jest także to, że Ap nie opowiada o wielu niebach, ale tylko o jednym niebie $^{173}$. Jedynym fragmentem NT, który jest zgodny z późnojudaistyczną doktryną o trzech niebach, jest 2 Kor 12, 3. Paweł nie podaje w nim jednak szczegółowych informacji. W NT, podobnie jak w ST, wyrażenie "niebo i ziemia" wskazuje na całe uniwersum (Mt 5, 18. 34; 11, 25; 24, 35; $Ł k$ 12, 56). Czasami do tego wyrażenia zostaje dołączone morze (Dz 4, 24; 14, 15; Ap 14, 7). Ponieważ w nowotestamentalnym postrzeganiu świata

171 Por. H. Traub, oủpavós, D. Neues Testament, w: Theologisches Wörterbuch zum Neuen..., dz. cyt., Bd. V, s. 529-536; H. Bietenhard, oủpavós, w: Dizionario dei concetti biblici..., dz. cyt., s. 290-291.

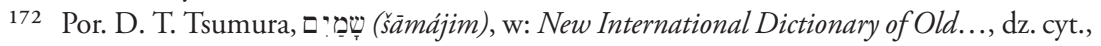
vol. 4, s. 165-166.

173 Por. H. Traub, oủpavós, D. Neues Testament, w: Theologisches Wörterbuch zum Neuen..., dz. cyt., Bd. V, s. 513-514. 
Kształtowanie się nauki o niebie w teologii patrystycznej I-III wieku

niebo zostaje opisywane jako „wyższa” (’’ $\propto \omega)$ część świata, dlatego do tak usytuowanego nieba wznoszą się ręce i oczy wiernych (Mk 6, 41 paral.; 7, 34; Łk 18, 13; J 17, 1; Dz 1, 11; 7, 55; Ap 10, 5). Terminem „niebo” NT określa także przestrzeń powietrzną (Mt 6, 26;16, 2; 8, 20; Mk 4, 32; Łk 8, 5; Dz 10, 12; 11, 6). Na niebie pojmowanym jako firmament umieszczone są gwiazdy. Porządek ten zostanie naruszony na końcu czasów, kiedy gwiazdy podczas paruzji spadną z firmamentu na ziemię (Mk 13, 25 paral.; Ap 6, 13; 8, 10; 9, 1; 12, 4). Na firmamencie mogą pojawić się znaki (Ap 12, 1. 3; 15). Jezus w swoim nauczaniu nie odwołuje się do cudownych znaków dokonujących się na firmamencie (Mk 8, 11 paral.). W przeciwieństwie do Chrystusa dokonuje ich natomiast apokaliptyczna „bestia” (Ap 13, 13) ${ }^{174}$. W NT zachował się także starotestamentalny pogląd, iż niebo jest wielkim zbiornikiem wodnym ponad firmamentem. Bóg zsyła na ziemię deszcz i urodzajne lata z nieba (oủp $\alpha \nu o ́ \theta \in \nu$ ), czyli z oceanu, który znajduje się ponad firmamentem (Dz 14, 17). Natomiast w okresie suszy, niebo pojmowane jako zbiór wód ponad firmamentem, pozostaje zamknięte z rozkazu Boga (Łk 4, 25; Jk 5, 18; Ap 11, 6) ${ }^{175}$.

Przechodząc do podsumowania najważniejszych kwestii związanych z rozwojem biblijnej koncepcji nieba, dobrze jest podkreślić, że ST i NT są spójne w przekazie głównych wątków teologicznych czy kosmologicznych. Zarówno ST, jak i NT podkreślają, że Bóg stworzył cały świat, czyli niebo i ziemię, które jako stworzenie są jednak przemijające, jednak po obecnych zostaną stworzone nowe niebo i ziemia. Obecne niebo jest sferą Boga. Jeżeli według ST, a także apokaliptyki międzytestamentalnej w niebie, oprócz aniołów, mógł przebywać szatan, to według NT został on z niego wygnany i nie może oskarżać wspólnoty Jezusa. Opisy nieba w NT podobne są do starotestamentalnych w wymiarze metafor przestrzennych, nie przekazują też normatywnych doktryn kosmologicz-

174 Por. H. Traub, oủp $\alpha \nu$ ós, D. Neues Testament, w: Theologisches Wörterbuch zum Neuen..., dz. cyt., Bd. V, s. 514-519.

175 Por. H. Bietenhard, oủpavós, w: Dizionario dei concetti biblici..., dz. cyt., s. 287-288. 
nych, ale wychodząc z bliskowschodniej obrazowości świata, opisują niebo w ujęciu teologicznym.

Nowotestamentalną nowością dotyczącą nieba jest jego wymiar chrystologiczny. Najważniejszy teologicznie staje się przekaz, że w osobie Jezusa Bóg zwraca się do ludzi, a Jego objawienie zstępuje od Boga z nieba. W niebie znajduje się prawdziwa ojczyzna uczniów Chrystusa, wiecznie trwałe mieszkanie od Boga. Jeśli niebo w ST z reguły pozostaje zamknięte dla ludzi, to w NT to Jezus otwiera niebo ludziom. Wyłącznie On, jako Pośrednik stworzenia, łączy niebo z ziemią oraz porządek stworzenia z porządkiem odkupienia, On z nieba zsyła Ducha Świętego na chrześcijan, On ma moc nad wyrokami Boga w sprawach świata, On znosi barierę pomiędzy Bogiem a człowiekiem i to On obdarza wierzących życiem wiecznym.

\subsection{Biblijne obrazy nieba}

Obok znaczenia pojęć i koncepcji wyrażonych w kontekście kultury hebrajskiej i greckiej, język Pisma Świętego przemawia przez wielość słownych obrazów i motywów. Biblijne obrazy odwołują się do obrazów znanych z ludzkiego doświadczenia. Jeśli biblijne terminy i koncepcje kształtują percepcję pod kontem analitycznym, racjonalnym i logicznym, to biblijne obrazy, metafory czy symbole kształtują zmysłowo-uczuciowe postrzeganie biblijnego przesłania. Omawiając biblijne obrazy nieba, stosuję definicję obrazu użytą przez Lelanda Rykena, Jamesa C. Wilhoita i Trempera Longmana III: „Obrazem jest każde słowo, które oznacza konkretną rzecz (np. drzewo lub dom) lub czynność (np. bieg lub młócenie). Każdy przedmiot lub czynność, które można przedstawić, staje się obrazem. Obraz wymaga od czytelnika Pisma Świętego podjęcia dwóch czynności. Po pierwsze, należy wyobrazić go sobie tak dosłownie, jak to tylko możliwe. Po drugie, wymaga ogarnięcia zakresu znaczeniowego i ukrytych w nim podtekstów"176. Biblijne obrazy nieba, podobnie jak reszta obrazowości

176 Wprowadzenie, w: Stownik symboliki biblijnej. Obrazy, symbole, motywy, metafory, figury stylistyczne i gatunki literackie w Piśmie Świętym, red. L. Ryken, J. C. Wilhoit, T. Longman III, tłum. Z. Kościuk, [red. wyd. pol. W. Chrostowski], Warszawa 2003, s. XV-XVI (PSB 20). 
Kształtowanie się nauki o niebie w teologii patrystycznej I-III wieku

biblijnej, mówią przede wszystkim o życiu wiary, dlatego równie istotne w ich studium jest wyjaśnienie dosłownego znaczenia warstwy obrazu, wskazanie znaczenia tego, co dany obraz przedstawia.

\section{„Ogród Eden” / „,ogród Boży” / „raj” / „ogród niebieski” / „eschatologiczne miasto - niebieskie Jeruzalem”}

Na płaszczyźnie fizycznej jest miejscem, w którym życie jest zasilane i otaczane stałą Bożą opieką, będąc jednocześnie źródłem radości dla Boga i mieszkańców. Tak opisywany ogród jest symbolem najdoskonalszej formy życia, zaopatrzenia, piękna, obfitości i zaspokojenia potrzeb, zaraz po niebie jest najważniejszym obiektem ludzkiej tęsknoty. Najistotniejszą cechą obrazowości rajskiego ogrodu Eden jest przekaz o doskonałej harmonii: to wspólnota przyjaźni Boga z ludźmi, ludzi między sobą oraz ludzi ze zwierzętami i roślinami ${ }^{177}$. Na podstawie analizy znaczeniowej biblijnego obrazu ogrodu Eden, opisywanego także jako ogród Boży czy raj, można stwierdzić, że Bóg pragnął, by w taki sposób wyglądało ludzkie życie. Jako że Bóg sam zasadził ogród Eden, w jego obrazie jest zawarty element nakazowy i opisowy. Odosobnienie ogrodu Eden wskazuje, że różni się on od znanego powszechnie życia: prostota życia w ogrodzie oraz nagość ludzi, która nie budzi wstydu - zostają przeciwstawione złożoności życia w cywilizacji. Ogrodzenie raju ukazuje zaś granicę pomiędzy pierwotną rajską doskonałością a doświadczeniem świata po grzechu. Pomimo zamknięcia raju, pozostaje on zawsze otwarty dla Boga. Rajski ogród Eden jest też jednocześnie miejscem idealnego odpoczynku i doskonałej pracy człowieka (praca jako źródło spełnienia dla człowieka i dla środowiska; miejsce pracy zapewnione przez Boga, jeśli praca obecnie wykonywana jest posłusznym wypełnieniem Bożego celu, stanowi jednocześnie zapowiedź nowej i doskonalszej formy i miejsca; pierwotny ogród Eden stanowi zapowiedź wiecznego nieba). Rajski ogród Eden jest też miejscem prób moralnych (motyw zakazanego drzewa), które w wyniku rajskiego grzechu doprowadziły

177 D. T. Olson, Ogród w Edenie, w: Stownik wiedzy biblijnej, red. B. M. Metzger, M. D. Coogan, [konsult. wyd pol. W. Chrostowski], Warszawa 1996, s. 576 (PSB 5). 
ludzi do utraty ich duchowego statusu wypływającego z przyjaźni z Bogiem oraz do utraty ogrodu jako rajskiego miejsca do życia ${ }^{178}$. Obraz wygnania z ogrodu w Eden jest u późniejszych proroków zarówno metaforą sądu Bożego nad narodami (Tyrem: Ez 28, 11-19; Egiptem: Ez 31, 8. 9. 16. 18), sądu w dniu Pańskim (Jl 2, 3), jak i obrazem obietnicy odrodzenia ziemi Izraela (Iz 51, 3; Ez 36, 35; por. Ap 22, 2-3) ${ }^{179}$.

W Biblii widać połączenie motywu ogrodu Eden z motywem nieba pojętego jako eschatologiczne miasto - niebieska Jerozolima. Jeśli w Rdz 2 Adam otrzymał od Boga ogród Eden jako doskonałe mieszkanie i doskonałe miejsce pracy, to w Ap 21 nowe Jeruzalem jest już opisane jako doskonałe połączenie ogrodu i miasta Bożego, które zstąpiło z nieba na ziemię. Mieszkają tam zbawieni. Obok znaczącego dla teologii NT motywu zstępowania z nieba, w symbolice eschatologicznego miasta - Nowego Jeruzalem występują motywy ogrodu Eden: rzeka życia wypływająca z Bożego tronu oraz aleja drzew życia, których owoce stanowią pokarm, a liście uzdrawiają narody (Ap 22, 1-2). Nowe Jeruzalem jest jak raj - otoczone murem w którym, w przeciwieństwie do raju, jest jednak stale otwartych 12 bram (Ap 21, 15). Ten ostatni obraz wskazuje na istnienie jakiejś świętej przestrzeni, cechującej się pełnią, jednością i wieczną wymianą (Ap 21, 26) ${ }^{180}$.

\section{Niebo}

Biblijne obrazy nieba wskazują, że jest ono miejscem odmiennym, niż te znane z obecnego świata. Ziemskie obrazy nie występują w niebie w sposób dosłowny, choć ich symbolika jest oddawana przez bardzo wymierne i materialne porównania ${ }^{181}$. To trwałe/wieczne miejsce przebywania Boga (Rdz 24, 7; 2 Krn 36, 23; Ne 2, 4; Iz 6, 1; Ez 1, 26-28), aniołów (Rdz 28, 12; $1 \mathrm{Krl}$ 22, 19; $2 \mathrm{Krn} \mathrm{18,18)} \mathrm{i} \mathrm{zbawionych} \mathrm{(Iz} \mathrm{65,} \mathrm{17-25;}$ Flp 1, 6; 2 P 3, 13). Niebo jest przyrównane do stolicy świętej i wspaniałej (Iz 63, 15; por. Pwt 26, 15), z salą tronową (Iz 6, 1), do przestrzeni ponad sklepieniem, gdzie widać Boga (Ez 1, 26-28), do miejsca na szczycie

\footnotetext{
178 Ogród, w: Stownik symboliki biblijnej. Obrazy, symbole..., dz. cyt., s. 638-639.

179 D. T. Olson, Ogród w Edenie, w: Stownik wiedzy..., dz. cyt., s. 576.

180 Ogród, w: Stownik symboliki biblijnej. Obrazy, symbole..., dz. cyt., s. 640.

181 D. A. de Silva, niebo, nowe niebo, w: R. P. Martin, P. H. Davids, Stownik późnych ksiag..., dz. cyt., s. 645.
} 
Kształtowanie się nauki o niebie w teologii patrystycznej I-III wieku

drabiny ze snu Jakuba, gdzie stoi Bóg ( $\mathrm{Rdz} 28,13)$, do „domu Ojca” „miejsca” (J 14, 2-3). Wizje Apokalipsy św. Jana ukazują, iż Bóg jest dominującą postacią nieba i punktem odniesienia wszystkich rozgrywających się tam wydarzeń. W biblijnych opisach nieba dominują przestrzenne obrazy o charakterze wertykalnym: niebo jest przestrzenią ponad ziemią, oddzieloną od ziemi (Koh 5, 1; Łk 16, 26), wejście do niego jest wkroczeniem na określone miejsce (J 14, 2-3), Bóg z nieba spogląda na ziemię (Ps 14, 2; 80, 15; 102, 20), z nieba na ziemię zstąpił Chrystus (J 6, 33. 38. 42), do nieba z ziemi wstąpił Chrystus (Dz 1, 2. 10. 11. 16), w niebo wpatrują się ludzie znajdujący się na ziemi (Pwt 30, 12; $2 \mathrm{Krl} 2$, 1; Łk 18, 13). Niebo jest opisywane jako: miasto z murami, bramami, ulicami (Ap 20 - 22); miasto to ma ewidentne cechy rajskiego ogrodu Eden (Ap 2, 7; 22, 1-2); to wielki dom z licznymi pokojami, przygotowanymi dla uczniów Chrystusa (J 14, 1-3); niebo ze względu na kult Boga ma też cechy świątyni (Iz 6, 1; Ap 3, 12; 4; 5; 7, 9-12; 11, 19; 15, 5) - choć nie ma w nim świątyni, którą zastępuje obecność Boga i Baranka (Ap 21, 22). W niebie zbawieni podążają wszędzie za Barankiem (Ap 14, 4). Stanowi ono przybytek i mieszkanie Boga z ludźmi, którzy są Jego ludem (Ap 21, 3) i mogą Go oglądać twarzą w twarz (1 Kor 13, 12). Powyższe obrazy oznaczają, iż niebo nie jest już, jak ogród Eden, czasowym miejscem próby, nie jest też znaną rzeczywistością ziemską, ale wyższą formą istnienia - nową ziemią i nowym niebem (Ap 21, 1; por. Hbr 11, 16; Rz 8, 18) ${ }^{182}$.

Odmienność nieba od obecnej ziemskiej rzeczywistości przekazują obrazy stworzeń nieznanych ludzkiemu doświadczeniu (Ez 1, 6-7. 13. 15 18. 21; Ap 4, 6-8; por. 1 Kor 2, 9) oraz obraz blasku i chwały nieba. Blask nieba jest oddawany przez symbolikę jego budulca: niebo jest zbudowane z cennych kruszców, szkła i drogich kamieni, ognia i błyskawic (Ez 1), posiada szklane morze, złote korony miasta niebieskiego, bramy z pereł, ulice ze złota (Ap 21, 2; 21, 11; 21, 18-21). Szkło, poprzez twardość surowca, symbolizuje trwałość, cenne kruszce i kamienie symbolizują wartość i chwałę. Budulec niebieskiego Jeruzalem odbija chwałę Boga, która oświetla miasto, której lampą jest Baranek, w której blasku będą chodzili zbawieni. (Ap 21, 23-24; Ap 22, 5). Trwały blask i chwała Boża nieba wyraźnie

182 Niebo, w: Stownik symboliki biblijnej. Obrazy, symbole..., dz. cyt., s. 579. 
kontrastują ze zmiennością obecnego świata. W teraźniejszości niebo jest przedmiotem tęsknoty i celem ludzkiego życia (Hbr 11, 13-14; 2 Tm 4, 7-8; $1 \mathrm{P} 5$, 4). Obecnie niebo jest niedostępne dla ludzi, co w NT jest oddane przez symbolikę zwierciadła i zasłony (1 Kor 13,13), obłoku (Dz 1, 9), zamkniętych drzwi (Ap 4, 1). Wejście ludzi do nieba jest możliwe dzięki otworzeniu w nim drzwi (Ap 4, 1; por. 15, 5; 19, 11). Ludzie zbawieni, po wejściu do nieba, są również trwale lśniący (Dn 12,3), gdyż stają się filarami świątyni Boga (Ap 3, 12), otrzymują blask gwiazdy porannej (Ap 2, 28), białego kamyka z wypisanym tajemnym imieniem i wody ze źródła życia (Ap 21, 6), wybielonych szat (Ap 7, 14), białych szat (Ap 3, 5. 18; 4, 4; 6, 11; 7, 9. 13), odzienia w bisior lśniący i czysty (Ap 19, 8), czystości moralnej bez plam (Ap 14, 4-5). W niebie dokona się usunięcie cech ułomnych życia ludzkiego po grzechu rajskim: nie będzie tam więcej głodu, pragnienia, palącego gorąca (Ap 7, 16), łez, śmierci, żałoby, bólu (Ap 7, 17; 21, 4), żadnego zła, nieczystości, ohydy i kłamstwa (Ap 21, 25). Człowiek w niebie doświadczy radości i zadowolenia, co wyrażają obrazy mieszkańców nieba jako: zwycięzców w białych szatach (Ap 7, 9), gości przybywających na ucztę weselną (Ap 19,1-9), uczestnictwa w uczcie (Łk 14, 15-24), uczestnictwa w radości swego Pana (Mt 25, 21. 23), uroczystego zebrania świętych (Ap 7, 17). Niebo jest też ukazywane jako miejsce nagrody (2 Tm 4, 7-8; 1 P 5, 4) i odpoczynku (Hbr 4, 9-11; Ap 14, 13) ${ }^{183}$.

\section{Trwałość}

Biblijny obraz trwałości odwołuje się do dwupoziomowej koncepcji wszechświata, która ma odzwierciedlenie w zwrocie: „Bóg jest w niebie, a ty na ziemi” (Koh 5, 1). Biblijne obrazy trwałości podkreślają przeciwieństwo pomiędzy obrazem Boga wiecznego i niezawisłego a czasowego i zależnego stworzenia, co nawiązuje do różnicy pomiędzy światem ziemskim a tym niebieskim. Bóg i niebo są określane w Biblii metodą via negationis - nie przypisuje się im cech będących udziałem śmiertelników. Cechy boskie to „nieprzemijający” (Rz 1, 23; 1 Tm 1, 17), „, niezniszczalny” (1 Kor 9, 25; 15, 24), "niewiędnący” (1 P 1, 4; 5, 4; por. Ps 1, 3; Ez 47, 12), przemienione cechy ciała zmartwychwstałego (1 Kor 15, 35-38). To, co ma związek z Bogiem

183 Por. Niebo, w: Stownik symboliki biblijnej. Obrazy, symbole..., dz. cyt., s. 580-581. 
Kształtowanie się nauki o niebie w teologii patrystycznej I-III wieku

staje się „trwałe”: Boże Prawo (Mt 5, 18), Słowo Pana (1 P 1, 25), łaska Boża (Ps 136; Iz 54, 10), Boża opieka (Ps 121, 8) i miłość (1 Kor 13, 8). Biblia, wskazując na trwałość Boga, przeciwstawia jej przemijalność i zmienność stworzeń (Ps 103, 15-18; Iz 54, 10; 1 P 1, 24-25). Charakterystycznym elementem opisu biblijnego, który wskazuje na trwałość, jest wykorzystanie symboliki szkła: twardość tego surowca łączy się z jasnym światłem, co symbolizuje trwałą sferę, odmienną od cyklicznego, zmiennego świata doczesnego (Ez 1). Innymi, bardziej już względnymi obrazami trwałości w Piśmie Świętym, są „odwieczne pagórki” (Pwt 33, 15), starożytne, dostojne góry (Ps 36, 7), stały cykl zmian w przyrodzie (Koh 1, 4-7) oraz istnienie wszechświata (1 Krn 16, 30; Ps 93, 1; 96, 10) ${ }^{184}$.

\section{Życie pośmiertne zbawionych}

Biblijne obrazy życia po śmierci mają charakter progresywny: od obrazu grobu jako ostateczności w ST do obrazu nieba jako celu ludzkich dążeń w NT. ST upowszechnia obraz śmierci jako ostatecznego oddzielenia zmarłych od żyjących, a nawet od Boga (Ps 6, 6; 30, 10; 31, 18; Iz 14, 11; 38, 1819; Hi 3, 13-19; 10, 21-22). Stan po śmierci opisuje hebrajskie pojęcie šéôl, które oddaje stan nieświadomości, schyłku, snu oraz rozkładu ciała w grobie. Inne fragmenty ST ukazują znikomość obrazów życia po śmierci, jako rzeczywistości, której człowiek chce uniknąć i na pewno nie oczekuje jej z nadzieją (Ps 16, 10; 86, 13; 102, 27). Życie pośmiertne w ST zdaje się nie istnieć, dlatego teksty biblijne tego okresu zachęcają do koncentracji na życiu z Bogiem w doczesności. Łaska Boża wobec wierzących jest wyrażana przede wszystkim w opisach ziemskiej troski o ludzi: błogosławieństwie ziemi i dobytku, błogosławieństwie licznego potomstwa oraz w karze Bożej (wygnanie, śmierć) wobec niewiernych Izraelitów, narodów pogańskich. W ST nieliczne są pozytywne obrazy życia pośmiertnego: myśl o powrocie ducha ożywiającego do Boga w chwili śmierci człowieka (Koh 12, 7); wzięcie do nieba Henocha $(\mathrm{Rdz} 5,24)$ i Eliasza (2 Krl 2, 1-18); nadzieja na życie z Bogiem po śmierci (Ps 1, 3; 12, 28; 16, 10-11; 49, 16; 73, 24; 139, 24); ufność Hioba, że po śmierci będzie oglądał Boga (Hi 19, 24-27); zachowanie świadomości po śmierci w przypadku czarownicy z Endor (1 Sm 28, 1-24);

184 Trwatość, w: Stownik symboliki biblijnej. Obrazy, symbole..., dz. cyt., s. 1024. 
wiara w przebudzenie po śmierci do życia wiecznego lub do hańby-wiecznej odrazy (Dn 12, 1-4; por. Iz 26, 19; Ez 37, 12) ${ }^{185}$.

NT, w przeciwieństwie do dosyć skromnych wypowiedzi ST o życiu pozagrobowym, kreśli szeroką panoramę życia ludzi po ich śmierci. Zasadniczą prawdą soteriologii NT dotyczącą życia po śmierci jest wiara, iż wierzący w Chrystusa już obecnie uczestniczą w mającym się dokonać zmartwychwstaniu i przebywaniu w niebie z Chrystusem (Rz 6, 5; Ef 2,6) oraz że przyszłe życie będzie udziałem wszystkich, lecz zbawieni będą w niebie (1 P 1, 4), a odłączeni od Boga w piekle (1 P 2, 17; Jud 13). Tekst z Łk 16, 17-31 przekazuje też zagadkowy obraz tzw. łona Abrahama, które ma swe paralele w literaturze rabinackiej, gdzie oznacza czasowe miejsce przebywania sprawiedliwych zaraz po śmierci, przed ostatecznym ich uniewinnieniem. Z przypowieści Łk 16, 23 może wynikać również, iż piekło jest także przejściowym miejscem przebywania niewierzącego. O nieskończonych karach piekła mówią natomiast inne teksty NT (Mt 3, 12; 25, 41; 2 Tes 1, 9; Jud 7; Ap 14, 11). Życie pośmiertne dla zbawionych jest przedstawione w NT jako stałe błogosławieństwo. Ap 22, 1-6 opisuje je w kategoriach powrotu zbawionych do stanu pierwotnego błogosławieństwa w ogrodzie Eden.

W nowotestamentalnych obrazach przeszłego życia zbawionych występuje zatem sześć podstawowych motywów teologicznych. Będą to:

(1) doświadczenie zwycięstwa, zwykle przedstawiane przez obraz korony (1 Kor 9, 25; 2 Tm 2, 5; 4, 8; Jk 1, 12; 1 P 5, 4; Ap 3, 11; 6, 2), powiązany z obrazami panowania (Ap 2, 26-27; 3, 21);

(2) nagroda (Mt 25, 21. 23; Kol 2, 18) lub zapłata za wytrwanie w wierze (1 Kor 3, 14; Ap 22, 12);

(3) nieprzemijająca lub niewiędnąca korona chwały (1 Kor 9, 25; 15, 42-57; 1 P 1, 4; 5, 4);

(4) przyszła chwała już istniejąca w niebie (przygotowywana przez Jezusa - J 14, 1-3; zarezerwowana dla wierzących - 1 P 1, 4);

(5) zachowanie tożsamości osobowej i cielesnej po przemianie duchowej w niebie (1 Kor 15; Ap 2, 17);

185 Życie pośmiertne, w: Stownik symboliki biblijnej. Obrazy, symbole..., dz. cyt., s. 1215-1216. 
Kształtowanie się nauki o niebie w teologii patrystycznej I-III wieku

(6) nieustanna aktywność zbawionych i oddawanie czci Bogu (Ap 4; $19,1-9)^{186}$.

Omówienie obrazów biblijnych dotyczących nieba wskazuje, że dosłowna warstwa tekstu biblijnego dotycząca przekazów o „ogrodzie Eden” / „ogrodzie Bożym” / „raju” / „ogrodzie niebieskim” / „eschatologicznym mieście niebieskim Jeruzalem”, niebie czy trwałości/wieczności i życiu wiecznym jest stosowana w Piśmie Świętym jako archetypy pozytywne. Stanowią one wiodące schematy wyobrażeniowe dotyczące miejsc nadprzyrodzonych i właściwości tych miejsc, a jako takie tworzą język uniwersalny, przez swą elementarność bliski każdemu człowiekowi. Biblijna obrazowość nieba dzięki zaangażowaniu wyobraźni niewątpliwie wzbogaca także uczuciowe reakcje czytelnika na orędzie Pisma Świętego dotyczące tematyki nieba. Systematyczne omówienie obrazów biblijnych związanych z niebem wskazuje również na jedność i progresywny charakter orędzia Pisma Świętego. Ową rozwojowość i jedność szczególnie obserwujemy w biblijnym ukazywaniu obrazu ogrodu Eden, który przez obraz raju staje się ostatecznie obrazem nieba. Podobny proces można zauważyć w ukazywaniu przez kolejnych autorów biblijnych jednego z głównych aspektów niebiańskości człowieka: obrazu trwałości życia, który staje się obrazem życia wiecznego.

\subsection{Niebo w koncepcjach filozofii starożytnej a ujęcie biblijne}

W filozofii greckiej pojmowanie nieba było związane przede wszystkim z opisem przestrzennym otaczającego świata. Niebo stanowiło przedmiot refleksji filozoficznej jako część lub miejsce świata, które posiada odmienne charakterystyki od pozostałych części lub miejsc. Było więc bardziej obiektem badań astronomii i kosmologii niż teologii. W czasach kultury presokratejskiej (VI-V wiek przed Chr.) opracowano filozoficznie pierwsze

186 Życie pośmiertne, w: Stownik symboliki biblijnej. Obrazy, symbole..., dz. cyt., s. 1217-1218. 
1. Biblijne terminy, koncepcje i obrazy dotyczące nieba

kosmologie typu naturalistycznego, gdzie niebo stanowiło jakościowe przeciwieństwo ziemi. Anaksagoras (500-428 przed Chr.) utrzymywał, np. że Słońce jest rozgrzanym kamieniem wielokrotnie większym niż półwysep Peloponez ${ }^{187}$.

Z tej perspektywy niebo stawało się przedmiotem badań typu kosmologicznego. Nie one jednak zdeterminowały dalszy rozwój refleksji filozoficznej, na którą wpłynęły przede wszystkim poszukiwania astronomii geometrycznej. Wypracowano wtedy tezę o sferyczności Ziemi (około połowy V wieku przed Chr.), która dość istotnie sugerowała również sferyczność nieba. Pod koniec V wieku przed Chr. w środowiskach pitagorejczyków była już powszechnie akceptowaną teza o uniwersum dwóch sfer, czyli wyobrażenie nieba sferycznego - zwanego także sferą gwiazd stałych, w których centrum znajduje się sferyczna Ziemia. Sokrates w Fedonie (399 rok przed Chr.) mówi już o sferyczności Ziemi jako o przekonaniu rozpowszechnionym niedawno oraz wspomina o sferyczności nieba ${ }^{188}$. Przyjęcie koncepcji sferyczności nieba i ziemi miało wpływ na ukształtowanie się modelowego wyobrażenia o układzie „niebo-ziemia” już nie według pierwotnego pozycjonowania typu „góra-dół”, ale według schematu „centrum-okrąg”. Upowszechnienie się tego ostatniego schematu opisu przestrzennego wpłynęło także na myślenie, iż niebo ogarnia swym zasięgiem wszystko. Wspomniane dwa modele przestrzenne pojmowania układu „niebo-ziemia” widać także w sferze rozwoju pojęć zarówno u Platona (Timajos), jak i u Arystotelesa (O niebie).

187 Por. A. Drozdek, Anaksagoras: kosmos i nieskończoność, „Przegląd Filozoficzny” 4 (2000), s. $5-16$.

188 Jak zauważa E. Voegelin, Platon, tłum. A. Legutko-Dybowska, Warszawa 2009, s. 23, zdaniem współczesnych badaczy historii filozofii antycznej rekonstrukcja Sokratesa „historycznego" jest zadaniem raczej niemożliwym ze względu na brak źródeł tekstualnych (np. W. Jaeger, Paideia, t. 2 - „kwestia sokratyczna”; A. E. Taylor, Socrates; O. Gigon, Sokrates. Sein Bild in Dichtung und Geschichte; R. Guardini, Der Tod der Sokrates). Jedynym bezpośrednim źródłem jest oświadczenie złożone przez jego oskarżyciela Meletosa zachowane w relacji Diogenesa Laertiosa, Żywoty i poglady stynnych filozofów II,40. Natomiast Sokrates, który ukształtował Platona, to Sokrates widziany oczyma Platona. R. Legutko, Sokrates. Filozofia męża sprawiedliwego, Poznań 2013, s. 28-29, wprowadza natomiast założenie, że podstawowym źródłem wiedzy o Sokratesie są wczesne dialogi Platońskie oraz część dialogów z okresu wczesnośredniego i średniego. R. Legutko uznaje także, że po przyjęciu zasady spójności w relacjach o Sokratesie, można korzystać z przekazów Arystofanesa i Ksenofonta, o ile dadzą się one uzgodnić z relacjami Platona, lub mogą na te relacje rzucić nowe światło. 
Kształtowanie się nauki o niebie w teologii patrystycznej I-III wieku

W filozofii greckiej była też znana koncepcja nieba pojmowanego jako miejsce, w którym dusze przebywają przed wcieleniem (opinia Heraklidesa z Pontu) i po śmierci (opinia Plotyna) ${ }^{189}$.

Inną ważna przesłanką, niezbędną przed podjęciem omówienia tematyki nieba w antycznej filozofii greckiej, jest podkreślenie wpływu, jaki wywarł na nią starożytny nurt religijny - orfizm, szczególnie w antropologii i eschatologii. Do najważniejszych nowości orfizmu (VI-V wiek przed Chr.), wobec wcześniejszych poglądów greckich (zapis u Homera - VIII wiek przed Chr. i Hezjoda - VIII-VII wiek przed. Chr.), należy zaliczyć: (1) dualistyczną koncepcję człowieka, która nieśmiertelną duszę przeciwstawia śmiertelnemu ciału i uważa ją za prawdziwego człowieka; (2) wiarę w metempsychozę uwarunkowaną winą w poprzednim wcieleniu; (3) ostateczny cel duszy to: wyzwolenie się z ciała jako miejsca pokuty i zdobycie eschatologicznej nagrody; (4) skłonność ludzi do dobra i zła wynika z podziału człowieka na część dionizyjską - tj. duszę (skłonność do dobra) i część tytaniczną - tj. ciało (skłonność do zła); zadaniem duszy jest wyzwolenie części dionizyjskiej od tej tytanicznej; metempsychoza i cykl kolejnych wcieleń jest bowiem karą za połączenie się ciała z duszą (w micie orfickim: „Tytani pożarli Dionizosa, spaleni piorunem przez Zeusa obrócili się w popiół, z ich prochów powstali ludzie”); (5) oczyszczanie duszy następuje przez udział w cyklu obrzędów i ceremonii oraz praktyki ascetyczne (główna reguła powstrzymywanie się od jedzenia mięsa) ${ }^{190}$.

Po zaznaczeniu istotnych kwestii wstępnych, w niniejszym paragrafie chcę przedstawić najważniejsze wątki antycznej filozofii greckiej dotyczące wyobrażenia nieba, by następnie zestawić je z teologią biblijną.

\section{Pitagorejczycy (koniec VI wieku - początek IV wieku przed Chr.)}

Najwcześniejsze spekulacje filozoficzne dotyczące nieba znajdujemy u pitagorejczyków. W systemie kosmologicznym opracowanym i spisanym przez

189 Por. F. F. Repellini, Cielo - cieli, w: Enciclopedia filozofica, vol. 2, ed. V. Melchiore, Milano 2006, s. 1890-1892.

190 Por. G. Reale, Historia filozofii starożytnej, t. 1. Od początków do Sokratesa, tłum. I. Zieliński, Lublin 2005, s. 447-465. Szerzej na temat orfickiej kosmogonii, zob. G. S. Kirk, J. E. Raven, M. Schofield, Filozofia przedsoktarejska. Studium krytyczne z wybranymi tekstami, tłum. J. Lang, Poznań 1999, s. 37-48. 
Filolaosa z Krotony / albo z Tarentu (lata 470-399 przed Chr.) obserwujemy próbę skoordynowania kosmologii sferycznej z pre-astronomicznym systemem miejsc religijnych. Najbardziej znaczącą dla pitagorejczyków była ich doktryna o muzyce nieba. Zdaniem filozofów tej szkoły cały świat jest zestrojony w harmonii i ukonstytuowany na każdym poziomie przez liczbę. Tak uporządkowany świat pitagorejczycy nazywali kosmosem (termin ten w tym znaczeniu przejmie od nich na stałe myśl zachodnia). W kosmosie pojmowanym przez nich jako harmonia i liczba ciała niebieskie, zataczając kręgi według liczby i harmonii, wydają najpiękniejsze tony, tworząc tym samym muzykę sfer niebiańskich ${ }^{191}$. Akordy i frazy muzyczne byłyby, według pitagorejczyków, efektem słyszalnym określonych ruchów regulowanych przez przekazy wyrażone numerycznie, a skodyfikowanych w teorii harmonii. Ruch nieba byłby regulowany na podstawie tych samych przekazów numerycznych, zatem wytwarzałby swoistą muzykę nieba. Jeśli sfery niebieskie wytwarzałyby muzykę o pełnej harmonii, to Ziemia tworzyłaby muzykę o harmonii częściowej i epizodycznej. Wspomniana muzyka nieba nie byłaby słyszalna przez ludzi (za wyjątkiem Pitagorasa ...), ponieważ ludzie albo są do niej przyzwyczajeni od samych narodzin, dlatego jej nie rozpoznają, albo ludzkie uszy nie są dostrojone do jej odbioru ${ }^{192}$.

Uprawianie nauki było dla pitagorejczyków środkiem do właściwego celu. Pitagoreizm, jako ruch filozoficzny, podobnie jak wcześniejszy nurt religijny orfizm, upatrywał bowiem sens życia ludzkiego w pozaziemskim celu eschatologicznym i w połączeniu się duszy z tym, co boskie. Samo połączenie duszy z ciałem stanowiłoby karę za jakąś pierwotną winę, a zarazem byłoby zadośćuczynieniem za to wykroczenie. Poprzez wielokrotne wcielenia dusza ma odpokutować popełnioną pierwotnie winę. Pitagoras był pierwszym filozofem, który głosił powyższą naukę metempsychozy. Jeśli jednak orficy uważali, że środkami do oczyszczenia duszy byłyby obchody i religijne praktyki świętych misteriów, to pitagorejczycy za drogę oczyszczenia uważali naukę. Jej praktykowanie oczyszcza duszę, to znaczy oswobadza ją od tych związków z ciałem, które zaciągnęła z powodu

191 Por. G. Reale, Historia filozofii starożytnej..., dz. cyt., t. 1, s. 116-117.

192 Por. F. F. Repellini, Cielo - cieli. w: Enciclopedia filozofica..., dz. cyt., vol. 2, s. 1892; G. Reale, Historia filozofii starożytnej..., dz. cyt., t. 1, s. 117. 
Kształtowanie się nauki o niebie w teologii patrystycznej I-III wieku

popełnionej winy i doprowadza ostatecznie do ponownego zjednoczenia duszy z tym, co boskie ${ }^{193}$.

\section{Platon (427-347)}

Dowodził, iż kosmos zmysłowy jest urzeczywistnionym przez Demiurga „obrazem” rzeczywistości ponadzmysłowej ${ }^{194}$. Zdaniem Giovanniego Reale powyższa platońska koncepcja czystego bytu jako „modelu” i tego, co się staje, czyli „obrazu” tegoż modelu oraz Demiurga jako koniecznej przyczyny sprawczej jest główną osią nośną pisanej nauki Platona. Na tej konstrukcji metafizycznej opiera się konstrukcja gnozeologiczna całego platońskiego traktatu kosmologicznego: pierwotny model (jako byt czysty) jest przedmiotem wiedzy. Obraz tego modelu, czyli nasz fizyczny kosmos, jest przedmiotem mniemania. Może być ono zasadne, ale nie osiąga pewności epistemologicznej, jest więc „mitem” (tu: opowiadaniem zasługującym na przyjęcie) ${ }^{195}$.

193 G. Reale, Historia filozofii starożytnej..., dz. cyt., t. 1, s. 119. Większość badaczy dostrzega bardzo wyraźne analogie w eschatologii orfików i pitagorejczyków (np. W. Burkert, Lore and Science in Ancient Pythagoreanism, Harvard 1972, s. 125-136; E. R. Dodds, Grecy i irracjonalność, tłum. J. Partyka, Bydgoszcz 2002, s. 32). Natomiast A. Izdebska, Pitagoreizm. Jedno jako „Arche” $w$ metafizyce, antropologii i polityce, Warszawa 2012, s. 118-119, choć nie zauważa w pitagoreizmie istnienia mitologii o tytaniczności duszy ludzkiej, podkreśla jednak podobieństwa pitagorejskiej i orfickiej wizji losów duszy i jej ostatecznego celu (niebiańskie pochodzenie duszy-element boski, poddanie całej duszy temu, co w niej boskie i podążanie za nim do „nieba”, z którego pochodzi).

194 Platon, Timajos 29a-b: „Świat bowiem jest rzeczą najpiękniejszą spośród zrodzonych, a jego budowniczy jest najdoskonalszą z przyczyn. Konsekwentnie, świat zrodzony w tych warunkach został utworzony według modelu, który jest przedmiotem rozumu i myśli, i jest tym samym. Jeśli tak się rzeczy mają, jest absolutnie konieczne, aby ten świat był obrazem jakiegoś innego świata", w: Platon, Timajos. Kritias albo

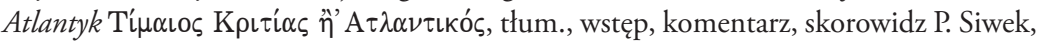
Warszawa 1986, s. 35 (BKF 153). Na temat pojęcia Boga w Dialogach Platona, zob. natomiast opracowanie A. Drozdek, Bóg Platona, „Studia Philosophiae Christianae” 34 (1998) nr 2, s. 87-102.

195 Por. G. Reale, Historia filozofii starożytnej, t. 2. Platon i Arystoteles, thum. I. Zieliński, Lublin 2005, s. 167; szerzej na temat interpretacji mitów platońskich, zob. E. Wolicka, Mimetyka i mitologia Platona. U początków hermeneutyki filozoficznej, Lublin 1994; M. Ksieniewicz, Funkcja mitu w filozofii Platona, „Philosophon Agora” 1 (1999), s. $32-38$. 
1. Biblijne terminy, koncepcje i obrazy dotyczące nieba

Inteligibilnym, niezmiennym i wiecznym bytem jest wyłącznie świat idei, pojmowany przez Platona jako paradygmat lub model dla ustawicznie stającego się, zmiennego, zmysłowego bytu, który jest jedynie obrazem tego pierwszego. Zasady panujące w platońskim kosmosie fizycznym Reale sprowadza do siedmiu podstawowych kanonów ${ }^{196}$ : (1) kosmos fizyczny jest jedynie jedynym obrazem jedynego modelu ${ }^{197}$; (2) na podstawie relacji liczbowych Demiurg ustanawia przyjaźń, tzn. wspólnotę wszystkich rzeczy ze sobą ${ }^{198}$; (3) kosmos jest ukonstytuowany jako jedna całość, ponieważ jest oparty na rachunku liczbowym ${ }^{199}$; (4) sferyczny kształt kosmosu doskonale urzeczywistnia kula, kosmos porusza się ruchem kołowym, który mu został nadany; rządzi się prawem autarkii, która sprawia, że świat jest jeden, ponieważ nie potrzebuje niczego innego ${ }^{200}$; (5) czas stworzony razem

196 G. Reale, Historia filozofii starożytnej..., dz. cyt., t. 2, s. 178-179.

197 Platon, Timajos 31a: „Czy zatem dobrze powiedzieliśmy, że tylko jedno niebo istnieje? Czy też byłoby lepiej powiedzieć, że są liczne nieba, a nawet nieskończona ich ilość? Nie. Istnieje tylko jedno, ponieważ musiało być zbudowane na wzór modelu. W rzeczy samej, ten model, który zawiera wszystkie żyjące jestestwa obdarzone rozumem, nie może być nigdy drugim z rzędu", BKF 153, s. 37. O rozważaniach Platona na temat nieskończoności, zob. natomiast studia A. Drozdek, Infinity in Plato, „Eos” 87 (2000) nr 1, s. 53-62; A. Drozdek, In the Beginning Was the Apeiron: Infinity in Greek Philosophy, Stuttgart 2008, s. 85-100.

198 Platon, Timajos 32b-c: „Dzięki temu postępowaniu z tych elementów tak określonych, w liczbie czterech, zrodziło się ciało świata. Uzgodniony proporcją matematyczną posiada on ze strony elementów taką przyjaźń, że spojony w jedną jedyną całość mógł się zrodzić niemożliwy do rozerwania przez nikogo z wyjątkiem tego jedynego, który go spoił", BKF 153, s. 39.

199 Platon, Timajos 31b-32a: „Otóż najpiękniejszym wiązadłem jest to, które tworzy, o ile to tylko możliwe, jedno jedyne jestestwo z rzeczami, które ono łączy. Skutek ten osiąga najpiękniej proporcja matematyczna. W rzeczy samej, gdy z jakichkolwiek trzech liczb, przedstawiających linie lub płaszczyzny, liczba średnia tak się ma do ostatniej jak pierwsza do średniej, i odwrotnie, jeśli liczba średnia tak się ma do pierwszej jak ostatnia do średniej, wtedy średnia staje się pierwszą i ostatnią. W ten sposób wszystkie terminy mają tę samą funkcję, wszystkie grają tę samą rolę względem siebie; i w tym wypadku wszystkie tworzą doskonałą jedność”, BKF 153, s. 38-39. Zdaniem P. Siwka, BKF 153 , s. 162 , przypis 28 , Platon w powyższym tekście mówi o proporcji geometrycznej, bo tylko w niej można przedstawić miejsca terminu środkowego i terminów skrajnych z zachowaniem proporcji,

200 Platon, Timajos 33b-34a: „Co do kształtu, to Bóg dał światu taki, jaki mu najlepiej odpowiadał i który jest zbliżony do niego. (...). W tym celu zaokrąglił go Bóg w kształt kuli i koła z równymi odległościami od środka do krańców. Ten kształt jest spośród wszystkich najdoskonalszy i najbardziej podobny do siebie samego. (...). Świat 
Kształtowanie się nauki o niebie w teologii patrystycznej I-III wieku

z kosmosem urzeczywistnia swym upływem jedność, ponieważ czas naśladuje wieczność, która jest trwaniem w jedności. Naśladowanie dokonuje się za pośrednictwem liczby ${ }^{201}$; (6) przy tworzeniu czterech zmysłowych elementów materialnych Demiurg, urzeczywistniając w nich obraz modeli idealnych, rozwija złożony układ form i liczb ${ }^{202}$; (7) dusza świata, którą Demiurg stworzył w celu urzeczywistniania inteligibilnego modelu w tym, co zmysłowe, jest jedna, jest jednością i całością ${ }^{203}$. Podsumowując w tym kontekście platońskie wypowiedzi o niebie, Reale potwierdza za Hansem Joachimem Krämerem ${ }^{204}$ i Konradem Gaiserem ${ }^{205}$, że u Platona ciała niebieskie i gwiazdy symbolizują metaidee i liczby idealne, słońce symbolizuje ideę Dobra-Jedna, a rzeczy realne symbolizują poszczególne idee

dostarcza sobie pokarmu za pomocą destrukcji samego siebie. Wszystkie wpływy, jakie odbiera, i wszystkie jego czynności mają źródło w nim samym. (...). Dał mu za to ruch fizyczny zastosowany do jego ciała, ten mianowicie spośród siedmiu ruchów, który ma przede wszystkim związek z rozumem i myślą; nadając mu obrót jednostajny w tym samym miejscu, sprawił, że się kręci w koło", BKF 153, s. 40-41.

201 Platon, Timajos 37d-38a: „Niestety, nie można było dostosować całkowicie do świata zrodzonego tej wieczności, która, jak widzieliśmy, cechuje substancję Żyjącego modelu. Toteż [Bóg] postanowił utworzyć pewien obraz ruchów wiecznych i zajęty tworzeniem nieba, utworzył wieczny obraz bytu wiecznego, nieruchomego, jedynego, i sprawil, że postępuje on według praw matematycznych - nazywamy go Czasem. Dnie i noce, miesiące i lata nie istniały zanim się zrodziło niebo: ich urodziny dokonały się w tym czasie, w którym niebo było budowane. Wszystkie one to część Czasu. Przeszłość i przyszłość są normami zrodzonymi z czasu. A gdy nieświadomie odnosimy je do substancji wiecznej, to dlatego, że nie znamy jej natury. Mówimy bowiem o niej, że była, że jest, że będzie. W rzeczywistości tylko wyrażenie „jest” stosuje się prawdziwie do substancji wiecznej, podczas gdy wyrażenie „był” i „będzie” należy wtedy używać, gdy mowa o tym, co się rodzi i rozwija w czasie. Oznaczają one bowiem ruchy, podczas gdy to, co „jest” nieruchome i niezmienne, ani się nie starzeje, ani nie odmładza w pochodzie czasu, ani nie było chwili, w której by go nie było, ani w której by się dopiero stawało sobą, ani w której miałoby być w przyszłości ”, BKF 153, s. 45. Jak zauważa P. Siwek, BKF, 153, przypis 37, s. 164, czas według Platona jest ściśle związany z ruchem, dlatego nie ma czasu dla rzeczy wiecznych. Każda gwiazda ma swój odrębny czas, także każda rzecz, która trwa, ma swój własny czas.

202 Platon, Timajos 53a-b, BKF 153, s. 68-69.

203 Platon, Timajos 34b-35b, BKF 153, s. 41-42.

204 Por. H. J. Krämer, Platone e i fondamenti della metafisica. Saggio sulla teoria dei principi e sulle dottrine non scritte di Platone, trad. G. Reale, Milano 20016 , s. 194.

205 Por. K. Gaiser, Il paragone della caverna: variazioni da Platone a oggi, Napoli 1985, s. 16 (Memorie dell'Istituto italiano per gli studi filosofici 13). 
1. Biblijne terminy, koncepcje i obrazy dotyczące nieba

gatunków ${ }^{206}$. Niebo fizyczne jest zatem pojmowane i opisywane u Platona astronomicznie i metaforycznie (jako symbol poszczególnych idei).

Eschatologiczne losy duszy przedstawiane przez Platona w mitach eschatologicznych różnią się od siebie, czasami w pewnych aspektach są nawet sprzeczne ze sobą. Jak uważa Reale, należy je odczytywać nie według logiki logosu, ale za pośrednictwem rozmaitych aluzyjnych przedstawień, które mają prowadzić do prawdy meta-logicznej, ale nie anty-logicznej. A zatem eschatologiczne mity platońskie podsuwają wiarę opartą na rozumie, która naucza, iż człowiek na ziemi jest jakby przejściowo, samo życie ziemskie jest zaś próbą. Prawdziwe życie jest na tamtym świecie, w niewidzialnym Hadesie ${ }^{207}$.

Po zakończeniu cyklu metempsychozy, która jest zadośćuczynieniem za życie moralnie złe ${ }^{208}$, właśnie w Hadesie dusza zostaje osądzona na podsta-

206 Por. G. Reale, Historia filozofii starożytnej..., dz. cyt., t. 2, s. 352.

207 Por. J. Wojtczak, Pośmiertne losy duszy $w$ dialogach Platona, „Studia Philosophiae Christianae" 29 (1993) nr 1, s. 73-86; B. Bibik, Wyobrażenia Platona o życiu pozagrobowym, „Nowy Filomata” 6 (2002) nr 1, s. 13-26.

208 Zdaniem G. Reale, Historia filozofii starożytnej..., dz. cyt., t. 2, s. 233-241, nauka o reinkarnacji dusz przyjmuje u Platona trzy formy i trzy znaczenia, które różnią się od siebie. Pierwsza, przedstawiona w Fedonie 81b-82c (tłum. W. Witwicki, Warszawa 1958, s. 80-83) oraz potwierdzona w Timajosie 42 b-d (BKF 153, s. 52), tłumaczy, że dusze, które prowadziły życie w nadmiernym przywiązaniu do ciał wraz ze śmiercią nie potrafią się całkowicie oderwać od tego, co cielesne. Dusze te z lęku przed Hadesem błąkają się przez pewien czas wokół grobów (jako zjawy), a pociągane tym, co cielesne, łączą się na nowo z ciałami, nie tylko ludzi, lecz i zwierząt - w zależności od tego, na jaki niski poziom życia moralnego zeszły w poprzednim życiu. Druga nauka o metempsychozie znajduje się w Państwie X, 617d-621b (tłum. W. Witwicki, Warszawa 1958, t. 2, s. 92-100). Według tej koncepcji liczba dusz jest ograniczona tak, że gdyby wszystkie dusze otrzymały na tamtym świecie wieczną nagrodę lub karę, w pewnej chwili żadna nie pozostałaby na ziemi. Stąd Platon utrzymuje, że pozaziemska nagroda i kara za życie spędzone na ziemi muszą mieć ograniczony czas trwania. Jako, że limitem życia ziemskiego jest ok. 100 lat, Platon przyjmuje w drugiej koncepcji metempsychozy, iż życie pozaziemskie powinno trwać 10 x po 100 lat, czyli tysiąc lat. Natomiast kara dla dusz, które popełniły najcięższe zbrodnie może trwać dłużej. Po przejściu tego cyklu dusze muszą powrócić na ziemię i na nowo wstąpić w ciała. Gdy dusze zakończą tysiącletnią podróż, zbierają się na nowo na równinie i tam zostaje określony ich przeszły los. Wzorce życia znajdują się na kolanach Mojry Lachesis, córki Konieczności. Wybór wzorca jest zaoferowany duszom i pozostawiony ich wolnej decyzji (wybór życia według cnót lub wad). Dokonany wybór zostaje potwierdzony przez dwie inne Mojry: Kloto i Atropos i tak staje się nieodwracalny. Następnie dusze wypijają zapomnienie z wód Rzek Beztroski, zstępują w ciała, w których realizują 
Kształtowanie się nauki o niebie w teologii patrystycznej I-III wieku

wie jednego kryterium: sprawiedliwości i niesprawiedliwości, umiarkowania i rozwiązłości, cnoty i wady ${ }^{209}$. Los dusz może być trojaki ${ }^{210}$ :

wybrane życie. Trzecia nauka o metempsychozie znajduje się w Fajdrosie 246a-249d (tłum. W. Witwicki, Warszawa 1958, s. 70-77). Według tej najbardziej złożonej koncepcji pierwotnie dusza była blisko bogów i w boskim orszaku pędziła życie boskie, a upadła w ciało na ziemię na skutek winy. Pierwotnie dusza byłaby uskrzydlonym powozem, ciągniętym przez dwa konie (dobrego i złego - które symbolizują dwie alogiczne części duszy) i powożonym przez jednego woźnicę (symbol rozumu). Dusze podążają za bogami po drogach nieba, a ich celem jest dotarcie aż do szczytu nieba, aby kontemplować to, co znajduje się ponad niebem (hiperuranium) - świat idei albo Równinę Prawdy. Dusze, którym udaje się Byt albo jego część - żyją razem z bogami, te zaś, którym nie udaje się dotrzeć na Równinę Prawdy, plączą się, zderzają ze sobą, stają się ciężkie i dzięki temu - upadają na ziemię. Dusza ludzka, spadając na ziemię, daje początek życiu ludzkiemu, które jest tym doskonalsze, im więcej dusza zobaczyła w miejscu nadniebnym (hiperuranium). Po śmierci ciała dusza zostaje osądzona i przez tysiąc lat ma się cieszyć nagrodą lub karą w zależności od jakości moralnej ludzkiego życia. Po upływie tysiąca lat znowu powróci, aby wcielić się na nowo. W Fajdrosie miejsce, w którym dusze żyją z bogami i do którego wracają po cyklu 10000 lat oraz miejsce, w którym cieszą się tysiącletnią nagrodą za każde jednostkowe życie na ziemi, są całkowicie różne. Reale podkreśla, że komplikacje losu dusz z Fajdrosa zostają uproszczone w Timajosie - przez wprowadzenie postaci Demiurga, który bezpośrednio stwarza dusze i umieszcza je w gwiazdach, pokazuje im na początku prawdę i powierza zadanie przyobleczenia ich w śmiertelne ciała. Jednak Platon nie jest konsekwentny w modyfikacjach wobec dusz w Timajosie: wprowadzenie Demiurga (który dokonuje wszystkiego ze względu na dobro) powinno bowiem zmienić twierdzenie, że dusze znajdują się w ciele z powodu upadku i doprowadzić do wytłumaczenia życia duszy w ciele w sposób pozytywny. Platon jednak podtrzymuje naukę o metempsychozie jako zadośćuczynieniu za jakieś popełnione przez duszę zło. W Timajosie 42 b-d (BKF 153, s. 52) nagrodą za dobre życie w ciele jest powrót duszy na gwiazdę, którą Demiurg przydzielił każdej duszy.

210 Platon, Fedon 113d-114c: „Otóż, kiedy tam tak jest, to skoro przybędą umarli na miejsce, do którego duch opiekuńczy każdego doprowadza, naprzód sąd się nad nimi odbywa: którzy też życie piękne i zbożne spędzili, a którzy nie. I których życie wyda się ani nadto złe, ani nazbyt dobre, ci idą nad Acheron, wsiadają do łodzi, które tu dla nich są, i przypływają w nich do jeziora. Tu mieszkają i oczyszczają się, a odbywszy pokutę za popełnione winy, wychodzą stamtąd, jeżeli który popełnił coś złego; i za dobre uczynki nagrody tam odbierają - każdy tak, jak zasłużył. A których stan wyda się nieuleczalny dla mnogości grzechów, bo się często wielkiego świętokradztwa dopuszczali albo często zabijali niesprawiedliwie i wbrew prawom, albo inne takie zbrodnie popełniali, tych los im należny miota do Tartaru, skąd nie wychodzą nigdy. A których grzechy wydadzą się wielkie, ale uleczalne, jak na przykład gwałt jakiś dokonany w gniewie na ojcu lub matce, którego potem żałowali i odmienili życie, albo się zabójcami stali w inny jakiś choć podobny sposób, ci muszą wprawdzie spaść do Tartaru 
1. Biblijne terminy, koncepcje i obrazy dotyczące nieba

(1) dusza, która żyła sprawiedliwie, otrzyma nagrodę: uda się do wspaniałych miejsc na Wyspach Szczęśliwych ${ }^{211}$ albo do miejsc jeszcze wyższych i niemożliwych do opisania (np. na swą gwiazdę) ${ }^{212}$;

(2) dusza żyjąca niesprawiedliwie tak, że stała się nieuleczalna w nieprawości, otrzyma wieczną karę i zostanie strącona do Tartaru ${ }^{213}$;

(3) dusza, która zaciągnęła nieprawości uleczalne (po części żyła sprawiedliwie, a po części niesprawiedliwie), a nadto żałuje za swe nieprawości, zostanie tylko czasowo ukarana, a gdy odcierpi za swe winy, wtedy otrzyma ostateczną nagrodę, na jaką zasługuje ${ }^{214}$.

i zostawać tam przez rok, ale ich po roku fala wyrzuca i mężobójców do Kokytosu niesie, a ojcobójców i matkobójców do Pyriflegetonu. A kiedy płynąc z nurtem, znajdą się w jeziorze Acheruzja, wtedy krzyczą głośno i wołają: jedni tych, których byli zabili, drudzy tych, którym wyrządzili krzywdę; wołają ich, zaklinają i proszą, żeby im pozwolili wyjść na brzeg jeziora i chcieli przyjąć do siebie; jeżeli zostaną wysłuchani, wychodzą na brzeg i przestają cierpieć, a jeśli nie, fala ich znowu do Tartaru niesie, a stamtąd na powrót do rzek wrzuca i to cierpienie nie kończy się prędzej, aż im się uda nakłonić i pozyskać tych, których pokrzywdzili. Taką im karę nałożyli sędziowie. A których życie wyda się osobliwie zbożne, ci będą wyzwoleni z tych czeluści podziemnych i wyjdą stamtąd, jak z więzienia, w górę i pójdą mieszkać w czystych stronach, na szczytach ziemi. Do nich należą ci, którzy się umiłowaniem mądrości dostatecznie od zmazy grzechu oczyścili; ci będą później żyli w ogóle bez ciała i pójdą do mieszkań jeszcze piękniejszych niż te, które i opisać nie łatwo i w tej chwili nie czas po temu", tłum., wstęp, objaśnienia i ilustracje W. Witwicki, Warszawa 1958, s. 141-143.

211 Platon, Gorgiasz 523d: „Kto z ludzi sprawiedliwie przez życie przeszedł i zbożnie, po śmierci na Wyspy Szczęśliwe odchodzi i mieszka w szczęściu zupełnym tam, gdzie nie ma zła, a kto niesprawiedliwie i bezbożnie, ten do więzienia idzie, gdzie jest pokuta i sprawiedliwość karząca, a nazywają to miejsce Tartarem”, tłum., wstęp, objaśnienia i ilustracje W. Witwicki, Warszawa 1958, s. 158.

212 Platon, Timajos 42 b: „Jeśli ludzie zapanują nad tymi skłonnościami, będą żyli w sprawiedliwości. Jeśli, przeciwnie, zostaną przez nie opanowani, będą żyli w niesprawiedliwości. Ten, kto będzie żył dobrze przez czas oznaczony, powróci mieszkać do swojej gwiazdy i będzie prowadził na niej życie szczęśliwe, podobne do życia tej gwiazdy", BKF 153, s. 52.

213 Platon, Gorgiasz 525c: „A którzy się już ostatnich zbrodni dopuścili i do tego doszli, że ich uleczyć nie można, z tych się przykłady robią. Ci sami nigdy żadnego pożytku nie mają, bo są nieuleczalni, ale mają pożytek inni: ci, którzy widzą, jak oni, za grzechy, męczarnie największe i najstraszniejsze znoszą przez całą wieczność; po prostu, takie przykłady wiszą tam w Hadesie, w więzieniu dla niegodziwców ustawicznie nadchodzących na widowisko i przestrogę", tłum., wstęp, objaśnienia i ilustracje W. Witwicki, Warszawa 1958, s. 161-162.

214 Platon, Gorgiasz 525b: „A wypada, żeby każdy, kto podlega karze, jeśli mu słusznie karę ktoś nakłada, albo się lepszym stawał i odnosił korzyść, albo był przykładem dla 
Kształtowanie się nauki o niebie w teologii patrystycznej I-III wieku

Reale podkreśla, iż platoński tekst z Gorgiasza 525b-c, niezależnie od zawartych tam pewnych niejasności, zawiera w sobie jedną z najważniejszych intuicji Platona - o oczyszczającej funkcji bólu i cierpienia ${ }^{215}$. Od Gorgiasza do Timajosa, pomimo że zmieniają się u Platona sposoby przedstawienia, pozostaje jednak nienaruszona zasada, iż przeznaczenie eschatologiczne, tzn. inne życie, nadaje sens temu życiu, a ten świat ma znaczenie, o ile ma odniesienie do tamtego świata ${ }^{216}$.

\section{Heraklides z Pontu (390-310 przed Chr.)}

Filozof ten był przedstawicielem koncepcji nieba pojmowanego jako miejsce, gdzie dusze przebywają przed wcieleniem. Pojmował on duszę jako istotę zbudowaną z materii gwiezdnej i świetlistej. Zanim tak rozumiane dusze zstąpią do ciał, przebywają na Drodze Mlecznej, gdzie tworzą niezliczone świecące punkty, które oglądamy z Ziemi. Po odrzuceniu platońskiego „drugiego żeglowania” Heraklides wrócił do ujęcia mistycznego i religijności misteryjnej ${ }^{217}$.

\section{Arystoteles (384-322 przed Chr.)}

Ujmował niebo w trzech znaczeniach: (1) jako wieczną sferę gwiazd stałych; (2) jako zespół sfer planetarnych, z których ostatnia dosięga sfery gwiazd stałych i ulega jej wpływom; (3) jako wszechświat, który obejmuje wszystko, cokolwiek istnieje ${ }^{218}$. Zdaniem Reale niebo w sensie ścisłym od-

innych, aby inni widząc, jak cierpi, cokolwiek by cierpiał, bali się i stawali się lepszymi. A korzyść odnoszą, kiedy cierpią karę z ręki bogów i ludzi ci, którzy uleczalne grzechy popełnili. Zawsze im przecież z bólów i mąk rośnie pożytek i tutaj, i tam, w Hadesie. Bo niepodobna inaczej pozbyć się niesprawiedliwości”, tłum., wstęp, objaśnienia i ilustracje W. Witwicki, Warszawa 1958, s. 161.

215 Por. G. Reale, Historia filozofi starożytnej..., dz. cyt., t. 2, s. 229-231.

216 Por. G. Reale, Historia filozofii starożytnej..., dz. cyt., t. 2, s. 241.

217 Por. G. Reale, Historia filozofii starożytnej, t. 3. Systemy epoki hellenistycznej, thum. I. Zieliński, Lublin 2004, s. 113.

218 Por. Arystoteles, $O$ niebie A 9,278: „Rozpocznijmy od wyjaśnienia, co rozumiemy przez niebo i w ilu znaczeniach jest brane to słowo [jest to sfera gwiazd stałych - uwaga Siwka], by w ten sposób uprzystępnić sobie przedmiot naszego badania. W pierwszym znaczeniu nazywamy niebem substancję najdalszego kręgu wszechświata, czyli ciało naturalne, które się znajduje w tym kręgu zwykliśmy bowiem odnosić nazwę nieba szczególnie do najdalszych i najwyższych regionów, które naznaczamy na siedzibę 
1. Biblijne terminy, koncepcje i obrazy dotyczące nieba

dają tylko dwa pierwsze znaczenia, gdyż trzecie jest synonimem kosmosu. Ten sam badacz uznaje, iż najbardziej typową koncepcją nieba była teoria Arystotelesa, w której twierdził, iż jest ono niezniszczalne, a dla objaśnienia tej niezniszczalności wprowadził teorię eteru ${ }^{219}$. Jak zaznacza Paweł Siwek, doktryna eteru ( $\alpha \imath \theta$ ń $\rho$ ) jako piątego elementu powstała w okresie, kiedy Arystoteles był jeszcze uczniem Platona ${ }^{220}$. W ostatniej fazie rozwoju swej myśli Arystoteles pojmował niebo w drugim znaczeniu, jako ciało, które zajmuje miejsce sąsiadujące z najodleglejszym kręgiem świata. Byłoby ono podzielone na 55 sfer poruszanych przez niematerialne Inteligencje, hierarchicznie podporządkowane Pierwszemu Poruszycielowi ${ }^{221}$.

To Arystotelesowskie niebo ontologicznie jest substancją pośrednią między substancją niematerialną, nieruchomą i wieczną (Bóg i Inteligencje) a substancją zmysłową, ruchomą i zniszczalną. Niebo jest zatem jedno i jest substancją zmysłową, czyli widzialną, ale porusza się tylko

wszystkiemu temu, co jest boskie. W innym znów znaczeniu nazywamy niebem ciało, które zajmuje miejsce sąsiadujące z najodleglejszym kręgiem świata, i gdzie znajduje się Księżyc, Słońce i niektóre gwiazdy, bo zwykliśmy mówić, że znajdują się w niebie [w tym znaczeniu wzięte niebo oznacza zespół sfer planetarnych; ostatnia z nich dosięga sfery gwiazd stałych i ulega jej wpływom - uwaga Siwka]. Jeszcze w innym znaczeniu stosujemy nazwę nieba do ciała zamkniętego najdalszym kręgiem, bo zwykle nazywamy niebem [termin niebo znaczy tutaj tyle co wszechświat i obejmuje wszystko, cokolwiek istnieje - uwaga Siwka] świat pojęty jako całość, w: Arystoteles, Dzieta wszystkie, t. 2, tłum., wstęp, komentarz P. Siwek, Warszawa 1990, s. 258.

219 Por. G. Reale, Historia filozofii starożytnej, t. 5. Stownik, Indeksy i bibliografia, tłum. I. Zieliński, Lublin 2005, s. 144.

220 P. Siwek, Wstęp ttumacza. O niebie חEPI OYPANOY DE CAELO, w: Arystoteles, Dzieta wszystkie, t. 2. Fizyka, O niebie, O powstawaniu i niszczeniu, Meteorologika, O świecie, Metafizyka, tłum., wstępy, komentarze K. Leśniak, A. Paciorek, L. Regner, P. Siwek, Warszawa 1990, s. 208. Jak dalej wyjaśnia Siwek na s. 218-219, dla Arystotelesa eter nazywany też „ciałem pierwszym”, „ciałem piątym”, „ciałem górnym”, „ciałem wiecznym”, „ciałem boskim”, unosi się przez cała wieczność swobodnie w górnych przestworzach, nie spada nigdy na Ziemię, nie dąży w swym ruchu do centrum wszechświata, zatem nie jest ciężki; nie ma też dążności do oddalania się od ziemi, stąd nie ma własności, którą nazywamy lekkością. Jako że zdaniem Arystotelesa wszystkie ciała niebieskie (gwiazdy stałe i planety) składają się z eteru, to z konieczności naturalnej wszystkie one wykonują tylko ruch kołowy. Ruch prostolinijny nie jest dla nich możliwy, bo nie posiadają w sobie żadnego z elementów sublunarnych (ziemi, wody, powietrza, ognia).

221 Por. Arystoteles, Metafizyka L 8, w: Arystoteles, Dzieta wszystkie..., dz. cyt., t. 2, s. 815818; G. Reale, Historia filozofii starożytnej..., dz. cyt., t. 5, s. 144. 
Kształtowanie się nauki o niebie w teologii patrystycznej I-III wieku

ruchem kołowym i jest wolne od wszelkich zmian, czyli jest niezniszczalne. Pierwszym niebem, czyli sferą gwiazd stałych, porusza Bóg rozumiany jako „Pierwszy Poruszyciel” (nieruchomy, porusza, byt wieczny i konieczny, substancja i akt, sposobem jego istnienia jest Dobro, byt

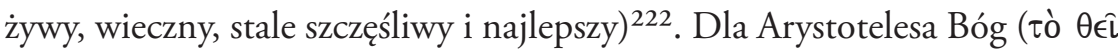
ov) jest nie tylko Pierwszym Poruszycielem, ale także pierwszą zewnętrzną przyczyną sprawczą skończoności świata (po pierwsze, bo jest przyczyną bytu świata, a więc tego, czym jest świat; po drugie, bo jest przyczyną celową skończoności świata jako określonego początku rzeczy, tj. harmonii i jedności ${ }^{223}$. Arystotelesowska koncepcja nieba zbudowanego z eteru upadła w epoce hellenistycznej ${ }^{224}$. Arystotelesowskie niebo opisywane przez Stagirytę z punktu widzenia mechanicznego stanowi zatem przede wszystkim system astronomiczny ${ }^{225}$.

Jak zaznacza Reale, Stagiryta nie dał żadnego wyjaśnienia, jakie dokładnie relacje zachodzą między Bogiem a substancjami czy sferami. Wydaje się, że Arystoteles skłaniał się raczej ku pojmowaniu Boga jako niemyślącego o świecie i ludziach. Arystotelesowski Bóg nie poznaje indywiduów jako takich, gdyż znajomość tego, co niedoskonałe, stanowiłaby jakieś pomniejszenie dla Boga ${ }^{226}$. Z przytoczonych tekstów Metafizyki Arystotelesa należy, zdaniem Realego, wyprowadzić wniosek, że empirycznie określone indywidua są niegodne myśli bożej właśnie ze względu na ich charakter empiryczny i jednostkowy. W koncepcji Arystotelesa Bóg nie stworzył świata, człowieka i poszczególnych dusz. Tak pojmowany Bóg kocha tylko samego siebie, ale nie zniża się do miłości i poznawania ludzi jako ogółu, a tym bardziej do miłości i poznawania pojedynczego człowieka. Aby uczynić krok dalej, trzeba było w refleksji filozoficznej dojść do koncepcji

222 Por. Arystoteles, Metafizyka L 7, w: Arystoteles, Dzieta wszystkie..., dz. cyt., t. 2, s. 813814 (por. A. Pokulniewicz, Problem wieczności świata w traktacie Arystotelesa „O niebie”, „Edukacja filozoficzna” 44 (2007), s. 217-229).

223 Por. A. Pokulniewicz, Zagadnienie pierwszych przyczyn skończoności świata w traktacie Arystotelesa „O niebie”, Warszawa 2010, s. 261.

224 Por. G. Reale, Historia filozofii starożytnej..., dz. cyt., t. 5, s. 144.

225 Por. P. Siwek, Wstęp ttumacza. O niebie חEPI OYPANOY DE CAELO, w: Arystoteles, Dzieta wszystkie..., dz. cyt., t. 2, s. 224-225.

226 Por. Arystoteles, Metafizyka $\Lambda$ 9, 1074b 21-28, w: Arystoteles, Dzieta wszystkie..., dz. cyt., t. 2, s. 818-819. 
stworzenia, lecz żadna spekulacja grecka, także ta neoplatońska, nie wypracowała takiej idei ${ }^{227}$.

\section{Epikur (341-271 przed Chr.)}

Po odrzuceniu zasad platońskiego „drugiego żeglowania” i tego, co jest ponadzmysłowe, niecielesne i niematerialne, Epikur zanegował także astronomię („bo jest próżna”), muzykę (,jest bezużyteczna, a nawet szkodliwa”), a nawet arystotelesowską logikę, a zajął się przede wszystkim światem fizycznym w ujęciu wyłącznie materialistycznym ${ }^{228}$ oraz skupił się na etosie jednostki, życia ukrytego, odosobnionego od wrzawy polityki ${ }^{229}$. Epikur utrzymywał, że całą rzeczywistość ( $\pi \hat{\alpha} \nu)$ wyznaczają dwa czynniki strukturalne: ciała i próżnia. Poza nimi nie ma niczego innego, ponieważ nie można pomyśleć niczego, co by istniało, a nie było właściwością ciał ${ }^{230}$.

Epikur, podobnie jak atomiści, a wbrew Platonowi i Arystotelesowi, zakładał, że w nieskończonej przestrzeni kosmicznej istnieje nieskończenie wiele światów, z których jedne są podobne do naszego, a inne nie ${ }^{231}$. Nieskończone światy powstają i rozpadają się w nieskończonym następstwie czasu. Nieskończonych światów, zdaniem Epikura, jest zatem nieskończenie wiele, tak fizycznie, jak czasowo. Pomimo ciąłych zmian fizyczno-kosmicznych i czasowych całość kosmosu nie zmienia się. Elementy konstytuujące tak pojęty wszechświat pozostają bowiem wiecznie takie same, lecz zawsze są zaktualizowane wszystkie ich możliwe kombinacje ${ }^{232}$. W pojmowanym mechanicystycznie wszechświecie Epikur, chcąc zanegować teleologiczne tłumaczenie kosmosu (głównie Platona i Arystotelesa), doszedł do negacji wszelkiej celowości, racjonalności czy koncepcji Demiurga.

\footnotetext{
227 Por. G. Reale, Historia filozofii starożytnej..., dz. cyt., t. 2, s. 435-437.

228 Por. G. Reale, Historia filozofii starożytnej..., dz. cyt., t. 3, s. 182.

229 Por. G. Reale, Historia filozofii starożytnej..., dz. cyt., t. 3, s. 188.

230 Epikur, List do Herodota, w: Diogenes Laertios, Żywoty i poglady stynnych filozofów X,39, przekład X księgi K. Leśniak, Warszawa 1982, s. 603-604.

231 Epikur, List do Herodota, w: Diogenes Laertios, Żywoty X,45, tłum. K. Leśniak..., dz. cyt., s. 604.

232 Epikur, List do Pytoklesa, w: Diogenes Laertios, Żywoty X,88, tłum. K. Leśniak..., dz.cyt., s. 626-627. Więcej na temat rozważań Epikura na temat nieskończoności, zob. A. Drozdek, In the Beginning Was the Apeiron: Infinity in Greek Philosophy, Stuttgart 2008, s. 133-141;
} 
Kształtowanie się nauki o niebie w teologii patrystycznej I-III wieku

Epikurejski kosmos był zatem całkowicie irracjonalny, poddany przypadkowości i losowi, brak w nim dobroci i logiki ${ }^{233}$. Według psychologii Epikura dusza, tak samo jak wszystkie inne rzeczy, stanowi wyłącznie zbitkę atomów ${ }^{234}$, nie jest wieczna, lecz śmiertelna (dusza po oddzieleniu się od ciała natychmiast ginie) ${ }^{235}$, podlegając tym samym fizycznym i mechanicystycznym prawom przemiany jak cały kosmos ${ }^{236}$.

\section{Szkoła stoicka - „stara szkoła” (III-II wiek przed Chr.)}

Według koncepcji stoickiej niebo stanowi sferę otaczającą i zamykającą w sobie kosmos, a poza nią znajduje się próżnia. Natomiast niebo razem z kosmosem jest pojmowane panteistycznie jako substancja Boga ${ }^{237}$. Podstawową cechą fizyki stoików był ich monizm panteistyczny. Negowali oni istnienie jakiejkolwiek rzeczywistości czysto duchowej (w kontrze do Platona). Byt był dla nich materialny i cielesny: ciałem jest Bóg, dusza, dobro, wiedza, namiętności, wady i cnoty ${ }^{238}$.

Całą rzeczywistość przenika, zdaniem stoików, cielesny Bóg ${ }^{239}$. Ciało jest pojęciem złożonym, jest i materią i jakością (lub forma), które są połączone tak, że pierwsza jest strukturalnie nierozerwalnie złączona z drugą i odwrotnie. "Jakość-forma” jest zasadą czynną, a materia jest zasadą

233 Por. G. Reale, Historia filozofii starożytnej..., dz. cyt., t. 3, s. 225-227.

234 Epikur, List do Herodota, w: Diogenes Laertios, Żywoty X,63, tłum. K. Leśniak..., dz. cyt., s. 615.

235 Epikur, List do Herodota, w: Diogenes Laertios, Żywoty X,67, tłum. K. Leśniak..., dz. cyt., s. 616-617.

236 Por. G. Reale, Historia filozofii starożytnej..., dz. cyt., t. 3, s. 234-236.

237 Por. G. Reale, Historia filozofii starożytnej..., dz. cyt., t. 5, s. 144.

238 Por. Seneka [Młodszy], List 106,3,3-11, w: Seneka [Młodszy], Listy moralne do Lucyliusza (Epistolae morales ad Lucilium), tłum. W. Kornatowski, Warszawa 2010, s. 501503; Seneka [Młodszy], List 113, tłum. W. Kornatowski..., dz. cyt., s. 530-537.

239 Por. Diogenes Laertios, Żywoty i poglady stynnych filozofów VII, 147: „Bóg - wedle sto-

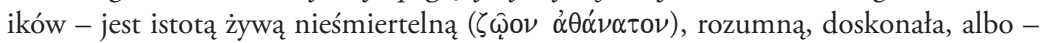
inaczej mówiąc - myślącym duchem zażywającym szczęścia, niedopuszczającym do siebie żadnego zła, opatrznościowo troszczącym się o świat i o wszystko, co w nim się znajduje; nie jest jednak antropomorficzny. Bóg jest twórcą i niejako ojcem wszechrzeczy, przenika wszystkie rzeczy, zarówno w całości, jak i we wszystkich częściach, a nazywa się go stosownie do sił, jakie objawia”, przekład VII księgi K. Leśniak, Warszawa 1982, s. 436 (por. Diogenes Laertios, Żywoty VII, 134, tłum. K. Leśniak..., dz. cyt., s. $430-433)$. 
bierną ${ }^{240}$. Materia i Bóg nie są dwoma bytami od siebie odrębnymi, rozróżnia się je logicznie i pojęciowo, natomiast ontologicznie stanowią one jedną jedyną rzeczywistość. Zatem, według stoików, jedna jest materia i jeden Bóg, jeden jest też kosmos, który wszystko w sobie mieści. Bóg utożsamia się z kosmosem, jest we wszystkim i jest wszystkim ${ }^{241}$. Bóg, według koncepcji stoików, jest także Logosem (jako zasada inteligencji, rozumności i duchowości), był często utożsamianym z twórczym ogniem, nie jest jednak Bogiem osobowym. Stoicy uznawali też, że ich naukę da się pogodzić z politeistyczną mitologią, kiedy tę ostatnią interpretuje się alegorycznie, jako poetycką ekspresję prawdy fizycznej. Bóg pojmowany w koncepcji stoickiej jako opatrzność immanentna i fizyczna zajmował się zatem bardziej gatunkiem niż jednostką, nie zajmował się także ludźmi jako jednostkami, gdyż tylko osobowe rozumienie bóstwa mogłoby doprowadzić do takiego ujęcia opatrzności ${ }^{242}$.

Logos będący zarodkiem wszystkich rzeczy formuje cztery elementy, które następnie formują cały kosmos i rzeczy w kosmosie. Stoicki wszechświat miałby kształt kulisty, na jego obrzeżach znajdowałyby się gwiazdy zbudowane z ognia, które byłyby bytami mającymi dusze, ożywionymi i boskimi. W centrum znajduje się ziemia, która jest ogniskiem boskiej budowli wszechświata. Wszechświat, według stoików, jest skończony i otoczony nieskończoną próżnią ${ }^{243}$. Na Ziemi - rośliny i zwierzęta istnieją ze względu na człowieka. Zdaniem Maxa Pohlenza ten stoicki antropocentryzm jest obcy dla starożytnego świata greckiego, a bliski przesłaniu Starego

240 Por. Seneka [Młodszy], List 65, 2, tłum. W. Kornatowski..., dz. cyt., s. 202; G. Reale, Historia filozofi starożytnej..., dz. cyt., t. 3, s. 364-365.

241 Por. Diogenes Laertios, Żywoty VII, 148: „Substancją Boga jest - według Zenona cały świat i niebo; to samo mówi Chryzyp w pierwszej księdze traktatu $O$ bogach i Poseidonios również w pierwszej księdze traktatu pod tym samym tytułem. Antypater natomiast w siódmej księdze pisma $O$ wszechświecie twierdzi, że substancją Boga jest coś podobnego do powietrza, Boetos zaś w dziele O naturze pisze, że substancją Boga jest sfera gwiazd stałych. Przez naturę rozumieją stoicy raz to, co jakby trzyma w skupieniu wszechświat, raz to, co rodzi wszystkie rzeczy na ziemi”, tłum. K. Leśniak..., dz. cyt., s. 436-437.

242 Por. G. Reale, Historia filozofii starożytnej..., dz. cyt., t. 3, s. 370-375.

243 Por. A. Drozdek, In the Beginning Was the Apeiron: Infinity in Greek Philosophy, Stuttgart 2008, s. 142-154. 
Kształtowanie się nauki o niebie w teologii patrystycznej I-III wieku

Testamentu. Stąd Pohlenz zakłada, iż koncepcję antropocentryczną wraz z ideą opatrzności Zenon z Kition przyniósł prawdopodobnie ze swojej ojczyzny (tj. jak się przypuszcza z fenickiej kolonii Kition na Cyprze) ${ }^{244}$. Reale odrzuca powyższą hipotezę Pohlenza ze względu na słabą bazę źródłową powyższej hipotezy (tylko dwa świadectwa tekstualne: Ksenofont, Wspomnienia o Sokratesie I, 4 oraz Arystoteles, Polityka I, 8, 1256b), choć przyznaje, że w myśli greckiej dopiero ze stoikami koncepcja antropocentryczna uzyskała siłę przebicia ${ }^{245}$.

Według kosmologii stoickiej świat, jaki powstał, jest zniszczalny: kiedy nastąpi dopełnienie się czasu, nastąpi wtedy również powszechny po-

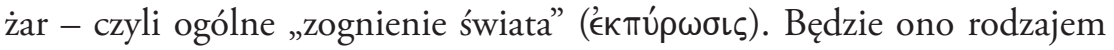
powszechnego oczyszczenia - kiedy będzie istniał jedynie ogień. Potem nastąpi „odrodzenie wszechświata” ( $\pi \alpha \lambda \iota \gamma \gamma \in \nu \in \sigma i ́ \alpha)$ i wszystko zostanie odbudowane dokładnie tak jak przedtem i przywrócone do poprzedniego sta-

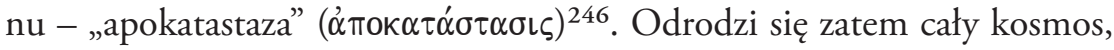
odrodzi się także każdy człowiek identyczny z tym, który istniał w poprzednim kosmosie ${ }^{247}$. W perspektywie zognienia kosmosu i jego apokatastazy jednostkowa śmierć człowieka jest tylko etapem do kolejnej palingenezy. Po śmierci jednostki, czyli oddzieleniu się duszy od ciała, sama dusza zdaniem jednych stoików może trwać aż do powszechnego zognienia (opinia Kleantesa), natomiast zdaniem innych (Chryzypa i Aëtiosa ${ }^{248}$ ) przywilej tak długiego trwania miałyby tylko dusze mędrców, natomiast pozostałe dusze istniałyby jedynie przez krótki czas. Po śmierci jednostki, a do zognienia świata, dusze przybierają kształt kulisty i przebywają w przygotowanym dla nich przez Logos miejscu poniżej Księżyca. Dusze zachowują swe władze poznawcze, odgrywają pewną rolę przy wróżeniu i w snach,

244 Por. M. Pohlenz, La Stoa. Storia di un movimento spirituale, vol. 1, trad. O. De Gregorio, B. Proto, Firenze 1978, s. 197.

245 Por. G. Reale, Historia filozofii starożytnej..., dz. cyt., t. 3, s. 388.

246 Por. J. Barnes, La doctrine du retour éternel, w: Les stoïciens et leur logique. Actes du Colloque de Chantilly (18-22 septembre 1976), ed. J. Brunschwig, Paris 1978, s. 3-20 (Bibliothèque d'Histoire de la Philosophie).

247 Por. A. A. Long, The stoics on world-conflagration and everlasting recurrence, „Southern Journal of Philosophy" 23 (1985, Supplement 1), s. 13-37.

248 Por. Diogenes Laertios, Żywoty VII,157, tłum. K. Leśniak..., dz. cyt., s. 440-441. 
1. Biblijne terminy, koncepcje i obrazy dotyczące nieba

a najlepsze $z$ nich stają się herosami ${ }^{249}$. Wobec cyklicznych zognień świata i konsekwentnych palingenez i apokatastaz stoików interesował przede wszystkim obecny świat, gdzie cnota ma swój raj, a wada swoje piekło ${ }^{250}$.

\section{Plotyn (204-269)}

Twórca systemu filozoficznego zwanego neoplatonizmem odrzucał istnienie eteru rozumianego po arystotelesowsku. Natomiast uznawał wieczność nieba, którą wyjaśniał przez odwołanie się do mocy duszy ${ }^{251}$. Plotyn był też chyba najbardziej znanym przedstawicielem opinii, wedle której niebo to miejsce, w którym dusze przebywają po śmierci ${ }^{252}$. W jego filozofii zauważamy, iż dokonał on spirytualizacji kosmosu aż do granic akosmizmu. Zdaniem Plotyna niebo, które jest najlepszą częścią widzialnego kosmosu, "graniczy” z ostatnimi stopniami świata Umysłu i jest zrobione ze światła, różnego od ognia ziemskiego. Niebo byłoby zatem pierwszym regionem, do którego wnikają dusze ${ }^{253}$, gwiazdy i ciała niebieskie są ożywione

249 Por. Diogenes Laertios, Żywoty VII,151, tłum. K. Leśniak..., dz. cyt., s. 438 (por. też A. A. Long, Soul and Body in Stoicism, „Phronesis” 27 (1982), s. 34-57).

250 Por. G. Reale, Historia filozofi starożytnej..., dz. cyt., t. 3, s. 393; szerzej na temat kwestii nieśmiertelności duszy według filozofii stoickiej, zob. R. Hoven, Stö̈cisme et stö̈ciens face au problème de l'au-delà, Paris 1971.

251 Plotyn, Enneady II,1,1-2, tłum., wstęp A. Krokiewicz, Warszawa 2000, s. 160-161, (Biblioteka Filozofii Klasycznej [dalej: BFK] 6, Enneady I-III).

252 Por. G. Reale, Historia filozofii starożytnej..., dz. cyt., t. 5, s. 144. Jak zauważa J. Bańka, Plotyn i odwieczne pytania metafizyki, t. 1. Monada pryncypialna, Katowice 1995, s. 261262, Plotyn przyjmuje za Platonem jego teorię nieba, szczególnie platoński „obieg niebieski” jako układ odniesienia do mierzenia czasu. Wieczność trwa wraz z niebem, a czas biegnie wraz z życiem. Razem z niebem powstał zatem z jednej strony wzór wieczności, a z drugiej jej wizerunek ruchliwy.

253 Plotyn, Enneady IV,3,17: „Że zaś dusze wchodzą z umysłowego świata najpierw w przestworze nieba, może ktoś wyrozumieć z następujących względów: Jeżeli w dziedzinie zmysłowej niebo jest «lepsze», to będzie chyba przylegać do ostatnich bytów umysłowych. Ożywiają się zatem te ciała niebieskie stamtąd duszą jako pierwsze i uczestniczą w niej jako podatniejsze do uczestniczenia. Ciało natomiast ziemiste, ostatnie i uczestniczące z natury tylko w duszy pośledniejszej, jest już daleko od niecielesnej natury. Wszystkie tedy dusze naświetlają niebo i użyczają mu swojej jakoby obfitości i pierwszych promieni, w innych zaś ciałach świecą, jakby resztkami, a tylko te, które schodzą głębiej, błyszczą w dole jaśniej, atoli dla nich samych nie jest to lepiej, że występują z siebie daleko. Jest mianowicie jakiś jakby punkt środkowy, po nim koło z niego jaśniejące, a po nich koło jeszcze inne, światło ze światła. Zewnątrz nich nie ma już innego koła świetlnego, lecz jest to, które potrzebuje obcego blasku w braku 
Kształtowanie się nauki o niebie w teologii patrystycznej I-III wieku

i są drugimi, czyli widzialnymi, bogami (są jakby obrazami bogów duchowych i inteligibilnych) ${ }^{254}$.

Plotyn jednoznacznie odrzucił chrześcijańską wiarę w zmartwychwstanie ciała, którą uważał za wyraz pewnej formy materializmu ${ }^{255}$, a odwołał się do metempsychozy ${ }^{256}$. Dla Plotyna człowiek ontologicznie jest duszą $^{257}$. Pierwotnie dusze przebywały jako czyste w świecie umysłowym ${ }^{258}$ i trwały w stanie zjednoczenia z Duszą powszechną 259 . Zejście dusz do ciał nastąpiło w wyniku dwóch odmiennych rodzajów win właściwych Duszy: (1) winy rozumianej jako zejście konieczne, nieuchronne i niedobrowolne, gdzie karą za tę winę jest samo bolesne doświadczenie zejścia do ciał ${ }^{260}$; (2) winy dotyczącej duszy, która już przywdziała ciało i przesadnie się o nie troszczy, oddaje służbie rzeczom zewnętrznym, zapomina o samej sobie, przez co oddala się od własnego źródła ${ }^{261}$. W zależności od tego, czy człowiek pozwala dominować części zmysłowej, czy też części duchowej, zależy

światła własnego. I niech to będzie krążek, a raczej kula taka, która od tej trzeciej z rzędu, do niej bowiem przylega, bierze cały blask przez nią promieniowany. Więc owo wielkie światło świeci, pozostając w sobie, i blask od niego przenika za sprawą wątku, inne zaś światła świecą z nim razem i częścią pozostają w sobie, a częścią dają się dalej pociągać blaskom oświetlanego ciała, ponieważ oświetlane ciała potrzebują większej troski, podobnie jak kiedy burza miota statkami i sternicy coraz bardziej troszczą się o okręty i niepostrzeżenie przestają dbać o siebie, tak iż często narażają się na to, że pochłonie ich głębia razem ze szczątkami okrętów, tak i te dusze zaszły zbyt daleko i zapomniały o sobie; popadły też w końcu i uległy więzom omanu, opętane swą pieczołowitą troską o naturę. Gdyby zaś każda poszczególna żywina była, tak jak świat, ciałem doskonałym i sprawnym oraz wolnym od niebezpieczeństw doznawania, to i ta przebywająca w niej, jak mówimy, dusza nie przebywałaby w niej sama, lecz użyczałaby jej życia, pozostając całkowicie w górze", tłum., wstęp A. Krokiewicz, Warszawa 2001, s. 390-391 (BFK 7, Enneady IV-V).

254 Por. G. Reale, Historia filozofii starożytnej, t. 6. Szkoty epoki cesarstwa, tłum. I. Zieliński, Lublin 1999, s. 573n, przypis 32.

255 Plotyn, Enneady III,6,6, BFK 6, s. 307-310.

256 Plotyn, Enneady III,2,16, BFK 6, s. 269-271.

257 Plotyn, Enneady I,1,10, BFK 6, s. 97.

258 Plotyn, Enneady VI,4,14, t. 3, tłum., wstęp A. Krokiewicz, Warszawa 2003, s. 706707 (BFK 9, Enneady VI).

259 Plotyn, Enneady IV,8,4, BFK 7, s. 495-497.

260 Plotyn, Enneady V,1,1, BFK 7, s. 506-507.

261 Por. Plotyn, Enneady IV,8,4, BFK 7, s. 495-497; Plotyn, Enneady V,1,1, BFK 7, s. 506-507. 
1. Biblijne terminy, koncepcje i obrazy dotyczące nieba

jego $\operatorname{los}^{262}$. Po wyjściu z cyklu wcieleń i po odrzuceniu wszystkiego ${ }^{263}$ ostatecznym przeznaczeniem dusz, które żyły w sposób najlepszy, jest ponowne zjednoczenie z Bogiem ${ }^{264}$. Zetknięcie się duszy z Jedynym Plotyn określa jako ekstazę ${ }^{265}$. Dojście do ekstazy zależy jednak wyłącznie od człowieka, który jest twórcą swej doskonałości i zbawienia. Plotynowi obce są natomiast pojęcia: ludzkiej niemożności wzniesienia się do Boga o własnych siłach, łaski i inicjatywy Bożej ${ }^{266}$.

W antycznej filozofii greckiej niebo było pojmowane i opisywane bardziej w kategoriach przestrzennych i naturalistycznych, niż w kategoriach religijnych i teologicznych, tak typowych dla teologii biblijnej. Od V wieku przed Chr. podstawowym greckim pozycjonowaniem nieba był model typu „centrum-okrąg”, natomiast biblijne pozycjonowanie nieba przebiega według schematu „góra-dół”.

W greckich modelach kosmologicznego wyobrażania nieba możemy wyróżnić następujące konstrukty filozoficzne: koncepcję kosmologiczno-

262 Por. G. Reale, Historia filozofii starożytnej..., dz. cyt., t. 4, s. 576-581.

263 Por. Plotyn, Enneady V,3,17, BFK 7, s. 541-543.

264 Por. Plotyn, Enneady IV,3,24: „Jeżeli więc dusze są i nie są nigdzie w ciele, bo przecież nie mają ciała, to tam, gdzie istnieje substancja i byt boskie w bogu, tylko tam i razem z nimi i w nim będzie istnieć taka dusza”, BFK 7, s. 398 (por. J. Bańka, Plotyn i odwieczne pytania metafizyki, t. 2. O rzeczywistości prawdziwej, pozornej i stanach mistycznych, Katowice 1996, s. 75-76, komentując pytanie „Dlaczego niebo jest jedno, mimo że mnogie i na każdym miejscu inne?”, stwierdza, iż u Plotyna Demiurgiem sprowadzającym wszystko we wszechświecie do harmonii jest dusza i jej siła, która utrzymuje w ładzie także samo niebo. Natomiast ostateczną granicą przypadkowości świata, pod wpływem Demiurga, będzie dusza, podnosząca wszystko do statusu boskiego - niebo, nasz świat, słońce i gwiazdy).

265 Por. Plotyn, Enneady VI,9,11: „Więc, jeśli ktoś ujrzy siebie na tej wysokości, to posiada Jego podobiznę w sobie samym, i jeśli jako podobizna przejdzie od siebie do Wzoru, to osiągnie kres i cel wędrówki. Spadając zaś z wyżyn widzenia niech tylko znowu tę cnotę w sobie rozbudzi i uświadomi sobie, że zdobią go jej umysłowe klejnoty, a doda mu znowu skrzydeł cnota w drodze do umysłu i dalej mądrość w drodze do Niego. I oto życie bogów oraz bożych i szczęsnych ludzi - poniechanie rzeczy innych, ziemskich, życie, które się nie lubuje w ziemskich rozkoszach, ucieczka samotnika do Samotnika!", BFK 9, s. 841.

266 Por. G. Reale, Historia filozofii starożytnej..., dz. cyt., t. 4, s. 587-603. 
Kształtowanie się nauki o niebie w teologii patrystycznej I-III wieku

-religijną (niebo według pitagorejczyków), koncepcję metafizyczno-fizyczną wg konstrukcji model-obraz (niebo według Platona), koncepcję fizyczno-religijną (Heraklides z Pontu), koncepcję astronomiczną (Arystoteles), koncepcję materialistyczno-mechanicystyczną (Epikur), koncepcję astronomiczno-panteistyczną (stoicy), koncepcję spirytualistyczną (Plotyn). Powyższe greckie konstrukcje filozoficzne zasadniczo różnią się od biblijnego pojmowania nieba. Omawiane ujęcia filozoficzne są bowiem najczęściej doktrynami kosmologicznymi z pewnymi dodatkami metafizycznymi czy religijnymi. Natomiast biblijna koncepcja nieba jest przede wszystkim teologiczna: niebo to jedynie kolejne stworzenie Boga, które jest jednak tajemniczą przestrzenią Boga.

Niebo w ujęciu filozofii greckiej jest opisywane najczęściej astronomicznie, czasami jest interpretowane metafizycznie i symbolicznie (Platon), a czasami spirytualizowane (Plotyn). W tak rozumianym niebie, w zależności od systemu filozoficznego, kontakt człowieka pojmowanego jako dusza zależy wyłącznie od inicjatywy tejże duszy. Jeśli chce ona żyć moralnie najlepiej, dzięki swemu postępowaniu sama zdobywa wyzwolenie z cyklu metempsychozy i dochodzi do zjednoczenia z bóstwem (mit orficki, tezy pitagorejczyków, idee Plotyna). W pozostałych systemach antycznej filozofii greckiej moralnie dobra dusza po wyzwoleniu z cyklu metempsychozy może dojść do indywidualnego szczęścia eschatologicznego w niewidzialnym Hadesie (Platon), na własnej gwieździe (Platon), na Drodze Mlecznej (Heraklides). Natomiast w systemach materialistycznych albo jest poddawana cyklicznemu zognieniu, odrodzeniu i apokatastazie (stoicy), albo ulega śmierci fizycznej jako zbiór atomów (Epikur). Najbardziej powściągliwy w kwestii eschatologicznego losu duszy pozostaje Arystoteles, który zostawia te kwestie wierze religijnej.

Powyższe ujęcia filozoficzne różnią się zatem zasadniczo od biblijnej teologii nieba, która wskazuje, iż niebo stanowi wyłączną sferę Boga i kochanych przez Niego stworzeń. Po zakończeniu jednego jedynego ludzkiego życia (a nie po ludzkim wyzwoleniu się z cyklu metempsychoz), po zmartwychwstaniu ciał i po Sądzie Ostatecznym - do biblijnego nieba kompletnych ludzi (a nie samych dusz) - wprowadza wyłącznie Jezus Chrystus (nie decyduje o tym staranie się samej, najlepszej moralnie duszy). Biblijne niebo jest dla człowieka synonimem trwałej, eschatologicznej relacji z Bogiem, 
relacji chcianej przez Boga, z Jego miłości do człowieka (a nie ekstazy duszy z bóstwem zainteresowanym tylko samym soba). Człowiek (a nie sama dusza) do nieba nie może wejść sam, z własnej woli, natomiast może być tam wprowadzony dzięki łasce Boga (nie jest to samozbawienie duszy).

\subsection{Podsumowanie pierwszego rozdziału}

Teologiczny przekaz Pisma Świętego dotyczący nieba jest spójny, a zarazem progresywny. W poświęconej tej tematyce narracji Biblii przeważają motywy przestrzenne, których spotykamy dziesięć, z czego dwa w ST („ogród (w) Eden”; „niebo”) i osiem w NT („wstępowanie” / „zstępowanie”. „powyżej” - „na wysokości - „ponad”; „niebo”, „raj”, „łono Abrahama”, „królestwo niebieskie”, „niebieskie Jeruzalem”, zamieszkanie „w domu Ojca mego"). Biblijne niebo to zatem błogosławione miejsce życia Boga z człowiekiem. Pozostałe to motywy jakościowe, których spotykamy w teologii biblijnej pięć, z czego jeden w ST („trwanie”) i cztery w NT („widzenie” Boga, „trwanie - wieczność”, „stać w obliczu Pana”, „być z Chrystusem”), te ostatnie wyraźnie związane z niebiańską relacją Boga z człowiekiem. W warstwie symbolicznej wszystkie biblijne obrazy nieba stanowią archetypy pozytywne, przekazujące schematy wyobrażeniowe o niebie uniwersalnie, w sposób figuratywny i uczuciowy („woda”, „ogród”, „życie”, „rozkosz”, „pojednanie”, „miłość”, „przyjaźñ”, „radość”, „zadowolenie”, „nagroda”, „odnowa”, „stałośc”, „błogosławieństwo”).

W biblijnej tematyce eschatologicznego bycia człowieka z Bogiem obserwujemy jej rozwój, zarówno na poziomie terminologii, jak koncepcji czy obrazowości. Ogród (w) Eden z Rdz 2, 8 jest później nazywany „rajem” / „ogrodem rozkoszy” (LXX) lub „ogrodem Boga” (Ez 28, 13, Jl 2, 3 i Iz 51,3). NT powraca pośrednio do tematyki ogrodu (w) Eden, kiedy jest mowa o niebie pojmowanym i wyobrażanym jako: „raj”, „ogród niebieski” lub „niebieskie Jeruzalem”. Wspominaną rozwojowość obserwujemy w Biblii także na poziomie obrazowości: obraz ogrodu Eden przechodzi w obraz raju, by stać się ostatecznie obrazem nieba. Podobny proces można zauważyć w ukazywaniu obrazu trwałości życia, który ostatecznie staje się obrazem życia wiecznego. Ogród (w) Eden, jako pierwotne 
Kształtowanie się nauki o niebie w teologii patrystycznej I-III wieku

miejsce szczęśliwości i przyjaźni człowieka z Bogiem, nie jest formą rzeczywistości ostatecznej. To miejsce próby dla ludzi, niestety w wyniku grzechu - nieudanej.

Wymiernym skutkiem wygnania ludzi z ogrodu w Eden jest: utrata przyjaźni z Bogiem, zamknięcie ogrodu dla ludzi oraz nieosiąalna dla człowieka nieśmiertelność. Stąd w ST brak wątków o potencjalnej nieśmiertelności człowieka. Motyw „trwania” nie posiada w ST znaczenia filozoficznej wieczności, terminem ôlām są określane jedynie przymierza Boga z ludźmi oraz ich niektóre konsekwencje (warunki przymierzy, przepisy Pięcioksięgu). Nowotestamentalny motyw trwania wskazuje zasadniczo na długość istnienia osoby. Związane z tym ostatnim pojęcie „życie wieczne" nie stanowi centrum orędzia o zbawieniu, przynależy do żydowskiego pojmowania czasu eschatologicznego (ewangelie synoptyczne), a powiązane z Wcieleniem Syna Bożego wskazuje na trwałość życia jako Bożego daru (pisma Janowe).

W nauczaniu Pisma Świętego o eschatologicznym byciu człowieka z Bogiem najważniejszym pojęciem teologicznym jest motyw nieba. Opisy nieba w NT pozostają takie same jak w ST - w wymiarze konceptualnych metafor przestrzennych. Niebo stopniowo zostaje ukazane jako ostateczne miejsce szczęśliwości człowieka z Bogiem. Tym ostatnim wątkiem narracja NT różni się jakościowo od narracji ST, według przesłania którego miejscem przebywania człowieka po śmierci jest Szeol. Rozwój biblijnej teologii nieba widać także w przechodzeniu w kolejnych księgach: od pierwotnej koncepcji kosmicznego „miejsca wody”, a zarazem mieszkania Boga (którego jako stworzone miejsce - objąć nie może), przez koncepcję nieba trwałego - lecz o przewidzianym końcu, do koncepcji „nowego nieba” i „królestwa Boga”, pojmowanego zarazem jako raj (czyli przyszłe miejsce szczęśliwości), a przede wszystkim jako mieszkanie Ojca, Syna i Ducha Świętego. Dla teologii nieba w NT najważniejszy teologicznie jest przekaz, że w osobie Jezusa Bóg zwraca się do ludzi, a Jego objawienie zstępuje od Boga z nieba. Jeśli niebo w ST z reguły pozostaje zamknięte dla ludzi, to w NT to Jezus otwiera niebo ludziom, znosi barierę pomiędzy Bogiem a człowiekiem i to On obdarza wierzących trwałą więzią z Bogiem - życiem wiecznym. Biblijne nauczanie o niebie różni się zatem diametralnie od koncepcji antycznej filozofii greckiej: niebo, według Biblii, jest eschatologiczną 
1. Biblijne terminy, koncepcje i obrazy dotyczące nieba

relacją Boga z kompletnymi ludzi oraz eschatologicznym miejscem wspólnoty Boga z ludźmi. Możliwość nieba oraz jakość stanu człowieka w niebie wynikają przede wszystkim z łaskawości Boga. 



\section{Kształtowanie się nauki o niebie w teologii patrystycznej - wiek I-II}

W drugim rozdziale przedstawiam kształtowanie się nauki o eschatologicznym niebie w teologii ojców i pisarzy okresu poapostolskiego I-II wieku $(\$ 2.1$.) oraz w teologii apologetów greckich II wieku (\$2.2.). Układ autorów i dzieł jest dokonany w porządku chronologicznym. W paragrafach obu podrozdziałów prezentuję najpierw zwięzły opis postaci autora oraz patrystyczną charakterystykę utworów, by następnie przejść do omówienia kontekstu teologicznego nauki o niebie, terminologii dotyczącej rzeczywistości niebiańskich oraz teologii nieba. Zarówno rozdział, jak i podrozdziały kończą się syntetycznymi podsumowaniami. Mam nadzieję, że taka forma opisu pomoże lepiej zrozumieć rozwój wczesnochrześcijańskiej eschatologii końcowej dotyczącej nieba.

\subsection{Kształtowanie się nauki o niebie w teologii ojców i pisarzy okresu poapostolskiego (I-II wiek)}

Okres ojców apostolskich, czyli lata po śmierci apostołów, był jednym z najistotniejszych etapów kształtowania się chrześcijaństwa. W atmosferze powoli wygasającego, ale jeszcze żywego oczekiwania na rychłą paruzję, wzrastała świadomość budowania doczesnych struktur Kościoła, po- 
Kształtowanie się nauki o niebie w teologii patrystycznej I-III wieku

czucie odrębności wobec judaizmu oraz nowości wobec religii pogańskich. Formowała się też wtedy chrześcijańska teologia, której źródłem nadal wprawdzie pozostawało Pismo Święte, ale część termionologii i pewne idee zapożyczano z filozofii stoickiej i platońskiej oraz z teologii żydowskiej ${ }^{1}$.

W niniejszym rodziale analizuję patrystycznie teksty autorów zaliczanych do grupy ojców apostolskich, w których odnalazłem wątki dotyczące eschatologicznego nieba. W badanej grupie utworów pod względem formy spotykamy przede wszystkim listy pastoralne (Didache, List Klemensa Rzymskiego, Listy Ignacego Antioceńskiego, List Pseudo-Barnaby), ale także dydaktyczną apokalipsę (Pasterz) oraz homilię (Homilia z II wieku). Ta żywa forma literacka jest pośrednio odzwierciedleniem ówczesnego nauczania katechetycznego. Pisma te, będące w swej treści i formie echem przepowiadania apostolskiego, mają charakter wyraźnie parenetyczny. Eschatologia końcowa nie stanowi zasadniczego tematu żadnego ze studiowanych utworów, są to najczęściej fragmentaryczne wzmianki, rozwijane przy okazji innej, najczęściej pastoralnej problematyki.

\subsubsection{Didache - niebo jako „Królestwo Jezusa”}

W opinii współczesnych komentatorów i wydawców Didachè tekst tego utworu nie stanowi pisma homogenicznego pochodzącego od jednego autora, ale jest anonimową kompilacją wywodzącą się z różnych źródeł wczesnochrześcijańskich (opinię taką wyrażają Jean-Paul Audet, Robert A. Kraft, Stanislas Giet, Kurt Niederwimmer, Willy Rordorf, André Tuilier, Giuseppe Visonà, Aaron Milavec) ${ }^{2}$. Redaktor, którym był judeochrześcijanin działający we wspólnocie etnochrześcijańskiej, zebrał w jednym

1 Por. W. Myszor, Kierunki rozwoju chrześcijaństwa w okresie poapostolskim, w: Ojcowie apostolscy, tłum. A. Świderkówna, wstęp i oprac. W. Myszor, Warszawa 1990, s. 5 (Pisma Starochrześcijańskich Pisarzy [dalej: PSP] 45).

2 Por. J.-P. Audet, La Didachè. Instructions des apôtres, Paris 1958, s. 197-205; R. A. Kraft, Barnabas and the Didache, w: The Apostolic Fathers. A New Translation and Commentary, vol. 3, ed. R. M. Grand, New York 1965, s. 1-3; S. Giet, L'énigme de la Didachè, Publications de la Faculté des Lettres de l'Université de Strasbourg, Paris 1970; K. Niederwimmer, Die Didachè, Göttingen 1993³; W. Rordorf, A. Tuilier, La doctrine des douze Apôtres (Didachè), SC 248 bis, Paris 1998², s. 11-21; G. Visonà, 
2. Kształtowanie się nauki o niebie w teologii patrystycznej - wiek I-II

utworze teksty użyteczne dla zbudowania w wierze swoich współwyznawców. Przyjmuję za Audetem, Niederwimmerem, Rordorfem, Tuilierem i Visoną, iż powstanie tego pisma należy datować na drugą połowę I wiekuª

\section{Kontekst teologiczny nauki o niebie}

Pierwsze odniesienie Didache do kwestii życia pośmiertnego zbawionych pojawia się w rozdziałach X i XII, które są poświęcone Eucharystii rozumianej w tych fragmentach przede wszystkim jako chrześcijańskie dziękczynienie Bogu przez Jezusa ${ }^{4}$. Wydźwięk nauczania jest wymownie chrystocentryczny i eklezjologiczny: Jezus Chrystus objawił Kościół5 , Eucharystię („łama-

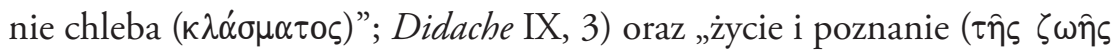

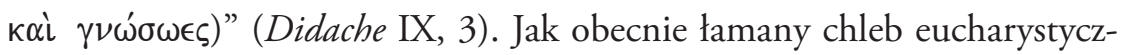
ny łączy fizycznie ziarna, a duchowo ziemski Kościół - tak w eschatonie Chrystusowy Kościół ma nadzieję, przez chwałę i moc Jezusa Chrystusa, zebrać się w ,jednym królestwie Twoim” (Didache IX, 4). Tym, który objawił doczesne rzeczywistości prowadzące do Królestwa (tj. „Twój Kościół”, „łamanie chleba”) i tym, którego mocą Kościół („Twój Kościół”) może

Didachè. Insegnamento degli Apostoli, Milano 2000, s. 25-37; A. Milavec, The Didache: Faith, Hope, and Life of Earliest Christianity 50-70 C.E., New York 2003, s. IX-XVII.

3 Por. J.-P. Audet, La Didachè..., dz. cyt., s. 119-120 (pomiędzy 50 a 70 rokiem); K. Niederwimmer, Die Didachè..., dz. cyt., s. 66-67, 78-80 (druga połowa I wieku); W. Rordorf, A. Tuilier, La doctrine des douze Apôtres..., dz. cyt., s. 245 (druga połowa I wieku); G. Visonà, Didachè..., dz. cyt., s. 42 (druga połowa I wieku); A. Milavec, The Didache..., dz. cyt., s. VII (druga połowa I wieku).

4 Didache IX,4, w: FCh 1. Didache. Zwölf-Apostel-Lehre, übersetzt und eingeleitet von G. Schöllgen, Freiburg im Breisgau 1991, s. 122; przekład polski Nauka Dwunastu Apostotów IX,4: „Jak ten chleb łamany, rozrzucony po górach, | Został w jedno zebrany, | Tak niech Kościół Twój aż po najdalsze krańce ziemi | Zbierze się w jednym królestwie Twoim, | Bo Twoja jest chwała i moc przez Jezusa Chrystusa na wieki!", w: Pierwsi świadkowie. Pisma Ojców Apostolskich, tłum. A. Świderkówna, wstęp, komentarz i oprac. M. Starowieyski, Kraków 1998², s. 37 (Biblioteka Ojców Kościoła [dalej: BOK] 10).

5 Didache IX,2, w: FCh 1, s. 120; „święta winorośl Dawida, sługi Twego”, BOK 10, s. 37. Marek Starowieyski, BOK 10, s. 43, przypisy 60-61, podkreśla, że sformułowanie z Didache IX,2 „winorośl” jest odniesieniem do Iz 5 i oznacza Lud Boży, objawiony przez Chrystusa, natomiast termin „sługa Twój” stanowi aluzję do cierpiącego sługi JHWH (Iz 42, 1-9; 49, 1-6; 50, 4-11; 52, 13 - 53, 12) i jest typowe dla pierwotnej katechezy chrześcijańskiej, która przedstawiała Jezusa jako tego Sługę (por. np. Dz 8, 32-35). 
Kształtowanie się nauki o niebie w teologii patrystycznej I-III wieku

zebrać się w Królestwie, jest wyłącznie Chrystus („Przez Jezusa Chrystusa”, Didache IX, 4; X, 2. 3). W doczesności udział w Eucharystii przygotowuje chrześcijan do przebywania w przyszłym Królestwie Chrystusa (Didache IX, $4 ; \mathrm{X}, 3)$.

\section{Terminologia dotycząca rzeczywistości niebiańskich}

Słownictwo eschatologiczne anonimowego autora Didache jest powtórzeniem nazewnictwa nowotestamentalnego opisującego problematykę nieba eschatologicznego. Terminy jakościowe („nieśmiertelność”, „życie wieczne”, „nadejście łaski”) przeważają nad pojęciami przestrzennych („Królestwo

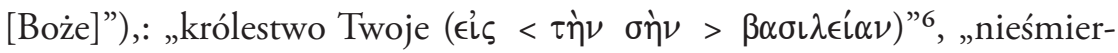

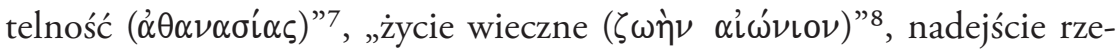
czywistości łaski związane z ostatecznym przyjściem Chrystusa i przeminięciem świata doczesnego - „Niechaj przyjdzie łaska i przeminie ten świat!

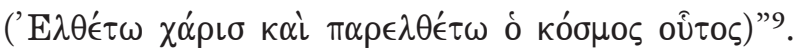

\section{Nauczanie o rzeczach niebiańskich}

Eschatologiczne życie zbawionych jest określone w Didache jako Królestwo Jezusa, do którego jest wezwany Kościół Jezusa. W przywołanych fragmentach Didache życie w eschatologicznym Królestwie jest osiągalne jedynie

6 Didache X,5,w: FCh 1, s. 124; „Pomnij, Panie, na Kościół Twój, i wybaw go od zła wszelkiego | I uczyń doskonałym w miłości Twojej. | I zgromadź go z czterech stron świata, uświęcony (

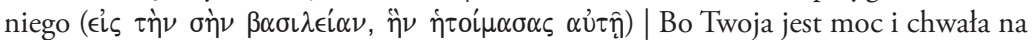
wieki!", BOK 10, s. 38.

7 Didache X,2, w: FCh 1, s. 122; „Dziękuję Ci, Ojcze Święty, | Za święte Imię Twoje, | Które z woli Twojej zamieszkało w sercach naszych, | I za poznanie, i za wiarę, i za

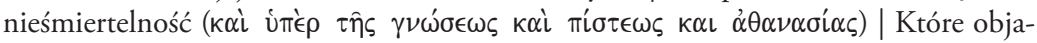
wiłeś nam przez Jezusa, sługę Twego, | Tobie chwała na wieki!", BOK 10, s. 37.

8 Didache X,3, w: FCh 1, s. 124; „Ty, Panie wszechmocny, | Stworzyłeś wszystko dla Imienia Twego, | Dałeś ludziom pokarm i napój, aby ciesząc się nim, Tobie dziękowali. | Nam zaś dałeś w swej łaskawości duchowy pokarm i napój, | i Życie wieczne

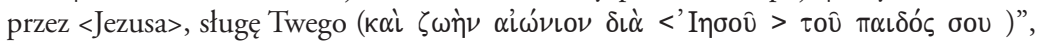
BOK 10, s. 37.

9 Didache X,6, w: FCh 1, s. 124; „Niechaj przyjdzie łaska i przeminie ten świat! | Hosanna Bogu Dawidowemu! | Kto święty, niech podejdzie, | Kto nim nie jest, niech czyni pokutę! | Marana tha. Amen", BOK 10, s. 38. 
przez Jezusa Chrystusa, dzięki któremu może go dostąpić cały Kościół ${ }^{10}$. Królestwo Jezusa jest dla chrześcijan wypełnieniem łaski Bożej, a zarazem końcem doczesnego świata ${ }^{11}$. Jakościowymi cechami Królestwa Jezusa są dla ludzi: zjednoczenie i jedność Kościoła zbawionych (Didache IX, 4), bycie członkami Chrystusowego Królestwa (Didache IX, 4; X, 5), „nieśmiertelność” (Didache X, 2), „życie wieczne” (Didache X, 3), „uświęcenie” (Didache X, 5. 6) i nastanie łaski (Didache X, 6).

Eschatologiczne wątki nauczania Didache o rzeczach niebieskich są zatem powtórzeniem katechezy nowotestamentalnej, zarówno pod względem terminologii, jak i treści. Utwór, będący w zamierzeniu tekstem ku zbudowaniu wiernych, podkreśla podstawę soteriologii NT: najważniejszym dla chrześcijańskiej wiary na ziemi oraz dla nieśmiertelności i życia wiecznego chrześcijan w Królestwie Bożym jest wyłącznie Jezus Chrystus.

\subsubsection{Klemens Rzymski, List do Kościoła w Koryncie - niebo jako realizacja obietnicy Jezusa i nagroda za uczynki}

List do Kościoła $w$ Koryncie autorstwa Klemensa Rzymskiego ${ }^{12}$ został napisany pomiędzy rokiem 96 a 98, niedługo po ustaniu prześladowań antychrześcijańskich za panowania cesarza Domicjana ${ }^{13}$. Tekst ten jest bardzo ważnym dokumentem dla poznania teologii i liturgii Kościoła Rzymskiego w I wie$\mathrm{ku}^{14}$. Bezpośrednim powodem powstania Listu do Kościota w Koryncie było

10 Didache IX,4, w: FCh 1, s. 124; „Niech Kościół Twój aż po najdalsze krańce ziemi | Zbierze się w jednym królestwie Twoim”; Didache X,5: FCh 1, s. 124; „I uczyń doskonałym w miłości Twojej. | I zgromadź go z czterech stron świata, uświęcony, | W królestwie Twoim, które przygotowałeś dla niego", BOK 10, s. 37.

11 Didache X,6, w: FCh 1, s. 124; „Niechaj przyjdzie łaska i przeminie ten świat!”, BOK 10, s. 38 .

12 Clemens Romanus, Epistola ad Corinthios, w: FCh 15. Clemens von Rom, Epistola ad Corinthios. Brief an die Korinther, übersetzt und eingeleitet von G. Schneider, Freiburg im Breisgau 1994; przekład polski List do Kościoła w Koryncie, w: Pierwsi świadkowie. Pisma Ojców Apostolskich..., dz. cyt., BOK 10, s. 51-87.

13 Por. P. F. Beatrice, Clemente Romano (Lettere di), NDPAC, vol. 1, Genova-Milano $2006^{2}$, s. 1073.

14 Por. H. E. Lona, Der erste Clemensbrief, Bd. 2, Göttingen 1998 (Kommentar zu den Apostolischen Vätern); H. Löhr, Studien zum frühchristlichen und frühjüdischen Gebet. 
Kształtowanie się nauki o niebie w teologii patrystycznej I-III wieku

złożenie z urzędu tamtejszych prezbiterów przez kilku zapalczywych agitatorów z kręgów „ascetów-entuzjastów”, przeciwnych władzy prezbiterów/ episkopów. Listowna interwencja biskupa Rzymu wyraża pragnienie przywołania wspólnoty w Koryncie do pokoju i jedności poprzez praktykę pokory i posłuszeństwa ${ }^{15}$.

Klemens Rzymski podaje w swoim liście szerszy teologicznie, niż Didache, opis nieba, który zawiera odniesienie do starotestamentalnej kosmologii, do chrystologicznego pojmowania eschatologii oraz do znaczenia uczynków doczesnych wobec możliwość osiągnięcia nieba.

\section{Kosmologia}

Bóg postrzegany przez chrześcijan na sposób duchowy ${ }^{16}$ jest przez Klemensa opisywany zgodnie z wcześniejszą myślą biblijną jako „Ojciec i Stwórca

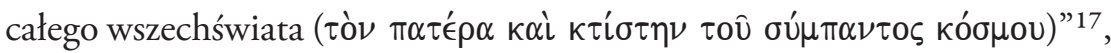

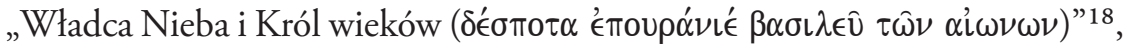

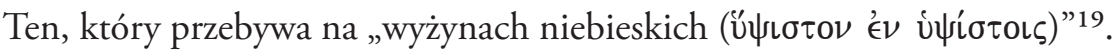
Samo niebo (oủp $\alpha \nu$ òs) jest tylko i wyłącznie dziełem Boga i nie jest przez Klemensa, w myśl Hi 15, 15, utożsamiane z Bogiem ${ }^{20}$. Wobec doczesności jest ono jednak czymś nieskazitelnym, siedzibą pobożnych $(\chi \omega \hat{\rho} \rho \nu \nu$

Untersuchungen zu 1 Clem 59 bis 61 in seinem literarischen, historischen und theologischen Kontext, Tübingen 2003.

15 Por. W. Ullmann, The Cosmic Theme of the Prima Clementis and Its Significance for the Concept of Roman Rulership, „Studia Patristica” 11/2 (1972), Berlin 1972, s. 85-91 (TU 108); G. Schneider, Einleitung [VI. Theologische Bedeutung], w: FCh 15. Clemens von Rom, Epistola ad Corinthios. Brief an die Korinther, übersetzt und eingeleitet von G. Schneider, Freiburg im Breisgau 1994, s. 34-56.

16 Klemens Rzymski, List do Kościota w Koryncie XIX,3, w: FCh 15, s. 112; „Patrzmy na Niego w myśli i oglądajmy oczyma duszy Jego wielką cierpliwość w urzeczywistnianiu

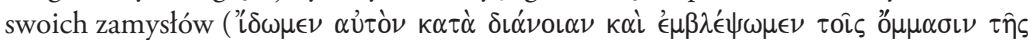

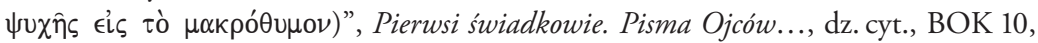
s. 60.

17 Klemens Rzymski, List do Kościota w Koryncie XIX,2, w: FCh 15, s. 112; BOK 10, s. 60.

18 Klemens Rzymski, List do Kościota w Koryncie LXI,2, w: FCh 15, s. 214; BOK 10, s. 80.

19 Klemens Rzymski, List do Kościota w Koryncie LIX,3, w: FCh 15, s. 208; BOK 10, s. 78.

20 Klemens Rzymski, List do Kościota w Koryncie XXXIX,5, w: FCh 15, s. 158; „Niebo nawet nie jest dlań czyste", BOK 10, s. 68. 
$\epsilon \cup ่ \sigma \epsilon \beta \omega \nu \nu)$ i nieskalanych ( $\alpha \mu \omega \mu \mathrm{ol})$, co zostanie ukazane podczas nastania

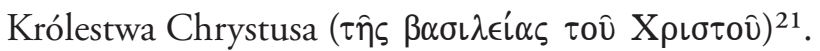

„XX,1. Niebiosa (oi oủpavoì) obracają się pod Jego ręką i w pokoju są Mu posłuszne. 2. Dzień i noc odbywają drogę przez Niego im wyznaczoną, nigdy sobie wzajemnie nie przeszkadzając. 3. Słońce, księżyc i chóry gwiazd biegną w zgodzie po wytyczonych im orbitach i ani na chwilę z nich nie zbaczają. 4. Ziemia $(\gamma \hat{\eta})$ brzemienna we właściwych porach rodzi zgodnie z Jego wolą przeobfite pożywienie dla ludzi, zwierząt i wszystkich istot, jakie na niej żyją, nie buntuje się ani nie próbuje zmieniać tego, co On postanowił. 5. W niezgłębionych otchłaniach przepaści ( $\alpha \beta u ́ \sigma \sigma \omega \nu \tau \epsilon \dot{\alpha} \nu \epsilon \zeta\left\llcorner\chi \nu^{\prime} \alpha \sigma \tau \alpha\right)$ i niezbadanych krainach podziemia

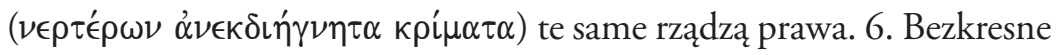

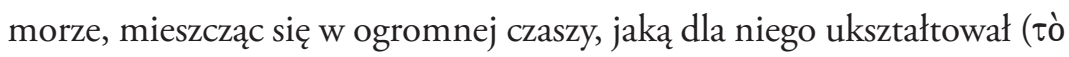

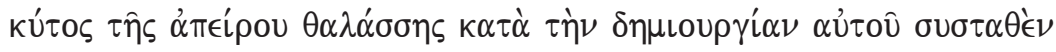

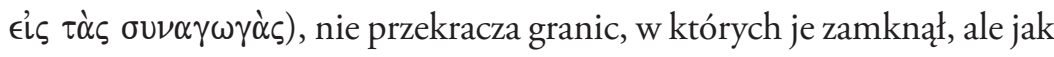
mu rozkazał, tak postępuje. 7. Rzekł bowiem: «Dotąd dojdziesz, a fale twoje będą rozbijać się w tobie». 8. Ocean nieprzebyty dla człowieka

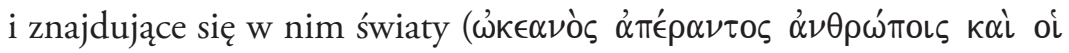

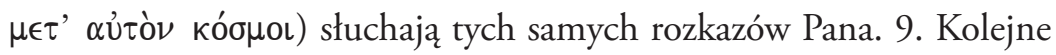
wiosny, lata, jesienie i zimy w pokoju jedne drugim ustępują miejsca. 10. Wiatry w czasie stosownym opuszczają swoje mieszkania wypełniając bezbłędnie swoją służbę. Wiecznie bijące źródła ( $\alpha \in \nu \alpha o i ́ ~ \tau \epsilon$ $\pi \eta \gamma \alpha i$ ), stworzone dla przyjemności i dla zdrowia ludzi, pozwalają im bez chwili przerwy czerpać życie ze swoich piersi. Najmniejsze nawet zwierzęta spotykają się w zgodzie i pokoju. 11. Wielki Pan i Stwórca

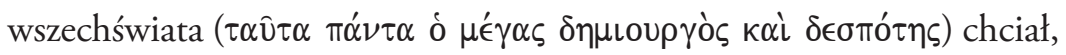
aby w zgodzie i pokoju żyło wszystko, wszystkim też stworzeniom czyni dobrze, a przeobficie obdarza zwłaszcza nas, którzy uciekamy się do

21 Klemens Rzymski, List do Kościota w Koryncie L,2-3, w: FCh 15, s. 186; „Prośmy więc i błagajmy Jego miłosierdzia, abyśmy mogli żyć w miłości nie znającej żadnych ludzkich względów, nieskazitelni. 3. Wszystkie pokolenia od Adama aż po dzień dzisiejszy przeminęły, lecz ci, co dzięki łasce Bożej byli w miłości doskonali, mieszkają w siedzibie świętych [„pobożnych” - tłumaczenie własne Autora], którzy ukażą się w godzinie przyjścia Królestwa Chrystusowego", BOK 10, s. 74. 
Kształtowanie się nauki o niebie w teologii patrystycznej I-III wieku

jego miłosierdzia przez naszego Pana Jezusa Chrystusa. 12. Jemu chwała i majestat na wieki wieków. Amen"22.

Powyższy fragment dowodzi, iż kosmologia Klemensa Rzymskiego jest kontynuacją wcześniejszej kosmologii biblijnej i posiada wyraźne odniesienie do Rdz 1, 5n i Hi 38, 11. Na wzorowanie się kosmologii Klemensa na myśli biblijnej wskazują fragmenty o trójczłonowej budowie wszechświata (niebiosa, ziemia, otchłanie przepaści) oraz o zachowaniu harmonii w stworzeniu dzięki przestrzeganiu Bożej woli („są Mu posłuszne”, „odbywają drogę przez Niego im wyznaczoną”, „zgodnie z Jego wolą”, „nie buntuje się, ani nie próbuje zmieniać tego, co On postanowił”, „te same rządzą prawa”, „jak mu rozkazał, tak postępuje”, „słuchają tych samych rozkazów Pana”). Nie mniej charakterystycznym jest odwołanie do woli Bożej dotyczącej powszechnej zgody pośród stworzeń („chciał, aby w zgodzie i pokoju żyło wszystko”), co stanowi aluzję do pierwotnej zgody wszystkich stworzeń w Ogrodzie w Eden.

\section{Terminologia „nagrody i wzoru”}

Życie po śmierci zostało określone przez Klemensa Rzymskiego w kategorii nagrody i wzoru - „odejście do [miejsca] chwały, na którą sobie dobrze za-

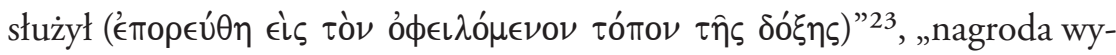

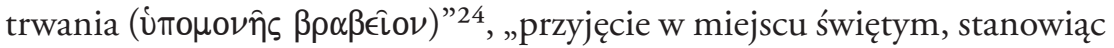

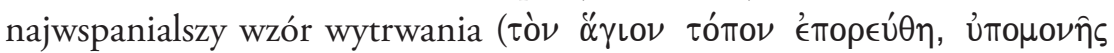

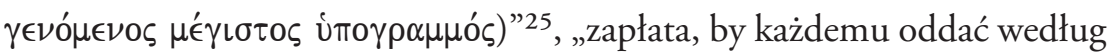

22 Klemens Rzymski, List do Kościoła w Koryncie XX,1-12, w: FCh 15, s. 114.116; BOK 10, s. 60-61.

23 Klemens Rzymski, List do Kościota w Koryncie V,4, w: FCh 15, s. 76; „Popatrzmy na świętych Apostołów: Piotra nie raz i nie dwa, ale wiele razy, spotykała ciężka próba z powodu niegodziwej zazdrości, a złożywszy w ten sposób swoje świadectwo, odszedł do [miejsca] chwały, na którą sobie dobrze zasłużył”, BOK 10, s. 53.

24 Klemens Rzymski, List do Kościota w Koryncie V,5-6, w: FCh 15, s. 76; „5. Przez zazdrość i niezgodę również Paweł [znalazł sposobność by nam] wskazać, jaka jest nagroda wytrwania: 6 . Więziony siedem razy, skazywany na wygnanie, kamienowany, stał się heroldem Pana na Wschodzie i na Zachodzie, pozyskał też za swoją wierność szlachetną sławę", BOK 10, s. 53 (por. 2 Kor 11, 24).

25 Klemens Rzymski, List do Kościota w Koryncie V,7, w: FCh 15, s. 76; „[Paweł] Uczył sprawiedliwości ziemię całą i dotarł aż do zachodnich jej granic (por. Rz 15, 24. 28), 
2. Kształtowanie się nauki o niebie w teologii patrystycznej - wiek I-II

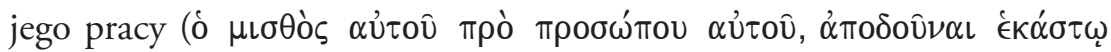

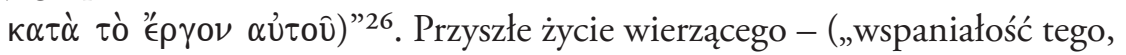

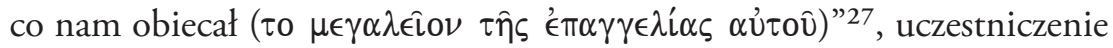

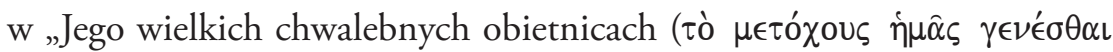

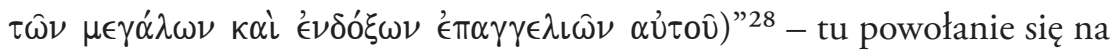
1 Kor 2, 9 - podobnie jak przyszłe zmartwychwstanie dokona się mocą Boga, dzięki Jego prawdomówności i wierności złożonym obietnicom ${ }^{29}$.

\section{Względna wartość uczynków}

Klemens naucza, że pośrednim sposobem odziedziczenia nieba są: praktykowanie sprawiedliwości przez posłuszeństwo Bogu jak Henoch ${ }^{30}$, dążenie

a złożywszy wobec przedstawicieli władz (por. Dz 24, 26) swoje świadectwo odszedł ze świata i został przyjęty w miejscu świętym, stanowiąc [dla nas] najwspanialszy wzór (por. 1 P 2, 21) wytrwania”, BOK 10, s. 53.

26 Klemens Rzymski, List do Kościota w Koryncie XXXIV,3, w: FCh 15, s. 144; BOK 10, s. 66. Cytat w tej formie jest nieznany w Biblii, tłumacze i komentatorzy odsyłają natomiast do podobnych znaczeniowo tekstów: Iz 40, 10; 62, 11; Prz 24, 12; Ps 61, 13; Rz 2, 6; Ap 22, 12.

27 Klemens Rzymski, List do Kościoła w Koryncie XXVI,1-2, w: FCh 15, s. 128; „1. Czyż zatem uznamy to za rzecz dziwną i nadzwyczajną, jeśli Stwórca wszechświata wskrzesi z martwych tych, co Mu służyli, święci, w ufności wiary doskonałej, skoro nawet przez ptaka [tu mit o feniksie - uwaga Autora] objawia wspaniałość tego, co nam obiecał? 2. Gdzieś bowiem jest powiedziane: «Wskrzesisz mnie i będę Cię sławił» (por. Ps 27,$7 ; 87,11$ ) oraz «Położyłem się i zasnąłem, lecz powstałem, bo Ty jesteś ze mną» (por. Ps 3, 6; 22, 4). A z kolei Hiob mówi: «I wskrzesisz moje ciało, to właśnie, które to wszystko wycierpiało (Hi 19, 26)»”, BOK 10, s. 63; Klemens Rzymski, List do Kościota w Koryncie XXXIV,5, w: FCh 15, s. 145 „Niech On sam będzie naszą chlubą i pewnością", BOK 10, s. 66.

28 Klemens Rzymski, List do Kościota $w$ Koryncie XXXIV,7-8, w: FCh 15, s. 146; „7. (...) abyśmy mogli stać się uczestnikami Jego wielkich chwalebnych obietnic. 8. Powiedziane jest bowiem: «Ani oko nie widziało, ani ucho nie słyszało, ani serce człowieka nie zdołało pojąć, jak wielkie rzeczy przygotował Pan tym, którzy na Niego czekają", BOK 10, s. 66 (por. 1 Kor 2, 9).

29 Klemens Rzymski, List do Kościota w Koryncie XXVII,1-2, w: FCh 15, s. 130; „Niechaj więc ta nadzieja sprawi, by dusze nasze przylgnęly do Tego, który jest wierny w swych obietnicach i sprawiedliwy w swoich sądach. 2. Ten, kto zabronił kłamstwa, tym bardziej sam nie kłamie. Dla Boga nie ma nic niemożliwego oprócz kłamstwa”, BOK 10, s. 63.

30 Klemens Rzymski, List do Kościota w Koryncie IX,3, w: FCh 15, s. 84; „Pomyślmy

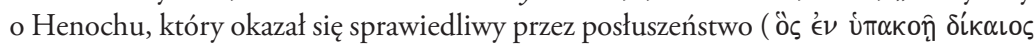

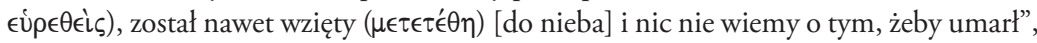
BOK 10, s. 55 (por. Rdz 5, 24). 
Kształtowanie się nauki o niebie w teologii patrystycznej I-III wieku

do własnego uświęcenia ${ }^{31}$, gdyż chrześcijanie są „wybranym dziedzictwem”32 Boga oraz czynienie dobra i życie w miłości ${ }^{33}$. Powyższe uczynki (praktyka sprawiedliwości, dobra i miłości, dążenie do świętości) nie mają jednak wartości zbawczej same z siebie, gdyż usprawiedliwienie człowieka dokonuje się jedynie z woli Bożej - przez wiarę:

„3. Wszyscy zatem zdobywają wielkość i chwałę nie sami z siebie ani przez swoje czyny, ani przez sprawiedliwe postępowanie, lecz z woli Boga. 4. Tak więc i my, z woli Jego powołani w Jezusie Chrystusie, jesteśmy usprawiedliwieni nie sami z siebie ani przez naszą mądrość, ani rozum, ani pobożność, ani przez nasze uczynki, choć nawet wypełniamy je w czystości serca, lecz przez wiarę. To przez nią Bóg Wszechmogący usprawiedliwia wszystkich ludzi od początku świata. Jemu chwała na wieki wieków. Amen"34.

Obecna w zacytowanym tekście Klemensa Rzymskiego teologia usprawiedliwienia wyłącznie z woli Boga, przez wiarę, stanowi wyraźną kontynuację Pawłowej teologii usprawiedliwienia (por. Rz 3, 28. 30; Ga 2, 16; 3, 8-11; Ef 2, 8). Uczynki pobożne i sprawiedliwie są zatem ludzkim

31 Klemens Rzymski, List do Kościota w Koryncie XXX,1, w: FCh 15, s. 136; „Skoro więc

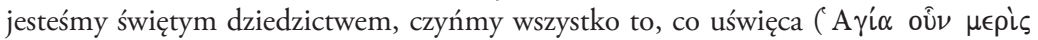

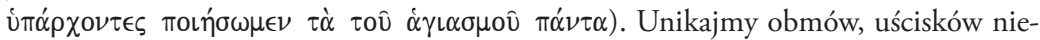
czystych i bezwstydnych, pijaństwa, pogoni za nowostkami, wstrętnych żądz, nienawistnego cudzołóstwa i obrzydłej pychy", BOK 10, s. 64.

32 Klemens Rzymski, List do Kościoła w Koryncie XXIX,1, w: FCh 15, s. 134; „Kochajmy naszego Ojca łaskawego i miłosiernego, który uczynił nas swoim wybranym dziedzi-

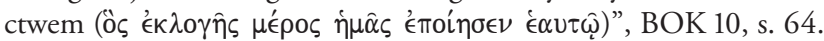

33 Klemens Rzymski, List do Kościota w Koryncie XXXIII,1, w: FCh 15, s. 142; „Jak więc mamy postępować, bracia? Zaniechamy czynienia dobrze i wyrzekniemy się miłości? Oby Pan nigdy nie dozwolił, by cos takiego z nami się stało!", BOK 10, s. 65.

34 Klemens Rzymski, List do Kościota w Koryncie XXXII,3-4, w: FCh 15, s. 140; „3. $\pi \dot{\alpha} \nu \tau \epsilon \varsigma$

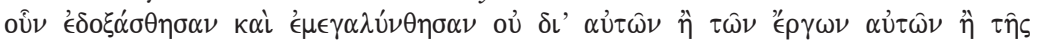

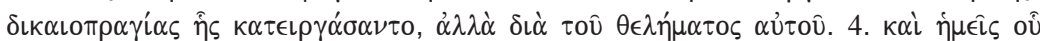

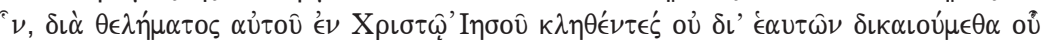

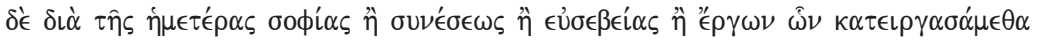

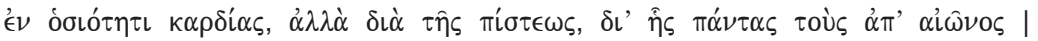

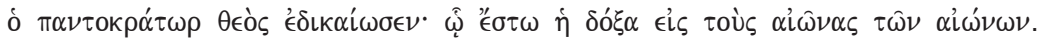
$\dot{\alpha} \mu \eta \nu^{\prime \prime}$, BOK 10, s. 65. 
potwierdzeniem przynależności do Boga, ale nie mają wartości czy zasługi samozbawiającej. Dlatego Klemens zaleca chrześcijanom przede wszystkim postawę wierności Bogu poprzez wypełnianie Jego woli i życie według zasad prawdy i dobra ${ }^{35}$.

\section{Cechy życia zbawionych}

Klemens charakteryzuje zbawionych jako tych, którzy posiadają „błogosławione i cudowne dary Boże”, tj. „życie w nieśmiertelności, sprawiedliwość w chwale, prawdę w wolności, ufność w wierze, wstrzemięźliwość i uświęcenie, a wszystko to dostępne naszemu rozumieniu"36. Życie zbawionych jest zatem darem Boga, darem charakteryzującym się kategoriami już teraz policzalnymi i pojmowalnymi przez rozum ludzki (jak powyższe) oraz tymi jeszcze niepoliczalnymi i niepojmowalnymi (znanymi teraz jedynie Bogu ${ }^{37}$, darem przewidzianym i przygotowanym przez Boga dla chrześcijan jeszcze przed ich narodzeniem ${ }^{38}$.

\section{Wizja Boga - przez Chrystusa i w Chrystusie}

Klemens wychodzi od wskazania na Jezusa jako obrońcę, wspomożyciela i zbawienie chrześcijan ${ }^{39}$. Mówiąc o Jezusie przebywającym w niebie,

35 Klemens Rzymski, List do Kościoła w Koryncie XXXV,5, w: FCh 15, s. 148; „A jak to osiągnąć, umiłowani? Trzeba nasze serca wiernie utwierdzić w Bogu, trzeba szukać tego, co Mu się podoba i co jest Mu miłe, trzeba czynić to, co zgadza się z Jego święta wolą i postępować naprzód drogą prawdy odrzuciwszy precz wszelką niegodziwość i przewrotność, chciwość, niezgodę, złośliwość i podstępy, potwarze i oszczerstwa, sprzeciwianie się Bogu, pychę i chełpliwość, próżność i niegościnność”, BOK 10, s. 66-67.

36 Klemens Rzymski, List do Kościota w Koryncie XXXV,1-2, w: FCh 15, s. 148; „1. ' $\Omega \varsigma$

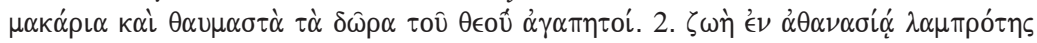

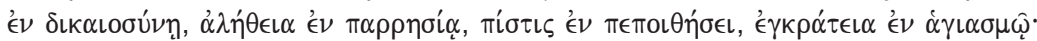

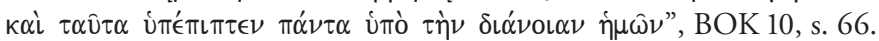

37 Klemens Rzymski, List do Kościota w Koryncie XXXV,3, w: FCh 15, s. 148; „Jakież zatem dobra przygotował tym, którzy na Niego czekają? Stwórca i Ojciec wieków, Jedyny

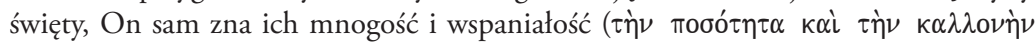
$\alpha \dot{\tau} \tau \omega \nu) "$, BOK 10, s. 66.

38 Klemens Rzymski, List do Kościota w Koryncie XXXVIII,3, w: FCh 15, s. 158; „Ten, który nas stworzył i ukształtował, przygotowując swoje dary dla nas, jeszcze przed naszym narodzeniem", BOK 10, s. 68.

39 Klemens Rzymski, List do Kościoła w Koryncie XXXVI,1, w: FCh 15, s. 152; „Taka jest droga, umiłowani, na której znajdujemy zbawienie nasze ( 
Kształtowanie się nauki o niebie w teologii patrystycznej I-III wieku

Klemens używa wyrażeń biblijnych: On „jest odblaskiem Jego chwały. O tyle stał się wyższy od aniołów, o ile odziedziczył wyższe od nich imię" (Hbr 1, 3) ${ }^{40}$, „o swoim zaś Synu tak Pan powiedział: «Tyś Synem moim, Ja Ciebie dziś zrodziłem. Żądaj ode mnie, a dam Ci narody w dziedzictwo i w posiadanie Twoje krańce ziemi» (Ps 2, 7)”41, „i mówi jeszcze do Niego: «Siądź po mojej prawicy, aż twych wrogów położę jako podnóżek pod twoje stopy» (Hbr 1, 13; por. Ps 109, 1)" 42 .

Z lektury przytoczonych passusów Listu do Kościoła w Koryncie wynika, że Klemens wierzył, iż Jezus jest wyższy od aniołów, jest Synem Bożym, zasiada jako panujący z Bogiem na tronie w niebie. Jako taki Chrystus jest władny udzielać łaski poznania Boga zarówno w doczesności, jak i w nieśmiertelności. Dzięki Jezusowi wierzący mogą również widzieć Boga. Klemens Rzymski precyzuje, że chodzi mu o wizję dokonującą się w doczesności. Ów duchowy zmysł wzroku ${ }^{43}$, realizujący się w wierze dzięki Jezusowi, stanowi jednak zapowiedź przyszłego poznania Boga gdyż „przez Niego Pan zechciał nam dać przedsmak nieśmiertelnego po-

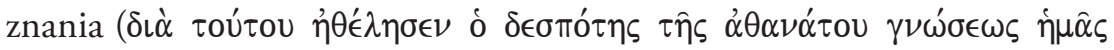
$\gamma \in \dot{\sigma} \sigma \alpha \sigma \theta \alpha \iota) " 44$.

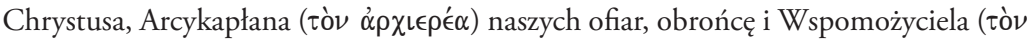

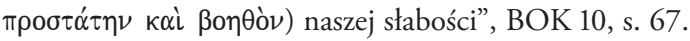

40 Klemens Rzymski, List do Kościoła $w$ Koryncie XXXVI,2, w: FCh 15, s. 152; BOK 10, s. 67.

41 Klemens Rzymski, List do Kościoła w Koryncie XXXVI,4, w: FCh 15, s. 152; BOK 10, s. 67.

42 Klemens Rzymski, List do Kościota w Koryncie XXXVI,5, w: FCh 15, s. 152.154; BOK 10, s. 67.

43 Klemens Rzymski jest prawdopodobnie pierwszym autorem chrześcijańskim, który dokonuje refleksji o duchowym zmyśle wzroku, choć nie używa jeszcze terminologii technicznej, którą stworzy dopiero w III wieku Orygenes. Więcej na temat rozumienia zmysłów duchowych w teologii patrystycznej, zob. D. Kasprzak, Sens duchowy Pisma Swiętego i doktryna o pięciu zmystach duchowych jako przyktad interpretacji stowa przez świętych, w: Hermeneutyka Pisma Świętego w Kościele: Wokół adhortacji Verbum Domini Benedykta XVI, o słowie Bożym w życiu i misji Kościoła, red. R. Pindel, S. Jędrzejewski, Kraków 2013, s. 67-97 (Hermeneutica et Judaica 6); Zmysty duchowe. Percepcja Boga w zachodnim chrześcijañstwie, red. P. L. Gavrilyuk, S. Coakley, tłum. A. Gomola, Kraków 2014, s. 37-158.

44 Klemens Rzymski, List do Kościota w Koryncie XXXVI,2, w: FCh 15, s. 152; „Przez

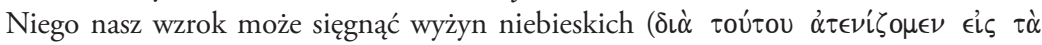
ư $\psi \tau \tau \hat{\omega} \nu$ oủp $\alpha \nu \hat{\omega} \nu)$, w Nim widzimy odbicie najczystszego i pełnego majestatu oblicza 
2. Kształtowanie się nauki o niebie w teologii patrystycznej - wiek I-II

\title{
2.1.3. Ignacy Antiocheński - „Chrystus - bramą Ojca”
}

\begin{abstract}
Zbiór siedmiu listów pasterskich Ignacego, drugiego następcy Piotra w Kościele Antiocheńskim ${ }^{45}$, powstał w latach 110-111, kiedy Ignacy był aresztowany przez Rzymian i przewożony do Rzymu, gdzie umarł śmiercią męczeńską. Większość współczesnych badaczy przyjmuje autentyczność wszystkich siedmiu listów w ich drugiej redakcji ${ }^{46}$. Zdaniem Hubertusa R. Drobnera podstawowymi tematami listów są: (1) ostrzeżenia chrześcijan
\end{abstract}

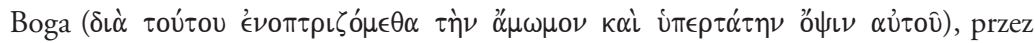
Niego otwarły się oczy naszego serca, przez Niego nasz umysł, niepojętny i ciemny, rozpromienił się światłem, przez Niego Pan zechciał nam dać przedsmak nieśmiertelnego poznania", BOK 10, s. 67.

45 Por. Ignatius Antiochenus, Epistula ad Ephesios (I), w: SU 1. Die Apostolischen Väter, eingeleitet, herausgegeben, übertragen und erläutert von J. A. Fischer, Darmstadt $1998^{10}$, s. 142-161; przekład polski Ignacy Antiocheński, List do Kościoła w Efezie, w: Pierwsi świadkowie. Pisma Ojców..., dz. cyt., BOK 10, s. 113-119.

Ignatius Antiochenus, Epistula ad Magnesios (II), w: SU 1. Die Apostolischen Väter, eingeleitet, herausgegeben, übertragen und erläutert von J. A. Fischer, Darmstadt $1998^{10}$, s. 162-171; przekład polski Ignacy Antiocheński, List do Kościoła w Magnezji, w: Pierwsi świadkowie. Pisma Ojców..., dz. cyt., BOK 10, s. 120-123.

Ignatius Antiochenus, Epistula ad Trallianos (III), w: SU 1. Die Apostolischen Väter, eingeleitet, herausgegeben, übertragen und erläutert von J. A. Fischer, Darmstadt $1998^{10}$, s. 172-181; przekład polski Ignacy Antiocheński, List do Kościoła $w$ Tralleis, w: Pierwsi świadkowie. Pisma Ojców..., dz. cyt., BOK 10, s. 124-127.

Ignatius Antiochenus, Epistula ad Romanos (IV), w: SU 1. Die Apostolischen Väter, eingeleitet, herausgegeben, übertragen und erläutert von J. A. Fischer, Darmstadt $1998^{10}$, s. 182-193; przekład polski Ignacy Antiocheński, List do Kościoła w Filadelfii, w: Pierwsi świadkowie. Pisma Ojców..., dz. cyt., BOK 10, s. 128-131.

Ignatius Antiochenus, Epistula ad Philadelphos (V), w: SU 1. Die Apostolischen Väter, eingeleitet, herausgegeben, übertragen und erläutert von J. A. Fischer, Darmstadt $1998^{10}$, s. 194-203; przekład polski Ignacy Antiocheński, List do Kościoła w Filadelfii, w: Pierwsi świadkowie. Pisma Ojców..., dz. cyt., BOK 10, s. 132-135.

Ignatius Antiochenus, Epistula ad Smyrnesios (VI), w: SU 1. Die Apostolischen Väter, eingeleitet, herausgegeben, übertragen und erläutert von J. A. Fischer, Darmstadt $1998^{10}$, s. 204-215; przekład polski Ignacy Antiocheński, List do Kościoła w Smyrnie, w: Pierwsi świadkowie. Pisma Ojców..., dz. cyt., BOK 10, s. 136-139.

Ignatius Antiochenus, Epistula ad Polycarpos (VII), w: SU 1. Die Apostolischen Väter, eingeleitet, herausgegeben, übertragen und erläutert von J. A. Fischer, Darmstadt $1998^{10}$, s. 246-265; przekład polski Ignacy Antiocheński, List do Polikarpa, w: Pierwsi świadkowie. Pisma Ojców..., dz. cyt., BOK 10, s. 140-142.

46 Por. P. Nautin, Ignazio di Antiochia, w: NDPAC, vol. 2, Genova-Milano $2007^{2}$, s. $2514-2016$. 
Kształtowanie się nauki o niebie w teologii patrystycznej I-III wieku

ortodoksyjnych przed doktrynami heterodoksyjnymi (głwnie przed sabatystami i doketami); (2) jedność teologii monoteizmu trynitarnego, eklezjologii - Kościół ziemski, nazwany po raz pierwszy „katolickim” - „ฑ $\kappa \alpha \theta \hat{\delta}$

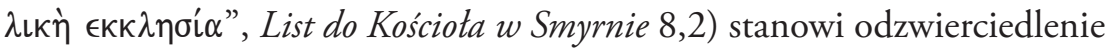
królestwa niebieskiego i jest wzorowany na modelu Trzech Osób Bożych); (3) teologia i pragnienie męczeństwa ${ }^{47}$.

Odniesienia do tematyki niebiańskiej znajdujemy w sześciu listach Ignacego (List do Kościota w Efezie, List do Kościota w Magnezji, List do Kościota w Tralleis, List do Kościota w Filadelfi, List do Kościota w Smyrnie, List do Polikarpa), natomiast brak tego zagadnienia w Liście do Kościota w Rzymie. W kontekście najważniejszych, zdaniem Ignacego, tematyk teologicznych biskup Antiochii, wspominając o sprawach niebieskich ( $\tau \dot{\alpha}$ $\epsilon \pi \operatorname{co} \rho \alpha \dot{\nu} \nu \alpha)$, prezentuje pedagogiczną pokorę. Dlatego za wiele nie pisze o nich do swych wiernych, gdyż są jeszcze niezbyt ugruntowani w wierze („bo jesteście jeszcze niemowlętami” - por. 1 Kor 3, 1, „byście się przypadkiem nie udławili, niezdolni do przyjęcia [stałego pokarmu]") ${ }^{48}$. Stąd Ignacy stwierdza, iż zarówno dla niego, jak i dla innych chrześcijan najistotniejszą dla ukształtowania się jego chrześcijaństwa kwestią - jest osobista więź z Bogiem, a nie rozważania o rzeczach niebieskich:

„Ja również, chociaż jestem więźniem i mogę rozważać rzeczy niebieskie, hierarchie aniołów i zastępy zwierzchności, byty widzialne i niewidzialne, nie jestem jeszcze $\mathrm{z}$ tego powodu uczniem. Wiele nam bowiem brakuje, aby Boga nam nie brakowało" ${ }^{49}$.

Ignacy, kontynuując nowotestamentalną teologię Janową i Pawłową, podkreśla istotową rolę Jezusa dla chrześcijańskiego dążenia do nieba.

47 Por. H. R. Drobner, Patrologia, Casale Monferrato 1998, s. 103.

48 Ignacy Antiocheński, List do Kościota w Tralleis V,1, w: SU 1, s. 174; BOK 10, s. 125.

49 Ignacy Antiocheński, List do Kościota $w$ Tralleis V,2, w: SU 1, s. 174.176: „, каi $\gamma \grave{\alpha} \rho$

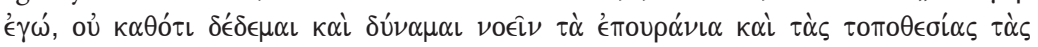

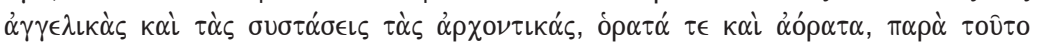

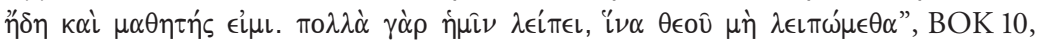
s. 125 . 


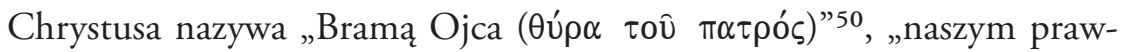

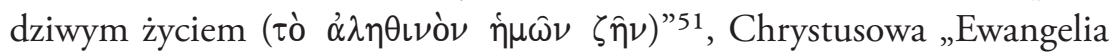

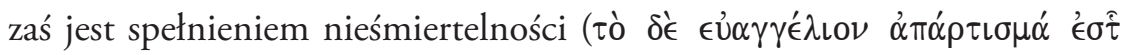
$\iota \nu \dot{\alpha} \phi \theta \alpha \rho \sigma i \alpha \varsigma)$ " 52 . Chrystus po zmartwychwstaniu jest opisany jako „isto-

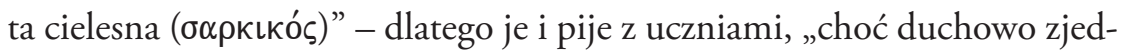

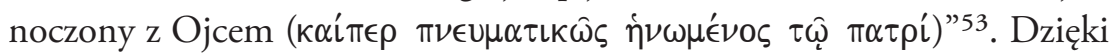
wierze oraz duchowemu i zmysłowemu kontaktowi ze zmartwychwstałym Jezusem - Jedenastu - „śmiercią wzgardzili i okazali się ponad śmierć wyżsi

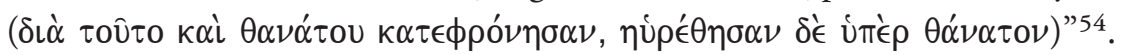

\section{Terminologia opisująca niebo}

Słownictwo, które występuje w listach Ignacego Antiocheńskiego, jest zależne od nazewnictwa NT, terminy jakościowe przeważają nad tymi przestrzen-

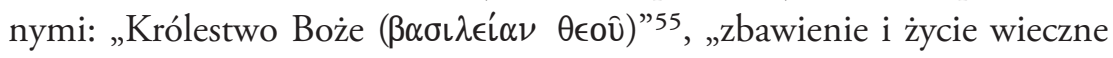

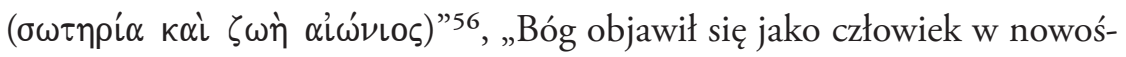
ci życia wiecznego [...] bo przygotowywało się unicestwienie śmierci ( $\theta \in 0 \hat{v}$

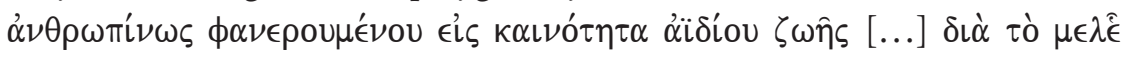

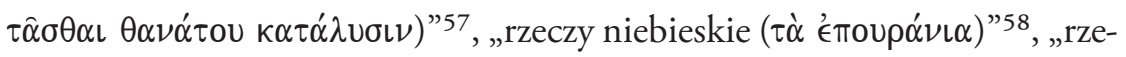
czy niebieskie, hierarchie aniołów i zastępy zwierzchności, byty widzialne

50 Ignacy Antiocheński, List do Kościota w Filadelfi IX,1, w: SU 1, s. 200; BOK 10, s. 134 (por. J 10, 7. 9).

51 Ignacy Antiocheński, List do Kościoła w Smyrnie IV,1, w: SU 1, s. 206; BOK 10, s. 137 (por. J 3, 36; 14, 6; 20, 31; Flp 1, 21; Kol 3, 4).

52 Ignacy Antiocheński, List do Kościota w Filadelfii IX,2, w: SU 1, s. 200; BOK 10, s. 134 (por. J 14, 6).

53 Ignacy Antiocheński, List do Kościota w Smyrnie III,3, w: SU 1, s. 206; „A po swym zmartwychwstaniu Jezus jadł i pił razem z nimi jak istota cielesna, chociaż duchowo był zjednoczony z Ojcem", BOK 10, s. 136 (por. J 10, 30).

54 Ignacy Antiocheński, List do Kościota w Smyrnie III,2, w: SU 1, s. 206; BOK 10, s. 136 (por. J 20, 20. 27; Łk 24, 39. 37).

55 Ignacy Antiocheński, List do Kościoła w Efezie XVI,1, w: SU 1, s. 154; BOK 10, s. 117 (por. Mt 24, 4; Mk 13, 5; Łk 21, 81; 1 Kor 6, 9; Ga 6, 7).

56 Ignacy Antiocheński, List do Kościota w Efezie XVIII,1, w: SU 1, s. 156; BOK 10, s. 118 (por. 1 Kor 1, 23).

57 Ignacy Antiocheński, List do Kościota w Efezie XIX,3, w: SU 1, s. 158; „Kiedy Bóg objawił się jako człowiek w nowości życia wiecznego: zaczynało się spełniać to, co Bóg postanowił. Toteż wszystko było poruszone, bo przygotowywało się unicestwienie śmierci”, BOK 10, s. 118 (por. Rz 6, 4).

58 Ignacy Antiocheński, List do Kościota w Tralleis V,1, w: SU 1, s. 174; BOK 10, s. 125. 
Kształtowanie się nauki o niebie w teologii patrystycznej I-III wieku

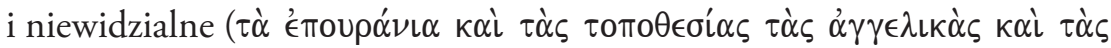

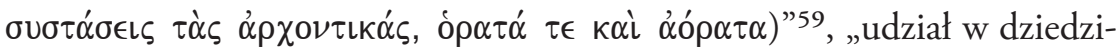

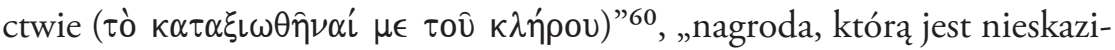

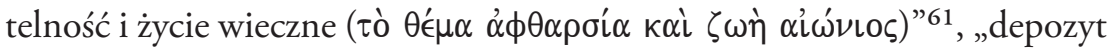

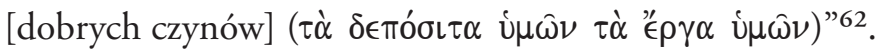

\section{Postawy uniemożliwiające odziedziczenie nieba}

To cudzołóstwo i głoszenie schizm lub herezji, propagujących rozwiązłość seksualną (por. 1 Kor 6, 9) ${ }^{63}$, wybór drogi złych uczynków, jako wybór śmierci i wierności światu doczesnemu, a nie Bogu („moneta świata”, „niewierni mają na sobie znak tego świata", brak wyboru Jezusa, a w konsekwencji życie niezgodne z przesłaniem Jezusa - to brak życia ${ }^{64}$.

59 Ignacy Antiocheński, List do Kościoła $w$ Tralleis V,2, w: SU 1, s. 174-176; BOK 10, s. 125 (por. Kol 1, 16; 2, 10; Ef 1, 21; 3, 10).

60 Ignacy Antiocheński, List do Kościota w Tralleis XII,3, w: SU 1, s. 180; „Abym stał się godnym udziału w dziedzictwie, jakie jestem gotów otrzymać i abym nie został uznany za niezdatnego", BOK 10, s. 127 (por. 1 Kor 9, 17).

61 Ignacy Antiocheński, List do Polikarpa II,3, w: SU 1, s. 218; „Bądź trzeźwy jak Boży zawodnik. Nagrodą jest nieskazitelność i życie wieczne, o czym ty również jesteś niezłomnie przekonany", BOK 10, s. 140.

62 Ignacy Antiocheński, List do Polikarpa VI,2, w: SU 1, s. 222; „Wasze depozyty to wasze czyny, abyście otrzymali sumy wam należne w całości”, BOK, 10, s. 142. Jak zaznacza M. Starowieyski, BOK 10, s. 148, przypis 16, zdanie to stanowi odniesienie do zwyczaju, jaki panował w rzymskich legionach, gdzie żołnierz regularnie otrzymywał połowę żołdu, a drugą połowę odkładano właśnie jako depozyt, który otrzymywał po zakończeniu służby. Dla chrześcijan analogicznym depozytem są dobre uczynki, które przynoszą częściowy pożytek w doczesności, a pełny - po śmierci i zmartwychwstaniu - w niebie (por. 1 Tm 1, 18).

63 Ignacy Antiocheński, List do Kościoła w Efezie XVI,1, w: SU 1, s. 154; „oi oíoфӨópol $\beta \alpha \sigma \iota \lambda \epsilon i \alpha \nu$ $\theta \in \circ \hat{\text { oủ } \kappa \lambda \eta \rho о \nu o \mu \eta ́ \sigma o v \sigma \iota \nu ”, ~ „ N i e ~ ł u d z ́ c i e ~ s i e ̨, ~ b r a c i a ~ m o i: ~ b u r z y c i e l e ~ r o-~}$ dzin nie odziedziczą Królestwa Bożego”, BOK 10, s. 117. Według opinii J. A. Fischera, SU 1, s. 155, przypis 71, sformułowanie „burzyciele rodzin” wynika z 1 Kor 6, 9 (por. Mt 24, 4; Mk 13, 5; Łk 21, 8; 1 Kor 15, 33; Ga 6, 7) i odnosi się do tych, którzy niszczą-burzą rodziny, do cudzołożników (por. A. Vögtle, Die Tugend - und Lasterkataloge im Neuen Testament, Münster 1936, s. 123). W sensie przenośnym może być także odnoszone członków sekt, które propagują rozwiązłość seksualną (por. Kpł 20, 10; J 8, 5). Natomiast według M. Starowiejskiego, BOK 10, s. 144, przypis 36, określenie „burzyciele rodzin” u Ignacego oznacza łącznie zarówno kategorię cudzołożników, jak i heretyków.

64 Ignacy Antiocheński, List do Kościota w Magnezji V,1-2, w: SU 1, s. 164; „Wszystko ma swój koniec i dwie rzeczy przed nami jednakowo do wyboru: życie i śmierć ( $\tau \dot{\alpha}$ 
2. Kształtowanie się nauki o niebie w teologii patrystycznej - wiek I-II

\section{Postawy sprzyjające odziedziczeniu nieba}

To więź wierzącego z Jezusem Chrystusem ${ }^{65}$, uczestnictwo w Eucharystii

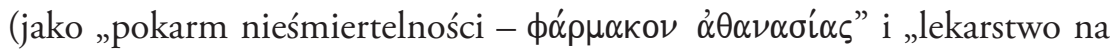

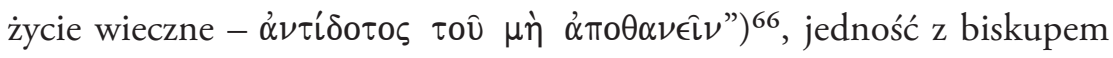
i kościelnymi przełożonymi (jako obraz i nauka nieśmiertelności) ${ }^{67}$, wybór drogi dobrych uczynków jako opcja za życiem ${ }^{68}$.

W tekstach Ignacego Antiocheńskiego obserwujemy charakterystyczną postawę „pedagogicznej pokory” w prezentacji „rzeczy niebieskich”: niewiele tam treści dotyczących eschatologii końcowej, gdyż jego wierni nie

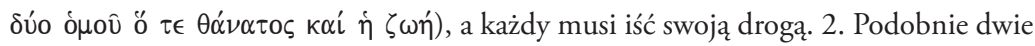

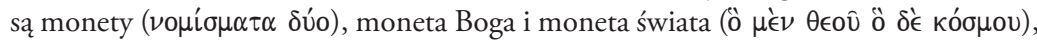

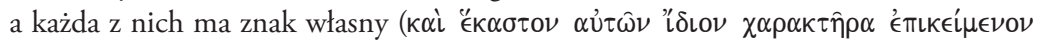

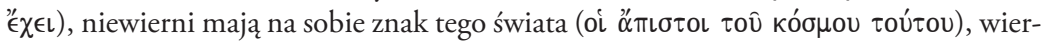

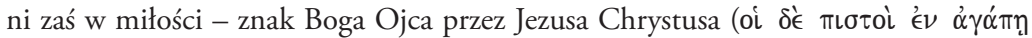

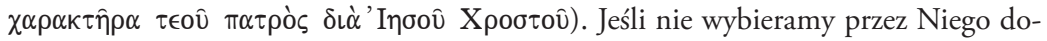
browolnie śmierci, aby mieć udział w Jego męce, nie ma w nas Jego życia”, BOK 10, s. 121 (por. Dz 1, 25).

65 Ignacy Antiocheński, List do Kościota w Magnezji I,2, w: SU 1, s. 162; „Sławię Kościoły i życzę im zjednoczenia z ciałem i duchem Jezusa Chrystusa, naszego wieczystego Życia

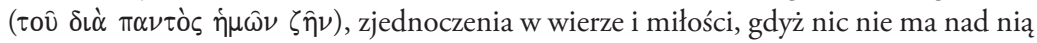
ważniejszego, a przede wszystkim zjednoczenia z Jezusem i z Ojcem. W Nim oprzemy się wszelkim groźbom księcia tego świata, a uniknąwszy ich, szczęśliwie dojdzie-

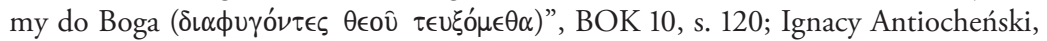
List do Kościota w Magnezji XI,1, w: SU 1, s. 168; „Wierzcie natomiast głęboko w narodzenie, mękę i zmartwychwstanie, które miało miejsce za rządów Poncjusza Piłata. A dokonał tego wszystkiego prawdziwie i niewątpliwie Jezus Chrystus, nadzieja nasza ( $\tau \hat{\eta} \varsigma$ '́ $\left.\lambda \pi^{\prime} \dot{\delta} \delta \varsigma_{\zeta} \dot{\eta} \mu \hat{\omega} \nu\right)$, od której oby nikt z was nigdy się nie odwrócił”, BOK 10, s. $122(1 \mathrm{Tm} 1,1)$.

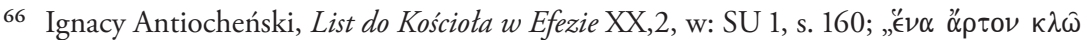

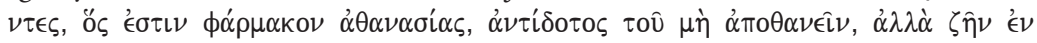
'I telności, lekarstwem pozwalającym nam nie umierać, lecz żyć wiecznie w Jezusie Chrystusie", BOK 10, s. 118-119.

67 Ignacy Antiocheński, List do Kościoła w Magnezji VI,2, w: SU 1, s. 164; „Jednoczcie się z biskupem i tymi, co wam przewodzą, a jedność ta ( $\alpha \lambda \lambda^{\prime}$ ' $\left.\epsilon \nu \omega ́ \theta \eta \tau \epsilon\right)$ stanie się obra-

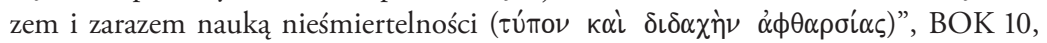
s. 121 (por. Ignacy Antiocheński, List do Kościota w Magnezji VII,2, w: SU 1, s. 166; BOK 10, s. 121).

68 Ignacy Antiocheński, List do Kościoła w Magnezji V,1, w: SU 1, s. 164; „Wszystko ma swój koniec i dwie rzeczy przed nami jednakowo do wyboru: życie i śmierć, a każdy musi iść swoją drogą", BOK 10, s. 121 (por. Pwt 30, 15; Syr 15, 17). 
Kształtowanie się nauki o niebie w teologii patrystycznej I-III wieku

są jeszcze ugruntowani w wierze. Podstawą mówienia o eschatologicznym niebie pozostaje nawiązanie już na ziemi osobistej więzi z Bogiem i życie Ewangelią („,spełnienie nieśmiertelności”). Dzięki wierze i kontaktowi zmysłowemu z Jezusem wierni, podobnie jak Jedenastu po Zmartwychwstaniu, przezwyciężą śmierć i przez Chrystusa („Brama Ojca”, „prawdziwe życie”) dostąpią udziału w eschatologicznym niebie opisywanym i jakościowo (przewaga tej terminologii), i przestrzenne. Biskup Antiochii akcentuje też postawy moralne sprzyjające i uniemożliwiające osiągnięcie nieba. Najważniejszą postawą pozytywną jest ewangeliczny wybór Jezusa przez wiarę i życie zgodne z Jego przesłaniem.

\subsubsection{List Psedo-Barnaby - moralność zasługi, przez „drugie millenium” do nieba}

List Pseudo-Barnaby ${ }^{69}$, tradycyjnie włączano do grupy tekstów ojców poapostolskich, jednak z teologicznego i literackiego punktu widzenia stanowi on typowy pseudoepigraf, dlatego powinien być zaliczany do grupy apokryfów chrześcijańskich, pomiędzy którymi umieszczali go już w IV wieku np. Euzebiusz z Cezarei Palestyńskiej czy Hieronim ze Strydonu ${ }^{70}$. Kompozycja tekstu jest określana na lata 96-98 (James Carleton Paget ${ }^{71}$ ) lub na lata 130-132 (Klaus Wengst) ${ }^{72}$. Podobnie dyskusyjne jest miejsce powstania utworu: Egipt / Aleksandria (Carleton Paget ${ }^{73}$, Ferdinand-Rupert

69 Pseudo-Barnaba, Epistula (Barnabae), w: SU 2. Didache (Apostellehre), Barnabasbrief, Zweiter Klemensbrief, Schrift an Diognet. Eingeleitet, herausgegeben, übertragen und erläutert von K. Wengst, Darmstadt 1998, s. 103-202; przekład polski List Barnaby, w: Pierwsi świadkowie. Pisma Ojców..., dz. cyt., BOK 10, s. 174-204.

70 Por. H. R. Drobner, Patrologia..., dz. cyt., s. 87.

71 Por. J. Carleton Paget, The Epistle of Barnabas: Outlook and Background, Tübingen 1994, s. 27 (Wissenschaftliche Untersuchungen zum Neuen Testament II.64); J. Carleton Paget, The Epistle of Barnabas, „The Expository Times” 117 (2006), s. 441-446.

72 Por. K. Wengst, Tradition und Theologie des Barnabasbrief, Berlin-New York 1971 (Arbeiten zur Kirchengeschichte, 42).

73 Por. J. Carleton Paget, The Epistle of Barnabas: Outlook..., dz. cyt., s. 36-41. 
2. Kształtowanie się nauki o niebie w teologii patrystycznej - wiek I-II

Prostmeier) ${ }^{74}$, Syria-Palestyna / Antiochia (Pierre Prigent ${ }^{75}$, Francesco Scorza Barcellona) ${ }^{76}$, Azja Mniejsza (Wengst) ${ }^{77}$.

Zasadnicza tematyka listu koncentruje się na pouczeniach o obowiązkach moralnych chrześcijan jako Nowego Ludu Bożego (charakterystyczna nauka o dwóch drogach) oraz na chrystologicznej i duchowej interpretacji całego ST (rozumianego jako proroctwo o Chrystusie i o sposobie życia chrześcijan $)^{78}$.

\section{Terminy odnoszące się do rzeczy niebieskich}

Określemia wykorzystane w Liście Pseudo-Barnaby osadzone są w teologii NT. Dominują wśród nich terminy przestrzenne: „rzeczy, które nadejdą /

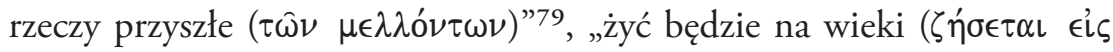

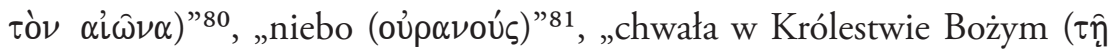

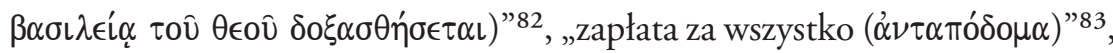

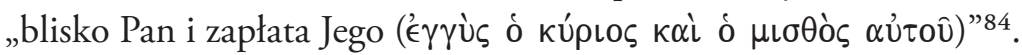

74 Por. F. R. Prostmeier, Der Barnabasbrief. Übersetzt und erklärt, Göttingen 1999, s. 111119 (Kommentar zu den Apostolischen Vätern 8).

75 Por. Épitre de Barnabé. Introduction, traduction et notes par Pierre Prigent. Texte grec établi et présenté par Robert A. Kraft, SCh 172, Paris 1971, s. 23.

76 Por. F. Scorza Barcellona, Epistola di Barnaba, Torino 1975, s. 64 (Corona Patrum 1).

77 Por. K. Wengst, Tradition und Theologie des Barnabasbrief..., dz. cyt., s. 118.

78 Por. F. Scorza Barcellona, Barnaba (epistola di), w: NDPAC, vol. 1, Genova-Milano $2006^{2}$, s. $710-714$.

79 List Barnaby I,7, w: SU 2, s. 140; Pierwsi świadkowie. Pisma Ojców..., dz. cyt., BOK 10, s. 179.

80 List Barnaby XI,11, w: SU 2, s. 172; „«Kto z nich jeść będzie, żyć będzie na wieki» znaczy to: «kto będzie słuchał słów tych i uwierzy, żyć będzie na wieki»", BOK 10, s. 191 (por. J 6, 35. 40. 51. 58).

81 List Barnaby XV,9, w: SU 2, s. 182; „Dlatego też świętujmy z radością dzień ósmy: w dniu tym Jezus powstał z martwych i ukazawszy się [uczniom] wstąpił do nieba", BOK 10, s. 195 (por. Łk 24, 51; J 20, 17).

82 List Barnaby XXI,1, w: SU 2, s. 192; „Dobrze jest zatem poznać wszystko, co Pismo Święte mówi o woli Pana, i według tego postępować. Ten bowiem, kto to czyni, dostąpi chwały w Królestwie Bożym”, BOK 10, s. 198.

83 List Barnaby XXI,1, w: SU 2, s. 192; „Dlatego właśnie jest zmartwychwstanie, dlatego jest zapłata za wszystko", BOK 10, s. 199.

84 List Barnaby XXI,2, w: SU 2, s. 192; BOK 10, s. 199 (por. Iz 40, 40). 
Kształtowanie się nauki o niebie w teologii patrystycznej I-III wieku

\section{Drugi millenaryzm}

Wstępnie chcę zaznaczyć, że podzielam tezę Henryka Pietrasa, o rozróżnieniu millenaryzmu wczesnochrześcijańskiego na dwa zasadnicze rodzaje: tzw. pierwszy millenaryzm według Apokalipsy św. Jana (ma za podstawę wiarę w zmartwychwstanie rozpoczynające się już w momencie chrztu, od przyjęcia którego rozpoczynało się dla chrześcijanina „millenium”, czyli królestwo mesjańskie na ziemi, mające trwać aż do końca czasów) oraz tzw. drugi millenaryzm (charakteryzujący się wyobrażeniami materialnymi i ziemskimi, oczekiwane królestwo mesjańskie miało być prawdziwym królestwem ziemskim, jego stolicą miała być Jerozolima niebiańska, gdzie Chrystus będzie królował wraz z wiernymi zmartwychwstałymi) ${ }^{85}$. Uznaję też podział drugiego millenaryzmu, dokonany przez Jeana Daniélou, na trzy zasadnicze typy: małoazjatycki, syryjsko-egipski oraz na ukształtowany na ich bazie millenaryzm pośredni ${ }^{86}$.

Przyjmujący pseudonim Barnaby autor omawianego Listu był według opisanych wcześniej klasyfikacji reprezentantem drugiego millenaryzmu typu syryjsko-egipskiego. Kierunek ten wychodził bardziej z pewnych kalkulacji astrologicznych odnośnie do kosmicznego tygodnia, który tworzy siedem mileniów. I tak owe siedem mileniów koresponduje w nim z siedmioma dniami stworzenia oraz wyobrażeniem królestwa mesjańskiego, pojętego jako „odpocznienie świętych”. Odmiennie od koncepcji azjatyckiej, która zakładała ustanie akcji stwórczej ze strony Boga, koncepcja milenaryzmu syryjsko-egipskiego zakładała jej wzmożenie. Według Listu Pseudo-Barnaby sześć dni stworzenia wyobraża okres sześciu tysięcy lat, ponieważ w oczach Boga tysiąc lat jest jak jeden dzień. W tych sześciu tysiącleciach wszystko się odbędzie, po czym ten czas zostanie zakończony i Syn Boży powróci. Osądzi On pustych, przekształci Słońce, Księżyc i gwiazdy i odpocznie siódmego dnia (czyli tysiąclecia). Wtedy też powstanie szabat królestwa

85 Por. H. Pietras, Eschatologia Kościoła pierwszych czterech wieków, Kraków 2007, s. $24-$ 30, 63-82 (MT 55); zob. też U. Vanni, Il millenarismo. Parametri per un discernimento cristiano alla luce di Apocalisse 20, 1-10, „Sette e religioni” 1 (1991), s. 110-147.

86 Por. J. Daniélou, Teologia judeochrześcijańska. Historia doktryn przed Soborem Nicejskim, tłum. S. Basista, Kraków 2002, s. 338-361(MT 39) (por. D. Kasprzak, Milenaryzm: „ziemski raj" tylko dla wybranych sprawiedliwych - okres patrystyczny, w: W oczekiwaniu na Królestwo. Nadzieje i obawy związane z końcem tysiąclecia, red. P. J. Śliwiński, Kraków 2000, s. 89-124). 
2. Kształtowanie się nauki o niebie w teologii patrystycznej - wiek I-II

milenijnego ${ }^{87}$. W opisie Listu Pseudo-Barnaby odpocznienie sprawiedliwych w okresie „drugiego millenium” nie jest jeszcze ostatecznym niebem, choć posiada jego niektóre charakterystyki, jak oczyszczenie ludzi ze złych postaw (czego przejawem jest ich czystość serca, brak niegodziwości, usprawiedliwienie i uświęcenie) oraz odpocznienie (rozumiane jako kres Niegodziwca, osąd bezbożnych, odnowa wszystkich rzeczy).

\section{Uczynki „zasługujące” na odziedziczenie nieba}

Eschatologiczna przyszłość będzie odpłatą i zasługą za obecne życie moralne ${ }^{88}$, za kroczenie drogą światła, a wystrzeganie się drogi ciemności ${ }^{89}$, za postępowanie zgodnie z wolą Pana90.

Ten duchowo-moralistyczny schemat myślenia autora Listu Pseudo-Barnaby jest też najbardziej charakterystyczny dla jego myśli eschatologicz-

87 Por. List Barnaby XV,1-7, w: SU 2, s. 180.182; „1. Czytamy także i o szabacie w owych Dziesięciu Słowach, które Bóg skierował do Mojżesza... 2. Szabat jest wspomniany na początku stworzenia: «I uczynił Bóg w sześć dni dzieła rąk swoich i były ukończone dnia siódmego. Dnia tego odpoczął i uświęcił go». 4. Zwróćcie uwagę, dzieci, co to znaczy: «ukończył w sześć dni». Znaczy to, że w sześć tysięcy lat Pan doprowadził wszechświat do kresu, bo dla Niego jeden dzień jest tym samym, co lat tysiąc. Sam mi to potwierdza, mówiąc: "Oto jeden dzień Pański będzie jak lat tysiąc». Tak więc, dzieci, «w sześć dni», w sześć tysięcy lat, wszechświat dojdzie do kresu. 5. «I odpoczął dnia siódmego». Znaczy to: Kiedy przyjdzie Syn Jego, by położyć kres czasom Niegodziwca, osądzić bezbożnych, przemienić słońce, księżyc i gwiazdy, wówczas odpocznie w dniu siódmym. 6. Powiedziano jeszcze także. «Będziesz święcił (szabat) z czystymi rękami i z czystym sercem». Gdyby, zatem w obecnym świecie mógł jakiś człowiek, tylko dlatego, że jest czystego serca, święcić ów dzień który Bóg uświęcit, my bylibyśmy całkowicie w błędzie 7 . Oto jednak dopiero wtedy osiągniemy prawdziwy odpoczynek ( $\kappa \alpha \lambda \omega \hat{\varsigma} \kappa \alpha \tau \alpha \pi \alpha \nu o ́ \mu \epsilon \nu o L)$, by móc go święcić, kiedy najpierw sami zostaniemy usprawiedliwieni, kiedy sami otrzymamy to, co nam obiecano, kiedy nie

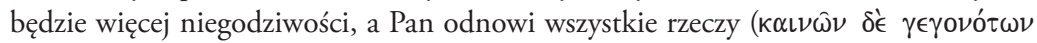

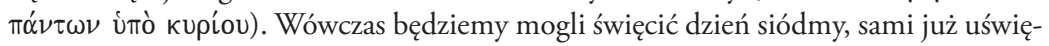
ceni", BOK 10, s. 194-195.

88 Por. List Barnaby IV,12, w: SU 2, s. 148; „Każdy otrzyma to, na co zasłużył. Jeśli jest dobry, poprzedzi go jego sprawiedliwość. Jeśli był zły, przed nim zapłata jego niegodziwości", BOK 10, s. 182.

89 Por. List Barnaby XVIII-XX, w: SU 2, s. 186-192; BOK 10, s. 197-198.

90 Por. List Barnaby XXI,1, w: SU 2, s. 192; „Dobrze jest zatem poznać wszystko, co Pismo Święte mówi o woli Pana, i według tego postępować. Ten bowiem, kto to czyni, dostąpi chwały w Królestwie Bożym, kto zaś wybierze drogę drugą, ten zginie razem ze swymi dziełami”, BOK 10, s. 198-199. 
Kształtowanie się nauki o niebie w teologii patrystycznej I-III wieku

nej traktującej drugie millenium jako swoistą premię dla sprawiedliwych, a eschatologiczne niebo i szczęśliwą wieczność jako ostateczną zapłatę za dobre uczynki w doczesności.

\subsubsection{Hermas Pasterz - Królestwo Boże osiągalne przez chrzest i praktykowanie cnót}

Pasterz Hermasa to apokalipsa powstała w rzymskich kręgach charyzmatycznych w drugiej połowie II wieku ${ }^{91}$. Jej autor powtarza elementy stylistyczne typowe dla apokalips żydowskich (opowiadanie w pierwszej osobie, nagłe pojawienia i zniknięcia, list niebiański), natomiast zastosowanie figur starszej kobiety i tytułowego pasterza wskazuje na przyswojenie modeli literackich znanych z literatury hermetycznej ${ }^{92}$. Podstawowym tematem teologii Pasterza jest możliwość uzyskania przez chrześcijan drugiego (choć jednorazowego) odpuszczenia grzechów (paenitentia secunda) popełnionych już po otrzymaniu chrztu ${ }^{93}$.

Swego czasu Philipp Vielhauer twierdził, iż pod względem zawartości brakuje w Pasterzu Hermasa typowego dla apokalips tematu antycypacji eschatologicznej przyszłości oraz wizji świata przeszłego, toteż badacz ten określał niniejszy utwór jako „pseudoapokalipsę”94. Pozwalam sobie nie zgodzić się z tą opinią. Poniżej postaram się wykazać, iż w Pasterzu Hermasa jest rozwijany, choć fragmentarycznie, temat antycypacji eschatologicznej przyszłości (opis w przypowieści dziewiątej), a jej autor rysuje przed czytelnikiem wizję świata przyszłego. W Pasterzu spotykamy bowiem symboliczną

91 Hermas, Pastor, w: SU 3. Papiasfragmente. Hirt des Hermas, eingeleitet, herausgegeben, übertragen und erläutert von M. Leutzsch, Darmstadt 1998, s. 107-497; przekład polski Hermas, Pasterz, w: Pierwsi świadkowie. Pisma Ojców..., dz.cyt., BOK 10, s. 205-299.

92 Por. H. J. Sheppard, A. Kehl, R. McL. Wilson, Hermetik, w: Reallexikon für Antike und Christentum, Bd. 14, Hrsg. E. Dassmann, Stuttgart 1988, s. 780-808; H. R. Drobner, Patrologia..., dz. cyt., s. 93. G. Filoramo, I. Ramelli, Ermetismo, w: NDPAC, vol. 1, ed. A. Di Berardino, Genova-Milano 2006² s. 1728-1739.

93 Por. Ph. Henne, Le pénitence et la rédaction du Pasteur d'Hermas, „Revue Biblique International" 98 (1991), s. 358-397.

94 P. Vielhauer, Geschichte der urchristlichen Literatur: Einleitung in das Neue Testament, die Apokryphen und die Apostolischen Väter, Berlin-New York 1975, s. 513-523. 
2. Kształtowanie się nauki o niebie w teologii patrystycznej - wiek I-II

wizję Królestwa Bożego, opisanego przy użyciu w przeważającej większości terminologii biblijnej (wyjątkiem jest introdukcyjne nawiązanie do poetyckiego obrazu Arkadii) oraz odnajdujemy preferowaną przez Hermasa moralność zasługiwania na niebo.

\section{Terminy odnoszące się do nieba}

Nazewnictwo stosowane przez Hermasa związane jest z nowotestamentalną teologią nieba. Przeważają terminy przestrzenne. Wyjątkiem od nazewnictwa o konotacji biblijnej jest odniesienie do eschatologicznego nieba jako do mitycznej Arkadii:

„niebo (ò oủ $\alpha \nu$ ós)"95, [niebo] usytuowane w kierunku wschodnim

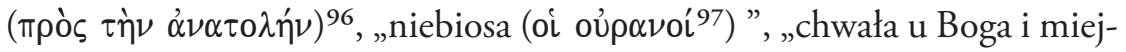

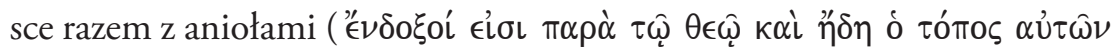

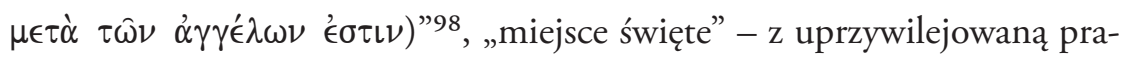

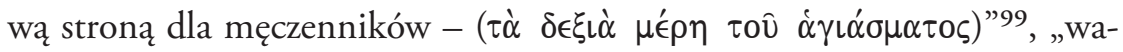

95 Hermas, Pasterz 1,4-6, w: SU 3, s. 146.148; „4. otworzyło się niebo (...). 5. „Zostałam wzięta do nieba” (...). 6. Bóg, który mieszka w niebie”, BOK 10, s. 211; Hermas, Pasterz 3,4, w: SU 3, s. 152; „Oto Bóg Zastępów... (...) możnym słowem rozpiął niebo

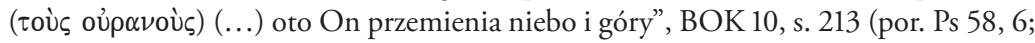
Iz 42, 5; Ps 135, 6).

96 Hermas, Pasterz 4,1.2, w: SU 3, s. 152.154; „1. Gdy [Rode] skończyła czytać i wstała z tronu, przyszło czterech młodzieńców. Ci zabrali tron i odeszli ku wschodowi (

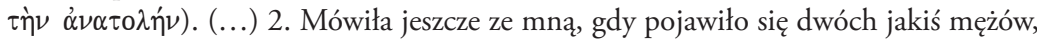
którzy wzięli ją pod ramiona i odeszli w tym samym kierunku, w jakim poniesiono

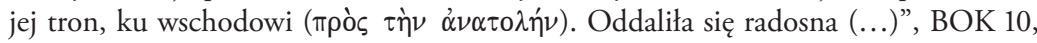
s. 213-214.

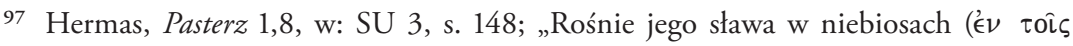
oủp $\alpha$ vố )”, BOK 10, s. 212; Hermas, Pasterz 2,1: "Zamknęły się niebiosa (oi oủ $\hat{\alpha}$ voí)", BOK 10, s. 212.

98 Hermas, Pasterz 104(27),3, w: SU 3, s. 344; BOK 10, s. 285.

99 Hermas, Pasterz 9(1),9-10(2),1, w: SU 3, s. 162; „(...) Miejsce po prawej stronie ( $\tau \dot{\alpha}$

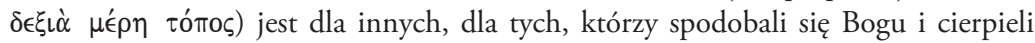
już dla jego imienia. Tobie jeszcze wiele brakuje, żebyś mógł zasiadać razem z nimi. Zachowaj jednak tylko swoją dotychczasowa prostotę, a zasiądziesz z nimi razem, podobnie jak i wszyscy, którzy będą czynić to, co oni czynili, i znosić to, co oni również znosili. 10.(2),1. «A cóż oni znosili» - zapytałem. «Posłuchaj, mówi: chłostę, więzienie, wielkie udręki, krzyż, dzikie zwierzęta, wszystko dla imienia bożego. Dlatego

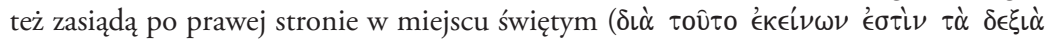

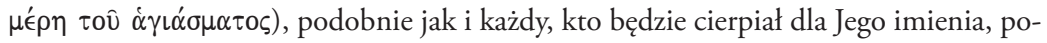
zostali zaś znajdą się po lewej stronie. Ale i dla jednych i dla drugich, tych z prawej 
Kształtowanie się nauki o niebie w teologii patrystycznej I-III wieku

sze miasto ( ('А

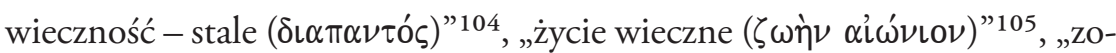

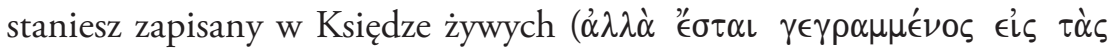

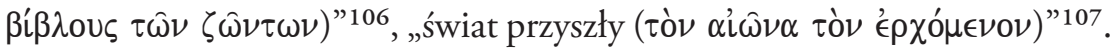

\section{Wizja antycypacji nieba - przypowieść dziewiąta Pasterza}

Najpełniejszy pod względem ciągłości i spójności tekstu fragment o rzeczywistości ostatecznej spotykamy w Pasterzu Hermasa w przypowieści dziewiątej o dwunastu górach i wieży na skale. Podczas wizji Anioł Pokuty przeniósł Hermasa do Arkadii na okrągłą górę, skąd ukazał mu wielką równinę, a na niej dwanaście różnych gór i skałę z bramą:

„78, 10. (...) Dwunasta góra była całkiem biała, a wygląd jej niezmiernie radosny; sama w sobie była to góra bardzo piękna. 79(2), 1. Pośrodku równiny pokazał mi wyrastającą z niej skałę, białą i wielką. Była ona wyższa od gór i czworokątna tak, że mogła cały świat pomieścić. 2. Skała ta była stara, a w niej wycięto bramę. Wydawało mi się jednak, że brama ta została niedawno wycięta. Jaśniała ona bardziej niż słońce, aż zdumiałem się jasnością owej bramy" ${ }^{108}$.

W samym Pasterzu spotykamy następujące wyjaśnienie tej wizji:

i tych z lewej strony, te same są dary, te same obietnice, tyle tylko, że ci zasiadają po

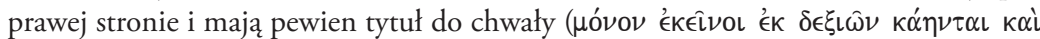

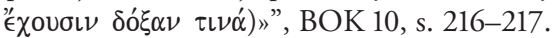

100 Hermas, Pasterz 50,1, w: SU 3, s. 242; BOK 10, s. 248 (por. Hbr 11).

101 Hermas, Pasterz 50,5, w: SU 3, s. 244; BOK 10, s. 248.

102 Hermas, Pasterz 78(1),4, w: SU 3, s. 300; BOK 10, s. 269.

103 Hermas, Pasterz 89(12),4, w: SU 3, s. 322; BOK 10, s. 277.

104 Hermas, Pasterz 104(27),3, w: SU 3, s. 344; BOK 10, s. 285.

105 Hermas, Pasterz 7(3),2, w: SU 3, s. 158; BOK 10, s. 215.

106 Hermas, Pasterz 51,9, w: SU 3, s. 250; BOK 10, s. 250.

107 Hermas, Pasterz 53,8, w: SU 3, s. 252; BOK 10, s. 252.

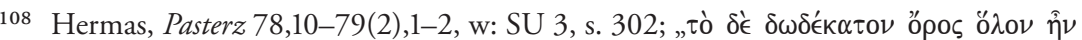

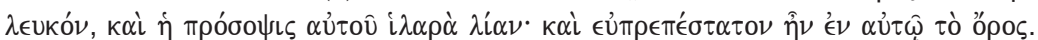

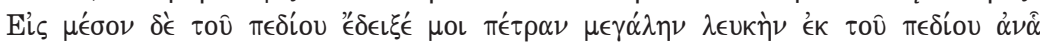

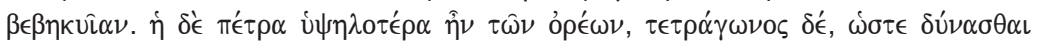

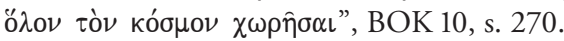


2. Kształtowanie się nauki o niebie w teologii patrystycznej - wiek I-II

„89(12), 1. Przede wszystkim, Panie, to jedno mi wytłumacz: co oznaczają skała i brama? "Ta skała, odparł, i brama to Syn Boży». "Jak to się dzieje, pytam, Panie, że skała jest stara, a brama nowa?». "Posłuchaj, mówi, i staraj się pojąć, o niepojętny! Syn Boży jest zrodzony przed wszystkim stworzeniem, tak, że był On doradcą Ojca, gdy Ten świat stwarzał. 3. Dlatego też skała jest stara». "A brama, ja mu na to, dlaczego jest nowa, Panie? - Ponieważ objawił się w dniach ostatnich, gdy czas się wypełnił. Dlatego to brama jest nowa, aby ci, co mają być zbawieni, mogli wejść przez nią do Królestwa Bożego. 4. Czy widziałeś, zapytał, że kamienie, które przeszły przez bramę, zostały użyte do budowy wieży, te zaś, które przez nią nie przeszły, wyrzucono z powrotem na ich własne miejsce?». «Widziałem, mówię, Panie». "Tak i do Królestwa Bożego, rzekł mi, nie wejdzie nikt, kto nie przyjmie Jego świętego Imienia. 5. Jeśli bowiem chcesz wejść do jakiegoś miasta, a miasto to jest otoczone murem i ma tylko jedną bramę, czy możesz wejść do owego miasta inaczej niż przez tę jedyną, jaką ma ono, bramę?». "Jakżeby to się mogło stać inaczej, Panie» - powiedziałem. "Jeżeli więc nie możesz wejść do miasta inaczej niż przez jego bramę, podobnie, rzecze, i do Królestwa Boga nie może wejść człowiek inaczej niż przez Imię Jego umiłowanego Syna»"109.

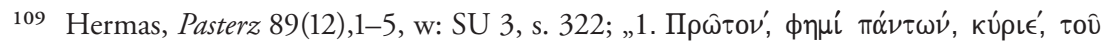

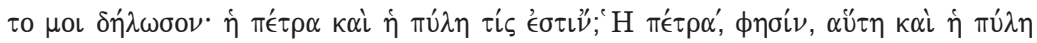

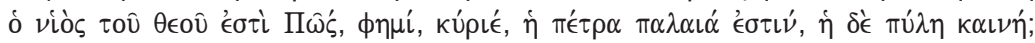

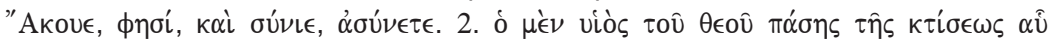

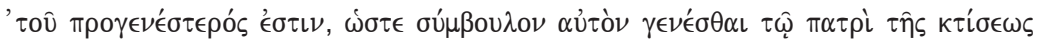

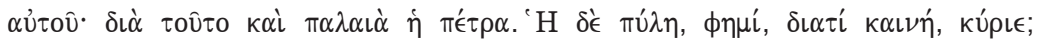

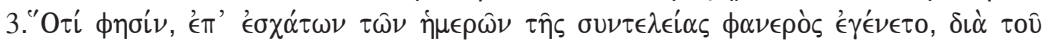

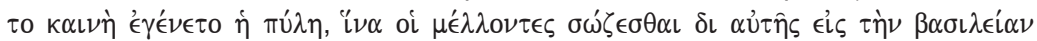

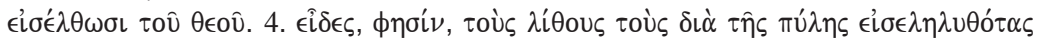

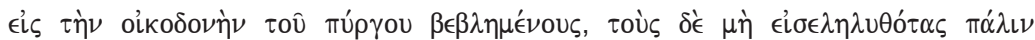

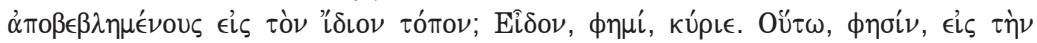

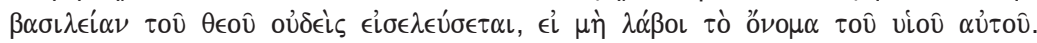

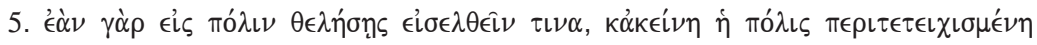

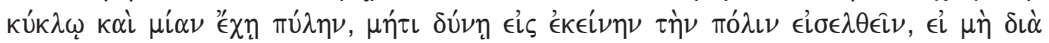

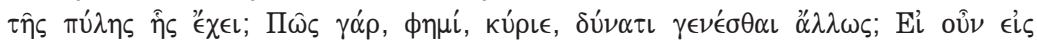

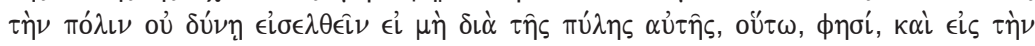

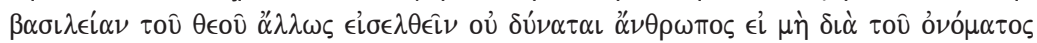

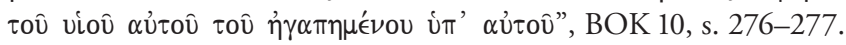


Kształtowanie się nauki o niebie w teologii patrystycznej I-III wieku

W przytoczonych powyżej fragmentach Pasterza przekazany został opis rzeczywistości eschatologicznej, wyrażony w konwencji apokalipsy chrześcijańskiej. W objaśnianiu wizji Hermas używa odniesień kulturowych, znanych mu zarówno ze świata symboliki pogańskiej (motyw Arkadii), jak i z symboliki objawienia biblijnego (eschatyczne obrazy: Królestwa Bożego, Miasta, nieba). Literacki motyw Arkadii stanowił znane ówczesnym greckim i rzymskim chrześcijanom odwołanie kulturowe, będące w zamierzeniu autora najprawdopodobniej wprowadzeniem do chrześcijańskiej obrazowości i symboliki biblijnej. Arkadia w poetyckich opisach Bukolik Wergiliusza została wyobrażona jako mityczna kraina szczęśliwości, pozbawiona trosk i chorób ${ }^{110}$.

Hermas został przeniesiony przez Anioła Pokuty w wizji do Arkadii, skąd obserwował 12 gór. W wizji Hermasa dwunasta góra była biała, jej wygląd był radosny i piękny, a pośrodku otaczającej ją równiny znajdowała się skała, również biała i wielka, wyższa od gór, czworokątna, a w niej nowa, jaśniejąca brama. Ową jedyną bramą do Królestwa Bożego ${ }^{111}$, w myśl przy-

110 Szerzej o literackim toposie mitycznej Arkadii w Bukolikach, zob. opracowania: G. Jachmann, L'Arcadia di Virgilio come passaggio bucolico, „Maia” 5 (1952), s. 161-74; B. Snell, Arcadia: The Discovery of a Spiritual Landscape, w: B. Snell, The Discovery of the Mind: The Greek Origins of European Thought, Oxford 1953, s. 281-309; Ch. P. Segal, Tamen cantabitis, Arcades: Exile and Arcadia in Eclogues 1 and 9, „Arion” 4 (1965), s. 237-66; Ch. Fantazzi, Golden Age in Arcadia, „Latomus” 33 (1974), s. 280-305; R. Jenkyns, Virgil and Arcadia, „Journal of Roman Studies” 79 (1989), s. 26-39; M. O. Lee, Death and Rebirth in Virgil's Arcadia., Albany (NY) 1989 (SUNY Series in Classical Studies); E. Anagnostou-Laoutides, Ancient Ritual and the Search for Arcadia: from Vergil to Poussin, „Transcultural Studies” 2-3 (2006-2007), s. 19-53.

111 Jezus jako jedyna brama do nieba to temat nowotestamentalny, łączący w sobie wątki bramy prowadzącej do miasta i nieba: w momencie chrztu niebiosa się otworzyły, a Jezus stał się bramą niebieską, która zstąpiła na ziemię (J 1, 51; por. Rdz 28, 17), On jest bramą wiodącą ku pastwiskom Bożym (J 10, 9); przez Niego ludzie mają dostęp do ojca (Ef 2, 18; Hbr 10, 19); On ma klucze Dawida (Ap 3, 7), które złożył On w ręce Piotra (Mt 16,19). Do wejścia potrzebne jest nawrócenie (Mt 7, 13; Łk 13, 24) i wiara (Dz 14, 27; Ef 3, 12). Kto nie będzie się miał na baczności, znajdzie bramę zamkniętą (Mt 25, 10; Łk 13, 25). Jezus posiada klucze do śmierci i piekieł i jest zwycięzcą zła (Ap 1,18), dzięki Jezusowi Jego Kościół jest potężniejszy niż złe moce (Mt 16, 18). Przy końcu świata miasto i niebo staną się jednym (Ap 21, 12 27; 22, 14-15) (por. hasło brama, w: Stownik teologii biblijnej, red. X. L. Dufour, thum. i oprac. K. Romaniuk, Poznań 1994, s. 102-104). 
toczonego wcześniej Pasterza 89(12), 1-5 czy Pasterza 89(12), 8 ${ }^{112}$, jest Chrystus, który wprowadza tam chrześcijan („ci co mają być zbawieni” Pasterz 89(12), 3; kto przyjął Jego święte Imię - Pasterz 89(12), 4; „przez imię Jego umiłowanego Syna” - Pasterz 89(12), 5; analogicznie w Pasterzu 89(12), 8). W apokaliptyce biblijnej kolor biały to kolor doskonałej czystości nieprzemijającego piękna, czyli kolor wybranych Pana ${ }^{113}$, a Królestwo Boże - niebo w cytowanych fragmentach nabiera charakterystyk miasta (czworokątna wieża, mur, jedyna brama). Chrześcijanie, dzięki wierze w Boga przez Jego Syna oraz dzięki praktykowaniu cnót w doczesności, są zjednoczeni w jednym Kościele, a w eschatonie będą jednością ${ }^{114}$.

\section{Postawy umożliwiające osiągnięcie zbawienia i odziedziczenie życia wiecznego}

Hermas dowodzi, że zbawienie człowieka dokonuje się poprzez chrzest (Pasterz 11, 5; 93, 1-7), który stanowi pieczęć Syna Bożego. Natomiast swoistym wkładem własnym człowieka, będącym także dziełem Ducha Świętego, jest $\mu \in \tau \alpha \dot{\nu} \nu$ ol $\alpha$ (metanoia), oznaczająca przemianę myślenia (zarówno w dobrym, jak i w złym kierunku). Hermas postuluje ewangeliczne nawrócenie serca, związane z uświadomieniem sobie obecności Boga i Jego sądu, oraz podjęcie nowego życia według Ewangelii Jezusa. Wyrazem tego nawrócenia jest przyjęcie wymiernych postaw moralnych ${ }^{115}$.

112 Hermas, Pasterz 89(12.),8, w: SU 3, s. 324; „Ów mąż pełen chwały, powiedział, jest Synem Bożym, a tamtych sześciu, to pełni chwały aniołowie, którzy towarzyszą Mu po prawicy i po lewicy. Spośród tych chwalebnych aniołów żaden bez Niego nie może wejść do Boga. Ktokolwiek by Jego Imienia nie przyjął, ten wejść nie może do Królestwa Bożego", BOK 10, s. 277 (por. J 3, 5).

113 Por. hasło biaty, w: Stownik obrazów i symboli biblijnych, red. M. Lurker, ttum. K. Romaniuk, Poznań 1989, s. 25-26.

114 Hermas, Pasterz 90(13),4, w: SU 3, s. 324; „Dlatego wieża w twoich oczach tworzy jeden głaz ze skałą: podobnie i ci, co uwierzyli Panu przez Jego Syna i przyoblekli się w owe duchy, będą jednym duchem, jednym ciałem, a szaty ich będą jednej barwy. Dla takich ludzi noszących imiona dziewic jest mieszkanie w wieży”, BOK 10, s. 278 (por. J 1, 7; Ef 4, 4).

115 Por. A. Baron, Świętość a ideaty cztowieka (Ojcowie apostolscy, Klemens Aleksandryjski, Orygenes). Studium teologiczne na tle modeli filozoficzno-religijnych, Kraków 2013, s. $218-222$. 
Kształtowanie się nauki o niebie w teologii patrystycznej I-III wieku

W całej apokalipsie jej autor prezentuje konsekwentnie swoistą moralność zasługi za dobre uczynki. Są zatem wymienianie przez Hermasa jako zasługujące na niebo: wytrwanie przy Bogu, prostota, wielka powściągliwość, niewinność, sprawiedliwość ${ }^{116}$, znoszenie cierpienia i męczeństwo dla imienia Bożego ${ }^{117}$, doczesność winna być traktowana jako mieszkanie na obczyźnie, przy zachowaniu postawy ewangelicznej małości w życiu - „nie zachowuj dla siebie nic ponad to, co ci jest naprawdę potrzebne"118, wykonywanie dzieł Bożych, pamiętanie o przykazaniach Bożych, wykup ludzi z niewoli (według swoich możliwości), odwiedzanie wdów i sierot, wystrzeganie się pogardy ${ }^{119}$, gościnność ${ }^{120}$, bogaci winni pomagać biednym materialnie, a biedni winni modlić się za swoich dobrodziejów (obie posta-

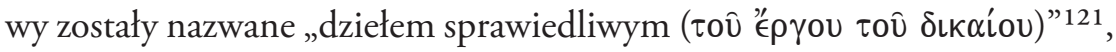
unikanie zbyt licznych zajęć i nie popełnianie żadnych grzechów ${ }^{122}$, bycie

116 Por. Hermas, Pasterz 7(3),2-3, w: SU 3, s. 158; „2. Zbawia cię jednak to, żeś nie odstąpił od Boga żywego, a także twoja prostota i wielka powściągliwość. Oto co jest twoim zbawieniem, jeśli wytrwasz, i co zbawia wszystkich, którzy tak postępują i chodzą drogą niewinności i prostoty. Ci przezwyciężą wszelkie zło i wejdą niezłomni do życia wiecznego. 3. Błogosławieni wszyscy czyniący sprawiedliwość. Nie zginą na wieki

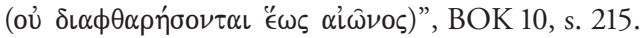

117 Por. Hermas, Pasterz 9(1),9-10(2),1, w: SU 3, s. 160.162; BOK 10, s. 216-217.

118 Hermas, Pasterz 50,6, w: SU 3, s. 244; „Uważaj zatem: mieszkaj jak na obczyźnie, nie zachowuj dla siebie nic ponad to, co ci jest naprawdę potrzebne ( $\mu \eta \delta \dot{\epsilon} \nu \pi \lambda \lambda^{\prime}{ }^{\prime} \nu \nu$

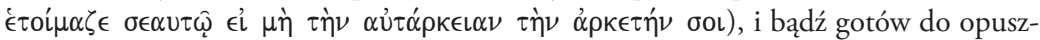
czenia tego miasta, gdy jego władca zechce cię wyrzucić jako tego, co sprzeciwia się jego prawom. A ty wówczas powrócisz do miasta ojczystego i będziesz tam żył bez przeszkód, w radości”, BOK 10, s. 248.

119 Por. Hermas, Pasterz 50,6, w: SU 3, s. 244; BOK 10, s. 248-249.

120 Por. Hermas, Pasterz 104(27)2.3, w: SU 3, s. 344; „Są to biskupi i ludzie gościnni, którzy zawsze chętnie przyjmowali w swych domach sługi Boże bez żadnej obłudy (...). 3. Ich więc wszystkich będzie Pan ochraniał przez całą wieczność. Ci, którzy tak postępowali, mają chwałę u Boga, a miejsce ich jest już razem z aniołami, jeśli tylko wytrwają aż do końca w służbie Panu", BOK 10, s. 285.

121 Por. Hermas, Pasterz 51,1-8, w: SU 3, s. 246.248; BOK 10, s. 249-250, co prowadzi Hermasa do konkluzji w Pasterzu 51,9: „Jedni i drudzy uczestniczą wspólnie w dziele sprawiedliwym. Jeśli zatem będziesz w ten sposób postępować, Bóg cię nie opuści i zostaniesz zapisany w Księdze żywych"; zob. SU 3, s. 250; BOK 10, s. 250.

122 Por. Hermas, Pasterz 53,5.8, w: SU 3, s. 252; „5. Unikaj zbyt licznych zajęć i nie popełniaj żadnych grzechów (...) 8. Jeśli tak będziesz postępował, możesz przynosić owoce w świecie przyszłym", BOK 10, s. 251-252. 
2. Kształtowanie się nauki o niebie w teologii patrystycznej - wiek I-II

chrześcijaninem $z$ imienia i z czynów ${ }^{123}$, życie według cnót ${ }^{124}$, przy unikaniu wad ${ }^{125}$, nawrócenie się i przyjęcie chrztu ${ }^{126}$, niewinność serca ${ }^{127}$.

Apokaliptyczny i charyzmatyczny styl Pasterza Hermasa w dużej mierze wpływa na opis eschatologii końcowej prezentowanej w utworze. Oprócz wzorowania się na apokaliptyce żydowskiej i powielania modeli literatury hermetycznej, w Pasterzu Hermasa rozwijany jest, choć fragmentarycznie, temat antycypacji eschatologicznej przyszłości. Wizja świata przyszłego zostaje oddana przez symboliczny opis Królestwa Bożego. Hermas wykorzystuje tu przede wszystkim wątki nowotestamentalne (wyjątkiem od tej reguły jest aluzja do poetyckiej Arkadii). W nazewnictwie eschatologicznego nieba przeważają w Pasterzu terminy przestrzenne nad tymi jakościowymi. Charakterystyczne jest też akcentowanie połączenia wątków soteriologii NT z moralnością zasługi: chrześcijanie dzięki wierze w Boga przez Jego Syna oraz dzięki praktykowaniu cnót w doczesności dostąpią nieba.

123 Por. Hermas, Pasterz 90(13),2, w: SU 3, s. 324; „ (...) A człowiek nie może się znaleźć w Królestwie Bożym, jeżeli one [tj. duchy święte, czyli cnoty - uwaga Autora] nie przyodzieją go w swoje własne szaty. (...) Jeśli będziesz nosił Imię, a nie przyodziejesz się mocą Jego, na próżno będziesz nosił Imię Jego", BOK 10, s. 277-278.

124 Por. Hermas, Pasterz 92(15),1b-2, w: SU 3, s. 328; „1b. Posłuchaj, rzekł mi, jakie są imiona tych najsilniejszych, które stały na rogach”. 2. Pierwsza to Wiara, druga Umiarkowanie, trzecia - Moc, czwarta - Cierpliwość. Te zaś inne, stojące pomiędzy nimi, mają na imię: Prostota, Niewinność, Świętość, Radość, Prawda, Zrozumienie, Zgoda, Miłość. Kto nosi te imiona i Imię Syna Bożego, ten będzie mógł wejść do Bożego Królestwa”, BOK 10, s. 279 (por. J 3, 5).

125 Por. Hermas, Pasterz 92(15),3, w: SU 3, s. 328; „Posłuchaj, dodał, także imion tych niewiast odzianych na czarno. Wśród nich również cztery najpotężniejsze: pierwsza to Niewiara, druga Nieumiarkowanie, trzecia Nieposłuszeństwo, czwarta Ułuda. A towarzyszki ich nazywają się: Smutek, Złość, Rozpusta, Gniew, Kłamstwo, Bezmyślność, Obmowa, Nienawiść. Sługa Boży te imiona noszący nie zobaczy Królestwa Bożego, ani do niego nie wejdzie", BOK 10, s. 279.

126 Por. Hermas, Pasterz 93(16),2, w: SU 3, s. 330; „Musiały koniecznie, odparł, wyjść z wody, aby znaleźć życie, gdyż nie mogły wejść do Królestwa Bożego inaczej, niż odrzucając śmierć, jaką było ich poprzednie życie. 3. Otrzymali zatem i ci pieczęć Syna Bożego i weszli do Bożego Królestwa”, BOK 10, s. 280 (por. J 3, 5).

127 Por. Hermas, Pasterz 106(29),1-2, w: SU 3, s. 346; „1. W końcu z dwunastej, białej góry przychodzą tacy oto wierzący: są oni jak niemowlęta, z których serca nie wypływa żadne zło, ani też nie poznali, czym jest zło, ale pozostają w całkowitej niewinności. 2. Oni z pewnością zamieszkają w Królestwie Bożym, bo żadnym czynem nie splamili przykazań Boga, ale wytrwali przez wszystkie dni swego życia w niewinności i w tym usposobieniu", BOK 10, s. 286. 
Kształtowanie się nauki o niebie w teologii patrystycznej I-III wieku

\subsubsection{Homilia z II wieku - niebo jako życie wieczne / odpoczynek za uczynki}

Homilia pokutna nieznanego autora, datowana na drugą połowę II wieku, jest najstarszym kazaniem chrześcijańskim, jakie zachowało się do naszych czasów. W literaturze kościelnej długi czas była znana pod nazwą Drugi list do Koryntian św. Klemensa (Secunda Clementis) ${ }^{128}$. Badania współczesnych patrologów wykazały jednak, że jest to pseudoepigraf, którego nieznany autor, będący najprawdopodobniej prezbiterem (z Syrii, z Egiptu bądź z Koryntu), kaznodziejsko przywoływał chrześcijańskich neokonwertytów do zachowywania przykazań oraz prowadzenia życia ascetycznego. Działania te, jego zdaniem, są wyrazem pełnego uznania Chrystusa. Silne napięcie ascetyczne autora przejawia się w powoływaniu się na tematy ascezy heterodoksyjnej, propagowane przez enkratytów (teza o przezwyciężeniu dualizmu ludzkiej seksualności, por. Ewangelia Egipcjan, Koptyjska Ewangelia Tomasza). Uderza brak odwołań do teologii Pawłowej, co pośrednio wzmacniałoby argumentację za syryjską proweniencją autora homilii ${ }^{129}$.

\section{Kontekst sądu z uczynków}

Nieznany autor analizowanej homilii w kontekście Sądu Ostatecznego ${ }^{130}$, gdzie Sędzią będzie Bóg Jezus Chrystus, wzywa chrześcijan do docenie-

128 Pseudo-Clemens Romanus, Epistula altera od Corynthios, w: SU 2. Didache (Apostellehre), Barnabasbrief, Zweiter Klemensbrief, Schrift an Diognet. Eingeleitet, herausgegeben, übertragen und erläutert von K. Wengst, Darmstadt 1998, s. 205-280; przekład polski Pseudo-Klemens Rzymski, Homilia z II wieku (zwana dawniej Drugim listem do Koryntian św. Klemensa), w: Pierwsi świadkowie. Pisma Ojców..., dz.cyt., BOK 10, s. 88-101.

129 Por. P. F. Beatrice, Clemente Romano..., dz. cyt., vol. 1, s. 1076-1077; E. Baasland, Der 2. Klemensbrief und frühchristliche Rhetorik: "Die erste christliche Predigt» im Licht der neueren Forschung, Berlin-New York 1993, s. 78-157 (Aufstieg und Niedergang der römischen Welt II.27.1).

130 Por. Homilia z II wieku XVI,3, w: SU 2, s. 260; „Wiedzcie zaś, że nadchodzi już Dzień

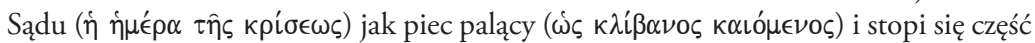

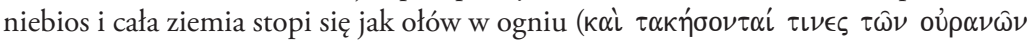

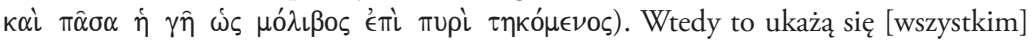
ukryte i jawne ludzkie czyny", BOK 10, s. 99 (por. Ml 3, 19; Iz 34, 4; 2 P 3, 10-12). 
2. Kształtowanie się nauki o niebie w teologii patrystycznej - wiek I-II

nia zbawienia, a przez to posiadania większej nadziei rzeczy ostatecznych ${ }^{131}$. Obecna radość Kościoła z posiadania zbawienia, dokonanego w Chrystusie ${ }^{132}$, winna być jednak dopełniana przez wierzących wypełnianiem woli Bożej i przestrzeganiem Bożych przykazań ${ }^{133}$. Ten dydaktyczno-moralistyczny aspekt homilii jest bardzo charakterystyczny dla całej eschatologii Homilii z II wieku. Spotykamy w niej stałe wezwanie do koncentrowania się nie tylko na samym wyznawaniu wiary, ale także do czynienia wymiernych uczynków sprawiedliwości ${ }^{134}$.

\section{Terminologia nieba jako nagrody za uczynki}

W tekście dominują określenia jakościowe, o wyraźnej konotacji nowotestamentalnej. Eschatologiczne życie zbawionych, uwiarygodnione dla chrześcijan przez obietnicę Jezusa Chrystusa - „Zbawiciela i Dawcę nieśmiertel-

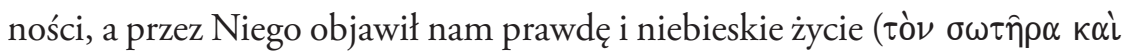

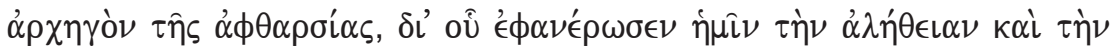

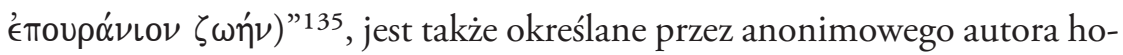
milii w kilku słowach — „odpoczynek w przyszłym królestwie i życiu wiecz-

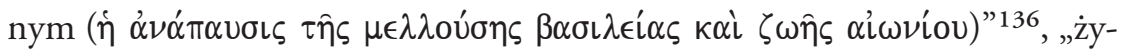

131 Por. Homilia z II wieku I,1, w: SU 2, s. 238; „Bracia, musimy patrzeć na Jezusa jak na Boga, jak na Tego, który będzie sądził żywych i umarłych, i nie powinniśmy zbyt nisko cenić sobie naszego zbawienia. Jeśli bowiem nisko je cenimy, nisko też sięga i nasza nadzieja”, BOK 10, s. 92 (por. Dz 10, 42; 2 Tm 4, 1; 1 P 4, 5).

132 Por. Homilia z II wieku II,1-7, w: SU 2, s. 240.242; BOK 10, s. 92-93.

133 Por. Homilia z II wieku III,4, w: SU 2, s. 242; „W jaki sposób mamy się do Niego przyznać? Czyniąc to, co mówi, nie lekceważąc Jego przykazań i czcząc Go nie tylko wargami, lecz całym sercem i całym umysłem", BOK 10, s. 93.

134 Por. Homilia z II wieku IV,1, w: SU 2, s. 242; „Nie poprzestawajmy na tym, że nazywamy Go Panem, bo to nas nie zbawi. 2. Powiada bowiem: «Nie każdy zostanie zbawiony, kto mi mówi «Panie, Panie», lecz ten, kto czyni sprawiedliwość»", BOK 10, s. 93 (por. Mt 7, 21).

135 Homilia z II wieku XX,5, w: SU 2, s. 268; BOK 10, s. 101.

136 Homilia z II wieku V,5, w: SU 2, s. 244; „I wiedzcie, bracia, że nasz pobyt w ciele na tym świecie to rzecz mała i trwa krótko, a obietnica Chrystusa jest wielka i przedziwna, zapowiedź odpoczynku w przyszłym królestwie i życiu wiecznym”, BOK 10, s. 94. Analogiczne rozumowanie i sformułowania spotykamy w powstałym około 166 roku Martyrio Sancti Polycarpi. Epistola Circularis XX,2, w: PG 5, Paris 1894, k. 1044; przekład polski Męczeństwo świętego Polikarpa, biskupa Smyrny: „Temu, który mocą swej łaski i daru może nas wszystkich wprowadzić do swojego wiecznego królestwa ( 
Kształtowanie się nauki o niebie w teologii patrystycznej I-III wieku

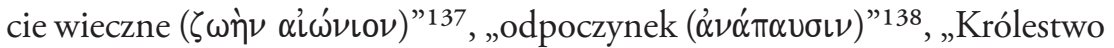

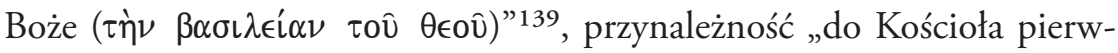

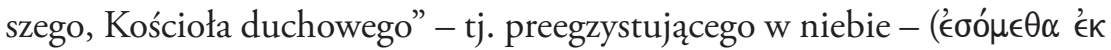

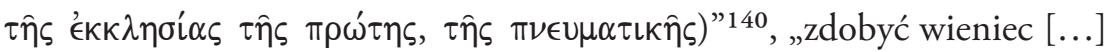

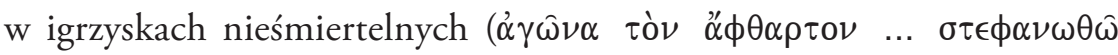
$\mu \epsilon \nu)$ "141, "wieniec w życiu przyszłym ( $\tau \hat{\omega} \mu \epsilon \operatorname{\epsilon } \lambda \lambda \sigma \nu \tau \iota \quad \sigma \tau \epsilon \phi \alpha \nu \omega \theta \hat{\omega} \mu \epsilon \nu)$ "142,

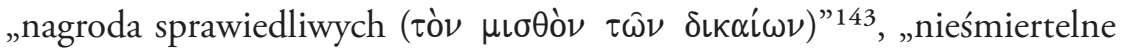

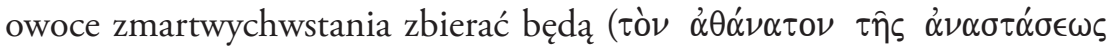

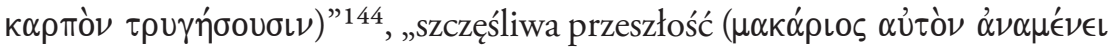

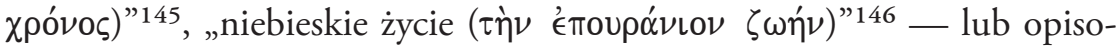
wo: „Tam w górze razem z Ojcami naszymi znajdzie on nowe życie i ra-

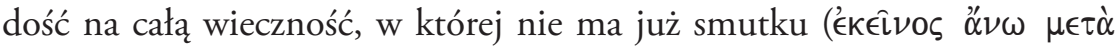

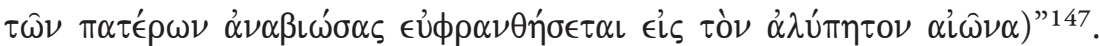

chwała, moc i majestat na wieki”, w: Pierwsi świadkowie. Pisma Ojców..., dz.cyt., BOK 10, s. 169.

137 Homilia z II wieku VIII,4, w: SU 2, s. 248; „A otrzymamy życie wieczne”, BOK 10, s. 95; Homilia z II wieku VIII,6, w: SU 2, s. 248; „Zachowajmy ciało w czystości

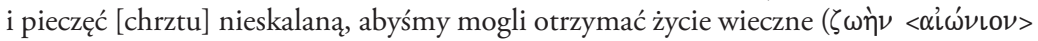

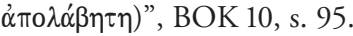

138 Homilia z II wieku VI,7a, w: SU 2, s. 246; „Pełniąc wolę Chrystusa znajdziemy odpoczynek", BOK 10, s. 94.

139 Homilia z II wieku VI,9a, w: SU 2, s. 246; „, (...) skąd my znajdziemy śmiałość, by wejść

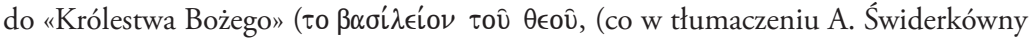
zostało oddane jako „pałace Boże”), jeśli nie zachowamy czystej i nieskalanej pieczęci chrztu naszego?”, BOK 10, s. 94; Homilia z II wieku IX,6, w: SU 2, s. 250; „Miłujmy się więc nawzajem, abyśmy wszyscy weszli do Królestwa Bożego", BOK 10, s. 96.

140 Homilia z II wieku XIV,1, w: SU 2, s. 256; „Tak więc, bracia, wypełniajmy wolę Ojca, naszego Boga, a będziemy należeć do Kościoła pierwszego, Kościoła duchowego, który został stworzony przed słońcem i księżycem”, BOK 10, s. 97 (por. Ef 1, 4).

141 Homilia z II wieku VII,3, w: SU 2, s. 246; „Biegnijmy drogą prostą w igrzyskach nieśmiertelnych, licznie na nie zjeżdżajmy i walczmy tak, abyśmy też wieniec zdobyli, a jeśli nie wszyscy możemy go zdobyć, to chociaż starajmy się jak najbardziej zbliżyć do niego", BOK 10, s. 95.

142 Homilia z II wieku XX,2, w: SU 2, s. 266; BOK 10, s. 100.

143 Homilia z II wieku XX,4, w: SU 2, s. 266; BOK 10, s. 101.

144 Homilia z II wieku XIX,3, w: SU 2, s. 266; BOK 10, s. 100.

145 Homilia z II wieku XIX,4, w: SU 2, s. 266; BOK 10, s. 100.

146 Homilia $z$ II wieku XX,5, w: SU 2, s. 268; BOK 10, s. 101 (por. 2 Kor 2, 14); Ignacy Antiocheński, Do Kościota w Magnezji 8,2.

147 Homilia z II wieku XIX,4, w: SU 2, s. 266; BOK 10, s. 100. 
2. Kształtowanie się nauki o niebie w teologii patrystycznej - wiek I-II

\section{Uczynki zasługujące na nagrodę w wieczności}

Według moralistycznego założenia autora Homilii z II wieku eschatologiczna obietnica Chrystusa stanowi zapłatę za sprawiedliwe czyny wierzących dokonane w doczesności ${ }^{148}$, wypełni się dla nich - jeśli będą: żyli „świę-

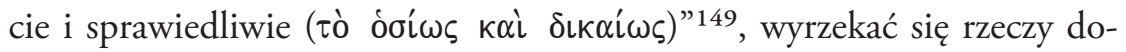
czesnych, a pragnąć tych wiecznych ${ }^{150}$, pełnić wolę Chrystusa ${ }^{151}$, walczyć w igrzyskach nieśmiertelnych ${ }^{152}$, strzec pieczęci [chrztu] ${ }^{153}$, jeśli w doczesności będą żałować za złe czyny i pokutować za nie ${ }^{154}$, czynić wolę Ojca,

148 Por. Homilia z II wieku XI,6-7, w: SU 2, s. 252; „Wierny jest bowiem Ten, który obiecał oddać każdemu zapłatę za czyny jego. Jeśli więc będziemy czynić sprawiedliwość wobec Boga, wejdziemy do Jego Królestwa i otrzymamy to, co nam obiecano, a czego «ani ucho nie słyszało, ani oko nie widziało, ani serce człowieka nie zdołało pojąć»", BOK 10, s. 96 (por. Hbr 10, 23; 1 Kor 2, 9); Homilia z II wieku XVII,4.7, w: SU 2, s. 262.264; „4. kiedy przyjdzie [Pan], by nas odkupić, każdego według jego czynów. 7. A sprawiedliwi, którzy czynili dobrze, znosili udręki i mieli w nienawiści wszelkie dogadzanie sobie, zobaczą, jak straszną karę ponoszą, cierpiąc w ogniu nieugaszonym ci wszyscy, którzy zdradzili i słowem lub czynem wyparli się Jezusa”, BOK 10, s. 99-100; Homilia z II wieku XIX,1, w: SU 2, s. 264; „Jako zapłaty domagam się waszego nawrócenia z całego serca, bo przez nie zdobędziecie sobie zbawienie i życie", BOK 10, s. 100.

149 Por. Homilia z II wieku V,6-7, w: SU 2, s. 244; „6. A chcąc to osiągnąć, cóż mamy czynić innego niźli żyć święcie i sprawiedliwie, a rzeczy tego świata nie uważać za własne ani ich nie pożądać? 7. Jeżeli bowiem pragniemy je zdobyć, schodzimy z drogi sprawiedliwości”, BOK 10, s. 94.

150 Por. Homilia z II wieku VI,5-6, w: SU 2, s. 244.246; „5. Nie możemy więc być przyjaciółmi obu: musimy jednego się wyrzec, aby żyć z drugim. 6. Sądzimy, że lepiej jest nienawidzić rzeczy doczesne, bo małe są, krótkotrwałe i zniszczalne, kochać natomiast

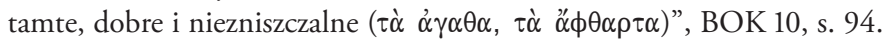

151 Homilia z II wieku VI,7, w: SU 2, s. 246; „Pełniąc wolę Chrystusa, znajdziemy odpoczynek. Gdybyśmy postępowali inaczej, nic nas nie wybawi od wiecznej kary, gdy zlekceważymy Jego przykazania”, BOK 10, s. 94.

152 Homilia z II wieku VII,2-3, w: SU 2, s. 246; „2. My zatem tak walczmy, abyśmy wszyscy wieniec zdobyli. 3. Biegnijmy droga prostą w igrzyskach nieśmiertelnych", BOK 10, s. 95.

153 Homilia z II wieku VII,5-6, w: SU 2, s. 246; „Jak myślicie? Co spotka tego, który zawiedzie w igrzyskach o nieśmiertelność? 6. O tych, co nie ustrzegli pieczęci ( $\gamma \hat{i} \delta \alpha)$ [chrztu], mówi [Pismo]: «Robak ich nie umrze i ogień ich nie zgaśnie i będą widowiskiem dla wszelkiej istoty żyjącej»", BOK 10, s. 95 (Iz 66, 24; por. Mk 9, 44-48).

154 Por. Homilia z II wieku VIII,2-3, w: SU 2, s. 248; „Jak długo jesteśmy na tym świe-

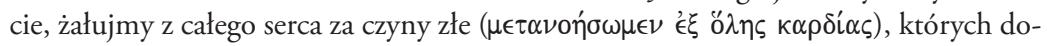
konaliśmy w ciele. A może zostaniemy zbawieniu przez Pana, dopóki jeszcze mamy

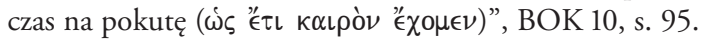


Kształtowanie się nauki o niebie w teologii patrystycznej I-III wieku

zachowywać ciało w czystości i przestrzegać przykazań Pana ${ }^{155}$, miłować się wzajemnie ${ }^{156}$.

Anonimowy autor Homilii z II wieku gubi niestety perspektywę wcielenia i odkupienia, co prowadzi go we wnioskowaniu do moralistycznego przerysowania ważności powinności etycznej i pozostawania w filozoficznej koncepcji intelektualizmu etycznego. Godność człowieka i jego zbawienie zdają się wynikać dla anonimowego autora bardziej z rozumnego wyboru norm moralnych, niż z przynależności wierzącego do Boga poprzez stworzenie, zbawienie, wiarę-przymierze. Brak podkreślenia więzi już zbawionych ze Zbawicielem i pomijanie wątku teologicznego o realizacji chrześcijańskiego życia moralnego przez miłość do Boga prowadzi natomiast autora analizowanej homilii do koncentracji na człowieku jako na jedynym podmiocie czynów moralnych, a w konsekwencji na zatrzymaniu się na stanowisku greckiego intelektualizmu etycznego.

\section{Wątek myślenia życzeniowego: androgyniczne niebo dla ascetów}

Passus z Homilii z II wieku XVI, 2-3 o wejściu do Królestwa Bożego dzięki androgynicznemu zrównaniu cech zewnętrznych z wewnętrznymi oraz męskich z żeńskimi ${ }^{157}$ posiada charakterystykę gnostycką i stanowi wyraźne zapożyczenie z apokryficznej Ewangelii Tomasza 22 (wersja koptyj-

155 Homilia z II wieku VIII,4, w: SU 2, s. 248; „Tak więc, bracia, czyńmy wolę Ojca, zachowujmy ciało w czystości, przestrzegajmy przykazań Pana, a otrzymamy życie wiecz-

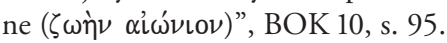

156 Homilia z II wieku IX,6, w: SU 2, s. 250; „Miłujmy się więc nawzajem, abyśmy wszy-

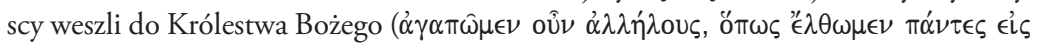

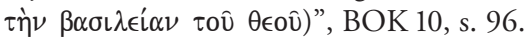

157 Homilia z II wieku XVI,1-6, w: SU 2, s. 258.260; „1. W miłości i sprawiedliwości oczekujmy zatem z godziny na godzinę Królestwa Bożego, ponieważ nie znamy dnia objawienia się Boga. 2. Sam bowiem Pan zapytany przez kogoś, kiedy przyjdzie Jego Królestwo, powiedział: «Kiedy dwa będą jednym, i to, co zewnątrz, będzie jak wewnątrz, a męskie z żeńskim ani męskie, ani żeńskie». 3. Dwa są jednym, kiedy mówimy sobie wzajemnie prawdę i w dwóch ciałach jest bez żadnej obłudy jedna dusza. 4. A to, co zewnątrz, jak to, co wewnątrz, znaczy: dusza jest tym, co wewnątrz, ciało, tym, co zewnątrz. Jak więc twoje ciało jest widzialne, podobnie i dusza twoja niech się ujawnia w dobrych uczynkach. 5. Męskie zaś z żeńskim, ani męskie, ani żeńskie, znaczy to: kiedy brat, widząc siostrę, nie myśli o niej jako o kobiecie, ani ona o nim jako o mężczyźnie. 6. Jeśli tak będziecie postępować, mówi Pan, przyjdzie Królestwo Ojca mego", BOK 10, s. 96-97. 
ska; pierwotna grecka wersja powstała około II wieku, prawdopodobnie w Edessie) ${ }^{158}$. Podobne wątki androgyniczne spotykamy też w apokryficznej Ewangelii wedtug Egipcjan ${ }^{159}$ (tekst z pierwszej połowy II wieku, powstały pośród egipskich etnochrześcijan ${ }^{160}$ ) czy w Agrafa 8 u Psuedo-Klemensa Rzymskiego (tekst z II wieku) ${ }^{161}$.

Przytoczone wzorowanie się Homilii z II wieku XVI, 2-3 na Ewangelii Tomasza jest intrygujące, gdyż głównym tematem owego apokryfu jest idea królestwa objawiana przez Jezusa Żywego / Zmartwychwstałego, Syna żyjącego Ojca, który uwolnił się od wszystkich związków z życiem doczesnym. Autor wspomnianego apokryfu koncentruje się na nauce dla wybranych na temat własnej relacji z Bogiem. Ta gnoza pomaga zbawić się tylko nielicznym, indywidualistycznie nastawionym ascetom. Gnostycka Ewangelia

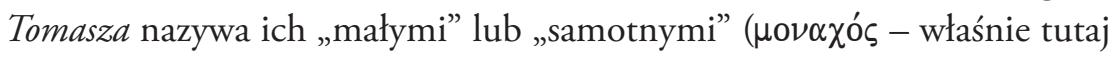
to określenie pojawia się po raz pierwszy w tekstach chrześcijańskich) ${ }^{162}$.

Wydaje się prawdopodobne, iż u anonimowego autora Homilii z II wieku nastąpiło przejęcie gnostyckiego myślenia o zbawieniu w kategoriach indywidualnego związku z Bogiem opartego na pochodzeniu i ascetycznej

158 Ewangelia Tomasza (wersja koptyjska) 22: „Jezus zobaczył malców pijących mleko. Rzekł do swych uczniów: «Te maleństwa pijące mleko podobne są do tych, co weszli do królestwa». Spytali go: «Jeśli staniemy się małymi, wejdziemy do królestwa?». Odrzekł im Jezus: «Wejdziecie, jeśli macie zwyczaj czynić dwa jednością i stronę wewnętrzną czynić tak, jak zewnętrzną, a stronę zewnętrzną tak, jak wewnętrzną, stronę górną tak, jak stronę dolną i jeśli macie zwyczaj czynić to, co męskie i żeńskie jednością, aby to, co jest męskie, nie było męskim, a to co żeńskie, nie było żeńskim, jeśli będziecie mieli zwyczaj czynić oczy jednym okiem, a jedną rękę dacie w miejsce ręki i nogę w miejsce nogi i obraz w miejsce obrazu, wtedy wejdziecie do królestwa»", w: Apokryfy Nowego Testamentu. Ewangelie apokryficzne, cz. 1. Fragmenty, Narodzenie i Dzieciństwo Maryi i Jezusa, red. M. Starowieyski, tłum. W. Myszor, A. Dembska, Kraków 2003, s. 189.

159 Ewangelia wedtug Egipcjan (EwEg) 2: „Sam bowiem Pan zapytany przez kogoś, kiedy przyjdzie Jego królestwo, powiedział: «Kiedy dwa będą jednym, i to, co na zewnątrz będzie jak wewnątrz, a męskie z żeńskim ani męskie, ani żeńskie»", w: Apokryfy Nowego Testamentu. Ewangelie apokryficzne..., dz. cyt., cz. 1, s. 122.

160 Por. M. Starowieyski, [Wstęp do] h. Ewangelia wedtug Egipcjan (EwEg), w: Apokryfy Nowego Testamentu. Ewangelie apokryficzne..., dz. cyt., cz. 1, s. 121.

161 Pseudo-Klemens Rzymski, Agrafa 8: „Sam bowiem Pan zapytany przez kogoś, kiedy przyjdzie Jego Królestwo, powiedział: «Kiedy dwa będą jednym, i to, co zewnątrz, będzie jak wewnątrz, a męskie z żeńskim ani męskie, ani żeńskie»", w: Apokryfy Nowego Testamentu. Ewangelie apokryficzne..., dz. cyt., cz. 1, s. 93.

162 Por. W. Myszor, Wersja koptyjska "Ewangelii Tomasza», w: Apokryfy Nowego Testamentu. Ewangelie apokryficzne..., dz. cyt., cz. 1, s. 181-182. 
Kształtowanie się nauki o niebie w teologii patrystycznej I-III wieku

ortopraksji, a nie za darmo danej łasce Bożej. Stąd w konsekwencji do życia wiecznego mieliby dochodzić wyłącznie tylko nieliczni, indywidualistycznie nastawieni asceci. Tego typu myślenie życzeniowe jest widoczne w analizowanej homilii, kiedy jej anonimowy autor uwypukla tezę, iż życie wieczne to przede wszystkim nagroda za dobre uczynki.

\subsubsection{Podsumowanie nauki o niebie w teologii patrystycznej ojców i pisarzy okresu poapostolskiego (I-II wiek)}

Przechodząc do zestawienia najważniejszych treści związanych z teologią nieba w pismach ojców i pisarzy poapostolskich, podam poniżej zwięzłe uogólnienia dotyczące omawianych zagadnień.

\section{Opisy nieba}

Są teologiczną kontynuacją wcześniejszej kosmologii i eschatologii biblijnej. Wyłącznym władcą nieba jest Bóg, który w nim przebywa ${ }^{163}$, samo niebo jest dziełem Boga, całkowicie Mu podległym, lecz nie jest z Nim tożsame $^{164}$, jest siedzibą pobożnych i nieskalanych istot ${ }^{165}$, w niebie panuje harmonia i zgoda pośród przebywających tam stworzeń ${ }^{166}$.

\section{Stosowana terminologia}

Najczęściej przywoływanymi pojęciami, które pisarze i ojcowe poapostolscy odnoszą do szczęśliwości eschatologicznej zbawionych, są określenia związane z motywami przestrzenno-rzeczowymi oraz motywami jakościowymi:

(1) określenia związane z motywami przestrzenno-rzeczowymi: „niebo”167 albo „niebiosa” ${ }^{168}$, „Królestwo Boże”169 względnie „Królestwo Twoje /

\footnotetext{
163 Por. Klemens Rzymski, List do Kościoła w Koryncie XIX,2; LIX 2.3.

164 Por. Klemens Rzymski, List do Kościoła w Koryncie XXXIX,5.

165 Por. Klemens Rzymski, List do Kościota w Koryncie L,2-3.

166 Por. Klemens Rzymski, List do Kościota w Koryncie XX,11.

167 Por. Klemens Rzymski, List do Kościota w Koryncie XXXIX; List Barnaby XV,9; Hermas, Pasterz 1,4-6; 3,4; 4,1-2.

168 Por. Klemens Rzymski, List do Kościoła $w$ Koryncie XX,1; Hermas, Pasterz 1,8; 2,1.

169 Por. Ignacy Antiocheński, List do Kościota w Efezie XVI,1; List Barnaby XXI,1; Hermas, Pasterz 89(12),3-4; Homilia z II wieku VI,9a.
} 
2. Kształtowanie się nauki o niebie w teologii patrystycznej - wiek I-II

Pańskie” ${ }^{170}$; „rzeczy niebieskie”171 oraz pojedynczo występujące określenia typu: „miasto wasze” 172 , „miasto ojczyste”173, „Arkadia”174, „góra”175, „tam, w górze”176, „miejsce święte”177;

(2) określenia związane z motywami jakościowymi: „życie wieczne”178, „nieśmiertelność” ${ }^{179}$, „wieczność-stale” ${ }^{180}$, „życie przyszłe”181, „świat przyszły” ${ }^{182}$, „rzeczy przyszłe” ${ }^{183}$, „niebieskie życie”184, „nadejście łaski, związane z końcem doczesności”185, „szczęśliwa przyszłość”186, „udział w dziedzictwie” 187 , „depozyt dobrych czynów” ${ }^{188}$, „być zapisanym w Księdze żywych” ${ }^{189}$, „Kościół pierwszy, duchowy” preegzystujący w niebie ${ }^{190}$.

Zdecydowana większość terminologii stosowanej przez ojców i pisarzy poapostolskich na określenie rzeczy niebiańskich jest pochodzenia biblijnego. Teologowie tego okresu, mówiąc o niebie, rozwijają zasadniczo wątki teologii Janowej oraz Pawłowej. Charakterystycznym wyjątkiem jest

170 Por. Didache X,5.

171 Por. Ignacy Antiocheński, List do Kościota w Tralleis V,1;V,2.

172 Por. Hermas, Pasterz 50,1.

173 Por. Hermas, Pasterz 50,5.

174 Por. Hermas, Pasterz 78(1),4.

175 Por. Hermas, Pasterz 78,10-79(2),1-2.

176 Por. Homilia z II wieku XIX,4.

177 Por. Hermas, Pasterz 9(1)-10 (2),1.

178 Por. Didache X,3; Ignacy Antiocheński, List do Kościota w Efezie XVIII,1; XIX,3; XX,2; Ignacy Antiocheński, List do Polikarpa II,3; List Barnaby XI,11; Hermas, Pasterz 7(3),2; Homilia z II wieku VIII,4; VIII,6.

179 Por. Didache X,2; Klemens Rzymski, List do Kościota w Koryncie XXXV,1-2; Ignacy Antiocheński, List do Kościota $w$ Efezie XX,2; Ignacy Antiocheński, List do Kościota w Filadelfii IX,2; Ignacy Antiocheński, List do Kościoła w Magnezji VI,2; Hermas, Pasterz 9(1)-10 (2),1; Homilia z II wieku VII,3; XIX,3; XX,5.

180 Por. Klemens Rzymski, List do Kościota w Koryncie XX,10; Ignacy Antiocheński, List do Kościota w Efezie XX,2; Hermas, Pasterz 104(27),3; Homilia z II wieku XIX,4.

181 Por. List Barnaby IV,12; Homilia z II wieku XX,2.

182 Por. Hermas, Pasterz 53,8.

183 Por. List Barnaby I,7.

184 Por. Homilia z II wieku XX,5.

185 Por. Didache X,6.

186 Por. Homilia z II wieku XIX,4.

187 Por. Ignacy Antiocheński, List do Kościota w Tralleis XII,3.

188 Por. Ignacy Antiocheński, List do Polikarpa VI,2.

189 Por. Hermas, Pasterz 51,9.

190 Por. Homilia z II wieku XIV,1. 
Kształtowanie się nauki o niebie w teologii patrystycznej I-III wieku

termin „Arkadia”, greckiej proweniencji mitologiczno-poetyckiej. Pośród dwóch wydzielonych przeze mnie klasyfikacji terminów dotyczących nieba, przeważają nieznacznie określenia związane z motywami jakościowymi. Najbardziej znaczącymi terminami tej grupy są najczęściej terminy „życie wieczne” oraz „nieśmiertelność”. Pośród grupy określeń związanych z motywami przestrzenno-rzeczowymi najbardziej specyficznymi są pojęcia „niebo”, „niebiosa” oraz „Królestwo Boże”, „Królestwo Pańskie”.

\section{Najważniejszy przekaz teologiczny dotyczący nieba}

W kwestii nieba teologicznie najważniejszym przesłaniem myśli ojców i pisarzy poapostolskich jest konkluzja, iż osiągnięcie nieba jest możliwe wyłącznie dzięki Jezusowi Chrystusowi i Bogu Ojcu, gdyż Bóg jest wierny swoim obietnicom ${ }^{191}$.

\section{Cechy zbawionych w niebie}

To właściwości wynikające z wiecznej relacji Boga ze zbawionymi, dzięki której zyskują oni nowe jakości życia. Cechami tymi jest obdarzony cały człowiek zbawiony. Nie odnotowuje się w teologii ojców i pisarzy poapostolskich dualizmu antropologicznego, uwarunkowanego filozoficznie grecką antropologią dychotomiczną, ale jest kontynuowana klasyczna myśl biblijna o istnieniu i zbawieniu całego człowieka.

Spośród najważniejszych cech zbawionych, którzy są w niebie, a jakie są wymieniane przez autorów okresu poapostolskiego, można wyróżnić: cechy wspólnotowe - odnoszące się do całej społeczności zbawionych (zjednoczenie i jedność Kościoła zbawionych ${ }^{192}$, uczestnictwo w Chrystusowym Królestwie) ${ }^{193}$, cechy zbawionych związane ze stałością ich życia (nieśmiertelność ${ }^{194}$, życie wieczne $)^{195}$, cechy zbawionych związane z nabyciem wiecz-

191 Por. Didache IX,4; X,2.3; Klemens Rzymski, List do Kościota w Koryncie XXVII,1-2; Ignacy Antiocheński, List do Kościota w Filadelfii IX,1; Ignacy Antiocheński, List do Kościota w Magnezji I,2; Hermas, Pasterz 89(12),1.3-5.8; Homilia z II wieku XX,5.

192 Por. Didache IX,4.

193 Por. Didache IX,4; X,5.

194 Por. Didache X,2; Klemens Rzymski, List do Kościoła w Koryncie XXXV,1-2.

195 Por. Didache X,3; Ignacy Antiocheński, List do Kościoła w Efezie XIX,3; List Barnaby $\mathrm{XV}, 7$. 
nych jakości znanych pośrednio już w doczesności (uświęcenie ${ }^{196}$, nieskazitelność $^{197}$, nastanie łaski ${ }^{198}$, odpocznienie ${ }^{199}$, brak smutku) ${ }^{200}$, posiadanie przez zbawionych darów w jakiś sposób już policzalnych i pojmowalnych w doczesności (nieśmiertelność, sprawiedliwość, prawda, ufność, wstrzemięźliwość) oraz tych jeszcze niepoliczalnych i niepojmowalnych ${ }^{201}$ - rozumienie otrzymanych darów Bożych ${ }^{202}$, nabycie przez zbawionych w niebie, dzięki Chrystusowi i w Chrystusie, wizji Boga, która będzie stanowić rodzaj nieśmiertelnego poznania ${ }^{203}$.

\section{Przygotowanie do osiągniecia nieba}

Ten wątek teologiczny stanowi przedłużenie teologii parenetycznej NT. Uczynki pobożne nie mają wartości zbawczej, ale stanowią potwierdzenie wyboru życia według woli Bożej objawionej w Jezusie Chrystusie. Do najczęściej powtarzanych zachęt, motywujących chrześcijan w ich podążaniu do nieba, należą wezwania do: przyjmowania w Kościele Eucharystii ${ }^{204}$, zachowania jedności z Kościołem ${ }^{205}$, życia w doczesności według norm postępowania objawionych przez Boga, przede wszystkim do życia wiarą w Boga, która usprawiedliwia człowieka ${ }^{206}$, a także do posłuszeństwa Bogu w doczesności przez: praktykowanie sprawiedliwości i świętości ${ }^{207}$, czynienie dobra i życia w miłości ${ }^{208}$, znoszenie cierpienia i męczeństwa dla Boga ${ }^{209}$; do za-

\footnotetext{
196 Por. Didache X,5.6; Klemens Rzymski, List do Kościoła w Koryncie XXXV,1-2.

197 Por. Ignacy Antiocheński, List do Polikarpa II,3.

198 Por. Didache X,6.

199 Por. List Barnaby XV,5.7; Homilia z II wieku V,5; Męczeństwo św. Polikarpa XX,2.

200 Por. Homilia z II wieku XX,5; Homilia z II wieku XIX,4.

201 Por. Klemens Rzymski, List do Kościota w Koryncie XXXV,1-2.

202 Por. Klemens Rzymski, List do Kościota w Koryncie XXXV,1-2.

203 Por. Klemens Rzymski, List do Kościota w Koryncie XXXVI,2.

204 Por. Didache IX 4; X,3; Ignacy Antiocheński, List do Kościoła w Efezie XX,2.

205 Por. Didache IX 4; Ignacy Antiocheński, List do Kościoła w Magnezji VI,2.

206 Por. Klemens Rzymski, List do Kościota w Koryncie XXXII,3-4; Ignacy Antiocheński, List do Kościota $w$ Tralleis V,2.

207 Por. Klemens Rzymski, List do Kościota w Koryncie IX,3XXX,1; Hermas, Pasterz 7(3),23; Homilia z II wieku V,6-7.

208 Por. Klemens Rzymski, List do Kościota $w$ Koryncie XXXIII,1; Ignacy Antiocheński, List do Kościota w Magnezji V,1; Homilia z II wieku IX,6.

209 Por. Hermas, Pasterz 9(1)9-10(2),1.
} 
Kształtowanie się nauki o niebie w teologii patrystycznej I-III wieku

chowania postawy ewangelicznej małości, ${ }^{210}$ pamiętania o Bożych przykazaniach $^{211}$, zachowywania gościnności ${ }^{212}$, pomocy biednym przez bogatych i modlitwy biednych za swych dobrodziejów ${ }^{213}$, unikania zbyt licznych zajęć i niepopełnianie grzechów ${ }^{214}$, do życia według cnót ${ }^{215}$, nawrócenia się i przyjęcia chrztu ${ }^{216}$, do zachowania niewinności serca ${ }^{217}$, do wyrzekanie się rzeczy doczesnych, żałowania za złe czyny i pokutowanie z nie ${ }^{218}$. Udział w czasie trwania „drugiego millenium” stanowiłby potwierdzenie życia według norm Bożych i dawałby sprawiedliwym millenijną gwarancję ich wiecznego życia w niebie ${ }^{219}$. Natomiast postawą uniemożliwiającą odziedziczenie nieba jest doczesny wybór przez człowieka drogi złych czynów ${ }^{220}$.

\section{Niebo pojmowane jako nagroda}

Niektórzy spośród ojców i pisarzy poapostolskich opisują też niebo w kategoriach wspaniałej nagrody w wieczności, którą chrześcijanin otrzymuje w wieczności za wytrwanie przy Bogu w doczesności ${ }^{221}$ lub jako Bożą zapłatę za dobre czyny w doczesności ${ }^{222}$.

Ojcowie i pisarze poapostolscy nie mówią zatem wiele o charakterze przyszłego świata zbawionych. Kontynuując w swej teologii podstawowe wątki kosmologii i parenezy biblijnej, podkreślają oni bardziej cechy, jakimi zbawieni będą się odznaczać oraz wskazują na doczesne wybory, które mogą przygotować chrześcijan do osiągnięcia życia w niebie. W teologii ojców i pisarzy poapostolskich najważniejszą myślą teologiczną dotyczącą nieba

\footnotetext{
210 Por. Hermas, Pasterz 50,6.

211 Por. Hermas, Pasterz 50,6; Homilia z II wieku VIII,4.

212 Por. Hermas, Pasterz 104(27),2.3.

213 Por. Hermas, Pasterz 51,1-8.

214 Por. Hermas, Pasterz 53,5.8.

215 Por. Hermas, Pasterz 92(15),1b-2.

216 Por. Hermas, Pasterz 93(16),2; Homilia z II wieku VII,5-6.

217 Por. Hermas, Pasterz 106(29),1-2.

218 Por. Homilia z II wieku VI,5-6; VIII,2-3.

219 Por. List Barnaby XV,1-7.

220 Por. Ignacy Antiocheński, List do Kościota w Magnezji VI,3; List Barnaby XVIII-XX.

221 Por. Klemens Rzymski, List do Kościoła w Koryncie V,4,5-6; XXVI,1-2; List Barnaby XXI,1.

222 Por. Klemens Rzymski, List do Kościota w Koryncie XXXIV,3; Ignacy Antiocheński, List do Polikarpa VI,2; List Barnaby IV,12; XXI,1-2; Homilia z II wieku XI,6-7.
} 
jest przesłanie, że jego osiągnięcie jest możliwe wyłącznie dzięki Jezusowi Chrystusowi i Bogu Ojcu, gdyż Bóg jest wierny swoim obietnicom.

\subsection{Kształtowanie się nauki o niebie w teologii apologetów greckich II wieku}

Komentowane w tym paragrafie teksty patrystyczne, które poruszają tematykę eschatologicznego nieba, pochodzą z czasu określanego w patrologii jako okres apologetów greckich II wieku. Są one zapisem konfrontacji chrześcijaństwa z pogańskim światem greckim i jego instytucjami, a także, choć w mniejszym stopniu, z judaizmem. Apologeci greccy w swych tekstach łączyli krytykę kultury i religii pogańskiej z pozytywnym wykładem chrześcijaństwa. Jednakże w tekstach tych apologetów nie istnieje jeszcze systematyczna prezentacja podstawowych elementów wiary, pojawia się jedynie próba wypracowania teologii opartej na Bożym Objawieniu, z wykorzystaniem ówczesnej filozofii platońskiej i stoickiej oraz teologii hellenistycznego judaizmu ${ }^{223}$.

Pisma siedmiu autorów epoki apologetów greckich II wieku, w których odnalazłem wątki eschatologii nieba, są zasadniczo apologiami (teksty Arystydesa z Aten, Justyna Męczennika, Tacjana Syryjczyka, Atenagorasa z Aten, Teofila z Antiochii oraz anonimowy List do Diogneta), a tylko jeden homilią o cechach deklamacji liturgicznej (Homilia Paschalna Melitona z Sardes). Rodzaj literacko-teologiczny, jakim była apologia chrześcijańska, warunkował też przekaz treści teologicznych. Tematyki eschatologii końcowej są dalej fragmentaryczne, rozwijane przy okazji prezentacji czy to teologii o transcendentnym Bogu Ojcu, Jego odwiecznym Logosie i Duchu prorockim / mocy Bożej, czy wykładu etyki chrześcijańskiej, opisywanej często w kategoriach stoickich. W metodologii analizowanych autorów przeważa dyskurs filozoficzno-apologetyczny oraz podstawowa argumentacja teologiczna, dostosowana do mentalności epoki. W antropologii teologicznej można natomiast zaobserwować przejęcie greckiego modelu

223 Por. L. Misiarczyk, Wstęp - Apologetyka wczesnochrześcijańska, w: Pierwsi apologeci greccy. Kwadratus, Arystydes z Aten, Aryston z Pelli, Justyn Męczennik, Tacjan Syryjczyk, Milcjades, Apolinary z Hierapolis, Teofil z Antiochii, Hermiasz, tłum., wstępy i komentarze L. Misiarczyk, oprac. J. Naumowicz, Kraków 2004, BOK 24, s. 11-13. 
Kształtowanie się nauki o niebie w teologii patrystycznej I-III wieku

antropologii dychotomicznej, przy stopniowym odchodzeniu od biblijnej antropologii całego człowieka. Dla wykładu eschatologii końcowej skutkowało to akcentowaniem jakościowych cech ciała zmartywychwstałego.

\subsubsection{Arystydes z Aten - życie wieczne w królestwie niebieskim przez Jezusa Chrystusa}

Apologia Arystydesa ${ }^{224}$ została napisana prawdopodobnie jesienią 124 lub zimą 124/125 roku. Autor apologii był chrześcijańskim filozofem ateńskim, który skierował swoje pismo do cesarza Hadriana, kiedy ten przebywał w Atenach. Te dwie informacje potwierdzają późniejsze świadectwa tekstualne Euzebiusza z Cezarei i Hieronima ze Strydonu oraz dedykacje tekstu w wersji syryjskiej i łacińskiej. Oryginalny tekst grecki zaginął, a obecny tekst tej apologii znamy z pięciu wersji: syryjskiej, gruzińskiej, armeńskiej, greckiej zrekonstruowanej na podstawie Opowieści Barlaama i Jozafata oraz powstałej z fragmentów papirusów z tekstem greckim. Apologia Arystydesa jest mową epideiktyczną (popisowa), którą niektórzy badacze (np. Bernard Pouderon) proponują określić jako mowę fikcyjną lub tzw. list otwarty do władcy. Autor kończy swój list zachętą do nawrócenia ${ }^{225}$.

\section{Kontekst teologiczny nauki o niebie}

Arystydes, starając się racjonalnie przedstawić wyższość religii i moralności chrześcijańskiej nad innymi religiami, podzielił ludzkość na cztery kategorie (barbarzyńską i grecką ${ }^{226}$, żydowską ${ }^{227}$ oraz chrześcijańska), analizował

224 Aristides, Apologia, w: SCh 470. Aristide, Apologie. Introduction, textes critiques, traductions et commentaire par B. Pouderon, M.-J. Pierre, B. Quttier, M. Guiorgadzé, Paris 2003; przekład polski Arystydes z Aten, Apologia, w: Pierwsi apologeci greccy..., dz. cyt., BOK 24, s. 111-133 [wstęp], s. 135-150 [tekst - wersja grecka].

225 Por. L. Misiarczyk, Arystydes z Aten. Wstęp, w: Pierwsi apologeci greccy..., dz. cyt., BOK 24, s. 117-124.

226 Kulty politeistyczne są wymysłem ludzkiego błędu i zguby, oddaje się w nich cześć idolom i stworzeniom, zamiast Niewidzialnemu Bogu (por. Arystydes z Aten, Apologia $13,7)$.

227 Żydzi, wierząc w prawdziwego Boga, zapomnieli jednak o Nim i okazali się Mu niewdzięczni przez praktykę kultów pogańskich i przez zabójstwa proroków i sprawiedliwych oraz Syna Bożego (por. Arystydes z Aten, Apologia 14,1-2), naprawdę więc 
błędy trzech pierwszych grup, by następnie pozytywnie przedstawić monoteizm chrześcijański jako podstawę do oceny innych religii. Arystydes, krytykując politeizm (Apologia 2 - 13), odniósł się też do kosmologii mezopotamskich, babilońskich i asyryjskich (Apologia 3,1-4, 2). Chaldejskie wierzenia dotyczące nieba były błędne, gdyż uznając niebo czy inne elementy świata za bóstwa, poglądy te bazowały na braku poznania prawdziwego Boga oraz wynikały z kultycznej idolatrii ${ }^{228}$. Podobnie opaczne były wierzenia babilońskie i asyryjskie, określające, że niebo jest bogiem. Wierzenia te pomylity po prostu kosmos / niebo z bóstwem, stworzenie ze Stwórcą 229.

\section{Terminologia dotycząca rzeczywistości niebiańskich}

Nazewnictwo eschatologicznego nieba, jakie Arystydes stosuje w swojej apologii, jest typowo nowotestamentalne. Autor ten używa albo bezpośrednie

nie znają Boga, ponieważ odrzucają Chrystusa, Syna Bożego (por. Arystydes z Aten, Apologia 14,3-4).

228 Arystydes z Aten, Apologia 3,1, w: SCh 470, s. 258; „I tak, Chaldejczycy, nie poznawszy prawdziwego Boga, pobłądzili, idąc za elementami świata, i zaczęli czcić stworzenie zamiast Stwórcy. Uczynili sobie nawet niektóre posągi, które nazwali obrazem nie-

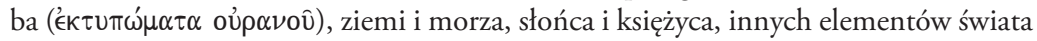
czy też ciał świecących. Zamknęli je w świątyniach, oddając im cześć i nazywając bogami - tych, których strzegą pilnie, aby nie zostały skradzione przez złodziei”, BOK 24, s. 136.

229 Arystydes z Aten, Apologia 4,2, w: SCh 470, s. 260.262; „Otóż, pobłądzili ci, któ-

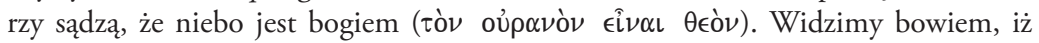
obraca się ono i porusza według praw natury oraz składa się z licznych elementów -

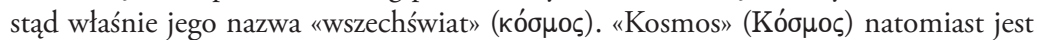
dziełem jakiegoś twórcy, a to, co zostało uczynione, posiada przecież jakiś początek i cel. Dalej, niebo (ò oủpavòs) przecież porusza się wraz ze swoimi ciałami świecącymi według określonych praw natury. Gwiazdy przesuwają się od znaku do znaku w ustalonej kolejności i odległości, niektóre zachodzą, inne zaś wschodzą, wykonując swoją drogę w określonym czasie, aby nastawały po sobie pory roku, jak im to zostało nakazane przez Boga, i aby nie przekroczyły swoich własnych granic wyznaczonych przez niezmienne prawo natury $\mathrm{w}$ harmonii z niebieskim wszechświatem $(\tau \omega \hat{\omega}$

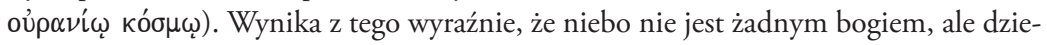
łem Boga", BOK 24, s. 136-137. Jak odnotowuje L. Misiarczyk, Pierwsi apologeci greccy..., dz. cyt., BOK 24, s. 147, przypis 9, w zacytowanym tekście Apologii 4,2 „chodzi zapewne o Babilończyków i Asyryjczyków, którzy otaczali szczególnym kultem niebo. Natomiast dla Hetytów niebo było nie tylko jednym z wielu bogów, lecz wręcz głównym bóstwem". 
Kształtowanie się nauki o niebie w teologii patrystycznej I-III wieku

zapożyczenia z NT, albo tworzy zbitki słowotwórcze z kilku fragmentów biblijnych odnoszących się do nieba i życia wiecznego:

„zstąpił z nieba ( $\alpha \pi^{\prime}$ oủ $\alpha \nu$ ov̂ $\left.\kappa \alpha \tau \alpha \beta \grave{\alpha} \varsigma\right)$ "230 / „powrócił do życia i wstą-

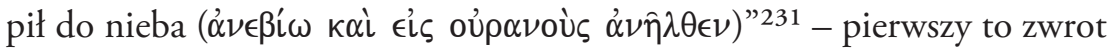
zaczerpnięty z J 6, 33, „powrócił do życia” - to określenie z 1 Kor 15, 4, formuła „wstąpił do nieba” - pochodzi z Łk 24, 51 i Dz 1, 9;

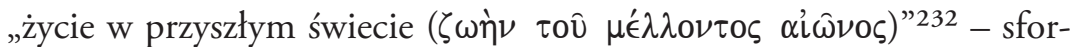
mułowanie oddające skrótowo sens chrześcijańskiej nadziei, a będące teologicznie zbitką różnych odniesień nowotestamentalnych: por. J 3, 16; Hbr 2, 5; 10, 19-39; Rz 6, 8;

„królestwo niebieskie obwieszczone przez Chrystusa w życiu wiecznym (

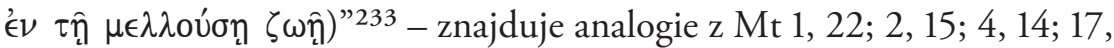
$23 ; 21,4 ; 27,9$;

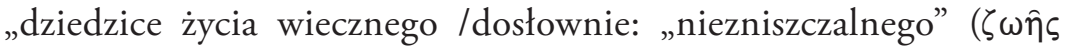

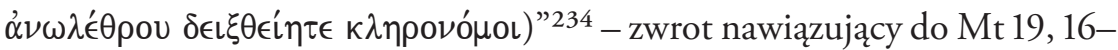
22 i paralelnych Mk 10, 17-22 i Łk 18, 18-23.

\section{Nauczanie o rzeczach niebiańskich - filozoficzna kosmologia i chrześcijańska wiara w eschatologiczne niebo}

Arystydes, opisując atrybuty jedynego prawdziwego Boga ${ }^{235}$, przy okazji podał zarys swej kosmologii filozoficznej, wykładając, iż niebo jest jedynie dziełem Boga ${ }^{236}$. Tezy o Bogu, wyrażone za pomocą określeń nega-

\footnotetext{
230 Arystydes z Aten, Apologia 15,1, w: SCh 470, s. 286; BOK 24, s. 144.

231 Arystydes z Aten, Apologia 15,1, w: SCh 470, s. 287; BOK 24, s. 144.

232 Arystydes z Aten, Apologia 15,3, w: SCh 470, s. 288; BOK 24, s. 144-145.

233 Arystydes z Aten, Apologia 16,1, w: SCh 470, s. 290; BOK 24, s. 145.

234 Arystydes z Aten, Apologia 17,3, w: SCh 470, s. 292; BOK 24, s. 146.

235 Arystydes z Aten, Apologia 1,2, w: SCh 470, s. 256; „Twierdzę wiec, że Bóg to ktoś,

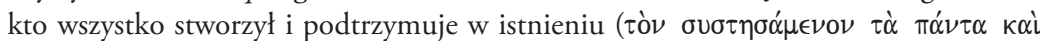

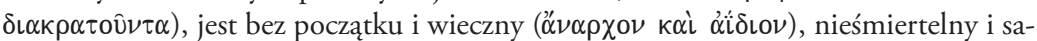

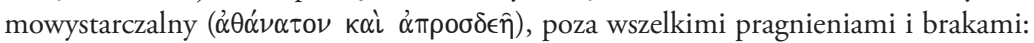
gniewem i zapomnieniem, ignorancją i innymi. Dzięki Niemu istnieją wszystkie rzeczy. Nie potrzebuje On ofiary, libacji ani żadnej z rzeczy widzialnych, ale wszyscy potrzebują Jego", BOK 24, s. 135.

236 Arystydes z Aten, Apologia 3,1, w: SCh 470, s. 258; BOK 24, s. 136; Arystydes z Aten, Apologia 4,2, w: SCh 470, s. 260.262; BOK 24, s. 136-137.
} 
tywnych, zainspirowanych terminologią judaizmu hellenistycznego (Filon z Aleksandrii Quod Deus Sit Immutabilis 55-56), średniego platonizmu oraz gnostycyzmu (Sophia Jesu Christi), w swym przekazie są zgodne z biblijną nauką o Bogu ${ }^{237}$. Arystydes w swych twierdzeniach o niebie jako stworzeniu i dziele Bożym odwoływał się do argumentacji rozumowej: cały kosmos obraca się i porusza według praw natury, składa się z licznych elementów, posiada jakiś początek i cel, gwiazdy przesuwają się w ustalonej kolejności, wykonują swą drogę w określonym czasie. Zarówno cały wszechświat widzialny, jak i jego części składowe posiadają ograniczenia nakazane przez Boga, a regulowane przez niezmienne prawo natury, którego wyznacznikiem jest bycie w harmonii z niebieskim wszechświatem ${ }^{238}$. Także poszczególne elementy składowe kosmosu, jako zniszczalne, zmienne, powstały z niebytu na polecenie prawdziwego Boga niezniszczalnego, niezmiennego i niewidzialnego ${ }^{239}$. Argumentacja Arystydesa o zniszczalności, zmienności i zależności stworzenia od Boga stanowi w apologii stały schemat dowodzenia ${ }^{240}$. Same tezy o niebie są też spójne z biblijną kosmologią nieba, jako wszechświata stworzonego i zależnego w swym istnieniu od Boga.

Od wyjaśnień kosmologicznych i nauki o błędach kultu politeistycznego i żydowskiego Arystydes przechodzi następnie w Apologii 15, 1-17, 3 do wykładu wiary chrześcijańskiej. W najstarszym pozabiblijnym credo chrześcijańskim, które przetrwało do naszych czasów, właśnie w Apologii Arystydesa ${ }^{241}$ znajdujemy też kilka istotnych sformułowań opisujących chrześcijańską wiarę w niebo eschatologiczne:

237 Por. W. C. van Unnik, Die Gotteslehre bei Aristides und in Gnostischen Schriften, „Theologische Zeitschrift“ 17 (1961), s. 166-174; G. Lazzati, Ellenismo e cristianesimo. Il primo capitolo dell'Apologia di Aristide, „Scuola Cattolica“ 66 (1968), s. 35-51.

238 Por. Arystydes z Aten, Apologia 4,2, w: SCh 470, s. 260.262; BOK 24, s. 136-137.

239 Por. Arystydes z Aten, Apologia 4,1, w: SCh 470, s. 260; BOK 24, s. 136.

240 Por. L. Misiarczyk, Arystydes z Aten. Wstęp, w: Pierwsi apologeci greccy..., dz. cyt., BOK 24, s. 147, przypis 8.

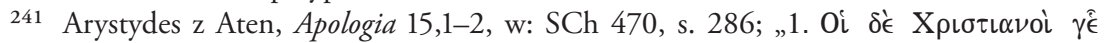

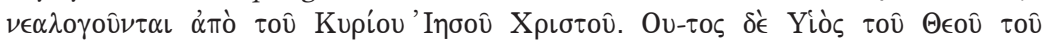

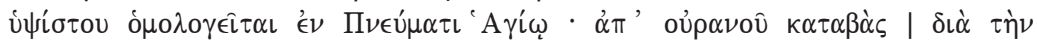

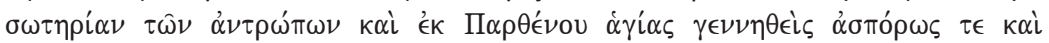

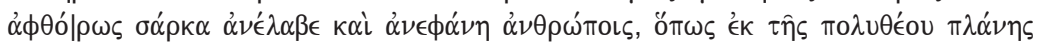

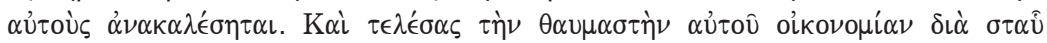

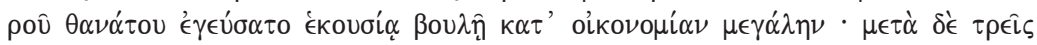


Kształtowanie się nauki o niebie w teologii patrystycznej I-III wieku

(1) Jezus Chrystus, Syn Boga Najwyższego „zstąpił z nieba dla zbawie-

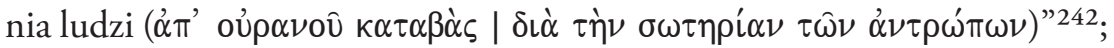

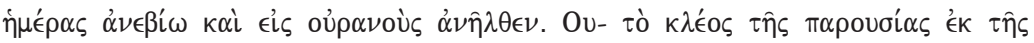

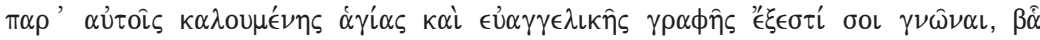

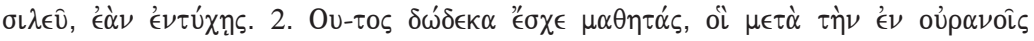

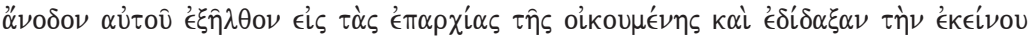
$\mu \in \gamma \alpha \lambda \omega \sigma u ́ \nu \eta \nu ”-~ „ 15,1$. Chrześcijanie natomiast biorą swój początek od Pana Jezusa Chrystusa. Wyznają w Duchu Świętym, że jest On Synem Boga Najwyższego; zstąpił z nieba dla zbawienia ludzi i został zrodzony ze świętej Dziewicy, bez udziału nasienia i nieskażony, przyjął ciało i ukazał się ludziom, aby odstąpili od błędu politeizmu. A po wypełnieniu swego wspaniałego planu zbawienia doświadczył w całej pełni śmierci na krzyżu według największego planu zbawienia; po trzech dniach powrócił do życia i wstąpił do nieba. Chwałę zaś jego przyjścia, o władco, możesz poznać, jeśli będziesz chciał, w tym, które oni nazywają świętym pismem Ewangelii. 15,2. Miał On dwunastu uczniów, którzy po Jego wniebowstąpieniu wyruszyli do wszystkich zakątków świata i głosili Jego majestat", BOK 24, s. 144 (wersja grecka). W credo rekonstruowanym z różnych fragmentów wersji syryjskiej przez J. Rendel Harris, The Apology of Aristides: on Behalf of the Christians, Cambridge 1891, s. 25, napotykamy drobne różnice w sformułowaniach: „(Wierzymy) w jedynego Boga, Wszechmogącego (Najwyższego), Stworzyciela nieba i ziemi (wszystkich rzeczy widzialnych i niewidzialnych); w jego Syna Jezusa Chrystusa, który zstąpił z nieba dla zbawienia ludzi, ukazał się dzięki Duchowi Świętemu, przyjął ciało z dziewicy (Maryi / żydówki / świętej), wybrał sobie dwunastu uczniów, według ekonomii, został ukrzyżowany (przez żydów), umarł, zasnął, zmartwychwstał trzeciego dnia (po trzech dniach), wstąpił do nieba, przyjdzie (sadzić żywych i umarłych)", BOK, 24, s. 127. Jak odnotowuje L. Misiarczyk (Arystydes z Aten. Wstęp, w: Pierwsi apologeci greccy..., dz. cyt., BOK 24, s. 128-129) G. C. O'Ceallaig („Marcianus” Aristides on the Worship of God, „The Harvard Theological Review" 51 (1958), s. 227-254), odrzucał możliwość istnienia w II wieku credo z tak rozbudowanymi elementami chrystologicznymi. Jednak opinia O'Ceallaig jest o tyle błędna, o ile dziwnie nieuwzględniająca faktu, że: (1) analogiczne elementy wyznania wiary spotykamy w już Nowym Testamencie (Rz 1, 3-4; Ef 1, 20; Kol 1, 15-20; Flp 2, 5-11); (2) występujące w credo Arystydesa sformułowania chrystologiczne (np. „zstąpił z nieba”, „przyjął ciało z dziewicy”)” też są już w Nowym Testamencie (J 3, 13; 6, 33. 38. 41; Ef 4, 9-10), napotykamy je również w tekstach Ignacego Antiocheńskiego (List do Smyrneńczyków 1,1; List do Efezjan 7,2); (3) analogiczna wzmianka o Duchu Świętym istnieje u Łk 1, 35, Tradycji Apostolskiej 21 i w Epistula Apostolorum 3; (4) natomiast termin „ekonomia” również występuje wcześniej u Ignacego Antiocheńskiego, List do Efezjan 18,2; 20,1. Więcej na temat chrystologii występującej w credo Arystydesa zob. opracowania: C. Alpigiano, Aristide di Atene, Apologia, Firenze 1988, s. 26-27; L. Misiarczyk, Teologia wcielenia u apologetów greckich II wieku, „Vox Patrum” 20 (2000), t. 38-39, s. 41-70 (odnośnie Arystydesa, L. Misiarczyk, Teologia wcielenia..., dz. cyt., s. 43-53).

242 Arystydes z Aten, Apologia 15,1, w: SCh 470, s. 286; BOK 24, s. 144. 
(2) „po trzech dniach powrócił do życia i wstąpił do nieba $(\mu \in \tau \dot{\alpha}$ ḋ

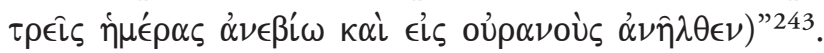

W katechetycznym wyjaśnianiu credo, jakie znajduje się w Apologii Arystydesa 15, 3-16, 1 napotykamy kolejne dwa wątki nauki o przyszłym życiu chrześcijan:

(1) chrześcijanie „oczekują zmartwychwstania umarłych i życia w przy-

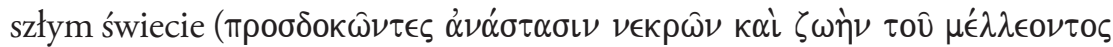

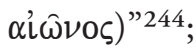

(2) chrześcijanie podążają drogą prawdy „prowadzącą tych, którzy ją wyznaja, do królestwa niebieskiego obwieszczonego przez Chrystusa w ży-

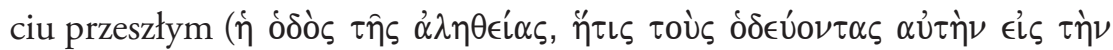

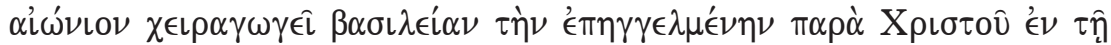
$\mu \in \lambda \lambda$ oúoṇ $\zeta \omega \hat{n}) " 245$.

Schemat teologiczny, w którym Arystydes przytacza w swej Apologii 15, 1 opis chrześcijańskiej wiary w niebo, jest wybitnie soteriologiczny. Chrystus, realizując „wspaniały plan zbawienia” - „zstąpił z nieba”, a po wypełnieniu „największego planu zbawienia” - „powrócił do życia i wstąpił do nieba”246.

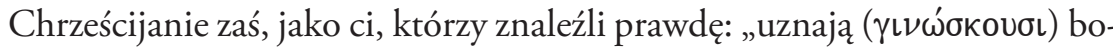
wiem Boga, Twórcę i Stworzyciela wszystkiego przez Syna Jednorodzonego i Ducha Świętego, i prócz Niego nie czczą żadnego innego boga"247, mają

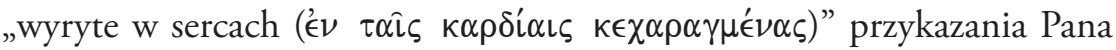
Jezusa Chrystusa i zachowują je „oczekując zmartwychwstania umarłych i życia w przeszłym świecie" 248 .

Chrześcijanie - przez wiarę w Boga objawioną dzięki Jezusowi Chrystusowi i zachowując wierne Jego przykazania ${ }^{249}$, „podazżają drogą prawdy

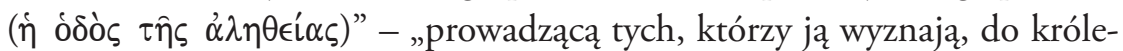
stwa niebieskiego, obwieszczonego przez Chrystusa w życiu przeszłym"250. Wyznawanie wiary w Boga, ogłoszonej przez Jezusa Chrystusa, a w konse-

\footnotetext{
243 Arystydes z Aten, Apologia 15,1, w: SCh 470, s. 286; BOK 24, s. 144.

244 Arystydes z Aten, Apologia 15,3, w: SCh 470, s. 288; BOK 24, s. 144-145.

245 Arystydes z Aten, Apologia 16,1, w: SCh 470, s. 290; BOK 24, s. 145.

246 Arystydes z Aten, Apologia 15,1, w: SCh 470, s. 286; BOK 24, s. 144.

247 Arystydes z Aten, Apologia 15,3, w: SCh 470, s. 288; BOK 24, s. 144.

248 Arystydes z Aten, Apologia 15,3, w: SCh 470, s. 286; BOK 24, s. 144-145.

249 Por. Arystydes z Aten, Apologia 15,4-6, w: SCh 470, s. 288; BOK 24, s. 144-145.

250 Arystydes z Aten, Apologia 16,1, w: SCh 470, s. 290; BOK 24, s. 145.
} 
Kształtowanie się nauki o niebie w teologii patrystycznej I-III wieku

kwencji zachowywanie Chrystusowych wskazań moralnych, ma doprowadzić chrześcijan do zapowiedzianego przez Chrystusa królestwa niebieskiego i życia wiecznego. Przyjęcie wiary, życie moralne i nadzieja wieczności opierają się na uznaniu słów Chrystusa za wiarygodne, gdyż są to „sło-

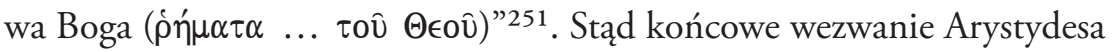
zarówno do cesarza, jak i do innych niechrześcijan stanowi zachętę do przyjęcia wiary chrześcijańskiej jako pożytecznej, gdyż usprawiedliwiającej wierzących przed sądem Bożym („ratując się od sądu i kar”) i określającej chrześcijan dziedzicami życia wiecznego (dosłownie: „niezniszczalnego”) ${ }^{252}$.

Arystydes nie mówił zatem wiele o cechach samego eschatologicznego królestwa niebieskiego, które jako takie nie stanowi części postrzegalnego kosmosu, ale znajduje się prawdopodobnie we „wszechświecie niebiańskim" (Apologia 4, 2). Autor analizowanej apologii nie komentował też specjalnie eschatycznych cech zbawionych, ale posługując się językiem katechetycznym, w kluczu soteriologicznym nauczał, że chrześcijanie w duchu zawierzenia słowom Chrystusa oczekują życia wiecznego w królestwie niebieskim.

251 Arystydes z Aten, Apologia 16,4-5, w: SCh 470, s. 290; „16.4. I abyś wiedział, o władco, iż nie mówię tych rzeczy tylko od siebie, pochyl się nad pismami chrześcijan i sam odkryjesz, że nie mówią oni nic oprócz prawdy. 16.5. [Dobrze to zrozumiał Twój syn i słusznie nauczył się czcić Boga żywego i zapewnić sobie zbawienie w życiu przeszłym (zdanie w nawiasie kwadratowym jest wyránym wtrąceniem w tekst Apologii z Opowieści Barlaama - uwaga L. Misiarczyka)]. Wielkie i godne podziwu są bowiem rzeczy nauczane i praktykowane przez chrześcijan: nie wypowiadają oni bowiem słów

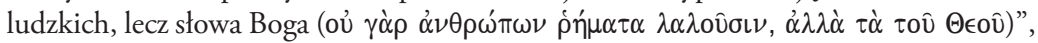
BOK 24, s. 145.

252 Arystydes z Aten, Apologia 17,3, w: SCh 470, s. 292; „Jest rzeczą pożyteczną również dla was czcić Boga Stworzyciela i nastawić ucha do Jego nieśmiertelnych słów

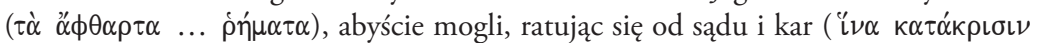

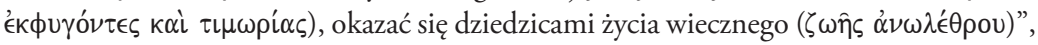
BOK 24, s. 145-146. 
2. Kształtowanie się nauki o niebie w teologii patrystycznej - wiek I-II

\subsubsection{Justyn Męczennik - nauka o niebie jako kontynuacja kerygmatu i próba syntezy Biblii, nauk rabinackich i filozofii antycznej (moralizm eschatologiczny)}

Justyn urodził się około 100 roku we Flavia Neapolis (biblijne Sychem, dziś Nablus), przeszedł na chrześcijaństwo prawdopodobnie w latach 20. II wieku. Przebywał w Efezie i dwukrotnie w Rzymie. W stolicy cesarstwa rzymskiego zorganizował jedną z pierwszych szkół chrześcijańskich, otwartą na wszystkich słuchaczy. Prowadzono w niej dysputy filozoficzne, wykorzystywane przez założyciela do głoszenia Ewangelii. Na podstawie donosu filozofa cynickiego Krescensa został oskarżony o wyznawanie chrześcijaństwa, a po procesie, jako obywatel rzymski, został ścięty mieczem w Rzymie, prawdopodobnie w 165 roku $^{253}$. Z kilkudziesięciu jego pism do naszych czasów zachowały się jedynie dwie apologie i jeden dialog. 1 Apologia, zaadresowana do rzymskich cesarzy Antonina Piusa oraz jego dwóch synów, Marka Aureliusza i Lucjusza Werrusa powstała w Rzymie latach 150-154, natomiast 2 Apologia ${ }^{254}$, skierowana także do Antonina Piusa i Marka Aureliusza, była napisana została również w Rzymie, około 153 roku $^{255}$. Dialog z Żydem Tryfonem ${ }^{256}$ powstał najprawdopodobniej około 160 roku $^{257}$.

\section{Kontekst teologiczny nauczania o niebie w pismach Justyna}

Celem Justynowych apologii były apele do cesarzy o zaprzestanie prześladowań antychrześcijańskich, zmianę polityki cesarstwa wobec chrześcijan

253 Por. L. Misiarczyk, Wstęp. 1 i 2 Apologia, w: Justyn Męczennik, 1 i 2 Apologia. Dialog z Żydem Tryfonem, tłum. i oprac. L. Misiarczyk, Warszawa 2012, s. 7-9 (BOK 24).

254 Iustinus martyr, Apologia, w: SCh 507. Justin, Apologie pour les chrétiens. Introduction, texte critique, traduction et notes par Ch. Munier, Paris 2006; przekład polski Justyn Męczennik, 1 i 2 Apologia. Dialog..., dz. cyt., s. 7-114.

255 Por. L. Misiarczyk, Wstęp. Justyn Męczennik, 1 i 2 Apologia, w: Justyn Męczennik, 1 i 2 Apologia. Dialog..., dz. cyt. s. 169-174.

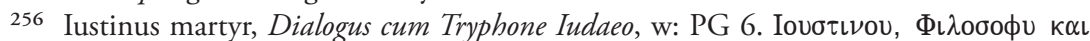

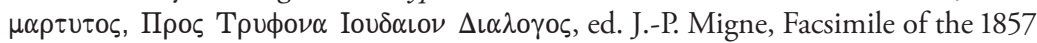
Paris Edition, Athens 2001, k. 471-800; przekład polski Justyn Męczennik, Dialog z Żydem Tryfonem, w: Justyn Męczennik, 1 i 2 Apologia. Dialog..., dz. cyt., s. 119-318.

257 Por. L. Misiarczyk, Wstęp. Dialog z Żydem Tryfonem, w: Justyn Męczennik, 1 i 2 Apologia. Dialog..., dz. cyt., s. 122. 
Kształtowanie się nauki o niebie w teologii patrystycznej I-III wieku

oraz odparcie zarzutów o ateizm. Kwestionując sensowność politeizmu, dowodził, iż to właśnie chrześcijanie czczą jedynego i prawdziwego Boga, Ojca i Stwórcę wszechrzeczy, Jego Syna Jezusa Chrystusa oraz Ducha prorockiego. Prezentując objawione nauczanie o Bogu, analizowany apologeta opisywał jedynie działania ad extra poszczególnych osób Bożych. Starał się również wskazywać na wspólne elementy chrześcijaństwa i filozofii antycznej oraz dowodzić wyższości nauki chrześcijańskiej nad filozofią grecką. Natomiast w Dialogu wykazywał, przy zastosowaniu typologii chrystologicznych, iż kluczową zasadą w rozumieniu Starego Testamentu nie jest tekst biblijny, ale osoba Jezusa Chrystusa. ST był cytowany przez Justyna na podstawie wersji LXX oraz tzw. Testimonia (judaistycznego zbioru mesjanistycznych proroctw ST, będących dla chrześcijan swoistym dicta probantia za mesjańskością i bóstwem Jezusa). NT był przywoływany przez apologetę najprawdopodobniej według systematycznej harmonizacji Ewangelii Mateusza i Łukasza oraz okazyjnie jako cytaty z tekstów liturgicznych i podręczników chrześcijańskich misjonarzy epoki (jest to hipoteza Helmuta Köstera i Arthura J. Bellinzoniego ${ }^{258}$. Justyn jest określany w patrologii jako pierwszy teolog chrześcijański, gdyż dał podwaliny pod teologię pojmowaną jako rozumowa refleksja nad objawieniem i zastosował metodę teologiczną polegającą na przyjęciu wiarą objawionej prawdy oraz na próbie rozumowego zgłębienia treści objawienia ${ }^{259}$.

\section{Nauczanie o niebie - wstęp}

W dyskusji patrologów wokół eschatologii Justyna spotykamy dwie linie interpretacyjne. Erwin Ramsdell Goodenought stwierdzał, że eschatologia Justyna byłaby zależna przede wszystkim od ówczesnego kontekstu historyczno-eklezjalnego: oczekiwania chrześcijan na rychłą drugą paruzję oraz od klimatu antychrześcijańskich prześladowań ze strony państwa.

258 Por. H. Köster, Septuaginta und Synoptischer Erzählungsstoff im Schriftbeweis Justins des Märtyrers, Heidelberg 1956; A. Bellinzoni, The Sayings of Jesus in the Writings of Justin Martyr, Leiden 1967; L. Misiarczyk, Wstęp. Dialog z Żydem Tryfonem, w: Justyn Męczennik, 1 i 2 Apologia. Dialog..., dz. cyt., s. 150-157.

259 Por. Ch. Munier, La méthode apologéthique de Justin le Martyr, „Revue des Sciences Religieuses” 62 (1988), s. 90-100; s. 227-239; L. Misiarczyk, Wstęp. 1 i 2 Apologia, w: Justyn Męczennik, 1 i 2 Apologia. Dialog..., dz. cyt., s. 20-30. 
Obserwując również apostazje od wiary, Justyn wyczekiwał zarówno upadku wrogiej chrześcijanom władzy, jak i końca doczesnego świata. Dominują w jego przesłaniu moralnym byłaby zatem nauka o konieczności życia pobożnego i świętego, jako swoistym przygotowaniu do odebrania oczekiwanej nagrody nieba, gdyż czas tego świata właśnie się dopełniał ${ }^{260}$. Leslie William Barnard zasugerował, że idee Justyna zmieniały się w związku z prowadzoną przez niego narracją apologetyczną. W związku z tym również eschatologiczne treści apologii skierowane do niechrześcijańskiego świata (pogańskiego bądź żydowskiego) podlegały również swoistej zależności od rodzaju literackiego apologii. Mówiąc o eschatologii, Justyn być może właśnie dlatego kładł większy nacisk na elementy racjonalne chrześcijańskiego przesłania niż na poprawność doktrynalną ${ }^{261}$. Wydaje się, że interpretacja Barnarda jest bardziej uzasadniona tekstualnie. W pismach Justyna teologia nieba była najczęściej wzmiankowana, przy okazji wyjaśniania chrześcijańskiego credo. Nie był to całościowy wykład wyznania, który systematycznie tłumaczyłby chrześcijańską eschatologię końcową. W kontekście apologetycznym i polemicznym, przy zastosowaniu metody apologetycznej ${ }^{262}$, Justyn, konfrontując przesłanie chrześcijańskie z kulturą grecko-rzymską, podawał fragmentaryczny wykład nauki o niebie eschatologicznym.

Poniżej postaram się wskazać zatem, jak w zgodności z przekazem biblijnym Justyn nauczał o niebie jako miejscu Boga, Jezusie zstępującym i wstępującym do nieba, o piekle jako miejscu potępionych, a niebie jako miejscu zbawionych. Efektem połączenia wątków biblijnych z nauczaniem rabinackim I-II wieku byłoby mówienie o drugim millenaryzmie. Łączenie wątków biblijnych z filozofią grecką zaowocowało w eschatologii Justyna tezami o zachowaniu świadomości w zaświatach przed sądem ostatecznym, eschatologicznym zognieniu doczesnego świata oraz o moralizmie eschatologicznym.

260 Por. E. R. Goodenought, Theology of Justin Martyr, Jena 1923, s. 279-291.

261 Por. L. W. Barnard, Justin Martyr: His Life and Thought, Cambridge 1967, s. 167.

$262 \mathrm{Tj}$. po domaganiu się traktowania chrześcijaństwa na równi z innymi wierzeniami, krytykuje on następnie inne postawy oraz prezentuje naukę chrześcijańską (por. Justyn Męczennik, 1 Apologia 6,2, w: Justyn Męczennik, 1 i 2 Apologia. Dialog..., dz. cyt., s. 46, przypis 7). 
Kształtowanie się nauki o niebie w teologii patrystycznej I-III wieku

\section{Niebo jako miejsce Boga}

Justyn objaśniał, że chrześcijanie wierzą tylko w objawionego Boga, Ojca sprawiedliwego, Jego Syna, który od Ojca przyszedł i wszystkiego nauczył chrześcijan oraz Ducha proroczego. Bóg Ojciec, Syn i Duch, przebywa w otoczeniu dobrych aniołów ${ }^{263}$. Bóg jest stwórcą niebios ${ }^{264}$. Eschatologiczne niebo jest miejscem, gdzie jest dobrze i gdzie przebywa Pan Bóg ${ }^{265}$, niewidzialny przez ludzi Ojciec i niewysłowiony $\operatorname{Pan}^{266}$, miejscem skąd zstąpił Syn Boży, aby zbawić ludzi ${ }^{267}$. Zgodnie z teologią biblijną (Iz 65, 17;

263 Por. Justyn Męczennik, 1 Apologia 6,1-2, w: SCh 507, s. 140.142; „6.1. Z tego właśnie powodu jesteśmy nazwani bezbożnikami. I przyznaję, że jesteśmy niewierzącymi, jeśli chodzi o tych tak zwanych bogów, ale nigdy w przypadku najprawdziwszego Boga, ojca sprawiedliwości, mądrości i wszystkich innych cnót, wolnego od wszelkiego zła. 6.2. Jego to właśnie i Syna, który od Niego przyszedł i tego wszystkiego nas nauczył, a także zastępy innych, dobrych aniołów, które Go otaczają i są na Jego obraz oraz Ducha proroczego czcimy i uwielbiamy, składając cześć zgodnie z rozumem i prawdą. I jak sami zostaliśmy pouczeni, tak również bez zazdrości przekazujemy tę naukę każdemu, kto pragnie ją poznać", w: Justyn Męczennik, 1 i 2 Apologia. Dialog..., dz. cyt., s. 46.

264 Justyn, nauczając, że Jezus nie był magiem, ale w jego życiu wypełniły się proroctwa żydowskie (por. 1 Apologia 30-53), wskazywał na Boga jako na stwórcę niebios. Apologeta z Flavia Neapolis powoływał się tutaj na Ps 96(95), 5 [„Bo wszyscy bogowie pogan to ułuda, a Pan uczynił niebiosa”] we własnej interpolacji: „Gdyż bogo-

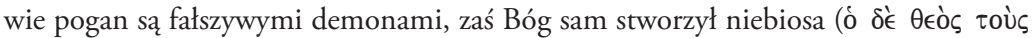

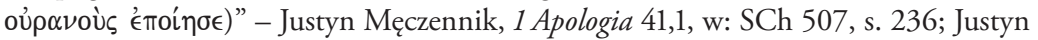
Męczennik, 1 i 2 Apologia. Dialog..., dz. cyt., s. 70.

265 Por. Justyn Męczennik, Dialog z Żydem Tryfonem 127,1, w: PG 6, k. 772B; „Niewysłowiony bowiem Ojciec i Pan wszechrzeczy nigdzie nie przychodzi, nie przechadza się, nie sypia ani nie budzi się, ale pozostaje zawsze w swoim miejscu, gdziekol-

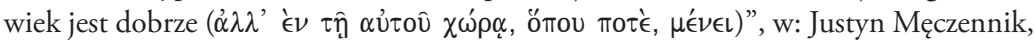
1 i 2 Apologia. Dialog..., dz. cyt., s. 303.

266 Por. Justyn Męczennik, Dialog z Żydem Tryfonem 127,4, w: PG 6, k. 773A; „A zatem ani Abraham, ani Izaak, ani Jakub, ani żaden inny człowiek nie widział ojca i niewysłowionego Pana wszystkiego i samego Chrystusa”, w: Justyn Męczennik, 1 i 2 Apologia. Dialog..., dz. cyt., s. 304 (por. Wj 19, 21; 1 Tm 1, 17).

267 Por. Justyn Męczennik, Dialog z Żydem Tryfonem 64,7, w: PG 6, k. 625A; „Z innych słów Dawida, które również już wcześniej cytowałem, przypomnijcie sobie, że On

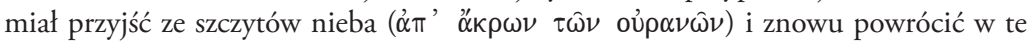

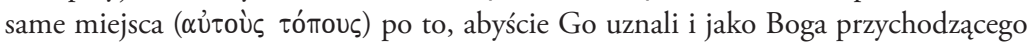
z wysokości i jako człowieka narodzonego z ludzi oraz że powróci ponownie jako Ten, którego zobaczą i będą bić się w piersi ci, którzy Go przebili”, w: Justyn Męczennik, 1 i 2 Apologia. Dialog..., dz. cyt., s. 232 (por. Za 12, 10; J 19, 37; Ap 1, 7). 
2. Kształtowanie się nauki o niebie w teologii patrystycznej - wiek I-II

66, 22; Ap 21, 1) Justyn nauczał, iż obecne niebo jest „zapowiedzią innego, nowego nieba"268.

\section{Jezus „zstąpił z nieba”}

Pośrednio prawda ta została wyrażona przy omawianiu proroctwa z Ps 23, 7-8 o wstąpieniu Jezusa do nieba ${ }^{269}$ razem z tzw. „proroctwa Jeremiasza” (w rzeczywistości jest to tekst z Daniela) ${ }^{270}$. Pełniejsze zastosowanie biblijnej formuły „zstępować/wstępować” napotykamy u Justyna, kiedy, odwołując się do zestawu cytatów z Ez 37, 7-8; Iz 45, 23; Za 12, 10 12; Jl 2, 13 i J 19, 37271, mówi o dwóch paruzjach Chrystusa: pierwszej w uniżeniu, a drugiej w chwale ${ }^{272}$. Druga paruzja opóźnia się ze względu

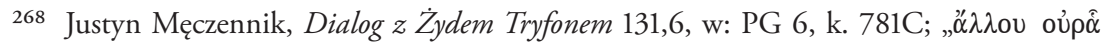

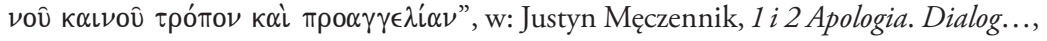
dz. cyt., s. 308.

269 Por. Justyn Męczennik, 1 Apologia 51,6-7, w: SCh 507, s. 262; „51.6. Posłuchajcie tak-

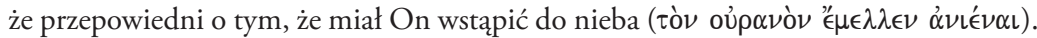
51.7. Oto te słowa: «Podnieście się bramy niebios, niech zostaną otworzone, aby wszedł król chwały. Któż jest tym królem chwały? Pan dzielny i potężny»”, w: Justyn Męczennik, 1 i 2 Apologia. Dialog..., dz. cyt., s. 76.

270 Por. Justyn Męczennik, 1 Apologia 51,8, w: SCh 507, s. 262; „Posłuchajcie wreszcie, jak zostało przepowiedziane przez proroka Jeremiasza o jego przyjściu z niebios w chwale

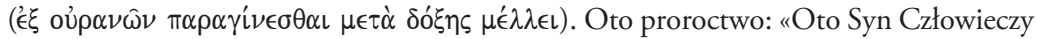
nadchodzi z nieba na obłokach i aniołowie razem z Nim»”, w: Justyn Męczennik, 1 i 2 Apologia. Dialog..., dz. cyt., s. 76. Justyn pomylił tutaj proroka. Jak odnotowuje Charles Munier, SCh 507, s. 263, przypis 3, chodzi tutaj oczywiście o proroctwo Dn 7, 13-14, które Justyn połączył z Za 14, 5.

271 Por. Justyn Męczennik, 1 Apologia 52,3-12, w: SCh 507, s. 262-266; Justyn Męczennik, 1 i 2 Apologia. Dialog..., dz. cyt., s. 76-77.

272 Por. Justyn Męczennik, 1 Apologia 52,3, w: SCh 507, s. 264; „Otóż prorocy zapowiedzieli dwie paruzje Chrystusa: jedna już nastąpiła jako człowieka pogardzanego i cierpiącego, druga natomiast, jak zapowiedziano, nastąpi, gdy zstąpi On z nieba w chwa-

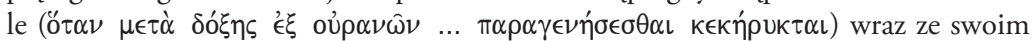
wojskiem anielskim >jak< zapowiedziano, gdy wskrzesi ciała wszystkich ludzi, którzy kiedykolwiek istnieli i godnych przyodzieje nieśmiertelnością, niesprawiedliwych zaś ześle na wieczne cierpienie wraz ze złymi demonami w ogień wieczny", w: Justyn Męczennik, 1 i 2 Apologia. Dialog..., dz. cyt., s. 76. Justyn Męczennik, Dialog z Żydem Tryfonem 14,7, w: PG 6, k. 505D; „Z tych słów wypowiedzianych przez proroków, o Tryfonie, powiedziałem, niektóre odnoszą się do pierwszego przyjścia Chrystusa, kiedy to według zapowiedzi przyjdzie wzgardzony, niepozorny i śmiertelny, inne natomiast dotyczą jego drugiego przyjścia, kiedy przyjdzie w chwale i «na obłokach niebieskich» a wasz naród «ujrzy go» i uzna «tego», którego przebodli, jak zapowiedział 
Kształtowanie się nauki o niebie w teologii patrystycznej I-III wieku

na Bożą cierpliwość do ludzi, w której daje On czas na przyjęcie pouczenia w imię Chrystusa i na nawrócenie ${ }^{273}$.

\section{Jezus ,wstąpił do nieba”}

Ten motyw nowotestamentalny u Justyna, oprócz ewidentnego znaczenia chrystologicznego ${ }^{274}$ i kerygmatycznego ${ }^{275}$, jest także przywoływany w celu antydemonicznym: co prawda po wstąpieniu Jezusa do nieba demony skłoniły niektórych ludzi do aktów ogłoszenia się bóstwami ${ }^{276}$, jednak Bóg powstrzymuje drugą paruzję i spalenie świata zarówno ze względu na pokonanie demonów, jak i na dopełnienie liczby dobrych i świętych ${ }^{277}$.

Ozeasz, jeden z dwunastu proroków i Daniel”, w: Justyn Męczennik, 1 i 2 Apologia. Dialog..., dz. cyt., s. 176 (por. Iz 55, 2-13; Dn 7, 13; Mt 24, 30; Za 12, 10; J 19, 37; por. też Justyn Męczennik, Dialog z Żydem Tryfonem 64,7).

273 Por. Justyn Męczennik, Dialog z Żydem Tryfonem 39,2, w: PG 6, k. 559C; „Jak więc ze względu na owe siedem tysięcy Bóg nie wywarł swojego gniewu, tak również i teraz nie rzucił i nie rzuca wyroku potępienia, gdyż wie, że każdego dnia znajdują się jeszcze tacy, którzy są pouczani w imię Chrystusa i porzucają drogę błędu. Ci właśnie ochrzczeni w imię tegoż Chrystusa otrzymują dary zgodnie z tym, jak na to zasługują", w: Justyn Męczennik, 1 i 2 Apologia. Dialog..., dz. cyt., s. 201 (por. 1 Krl 19, 18).

274 Por. Justyn Męczennik, 1 Apologia 42,4, w: SCh 507, s. 238; „Nasz zaś Jezus Chrystus został ukrzyżowany, umarł i zmartwychwstał, objął królowanie i wstąpił do nieba

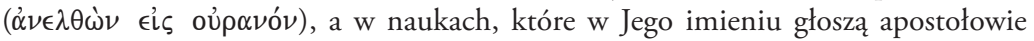
wszystkim narodom jest szczęście dla oczekujących zapowiedzianej przez Niego nie-

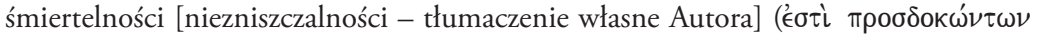

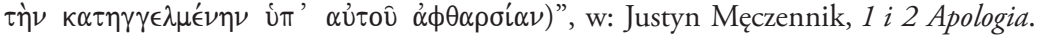
Dialog..., dz. cyt., s. 70. Justyn Męczennik, Dialog z Żydem Tryfonem 132,1, w: PG 6, k. 781D-783A; „Ten Jezus, którego my uznajemy za Chrystusa, Syna Bożego, któ-

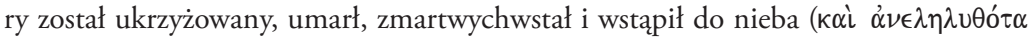

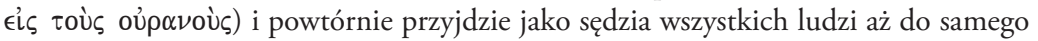
Adama”, w: Justyn Męczennik, 1 i 2 Apologia. Dialog..., dz. cyt., s. 309.

275 Por. Justyn Męczennik, 1 Apologia 50,12, w: SCh 507, s. 260; „(...) I gdy ujrzeli Go

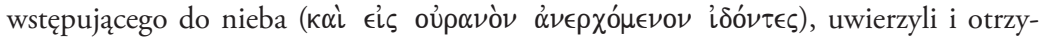

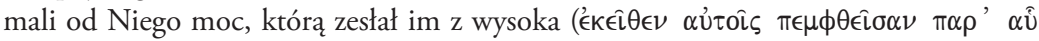

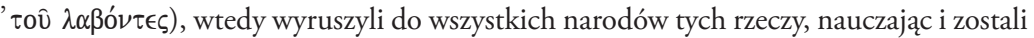
nazwani apostołami”, w: Justyn Męczennik, 1 i 2 Apologia. Dialog..., dz. cyt., s. 75 (por. Dz 1, 9).

276 Por. Justyn Męczennik, 1 Apologia 26,1, w: SCh 507, s. 198; „Gdy po wstąpieniu

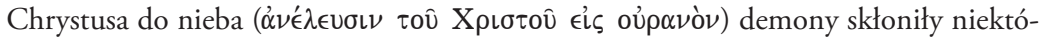
rych ludzi do tego, by sami nazwali się bogami”, w: Justyn Męczennik, 1 i 2 Apologia. Dialog..., dz. cyt., s. 59.

277 Por. Justyn Męczennik, 1 Apologia 45,1, w: SCh 507, s. 246; „A że Bóg, Ojciec wszech-

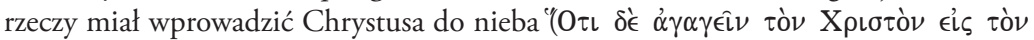


2. Kształtowanie się nauki o niebie w teologii patrystycznej - wiek I-II

Do czasu powtórnego przyjścia Chrystusa chrześcijanie otrzymują z nieba duchowe umocnienie ${ }^{278}$.

\section{Niebo jako miejsce zbawionych (terminologia i teologia)}

Chrześcijanie rozumnie wybierający wolę Bożą ${ }^{279}$ wierzą, że Bóg ich wskrzesi

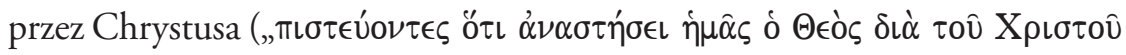

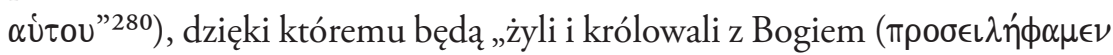

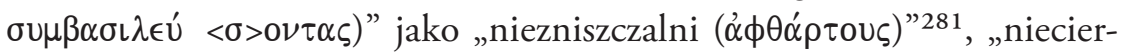

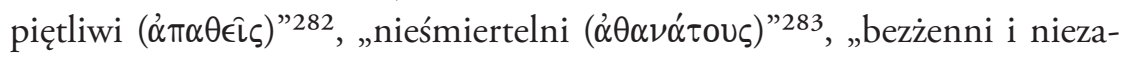

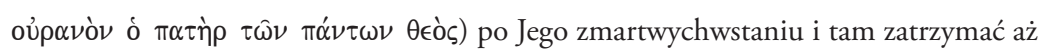
do pokonania wrogich $\mathrm{Mu}$ demonów i dopełnienia liczby dobrych i świętych, których przewidział i ze względu właśnie na nich nie wydał jeszcze świata na spalenie, posłuchajcie co na ten temat przepowiedział prorok Dawid (Ps 110, 13)", w: Justyn Męczennik, 1 i 2 Apologia. Dialog..., dz. cyt., s. 72.

278 Por. Justyn Męczennik, Dialog z Żydem Tryfonem 39,5, w: PG 6, k. 560C; „My

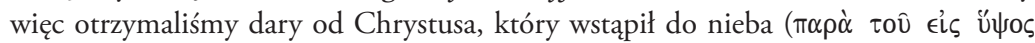

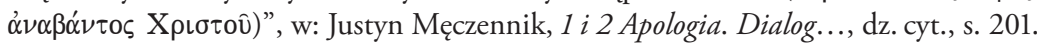

279 Por. Justyn Męczennik, 1 Apologia 10,4, w: SCh 507, s. 152; „Bóg nas nakłania i zachęca do wiary, byśmy szli za tym, co jest Mu miłe i wybierali to przy pomocy władz rozumu, którym nas obdarzyl”, w: Justyn Męczennik, 1 i 2 Apologia. Dialog..., dz. cyt., s. 48.

280 Justyn Męczennik, Dialog z Żydem Tryfonem 46,7, w: PG 6, k. 576C; Justyn Męczennik, 1 i 2 Apologia. Dialog..., dz. cyt.

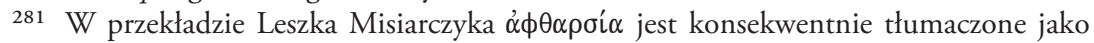
„nieśmiertelność”. Rozumiem zabieg interpretacyjny tłumacza, który chce dostosować i przybliżyć tekst grecki z II wieku dzisiejszemu czytelnikowi. Uznając całość tłumaczenia, z którego z korzyścią korzystam w niniejszej pracy, zaznaczam jednak, że Justyn, stosując ten termin, miał na myśli „niezniszczalność”.

282 Justyn Męczennik, 1 Apologia 10,2, w: SCh 507, s. 150; „Otrzymaliśmy również naukę, że jeśli ludzie dzięki swoim czynom staną się sami godni Jego zamysłu, wtedy dostąpią z Nim życia i królowania oraz staną się nieśmiertelni i nie poddani cierpieniom”, w: Justyn Męczennik, 1 i 2 Apologia. Dialog..., dz. cyt., s. 48 (por. 2 Tm 2, 12; 1 Kor 15, 52). Justyn Męczennik, 1 Apologia 10,3, w: SCh 507, s. 152; „Tak również On sam, jesteśmy przekonani, obdarzy nieśmiertelnością [„niezniszczalnością” -

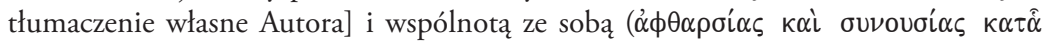
$\xi\llcorner\omega \theta \eta \hat{\nu} \alpha \iota)$ tych, którzy zbliżają się do Niego i czynią to, co jest Mu miłe", w: Justyn Męczennik, 1 i 2 Apologia. Dialog..., dz. cyt., s. 48. Justyn Męczennik, 1 Apologia 42,4, w: SCh 507, s. 238; „Nasz zaś Jezus Chrystus został ukrzyżowany, umarł i zmartwychwstał, objął królowanie i wstąpił do nieba, a w naukach, które w Jego imieniu głoszą apostołowie wszystkim narodom, jest szczęście dla oczekujących zapowiedzianej przez Niego nieśmiertelności [ả $\phi \theta \alpha \rho \sigma i \alpha \nu$; „niezniszczalności” - tłumaczenie własne Autora]”, w: Justyn Męczennik, 1 i 2 Apologia. Dialog..., dz. cyt., s. 70.

283 Justyn Męczennik, Dialog z Żydem Tryfonem 46,7, w: PG 6, k. 576C; „My natomiast, by nie składać ofiar tym, którym niegdyś je składaliśmy, znosimy największe cierpienia 
Kształtowanie się nauki o niebie w teologii patrystycznej I-III wieku

mężne, równi aniołom, będąc dziećmi Boga zmartwychwstania ("O $\tau \iota$ oü $\tau \epsilon$

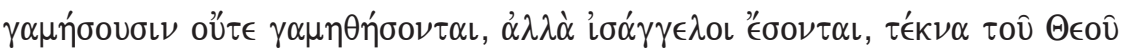
$\tau \eta\rceil \varsigma \alpha \nu \alpha \sigma \tau \alpha \dot{\alpha} \sigma \epsilon \omega \varsigma$ o’ $\nu \tau \epsilon \varsigma) " 284$. Chrześcijanie oczekują pełni zbawienia, które dokona się w eschatologicznym „Królestwie Bożym ( $\beta \alpha \sigma \iota \lambda \epsilon i \alpha \nu$... $\dot{\eta} \mu \hat{\omega} \nu$

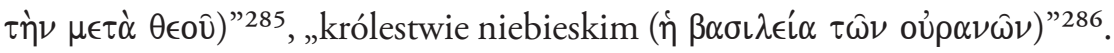
Eschatologiczne Królestwo Jezusa, w myśl proroctwa Dn 7, 9-28, będzie

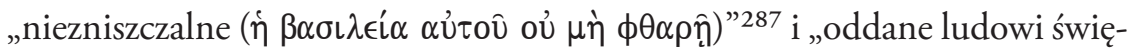

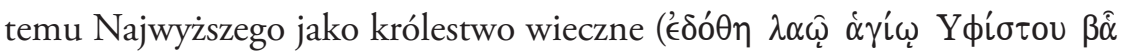

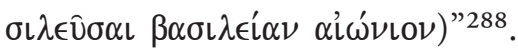

a będąc wydawani na śmierć, cieszymy się, wierząc, że Bóg nas wskrzesi przez swojego Chrystusa i obdarzy nieskazitelnością [„niezniszczalnością” - tłumaczenie własne

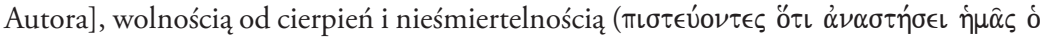

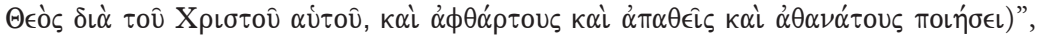
w: Justyn Męczennik, 1 i 2 Apologia. Dialog..., dz. cyt., s. 208-209.

284 Justyn Męczennik, Dialog z Żydem Tryfonem 81,4, w: PG 6, k. 669A; „Powiedział także o tym nasz Pan: "Nie będą się żenić ani za mąż wychodzić, ale będą równi aniołom będąc dziećmi Boga zmartwychwstania»", w: Justyn Męczennik, 1 i 2 Apologia. Dialog..., dz. cyt., s. 253 (por. Łk 20, 35-36).

285 Justyn Męczennik, 1 Apologia 11,1, w: SCh 507, s. 152; „Wy natomiast, gdy słyszycie, że oczekujemy jakiegoś królestwa, sądzicie, bez dokładnego zbadania, że chodzi nam o królestwo ludzkie, podczas gdy my mówimy o Królestwie Bożym, jak to zresztą widać wyraźnie podczas przesłuchań. Wyznajemy wtedy, że jesteśmy chrześcijanami, wiedząc przecież doskonale, iż wyznającemu grozi kara śmierci”, w: Justyn Męczennik, 1 i 2 Apologia. Dialog..., dz. cyt., s. 48.

286 Justyn Męczennik, Dialog z Żydem Tryfonem 51,2, w: PG 6, k. 589A; „ (...) Odtąd królestwo niebieskie cierpi gwałt i gwałtownicy je zdobywają. A jeśli chcecie uznać, on jest Eliaszem, który miał przyjść. Kto ma uszy do słuchania, niech słucha", w: Justyn Męczennik, 1 i 2 Apologia. Dialog..., dz. cyt., s. 214 (harmonizacja Łk 16, 16 i Mt 11, 12-15). Justyn Męczennik, Dialog z Żydem Tryfonem 140,4, w: PG 6, k. 797B; „Przyjdą z zachodu i ze wschodu i zasiądą przy stole z Abrahamem, Izaakiem i Jakubem w królestwie niebieskim ( $\epsilon \nu$ ๆ

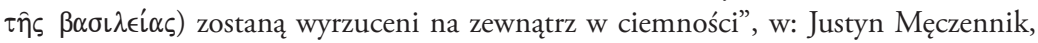
1 i 2 Apologia. Dialog..., dz. cyt., s. 316 (por. Mt 8, 11-12).

287 Justyn Męczennik, Dialog z Żydem Tryfonem 31,4, w: PG 6, k. 541A; Justyn Męczennik, 1 i 2 Apologia. Dialog..., dz. cyt. (por. Dn 7, 9-28).

288 Por. Justyn Męczennik, Dialog z Żydem Tryfonem 31,1-7, w: Justyn Męczennik, 1 i 2 Apologia. Dialog..., dz. cyt., s. 192-193; E. dal Covolo, "Regno di Dio» nel Dialogo di Giustino con Trifone Giudeo, „Augustinianum” 28 (1988), s. 111-123, odnotowuje, iż wzmianki Justyna o „Królestwie Bożym” są bardziej zgodne z tradycją synoptyczną niż judeochrześcijańskimi testimonia. Podstawową optyką teologiczną Justyna pozostaje nowotestamentalna soteriologia, choć zauważa się wyakcentowaną funkcję cnót. 
2. Kształtowanie się nauki o niebie w teologii patrystycznej - wiek I-II

Wiara w eschatologiczne królestwo niebieskie i życie wieczne zbawionych zasadzały się w teologicznej argumentacji Justyna przede wszystkim na zaufaniu Bogu, który jest wierny swoim obietnicom. Dowodząc, iż Chrystus jest prawdziwym Synem Bożym, apologeta z Flavia Neapolis przytoczył fragment, ze znanego mu być może z Efezu albo z Rzymu, a używanego na początku II wieku, wyznania wiary ${ }^{289}$. W wersecie poprzedzającym formułę owego credo Justyn, uzasadniając powody oddawania czci Bogu (za stworzenie ludzi, za opatrzność, za różnorodność dzieł stwórczych i zmiany pór roku), wskazywał, iż chrześcijanie, ufając Bogu, zawierzają $\mathrm{Mu}$ swą eschatologiczną przyszłość, dlatego ich powinnością jest też: „wznosić

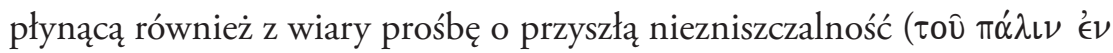

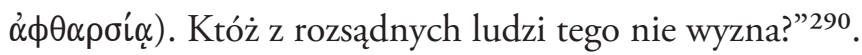

Powołując się natomiast na argumentację filozofów antycznych (Empedokles, Pitagoras, Platon, Sokrates), na praktyki kultyczne greckich wyroczni (Amfilochosa, Dodony, Pytii) i przekazy mitologii o studni Homera i Odyseusza, w 1 Apologii 18-21 Justyn dowodził nieśmiertelności duszy ludzkiej, przy czym argumentację filozoficzną wzmocnił teologicznie w Dialogu 5, 3-4 dowodzeniem z wszechmocy i woli Bożej ${ }^{291}$, a tezę o komplementarności człowieka (jako złożenia ciała i duszy) - wyznaniem wiary w zmartwychwstanie ciał (argumentacja również z wszechmocy Bożej) ${ }^{292}$.

289 Por. Justyn Męczennik, 1 Apologia 13, 3, w: SCh 507, s. 160; „Wykażemy Wam także, że słusznie czcimy Nauczyciela, który nas o tym pouczył i po to się narodził, Jezusa Chrystusa, ukrzyżowanego pod Poncjuszem Piłatem, prokuratorem Judei w czasach cezara Tyberiusza, jak również uznajemy Go za Syna Boga prawdziwego i na drugim miejscu umieszczamy, na trzecim zaś Ducha proroczego", w: Justyn Męczennik, 1 i 2 Apologia. Dialog..., dz. cyt., s. 50.

290 Justyn Męczennik, 1 Apologia 13,2, w: SCh 507, s. 160; Justyn Męczennik, 1 i 2 Apologia. Dialog..., dz. cyt., s. 50.

291 Por. Justyn Męczennik, 1 Apologia 18-21, w: SCh 507, s. 178-190; Justyn Męczennik, 1 i 2 Apologia. Dialog..., dz. cyt., s. 54-57; Justyn Męczennik, Dialog z Żydem Tryfonem 5,3-4, w: PG 6, k. 487B; Justyn Męczennik, 1 i 2 Apologia. Dialog..., dz. cyt., s. $166-167$.

292 Por. Justyn Męczennik, 1 Apologia 18,6, w: SCh 507, s. 180; „Przyjmijcie więc i nasze argumenty na równi z tamtymi, (gdyż my wcale nie mniej, a nawet silniej w Boga wierzymy i oczekujemy), że te same ciała umarłe i do ziemi złożone znowu otrzymamy, ponieważ twierdzimy, iż dla Boga nie ma nic niemożliwego", w: Justyn Męczennik, 1 i 2 Apologia. Dialog..., dz. cyt., s. 55; Justyn Męczennik, 1 Apologia 39,5, w: SCh 507, s. 232; „Śmieszną bowiem byłoby rzeczą, gdyby żołnierze przez was powołani i posłani 
Kształtowanie się nauki o niebie w teologii patrystycznej I-III wieku

\section{Stan przejściowy? Lepsze lub gorsze miejsce w zaświatach}

Apologeta z Flavia Neapolis uznawał, że człowiek zachowuje po śmierci świadomość, stąd po śmierci, a przed zmartwychwstaniem ciał, dusze ludzi sprawiedliwych za życia ziemskiego miałyby przebywać „w jakimś lep-

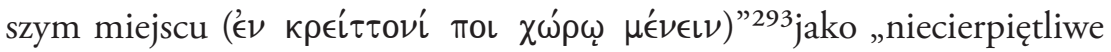

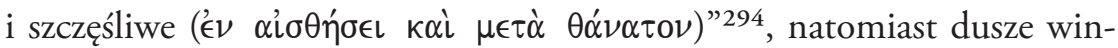

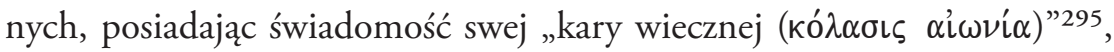

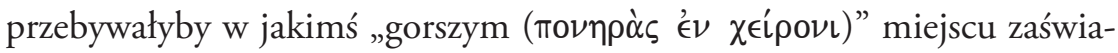
tów, oczekując ostatecznego sądu ${ }^{296}$.

\section{Drugi millenaryzm}

Według klasyfikacji drugiego millenaryzmu ${ }^{297}$ podanych przez Daniélou ${ }^{298}$, Justyn męczennik byłby przedstawicielem chiliazmu - nurtu syryjsko-egipskiego, według którego po zmartwychwstaniu ciał wybrani wskrzeszeni żyliby w Jerozolimie odbudowanej, upiększonej i powiększonej299,

do służby wojskowej nie ślubowali Wam wierności ponad życie, rodziców, [ojczyznę] i własne sprawy, choć Wy w zamian nie możecie dać im żadnej nieśmiertelności. My tymczasem, skoro pragniemy nieśmiertelności, nie moglibyśmy znieść tego wszystkiego, by otrzymać czego pragniemy od Tego, który ma moc nas obdarować?”, w: Justyn Męczennik, 1 i 2 Apologia. Dialog..., dz. cyt., s. 68.

293 Justyn Męczennik, Dialog z Żydem Tryfonem 5,3, w: PG 6, k. 488B; „Otóż dusze ludzi pobożnych przebywają w jakimś lepszym miejscu (...). Tak oto te, które okazały się godne Boga, już nigdy więcej nie umrą", w: Justyn Męczennik, 1 i 2 Apologia. Dialog..., dz. cyt., s. 166-167.

294 Justyn Męczennik, 1 Apologia 20,4, w: SCh 507, s. 186; „Gdy dalej głosimy, że po śmierci dusze ludzi złych zachowują nadal świadomość i ponoszą karę, zaś dusze sprawiedliwych są wolne od cierpień i doświadczają szczęśliwości, zgadzamy się chyba z poetami i filozofami”, w: Justyn Męczennik, 1 i 2 Apologia. Dialog..., dz. cyt., s. 56.

295 Justyn Męczennik, 1 Apologia 18,2, w: SCh 507, s. 178; „Lecz przeciwnie, każdy, kto posiadł świadomość, zachowuje ją i czeka go kara wieczna. Pozwólcie się więc przekonać i uwierzcie, że to jest prawdą", w: Justyn Męczennik, 1 i 2 Apologia. Dialog..., dz. cyt., s. 55.

296 Justyn Męczennik, Dialog z Żydem Tryfonem 5,3, w: PG 6, k. 488B; „(...) natomiast dusze ludzi niesprawiedliwych i złych, w gorszym oczekując tam na czas sądu”, w: Justyn Męczennik, 1 i 2 Apologia. Dialog..., dz. cyt., s. 167.

297 Por. H. Pietras, Eschatologia Kościota pierwszych..., dz. cyt., (MT 55), s. 24-30, 63-82.

298 Por. J. Daniélou, Teologia judeochrzésijaniska..., dz. cyt., s. 360-361.

299 Por. Justyn Męczennik, Dialog z Żydem Tryfonem 80,5, w: PG 6, k. 667A; Justyn Męczennik, 1 i 2 Apologia. Dialog..., dz. cyt., s. 252. 
2. Kształtowanie się nauki o niebie w teologii patrystycznej - wiek I-II

po upływie millenium nastąpi dopiero „powszechne zmartwychwstanie

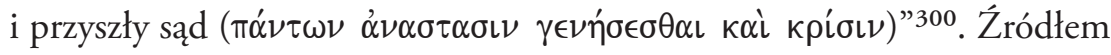
millenarystycznych poglądów Justyna była żydowska tradycja teologiczna pochodząca z Księgi Jubileuszy 4, 29 oraz z ezoterycznych środowisk żydowskich $^{301}$, w duchu której Justyn materialistycznie interpretował (używając LXX) fragmenty Rdz 2, 17; Ez 37, 12-14; Iz 65, 17-25; Ps 90, 4 oraz Ap 20, $4^{302}$. Justyn dostrzegał jednak, iż podzielany przez niego drugi millenaryzm nie był nauką powszechną w Kościele, choć nie stanowił też wtedy herezji ${ }^{303}$.

\section{Doczesny świat spłonie w ogniu}

W nauczaniu Justyna o końcu świata widać analogię do stoickiego zognienia świata, jednak apologeta, głosząc podobną naukę o końcu świata w ogniu - do stoików raz się przyznaje ${ }^{304}$, a raz paradoksalnie odżegnuje ${ }^{305}$ lub też powołuje na Mojżesza i Platona (a w rzeczywistości - na Pseudo-Platona) ${ }^{306}$.

300 Por. Justyn Męczennik, Dialog z Żydem Tryfonem 81,4, w: PG 6, k. 669B; Justyn Męczennik, 1 i 2 Apologia. Dialog..., dz. cyt., s. 253.

301 Por. J. Daniélou, Teologia judeochrześcijańska..., dz. cyt., s. 355, za: W. Bauer, Chiliasmus, RAC II, s. 1075, wymieniał tu szczególnie Samarytan.

302 Por. Justyn Męczennik, Dialog z Żydem Tryfonem 80,5-81,4, w: PG 6, k. 665B-669B; Justyn Męczennik, 1 i 2 Apologia. Dialog..., dz. cyt., s. 252-253.

303 Por. Justyn Męczennik, Dialog z Żydem Tryfonem 80,2, w: PG 6, k. 664BC; „Powiedziałem ci jednak również, że są także inni prawowierni i pobożni chrześcijanie, którzy nie uznają tej nauki”, w: Justyn Męczennik, 1 i 2 Apologia. Dialog..., dz. cyt., s. 251.

304 Por. Justyn Męczennik, 1 Apologia 20,4, w: SCh 507, s. 186; „Jeśli bowiem twierdzimy, że Bóg wszystko dobrze urządził i stworzył, głosimy naukę podobną do Platona, jeśli zaś nauczamy, że wszystko rozpłynie się w ogniu, wyznajemy poglądy stoików", w: Justyn Męczennik, 1 i 2 Apologia. Dialog..., dz. cyt., s. 56.

305 Por. Justyn Męczennik, 2 Apologia 7,3, w: SCh 507, s. 336; „W tym sensie twierdzimy, że świat spłonie w ogniu, nie zaś, jak sądzą stoicy, że wszystko jedno w drugie się przemieni, co wydaje się absurdalne", w: Justyn Męczennik, 1 i 2 Apologia. Dialog..., dz. cyt., s. 95.

306 Por. Justyn Męczennik, 1 Apologia 60,8-9, w: SCh 507, s. 286; „60.8. Posłuchajcie również, jak Duch prorocki przepowiedział przez Mojżesza, że świat spłonie w ogniu. 60.9. Oto jego słowa: «Zstąpi ogień nieugaszony i sięga aż do najdalszych głębin”", w: Justyn Męczennik, 1 i 2 Apologia. Dialog..., dz. cyt., s. 82 (por. Dt 32, 22, po uprzednim odwołaniu się do Pseudo-Platona, List 2, 321E). 
Kształtowanie się nauki o niebie w teologii patrystycznej I-III wieku

\section{Piekło jako miejsce potępienia}

Wątek piekła jako miejsca potępienia pojawia się kilka razy w dziełach Justyna. Wychodząc od harmonizacji i parafrazy Łk 12, 4-5 i Mt 10, 28, Justyn stwierdzał, że piekło jest miejscem kary dla ludzi, którzy żyli źle i nie uwierzyli w Boże obietnice ogłoszone przez Chrystusa ${ }^{307}$. W eschatonie złe anioły ${ }^{308}$, demony ${ }^{309}$ oraz niesprawiedliwi ludzie (już po zmartwychwstaniu, w ciele i duszy) jako winni zostaną ukarani mękami wiecznymi ${ }^{310}$.

307 Por. Justyn Męczennik, 1 Apologia 19.7-8, w: SCh 507, s. 184; „19.7. A także: „Nie bójcie się tych, którzy was zabijają, a potem nic więcej nie mogą uczynić. Bójcie się raczej Tego, który po śmierci może i duszę i ciało zatracić w piekle”. 19.7. Piekło jest

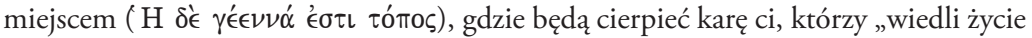
złe i nie uwierzyli, że spełni się to, co Bóg zapowiedział przez Chrystusa”, w: Justyn Męczennik, 1 i 2 Apologia. Dialog..., dz. cyt., s. 55-56.

308 Por. Justyn Męczennik, 1 Apologia 28,1, w: SCh 507, s. 204; „My zaś przywódcę złych demonów nazywamy Wężem, Szatanem lub diabłem, jak tego z naszych pism możecie się dowiedzieć. On to, jak przepowiedział Chrystus, zostanie wrzucony w ogień razem ze swymi zastępami i ludźmi, którzy za nim idą, by tam cierpieć przez całą wiecz-

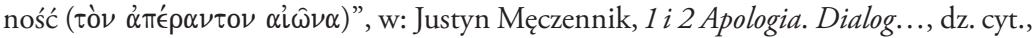
s. 61 (por. Mt 25, 41).

309 Justyn, idąc za interpretacją biblijną przejętą z apokaliptyki żydowskiej (por. 1 Księga Henocha 1-36), uznawał natomiast, że aniołowie upadli oraz ich ziemskie potomstwo (tzw. giganci) byli odpowiedzialni za deprawację świata ziemskiego przed potopem. Bóg zamknął upadłe anioły w piekle, a gigantów skazał na wzajemne wyniszczenie się. Po potopie duchy gigantów pozostały na ziemi, wzniecając zło aż do dnia sądu ostatecznego. To właśnie duchy gigantów, które Justyn nazywa demonami, byłyby odpowiedzialne za powstanie religii pogańskich; por. Justyn Męczennik, 1 Apologia 5,2, w: SCh 507, s. 138; Justyn Męczennik, 1 i 2 Apologia. Dialog..., dz. cyt., s. 45-46 (por. Ch. Munier, SCh 507, s. 138, przypis 2); Justyn Męczennik, 1 Apologia 26,1, w: SCh 507, s. 198; „Gdy po wstąpieniu Chrystusa do nieba demony skłoniły niektórych ludzi do tego, by sami nazwali się bogami", w: Justyn Męczennik, 1 i 2 Apologia. Dialog..., dz. cyt., s. 59. Justyn Męczennik, 1 Apologia 40,7, w: SCh 507, s. 234; „(...) dalej, że demony jak tylko mogą, usiłują wyrwać się spod władzy Boga Ojca i Pana wszechrzeczy i samego Chrystusa”, w: Justyn Męczennik, 1 i 2 Apologia. Dialog..., dz. cyt., s. 69; więcej o wątku buntu aniołów w niebie i jego skutkach według apokaliptyki żydowskiej, zob. P. D. Hanson, Rebellion in Heaven, Azazel, and Euhemeristic Heroes in 1 Enoch 611, „Journal of Biblical Literature” 96/2 (1977), s. 195-233.

310 Por. Justyn Męczennik, 1 Apologia 8,3-4, w: SCh 507, s. 146; „8.3. Tak oto więc przedstawia się syntetycznie nauka, którą otrzymaliśmy pouczeni przez Chrystusa i którą także innym głosimy. 8.4. Przecież już Platon podobnie twierdził, że Radamantys i Minos ukarzą winnych, którzy przed ich obliczem staną. My głosimy, że to samo się stanie, tylko że za sprawą Chrystusa, gdy winni staną z ciałem i duszą, by cierpieć męki nie tylko tysiącletnie, jak twierdził Platon, lecz wieczne ( $\alpha i \omega \nu i \alpha \nu$ кó $\alpha \sigma \sigma \nu)$ ", 
Eschatologiczna kara dla bezbożnych i niesprawiedliwych była przez Justyna najczęściej opisywania jako „wieczna” ( $\alpha i \omega \nu i \alpha \nu$ kó $\lambda \alpha \sigma \nu \nu)$, jednak w Dialogu z Żydem Tryfonem 5, 3b napotykamy na znaczący passus, gdzie apologeta w swym przesłaniu nie absolutyzuje już kary dla dusz niesprawiedliwych i złych, ale jej wymiar oraz zasadność pozostawia wyłącznie $\mathrm{Bogu}^{311}$.

\section{Moralizm eschatologiczny}

Charakterystyczne dla teologii Justyna było systematyczne przesuwanie akcentu w jego nauczaniu eschatologicznym: $\mathrm{z}$ nowotestamentalnego przepowiadania o usprawiedliwieniu darmowo ofiarowanym wierzącym w Jezusie Chrystusie i dobrych uczynkach jako owocach usprawiedliwienia w kierunku konsekwencji moralnych wyborów człowieka w doczesności. Oto trzy fragmenty z tekstów Justyna reprezentatywne dla takiego moralizującego dowodzenia:

„O wstrzemięźliwości tak nauczał: «Kto patrzy na kobietę w celu jej pożądania, już dopuścił się z nią cudzołóstwa w sercu przed Bogiem» (por. Mt 5, 29). 15. 2. Albo: «Jeśli prawe twoje oko jest ci powodem do grzechu, wyłup je. Lepiej jest dla ciebie z jednym okiem wejść do królestwa niebieskiego, niż z dwojgiem oczu być posłanym w ogień wieczny» (por. Mt 9, 29; 18, 9). 15. 3. A także: «Jeśli ktoś bierze za żonę kobietę rozwiedzioną z innym mężczyzną, cudzołoży» (por. Mt 5, 32). 15. 4. I jeszcze: «Są ludzie, których inni ludzie uczynili niezdolnymi do małżeństwa, są też i tacy, którzy urodzili się niezdolni do małżeństwa, ale są również i tacy, którzy wybrali bezżenność ze względu na królestwo

w: Justyn Męczennik, 1 i 2 Apologia. Dialog..., dz. cyt., s. 47 (por. Platon, Gorgiasz 523e; Platon, Obrona Sokratesa 41a; Rz 8, 10; 1 Kor 15, 35).

311 Por. Justyn Męczennik, Dialog z Żydem Tryfonem 5,3, w: PG 6, k. 488B; „Tak oto te, które okazały się godne Boga, już nigdy więcej nie umrą, inne natomiast zostaną uka-

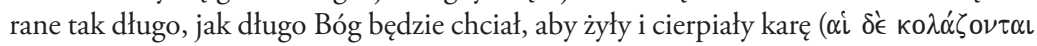

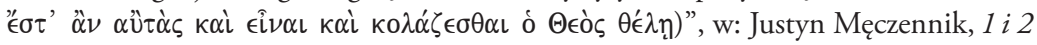
Apologia. Dialog..., dz. cyt., s. 167. 
Kształtowanie się nauki o niebie w teologii patrystycznej I-III wieku

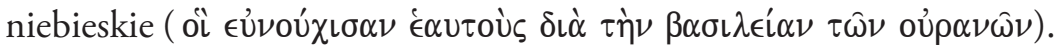
Lecz nie wszyscy pojmują sens tego»" (por. Mt 19, 12) ${ }^{312}$.

„Zostaliśmy bowiem pouczeni, że nieśmiertelności dostąpią tylko ci, którzy wiodą życie święte i cnotliwe w bliskości Boga $(\dot{\alpha} \pi \alpha \theta \alpha \nu \alpha \tau i \zeta \epsilon \sigma \theta \alpha \iota$

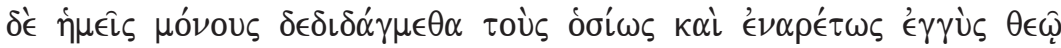

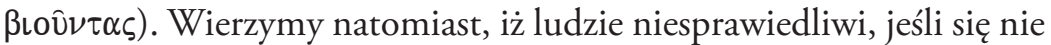

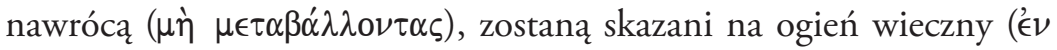

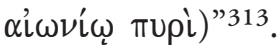

„Bóg bowiem, stwarzając aniołów i ludzi jako istoty wolne i autono-

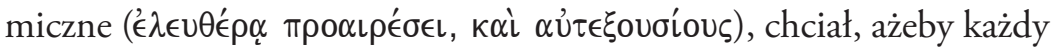
czynił to do czego Bóg go uzdolnił rezerwując sobie prawo do zachowania ich w niezniszczalności i bez kary, jeśli będą wybierać to, co Jemu jest miłe lub też wymierzyć karę każdemu, jeśli będzie czynił zło"314.

W nauczaniu o wstrzemięźliwości Justyn odwoływał się do tekstów Mt, choć sam tekst NT użyty w 1 Apologii różni się od tego z dzisiejszych wydań krytycznych NT ${ }^{315}$. Natomiast w uogólnieniach występujących w kolejnym cytowanym powyżej fragmencie apologeta nie powoływał się na jakiś określony fragment Nowego Testamentu o nieśmiertelności jako nagrodzie za życie święte i cnotliwe, ale prawdopodobnie czerpał tę myśl z dostępnych

312 Justyn Męczennik, 1 Apologia 15,1-4, w: SCh 507, s. 166; Justyn Męczennik, 1 i 2 Apologia. Dialog..., dz. cyt., s. 51.

313 Justyn Męczennik, 1 Apologia 21,6, w: SCh 507, s. 190; Justyn Męczennik, 1 i 2 Apologia. Dialog..., dz. cyt., s. 57.

314 Justyn Męczennik, Dialog z Żydem Tryfonem 88,5, w: PG 6, k. 685C.688A;

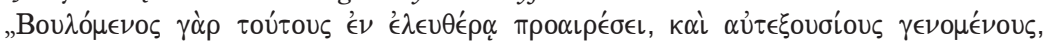

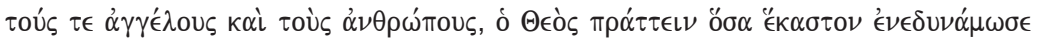

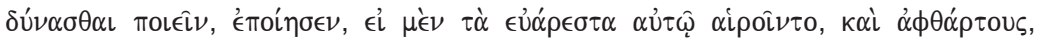

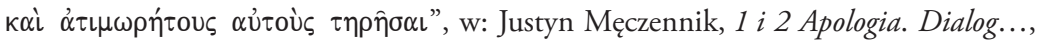
dz. cyt., s. 261.

315 Zdaniem J. Blinzler, Justinus Apol. 1, 15, 4 und Matthàus 19, 11-12, w: Mélanges Bibliques en hommage au R. P. Béda Rigaux, ed. A. Descamps, A. de Halleux, Gembloux 1970, s. 45-55, Justyn uznawał też, że obecność we wspólnotach chrześcijańskich ascetów „wstrzemięźliwych”, którzy od wczesnej młodości ślubowali czystość seksualną stanowi dodatkowy argument za prawdziwością chrześcijaństwa. 
2. Kształtowanie się nauki o niebie w teologii patrystycznej - wiek I-II

mu podręczników katechetycznych ówczesnych misjonarzy ${ }^{316}$ i starał się apologetycznie harmonizować grecki idealizm etyczny Platona i stoicki pogląd o prymacie cnoty z przekazem biblijnym o uznaniu w wierze objawionego Boga i konsekwencjach życia w wierze.

W próbie godzenia platońsko-stoickiej koncepcji powinności etycznej z soteriologią i moralnością nowotestamentalną dostrzega się u Justyna przerost roli etyki nad nauką o zbawieniu. Apologeta rzadziej odwoływał się do podstawowych tez soteriologii chrześcijańskiej: o Jezusie jako Zbawicielu i zbawieniu przez Niego już dokonanym ${ }^{317}$, o odkupieniu z grzechów rodzaju ludzkiego ${ }^{318}$, o przyjęciu ofiarowanego przez Boga zbawienia jako skutku nawrócenia ${ }^{319}$ i przyjęcia w tym duchu chrztu ${ }^{320}$.

316 Por. H. Köster, The Text of the Synoptic Gospels in the Second Century, w: W. L. Petersen, Gospel Traditions in the Second Century, Notre Dame 1990, s. 19-38; J. Verheyden, Justin's text of the Gospels: another look at the citations in 1 Apol. 15,1-8, w: The early text of the New Testament, ed.Ch. E. Hill, M. J. Kruger, New York-Oxford 2012, s. 313-335.

317 Por. Justyn Męczennik, 2 Apologia 6,4-5, w: SCh 507, s. 332.334; „6.4. «Jezus» wreszcie jest imieniem oznaczającym człowieka i Zbawiciela. 6.5. Chrystus bowiem, jak już powiedziałem, stał się człowiekiem i narodził się z woli Boga Ojca dla >zbawienia< ludzi wierzących $\mathrm{i}>\mathrm{dla}<$ zguby demonów, $>\mathrm{o}$ czym $<$ zresztą teraz możecie przekonać się na własne oczy”, w: Justyn Męczennik, 1 i 2 Apologia. Dialog..., dz. cyt., s. 95. Justyn Męczennik, Dialog z Żydem Tryfonem 91,4, w: PG 6, k. 693B; „W figurze jawi się również krzyż w owym znaku przeciw wężom, które kąsały Izraelitów. Został on wzniesiony ku zbawieniu wierzących $\mathrm{w}$ ukrzyżowanego, którzy wierzą w zapowiedź, iż dzięki ukrzyżowanemu śmierć spotka węża a zbawienia dostąpią ci, którzy zostali ukąszeni przez węża, a ucieczki będą szukać u Tego, który posłał na świat swego Syna ukrzyżowanego", w: Justyn Męczennik, 1 i 2 Apologia. Dialog..., dz. cyt., s. 264.

318 Por. Justyn Męczennik, Dialog z Żydem Tryfonem 88,4, w: PG 6, k. 685B; „Wiemy jednak, że nie udał się nad rzekę, bo potrzebował chrztu albo zstąpienia na Niego Ducha Świętego w postaci gołębicy, tak jak nie potrzebował narodzić się ani zostać ukrzyżowanym, a jednak zniósł to wszystko dla rodzaju ludzkiego, który od Adama wpadł w moc śmierci i oszustwa węża, popełniając zło każdy człowiek z własnej winy", w: Justyn Męczennik, 1 i 2 Apologia. Dialog..., dz. cyt., s. 261.

319 Por. Justyn Męczennik, 1 Apologia 28,2, w: SCh 507, s. 204; „Jeśli więc Bóg w swojej cierpliwości tej kary jeszcze nie wymierza, czyni to ze względu na rodzaj ludzki. Wie On bowiem, że niektórzy nawet z tych, co się jeszcze nie narodzili dzięki nawróceniu dostąpią zbawienia”, w: Justyn Męczennik, 1 i 2 Apologia. Dialog..., dz. cyt., s. 61. Justyn Męczennik, 1 Apologia 40,7, w: SCh 507, s. 234; „Bóg wzywa wszystkich ludzi do nawrócenia zanim nadejdzie dzień sądu”, w: Justyn Męczennik, 1 i 2 Apologia. Dialog..., dz. cyt., s. 69.

320 Por. Justyn Męczennik, 1 Apologia 61.3.4, w: SCh 507, s. 288.290; „61.3. (...) w imię bowiem Boga, Ojca i Pana wszechrzeczy i naszego Zbawiciela Jezusa Chrystusa oraz Ducha Świętego dostępują oni wtedy obmycia w wodzie. 61.4. Rzekł bowiem 
Kształtowanie się nauki o niebie w teologii patrystycznej I-III wieku

Częściej, przypuszczalnie, z racji apologetycznych, aby przybliżyć przesłanie chrześcijańskie wykształconym filozoficznie poganom - przez akcentowanie tego, co jego zdaniem może łączyć etykę filozoficzną i moralność chrześcijańską, Justyn powracał do wykładu teologii według norm greckiego idealizmu etycznego. Mimo korzystania z terminów i zasad etyki medio-platońskiej i stoickiej Justyn starał się być wobec niej krytyczny i wykluczać $\mathrm{z}$ niej to, co obce teologii chrześcijańskiej ${ }^{321}$. Przeciwstawiając się zatem greckiemu fatalizmowi moralnemu i nauce o losie ${ }^{322}$, krytykując mityczny pogląd o moralnej predestynacji człowieka ${ }^{323}$, czy też obalając zarzut

Chrystus: «Jeśli się nie odrodzicie, nie wejdziecie do królestwa niebieskiego»", w: Justyn Męczennik, 1 i 2 Apologia. Dialog..., dz. cyt., s. 82, jak zaznacza L. Misiarczyk w przypisie 151 na s. 82 i przypisie 153 na s. 83, ostatni cytat stanowi rzadki u Justyna rodzaj harmonizacji J 3, 3-5 i Mt 18, 3, natomiast teologia chrztu zostaje zaprezentowana przez apologetę w kategoriach oświecenia umysłu. Zob. Justyn Męczennik, Dialog z Żydem Tryfonem 8,1, w: PG 6, k. 492D-493A; „Jeśli więc tobie samemu drogi jest twój własny los, pragniesz zbawienia i pokładasz nadzieję w Bogu, a te sprawy nie są ci obojętne, możesz poznać Mesjasza Bożego i po przejściu inicjacji osiągnąć szczęście”, w: Justyn Męczennik, 1 i 2 Apologia. Dialog..., dz. cyt., s. 169. Justyn przekazuje też pozabiblijną, antyczną tradycję chrześcijańską o nadzwyczajnym świetle wydobywającym się z wód Jordanu podczas chrztu Jezusa, odczytywaną jako znak uwolnienia ludzkości od ognia sądu (por. Justyn Męczennik, Dialog z Żydem Tryfonem 88,3, w: PG 6, k. 685B; Justyn Męczennik, 1 i 2 Apologia. Dialog..., dz. cyt., s. 261).

321 Por. G. Bardy, St. Justin et la filosophie stö̈cienne, „Recherches de Science Religieuse” 13 (1923), s. 491-510; J. M. Edwards, On the Platonic Schooling of Justin Martyr, „The Journal of Theological Studies" 42 (1991), s. 17-34; G. Grigenti, Giustino Martire. Il primo Cristiano platonico, Milano 1995.

322 Por. Justyn Męczennik, 1 Apologia 43,2, w: SCh 507, s. 240; „Prawdą jest, że kary, chłosty i nagrody każdy otrzymuje >sprawiedliwie< według swoich czynów, jak o tym nas pouczyli prorocy. Gdyby bowiem tak nie było, lecz wszystko działoby się jedynie według ślepego przeznaczenia, wtedy nie posiadalibyśmy wolnej woli. Jeśli więc tylko na podstawie ślepego losu jeden jest dobry a drugi zły, wtedy ani pierwszy nie zasługuje na pochwałę ani drugi na naganę", w: Justyn Męczennik, 1 i 2 Apologia. Dialog..., dz. cyt., s. 70.

323 Por. Justyn Męczennik, 1 Apologia 43,7-8, w: SCh 507, s. 242; „43.7. Według naszych przekonań można mówić tylko o takim przeznaczeniu: ci, którzy czynią dobro, słusznie otrzymują nagrodę, zaś ci, którzy przeciwnie postępują, słuszną otrzymują karę. 43.8. Bóg bowiem nie stworzył człowieka podobnego innym istotom jak drzewa czy zwierzęta czworonożne, które z własnej woli nic nie mogą czynić. Nie byłby przecież człowiek godnym nagrody ani kary, gdyby był dobry z natury a nie wybierał dobra z własnej woli ani zły człowiek słusznej podlegał karze tylko dlatego, że takim jest $\mathrm{z}$ natury a nie z własnego wyboru i innym nie może się stać, jak tylko takim, jakim się urodzil”, w: Justyn Męczennik, 1 i 2 Apologia. Dialog..., dz. cyt., s. 71; Justyn 
2. Kształtowanie się nauki o niebie w teologii patrystycznej - wiek I-II

„nowinkarstwa” nauki chrześcijańskiej ${ }^{324}$, Justyn głosił, że szczęśliwe życie wieczne jest nagrodą za dobre czyny (przy uprzednim założeniu moralnym, że „ludzka natura posiada zdolność poznania dobra i zła”325 i że przez swój wolny wybór to człowiek decyduje o zbawieniu lub potępieniu) ${ }^{326}$. Stąd w interpretacji apologety kara ognia wiecznego stanowiłaby właściwie konsekwencję złych czynów. Podobne rozumowanie o eschatologicznej nagrodzie lub karze, odpowiednio dostosowanej do rodzaju życia ziemskiego, spotykamy w 2 Apologii ${ }^{327}$ i w Dialogu z Żydem Tryfonem ${ }^{328}$.

Męczennik, 1 Apologia 44,7, w: SCh 507, s. 244; „Dlatego też i Platon, gdy mówit: «Wina jest zawsze po stronie człowieka, który z wolnej wybiera woli, Bóg nie ponosi żadnej winy", przejął tę myśl od Mojżesza, gdyż Mojżesz starszy jest od Platona i wszystkich pisarzy greckich", w: Justyn Męczennik, 1 i 2 Apologia. Dialog..., dz. cyt., s. 71-72 (por. Platon, Państwo X,617).

324 Por. Justyn Męczennik, 1 Apologia 46,3-4, w: SCh 507, s. 250.252; „Ci więc, którzy wiedli życie zgodne z Logosem, są chrześcijanami nawet gdyby byli nazwani ateistami, jak na przykład Sokrates, Heraklit im podobni, a także wśród barbarzyńców Abraham, Ananiasz, Azariasz, Miszael, Eliasz i wielu innych, których wyliczanie czynów i imion zajęłoby tutaj zbyt wiele czasu. 46.4. Tak więc ci, którzy żyli wbrew Logosowi byli ludźmi bezużytecznymi, wrogami Chrystusa i mordercami tych, którzy zgodnie z Nim, natomiast ci, którzy żyli i żyją zgodnie z Logosem, są chrześcijanami i nie znają ani lęku ani trwogi”, w: Justyn Męczennik, 1 i 2 Apologia. Dialog..., dz. cyt., s. 73.

325 Justyn Męczennik, 2 Apologia 14,2, w: SCh 507, s. 366; Justyn Męczennik, 1 i 2 Apologia. Dialog..., dz. cyt., s. 100; podobnie wcześniej, Justyn Męczennik, 2 Apologia 7,56, w: SCh 507, s. 336.338; „Bóg natomiast, stwarzając na początku aniołów i ludzi, obdarzył ich wolną wolą, dlatego też sprawiedliwie za swoje przewinienia będą karani oni ogniem wiecznym. 7.6. Każde bowiem stworzenie ze swej natury zdolne jest do złego i do cnoty. Żadne z nich nie mogłoby nigdy mieć zasług, gdyby nie posiadało możliwości wyboru pomiędzy jednym a drugim”, w: Justyn Męczennik, 1 i 2 Apologia. Dialog..., dz. cyt., s. 95.

326 Por. Justyn Męczennik, Dialog z Żydem Tryfonem 102,4, w: PG 6, k. 713B; „Ponieważ jednak uznał za rzecz dobrą, by tak się stało, stworzył więc aniołów i ludzi jako istoty zdolne do czynienia sprawiedliwości w sposób wolny i wyznaczył czas do którego uznał za dobre, aby cieszyli się wolnością. Skoro więc uznał to za rzecz dobrą, ustanowił sądy ogólne i szczegółowe, w niczym nie naruszając wolnej woli”, w: Justyn Męczennik, 1 i 2 Apologia. Dialog..., dz. cyt., s. 274.

327 Por. Justyn Męczennik, 2 Apologia 1,2, w: SCh 507, s. 318.320; „(...) nie czynią tego tylko ci, którzy są przekonani, że niesprawiedliwi i rozpustnicy zostaną ukarani w ogniu wiecznym, zaś ludzie żyjący cnotliwie i podobnie do Chrystusa, wolni od cierpień zostaną odrodzeni w Bogu, a mam na myśli chrześcijan”, w: Justyn Męczennik, 1 i 2 Apologia. Dialog..., dz. cyt., s. 91; podobnie 2 Apologia 2,2, w: SCh 507, s. 320; Justyn Męczennik, 1 i 2 Apologia. Dialog..., dz. cyt., s. 91.

328 Por. Justyn Męczennik, Dialog z Żydem Tryfonem 28,2, w: PG 6, k. 535AB; „Pozostaje zaś wam niewiele czasu na nawrócenie się. Gdy nastanie przyjście Chrystusa, na próżno 
Kształtowanie się nauki o niebie w teologii patrystycznej I-III wieku

Charakterystyczny dla moralizmu eschatologicznego Justyna jest fragment z 1 Apologii 16, 8-14, który stanowi swoistą kumulację wybranych cytatów biblijnych, podtrzymujących tezę, że dobre uczynki są wymiernym dowodem wyznawanej wiary, przy jednoczesnym pominięciu jakiegokolwiek odniesienia do osobistej relacji zbawionego z Chrystusem czy do jego wiary.

„16. 8. Ludzie natomiast, których zobaczycie, że nie żyją tak, jak On pouczył, nie są chrześcijanami, choćby nawet mieli usta pełne nauk Chrystusa. On sam bowiem powiedział, iż zbawienia dostąpią nie ci, którzy tylko mówią, ale ci, którzy pełnią czyny. 16. 9. Tak mówił: «Nie każdy, kto Mi mówi: Panie, Panie!, wejdzie do królestwa niebieskiego, lecz ten, kto spełnia wolę Ojca mojego, który jest w niebie» (por. Mt 7, 21). 16. 10. «Kto zaś słucha mnie i czyni to, co mówię, słucha tego, który mnie posłał» (por. Mt 7, 24; 10, 40). 16. 11. "Wielu bowiem powie mi: Panie, Panie, czy nie jedliśmy i nie piliśmy w twoje imię albo cudów nie czyniliśmy? Odpowiem im wtedy: Idźcie precz ode mnie dopuszczający się nieprawości» (por. harmonizacja Mt 7, 22-23 i Łk 13, 26-27). 16. 12. Tam będzie płacz i zgrzytanie zębów, gdy sprawiedliwi będą jaśnieć jak słońce, a niesprawiedliwi będą posłani w ogień wieczny” (por. Mt 13, 42-43). 16. 13. «Wielu bowiem przyjdzie w moje imię, zewnętrznie przyodzianych w skóry owcze, lecz wewnętrznie będą

będziecie pokutować i na próżno będziecie płakać, bo wtedy już was nie wysłucha", w: Justyn Męczennik, 1 i 2 Apologia. Dialog..., dz. cyt., s. 189. Justyn Męczennik, Dialog z Żydem Tryfonem 124,4, w: PG 6, k. 765B; „Duch Święty wyrzuca ludziom, którzy podobnie jak Bóg, staliby się nie poddani cierpieniom i nieśmiertelni, gdyby zachowali Jego przykazania, zostając uznani za godnych nazwania przez Niego synami Bożymi, że sami sobie przygotowują śmierć podobnie jak Adam i Ewa, i dlatego trzymam się tłumaczenia Psalmu jakie akceptujecie”, w: Justyn Męczennik, 1 i 2 Apologia. Dialog..., dz. cyt., s. 300 (por. Ps 82, 1-8). Justyn Męczennik, Dialog z Żydem Tryfonem 140,4, w: PG 6, k. 797B; „Czyż nasz Pan nie powiedział zgodnie z wolą Ojca i Pana wszechrzeczy, który Go posłał: „Przyjdą z zachodu i ze wschodu i zasiądą przy stole z Abrahamem, Izaakiem i Jakubem w królestwie niebieskim, synowie zaś królestwa zostaną wyrzuceni na zewnątrz w ciemności”. Bóg jednak nie jest odpowiedzialny, nawet jeśli już wie, że staną się niesprawiedliwi, zarówno aniołowie, jak i ludzie, że będą niegodziwi, ale każdy jest odpowiedzialny za samego siebie jakim będzie, co zresztą wykazałem już wcześniej”, w: Justyn Męczennik, 1 i 2 Apologia. Dialog..., dz. cyt., s. 316-317 (por. Mt 8, 11-12). 
2. Kształtowanie się nauki o niebie w teologii patrystycznej - wiek I-II

wilkami drapieżnymi. Po ich czynach rozpoznacie ich. Każde bowiem drzewo, które nie przynosi dobrego owocu, będzie wycięte i w ogień wrzucone» (por. Mt 7, 15. 16. 19). 16. 14. «Skazujcie więc tych, którzy nie żyją zgodnie z naukami Chrystusa, a tylko mówią, że są chrześcijanami. O to wręcz Was prosimy»"329.

Przy tak jednostronnym ujęciu i uzasadnianiu usprawiedliwienia dobrymi uczynkami rodzaj eschatologicznego życia zbawionych zależałby nie od Chrystusa, ale od ludzkich wyborów moralnych w doczesności, co Justyn potwierdzał także w 2 Apologii 7, 3, kiedy, negując grecki determinizm losu, uznawał, iż „czyny ludzkie i losy nie zależą tylko od ślepego przeznaczenia, ale każdy z wolnej woli czyni dobro lub zło" ${ }^{330}$. Eschatologia Justyna staje się jeszcze bardziej zhellenizowana w schemacie „przyszła nieśmiertelność za cnotliwe życie doczesne”, kiedy, powołując się na Ksenofonta, Memorabilia 2, 1, 21 i jego mit o spotkaniu Cnoty i Wady, spersonifikowanych jako dwie kobiety, Justyn wprowadził do swojego wykładu to klasyczne dla etyki greckiej kategoryzowanie ${ }^{331}$. Używając jako swoistych „przed-założeń” greckich kategorii etycznych cnoty i wady oraz odwołując się do zasady intelektualizmu etycznego ${ }^{332}$, Justyn wyprowadzał z nich chrześcijański wniosek końcowy:

329 Justyn Męczennik, 1 Apologia 16,8-14, w: SCh 507, s. 174.176; Justyn Męczennik, 1 i 2 Apologia. Dialog..., dz. cyt., s. 53-54.

330 Por. Justyn Męczennik, 2 Apologia 7,3, w: SCh 507, s. 336; „' $\alpha \lambda \lambda$ ' oủo'́ $\kappa \alpha \theta$

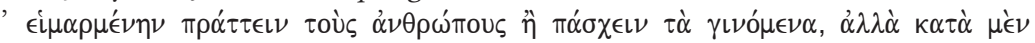

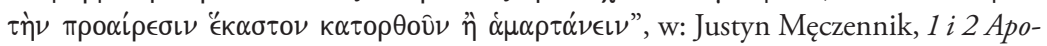
logia. Dialog..., dz. cyt., s. 5; podobnie Justyn mówi o: „słusznej karze i męce ognia wiecznego" (2 Apologia 8,3-4, w: SCh 507, s. 340.342; Justyn Męczennik, 1 i 2 Apologia. Dialog..., dz.cyt., s. 96) i „przeszłej karze niesprawiedliwych w ogniu wiecznym" (2 Apologia 9,1, w: SCh 507, s. 342; Justyn Męczennik, 1 i 2 Apologia. Dialog..., dz. cyt., s. 96), będącej konsekwencją wyborów zła tak przez demony, jak i niesprawiedliwych ludzi.

331 Por. Justyn Męczennik, 2 Apologia 11,2-7, w: SCh 507, s. 352.354; Justyn Męczennik, 1 i 2 Apologia. Dialog..., dz. cyt., s. 97-98. Por. też T. Ślipko, Historia etyki, Kraków 2010, s. 16-20 (idealizm etyczny Platona), s. 30-32 (stoicki prymat cnoty).

332 Jak zauważył G. Grigenti, Teologia, cosmologia e antropologia di Giustino Martire, „Rivista di Filosofia Neo-Scolastica” 83 (1991), s. 87-88, teologia moralna Justyna charakteryzuje się, typowymi dla greckiej etyki filozoficznej, kryteriami: (1) moralności wolnego wyboru; (2) odpowiedzialności, która niesie za sobą retrybucję (za zachowanie 
Kształtowanie się nauki o niebie w teologii patrystycznej I-III wieku

„Ci zaś, którzy poznali dobra prawdziwe właściwe Cnocie, dzięki niej stali się nieśmiertelni. Każdy człowiek rozsądny będzie tak sądził o chrześcijanach, atletach i innych ludziach, którzy czynili rzeczy przypisane przez poetów ich rzekomym bogom. Na podstawie tego każdy chyba człowiek rozsądny zrozumie, dlaczego my gardzimy śmiercią, nawet gdybyśmy mogli jej uniknąć"333.

Kategorię eschatologicznej zasługi z dobrych uczynków Justyn stosował również w Dialogu z Żydem Tryfonem 39, 6334. W strukturze tego dosyć niespójnego konstruktu teologicznego, który nazwałem moralizmem eschatologicznym, widzimy w tekstach Justyna zarówno elementy etyki platońskiej (kierowanie się cnotami moralnymi; wysiłki na rzecz wyzwolenia się z cielesności i wad; koncentracja na tym, co duchowe; stała praktyka ascezy), etyki stoickiej (natura ludzka punktem wyjścia; panowanie rozumu nad instynktowną sferą natury; opanowanie siebie na drodze podporządkowania się cnocie) oraz elementy soteriologii chrześcijańskiej (Jezus Chrystus Zbawicielem; zbawienie już dokonane w Jezusie; zrealizowane w Jezusie odkupienie z grzechów rodzaju ludzkiego, przyjęcie ofiarowanego przez Boga zbawienia jako skutku nawrócenia; przyjęcie w tym duchu chrztu).

Odnosi się wrażenie, że greckie kategorie etyki filozoficznej zdają się w Justynowym wykładzie o rzeczach ostatecznych przeważać nad soteriologią i moralnością nowotestamentalną. W jego Apologiach i Dialogu często powtarza się argumentacja, iż dzięki postępowaniu opartemu o autonomiczną wolę człowieka oraz dzięki rozumnym wyborom jednostkowym

normy jest nagroda, a za przekroczenie normy jest kara); (3) prawa, jako pochodzącego od Boga.

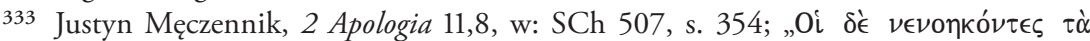

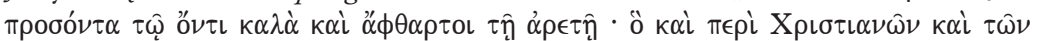

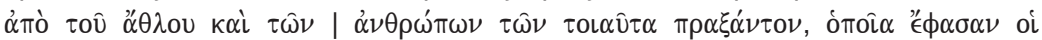

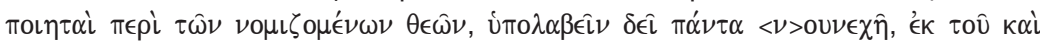

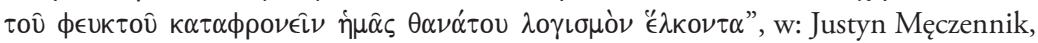
1 i 2 Apologia. Dialog..., dz. cyt., s. 98.

334 Por. Justyn Męczennik, Dialog z Żydem Tryfonem 39,6, w: PG 6, k. 561A; „...) nie przestają zabijać i prześladować wyznawców Chrystusa aż do chwili, kiedy On ponownie przyjdzie w chwale, wszystko zniszczy i każdemu odda według jego zasług

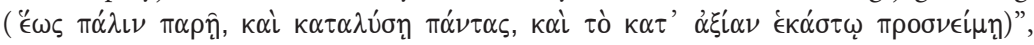
w: Justyn Męczennik, 1 i 2 Apologia. Dialog..., dz. cyt., s. 202. 
człowiek poprzez wybór cnoty sam dochodzi do zbawienia. Według takiego moralizmu eschatologicznego Jezus Chrystus stałby się ,jedynie” chrześcijańskim modelem życia cnotliwego i eschatologicznym sędzią sprawdzającym zgodność życia jednostki z zapisanym przez Stwórcę w każdej naturze ludzkiej kodem cnót, potwierdzonym przez Wcielenie Mesjasza i Jego nauczanie. Oprócz teologicznej niespójności moralizującego dowodzenia Justyna wobec soteriologii nowotestamentalnej, w teologii moralnej Justyna wyraźnie brak jednoznacznego wskazywania na Boga jako ostateczny cel człowieka i całego stworzenia oraz na stałą potrzebę łaski Bożej na drodze moralnego doskonalenia się wierzącego ${ }^{335}$. Wynika to, jak już zaznaczałem, zapewne z wyjaśniania doktryny chrześcijańskiej niechrześcijanom (poganom, żydom) za pomocą apologii. W tym ujęciu metodologicznym z samego założenia wykład wiary będzie niepełny. W tekstach apologety z Flavia Neapolis brakuje ewidentnie wyważenia pomiędzy soteriologią a moralnością. Moralność chrześcijańska wywodząca się z Biblii jest bowiem zawsze potwierdzeniem wyboru wiary, nie wypracowuje zbawienia jako swoista praktyka autosoteryjna. Dobre uczynki wynikają wyłącznie z Chrystusowego usprawiedliwienia i są jego owocami ${ }^{336}$. W historii teologii chrześcijańskiej pisma Justyna stanowią niewątpliwie pierwszy wyraźny zapis całościowej próby połączenia soteriologii biblijnej z etycznym idealizmem platońskim i etyką stoicką. Odnotowany moralizm eschatologiczny

335 Justyn dostrzegał potrzebę łaski Bożej, ale zdaje się, że mówił o niej głównie w kontekście przyjęcia wiarą Bożego objawienia oraz kiedy podkreślał konieczność łaski do rozumienia Biblii (por. N. Pycke, Connaissaince rationnelle et conaissance de grace chez saint Justin, „Ephemeredies Theologicae Lovaniensis” 17 (1961), s. 52-85; L. Misiarczyk, Wstęp. Dialog z Żydem Tryfonem, w: Justyn Męczennik, 1 i 2 Apologia. Dialog..., dz. cyt., s. 133).

336 Komentując biblijny przekaz o istnieniu ścisłego związku pomiędzy orędziem o zbawieniu a orędziem moralnym, J. Nagórny, Historiozbawczy fundament moralności chrześcijańskiej, w: Teologia moralna u kresu II tysiąclecia, red. J. Nagórny, K. Jeżyna, Lublin 1998, s. 153-170, trafnie konkluduje, iż wezwania Jezusa Chrystusa nie mogą być traktowane jedynie jako wzniosłe zasady moralne, gdyż Jezus stawia wymagania chrześcijanom jako zbawionym, członkom Królestwa Bożego, obdarowanym duchowymi darami. „Dokonane zbawienie tworzy jakby «przestrzeń» dla wypełnienia woli Bożej zawartej w przykazaniach. Stąd też to zachowywanie przykazań nie ma charakteru zewnętrznego, lecz wyrasta z łaski, czyli z daru zbawienia, z daru uczestnictwa w Jego życiu. Biblijna wizja moralności ukazuje bardzo wyraźnie, że najbardziej podstawowym fundamentem imperatywu moralnego jest zbawcze działanie Boga”. 
Kształtowanie się nauki o niebie w teologii patrystycznej I-III wieku

nie stał się wprawdzie jakąś doktryną katechizmową Kościoła II wieku, ale najprawdopodobniej natchnął wielu chrześcijan do postrzegania nieba w kategoriach zasługiwania nań przede wszystkim przez cnotę moralną.

W swym fragmentarycznym i uwarunkowanym stylem apologetyczno-polemicznym przekazie o eschatologicznym niebie Justyn był zasadniczo kontynuatorem tradycji biblijnej (niebo miejscem Boga, Jezus zstępujący i wstępujący do nieba, piekło miejscem potępionych, niebo miejscem zbawionych), którą starał się łączyć z nauczaniem rabinackim I-II wieku (wątek drugiego millenium) oraz z filozofią grecką (tezy o zachowaniu świadomości w zaświatach przed sądem ostatecznym, eschatologiczne zognienie doczesnego świata, moralizm eschatologiczny). W Justynowym wykładzie wiary dotyczącym eschatologicznego nieba podkreślane zostały aspekty jakościowe zbawionych, szczególnie ich nieśmiertelność, niecierpiętliwość, nieskazitelność oraz bezżenność / niezamężność jako kategoria równości $\mathrm{z}$ aniołami.

\subsubsection{Tacjan Syryjczyk, Mowa do Greków - niebo jako „nieśmiertelność z radością”, osiągnięte dzięki dobrym wyborom duszy}

Tacjan pochodził z Mezopotamii lub Syrii (Mowa do Greków 42), po przybyciu do Rzymu przeszedł na chrześcijaństwo i stał się uczniem Justyna Męczennika. Po męczeństwie Justyna pozostawał przez jakiś czas w Rzymie. Był zwolennikiem enkratyzmu ${ }^{337}$, co doprowadziło go w roku 172 do zerwania więzi z Kościołem rzymskim (według Euzebiusza z Cezarei, Kro-

337 Od greckiego $\epsilon \nu \kappa \rho \alpha ́ \tau \epsilon\llcorner\alpha$ - „wstrzemię́liwość”; enkratyzm był heterodoksyjnym ruchem ascetycznym w Kościele II-III wieku, inspirującym się pogańskimi nurtami ascetycznymi, gardząc materialnością i ciałem ludzkim, enkratyci propagowali rygoryzm ascetyczny jako prawdziwe chrześcijaństwo: udzielali chrztu tylko tym, którzy uczynili ślub czystości, powstrzymywali się od spożywania wina i mięsa, odrzucali mał-

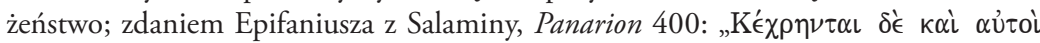

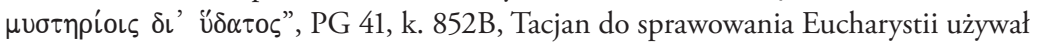
tylko wody zamiast wina, stąd jego zwolenników z czasem zaczęto nazywać acquarii (por. F. Bolgiani, encratismo, w: NDPAC 1, ed. A. Di Berardino, Genova-Milano $2006^{2}$, k. 1653-1655). 
niki 4, 29, 1). Ekskomunikowany ze wspólnoty rzymskich chrześcijan udał się do Mezopotamii, gdzie upowszechniał swe heterodoksyjne nauki ascetyczne. W duchu enkratyzmu i pesymizmu eschatologicznego głosił potępienie pierwszego człowieka, podobnie enkratystycznie interpolował Pismo Święte, zmieniając oryginalne zwroty biblijne i odrzucając Listy św. Pawła oraz Dzieje Apostolskie. Ułożył Diatesseron, będący enkratyczną harmonizacją czterech ewangelii kanonicznych (tekst grecki zaginął, istnieje w tłumaczeniu łacińskim, perskim, armeńskim i arabskim), zaginęły też jego inne traktaty: $O$ zwierzętach, $O$ doskonaleniu się wedtug Zbawiciela, Zagadnienia ${ }^{338}$. Zachowała się natomiast Mowa do Greków (napisana pomiędzy rokiem 166 a 172), apologia stawiającą sobie za cel obronę chrześcijaństwa poprzez zdecydowane odrzucenie tego, co greckie i poprzez atak na całość kultury helleńskiej339.

\section{Kontekst teologiczny nauki o niebie w Mowie do Greków}

Nauczanie o eschatologicznym niebie jest fragmentaryczne i nie przynależy do głównych nurtów antyhelleńskiej polemiki Tacjana. Passusy o niebie czy stanie człowieka po śmierci znajdujemy w kontekście wywodów przemawiających za zmartwychwstaniem $(6,3)$, w opowiadaniu o upadku aniołów $(7,1-3)$, o dwóch rodzajach duchów (12, 1-7), o naturze duszy ludzkiej (13,1-6), o karze dla demonów (14, 5-6), o próżnej mocy demonów (16. 1. 5-8) oraz o tym, że dziękczynienie należy się tylko Bogu (20, 2-6). W argumentacji moralnej, pomimo zadeklarowanej wrogości wobec tego, co greckie, Tacjan odwoływał się jednak do koncepcji stoickich. Jego teologia, prezentowana w Mowie do Greków, stanowi wypadkową trzech elementów: archaizującej teologii zbieżnej z myślą judeochrześcijańską I-II wieku (archaizująca pneumatologia i protologia; teoria o kosmicznym upadku aniołów), teologii II wieku zbieżnej z tą Justynową (opis

338 Por. L. Misiarczyk, Tacjan Syryjczyk. Mowa do Greków - Wstęp, w: Pierwsi apologeci greccy..., dz. cyt., BOK 24, Kraków 2004, s. 301-305; F. Bolgiani, Taziano, w: NDPAC 3, Genova-Milano 2008², k. 5205-5209.

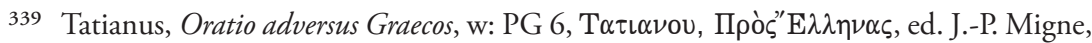
Facsimile of the 1857 Paris Edition, Athens 2001, k. 804-888; przekład polski Tacjan Syryjczyk, Mowa do Greków, w: Pierwsi apologeci greccy...., dz. cyt., BOK, 24, s. 301310 [wstęp], s. 311-355 [tekst]. 
Kształtowanie się nauki o niebie w teologii patrystycznej I-III wieku

pochodzenia Logosu, argumentacja za zmartwychwstaniem ciał, demonologia) oraz enkratycznej, czasami gnostycyzującej teologii moralnej (zradykalizowana, antymaterialnie nastawiona ascetyka i moralność) ${ }^{340}$.

\section{Protologia i antropologia Tacjana}

Zdaniem syryjskiego apologety człowiek pierwotnie stworzony jako nieśmiertelny przez Ducha i Logos na podobieństwo obrazu Boga Ojca, miał częściowy udział w życiu samego Boga ${ }^{341}$. Jednak posiadając wolną wolę, zbuntował się przeciw Prawu Bożemu i poszedł wraz z niektórymi aniołami za najbardziej inteligentnym $\mathrm{z}$ aniołów. Wtedy też człowiek utracił wspólnotę z Bogiem i stał się śmiertelny ${ }^{342}$. Człowiek, który oddalił się od Boga

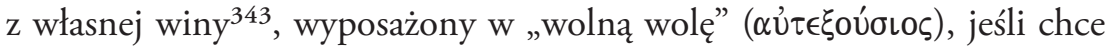
zjednoczyć się z Bogiem i wejść do nieba musi w doczesności zdobywać do-

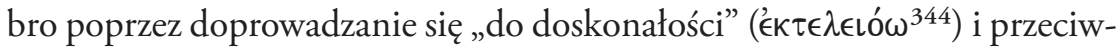
stawianie się „namiętnościom” ( $\pi \alpha \dot{\theta} \theta \in \mathrm{\epsilon} \nu)$, którym został poddany ${ }^{345}$. Tacjan, podobnie jak Justyn, odrzucając greckie pojęcie „fatum” (єi $\left.\mu \alpha \rho \mu \epsilon^{\prime} \nu \circ \varsigma\right)$, ak-

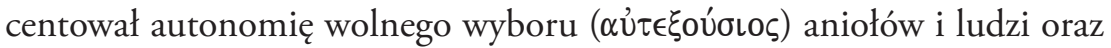
pedagogiczną etykę Logosu, który „zakazami starał się zapobiegać złu, natomiast pochwałami nagradzać dobro"346. Gdy istoty te wybrały życie wbrew

340 Por. G. Sfameni Gasparro, Enkrateia e antropologia. Le motivazioni protologiche della continenza e della verginità nel cristianesimo dei primi secoli e nello gnosticismo, Roma 1984, s. 32-56 (SEA 20); L. Misiarczyk, Tacjan Syryjczyk. Mowa do Greków - Wstęp, w: Pierwsi apologeci greccy..., dz. cyt., BOK, 24, s. 306.

341 Por. Tacjan Syryjczyk, Mowa do Greków 7,1, w: PG 6, k. 820B; BOK 24, s. 317-318.

342 Por. Tacjan Syryjczyk, Mowa do Greków 7,4-5, w: PG 6, k. 820C-821A; BOK 24, s. 318.

343 Por. Tacjan Syryjczyk, Mowa do Greków 8,1, w: PG 6, k. 821B; BOK 24, s. 318.

344 Tacjan Syryjczyk, Mowa do Greków 7,2, w: PG, 6, k. 820B; „Logos jednak, zanim stworzył człowieka, wcześniej jeszcze powołał do istnienia anioły. Oba te rodzaje stwo-

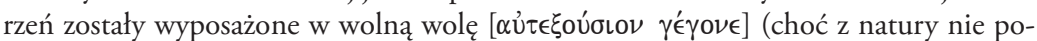
siadały tego dobra, które jest właściwe tylko samemu Bogu, a ludzie muszą je zdo-

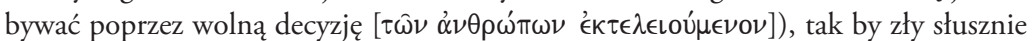
został ukarany za to, że sam z własnej winy stał się taki, natomiast sprawiedliwy słusznie otrzymał nagrodę za swoje dobre czyny dlatego, że nie wykorzystał wolnej woli, by przekroczyć wolę Boga", BOK 24, s. 318 .

345 Tacjan Syryjczyk, Mowa do Greków 8,2, w: PG 6, k. 824A; BOK 24, s. 319.

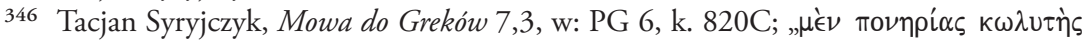

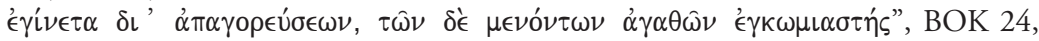
s. 318. 
woli Bożej, Logos pozostawił je „ich własnemu szaleństwu ( dy też człowiek „stał się śmiertelny ( $\theta \nu \eta$ tòs $\gamma(\nu \in \tau \alpha L)$ ”, utracił wspólnotę

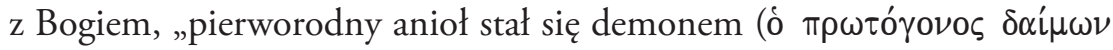

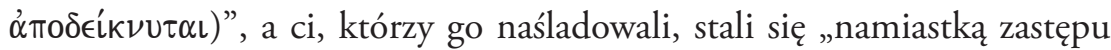

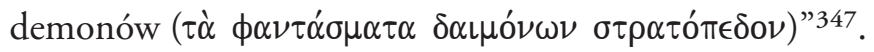

Wyraźnym elementem enkratyckim w tekście Mowy do Greków są postulaty o odrzuceniu materii jako złej i skłaniającej człowieka ku złu. Złe anioły otrzymały swą formę z „materii i przyjęły jej ducha, stając się nie-

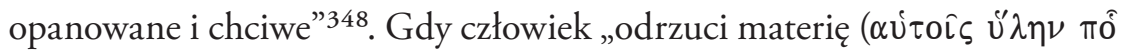
$\lambda \in \mu o v ̂ \sigma \iota)$ ", wtedy też posiądzie Ducha Bożego i przezwycięży demony ${ }^{349}$.

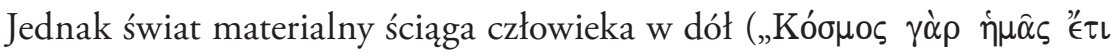
$\left.\kappa \alpha \theta^{\prime} \lambda \kappa \in \iota^{\prime \prime}\right)^{350}$. Tacjan, opisując działania wewnętrzne człowieka, odwoływał się pośrednio do trzeciej nauki Platona o metempsychozie. Apologeta syryjski stosował metaforę, według której przed grzechem skrzydłami duszy był Duch doskonały, natomiast po grzechu dusza porównana do małego ptaszka upadła na ziemię, pozostawiła związek z rzeczami niebiańskimi, a weszła w związek z rzeczami ziemskimi (według Platona, Fajdros 246a-249d - pierwotnie dusza byłaby uskrzydlonym powozem, ciągniętym przez dwa konie, dobrego i złego, a powożonym przez rozum). Kiedy źli aniołowie, już jako demony, zostali wyrzuceni z nieba, dusza została wypędzona z tzw. ziemi doskonałej, innej, urządzonej doskonale niż ta tutaj ${ }^{351}$.

Według przyjętej przez Tacjana trójdzielnej antropologii greckiej człowiek składałby się z ciała i dwóch rodzajów ducha: duszy i ducha większego od duszy, będącego obrazem i podobieństwem Boga. Dusza kierowałaby wyborami materialnymi człowieka, a duch tymi ponadmaterialnymi ${ }^{352}$.

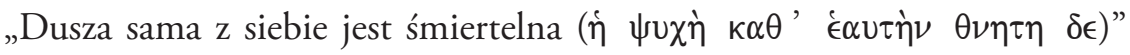
i umiera wraz z ciałem, może jednak nie umrzeć, kiedy w życiu doczesnym

347 Tacjan Syryjczyk, Mowa do Greków 7,5, w: PG 6, k. 821A; BOK 24, s. 318.

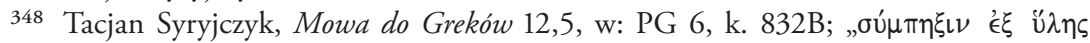

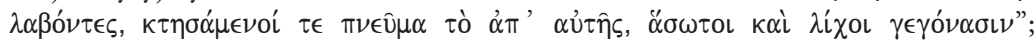
BOK 24, s. 324.

349 Por. Tacjan Syryjczyk, Mowa do Greków 16,7-8, w: PG 6, k. 841AB; BOK 24, s. 329.

350 Tacjan Syryjczyk, Mowa do Greków 20,1, w: PG 6, k. 852A; BOK 24, s. 333.

351 Por. Tacjan Syryjczyk, Mowa do Greków 20,2, w: PG 6, k. 852A; BOK 24, s. 324.

352 Por. Tacjan Syryjczyk, Mowa do Greków 12,1, w: PG 6, k. 829C; BOK 24, s. 323; Tacjan Syryjczyk, Mowa do Greków 15,1-3, w: PG 6, k. 837B; BOK 24, s. 327. 
Kształtowanie się nauki o niebie w teologii patrystycznej I-III wieku

zdobędzie poznanie Boga. Wtedy „całkowicie nie umiera, choć po śmier-

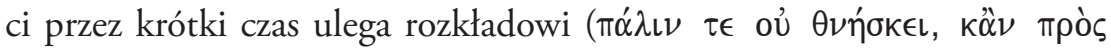

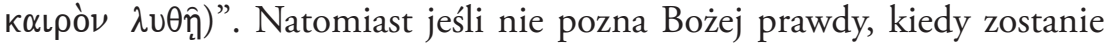
wskrzeszona wraz z ciałem przy końcu świata, nadal będzie doświadczała śmierci przez skazanie za karę na nieśmiertelnośćc ${ }^{353}$. Duch utrzymuje duszę w istnieniu, jeśli dusza działa sama, tj. ciągnie człowieka „w dół do

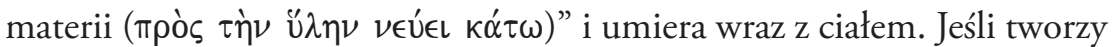

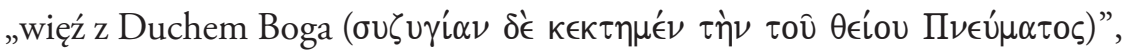
wtedy idzie do góry, tam, gdzie prowadzi ją Duch ${ }^{354}$. Do grzechu pierwszych ludzi Duch Boży stale był z duszą i prowadził ją, jednak po grzechu dusza sama z siebie nie jest w stanie poznawać rzeczy doskonałych i w poszukiwaniu Boga poszła za oszustwami demonów ${ }^{355}$. Duch Boży nie przebywa we wszystkich ludziach, ale tylko w sprawiedliwych, pomagając im wewnętrznie. Dusze posłuszne mądrości Boga przyciągają do siebie Ducha Boga, natomiast nieposłuszne, które odtrąciły Chrystusa

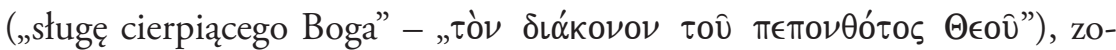
stały uznane za walczące z Bogiem ${ }^{356}$. Człowiek, któremu „poprzez wia-

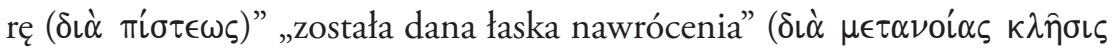

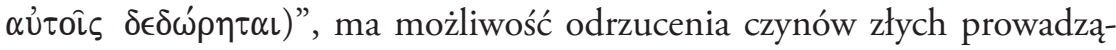
cych do śmierci ${ }^{357}$.

Po śmierci jednostkowej człowiek, już jako istota duchowa, zostaje

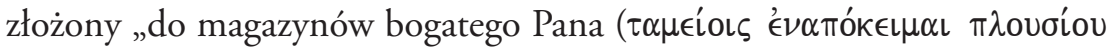
$\Delta \in \sigma \pi$ ó $0 u)$ ", skąd wszechmocą Boga zostanie powołany do życia ${ }^{358}$. Wbrew tezie stoików o cykliczności kosmosu, Tacjan przytaczał chrześcijańską

\footnotetext{
353 Tacjan Syryjczyk, Mowa do Greków 13,1, w: PG 6, k. 833B; BOK 24, s. 325.

354 Tacjan Syryjczyk, Mowa do Greków 13,2-3, w: PG 6, k. 833B; BOK 24, s. 325-326 (por. Tacjan Syryjczyk, Mowa do Greków 16,5, w: PG 6, k. 841AB; BOK 24, s. 329).

355 Por. Tacjan Syryjczyk, Mowa do Greków 13,4, w: PG 6, k. 833B; BOK 24, s. 326.

356 Por. Tacjan Syryjczyk, Mowa do Greków 13,5-6, w: PG 6, k. 833C.836A; BOK 24, s. 326.

357 Tacjan Syryjczyk, Mowa do Greków 15,9-10, w: PG 6, k. 840B; BOK 24, s. 328 (por. Tacjan Syryjczyk, Mowa do Greków 11,4, w: PG 6, k. 829B; BOK 24, s. 323).

358 Tacjan Syryjczyk, Mowa do Greków 6,4, w: PG 6, k. 820A; „Gdyby jednak nawet ogień zniszczył moją powłokę cielesną, wszechświat przyjmie lotna materię albo gdybym utopił się w rzece lub w morzu bądź też został rozszarpany przez dzikie zwierzęta, zostanę złożony do magazynów bogatego Pana", BOK 24, s. 317.
} 
2. Kształtowanie się nauki o niebie w teologii patrystycznej - wiek I-II

wiarę, że przy końcu świata nastąpi ostateczne zmartwychwstanie ciał ${ }^{359}$, a ludzie zostaną wskrzeszeni na sąd Boga Stwórcy ${ }^{360}$.

\section{Kosmologia i nauka o niebie}

Zarówno terminologia, jakiej Tacjan używa na określenie eschatologicznego nieba ${ }^{361}$, jak i jego eschatologiczne wywody mają konotację biblijną. Uwagi Roberta M. Granta tym, że Tacjan, stosując np. pojęcie $\alpha \mathbf{\imath} \omega \hat{\nu \in \varsigma}$ (Mowa do Greków 20, 4), odwoływał się do „eonu pleromy”, według terminologii walentynian, zostały obalone przez Emily J. Hunt, która wykazała, że Tacjan, mówiąc o dziele stworzenia, wcale nie odnosił się do walentyniańskiego emanatyzmu (mit pleromy o podziale boskiej natury), ale do biblijnego przekazu o stworzeniu (zasada Bożego uporządkowania stworzenia przez harmonię piękna i duchowości), a sam termin $\alpha i \omega \hat{\imath} \in \varsigma$ był użyty przez Tacjana w znaczeniu nowotestamentalnym i oznaczał „świat” (por. Mt 13, 22; Mk 4, 19; Łk 16, 8; Rz 12, 2; 2 Kor 4, 4; Ef 2, 2; 1 Tm 6, 17; $2 \operatorname{Tm} 4$, 10; Tt 2, 12; Hbr 11, 3). Co więcej, technicznym terminem walentyniańskim opisującym emanacje było słowo $\pi \rho \circ \beta o \lambda \eta ́$. Podobnie użycie przez Tacjana terminu $\sigma u \zeta u \gamma\llcorner\alpha$ na opisanie unii pomiędzy duszą i Bożym Duchem (Mowa do Greków 13, 2; 15, 1) wskazuje na proces odkupienia i wyraża zjednoczenie pomiędzy tym, co boskie a co ludzkie i nie jest (jak chciałby Grant) terminem walentyniańskim oznaczającym „powrót pneumatycznych cząstek do pleromy” czy „boską więź eonów w parach”. Analogicznie, identyfikacja przez Granta „ziemi innej, urządzonej doskonalej niż ta tutaj”

359 Por. Tacjan Syryjczyk, Mowa do Greków 6,1, w: PG 6, k. 817B; „I dlatego wierzymy, że przy końcu świata będzie miało miejsce zmartwychwstanie ciał. Nie w taki sposób jednak, jak nauczają stoicy, tzn. że te same rzeczy cyklicznie będą powracać i znowu niszczeć bez celu, ale raz na zawsze, gdy okresy naszej egzystencji zakończą swój bieg ( $\tau \omega \hat{\omega} \nu \kappa \alpha \theta^{\prime} \dot{\eta} \mu \hat{\alpha} \varsigma \alpha i \omega^{\prime} \nu \omega \nu \quad \pi \epsilon \pi \epsilon \rho \sigma \mu \epsilon^{\prime} \nu \omega \nu$ ), a będzie to dotyczyło tylko ludzi, którzy zmartwychwstaną na sąd", BOK 24, s. 317.

360 Por. Tacjan Syryjczyk, Mowa do Greków 6,4, w: PG 6, k. 820A; „(...). Biedny ateusz

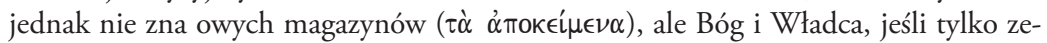
chce, może przywrócić do stanu początkowego tę substancję, która tylko Jemu jest

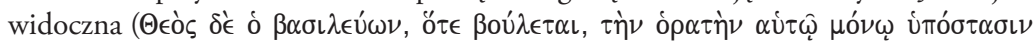

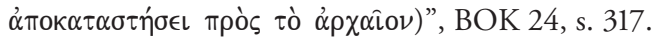

361 Por. R. M. Grant, The heresy of Tatian, „Journal of Theological Studies (New Series)” 5 (1954), s. 62-68; E. J. Hunt, Christianity in the Second Century. The Case of Tatian, London-New York 2003, s. 22-45. 
Kształtowanie się nauki o niebie w teologii patrystycznej I-III wieku

(Mowa do Greków 20, 2), z rajem gnostyckim według Theodota, jest błędna, gdyż Tacjan raczej sugerował biblijny ogród w Eden, a nie gnostycki „raj” / „czwarte niebo”. Podobnie nie ma paraleli pomiędzy zastosowaniem przez Tacjana Pawłowego sformułowania o „przyobleczeniu ciała w nieśmiertelność" (Mowa do Greków 20, 6; por. 2 Kor 5, 2-4) a egzegezą walentyniańską o wyzwoleniu boskich cząstek zagubionych w ciele pneumatyków i symbolicznej interpretacji małżeństwa pomiędzy pneumatykiem a boskim partnerem ${ }^{362}$.

W Mowie do Greków 5 Tacjan powtarza protologiczne i kosmologiczne poglądy Justyna Męczennika o Logosie. Podobne zależności ucznia od mistrza widać również w Tacjanowym opisie stworzenia jako uporządkowania materii, opisie końca świata, opisie dnia sądu oraz opisie fizycznych jakości zmartwychwstania. Eschatologia Tacjana nie ma natomiast odniesienia do, obecnych u Justyna, dwóch paruzji, drugiego millenaryzmu i odniesień apokaliptycznych. Idea obdarzenia przez Boga każdej rzeczy stworzonej duszą materialną powstała u Tacjana prawdopodobnie pod wpływem idei stoickich. Podobnie jak u Justyna, także u Tacjana nie ma natomiast odniesień do gnostyckiej kosmologii. Optyka eschatologii Tacjana, jak wcześniej Justyna, pozostaje soteriologiczna ${ }^{363}$.

W Mowie do Greków znajdujemy zatem następujący zarys kosmologii i nauki o eschatologicznym niebie. Bóg stworzył bezładną i bezkształtną

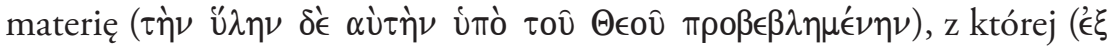

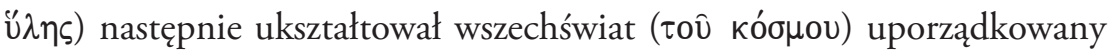
i piękny (’’

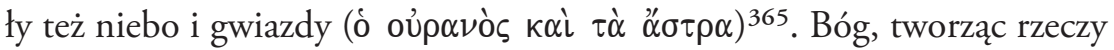
materialne, nadawał im splendor i strukturalną funkcjonalność według za-

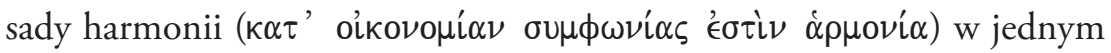

362 Por. E. J. Hunt, Christianity in the Second Century..., dz. cyt., s. 71-74 (por. też Klemens Aleksandryjski, Wypisy z Theodota 51,1, w: SCh 23, s. 164; ŹMT 22, tlum. i oprac. P. Siejkowski, Kraków 2001, s. 60).

363 Por. L. W. Barnard, Justin Martyr's Eschatology, „Vigiliae Christianae” 19 (1965), s. 86 98; S. P. Brock, Studies in Syriac Christianity: History, Literature and Theology, Aldershot 1992, XI; E. J. Hunt, Christianity in the Second Century..., dz. cyt.,s. 130-133.

364 Tacjan Syryjczyk, Mowa do Greków 12,2, w: PG 6, k. 829C; BOK 24, s. 323.

365 Tacjan Syryjczyk, Mowa do Greków 12, 2, w: PG 6, k. 832A; BOK 24, s. 323. 
organizmie wszechświata $^{366}$, a każda z rzeczy stworzonych otrzymała swego materialnego ducha ${ }^{367}$. Z woli Stwórcy obecny świat dobiegnie kresu, rozpadnie się i zostanie przez Boga osądzony ${ }^{368}$. Po zmartwychwstaniu ciał człowiek ze względu na swe czyny ma otrzymać „nieśmiertelność

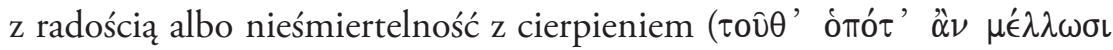

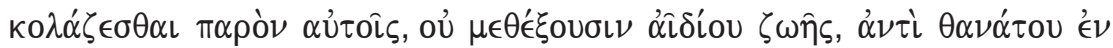
$\dot{\alpha} \theta \alpha \nu \alpha \dot{\alpha} \omega \mu \epsilon \tau \alpha \lambda \alpha \mu \beta \alpha \dot{\alpha} \nu 0 \nu \tau \epsilon \zeta) " 369$.

Eschatologiczne niebo, zdaniem Tacjana, stanowi rodzaj Bożej nagrody za dobre życie (por. Mowa do Greków 20, 4), stąd autor ten uwypukla przede wszystkim jakość życia wiecznego. Podobnie jak u Justyna Męczennika, także i u Tacjana dostrzegamy brak soteriologii łaski (gdzie szczęśliwa wieczność jest konsekwencją wyboru Jezusa), natomiast obserwujemy perspektywę moralnego zasługiwania na szczęśliwe życie wieczne. Eschatologia moralistycznego zasługiwania jest u Tacjana podyktowana prawdopodobnie przyjętą przezeń literacką formą apologii, w ramach której autor ten bardziej próbuje przybliżyć chrześcijańskie przesłanie przez bliskie filozofii antycznej rozsądne postępowanie moralne, niż używać wynikających z objawienia argumentacji darmowej łaski i więzi z Jezusem. Opis wizji takiego wypracowanego przez zasługi nieba znajdujemy w Mowie do Greków 20, 4-6:

„20.4. Toteż, jeśli tęskniąc za owym pierwotnym stanem życia, chcemy do niego powrócić, powinniśmy odrzucić wszystko, cokolwiek by temu przeszkadzało. Niebo, o człowiecze, nie jest nieskończone, ale skończone i ograniczone. Ponad nim istnieją wyższe światy, które nie mają zmieniających się pór roku (to właśnie z ich powodu powstają równe choroby), ale panuje tam łagodny klimat, bez przerwy trwa dzień i ciagle

366 Tacjan Syryjczyk, Mowa do Greków 12,3, w: PG 6, k. 831AB; BOK 24, s. 324.

367 Tacjan Syryjczyk, Mowa do Greków 12,8, w: PG 6, k. 832C; „Choć więc jeden i ten sam duch jest w gwiazdach, aniołach, roślinach i wodzie, ludziach i zwierzętach, to jednak

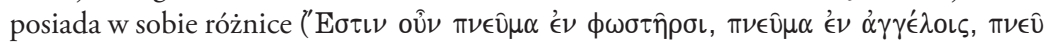

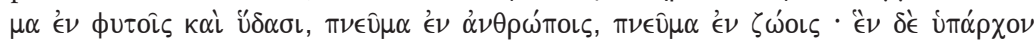

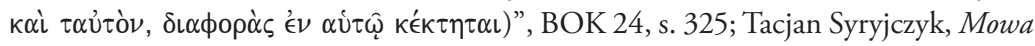

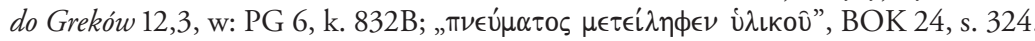

368 Por. Tacjan Syryjczyk, Mowa do Greków 12,7, w: PG 6, k. 832C; BOK 24, s. 324.

369 Tacjan Syryjczyk, Mowa do Greków 14,5, w: PG 6, k. 830BC; BOK 24, s. 327. 
Kształtowanie się nauki o niebie w teologii patrystycznej I-III wieku

panuje światłość niedostępna ludziom z dołu. 20.5. Geografowie próbowali na miarę ludzkich sił opisać te rejony, ale ponieważ nie potrafili powiedzieć nic o tym, co jest ponad nimi (ze względu na niemożliwość osobistej obserwacji), określili je jako odpływy, zalewy czy morza, z których jedno jest jakby lazurowe, inne zaś wypełnione mułem, wreszcie jeszcze inne jako miejsca spalone ogniem lub zimne i mroźne. 20.6. My natomiast poznaliśmy te rzeczy nieznane dzięki nauczaniu proroków, którzy, wiedząc doskonale, że jeśli razem z duszą Duch niebieski przyjmie ciało jako odzienie i pancerz chroniący je przed śmiercią przyoblecze w nieśmiertelność, przepowiedzieli podobne rzeczy również innym duszom. Jeśli więc rzeczą możliwą dla każdego, kto jest nagi, przyoblec się w ten pancerz i powrócić do dawnego stanu, w jakim na początku został stworzony" ${ }^{370}$.

Niebo, w jakie wierzył Justyn, stanowiłoby dla człowieka powrót do kiedyś utraconego („powrócić do dawnego stanu, w jakim na początku został stworzony”, Mowa do Greków 20, 6), a teraz utęsknionego „pierwotnego stanu życia”, czyli przede wszystkim do „nieśmiertelności i posiadania przynajmniej częściowego udziału w życiu samego Boga” (por. Mowa do Greków 7, 1). Tacjan, odwołując się prawdopodobnie do 1 Kor 15, 53-54, podkreśla jakość „nieśmiertelności” zbawionych, którą uzyskują oni dzięki ścisłej więzi ciała i duszy z Duchem niebieskim, dzięki Któremu ciało staje

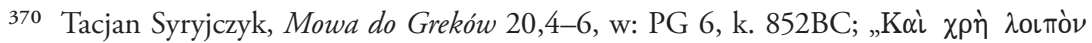

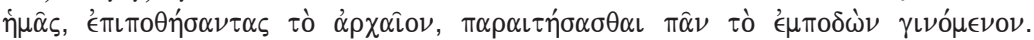

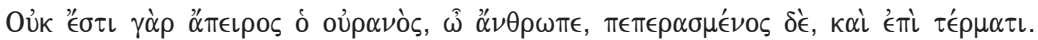

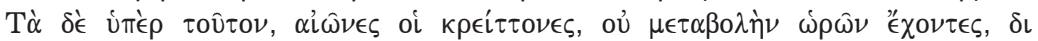

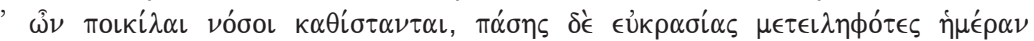

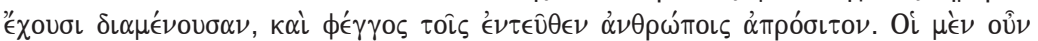

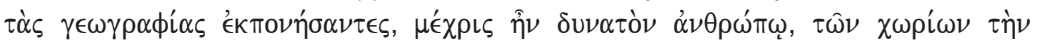

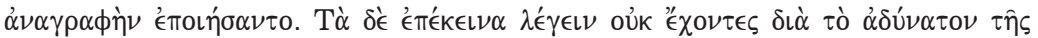

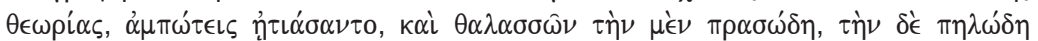

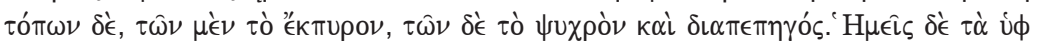

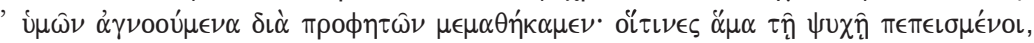

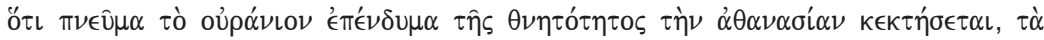

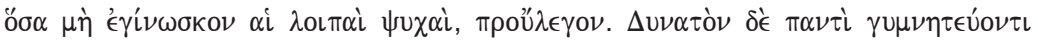

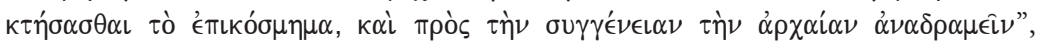
BOK 24, s. 334. 
się odzieniem i pancerzem nieśmiertelności (,jeśli razem z duszą Duch niebieski przyjmie ciało jako odzienie i pancerz chroniący je przed śmiercią przyoblecze w nieśmiertelność”, Mowa do Greków 20, 6).

Tacjan nie nazywa nieba „ogrodem w Eden”, choć w jego opisie przyjmuje ono niektóre z charakterystyk zarówno biblijnego ogrodu z Rdz 2, 8-15 (woda; łagodny klimat), jak i Niebieskiego Miasta z Ap 21 (ciąły dzień; światłość). Eschatologiczne niebo jest zatem gdzieś powyżej ziemi (por. „ciągle panuje światłość niedostępna ludziom z dołu”, Mowa do Greków 20, 4), jest niemożliwe do opisania przez ludzi z ziemi, gdyż ,jest ponad nimi; ze względu na niemożliwość osobistej obserwacji” (Mowa do Greków 20, 5), jest „skończone i ograniczone”, choć istnieją ponad nim wyższe światy z niezmiennymi porami roku, łagodnym klimatem, ciągłym dniem i ciągłą światłością (Mowa do Greków 20, 4). Jest natomiast możliwe do jakiegoś wstępnego poznania w wierze („My natomiast poznaliśmy te rzeczy nieznane dzięki nauczaniu proroków”, Mowa do Greków 20, 6).

\subsubsection{Meliton z Sardes, Homilia Paschalna - Chrystus wprowadza zbawionych na wyżyny niebiskie}

W tekście Homilii Paschalnej371 (napisanej pomiędzy rokiem 160 a 170) ${ }^{372}$, która jako gatunek literacki bliższa jest deklamacji liturgicznej (np. późniejszemu, gallikańskiemu Exsultet vel Praeconium Paschale ${ }^{373}$ ), Meliton, biskup Sardes, typologicznie objaśniał opis zabicia baranka paschalnego, a następnie zgodnie z tym samym kluczem interpretacyjnym (wzór

371 Melito Sardensis, De Pascha, w: SCh 123. Méliton de Sardes, Sur la Pâque et fragments. Introduction, texte critique, traduction et notes par O. Perler, Paris 1966; przekład polski Meliton z Sardes, Homilia paschalna, w: Pierwsi świadkowie. Pisma Ojców..., dz. cyt., BOK, 10, s. 308-333.

372 Tak sądził Otto Perler, Introduction, w: SCh 123, s. 24.

373 Por. R. Cantalamessa, I più antichi testi pasquali della Chiesa. Le omelie di Melitone di Sardi e dell'Anonimo Quartodecimano e altri testi del II secolo, Introduzione, traduzione e commento di R. Cantalamessa, Roma 1991, s. 16. Najstarsze manuskrypty zawierające Exsultet pochodzą z liturgii gallikańskiej z VII wieku (por. The Bobbio Missal: Liturgy and Religious Culture in Merovingian Gaul, ed. Y. Hen, R. Meen, Cambridge 2004; G. Fuchs, H. M. Weikmann, Das Exsultet. Geschichte, Theologie und Gestaltung der österlichen Lichtdanksagung, Regensburg 2005²). 
Kształtowanie się nauki o niebie w teologii patrystycznej I-III wieku

i zapowiedź dopełnione przez urzeczywistnienie) opisywał, jak figury i zapowiedzi zbawczych wydarzeń ST realizowały się w NT ${ }^{374}$.

\section{Terminy odnoszące się do nieba}

Nazewnictwo stosowane przez Melitona ma pochodzenie nowotestamen-

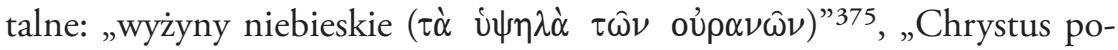

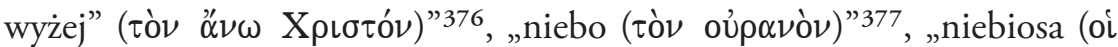

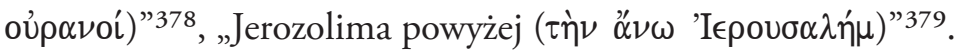

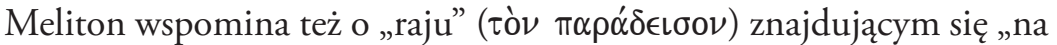

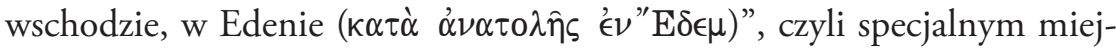
scu stworzonym przez Boga, gdzie człowiek „żył w szczęśliwości” ('€́ લ̂́ $\tau \rho u \phi \hat{\alpha} \nu)^{380}$. Meliton zgodnie z teologią biblijną przekazuje, iż nie była to jednak rzeczywistość eschatologicznie ostateczna. W jego interpretacji raj

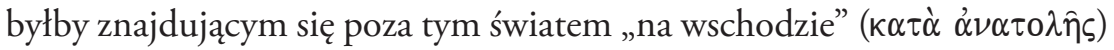
miejscem pierwszej, niestety nieudanej dla człowieka, próby wierności wobec Boga (poprzez zły wybór moralny, złamanie przykazania i nieposłu-

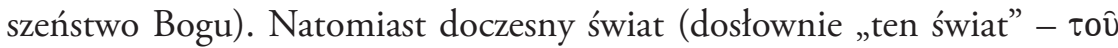

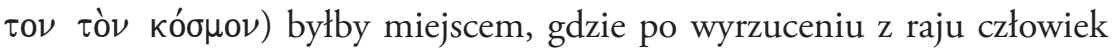

374 Por. O. Perler, Introduction, w: SCh 123, s. 29-32.

375 Meliton z Sardes, Homilia Paschalna 47, w: SCh 123, s. 84; BOK 10, s. 317; Meliton z Sardes, Homilia Paschalna 70, w: SCh 123, s. 98 (por. Ef 1, 20); BOK 10, s. 322 (por. Mk 16, 19; Dz 1, 11; 1 Tm 3, 16); Meliton z Sardes, Homilia Paschalna 100, w: SCh 123, s. 120; BOK 10, s. 329; Meliton z Sardes, Homilia Paschalna 102, w: SCh 123, s. 122; BOK 10, s. 330; Meliton z Sardes, Homilia Paschalna 103, w: SCh 123, s. 122; BOK 10, s. 330 (por. Ef 4, 8-10); Meliton z Sardes, Homilia Paschalna 104, w: SCh 123, s. 124; BOK 10, s. 331 (por. Mk 16, 19; Dz 1, 2. 11. 22; $1 \mathrm{Tm} \mathrm{3,} \mathrm{16).}$

376 Meliton z Sardes, Homilia Paschalna 45, w: SCh 123, s. 84; BOK 10, s. 316 (por. Ap 21, 22).

377 Meliton z Sardes, Homilia Paschalna 47, w: SCh 123, s. 84; BOK 10, s. 317 (por. Rdz 1, 2; $2,4)$.

378 Meliton z Sardes, Homilia Paschalna 98, w: SCh 123, s. 118; BOK 10, s. 329 (por. Ps 17, 14).

379 Meliton z Sardes, Homilia Paschalna 45, w: SCh 123, s. 84; BOK 10, s. 316 (por. Ga 4, 26; Hbr 12, 22; Ap 3, 12; 21, 2-5).

380 Por. Meliton z Sardes, Homilia Paschalna 47, w: SCh 123, s. 84.86; „(...) Bóg przez swoje Słowo stworzył na początku niebo i ziemię i wszystko, co w nich jest, a następnie ulepił z prochu ziemi człowieka i jego kształtowi dał tchnienie życia. Tego człowieka umieścił w raju, na wschodzie, w Edenie, aby żył tam szczęśliwie”, BOK 10, s. 317 (por. $\operatorname{Rdz} 2,8.16$ ). 
został wtrącony "jak w więzienie dla skazańców ( $\kappa \alpha \tau \alpha \delta i ́ \kappa \omega \nu) " 381$.

\section{Chrystus - sposobem na wejścia człowieka do nieba}

Meliton, w kontekście zestawień typologicznych ST z NT, wspominał o niebie jedynie okazjonalnie, wskazując, że tajemnica zbawienia jest związana z Paschą Chrystusa, której znaczenie wywodził on „od $\pi \alpha \theta \in \hat{\iota} \nu$ (doznać cierpienia) pochodzi $\pi \alpha ́ \alpha \chi \in \iota \nu$ (cierpieć albo obchodzić Paschę)"382, a spo-

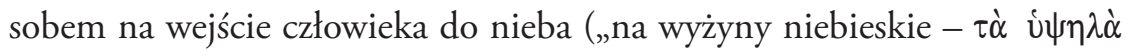
$\tau \hat{\omega} \nu$ oủ $\alpha \nu \hat{\omega} \nu$ ”) jest jedynie Chrystus ${ }^{383}$. Dlatego po Jego przyjściu na

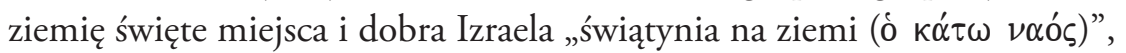

381 Meliton z Sardes, Homilia Paschalna 48, w: SCh 123, s. 86; „Ponieważ zaś człowiek jest z natury skłonny do przyjmowania dobrego i złego, jak skiba ziemi przyjmująca ziarno ze stron obu, przyjął też doradcę wrogiego i żarłocznego: a dotknąwszy drzewa, przekroczył przykazanie i stał się nieposłuszny Bogu. Został więc wyrzucony [i wtrącony]

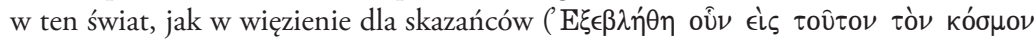

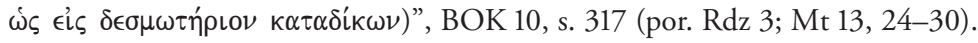

382 Meliton z Sardes, Homilia Paschalna 46, w: SCh 123, s. 84; BOK 10, s. 317 . Zgodnie z terminem średnio-hebrajskim פספ (polskim „przejść”, „skoczyć”) znaczenie termi-

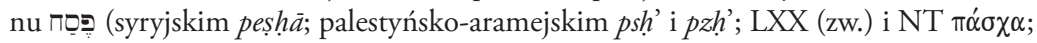

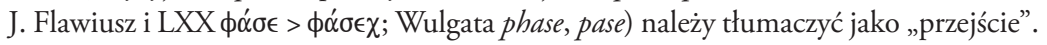
Por. t. 2, red. L. Koehler, W. Baumgartner, J. J. Stamm, [red. nauk. wyd. pol. P. Dec], Warszawa 2008, s. 35-36 (Prymasowska Seria Biblijna [dalej: PSB] 30). Natomiast Meliton użył w tekście terminu đó $\sigma \chi \epsilon \nu \nu$ („czynić Paschę”, co ciekawe G. W. H. Lampe, A Patristic Greek Lexicon, Oxford $1991^{10}$ nie odnotowuje tego znaczenia), co zauważył natomiast R. Cantalamessa, La Pasqua nella Chiesa antica, Torino 1978 (Traditio Christiana III), s. 22, przypis 1 . Ten ostatni badacz podkreśla, że naiwne wyjaśnienie etymologii terminu pascha bierze się stąd, iż termin hebrajski byłby wyprowadzany od terminu greckiego - powstało najpierw u Filona Aleksandryjskiego, De congressu eruditionis gratia 106 („Pascha duszy oznacza przejście od wszelkiej pasji i od wszelkiej rzeczy zmysłowej w kierunku «dziesiątego, czyli w kierunku tego, co jest inteligibilne i boskie»"), zostało następnie przejęte przez środowisko azjatyckich kwartodecymanów. Pomimo krytyki takiej etymologii, jaką w III wieku przeprowadził Orygenes, schemat pascha-pathos przyjął się szczególnie w Kościele łacińskim.

383 Por. Meliton z Sardes, Homilia Paschalna 47, w: SCh 123, s. 84; „Dowiedzcie się zatem, kim jest ten, kto cierpi, i kim ten, kto z cierpiącym współcierpi i dlaczego Pan przyszedł na ziemię: aby przyoblekłszy się w cierpiącego wyniósł go na wyżyny nie-

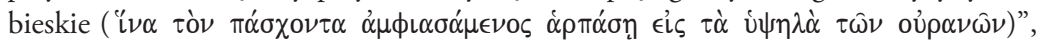
BOK 10, s. 317. 
Kształtowanie się nauki o niebie w teologii patrystycznej I-III wieku

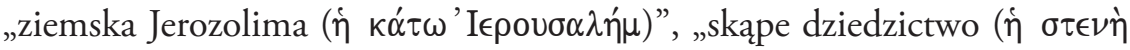
$\kappa \lambda \eta \rho о \nu о \mu i ́ \alpha) ”$, „nie w jednym miejsce i nie na małym strzępie ziemi (/ oủ

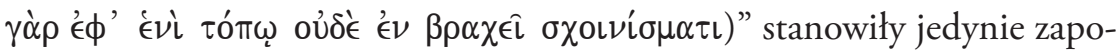
wiedź i straciły swą wartość, gdyż ich urzeczywistnieniem są miejsca i dobra uświęcone łaską Chrystusa („Chrystus powyżej / w niebie (

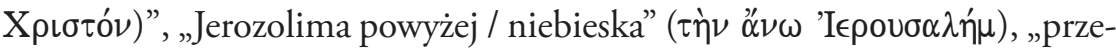

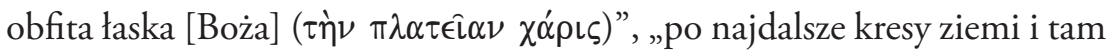
właśnie Bóg wszechmocny rozbił swój namiot przez Jezusa Chrystusa (/ $\alpha \lambda \lambda$

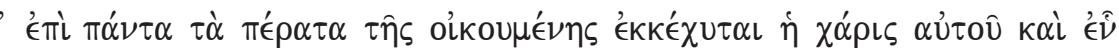

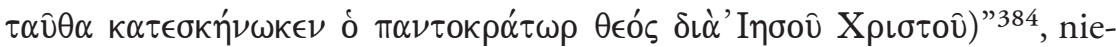
nawrócony Izrael jest martwy, a Chrystus po zmartwychwstaniu „wstąpił

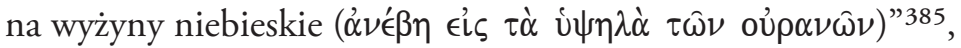

Chrystus jako Ten, który zniszczył śmierć, zwyciężył i pozbawił mocy diabła i piekło - domenę tego ostatniego, jest też Tym, który oznaj-

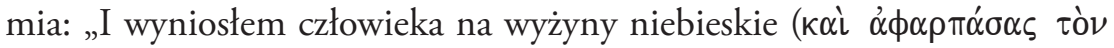

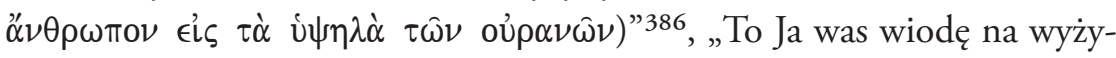
ny niebieskie. To ja wam pokażę Ojca przedwiecznego. To ja was wskrze-

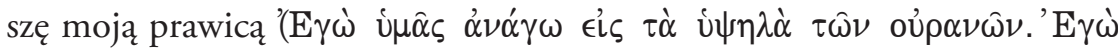

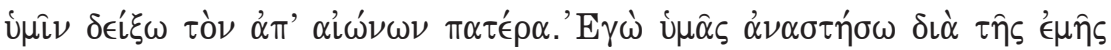
$\delta \epsilon \xi\llcorner\hat{\alpha} \varsigma)$ "387. Chrystus jako Stwórca nieba i ziemi i człowieka ${ }^{388}$ dokonuje dzieła zbawienia, które wieńczy swoim zmartwychwstaniem i wstąpieniem

384 Meliton z Sardes, Homilia Paschalna 45, w: SCh 123, s. 84; „Cenna świątynia na ziemi, a dziś bez wartości, gdyż jest Chrystus powyżej [w niebie], cenna ziemska Jerozolima, a dziś bez wartości, gdyż jest Jerozolima powyżej [niebieska], cenne skąpe dziedzictwo, a dziś bez wartości, gdyż przeobfita jest łaska. Nie w jednym bowiem miejscu i nie na małym strzępie ziemi zamieszkałą Chwała Boża, lecz Łaska Jego rozlała się aż po najdalsze kresy ziemi i tam właśnie Bóg wszechmocny rozbił swój namiot przez Jezusa Chrystusa, któremu chwała na wieki. Amen”, BOK 10, s. 316-317.

385 Meliton z Sardes, Homilia Paschalna 100, w: SCh 123, s. 120; BOK 10, s. 329.

386 Meliton z Sardes, Homilia Paschalna 102, w: SCh 123, s. 122; BOK 10, s. 330.

387 Meliton z Sardes, Homilia Paschalna 103, w: SCh 123, s. 122; BOK 10, s. 330.

388 Por. Meliton z Sardes, Homilia Paschalna 104, w: SCh 123, s. 124; „On jest Ten, któ-

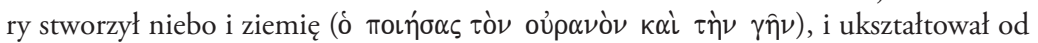

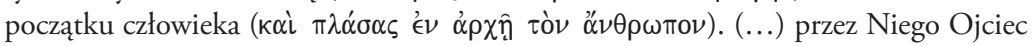

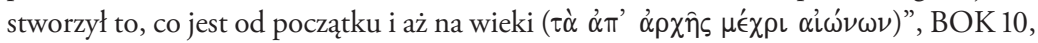
s. $330-331$. 
2. Kształtowanie się nauki o niebie w teologii patrystycznej - wiek I-II

na wyżyny niebieskie ${ }^{389}$. Chrystus przebywający w niebie ma moc sądzenia i zbawienia wszystkiego ${ }^{390}$, a jako zasiadający po prawicy Ojca - ob-

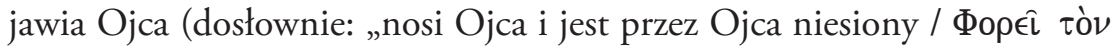

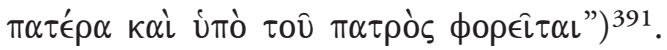

\section{Cechy Paschy Chrystusa - cechami zbawionych w niebie}

$\mathrm{Na}$ zasadzie przeciwieństw i dopełnienia Paschy żydowskiej w Passze

Chrystusa - ta ostatnia, będąc znakiem i tajemnicą zbawienia dokonanego w Chrystusie ${ }^{392}$, który jest Bogiem i człowiekiem (o a $\left.\alpha \theta \rho \omega \pi \circ \varsigma \theta \epsilon o ́ \varsigma\right){ }^{393}$, zawierając Jego osobowe cechy, świadczy też pośrednio o cechach zbawionych przez Niego, gdyż On jest symbolem i zapowiedzią oraz modelem przyszłości, rzeczywistości i prawdziwości ${ }^{394}$, obdarzającym wie-

389 Por. Meliton z Sardes, Homilia Paschalna 104, w: SCh 123, s. 124; „On powstał z mar-

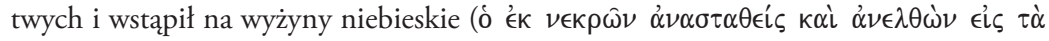
ư $\psi \lambda \lambda \dot{\alpha} \tau \hat{\omega} \nu$ oủp $\alpha \nu \hat{\omega} \nu) ”$, BOK 10, s. 331.

390 Por. Meliton z Sardes, Homilia Paschalna 104, w: SCh 123, s. 124; „On zasiada po

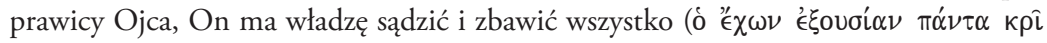

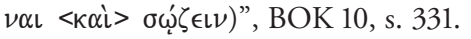

391 Meliton z Sardes, Homilia Paschalna 105, w: SCh 123, s. 126; BOK 10, s. 331. Zdaniem Raniera Cantalamessy, Méliton de Sardes. Une christologie antignostique du II siècle, w: R. Cantalamessa, Dal kerygma al dogma. Studi sulla cristologia dei Padri Milano 2006, s. 241-263 (Studia Patristica Mediolanensia 26), chrystologia Melitona była wybitnie antygnostycka, o czym świadczą rozwijanie w Homilii Paschalnej tematyki boskości Chrystusa, Jego Wcielenia z Maryi, Jego doskonałego człowieczeństwa oraz koegzystencji Jego dwóch natur,

392 Por. Meliton z Sardes, Homilia Paschalna 5-6, w: SCh 123, s. 62.64; „5. Zamiast baranka Bóg przyszedł, i zamiast owcy człowiek, a w człowieku Chrystus, który ogarnie wszystko. 6. Tak więc zabicie baranka i uroczystość Paschy i litera Prawa wypełniły się w Chrystusie Jezusie, do którego zmierzało wszystko w Starym Prawie, a tym bardziej jeszcze w porządku nowym”, BOK 10, s. 309.

393 Por. Meliton z Sardes, Homilia Paschalna 7-9, w: SCh 123, s. 64; „7. Prawo bowiem także stało się Słowem, stare stało się nowym - jedno i drugie wyszło z Syjonu i z Jerozolimy - i przykazanie stało się łaską, i figura rzeczywistością, i baranek Synem, i owca człowiekiem, i człowiek Bogiem. 8. Zaiste, zrodzony jak Syn, prowadzony na rzeź jak baranek, złożony na ofiarę jak owca, i pogrzebany jak człowiek, powstał z martwych jak Bóg, gdyż z natury był Bogiem i człowiekiem. 9. On sam jest wszystkim: prawem, jako że sądzi, Słowem, jako że uczy, łaską jako że zbawia, Ojcem, jako że daje życie, Synem, jako że otrzymuje życie, barankiem, jako że cierpi, człowiekiem, jako że jest pogrzebany, Bogiem, jako że zmartwychwstaje”, BOK 10, s. 309.

394 Por. Meliton z Sardes, Homilia Paschalna 35-38, w: SCh 123, s. 78.80; BOK 10, s. 314-315. 
Kształtowanie się nauki o niebie w teologii patrystycznej I-III wieku

rzących Mu - Jego darami: odpuszczenia grzechów, zbawienia, życia, zmartwychwstania, światła, wejścia na wyżyny niebieskie, ukazania Ojca przedwiecznego $^{395}$.

Meliton wymienia cztery podstawowe cechy Paschy Chrystusa, jest ona:

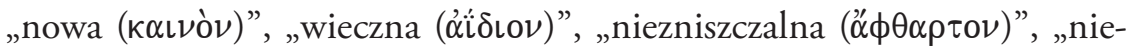

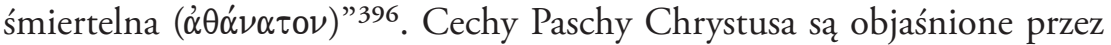
Melitona na zasadzie antytezy w kluczu chrystologicznym. I tak: (1) nowa,

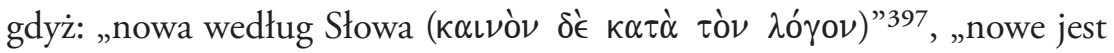

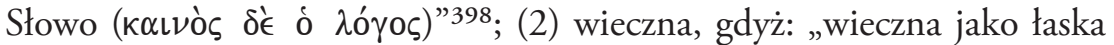

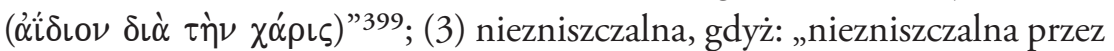

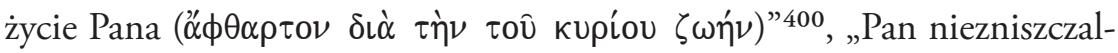

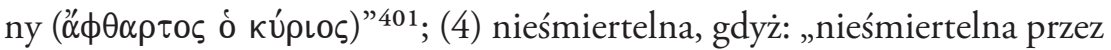

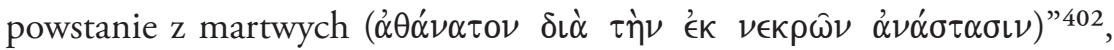

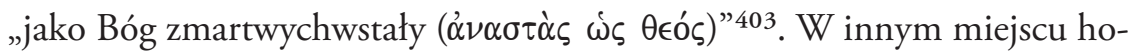
milii Meliton zaznacza, iż Chrystus, dokonując zbawienia, obdarza

395 Por. Meliton z Sardes, Homilia Paschalna 103, w: SCh 123, s. 122; „Ja bowiem jestem waszym odpuszczeniem, Ja - Pascha zbawienia, Ja - baranek za was ofiarowany, Ja wasz okup, Ja - życie wasze, Ja - zmartwychwstanie wasze, Ja - światło wasze, Ja zbawienie wasze, Ja - król wasz. To ja was wiodę na wyżyny niebieskie, To Ja wam pokażę Ojca przedwiecznego. To Ja was wskrzeszę moją prawicą", BOK 10, s. 330.

396 Meliton z Sardes, Homilia Paschalna 2, w: SCh 123, s. 60; „Nowa i stara, wieczna i przemijająca, zniszczalna i niezniszczalna, śmiertelna i nieśmiertelna jest tajemnica Paschy", BOK 10, s. 308.

397 Meliton z Sardes, Homilia Paschalna 3, w: SCh 123, s. 60; „Stara według Prawa, nowa według Słowa”, BOK 10, s. 308.

398 Meliton z Sardes, Homilia Paschalna 4, w: SCh 123, s. 62; „Stare jest Prawo, nowe jest Słowo", BOK 10, s. 308.

399 Meliton z Sardes, Homilia Paschalna 3, w: SCh 123, s. 60; „Przemijająca jako figura, wieczna jako łaska", w: SCh 123, s. 60; BOK 10, s. 308. Meliton z Sardes, Homilia

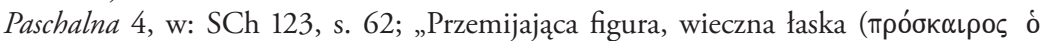

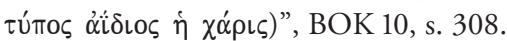

400 Meliton z Sardes, Homilia Paschalna 3, w: SCh 123, s. 60; „Zniszczalna przez zabicie baranka, niezniszczalna przez życie Pana”, BOK 10, s. 308.

401 Meliton z Sardes, Homilia Paschalna 4, w: SCh 123, s. 62; „Zniszczalna owca, Pan niezniszczalny", BOK 10, s. 308.

402 Meliton z Sardes, Homilia Paschalna 3, w: SCh 123, s. 62; „Śmiertelna przez pogrzebanie w ziemi, nieśmiertelna przez powstanie z martwych", BOK 10, s. 308.

403 Meliton z Sardes, Homilia Paschalna 4, w: SCh 123, s. 62; „Zabity jako baranek, jak Bóg zmartwychwstały "Jak baranek na rzeź prowadzony», a przecież nie był barankiem; i jak «owca niema», a przecież nie był owcą", BOK 10, s. 308 (por. Iz 53, 7; Dz 8, 32). 


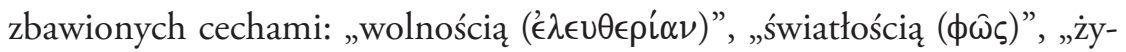

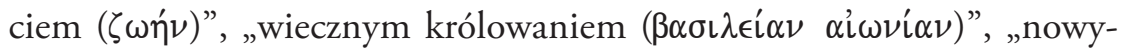

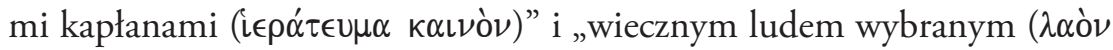

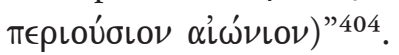

W swej deklamacji liturgicznej Meliton biskup Sardes, stosując typologiczną i chrystologiczną interpretację Pisma Świętego, rozwijał też okazyjnie wątki eschatologii końcowej. Do opisu nieba autor ten używał przestrzennej terminologii nowotestamentalnej („wyżyny niebieskie”, „Chrystus powyżej”, „niebo”, „niebiosa”, „Jerozolima powyżej”, „raj”). Meliton nauczał, że człowiek ma szansę zarówno na zbawienie, jak i eschatologiczne niebo jedynie dzięki pośrednictwu Jezusa Chrystusa. Zbawieni w niebie posiadają charakterystyki paschlne: odpuszczenie grzechów, zbawienie, życie, zmartwychwstanie, światło, wejście na wyżyny niebieskie, ukazanie Ojca przedwiecznego. Dzięki Passze Chrystusa są one: nowe, wieczne, niezniszczalne i nieśmiertelne.

\subsubsection{Atenagoras $z$ Aten - życie wieczne za dobre czyny}

Atenagoras był filozofem chrześcijańskim z Aten, zmarł po 180 roku. W patrologii przypisuje się mu autorstwo dwóch traktatów. W roku 177 napisał apologię zatytułowaną Prośba z chrześcijanami ${ }^{405}$, w której przy użyciu środków antycznej retoryki odpierał pogańskie zarzuty przeciwko chrześcijanom o ateizm (rozdziały 4-30), o kazirodztwo (rozdziały 31-34 i o antropofagię (rozdziały $35-36)^{406}$. Drugim jego dziełem, które powstało niedłu-

404 Meliton z Sardes, Homilia Paschalna 68, w: SCh 123, s. 96.98; „On to wyprowadzit nas z niewoli na wolność, z ciemności na światło, ze śmierci do życia, z tyranii do wiecznego królowania i uczynił nas nowymi kapłanami i ludem wybranym, wiecznym", BOK 10, s. 321.

405 Athenagoras Philosophus, Suplicatio pro Christianis, w: SCh 379. Athénagore, Supplique au sujet des chrétiens et Sur la resurrection des morts. Introduction, texte critique, traduction et notes par B. Pouderon, Paris 1992, s. 70-209; przekład polski Atenagoras z Aten, Prośba za chrześcijanami, w: PAX 24, tłum., wstęp i oprac. S. Kalinkowski, Warszawa 1985 , s. 27-80.

406 Por. C. Bruni, Atenagora, Introduzione, w: Gli apologeti greci. Traduzione, introduzioni e note a cura di Clara Bruni, Roma 1986, s. 235-241 (Collana di Testi Patristici 59) 
Kształtowanie się nauki o niebie w teologii patrystycznej I-III wieku

go po 177 roku jest traktat $O$ zmartwychwstaniu umartych ${ }^{407}$. Wątpliwości badaczy (np. wspomnianego już w pracy Granta, Williama R. Schoedela, Nicole Zeegers-Vander Vorst ${ }^{408}$ ) co do autorstwa Atenagorasa zostały drobiazgowo rozpatrzone i przekonująco odrzucone przez Bernarda Pouderona ${ }^{409}$. Atenagoras wykazywał w traktacie, że chrześcijańska doktryna o zmartwychwstaniu ciał jest prawdziwa, a zmartwychwstanie jest celem stworzenia (rozdział 12), gdyż człowiek został stworzony dla życia wiecznego (rozdział 13), według zbawczej woli Boga (rozdział 14). Autor, przyjmując grecką antropologię dychotomiczną, udowadniał, że jeśli śmierć fizyczna rozdziela jedność ludzkiej duszy i ciała, to dzięki zmartwychwstaniu te dwa składowe elementy człowieka zostaną złączone na wieczność (rozdział 15). Argumentacją za zmartwychwstaniem jest również otrzymanie przez pełnego człowieka, tak w duszy i w ciele, wiecznego szczęścia i błogosławieństwa $\left(\right.$ rozdział 25) ${ }^{410}$.

\section{Kontekst teologiczny nauki o niebie w traktatach Atenagorasa}

Ateński apologeta, czy to broniąc chrześcijaństwa przed fałszywymi zarzutami pogan, czy to starając się wykazać poganom prawdę o zmartwychwstaniu, przyjął w swych traktatach metodę, która bardziej posługiwała się kryteriami logiki i retoryki niż dowodzeniem z Pisma Świętego ${ }^{411}$. Teologicznie pierwszoplanową tematyką było dla Atenagorasa wykazanie

407 Athenagoras Philosophus, De resurrection mortuorum, w: SCh 379. Athénagore, Supplique au sujet des chrétiens et Sur la resurrection des morts. Introduction, texte critique, traduction et notes par B. Pouderon, Paris 1992, s. 214-317; przekład polski Atenagoras z Aten, $O$ zmartwychwstaniu umartych, w: PAX 24, tłum., wstęp i oprac. S. Kalinkowski, Warszawa 1985, s. 83-115.

408 Por. R. M. Grant, Athenagoras or Pseudo-Athenagoras?, „Harvard Theological Review” 47 (1954), s. 121-129; W. R. Schoedel, Athenagoras. «Legatio» and "De resurrectione», Oxford 1972, XXV-XXXII; N. Zeegers-Vander Vorst, Adversaires et destinataires du "De resurrectione» attribué à Athénagore d'Athènes, „Salesianum” 57 (1995), s. 75-122, 199-250, 415-442, 611-656.

409 Por. B. Pouderon, L'autenticité du "De resurrectione», w: B. Pouderon, D'Athènes à Alexandrie. Etudes sur Athènagore et les origines de la philosophie chrétienne, Québec 1997, s. 71-144.

410 Por. C. Bruni, Atenagora, Introduzione, w: Gli apologeti greci..., dz. cyt., s. 241-243.

411 Por. L. W. Barnard, Athenagoras. A Study in Second Century Christian Apologetic, Théologie Historique 18, Paris 1972, s. 69-80; D. I. Rankin, Athenagoras: Philosopher and Theologian, Farnham (GB)-Burlington (USA) 2009, s. 1-19, 41-72. 
2. Kształtowanie się nauki o niebie w teologii patrystycznej - wiek I-II

jedyności Boga (por. Prośba za chrześcijanami 5; 9; 10), następnie ukazanie istnienia Syna Bożego i Ducha Świętego (Prośba za chrześcijanami 10, 3-5; 24, 2). Kolejną problematyką teologiczną, spotykaną już u wcześniejszych apologetów greckich II wieku, była kwestia istnienia aniołów dobrych i złych (zbuntowanych przeciw Bogu), wszystkich stworzonych pierwotnie przez Syna Bożego jako dobrzy słudzy Boga (Prośba za chrześcijanami 10, 5; 24, 5; 25, 1; 26, 1; 27, 2). Ważnymi zagadnieniami teologicznymi była wreszcie: kwestia życia stworzeń wspólnie z Bogiem (Prośba za chrześcijanami 31; 36; O zmartwychwstaniu umartych 10; 13; 15; 16; 25) oraz moralność, która wypływa z posłuszeństwa Bogu (Prośba za chrześcijanami 11, 4; 34, 5; 35, 6). W wykładzie teologii chrześcijańskiej treści eschatologiczne były zatem uwarunkowane u Atenagorasa przyjętą metodą apologetyczną i polemiką z zarzutami pogańskimi. Wzmianki o eschatologicznym niebie i cechach jakościowych życia zbawionych nie są liczne i pojawiają się w obu traktatach przede wszystkim przy okazji omawiania zagadnienia wspólnego życia z Bogiem oraz moralności chrześcijańskiej.

\section{Nauka o eschatologicznym niebie (terminy i koncepcje)}

Według Atenagorasa, powołującego się na autorytet niestety niewymienionych z imienia czy tekstu proroków ${ }^{412}$, niebo składałoby się ze sklepień, o których jednak nic więcej autor ten nie mówi. Natomiast władzę „nad

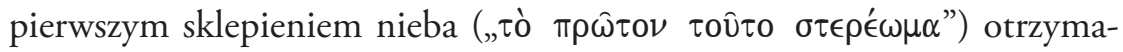
ła pierwotnie część aniołów odpowiedzialna za „zarząd nad materią i jej formami”, którzy z czasem zbuntowali się przeciw Bogu ${ }^{413}$, „spadli z nie-

412 Por. Atenagoras z Aten, Prośba za chrzéscijanami 24, w: SCh 379, s. 164; „My nic nie mówimy bez poparcia świadectwami, lecz donosimy o tym, co zostało wygłoszone przez proroków", PAX 24, s. 63.

413 Atenagoras z Aten, Prośba za chrześcijanami 24, w: SCh 379, s. 164; „Ów duch został stworzony przez Boga podobnie jak pozostali aniołowie, a powierzony mu został zarząd nad materią i jej formami. Bóg bowiem stworzył substancję aniołów dla sprawowania opieki nad tym, co urządził, a wszystko po to, by Bóg sprawował ogólną i główną opatrzność nad wszystkim, natomiast ustanowieni przez Niego aniołowie opiekowali się poszczególnymi cząstkami wszechrzeczy. (...). Jedni, obdarzeni przez Boga wolną wolą, wytrwali przy tym, do czego Bóg ich stworzył i ustanowił, inni znieważyli substancję bytu oraz powierzoną im władzę: są to władca materii i zawartych w niej form oraz inni aniołowie, którzy otrzymali władzę nad tym oto pierwszym sklepieniem", PAX 24, s. 62-63. 
Kształtowanie się nauki o niebie w teologii patrystycznej I-III wieku

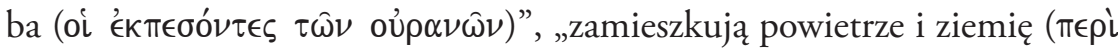

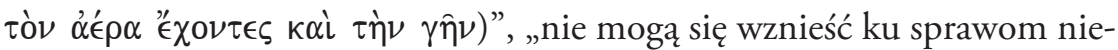

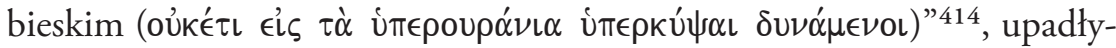
mi aniołami owładnęła namiętność, a ze związków z kobietami narodzili się giganci, których dusze są demonami ${ }^{415}$. Jak widać, Atenagoras w opowiadaniu o upadku z nieba części aniołów, podobnie jak inni apologeci, poszedł w swoim wykładzie nie tylko za Rz 6, 4, ale także za apokryficzną Ksiega Henocha 12, 4; 15, $3^{416}$.

Zbawienie oraz życie wieczne są ujmowane przez Atenagorasa w kategoriach etycznej zasługi za dobre czyny. Dlatego chrześcijanie, „dla których

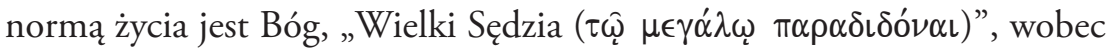

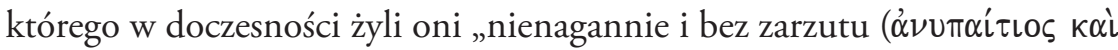
$\dot{\alpha} \nu \in \pi i \lambda \eta \pi \tau 0 \varsigma$ )”, nie „służąc ciału i krwi oraz (nie) ulegając chciwości lub

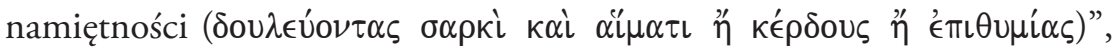
„jesteśmy przekonani, iż po wyzwoleniu z obecnego ciała będziemy wieść inne życie, doskonalsze od obecnego, życie niebiańskie, a nie ziemskie, bo będziemy trwać z Bogiem i przy Bogu niezłomni i nie doznając namiętności w duszy, nie jak istoty cielesne, chociaż i ciało mieć będziemy, ale jako Duch niebieski" ${ }^{417}$. Obok typowo nowotestamentalnego przekonania, że wieczność to przebywanie z Bogiem, ateński apologeta odwołuje się pośrednio do poglądów stoików, którzy uważali, że prawdziwym mędrcem jest człowiek uwolniony od wszelkich namiętności ${ }^{418}$.

414 Atenagoras z Aten, Prośba za chrześcijanami 25, w: SCh 379, s. 164.166; „Owi więc aniołowie, którzy spadli z nieba, którzy zamieszkują powietrze i ziemię i nie mogą już wznieść się ku sprawom niebieskim, a nadto dusze gigantów są demonami tułającymi się po świecie”, PAX 24, s. 63 (por. Łk 10, 18).

415 Por. Atenagoras z Aten, Prośba za chrześcijanami 24, w: SCh 379, s. 164; „Otóż aniołami tymi owładnęło pożądanie kobiet i okazało się, że pokonała ich namiętność cielesna; natomiast wspomniany wyżej duch okazał się niedbały i występny w zarządzaniu sprawami, jakie zostały mu powierzone. $\mathrm{Z}$ tych więc, którymi owładnęła miłość do kobiet, narodzili się tak zwani giganci", PAX 24, s. 63 (por. Rdz 6, 1-6).

416 Por. B. Pouderon, SCh 379, s. 165, przypis 7.

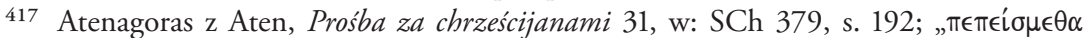

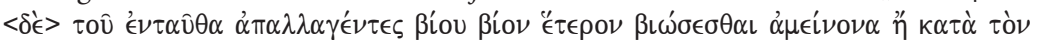

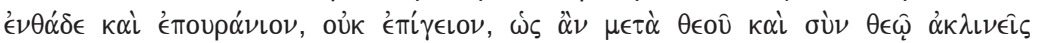

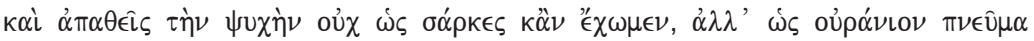
$\mu \in \in \omega \omega \mu \in \nu^{\prime \prime}$, PAX 24, s. 74.

418 Por. S. Kalinkowski, PAX 24, s. 74, przypis 237. 
2. Kształtowanie się nauki o niebie w teologii patrystycznej - wiek I-II

Eschatologiczne niebo w teologii Atenagorasa z Aten to „trwanie” czło-

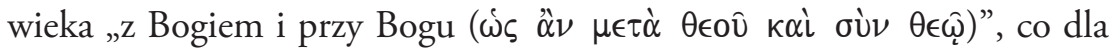
zbawionych okazuje się także zmianą jakościową ich życia - poprzez „wy-

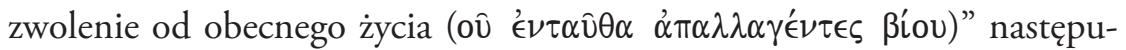
je kontynuacja życia, ale już odmienionego, „innego i doskonalszego od

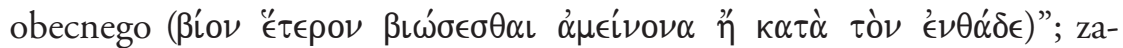

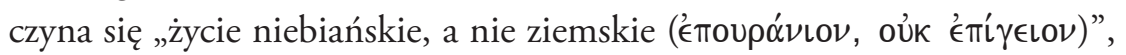

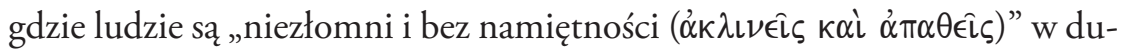
szy i ciele ${ }^{419}$, charakteryzują się też „niezniszczalnością $(\alpha \phi \theta \alpha \rho \sigma i \alpha)$ ” i „niecierpiętliwością $(\dot{\alpha} \pi \alpha \theta \epsilon \hat{\imath} \alpha)$ ” duszy i ciała oraz brakiem potrzeby korzystania ze zwierząt ${ }^{420}$.

Szczególnie zostaje przez apologetę ateńskiego podkreślona nieśmier-

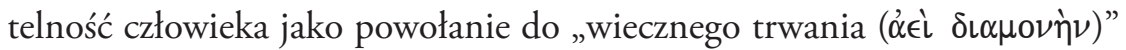
z Bogiem, aby miał on udział w rozumnym życiu Boga i oglądał Bożą wspaniałość. Cecha ta wynika zdaniem Atenagorasa zarówno z bezpośredniej przyczyny stworzenia człowieka przez Boga ${ }^{421}$, jak i z zamysłu Bożego,

419 Por. Atenagoras z Aten, Prośba za chrześcijanami 31, w: SCh 379, s. 192; PAX 24, s. 74.

420 Atenagoras z Aten, $O$ zmartwychwstaniu ciat 10, w: SCh 379, s. 250; „(...) po wyzwoleniu z niewoli, kiedy to ludzie staną się „nieśmiertelni” / „niezniszczalni” [w oryginale jest niezniszczalni $(\dot{\alpha} \phi \theta \dot{\alpha} \rho \tau \omega \nu)$ - uwaga Autora] i nie będą potrzebowali z nich korzystać [tj. z „,istot pozbawionych rozumu i duszy” - dopowiedzenie Autora]. (...). Jeśli zatem dusza nie doznaje krzywdy, gdy przebywa w śmiertelnym i podlegającym cierpieniom ciele, to tym bardziej nie będzie jej doznawać, żyjąc w ciele nieśmiertel-

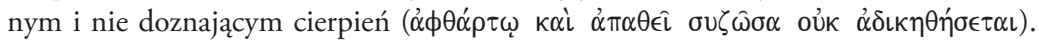
Również i ciało nie doznaje krzywdy: jeśli bowiem nie doznaje jej śmiertelne ciało współistniejące z nieśmiertelną duszą, to nie będzie też doznawać krzywdy ciało nieśmiertelne współistniejące z nieśmiertelną duszą", PAX 24, s. 94-95.

421 Atenagoras z Aten, $O$ zmartwychwstaniu ciat 12, w: SCh 379, s. 262; „(...) bezpośrednią przyczyną stworzenia człowieka, ludzi jest ich życie, i to nie takie, które na krótko się zapala, a potem zupełnie gaśnie. Według mnie życie takie przydzielił Bóg istotom pełzającym, fruwającym i pływającym, ogólnie mówiąc wszystkim istotom nierozumnym; tym zaś którzy noszą w sobie obraz Stwórcy (por. Rdz 1, 26), którzy otrzymali w udziale rozum i zdolność rozumnej oceny, Stworzyciel udzielił wiecznego życia ( $\dot{\alpha} \in \grave{i}$

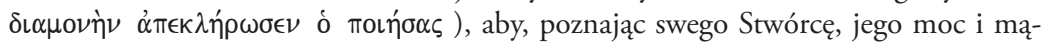
drość oraz posłuszni prawu i sprawiedliwości, mogli bez trudów istnieć wiecznie pełni cnót, którymi umocnili swoje poprzednie życie, choć wówczas przebywali w śmiertelnych i ziemskich ciałach”, PAX 24, s. 98. Atenagoras z Aten, O zmartwychwstaniu ciat 13, w: SCh 379, s. 266; „ (...) jeśli więc Stwórca wszechświata stworzył człowieka po to, żeby człowiek miał udział w rozumnym życiu i żeby oglądał Jego wspaniałość i przejawiającą się we wszystkim mądrość oraz żeby trwał w tym oglądaniu zgodnie 
Kształtowanie się nauki o niebie w teologii patrystycznej I-III wieku

o którym zapewnia wierzących sam Stwórca ${ }^{422}$. Biorąc pod uwagę te dwie przesłanki, ateński apologeta doszedł do poprawnego biblijnie wniosku, że „natura stworzonych ludzi jest skutkiem samej przyczyny ich stworzenia, w naturze zaś stworzonych istot przejawia się sprawiedliwy sąd Stwórcy nad nimi oraz cel ich życia" ${ }^{423}$. Opisywana dalej dychotomicznie natura ludz$\mathrm{ka}^{424}$ jako zbudowana $\mathrm{z}$ „nieśmiertelnej duszy i śmiertelnego ciała” ${ }^{425}$ dąży do „harmonijnej jedności całej istoty żywej oraz zgodności jej doznań” ${ }^{426}$. Dlatego przy założeniu konieczności zmartwychwstania ciał chrześcijanie

z zamysłem Stworzyciela i zgodnie z naturą, to trzeba uznać, że powodem stworzenia człowieka jest jego wieczne bytowanie, a przyczyną wiecznego bytowania jest zmar-

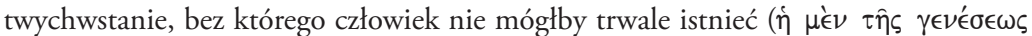

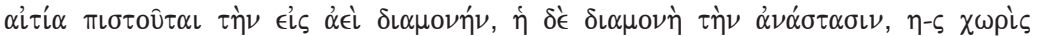

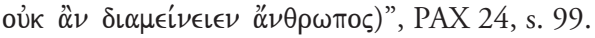

422 Atenagoras z Aten, $O$ zmartwychwstaniu ciat 13 , w: SCh 379 , s. $264 ;$ „.... żywimy

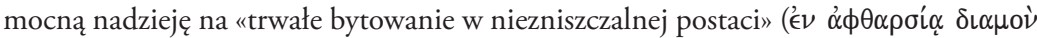
$\eta \nu ' \epsilon \lambda \pi^{\prime} \zeta o \mu \in \nu \beta \in \beta \alpha i \omega \varsigma$ [tłumacz PAX 24, S. Kalinkowski oddaje to sformułowanie jako „trwałe bytowanie w nieśmiertelnej postaci”, stąd moja niniejsza korekta]; nie wymyślamy go sobie, opierając się na ludzkich mniemaniach i nie mamimy się na próżno fałszywą nadzieją, lecz wierzymy mocno w niezawodną rękojmię, którą jest zamysł naszego Stwórcy; zgodnie z tym zamysłem zbudował On człowieka z nieśmiertel-

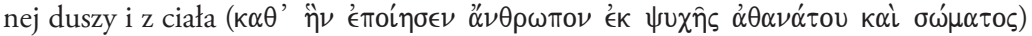
oraz dał mu rozum i wrodzone prawo dla ocalenia i ochrony swych darów, zgodnych z rozsądnym i rozumnym życiem: wiemy doskonale, że nie stworzyłby takiej istoty żywej i nie udzieliłby jej wszystkiego, co niezbędne do przetrwania, gdyby nie chciał, aby stworzenie Jego przetrwało", PAX 24, s. 99.

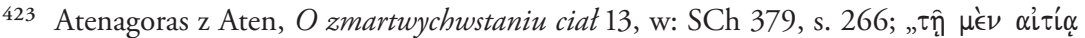

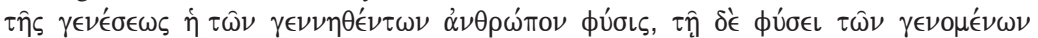

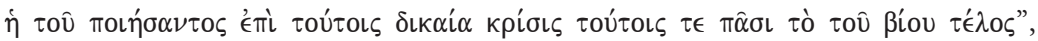
PAX 24, s. 100.

424 Por. Platon, Fajdros 246C, tłum., wstęp, objaśnienia i ilustracje W. Witwicki, Warszawa

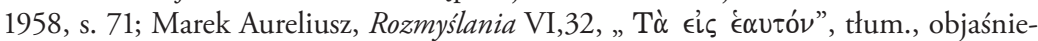
nia M. Reiter, wstęp T. Sinko, Łódź 1948, s. 129 (por. też B. Pouderon, w: SCh 379, s. 272, przypis 2).

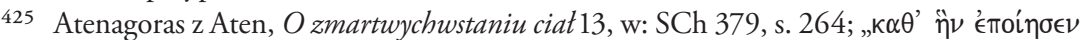

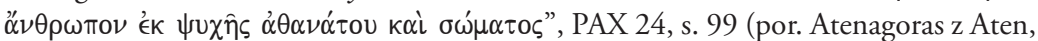

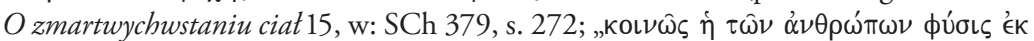

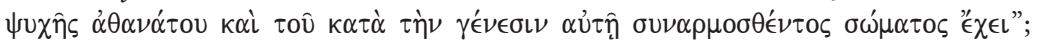
„cała w ogóle natura ludzka zbudowana jest z nieśmiertelnej duszy i z ciała, które zostało zespolone z duszą w akcie stworzenia", PAX 24, s. 102).

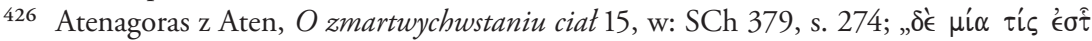

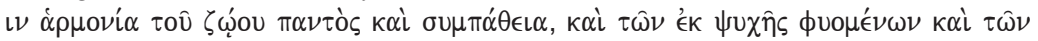

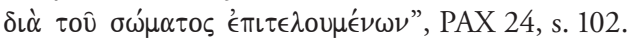


oczekują „wiecznego istnienia człowieka w nieśmiertelności” ${ }^{27}$ oraz szczęścia wiecznego całego człowieka ${ }^{428}$.

Potępieni natomiast, czyli ludzie, którzy upadli i czynili przez życie zło, zostaną przez Boga ukarani „gorszym życiem pośród ognia” ${ }^{429}$, co jest prawdopodobnie aluzją do Mt 25, 31-45430. Według Atenagorasa kryterium sądu nad każdym człowiekiem będą jego czyny, wyznaczające cel życia ludzkiego, w zależności od których otrzyma on „nagrodę lub karę”431.

W tak budowanej eschatologii końcowej nauka o eschatologicznym niebie była niewątpliwie uwarunkowana w traktatach Atenagorasa z Aten, podobnie jak wcześniej choćby u Justyna czy u Tacjana, samą apologią jako gatunkiem prowadzenia rozumowania. Poganom chrześcijański apologeta starał się przybliżyć etykę sprawiedliwości i posłuszeństwa przykazaniom Bożym, jako zapisanym w naturze człowieka. Szczęśliwa wieczność, również zapisana w naturze człowieka, byłaby zatem efektem konsekwentnych ludzkich wyborów dokonywanych w życiu doczesnym. Po raz kolejny,

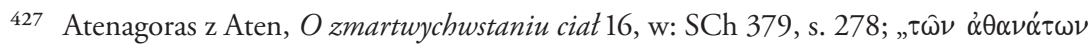

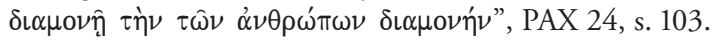

428 Atenagoras z Aten, $O$ zmartwychwstaniu ciat 25, w: SCh 379, s. 312; „Celem człowie-

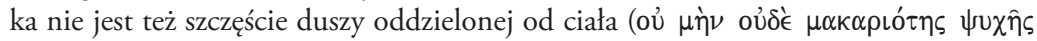

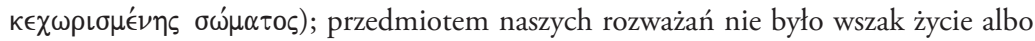
cel jednego z dwóch elementów, z których został zbudowany człowiek, lecz życie i cel

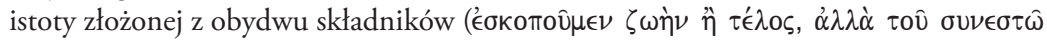

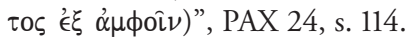

429 Atenagoras z Aten, Prośba za chrześcijanami 31, w: SCh 379, s. 192; „....) albo że upadt-

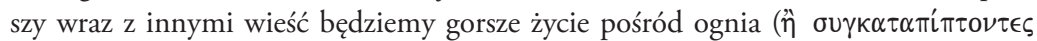

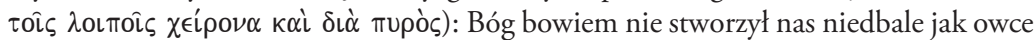
czy juczne zwierzęta, byśmy mieli zginąć i zostać unicestwieni; a skoro takie są nasze przekonania, to nie jest prawdopodobne, byśmy rozmyślnie popełniali zło i sami wydawali siebie Wielkiemu Sędziemu na ukaranie”, PAX 24, s. 74. W poglądzie o unicestwieniu zwierząt w wieczności Atenagoras powtarza opinię Justyna Męczennika, 1 Apologia 43,8.

430 Jak zauważa B. Pouderon, w: SCh 379, s. 192, przypis 2, podobne odwołanie znajdujemy wcześniej także u Justyna Męczennika, 2 Apologia 1,2.

431 Atenagoras z Aten, $O$ zmartwychwstaniu ciat 25, w: SCh 379, s. 316; „Nie przekreśla przecież wspólnego wszystkim przeznaczenia wielka rzesza tych, którzy odstępują od właściwego im celu, bo sąd dotyczy każdego człowieka z osobna i każdy człowiek otrzymuje należną nagrodę lub karę za dobre albo złe uczynki dokonane w życiu

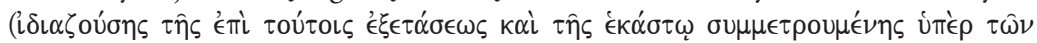

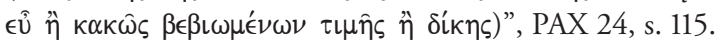


Kształtowanie się nauki o niebie w teologii patrystycznej I-III wieku

prawdopodobnie ze względu na apologetyczność wywodu teologicznego, została zagubiona, czy też pominięta, biblijna podstawa usprawiedliwienia dokonującego się przede wszystkim przez wiarę w Jezusa i uczynki jako konsekwencje wyborów wiary.

\subsubsection{Teofil z Antiochii - Do Autolika - powrót do raju w nieśmiertelności, w perspektywie nieba?}

Szósty po św. Piotrze biskup Antiochii (169-183/185), jest autorem trzech ksiąg apologii Do Autolika ${ }^{432}$, ukończonej krótko po śmierci cesarza Marka Aureliusza (17 marca 180 roku). W patrologii nie jesteśmy dziś w stanie określić osoby adresata dzieła (czy Autolik to postać autentyczna czy fikcyjna?). Teofil w swoim dziele bronił sensowności chrześcijaństwa odmiennie niż większość apologetów greckich II wieku, nie filozoficznie, lecz biblijnie i chronologicznie. Apologeta skupiał się na pozytywnej wykładni wiary chrześcijańskiej, używając prostego i obrazowego języka. Wersją Biblii ST używaną przez Teofila była LXX, do NT spotykamy 60 odniesień (13 z MT, 47 głównie z tekstów św. Pawła ${ }^{433}$. Odpierając w pierwszej księdze zarzuty antychrześcijańskie, autor starał się zarazem wyjaśniać motywy swej wiary, koniecznej, aby rozpoznać Boga poprzez Jego dzieła, nieodzownej do przyjęcia zmartwychwstania. W drugiej księdze biskup Antiochii krytykował politeizm, mitologię oraz poglądy pogańskich filozofów, poetów i historyków. Ich sprzecznym naukom apologeta przeciwstawiał teksty biblijne, które interpretował przede wszystkim literalnie. W trzeciej księdze

432 Theophilus Antiochenus, Ad Autolycum libri III, w: SCh 20. Théophile d'Antioche, Trois livres a Autolycus, texte grec, introduction et notes de G. Bardy, traduction de J. Sender, Paris 1948; przekład polski Do Autolika, w: Pierwsi apologeci greccy..., dz. cyt., BOK, 24, s. 373-384 [wstęp], s. 385-464 [tekst].

433 Por. N. Zeegers, Les trois cultures de Théophile d'Antioche, w: Les apologistes chrétiens et la culture grecque, ed. J. Doré, B. Pouderon, Paris 1998, s. 159; F. R. Prostmeier, Gen 1-3 in Theophilos von Antiochia "An Autolykos". Beobachtungen zu Text und Textgeschichte der Septuagintagenesis, w: Textgeschichte und Schriftrezeption im frühen Christentum / Textual History and the Reception of Scripture in Early Christianity, ed. J. de Vries, M. Karrer, Missoula (Montana) 2013, s. 359-393 (Septuagint and Cognate Studies 60). 
apologeta antiocheński dowodził wyższości moralnej chrześcijaństwa nad politeizmem $^{434}$.

\section{Kontekst teologiczny nauki o niebie w traktacie Teofila}

Prezentowana w księgach Do Autolika teologia Teofila była uwarunkowana obroną monoteizmu przeciwko politeizmowi i bałwochwalstwu, a także krytyką dualizmu teologicznego Marcjona (Teofil podkreślał tożsamość Boga Ojca i Stwórcy) oraz wątkami judaizmu hellenistycznego (Bóg z jednej strony był przedstawiany w kategoriach średniego platonizmu jako niezmienny i niepojęty, niewidzialny, niestworzony i niewysłowiony, a z drugiej był opisywany jako Stwórca wszechświata i człowieka, opiekujący się stworzeniem za pomocą swego Logosu). Teofil, jako pierwszy autor chrześcijański, użył terminu „triada” ( $\tau \hat{\jmath} \varsigma \tau \rho i ́ \alpha \delta o \varsigma)$ w odniesieniu do „Boga, Jego Logosu i Jego Mądrości”435.

Nauka o niebie w tekście Do Autolika jest urywkowa i drugoplanowa, jej wątki są poruszane przez Teofila przy okazji jego wykładu o Bogu (Do Autolika I, 4, 3; I, 7, 4), wykładu o wierze w zmartwychwstanie (Do Autolika I, 8, 3; I, 13, 9-10) oraz przy nauczaniu o stworzeniu przez Logos świata (Do Autolika II, 10, 8; II, 11, 1; II, 13, 1-7) i człowieka (Do Autolika II, 19, 5; II, 20, 1; II, 22, 1-2; II, 23, 1; II, 24, 1-8; II, 25, 2. 4 - 5. 8; II, 26, 1-4; II, 27, 1-7).

\section{Bóg transcendentny wobec nieba i raju}

Teofil, mówiąc o chrześcijańskiej wierze w Boga jako jedynego Stwórcę, przypomniał biblijną naukę o transcendencji Boga wobec całego stworzenia. Wychodząc najpierw od filozoficznego opisu Boga jako nie mającego początku, niestworzonego, niezmiennego i nieśmiertelnego, przeszedł dalej do teologicznego opisu Boga jako jedynego Pana, Ojca, Założyciela i Stwórcy, Najwyższego i Wszechmocnego, który wszytko podtrzymuje w istnieniu ${ }^{436}$.

434 Por. L. Misiarczyk, Teofil z Antiochii, Do Autolika - Wstęp, w: Pierwsi apologeci greccy..., dz. cyt., BOK, 24, s. 373-379.

435 Por. L. Misiarczyk, Teofil z Antiochii, Do Autolika - Wstęp, w: Pierwsi apologeci greccy..., dz. cyt., BOK, 24, s. 379-382; Teofil z Antiochii, Do Autolika II,15,4, w: SCh 20, s. 130; BOK 24, s. 414.

436 Por. Teofil z Antiochii, Do Autolika I,4,1-3, w: SCh 20, s. 64; BOK 24, s. 387-388. 
Kształtowanie się nauki o niebie w teologii patrystycznej I-III wieku

Kontynuując dowodzenie za pomocą dosłownej argumentacji biblijnej (Ps 94, 4; Iz 66, 1; Rdz 1, 14; Ps 103, 14; Ps 146, 8; 2 Mch 7, 28), biskup Antiochii stwierdza następnie, że Bóg jest transcendentny wobec całego stworzenia, także wobec nieba $(\tau \hat{\omega} \nu \text { oủ } \alpha \alpha \omega \hat{\omega} \nu)^{437}$ czy raju ( $\pi \alpha \rho \alpha ́ \delta \epsilon\llcorner\sigma o \nu)^{438}$, jako swoich dzieł.

\section{Kosmologia}

Wychodząc od przesłanek teologii biblijnej i motywując, że nauczanie Pisma Świętego jest wiarygodne, gdyż prorocy byli nauczycielami prawdy jako ludzie „będący pod tchnieniem Boga i pouczeni przez samego Boga” ${ }^{439}$, an-

437 Teofil z Antiochii, Do Autolika I,4,3-5, w: SCh 20, s. 64; „4.3. Gdyż w Jego ręku sq wysokości niebios ( $\tau \dot{\alpha}$ yò ta (por. Ps 94, 4). I nie istnieje miejsce Jego odpoczynku (por. Iz 66, 1). 4.4. Niebiosa

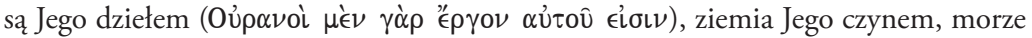
Jego tworem, człowiek Jego dziełem i obrazem. Słońce, księżyc i gwiazdy są Jego żywiołami, stworzone jako znaki i pory roku, dnie i lata, by służyły i pomagaty ludziom (por. Rdz 1, 14; Ps 103, 14; Ps 146, 8). 4.5. Bóg wszystko stworzyt z niebytu, aby z Jego dziet można byto poznać i pojać Jego majestat (por. 2 Mch 7, 28)”, BOK 24, s. 388.

438 Teofil z Antiochii, Do Autolika II,22,2, w: SCh 20, s. 154; „Bóg i Ojciec wszechrzeczy nie jest ograniczony miejscem ani w żadnym miejscu się nie znajduje, gdyż nie istnieje miejsce Jego odpoczynku (Iz 66, 1). Lecz Jego Logos, za pomocą którego wszystko stworzył, jest Jego Moca i mądrością (1 Kor 1,24) i przyjął rolę Ojca i Pana wszech-

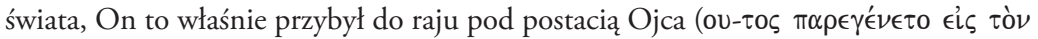

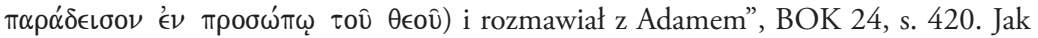
słusznie wykazuje Misiarczyk, BOK 24, s. 471, przypis 98, tekst ten nie oznacza, że Teofil nie robił różnicy pomiędzy Ojcem a Synem, bo inne fragmenty jego traktatu potwierdzają to wystarczająco. Bardziej natomiast cytowany tekst dowodzi, iż apologeta antiocheński posiadał ideę całkowicie transcendentnego Ojca, który nigdy nie objawia się bezpośrednio, którą to myśl przejął albo z judaizmu hellenistycznego, albo ze średniego platonizmu. Nie jest to też jakiś ślad modalizmu, ale próba podkreślenia jedności natury Ojca i Syna. O kwestiach opisu transcendencji Boga u apologetów greckich II wieku i możliwych zapożyczeniach tak z judaizmu hellenistycznego, jak i średniego platonizmu, zob. też J. Daniélou, Message évangelique et culture hellenistique aux II et III siècles, Paris 1990, s. 297-316.

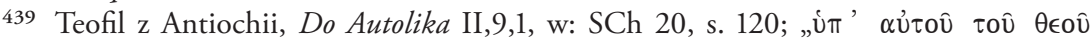

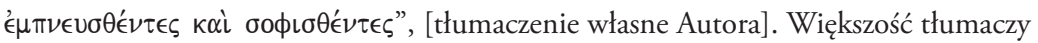
termin ' $\epsilon \pi \nu \nu \in \sigma \theta^{\prime}{ }^{\prime} \nu \tau \epsilon \varsigma$ jako „natchnieni”, moim zdaniem, bardziej uzasadniony jest

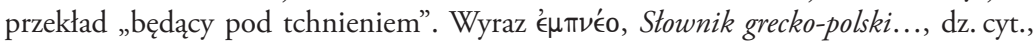
t. 2, s. 116, oznacza bowiem: intr. dmuchać, dyszeć nad; oddychać, żyć, być żywym; dyszeć; a trans.: wydąć, nadąć, natchnąć, wlać, pass. być natchnionym. Jednak w II wie-

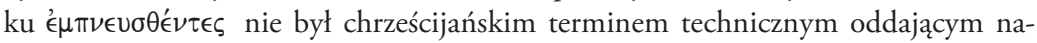
tchnienie biblijne. Dopiero Hieronim ze Strydonu w Wulgacie przełożył $\theta \epsilon o ́ m \nu \in \cup \sigma \tau o \varsigma$ 
2. Kształtowanie się nauki o niebie w teologii patrystycznej - wiek I-II

tiocheński apologeta dowodził, że Bóg stworzył wszystko przez swój Logos

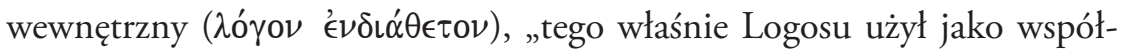

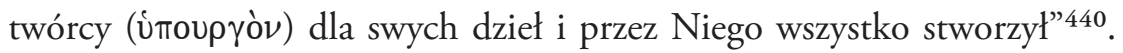
Teofil, powołując się na Rdz 1, lb (LXX), nauczał, iż Bóg najpierw „stworzył i ukształtował świat z materii stworzonej, którą sam wcześniej powołał do istnienia" ${ }^{441}$.

Idąc za wykładnią Rdz 1 - 2, 4 (LXX), tworząc świat, „na początku stworzył Bóg niebo i ziemię" ${ }^{442}$, a elementem porządkującym stworzenie było „światło ( $\tau$ ò $\phi \omega \hat{\varsigma} \varsigma$ )" ${ }^{443}$. Przyrównując akt stworzenia świata

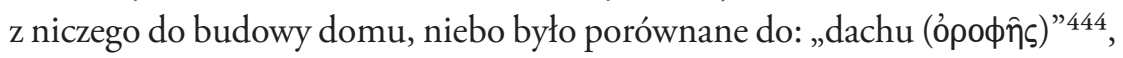

z 2 Tm 3, 16 jako łacińskie „inspirata”, a za Wulgatą zostało stąd urobione pojęcie techniczne, choć ostateczna akceptacja kościelna tego terminu dokonała się dopiero na Soborze Florenckim (sesja XI z 4 lutego 1442; według kalendarza florenckiego rok 1441). Więcej na ten temat, zob. D. Kasprzak, Teologia natchnienia biblijnego w okresie patrystycznym, w: Z badań nad Biblia 12. Gwiazda z Jakuba - demony - Niewiasta Apokalipsy, red. T. Jelonek, Kraków 2007, s. 93-129.

440 Teofil z Antiochii, Do Autolika II,10,2, w: SCh 20, s. 122; BOK 24, s. 406. Tłumacz polskiego tekstu, Misiarczyk zaznacza w BOK 24, s. 468, przypis 69, że „grecki termin hypourgós, który oznacza: «narzędzie», "pomocnik», «asystent», tłumaczę tutaj przez "współtwórca», w nadziei, że lepiej oddaję myśl teologiczną Teofila". Temat rozwija też F. R. Prostmeier, Der Logos im Paradies. Theophilos von Antiochia und der Diskurs über eine zutreffende theologische Sprache, w: Logos der Vernunft - Logos des Glaubens, ed. C. E., F. R. Prostmeier, H. E. Lon, Berlin-New York 2010, s. 207-228 (Millennium Studies in the Culture and History of the First Millennium 31).

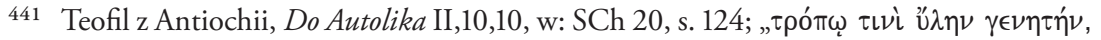

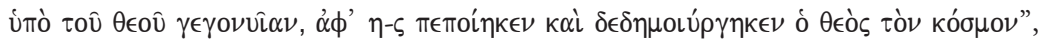
BOK 24, s. 407.

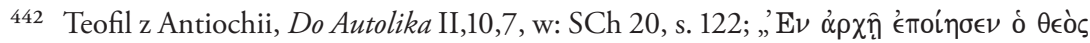

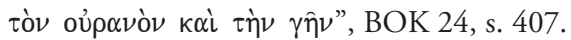

443 Teofil z Antiochii, Do Autolika II,11,1, w: SCh 20, s. 124; „Początkiem zaś stworzenia

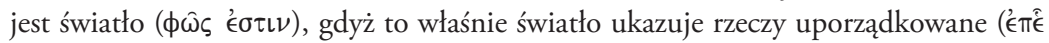

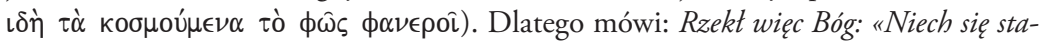
nie świattośćl». I stata się swiattość. Widziat zaś Bóg, że świattość jest dobra (stała się dobra oczywiście dla człowieka)", BOK 24, s. 407.

444 Teofil z Antiochii, Do Autolika II,13,2, w: SCh 20, s. 132; „Najpierw zostało stworzone niebo na kształt dachu, mówiąc: Na początku stworzyt Bóg niebo, co oznacza, że przez Początek, jak to już wykazaliśmy, niebo zostało stworzone ( $\pi \rho \omega \hat{\tau} \tau \nu$

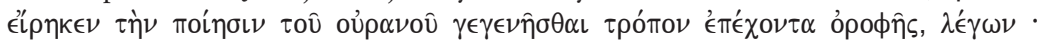

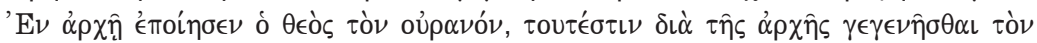

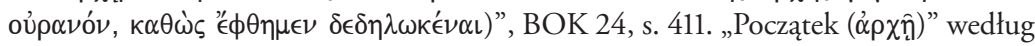
chrystologicznej interpretacji Rdz 1, 1 oznacza u Teofila preegzystujący Logos ( $\lambda$ ó ${ }^{\circ} \nu$ $\dot{\epsilon} \nu \delta\llcorner\dot{\alpha} \theta \in \tau o \nu)$. 
Kształtowanie się nauki o niebie w teologii patrystycznej I-III wieku

jakiejś „pokrywy $(\pi \hat{\omega} \mu \alpha)$ ” zasłaniającej wodę i ziemię ${ }^{445}$, „sklepienia

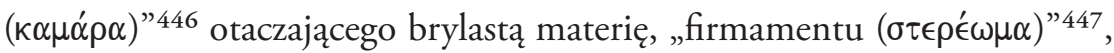
czy - za Iz 40, 22 - do „rozciągniętej tkaniny i mieszkalnego namiotu ( $\omega \varsigma$

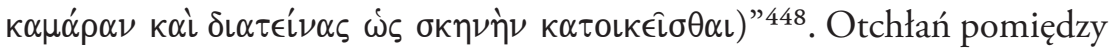
niebem a ziemią wypełniały wody, sama ziemia była porównana do „bazy

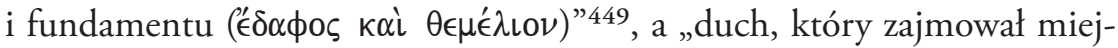
sce światła”, nie dopuszczał, „aby w jakimś punkcie ciemność nie dotykała nieba, najbliższego Boga, zanim Bóg nie wypowiedział: «Niech się stanie światłość»"450. Podzielając judaistyczną kosmologię, Teofil wspomina także

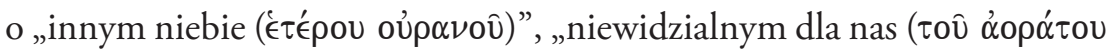

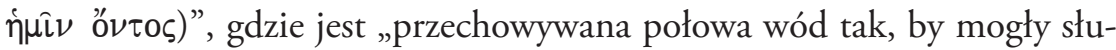
żyć rodzajowi ludzkiemu jako deszcze, rosy i szrony”451. Tak judaistycznie wyobrażane niebo byłoby zatem bardziej siedzibą wód, które mają nawadniać ziemię, niż miejscem przebywania Boga, aniołów i zbawionych.

\section{Nauka o raju}

W poglądach Teofila z Antiochii dotyczących raju znajdujemy wyraźne zapożyczenia z przedchrześcijańskiej apokaliptyki żydowskiej, która utożsamiała raj pierwotny z rajem ostatecznym, już otwartym dla ludzi ${ }^{452}$. Łącząc teologię judaistyczną z elementami przepowiadania chrześcijańskiego, biskup Antiochii dał odmienny od większości autorów chrześcijańskich II wieku obraz eschatologii końcowej. Zdaniem antiocheńskiego apologety człowiek stworzony na obraz i podobieństwo Boga, jako dzieło godne Jego rąk, uczyniony wspólnym aktem stwórczym Ojca, Logosu i Mądrości ${ }^{453}$, po

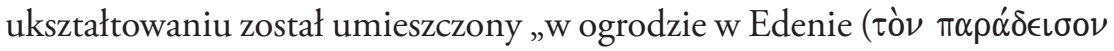

\footnotetext{
445 Teofil z Antiochii, Do Autolika II,13,3, w: SCh 20, s. 132; BOK 24, s. 411.

446 Teofil z Antiochii, Do Autolika II,13,5, w: SCh 20, s. 132; BOK 24, s. 411.

447 Teofil z Antiochii, Do Autolika II,13,7, w: SCh 20, s. 134; BOK 24, s. 412.

448 Teofil z Antiochii, Do Autolika II,13,5, w: SCh 20, s. 134, BOK 24, s. 411-412.

449 Teofil z Antiochii, Do Autolika II, 13,3, w: SCh 20, s. 132; BOK 24, s. 411.

450 Teofil z Antiochii, Do Autolika II, 13,4, w: SCh 20, s. 132; BOK 24, s. 411.

451 Teofil z Antiochii, Do Autolika II,13,7, w: SCh 20, s. 134; BOK 24, s. 412.

452 Por. niniejsza praca, rodział I, paragraf $\pi \alpha \rho \alpha ́ \delta \epsilon \iota \sigma o \varsigma$ (parádeisos) - ogród, park, raj; o możliwych wpływach ówczesnej teologii rabinackiej na myśl Teofila, zob. też N. Zeegers, Les trois cultures de Théophile d'Antioche..., dz. cyt., s. 138-159.

453 Por. Teofil z Antiochii, Do Autolika II,18,1, w: SCh 20, s. 144; BOK 24, s. 416.
} 
2. Kształtowanie się nauki o niebie w teologii patrystycznej - wiek I-II

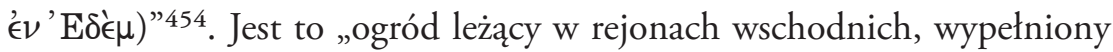
światłem, czystym powietrzem i różnymi wspaniałymi drzewami" ${ }^{455}$, który Teofil najczęściej nazywa „rajem $(\pi \alpha \rho \alpha \dot{\delta} \delta\llcorner\sigma o \varsigma)$ ”456. Jest on położony „w najlepszym miejscu i najodpowiedniejszym obszarze” ${ }^{457}$. Nie ma tam bólu rodzenia dla kobiet i zwodzenia człowieka do grzechu przez szatana ${ }^{458}$, „roślinność w raju była bardzo dobra i piękna”, gdyż samo określenie „raj” oznacza właśnie „zasadzony przez Boga” 459 - „tylko w raju rosły drzewa życia i drzewa poznania" ${ }^{460}$. Teofil wykazywał, że raj jest rzeczywistością ziemską („z ziemi i na ziemi został utworzony”), położoną „na ziemi pod wschodnim niebem”, a sam termin ogrodu - „Eden” oznaczał według niego w języku hebrajskim - „rozkosz” ${ }^{461}$. W wyjaśnieniu znaczenia

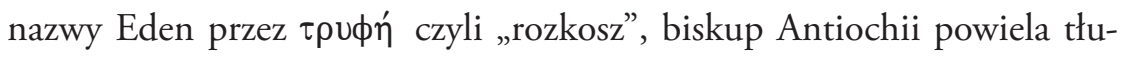
maczenie LXX. Sam raj byłby pod względem piękna czymś pośrednim pomiędzy niebem a ziemią ${ }^{462}$.

Raj stał się dla człowieka miejscem próby, kiedy Bóg przeniósł go tam z ziemi, z której został uczyniony. Bóg w raju dał człowiekowi „okazję

454 Teofil z Antiochii, Do Autolika II,20,1, w: SCh 20, s. 148; BOK 24, s. 417.

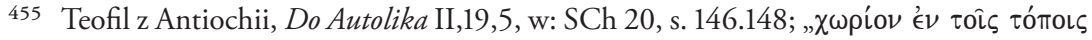

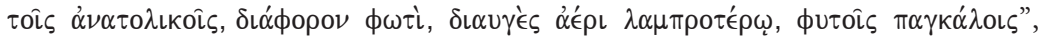
BOK 24, s. 417.

456 Teofil z Antiochii, Do Autolika II,20,1, w: SCh 20, s. 148; BOK 24, s. 417.

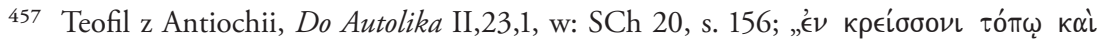

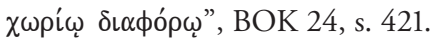

458 Por. Teofil z Antiochii, Do Autolika II,23,2-3, w: SCh 20, s. 156; BOK 24, s. 421.

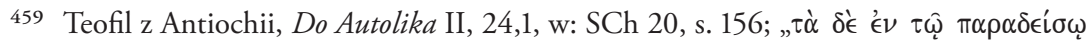

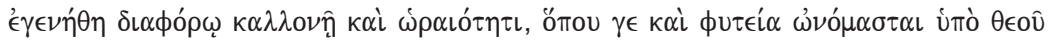
$\pi \in \phi \cup \tau \epsilon \cup \mu \epsilon \in v \eta ”$, BOK 24, s. 421.

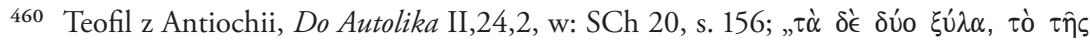

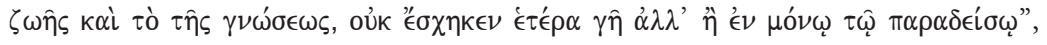
BOK 24, s. 421.

461 Teofil z Antiochii, Do Autolika II,24,3, w: SCh 20, s. 156.158; „(...) ó $\pi \alpha \rho \alpha ́ \delta \epsilon \iota \sigma o \varsigma ~ \gamma \hat{\eta}$

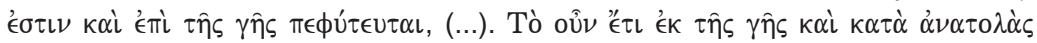

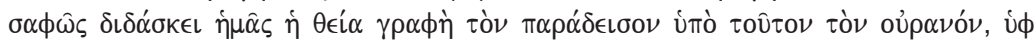

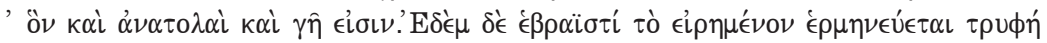

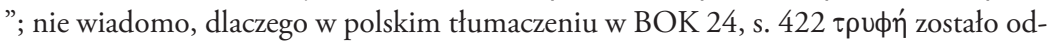
dane jako „upodobanie”?

462 Teofil z Antiochii, Do Autolika II,24,7, w: SCh 20, s. 158; „Podobnie zresztą jak i sam raj, jeśli chodzi o piękno, został stworzony pośrodku, pomiędzy ( $\mu$ '́⿴囗б) $)$ niebem a ziemią", BOK 24, s. 422. 
Kształtowanie się nauki o niebie w teologii patrystycznej I-III wieku

do postępowania w doskonałości, tak aby poprzez wzrastanie stał się doskonały, został nawet nazwany Bogiem, mógł wstąpić do nieba i posiąść wieczność" ${ }^{663}$. Kolejną motywacją do owej próby było sprawdzenie posłuszeństwa człowieka wobec Bożego przykazania oraz Boża chęć, aby człowiek, „będąc prosty i szczery, dłużej pozostał w stanie młodości”464. Polecenie uprawy ziemi w ogrodzie w Eden Teofil tłumaczył metaforycznie jako zachowywanie przykazań boskich i trwanie w posłuszeństwie wobec Boga ${ }^{465}$. Biskup Antiochii wykazywał, że pierwszy człowiek nie był nieśmiertelny w raju, ale został stworzony, jak sam raj, „w stanie pośrednim, ani całkowicie śmiertelny, ani całkowicie nieśmiertelny, lecz zdolny do stania się jednym i drugim”466. Człowiek jako młode stworzenie (dosłownie „dziecko”) nie był zdolny do właściwego poznania ${ }^{467}$, przez swe nieposłuszeństwo wobec Boga został wyrzucony z raju i zaczął odczuwać ból, cierpienie, trudy i śmierć ${ }^{468}$.

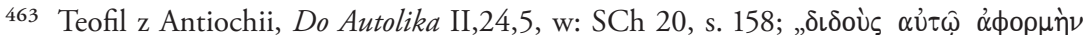

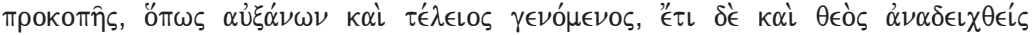

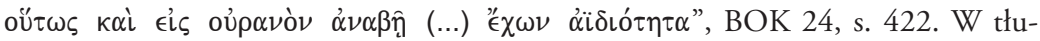

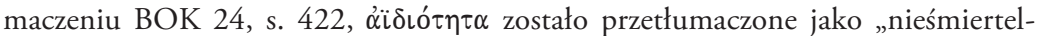

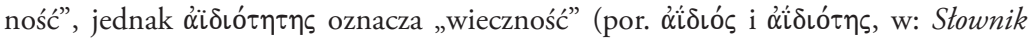
grecko-polski, red. Z. Abramowiczówna, t. 1, Warszawa 1958, s. 48, tłumaczy jako

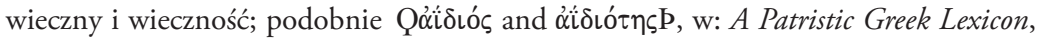
ed. G. W. H. Lampe, Oxford $1991^{10}$, s. 47-48, podaje odpowiednio „eternal, everlasting" i „eternity").

464 Teofil z Antiochii, Do Autolika II,25,4, w: SCh 20, s. 160; BOK 24, s. 423.

465 Por. Teofil z Antiochii, Do Autolika II,24,8, w: SCh 20, s. 158; „Nakaz natomiast, aby go uprawiać, nie oznacza żadnego innego zajęcia jak właśnie zachowywanie przykazań

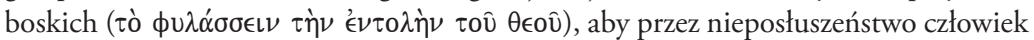
nie zniszczył samego siebie, tak jak to rzeczywiście uczynił poprzez grzech", BOK 24, s. 422.

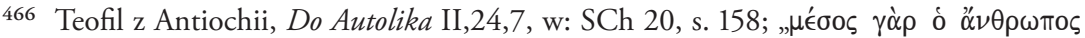

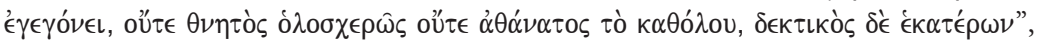
BOK 24, s. 422.

467 Teofil z Antiochii, Do Autolika II,25,2, w: SCh 20, s. 160; „Jeśli zaś chodzi o wiek, to Adam był $\nu$ ท́тा tłumaczy, nie wiadomo dlaczego, „młodzieńcem”); dlatego właśnie nie był zdolny do właściwego używania poznania”, BOK 24, s. 423. W kolejnych fragmentach Do Autolika 25,4-7 Teofil również przyrównuje pierwszego człowieka właśnie do dziecka

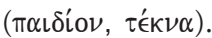

468 Por. Teofil z Antiochii, Do Autolika II,25,8, w: SCh 20, s. 162; BOK 24, s. 423-424. 
2. Kształtowanie się nauki o niebie w teologii patrystycznej - wiek I-II

Wypędzony z raju człowiek, „aby nie pozostawał w stanie grzechu na wieki”, został skazany przez Boga „jakby na wygnanie, aby poprzez karę w określonym czasie odpokutował za grzech i po odbyciu kary znów mógł być wezwany" ${ }^{469}$, w domyśle - do raju. W doczesności cierpliwy ( $\mu \alpha \kappa \rho o ́ \theta u \mu \circ \varsigma)$ Bóg daje człowiekowi czas „nawrócenia i pokuty ( $\mu \in \tau \alpha \nu$ oí $\alpha \varsigma$

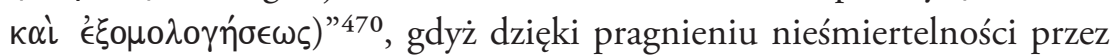
zachowywanie Bożych przykazań człowiek otrzyma nieśmiertelność i będzie upodabniał się do Boga („stał się jakby Bogiem”) ${ }^{471}$. Sama śmierć jest etapem kształtowania człowieka (porównanie śmierci człowieka do kształtowania naczynia ze skazą przez „ponowne roztopienie i przeformowanie, aby stało się nowe i doskonałe”) i dostosowywania go przez zmartwychwstanie do „uzdrowienia, tzn. (aby) stał się znowu czysty, sprawiedliwy i nieśmiertelny" ${ }^{472}$ oraz niezniszczalny ${ }^{473}$. Powrót człowieka do raju ma się dokonać, zdaniem Teofila, „po zmartwychwstaniu i sądzie” ${ }^{474}$.

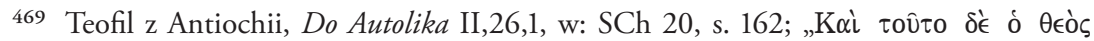

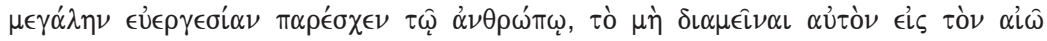

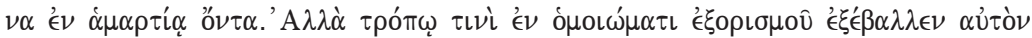

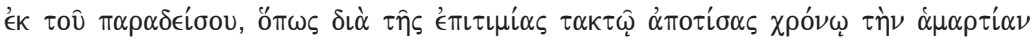

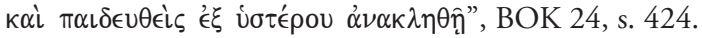

470 Teofil z Antiochii, Do Autolika II,26,4, w: SCh 20, s. 164 [tłumaczenie własne Autora].

471 Teofil z Antiochii, Do Autolika II,27, 3, w: SCh 20, s. 164; „ (...) jeśli będzie skłaniał

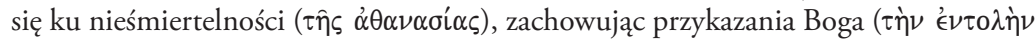

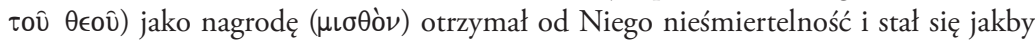

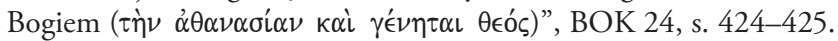

472 Teofil z Antiochii, Do Autolika II,26,3, w: SCh 20, s. 164; „ Co więcej, podobnie jak naczynie po ukształtowaniu, gdy posiada jakąś skazę, jest ponownie roztopione i przeformowane, by stało się nowe i doskonałe, tak również dzieje się z człowiekiem w mo-

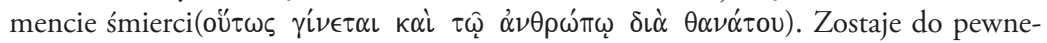
go stopnia roztopiony, by poprzez zmartwychwstanie dostąił uzdrowienia, tzn. stał

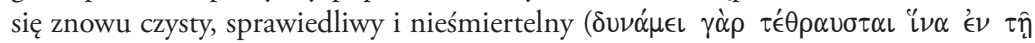

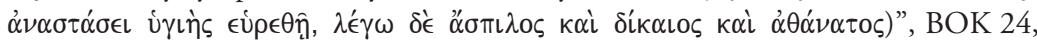
s. 424.

473 Teofil z Antiochii, Do Autolika II,27,7, w: SCh 20, s. 166; „Dał nam bowiem Bóg prawa i święte przykazania, a każdy, kto je zachowuje, może dostąpić zbawienia i odzie-

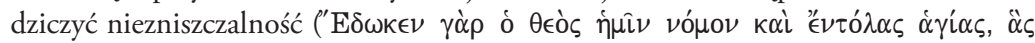

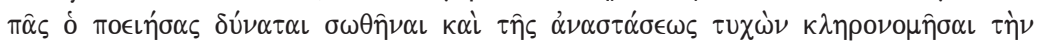
$\dot{\alpha} \phi \theta \alpha \rho \sigma i \alpha \nu) ”$, BOK 24, s. 425 (por. 1 Kor 15, 50).

474 Teofil z Antiochii, Do Autolika II,26,2, w: SCh 20, s. 162.164; „Z tego właśnie powodu Księga Rodzaju opowiada w tajemniczy sposób, że człowiek został umieszczony 
Kształtowanie się nauki o niebie w teologii patrystycznej I-III wieku

\section{Widzenie Boga dzięki doczesnej wierze w Boga}

Powołując się na 1 Kor 15, 53, Teofil argumentował, iż człowiek, uznając Boga przez wiarę i bojaźń Bożą, a także żyjąc w czystości, świętości i sprawiedliwości, może ujrzeć Boga, co dokona się po zmartwychwstaniu, kiedy ciało dzięki wskrzeszeniu przez Boga stanie się nieśmiertelne wraz z duszą, „i wówczas stając się nieśmiertelny, ujrzysz nieśmiertelnego, jeśli teraz Jemu uwierzysz" ${ }^{475}$. Tak stworzenie, jak i zmartwychwstanie oraz życie w nieśmiertelności dokonują się dla człowieka dzięki Bogu, jednak do uznania tych spraw jest wymagana w doczesności wiara ${ }^{476}$.

Według Teofila z Antiochii po zmartwychwstaniu i sądzie zbawiony człowiek ma iść do raju, w którego opisie akcent został rozłożony zarówno na doznania zmysłowe („ogród rozkoszy”, wypełniony światłem, czystym powietrzem, wspaniałymi drzewami), jak i na cechy jakościowe (brak cierpień, czystość, sprawiedliwość, nieśmiertelność, niezniszczalność, widzenie Boga). Paradoksalnie raj jest opisany jako miejsce pośrednie, tak pod względem piękna, jak i w kontekście pierwszego w nim pobytu człowieka (z raju miał wstąpić do nieba i posiąść nieśmiertelność). Przyjęcie do raju jest uwarunkowane przez nawrócenie i pokutę człowieka na ziemi. Przy opisie swej eschatologii końcowej antiocheński apologeta używał argumentacji dosłownej, głównie ze ST oraz korzystał z teologii judaizmu helleńskiego (koncepcja kosmologiczna, koncepcja powrotu do raju). Stąd nie dziwi zarówno brak podkreślania wątków chrystologicznych, jak i teologii łaski.

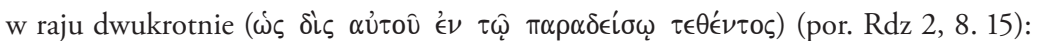
pierwszy raz człowiek został tam umieszczony rzeczywiście (" $i \nu \alpha \ldots \pi \epsilon \pi \lambda \eta \rho \omega \mu \in \operatorname{c} \nu 0 \nu$ ö $\tau \epsilon$

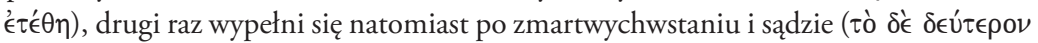

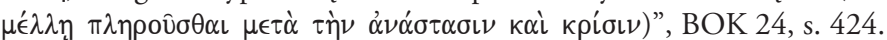

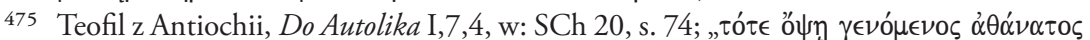

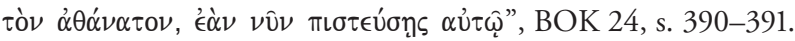

476 Por. Teofil z Antiochii, Do Autolika I,8,1-3, w: SCh 20, s. 74.76; BOK 24, s. 391; Teofil z Antiochii, Do Autolika I,13,1-9, w: SCh 20, s. 86.88; BOK 24, s. 394-395. 
2. Kształtowanie się nauki o niebie w teologii patrystycznej - wiek I-II

\subsubsection{List do Diogneta - nieśmiertelna dusza mieszkająca w namiocie śmiertelnym oczekuje niezniszczalności człowieka w niebie}

List do Diogneta ${ }^{477}$ jest apologią chrześcijańską napisaną pod koniec II wieku, najprawdopodobniej w Aleksandrii ${ }^{478}$. Niektórzy badacze, jak np. Enrico Norelii, sugerują Azję Mniejszą bądź Rzym jako miejsce powstania tego tekstu ${ }^{479}$. Autor listu pozostaje dla większości patrologów anonimowy, choć Henri Irénée Marrou, wydawca tekstu krytycznego Listu do Diogneta w serii SCh, wyprowadził ciekawą hipotezę o związanym z Aleksandrią Pantajnosie z Sycylii jako o możliwym autorze tekstu ${ }^{480}$. Podstawowymi wątkami teologicznymi listu są: transcendencja objawienia chrześcijańskiego oraz Boża ekonomia zbawienia z jej kluczowymi elementami - Wcieleniem Słowa i ofiarą odkupieńczą Zbawiciela. Anonimowy autor dzieła wskazuje, iż przyjęcie orędzia chrześcijańskiego wymaga przemiany człowieka w jego relacjach do Boga (wiara i miłość) i do ludzi (naśladowanie dobroci Boga, odrzucanie egoizmu, pychy i przemocy) oraz wprowadzanie już na ziemi atmosfery oczekiwania na eschatologiczne Królestwo Boże (rozdziały VII-X) ${ }^{481}$.

Teologia nieba jest fragmentaryczna i wspominana w Liście do Diogneta przy okazji omawiania chrześcijańskiej moralności. Dla zrozumienia kontekstu teologicznego nauki o niebie, jaka została poruszona w tekście omawianego teraz listu, należy najpierw rozważyć postulowaną przez jej anonimowego autora antropologię, naukę o wiarygodności chrześcijaństwa oraz kosmologię.

477 Anonymus ad Diognetum, w: SCh 33bis. A Diognète. Introduction, édition critique, traduction et commentaire de Henri Irénée Marrou, Paris 1997; przekład polski List do Diogneta, w: Pierwsi świadkowie. Pisma Ojców..., dz. cyt., BOK 10, s. 339-348.

478 Por. S. Zincone, Diogneto (A), w: NDPAC 1, Genova-Milano 2006², k. 1428-1430.

479 Por. E. Norelli (a cura di), A Diogneto, Milano 1991, s. 49-52 (Letture Cristiane del Primo Millennio 11).

480 Por. H. I. Marrou, Commentaire, w: SCh 33bis, s. 265.

481 Por. H. Drobner, Patrologia..., dz.cyt., s. 128-131; S. Zincone, Diogneto (A), w: NDPAC 1..., dz. cyt., s. 1429. 
Kształtowanie się nauki o niebie w teologii patrystycznej I-III wieku

\section{Dualizm ontologiczny w antropologii}

Nieznany autor Listu do Diogneta rozwijał typowo platońską antropolo-

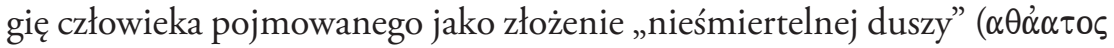
ๆे $\psi \cup \chi \eta)$ ze śmiertelnym ciałem, opisanym za 2 P 1, 13 jako „śmiertelny namiot" ( $\theta \nu \eta \tau \hat{\omega} \quad \sigma \kappa \eta \nu \omega \dot{\mu} \mu \alpha \iota)^{482}$. Uprzywilejowanym elementem tego połączenia z założenia jest dusza: znajdująca się we wszystkich członkach ciała; mieszkająca w ciele, ale nie będącą z ciała; niewidzialna i zamknięta w widzialnym ciele; będąca znienawidzoną i zwalczaną przez ciało, bo przeszkadza mu w korzystaniu z rozkoszy; kochająca ciało i jego członki; zamknięta w ciele, ale stanowiąca o jedności ciała; nieśmiertelna, ale mieszkająca w śmiertelnym namiocie ciała; staje się lepsza przez umartwienia głodu i pragnienia ${ }^{483}$. Porównując do roli duszy w ciele, rolę chrześcijan w świecie $^{484}$, autor utworu uznaje, że wynika to z woli samego Boga - „tak za-

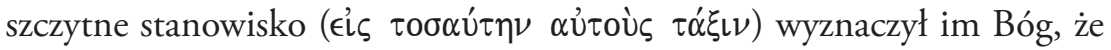
nie godzi się go opuścić” 485 .

\section{Wiarygodność chrześcijaństwa i kosmologia - dzięki objawieniu Syna Bożego}

Zdaniem anonimowego autora listu nauka chrześcijańska jest wiarygodna, gdyż nie jest pochodzenia ziemskiego, śmiertelnego, lecz Bożego, z nieba, bo dzięki Wcieleniu wśród ludzi zamieszkał Bóg ${ }^{486}$. Autor Listu do Diogneta

482 List do Diogneta VI,8, w: SCh 33bis, s. 66; BOK 10, s. 343.

483 List do Diogneta VI,1-9, w: SCh 33bis, s. 64.66; BOK 10, s. 342-343.

484 Według autora Listu do Diogneta VI,1-9 chrześcijanie - mieszkają we wszystkich miastach świata; mieszkają w świecie, ale nie są ze świata; są w widzialnym świecie, ale oddają niewidzialny kult Bogu; są znienawidzeni przez świat, bo są przeciwni rozkoszom świata; kochają tych, co ich nienawidzą; są zamknięci w świecie jak w więzieniu, ale stanowią o jedności świata; mieszkają w zniszczalnym świecie, oczekując niezniszczalności w niebie; prześladowani, mnożą się z dnia na dzień.

485 List do Diogneta VI,10, w: SCh 33bis, s. 66; BOK 10, s. 343.

486 List do Diogneta VII,1-2, w: SCh 33bis, s. 66; „1. Przekazana im nauka nie jest, jak

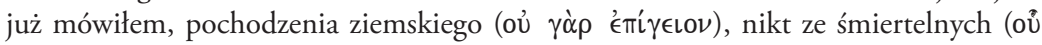

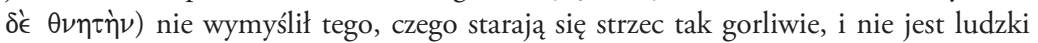

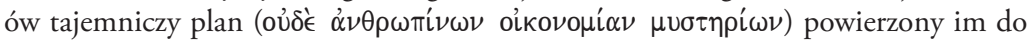
wykonania. 2. Zaiste, sam Wszechmogący, Stwórca wszechrzeczy, Bóg niewidzialny

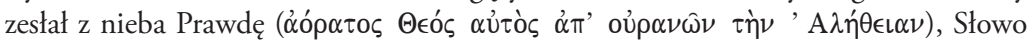
Święte przewyższające wszelkie rozumienie, sprawiając, że zamieszkało Ono wśród ludzi i utwierdziło się w ich sercach”, BOK 10, s. 343 (por. Ga 1, 12; J 14, 6; Ap 3, 7). 
w przekazie o prawdziwości nauki chrześcijańskiej podaje także skróconą kosmologię biblijną, z odwołaniem do Hbr 11, 10; Ps 103, 9; Prz 8, 27-29; Hi 26, 10; 38, 8-11; 2 Kor 10, 1. Jest ona jednoznacznie chrystocentryczna:

„Przez Niego to Bóg stworzył niebo ( Niego zamknął morze w określonych granicach, do Jego praw tajem-

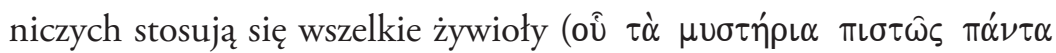

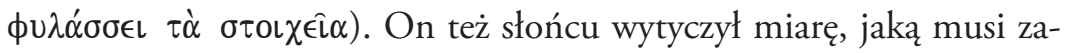
chowywać w swoich dziennych podróżach. Jemu posłuszny jest księżyc, gdy mu rozkazuje, by w nocy świecił; od Niego wszechświat bierze swój porządek i granice, Jemu cały podlega: niebo i wszystko, co w niebie $(\hat{\omega}$

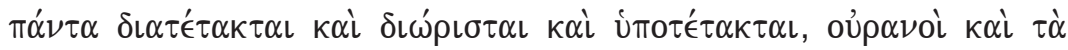

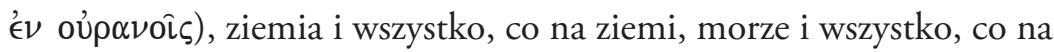
morzu, ogień, powietrze, otchłań, to, co w górze, to, co w dole, i regio-

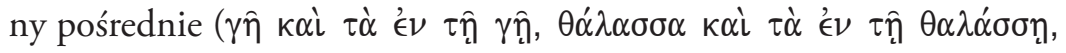

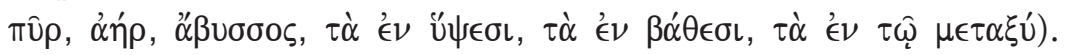
Jego to właśnie Bóg posłał do ludzi” ${ }^{487}$.

Chrystus zostaje nazwany „Architektem i Budowniczym wszechświa-

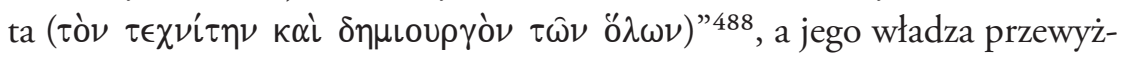

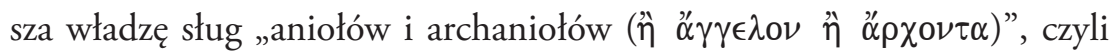
duchów zawiadujących sprawami ziemskimi „czy rządzących w niebie”

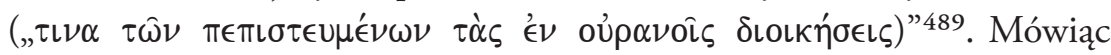
o Bogu i Jego objawieniu w świecie, autor Listu do Diogneta powołuje się na Łk 10, 22 i J 1, 18 oraz Rz 3, 25 i powtarza zasadniczą prawdę teologii biblijnej, że „nikt z ludzi Go nie widział, ani nie poznał, On sam sie-

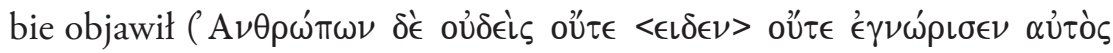

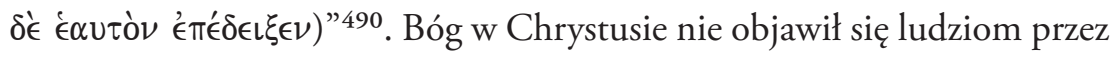
rozmaite systemy filozofii greckiej ${ }^{491}$, „objawił się zaś przez wiarę, gdyż jej

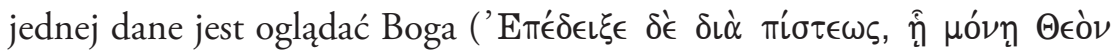

487 List do Diogneta VII,2, w: SCh 33bis, s. 66.68; BOK 10, s. 343 (por. Klemens Rzymski, List do Kościota $w$ Koryncie XXX,8; XXXIII,3).

488 List do Diogneta VII,2, w: SCh 33bis, s. 66; BOK 10, s. 343 (por. Hbr 11, 10).

489 List do Diogneta VII,2, w: SCh 33bis, s. 66; BOK 10, s. 343.

490 List do Diogneta VIII,5, w: SCh 33bis, s. 70; BOK 10, s. 344.

491 Por. List do Diogneta VIII,1-4, w: SCh 33bis, s. 70; BOK 10, s. 344. 
Kształtowanie się nauki o niebie w teologii patrystycznej I-III wieku

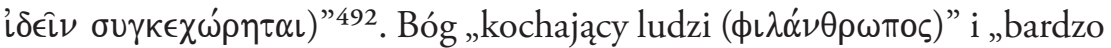

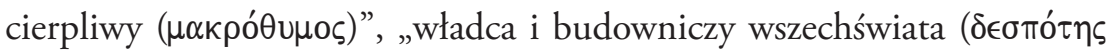

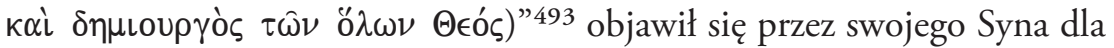
zbawienia ludzi, „odsłonił i objawił to, co przygotował od początku, jednocześnie wszystko nam razem ofiarował: pozwolił i uczestniczyć w swoich dobrodziejstwach, pozwolił i wiedzieć, i rozumieć" ${ }^{494}$.

\section{Terminy}

Nazewnictwo używane przez autora Listu do Diogneta jest pochodzenia biblijnego. Przeważają pojęcia rzeczowe, najczęściej związane z pojęciami kosmologii ST („niebo” jako górna część stworzenia) oraz z soteriologia NT („Królestwo Boże”; „królestwo niebieskie”, rozumiane jako doskonałe i wieczne panowanie Boga nad zbawionymi). Rzadziej występują pojedyncze określenia jakościowe, opisujące którąś z cech przebywających w niebie ludzi zbawionych („niezniszczalność”; „ogród rozkoszy”).

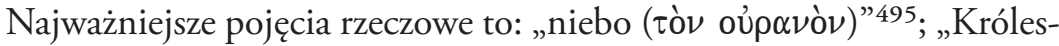

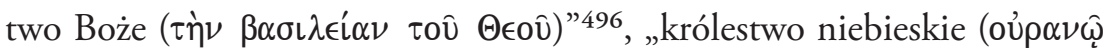
$\beta \alpha \sigma \iota \lambda \in i \alpha \nu) " 497$.

492 List do Diogneta VIII,6, w: SCh 33bis, s. 70; BOK 10, s. 344.

493 List do Diogneta VIII,7, w: SCh 33bis, s. 70; BOK 10, s. 344 (por. Rz 2, 4).

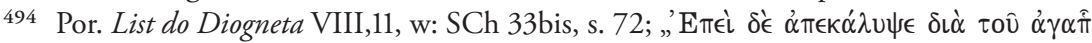

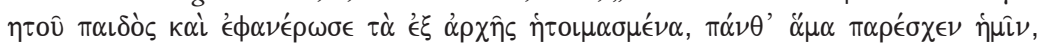

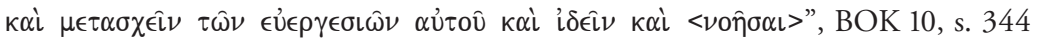
(por. Mt 3, 17; 17, 5; Ef 3, 9; Ga 4, 4-5; Rz 8, 32).

495 List do Diogneta III,4 w: SCh 33bis, s. 58; „Ten bowiem, kto stworzył niebo i ziemię

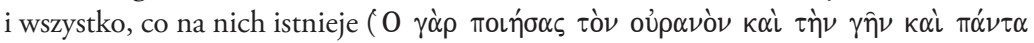

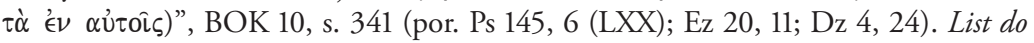

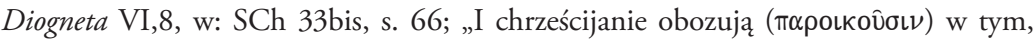

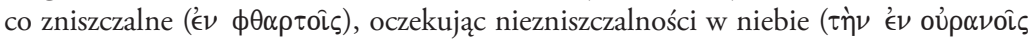

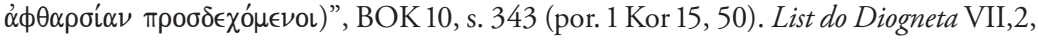

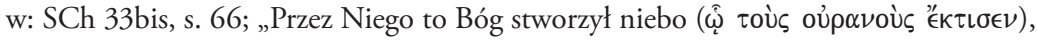
przez Niego zamknął morze w określonych granicach", BOK 10, s. 343 (por. Ps 103, 9; Prz 8, 27-29; Hi 26, 10; 38, 8-11). List do Diogneta X,2, w: SCh 33bis, s. 76; „Im tylko

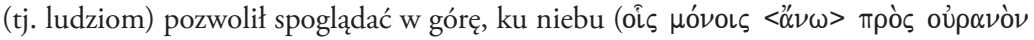

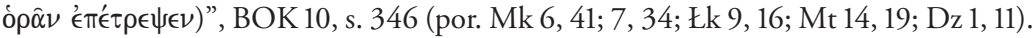

496 List do Diogneta IX,1, w: SCh 33bis, s. 72; „Pozostawieni sobie okazaliśmy się niezdolni wejść do Królestwa Bożego, a dzisiaj zdolność tę daje nam moc Boża”, BOK 10, s. 345 (por. J 3, 5).

497 List do Diogneta X,2, w: SCh 33bis, s. 76; „Im również obiecał królestwo niebieskie i da je tym, którzy Go miłują”, BOK 10, s. 346 (por. Łk 12, 32; J 14, 23). 
2. Kształtowanie się nauki o niebie w teologii patrystycznej - wiek I-II

Natomiast podstawowe pojęcia jakościowe to: „niezniszczalność w niebie (oủ $\left.\alpha \alpha \nu 0 \hat{\varsigma} \varsigma \alpha \phi \theta \alpha \rho \sigma^{\prime} \alpha \nu\right)$ " ${ }^{498}$; stawanie się „ogrodem rozkoszy (oi

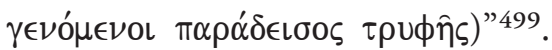

\section{Teologia nieba}

Autor Listu do Diogneta, rozwijając wątki biblijne z Dz 14, 15; 17, 30 oraz Tt 3, 3 i Rz 3, 25, nauczał, że Bóg dopuszcza, aby ludzie w doczesności ulegali własnym zachciankom i nieuporządkowanym popędom, aby człowiek przekonał się najpierw, że „nasze własne postępowanie czyni nas niegodnymi życia, dzięki Bożemu miłosierdziu staliśmy się teraz godni tego daru. Pozostawieni sobie okazaliśmy się niezdolni wejść do Królestwa Bożego, a dzisiaj zdolność tę daje nam moc Boża" ${ }^{500}$. Bóg, zakrywając ludzkie grzechy przez swoją sprawiedliwość, dokonał usprawiedliwienia ludzi w Synu Bożym ${ }^{501}$. Bóg stworzył człowieka na swój obraz ${ }^{502}$, umiłował go, stworzył dla niego świat i poddał mu ziemię, obdarzył myślą i rozumem i „pozwolił spoglądać w górę, ku niebu” ${ }^{503}$, ludziom został posłany Syn jednorodzony, Bóg ludziom obiecał „królestwo niebieskie i da je tym, którzy Go miłują”504.

W parenezie autora Listu do Diogneta Królestwo Boże, w myśl teologii $1 \mathrm{~J}$ 4, 19 oraz Ef 5, 1; Ga 6, 2 i 1 Kor 14, 2, jest pojmowane jako obietnica samego Boga, która zrealizuje się, kiedy człowiek będzie kochał Go i naśladował Jego dobroć ${ }^{505}$. Naśladując Boża dobroć, głosząc Boże tajemnice innym, kochając i podziwiając męczenników za wiarę, nie zapierając się Boga w życiu, odrzucając ułudę i oszustwo świata, wierzący zaczyna rozumieć, co to znaczy „żyć w niebie” i może już na ziemi „widzieć, jak Bóg rządzi w niebie" 506 . Natomiast tyranizując bliźniego i krzywdząc innych,

498 List do Diogneta VI,8, w: SCh 33bis, s. 66; „I chrześcijanie obozują w tym, co zniszczalne, oczekując niezniszczalności w niebie”, BOK 10, s. 343 (por. 1 Kor 15, 50).

499 List do Diogneta XII,1, w: SCh 33bis, s. 80; „1. Zbliżcie się i słuchajcie gorliwie, a dowiecie się, jak wielkie łaski daje Bóg tym, którzy Go prawdziwie miłują. Stają się oni ogrodem rozkoszy. Wyrasta w nim nadzwyczaj płodne drzewo, pełne soków żywotnych, i oto zdobią się w najróżniejsze owoce", BOK 10, s. 347 (por. Rdz 2, 8-25).

500 List do Diogneta IX,1, w: SCh 33bis, s. 72; BOK 10, s. 345.

501 Por. List do Diogneta IX,3-4, w: SCh 33bis, s. 74; BOK 10, s. 345.

502 Por. List do Diogneta X,2, w: SCh 33bis, s. 76; BOK 10, s. 364.

503 List do Diogneta X,2, w: SCh 33bis, s. 76; BOK 10, s. 345.

504 List do Diogneta X,2, w: SCh 33bis, s. 76; BOK 10, s. 346.

505 Por. List do Diogneta X,3-4; 6, w: SCh 33bis, s. 76.78; BOK 10, s. 346.

506 List do Diogneta X,7, w: SCh 33bis, s. 78; BOK 10, s. 346. 
Kształtowanie się nauki o niebie w teologii patrystycznej I-III wieku

okazuje się wzgardę Bogu i skazuje się tym samym na ogień wieczny, karę ostateczną ${ }^{507}$. Przyjęcie nauki Bożej i umiłowanie Boga w myśl 1 Kor 2, 9 oraz $\mathrm{Rdz}$ 2, 8 i 3, 7 skutkuje natomiast w człowieku wierzącym obdarzeniem go pełnią łaski, której formę autor Listu do Diogneta porównuje do stania się przez człowieka - „ogrodem rozkoszy” 508 , który będzie zawsze trwał i nie będzie zagrożony diabłem i jego podstępami i skazą, jak to miało miejsce w ogrodzie Eden ${ }^{509}$.

W apologii, jaką jest List do Diogneta, wątki eschatologii końcowej dotyczącej nieba są rozwijane fragmentarycznie, przy okazji omawiania chrześcijańskiej moralności. Człowiek definiowany jest antropologicznie przy użyciu terminologii platońskiej jako złożenie „nieśmiertelnej duszy” ze śmiertelnym ciałem, oczekuje on dzięki Wcieleniu Boga nieba eschatologicznego. Jest ono opisywane głównie biblijnymi terminami rzeczowymi i soteriologicznymi („niebo”, „Królestwo Boże”; „królestwo niebieskie”), rzadziej jakościowymi („niezniszczalność”; „ogród rozkoszy”). Zgodnie z chrystologiczną teologią NT, na którą powołuje się anonimowy autor utworu, eschatologiczne niebo w Liście do Diogneta stanowi obietnicę Boga dla ludzi kochających Go i naśladujących Jego dobroć. Jest dostępne ludziom dzięki Wcieleniu Chrystusa - „Architekta i Budowniczego wszechświata”.

\subsubsection{Podsumowanie nauki o niebie w teologii patrystycznej apologetów greckich II wieku}

Odniesienia do eschatologicznego nieba nadal pozostają fragmentaryczne i pojawiają się okazyjnie, nie stanowiąc nigdy pełnego wykładu teologicznego, co jest w dużej mierze uwarunkowane apologią jako zasadniczym rodza-

507 Por. List do Diogneta X,5; 7, w: SCh 33bis, s. 76.78; BOK 10, s. 346.

508 List do Diogneta XII,1-2, w: SCh 33bis, s. 80.82; „Zbliżcie się i słuchajcie gorliwie, a dowiecie się, jak wielkie łaski daje Bóg tym, którzy Go prawdziwie miłują. Stają się oni ogrodem rozkoszy. Wyrasta w nim nadzwyczaj płodne drzewo, pełne soków żywotnych, i oto zdobią się w najróżniejsze owoce. W tym ogrodzie posadzone zostało drzewo poznania i drzewo życia, lecz to nie drzewo poznania zabija: zabija nieposłuszeństwo", BOK 10, s. 347.

509 List do Diogneta XII,8, w: SCh 33bis, s. 82; „Jeśli takie drzewo w tobie wyrośnie i jeśli zapragniesz jego owoców, zawsze będziesz zbierał to, co chcesz otrzymać od Boga, to, czego wąż nie może dosięgnąć ani jego podstęp skazić”, BOK 10, s. 347. 
jem przekazu większości autorów chrześcijańskich w II wieku. Wyjątkiem w omawianej grupie jest Homilia Paschalna będąca deklamacją liturgiczną. Wiara w eschatologiczne niebo staje się w II wieku częścią chrześcijańskiego credo. Odniesienia do opisywanego przestrzennie nieba, oznaczającego ściślejszą relację zbawionych z Bogiem, spotykamy w pierwszych pozabiblijnych wyznaniach wiary, kiedy jest mowa o działalności zbawczej Chrystusa zstępującego i wstępującego do nieba ${ }^{510}$, co dla chrześcijan stanowi zapowiedź i nadzieję na ich życie w przyszłym świecie ${ }^{511}$ (credo Arystydesa) albo przy okazji wyjaśnień do credo (Justyn Męczennik, Meliton z Sardes). Dla części apologetów II wieku osiągnięcie eschatologicznego nieba jest coraz bardziej uzależniane etycznie (Atenagoras z Aten, Justyn Męczennik, Tacjan Syryjczyk), co w dużej mierze wynika z apologetyczności ich wykładu. Natomiast dwóch autorów syryjskich (Tacjan Syryjczyk, Teofil z Antiochii) szczęśliwą eschatologiczną wieczność opisywało jako powrót do lepszej wersji „rajskości”, do pierwotnego stanu życia, ale już w nieśmiertelności i częściowej wizji Boga (Tacjan Syryjczyk), być może z perspektywą wejścia do eschatologicznego nieba (Teofil z Antiochii).

\section{Opisy nieba}

Eschatologiczne niebo jest stworzone przez Boga ${ }^{512}$ i pozostaje dziełem Bożym, wobec którego jest On transcendentny ${ }^{513}$; związane ze zbawiającym Chrystusem ${ }^{514}$; znajduje się w niepostrzegalnym przez ludzi „wszechświecie niebiańskim" ${ }^{15}$; jest miejscem, gdzie jest dobrze i gdzie przebywa Bóg i dobrzy aniołowie $e^{516}$, jednak obecne niebo jest zapowiedzią innego, nowego nieba ${ }^{517}$. Dla zbawionych eschatologiczne niebo jest trwaniem człowieka z Bogiem i przy Bogu ${ }^{518}$; jest miejscem zbawionych ${ }^{519}$.

\footnotetext{
510 Por. Arystydes z Aten, Apologia 15,1-2.

511 Por. Arystydes z Aten, Apologia 15,3.

512 Por. Arystydes z Aten, Apologia 3,1; 4,2; Justyn Męczennik, 1 Apologia 41,1.

513 Por. Teofil z Antiochii, Do Autolika I,4,3-5; II,22,2.

514 Por. Arystydes z Aten, Apologia 15,1.

515 Por. Arystydes z Aten, Apologia 4,2.

516 Por. Justyn Męczennik, 1 Apologia 6,1-2.

517 Por. Justyn Męczennik, Dialog z Żydem Tryfonem 131,6.

518 Por. Atenagoras z Aten, Prośba za chrześcijanami 31.

519 Por. Justyn Męczennik, 1 Apologia 10,2.4.
} 
Kształtowanie się nauki o niebie w teologii patrystycznej I-III wieku

W niektórych opisach (Tacjan Syryjczyk, Teofil z Antiochii, częściowo List do Diogneta) niebo jest też powrotem człowieka zbawionego do utraconego, utęsknionego pierwotnego stanu życia, czyli do nieśmiertelności i częściowej wizji Boga ${ }^{520}$. Tak wyobrażany raj posiada wybrane cechy zarówno biblijnego ogrodu w Eden, jak i Niebieskiego Miasta z Ap $21^{521}$. W opisie Teofila z Antiochii niebo przyjmuje judaistyczne charakterystyki kosmologiczne i jest przede wszystkim albo widzialnym sklepieniem-firmamentem, albo innym niebem, opisywanym jako niewidzialne dla ludzi miejsce przechowywania połowy wód (druga połowa wód jest już na ziemi). Dlatego u tego apologety nie staje się ono miejscem Boga i zbawionych. Odpowiednikiem nieba dla Teofila, dalej zgodnie z przekonaniami judaistycznymi, staje się zaś raj. Natomiast dla anonimowego autora Listu do Diogneta niebo jest zarówno „królestwem niebieskim”, jak i „ogrodem rozkoszy”.

\section{Stosowana terminologia}

Słownictwo odnoszone do opisania eschatologicznego nieba i jakości życia zbawionych jest zdecydowanie pochodzenia nowotestamentalnego, są to bezpośrednie zapożyczenia z NT (rzadziej ze ST) lub zbitki słowotwórcze fragmentów biblijnych:

(1) określenia związane $\mathrm{z}$ motywami przestrzenno-rzeczowymi: „niebo” 522 , „niebiosa”523, „wyżyny niebieskie” ${ }^{24}$, „Chrystus powyżej”525, „zstąpił z nieba / wstąpił do nieba” ${ }^{26}$; „królestwo niebieskie” ${ }^{27}$, „Królestwo Boże”528, „królestwo niezniszczalne” ${ }^{29}$, „królestwo wieczne”530, opisowe

\footnotetext{
520 Por. Tacjan, Mowa do Greków 7,1.

521 Por. Tacjan, Mowa do Greków 20,4.

522 Por. Meliton z Sardes, Homilia Paschalna 47; List do Diogneta III,4; VI,8; VII,2; X,2.

523 Por. Meliton z Sardes, Homilia Paschalna 98.

524 Por. Meliton z Sardes, Homilia Paschalna 47; 70; 100; 102; 103; 104.

525 Por. Meliton z Sardes, Homilia Paschalna 45.

526 Por. Arystydes z Aten, Apologia 15,1; Justyn Męczennik, 1 Apologia 42,4; 50,12; 51,8; Justyn Męczennik, Dialog z Żydem Tryfonem 64,7; 132,1.

527 Por. Arystydes z Aten, Apologia 16,1; Justyn Męczennik, Dialog z Żydem Tryfonem 51,2; List do Diogneta X,2.

528 Por. Justyn Męczennik, 1 Apologia 11,1; List do Diogneta IX,1.

529 Por. Justyn Męczennik, Dialog z Żydem Tryfonem 31,4.

530 Por. Justyn Męczennik, Dialog z Żydem Tryfonem 31,1-7.
} 
charakterystyki połączonej rajskości i Niebieskiego Miasta z Ap 21 (woda, łagodny klimat i ciągły dzień, światłość, powyżej ziemi, ponad ludźmi, niemożliwe do obserwacji przez ludzi z ziemi, jest skończone i ograniczone, są ponad nim wyższe światy) ${ }^{531}$, „Jerozolima powyżej” ${ }^{532}$, „ogród w Eden” ${ }^{533}$, „raj” - rozumiany jako „rozkosz” ${ }^{34}$;

(2) określenia związane z motywami jakościowymi, które oddają cechy zbawionych w niebie / raju (dla obu autorów syryjskich):

„życie w przyszłym świecie" 535 , „życie wieczne”536, „życie i królowanie z Bogiem”537, „życie niebiańskie” [jako] „niezłomność i bez namiętności w duszy i ciele" 538 , „niezniszczalność" ${ }^{39}$, „niecierpiętliwość” 540 , „nieśmiertelność” ${ }^{441}$, „bezżenność i niezamężność zbawionych i równość aniołom jako dzieci Boże” ${ }^{442}$, „nieśmiertelność z radością”543, „udział w rozumnym życiu Boga i oglądanie Bożych wspaniałości” ${ }^{44}$, „widzenie Nieśmiertelnego przez nieśmiertelnych” ${ }^{445}$, „szczęście wieczne całego człowieka” ${ }^{446}$, brak potrzeby korzystania ze zwierząt ${ }^{547}$, „czystość-sprawiedliwość-nieśmiertelność-niezniszczalność”548, stawanie się „ogrodem rozkoszy" 549 .

531 Por. Tacjan, Mowa do Greków 20,4-6.

532 Por. Meliton z Sardes, Homilia Paschalna 45.

533 Por. Teofil z Antiochii, Do Autolika II,20,1.

534 Por. Teofil z Antiochii, Do Autolika II,24,3.

535 Por. Arystydes z Aten, Apologia 15,3.

536 Por. Arystydes z Aten, Apologia 16,1; 17,3.

537 Por. Justyn Męczennik, 1 Apologia 10,2.

538 Por. Atenagoras z Aten, Prośba za chrześcijanami 31.

539 Por. Justyn Męczennik, 1 Apologia 10,2; Justyn Męczennik, Dialog z Żydem Tryfonem 46,7; Atenagoras z Aten, O zmartwychwstaniu ciat 10; List do Diogneta VI,8.

540 Por. Justyn Męczennik, 1 Apologia 10,2; Justyn Męczennik, Dialog z Żydem Tryfonem 46,7; Atenagoras z Aten, O zmartwychwstaniu ciat 10.

541 Por. Justyn Męczennik, 1 Apologia 10,2; Justyn Męczennik, Dialog z Żydem Tryfonem 46,7; Atenagoras z Aten, O zmartwychwstaniu ciat 16.

542 Por. Justyn Męczennik, Dialog z Żydem Tryfonem 81,4.

543 Por. Tacjan, Mowa do Greków 14,5.

544 Por. Atenagoras z Aten, $O$ zmartwychwstaniu ciat 12.

545 Por. Teofil z Antiochii, Do Autolika I,7,4.

546 Por. Atenagoras z Aten, $O$ zmartwychwstaniu ciat 25.

547 Por. Atenagoras z Aten, $O$ zmartwychwstaniu ciat 10.

548 Por. Teofil z Antiochii, Do Autolika II,26,3; II,27,7.

549 Por. List do Diogneta XII,1. 
Kształtowanie się nauki o niebie w teologii patrystycznej I-III wieku

Odmienne natomiast od opisów większości apologetów greckich II wieku są typowo pastoralne powiązania, których dokonuje Meliton z Sardes. W jego deklamacji cechy Paschy Chrystusa stają się definitywnie cechami zbawionych. W „nowości-wieczności-niezniszczalności-nieśmiertelności” 550 zbawieni zyskują „odpuszczenie grzechów-zbawienie-życie-zmartwychwstanie-światłość-wejście na wyżyny niebieskie-ukazanie Ojca przedwiecznego” 551 oraz są obdarzeni „wolnością-światłością-życiem-wiecznym królowaniem (i są:) nowymi kapłanami-wiecznym ludem wybranym" 552 .

\section{Najważniejszy przekaz teologiczny dotyczący nieba}

Niebo, zgodnie z teologią NT, jest prezentowane jako obietnica samego Boga, który jest prawdomówny ${ }^{553}$. Wyznawanie i praktykowanie wiary w Boga ogłoszonej przez Jezusa Chrystusa ma doprowadzić chrześcijan do zapowiedzianego przez Chrystusa życia wiecznego i królestwa niebieskiego $^{554}$. Chrześcijanie ufają Bogu i zawierzają Mu swą eschatologiczną przyszłośćc55. Sposobem na wejście człowieka do nieba jest jedynie Chrystus ${ }^{556}$.

\section{Stan przejściowy i drugi millenaryzm}

Przyjęcie greckiej koncepcji dualizmu antropologicznego skutkowało w eschatologii chrześcijańskiej w II wieku początkiem rozważań o losach duszy rozdzielonej w momencie śmierci od ciała. Dusze sprawiedliwych, zachowując świadomość, przebywałyby bez cierpień i szczęśliwe w jakimś pozaświatowym lepszym miejscu, a dusze złych w jakimś gorszym pozaświatowym miejscu ${ }^{557}$, czy też w „magazynach bogatego Pana”558, oczekując zmartwychwstania i ostatecznego sądu Bożego.

\footnotetext{
550 Por. Meliton z Sardes, Homilia Paschalna 2.

551 Por. Meliton z Sardes, Homilia Paschalna 103.

552 Por. Meliton z Sardes, Homilia Paschalna 68.

553 Por. List do Diogneta X,2-7.

554 Por. Arystydes z Aten, Apologia 16,1.4-5; 17,3; Justyn Męczennik, 1 Apologia 10,2.

555 Por. Justyn Męczennik, 1 Apologia 13,2.

556 Por. Meliton z Sardes, Homilia Paschalna 47.

557 Por. Justyn Męczennik, 1 Apologia 18,2; 20,4; Justyn Męczennik, Dialog z Żydem Tryfonem 5,3.

558 Por. Tacjan Syryjczyk, Mowa do Greków 6,4.
} 
Natomiast przejęcie żydowskiej tradycji millenarystyczno-ezoterycznej przez niektórych teologów chrześcijańskich II wieku (np. Justyn Męczennik) zaowocowało rozważaniami o tzw. drugim millenium jako zmysłowym wynagrodzeniu dla wskrzeszonych wtedy tylko sprawiedliwych ${ }^{559}$.

\section{Moralizm eschatologiczny}

Oprócz typowo pastoralnych zachęt do dobrego życia chrześcijańskiego (wyznawanie i praktykowanie wiary chrześcijańskiej ${ }^{560}$; zaufanie Bogu i modlitwa o przyszłą niezniszczalność) ${ }^{561}$ pojawia się w teologii apologetów II wieku znacząca tendencja, którą nazwałem „moralizmem eschatologicznym”. Tym pojęciem określiłem linię teologiczną przeakcentowującą znaczenie ludzkich czynów i wskazującą, że wieczność jest przede wszystkim owocem moralnych wyborów człowieka, przy jednoczesnym pomijaniu przepowiadania o darmowym usprawiedliwieniu człowieka w Chrystusie i pomijaniu znaczenia łaski Bożej. W wykładzie teologicznym skutkowało to przerostem etyki i ludzkiego zasługiwania nad nowotestamentalną soteriologią. Tendencja ta pojawia się czasami w nauczaniu Justyna Męczennika, co, moim zdaniem, jest skutkiem apologetycznego harmonizowania przez tego orędownika platońskiego idealizmu etycznego i stoickiego poglądu o prymacie cnoty z przekazem biblijnym o uznaniu w wierze Bożego objawienia i konsekwencjach życia w wierze.

U Tacjana Syryjczyka enkratyckie postulaty odrzucenia złej materiii ${ }^{562} \mathrm{w}$ powiązaniu z grecką antropologią trójdzielną (szczególnie z ideą podążania duszy za duchem ${ }^{563}$ ) zaowocowały ascetyczną wizją zasługiwania na eschatologiczne niebo dzięki dobrym uczynkom ${ }^{564}$. Natomiast u Atenagorasa z Aten - zbawienie i życie wieczne - były pojmowane jako etyczna zasługa za dobre czyny, co mogło wynikać zarówno z apologetyczności jego wykładu teologicznego, jak i z etycznego pojmowania celowości ludzkiego życia.

\footnotetext{
559 Por. Justyn Męczennik, Dialog z Żydem Tryfonem 80,5-81,4.

560 Por. Arystydes z Aten, Apologia 16,1.

561 Por. Justyn Męczennik, 1 Apologia 13,2.

562 Por. Tacjan, Mowa do Greków 16,7-8.

563 Por. Tacjan, Mowa do Greków 12,1; 13,1-6.

564 Por. Tacjan, Mowa do Greków 14,5; 20,4-6.
} 
Kształtowanie się nauki o niebie w teologii patrystycznej I-III wieku

Nauka apologetów greckich II wieku o eschatologicznym niebie nie stanowiła podstawowej tematyki rozważań autorów chrześcijańskich. Pomimo fragmentaryczności przekazu znajdujemy w utworach tamtego okresu wzmianki o niebie w pierwszych pozabiblijnych credo lub komentarzach do nich. W opisach teologii apologetów II wieku eschatologiczne niebo pozostaje miejscem przebywania Boga i dobrych aniołów oraz sposobem istnienia zbawionych - z Bogiem i przy Bogu. Terminologia odnosząca się do nieba jest pochodzenia głównie biblijnego, przeważają określenia jakościowe nad przestrzennymi. Powiązanie teologii biblijnej z antropologią i etyką filozofii greckiej rozpoczyna w teologii apologetów II wieku refleksję nad stanem pośrednim, a także uwarunkowuje etycznie soteriologię chrześcijańską (moralizm eschatologiczny). Podstawowym przesłaniem teologicznym apologetów greckich II wieku dotyczącym eschatologicznego nieba pozostaje myśl, że niebo stanowi obietnicę Boga dla zbawionych, którą mogą osiągnąć przez wyznawanie i praktykowanie wiary ogłoszonej przez Jezusa Chrystusa. Sposobem na wejście człowieka do nieba jest jedynie Jezus Chrystus.

\subsubsection{Podsumowanie nauki o niebie w teologii patrystycznej ojców i pisarzy okresu poapostolskiego i apologetów greckich II wieku}

W obu analizowanych okresach opisy eschatologicznego nieba są fragmentaryczne i okazyjne. W okresie poapostolskim są one zależne od kontekstu parenetycznego, a w okresie apologetów greckich II wieku od rodzaju dyskursu, jakim była sama apologia. Dopiero w tekstach apologetów odnotowujemy, że wiara w niebo staje się częścią pierwszych pozabiblijnych wyznań wiary. Jeśli w okresie poapostolskim opisy nieba są kontynuacją kosmologii i eschatologii biblijnej, to w tekstach apologetów II wieku można zaobserwować podkreślanie związku zbawionych z Bogiem.

Terminologia oddająca eschatologiczne niebo w obu okresach jest zasadniczo biblijna, w pierwszym przeważają określenia związane z motywami 
rzeczowo-przestrzennymi, a w drugim z jakościowymi. Symbolika i obrazowość eschatologicznego nieba zawsze pozostają pozytywne. Cechy zbawionych w niebie są opisywane najczęściej przez terminy jakościowe, odnoszące się do całego człowieka, już po jego zmartwychwstaniu. W drugim okresie można zaobserwować większą częstotliwość stosowania takich terminów jak „niezniszczalność”, „niecierpiętliwość” czy „nieśmiertelność”.

Przygotowanie do osiągnięcia nieba przez dobre uczynki w nauce poapostolskiej nie ma wartości zbawczej, ale stanowi potwierdzenie wiary chrześcijańskiej. W nauce apologetów greckich II wieku obserwujemy tendencję do moralizmu eschatologicznego, pośrednio potwierdzanego przez naukę o stanie przejściowym (Justyn i Tacjan) oraz naukę o drugim millenium (Justyn). Akcentowanie większej roli człowieka w dziele zbawienia wynika w dużej mierze z przejęcia przez apologetów platońskiego idealizmu etycznego oraz stoickiego prymatu cnoty oraz greckiej antropologii duo- i trychotomicznej.

Najważniejszym przekazem teologicznym dotyczącym nieba pozostaje w obu analizowanych okresach nauczanie, że eschatologiczne niebo jest obietnicą samego Boga, osiągalną przez wiarę w Jezusa Chrystusa. 



\section{Kształtowanie się nauki o niebie w teologii patrystycznej - wiek III}

Trzeci rozdział składa się z czterech paragrafów, w których kolejno przedstawiam eschatologiczną naukę o niebie pojawiającą się u najbardziej reprezentatywnych teologów chrześcijańskich III wieku: Ireneusza z Lyonu (\$ 3.1.), Klemensa Aleksandryjskiego (\$ 3.2.), Orygenesa $(\$ 3.3$.$) oraz przedsta-$ wicieli teologii łacińskiej tego okresu - Tertuliana, Cypriana z Kartaginy, Laktancjusza, Wiktoryna z Poetovium oraz w Męczeństwie świętych Perpetui $i$ Felicyty (\$3.4.). Zachowując zasadniczy schemat opisu problematyki, jaki stosowałem w poprzednich rozdziałach (uporządkowanie chronologiczne, opis postaci, kontekst nauki o eschatologicznym niebie, terminologia i teologia eschatologicznego nieba), w niniejszym rozdziale, w $\$ \$ 3$ 3.3. i 3.4 . zrezygnowałem z patrystycznej charakterystyki traktatów poszczególnych autorów. Było to podyktowane zarówno dużą ilością dzieł omawianych teologów (zwłaszcza w przypadku Orygenesa i Tertuliana), jak i powtarzającym się rodzajem literackim, jakim były alegoryczne komentarze Orygenesa do ksiąg biblijnych i polemiczno-moralizatorskie traktaty Tertuliana. Wydaje mi się, że takie ujęcie analizowanej tematyki pozwala lepiej skoncentrować się na przedstawieniu rozwoju samej myśli dotyczącej eschatologicznego nieba. Teologia tego okresu, w przeciwieństwie do pierwszych dwóch wieków chrześcijaństwa, była bowiem bardziej spekulatywna niż katechetyczna. 
Kształtowanie się nauki o niebie w teologii patrystycznej I-III wieku

\subsection{Ireneusz z Lugdunum (130/140 - około 200) - nieśmiertelni i niezniszczalni zbawieni w niebiańskiej Jerozolimie}

W tekstach Ireneusza odnajdujemy dwa motywy niebiańskie opisujące teologię eschatologicznego nieba: motyw miasta (Jerozolimy) - przede wszystkim w dziele Zdemaskowanie i odparcie fatszywej gnozy oraz motyw nieśmiertelności i niezniszczalności występujący głównie w Wykładzie nauki apostolskiej. Pierwszy motyw niebiański, czyli teologia Jerozolimy millenijnej i niebiańskiej, jest możliwą kontynuacją teologii judeochrześcijańskiej, opracowaną przez Ireneusza w jego perspektywie drugiego millenaryzmu. Drugi motyw niebiański (niebiańska niezniszczalność i nieśmiertelność) wydaje się być kontynuacją teologii nieba obecnej u apologetów greckich II wieku, zarówno w formie wykładu apologetyczno-katechetycznego, jak i w treści (teologiczny opis cech ludzi w niebie).

\section{Motyw Jerozolimy millenijnej i niebieskiej}

Zdaniem Joachima Jeremiasa autorzy biblijni NT rzadko stosowali termin $\pi \alpha \rho \alpha ́ \delta \epsilon\llcorner\sigma o \varsigma$, gdyż nie chcieli, aby zwracał on uwagę na rzeczy zewnętrzne, jakby obawiając się, że sam eschaton zostanie wypaczony ${ }^{1}$. W swoim nowym studium poświęconym kwestii raju Jean Delumeau wykazał, iż pisarze judeochrześcijańscy I i II wieku, przejmując terminologię biblijną i międzytestamentalną, rozwinęli motyw apokaliptyki judaistycznej o raju zamkniętym i później otwartym² ${ }^{2}$. Wspomniani pisarze, obliczając, że raj był zamknięty przez około 5000 lat, a został otwarty dla skruszonego łotra, nie identyfikowali jednak raju z eschatologią definitywną, ale rozumieli go jako rodzaj przedpokoju, zarezerwowanego dla sprawiedliwych. Według Jeana Daniélou to idea tożsama z wierzeniem, że dusze sprawiedliwych oczekują zmartwychwstania ciał w specjalnym miejscu - raju ${ }^{3}$. To rozróżnienie żydowskiej apokaliptyki na dwa Edeny / raje przeszło następnie do

1 Por. J. Jeremias, $\pi \alpha \rho \alpha ́ \delta € \iota \sigma o \varsigma \ldots$, w: Theologisches Wörterbuch zum Neuen Testament, Hrsg. G. Kittel, G. Friedrich, Bd. V, Stuttgart-Berlin-Köln 1990, 599.

2 Por. J. Delumeau, Alla ricerca del paradiso, Cinisello Balsamo (Milano) 2012, s. 231-232.

3 Por. J. Daniélou, Terre et paradis chez le Pères de l'Église, „Eranos Jahrbuch” 22 (1953), s. 448 . 
3. Kształtowanie się nauki o niebie w teologii patrystycznej - wiek III

apokaliptyki chrześcijańskiej. Wyraźne ślady zapożyczenia tematyki raju ziemskiego i raju, będącego miejscem oczekiwania dusz sprawiedliwych na wieczną szczęśliwość znajdujemy w judeochrześcijańskiej Apokalipsie Piotra (powstałej przed rokiem 1354) oraz w Apokalipsie Pawła (powstałej między połową II a połową III wieku) $)^{5}$. Co więcej, w tym samym czasie w literaturze judeochrześcijańskiej nastąpiło kolejne połączenie wątków teologicznych. Otóż obietnica złożona przez Jezusa nawróconemu łotrowi „Dziś ze mną będziesz w raju” (Łk 23, 43) została prawdopodobnie połączona przez judeochrześcijan z dwoma kolejnymi wątkami tego, co nazywamy dzisiaj stanem eschatologii pośredniej: po pierwsze, z apokaliptycznymi opisami dusz sprawiedliwych oczekujących na zmartwychwstanie w jakiejś rajskiej rzeczywistości oraz po drugie, z tzw. łonem Abrahama, gdzie został po swej śmierci wprowadzony Łazarz ${ }^{6}$.

Motyw Jerozolimy millenijnej i niebieskiej był kontynuowany przez Ireneusza z Lyonu w jego głównym dziele teologicznym Zdemaskowanie i odparcie fatszywej gnozy, które w całości zachowało się tylko w języku łacińskim, w dużej mierze w dosłownym tłumaczeniu znanym jako Adversus haereses. W przekładzie ormiańskim posiadamy księgi IV i V, natomiast

${ }^{4}$ Apokalipsa Piotra, $\alpha$. Tekst etiopski i grecki, 14. (tekst etiopski) i 17. (tekst grecki): 14. (tekst etiopski): „Wówczas dam moim wybranym, moim sprawiedliwym chrzest i zbawienie, o które mnie prosili przy polu Akrosja, które nazywa się [też] Aneslasja, dam łaskawie część [należną] sprawiedliwym”; 17. (tekst grecki): „Udzielę powołanym przeze mnie i wybranym to, o co będą mnie błagali z udręki, i dam im cenny chrzest jeziora acheruzyjskiego, o którym mówią, że znajduje się na Polach Elizejskich, [to jest] udział sprawiedliwym z moimi świętymi”, w: Apokryfy Nowego Testamentu. Listy i apokalipsy chrześcijańskie, tłum. S. Kur (etiopski), M. Starowieyski (grecki), Kraków 2001, s. 238; Apokryfy Nowego Testamentu. Listy..., dz. cyt., 16. (etiopski): „I pokazał mi wielki ogród otwarty, pełen drzew urodzajnych i błogosławionych owoców”; 15. (grecki): „Pan pokazał mi ogromną przestrzeń poza tym światem zalaną światłem”, 19. (grecki) „Chwała tam mieszkających była równa, i jednym głosem pełnym radości sławili Pana Boga, w owym miejscu”; 20. (grecki). Rzecze do nas Pan: «Oto jest miejsce waszych braci, ludzi sprawiedliwych»", s. 240.

5 Apokalipsa Pawta 14.5: „Nie lękaj się, duszo, ani nie niepokój, aż dojdziesz do miejsca, którego dotąd nie widziałaś, a ja dla ciebie będę wspomożycielem”, w: Apokryfy Nowego Testamentu. Listy..., dz. cyt., s. 250; Apokalipsa Pawta, 14.8: „Niech więc zostanie ona wydana Michałowi aniołowi Przymierza i niech ją wprowadzą do Raju radości, aby i ona stała się współdziedziczką świętych”, w: Apokryfy Nowego Testamentu. Listy..., dz. cyt., s. 252.

6 Por. J. Delumeau, Alla ricerca del paradiso..., dz. cyt., s. 233. 
Kształtowanie się nauki o niebie w teologii patrystycznej I-III wieku

w greckim i syryjskim zachowały się fragmenty. Tekst tego pisma powstawał pomiędzy rokiem 180 a 185, kiedy Ireneusz zakończył działalność duszpasterską w Lugdunum (późniejszy Lyon) ${ }^{7}$. Celem Ireneusza, jaki podjął w swoim dziele, było opisanie, zdemaskowanie i zwalczenie fałszywej gnozy, często negującej Stary Testament, oraz interpretującej Boże objawienie za pomocą filozofii helleńskiej czy tradycji orientalnych ${ }^{8}$. Tematykę eschatologiczną, w głównej mierze kwestię zmartwychwstania ciała - co odrzucali gnostycy ${ }^{9}$, biskup Lyonu poruszył przede wszystkim w V księdze tego traktatu ${ }^{10}$.

Powołując się na nauczanie judeochrześcijańskich prezbiterów, będących uczniami apostołów, Ireneusz z Lyonu, w V księdze Zdemaskowania i odparcia fatszywej gnozy, wyprowadził twierdzenie, że:

„Sprawiedliwi, którzy dostąpią tego przywileju, zostaną wyniesieni powyżej, gdyż dla sprawiedliwych, którzy posiadają Ducha jest przygotowany raj, gdzie był też przeniesiony apostoł Paweł, który słyszał tam słowa niewypowiadalne dla nas obecnie, i pozostaną tam aż do końca świata, rozkoszując się niezniszczalnością" ${ }^{11}$.

Wydaje się, że Ireneusz zamiennie wykorzystuje raj sprawiedliwych i królestwo millenijne, co dla sprawiedliwych będzie się realizowało na czas owego drugiego millenium w przebudowanej Jerozolimie:

7 Por. N. Brox, Einführung in Adversus Haereses, Freiburg im Breisgau 1993, s. 17 (Fontes Christiani [dalej: FCh] 8/1)

8 Por. J. Comby, D. Singles, św. Ireneusz z Lyonu, Chwata Boga żyjący cztowiek, tłum. W. Myszor, Kraków 1999, s. 14.

9 Por. A. Orbe, Teologia de San Ireneo. Comentario al Libro V del "Adversus haereses", vol. 3, Madrid 1985-1988.

10 Irenaeus Lugdunensis, Adversus haereses V. Ubersetzt und eingeleitet von N. Brox, Freiburg im Breisgau 2001 (FCh 8/5); częściowy przekład polski W. Myszor, Tysiąc lat panowania Chrystusa na ziemi. Millenaryzm w ujęciu Ireneusza z Lyonu ("Adversus Haereses» V,30,4-36,3), „Śląskie Studia Historyczno-Teologiczne” 33 (2000), s. 5-24.

11 Irenaeus Lugdunensis, Adversus haereses 5,5,1; „Quapropter dicunt Presbyteri qui sunt Apostolorum discipuli eos qui translati sunt illuc translatos esse - iustis enim hominibus et Spiritum habentibus praeparatus est paradisus, in quem et Paulus Apostolus apportatus audivit sermones inenarrabiles quantum ad nos in | praesenti - et ibi manere eos qui translati sunt usque ad consummationem, coauspicantes incorruptelam", FCh 8/5, s. 52. 
3. Kształtowanie się nauki o niebie w teologii patrystycznej - wiek III

„Tego rodzaju powszechnych wydarzeń nie można rozumieć, że rozegrają się ponad niebiosami. «Bóg bowiem - mówi [prorok] - ukaże jasność twoją tej całej ziemi, która jest pod niebem» (Ba 5, 3). Ale stanie się to w czasach Królestwa, gdy ziemia zostanie odnowiona przez Chrystusa i na nowo zostanie zbudowana Jerozolima na wzór Jerozolimy z wysoka. Mówi o tym prorok Izajasz: "Oto na rękach moich namalowałem twoje mury i jesteś zawsze przed mymi oczyma» (Iz 49, 16). Podobnie pisze Paweł Apostoł do Galatów: «Ta zaś w górze Jerozolima wolna jest i ona jest naszą matką» $(\mathrm{Ga} 4,26)$. Nie mówi tu o «Enthymesis», oddzielonym eonie, ani o Mocy oddzielonej od Pleromy i nazwanej «prunikos», ale o Jerozolimie namalowanej na rękach Boga. (...). Obrazem tej Jerozolimy jest Jerozolima pierwszej ziemi, gdzie sprawiedliwi ćwiczą się dla nieskazitelności i przygotowują się na zbawienie. Obraz tego przybytku przyjął Mojżesz na Górze"12.

Komentując powyższe teksty, Wincenty Myszor trafnie zauważa, że Ireneusz rozróżniał dwie eschatologiczne Jerozolimy: ziemską w czasie millenium i niebieską. Model Jerozolimy ziemskiej czasu millenium był oparty na wzorze „odgórnym” / „zstępującym”. Zbudowanie tej ziemskiej Jerozolimy być może należy połączyć z pokonaniem Antychrysta, który panował w niej przed przyjściem Chrystusa, a miasto zbezczeszczone przez pobyt Antychrysta zostanie na nowo odbudowane ${ }^{13}$. Ireneusz, dwukrotnie powołując się na naukę judeochrześcijańskich prezbiterów (Adversus

12 Irenaeus Lugdunensis, Adversus haereses 5,35.2, w: FCh 8/5, s. 264-266; „Haec autem talia universa non in supercaelestibus possunt intellegi - „Deus enim” ait, „demonstrabit ei quae sub caelo est universae tuum fulgorem" -, sed in regni temporibus, | renovata terra a Christo et reaedificata Hierusalem secundum characterem quae sursum est Hierusalem. De qua ait propheta Esaias: „Ecce in manibus meis depinxi muros tuos, et in conspectu meo es semper". Et Apostolus autem scribens ad Galatas similiter ait: „Illa autem quae sursum est Hierusalem libera est, quae est mater omnium nostrum", non de cogitatione erratici Aeonis dicens hoc, neque de virtute aliqua quae abscessit $<$ a $>$ Pleromate et Prunico, sed de Hierusalem quae in manibus $<$ Dei $>$ descripta est. (...) Huius Hierusalem imago illa quae in priori terra Hierusalem, in qua iusti praemeditantur incorruptelam et parantur in salutem, et huius tebernaculi typum accepit Moyses in monte", przekład polski W. Myszor, Tysiac lat panowania Chrystusa na ziemi. Millenaryzm..., dz. cyt., s. 21-22.

13 Por. W. Myszor, Tysiac lat panowania Chrystusa na ziemi. Millenaryzm..., dz. cyt., s. 11. 
Kształtowanie się nauki o niebie w teologii patrystycznej I-III wieku

haereses 5,5,1 i Adversus haereses 5,36,1-36,2), stworzył zatem konstrukt teologiczny opisujący eschatologiczne niebo:

„36,1. (...) Jak uczą nas prezbiterzy, ci którzy są godni przebywania w niebie, tam właśnie przejdą, to jest do nieba, inni zaś będą korzystać z przyjemności raju, wreszcie inni posiądą wspaniałość miasta. Wszędzie będą oglądać Boga według miary, na jaką każdy z nich stał się godny. 36.2. (...) Jedni z nich będą przyjęci do nieba, inni będą przebywać w raju, a jeszcze inni będą zamieszkiwać w mieście. Dlatego Pan powiedział, że u Ojca jest wiele mieszkań" ${ }^{14}$.

Myszor, wskazując na wzmiankę Ireneusza o prezbiterach, powołuje się na opinię Antonia Orbego ${ }^{15}$, zdaniem którego uczyli oni o Jerozolimie ostatecznej, niebieskiej. Ireneusz mógłby jednak zastosować obraz millenijnej Jerozolimy jako miasta, w którym jest wiele różnych mieszkań ${ }^{16}$, Uznając zasadność tez Orbego, także i moim zdaniem, Ireneusz w powyższych fragmentach mówił o trzech różnych rzeczywistościach zbawczych, w zależności od osobistej zasługi zbawionych: wszędzie będą oni oglądać Boga, ale jedni w niebie, inni w raju, a pozostali właśnie w mieście, czyli w Jerozolimie ziemskiej okresu millenium. Co więcej, w myśl tego, co Ireneusz mówił o niebie pojmowanym jako Królestwo Ojca (Adversus haereses $5,35,2$ ), miasto i raj byłyby stanami przygotowawczymi do nieba.

W tekście wprowadzającym do opisu niebieskiej Jerozolimy, która miałaby zstąpić na ziemię na czas królestwa millenijnego, Ireneusz z Lyonu stwierdzał, że samo miasto królestwa sprawiedliwych w okresie millenium, określone też jako „Królestwo Syna” czy „dziedzictwo ziemi” (Adversus

14 Irenaeus Lugdunensis, Adversus haereses 5,36.1-36.2, w: FCh 8/5, s. 270-272; „36.1 (...) et quemadmodum Presbyteri dicunt, tunc qui digni fuerint caelorum conversatione illuc transibunt, id est in caelos, alii autem paradisi deliciis uterunt, alii autem speciositatem civitatis possidebunt, ubique autem Deus videbunt, quemadmodum et digni videntes eum. 36.2. (...). quorum quidam in caelum assumentur, alii in paradiso coversabuntur, alii in civitate inhabitabunt: et propter hoc dixisse Dominum multas esse apud Patrem mansiones", przekład polski W. Myszor, Tysiac lat panowania Chrystusa na ziemi. Millenaryzm..., dz. cyt., s. 22-23.

15 Por. A. Orbe, Introducción a la teología de los siglos II y III, Roma 1987, s. 1008-1024.

16 Por. W. Myszor, Tysiąc lat panowania Chrystusa na ziemi. Millenaryzm..., dz. cyt., s. 11. 
3. Kształtowanie się nauki o niebie w teologii patrystycznej - wiek III

haereses 5,36,3), będzie okresem przygotowania i przyzwyczajania się sprawiedliwych do pojmowania chwały Boga Ojca, co będzie następowało przez „wzrastanie z oglądu Pana”:

„Te wszystkie proroctwa (por. Iz 6, 11; 13, 9; 26, 10 według LXX; 6, 12 według LXX; 65, 21) bezsprzecznie zostały powiedziane o zmartwychwstaniu sprawiedliwych, które nastąpi po nadejściu Antychrysta i wytraceniu wszystkich pogan, poddanych jego władzy. Sprawiedliwi będą królować na ziemi, wzrastając z oglądu Pana i dzięki Niemu będą się przyzwyczajać do pojmowania chwały Boga Ojca, a w Królestwie dostąpią przestawania ze świętymi aniołami oraz łączności i jedności duchowych bytów. Ci zaś, których Pan zastanie w ciele, gdy wyczekują Go z niebios, znoszą cierpliwie smutek, którzy uszli z rąk Nieprawego, są właśnie tymi, o których mówi prorok: «opuszczeni rozmnożą się na ziemi»" $" 17$.

Wydaje się, że według Ireneusza królestwo millenijne na ziemi byłoby tysiącletnim okresem przygotowawczym do spotkania z Ojcem. Jak powiada Ireneusz, po „pierwszym zmartwychwstaniu sprawiedliwych i dziedzictwie ziemi” (Adversus haereses 5,36,3: „primam iustorum resurrectionem et in regno terrae hereditatem"), czyli po upływie siódmego tysiąclecia królestwa sprawiedliwych (Adversus haereses 5,36,3: „septies millesimum annum regnii iustorum"), Bóg Ojciec najpierw w:

„zmartwychwstaniu sprawiedliwych wypełnia przyrzeczenia w królestwie swego Syna. To On następnie rozdaje w swojej ojcowskiej dobroci

17 Irenaeus Lugdunensis, Adversus haereses 5,35,1, w: FCh 8/5, s. 260-262; „Haec enim talia universa in resurrectionem iustorum sine controversia dicta sunt, quae fit post adventum Antichristi et perditionem omnium gentium sub eo exsistentium, in qua regnabunt iusti in terra, crescentes ex visione Domini, et per ipsum assuescent capere gloriam Dei Patris, et caum sanctis angelis conversationem et communionem et unitatem spiritalium in regno capient. Et illi quos Dominus in carne inveniet exspectantes eum de caelis et perpessos tribulationem, qui et effugerunt iniqui manus", przekład polski W. Myszor, Tysiąc lat panowania Chrystusa na ziemi. Millenaryzm..., dz. cyt., s. 21. 
Kształtowanie się nauki o niebie w teologii patrystycznej I-III wieku

to, czego ani oko nie widziało, ani ucho nie słyszało, ani w serce człowieka nie wstąpiło. (...) aby stworzenie przyjęło Słowo, aby wstąpiło do Niego, wynosząc się ponad aniołów i stając się obrazem i podobieństwem Boga"18.

W powyższych sformułowaniach Ireneusza istotna jest kolejność: najpierw - „w” („in”) millenium sprawiedliwych na ziemi, potem - „następnie” („postea”), nieopisane zmysłami (1 Kor 2, 9) szczęście przygotowane dla już po Bożemu ukształtowanych zbawionych. Orbe, komentując Adversus haereses 5,35-36, podkreśla, że w omawianym tekście istnieje różnica pomiędzy Jerozolimą millenijną a Jerozolimą, która zstąpi z nieba. Ta druga nastąpi po zakończeniu millenium, po powszechnym zmartwychwstaniu i sądzie ostatecznym. W Jerozolimie millenijnej nie będzie już grzechu, sprawiedliwi będą obdarzeni błogosławieństwem i uzyskają cechy aniel-

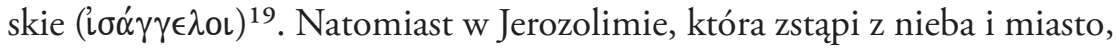
i jego obywatele uzyskają cechy niebiańskie, będą w łączności z boskością i staną się nieśmiertelni, wieczni, zamieszkani przez Ducha Bożego, przyjęci przez Logos, wyniesieni ponad aniołów, stając się obrazem i podobień-

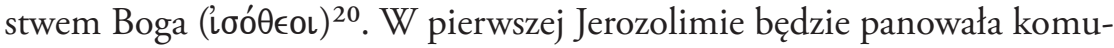
nia i jedność duchowa aniołów i ludzi ${ }^{21}$, w drugiej komunia zbawionych z Bogiem przyrównana za Ap 21, 1-4 do więzi małżeńskiej - „jak oblubienica

18 Irenaeus Lugdunensis, Adversus haereses 5,36,3, w: FCh 8/5, s. 274; „In resurrectione iustorum et promissiones adimplet in Filii sui regnum, postea praestans illa paternaliter quae neque oculus vidit negue auris audivit neque in cor hominis ascendit. (...).”, przekład polski W. Myszor, Tysiąc lat panowania Chrystusa na ziemi. Millenaryzm..., dz. cyt., s. 23.

19 Irenaeus Lugdunensis, Adversus haereses 5,35,1, w: FCh 8/5, s. 260-262; przekład polski W. Myszor, Tysiąc lat panowania Chrystusa na ziemi. Millenaryzm..., dz. cyt., s. 21: „Sprawiedliwi będą królować na ziemi, wzrastając z oglądu Pana i dzięki Niemu będą się przyzwyczajać do pojmowania chwały Boga Ojca, a w Królestwie dostąpią przestawania ze świętymi aniołami oraz łączności i jedności duchowych bytów".

20 Por. Irenaeus Lugdunensis, Adversus haereses 5,36,2-3, w: FCh 8/5, s. 270-276; przekład polski W. Myszor, Tysiąc lat panowania Chrystusa na ziemi. Millenaryzm..., dz. cyt., s. $22-23$.

21 Irenaeus Lugdunensis, Adversus haereses 5,35,1, w: FCh 8/5, s. 260-262: „(...) et cum sanctis angelis conversationem et communionem et initatem spiritalium in regno capient". 
3. Kształtowanie się nauki o niebie w teologii patrystycznej - wiek III

przystrojona dla swego męża i to jest przybytek Boga, w którym Bóg zamieszka z ludźmi”22.

Zbawieni najbardziej zasłużeni mają osiągnąć niebo Ojca, średnio zasłużeni - raj, a najmniej zasłużeni - wieczne błogosławieństwo miasta ${ }^{23}$. Ireneusz, używając języka metaforycznego, przechodzi w swym opisie od jednej metafory wieczności do drugiej (np. motyw połączenia w domu Ojca z J 14, 2 zastosowany do trzech stanów - nieba, raju, miasta - jako połączonych mieszkań lub uczynienia jednego miasta z trzech stanów). Wspierając się w dosyć swobodny sposób o teksty biblijne, rozwija także tradycję przekazu o eschatologicznym niebie wywodzącą się od judeochrześcijańskich prezbiterów $^{24}$. Zdaniem Orbego ta właśnie tradycja sugerowała, że w fazie ostatecznej niebieska Jerozolima, zstąpiwszy na ziemię, zjednoczyła się (w omawianych stanach) i ponownie została uniesiona do nieba ${ }^{25}$.

22 Irenaeus Lugdunensis, Adversus haereses 5,35,2, w: FCh 8/5, s. 266; „Quemadmodum sponsam ornatam viro suo, et hoc esse tabernaculum Dei in quo inhabitabit Deus", przekład polski W. Myszor, Tysiąc lat panowania Chrystusa na ziemi. Millenaryzm..., dz. cyt., s. 22.

23 Por. Irenaeus Lugdunensis, Adversus haereses 5,36,1, w: FCh 8/5, s. 270; przekład polski W. Myszor, Tysiac lat panowania Chrystusa na ziemi. Millenaryzm..., dz. cyt., s. 22: „Ukazaliśmy także, jak to było możliwe, przyczynę doczesności stworzonego świata. Gdy jednak postać ta minęła, a człowiek został odnowiony i umocniony ku nieskazitelności, aby już nie mógł się starzeć, powstanie nowe niebo i nowa ziemia i na nich będzie trwał nowy człowiek w stale na nowo przyjmowanym związku z Bogiem. To pozostanie już zawsze i bez końca, jak stwierdza Izajasz: «Bo jak niebiosa nowe i ziemia nowa, które ja czynię, istnieją przede mną, mówi Pan, tak będzie istnieć wasze potomstwo i wasze imię» (Iz 66, 22). Jak uczą prezbiterzy, ci, którzy będą godni przebywania w niebie, tam właśnie przejdą, to jest do nieba, inni zaś będą korzystać z przyjemności raju, wreszcie inni posiądą wspaniałość miasta. Wszędzie będą oglądać «Boga według miary, na jaką każdy z nich stał się godny»"; myśl tę Ireneusz powtarza także w Adversus haereses 5,36,2.

${ }^{24}$ Ireneusz w swym ujęciu drugiego millenaryzmu nawiązywał do tzw. średniej tradycji millenaryzmu małaoazjatyckiego (por. J. Daniélou, Teologia judeochrześcijańska, Kraków 2002, s. 357-361), ale odrzucał niektóre z interpretacji prorockich zapowiedzi; przede wszystkim odrzucił alegoryczną interpretację tekstów biblijnych; odrzucił skrajny eschatologizm (opinię o przeniesieniu przedostatnich wydarzeń w zaświaty), odrzucił też interpretacje żydowskie. Zaczerpnął natomiast niektóre szczegóły z tradycji hellenistycznej, np. nieznany w tradycji żydowskiej podział historii ludzkości na siedem tysiącleci (por. W. Myszor, Tysiąc lat panowania Chrystusa na ziemi. Millenaryzm..., dz. cyt., s. 13-14).

25 Por. A. Orbe, La teologia dei secoli II e III. Il confronto della Grande Chiesa con lo gnosticismo, vol. 2. Temi neotestamentarii, Roma 1995, s. 590-593. 
Kształtowanie się nauki o niebie w teologii patrystycznej I-III wieku

Ireneusz nie opowiada nic o końcowej fazie Jerozolimy niebieskiej i nie mówi, że po zstąpieniu na ziemię ma tam ona pozostać. Natomiast stwierdza, że ma dokonać się w niej tajemnicza transformacja salus carnis według Ducha. W swym ideowym przesłaniu Ireneusz pojmowałby zatem Jerozolimę niebieską jako miasto idealne, obdarzone jednością według Ducha oraz Jerozolimę ziemską jako miasto złożone. Zstąpienie tej niebieskiej na ziemską, w perspektywie teologicznej, oznaczało udział w przyszłym mieście świętych, w ciele i duszy, zjednoczonych Duchem o cechach boskich, swoistą sublimację Jerozolimy materialnej do poziomu niezniszczalności dzięki Duchowi Ojca. W teologii nieba Ireneusza z Lyonu spotykamy zatem opis podwójnej metamorfozy Jerozolimy ziemskiej: na początku millenium i przed wiecznością. Podobnie następowałaby podwójna metamorfoza substancji materialnej człowieka: najpierw w czasie millenium dochodziłoby do jej przejścia w jakość anielską, aby ostatecznie w życiu wiecznym nastąpiło jej przejście w jakość boskości.

\section{Motyw niezniszczalności i nieśmiertelności}

Tematyka ta występuje przede wszystkim w Wyktadzie nauki apostolskiej (Demonstratio praedicationis apostolicae) ${ }^{26}$, traktacie napisanym przez Ireneusza około roku 190, a zrekonstruowanym ostatnio w wersji łacińskiej na podstawie zachowanej wersji ormiańskiej (Manuskrypt z Erewania 3710 oraz fragmentów Galata 54 i Le Sceau de la foi) przez Adelin Rousseau ${ }^{27}$. Dzieło to jest określane w patrologii pod względem formy literackiej i celu utworu albo jako katecheza (jest to opinia Adolfa von Harnacka ${ }^{28}$, Paula Drewsa) ${ }^{29}$,

26 Irenaeus Lugdunensis, Demonstratio praedicationis apostolicae (Epideixis), w: SCh 406. Irénée de Lyon, Démonstration de la prédication apostolique. Introduction, traduction et notes par A. Rousseau, Paris 1995; przekład polski Ireneusz z Lyonu, Wyktad nauki apostolskiej, w: ŹMT 7, Ireneusz z Lyonu, Wyktad nauki apostolskiej, tłum., wstęp i oprac. W. Myszor, Kraków 1997.

27 Por. S. Weber, Des hl. Irenaeus Schrift zum Erweis der apostolischen Verkündigung, Bd. IV, Kempten 1912, V (Bibliothek der Kirchenväter); W. Myszor, Wprowadzenie. Kościelne nauczanie w II wieku, w: Ireneusz z Lyonu, Wyktad nauki apostolskiej..., dz. cyt., s. 7.

28 Por. A. von Harnack, Nachwort und Anmerkungen, w: Des hl. Irenäus Schrift „Zum Erweise der apostolischen Verkündigung" in armenischer Version entdeckt, Hrsg. K. TerMekerttschian, E. Ter-Minassianz, Leipzig 1907, s. 55 (Texte und Untersuchungen 31)

29 Por. P. Drews, Der literarische Charakter der neuentdeckten Schrift des Irenäus «Zum Erweise der apostolischen Verkündigung”, „Zeitschrift für Neutestamentliche Wissenschaft" 8 (1907), s. 226-233. 
albo jako apologia (opinia Ottona Bardenhewera ${ }^{30}$, Johannesa Quastena) ${ }^{31}$, czy też łącznie jako katecheza i apologia (opinia Norberta Broxa ${ }^{32}$ i Alberta Houssiau $)^{33}$. Natomiast tematykę Wyktadu Simon Weber uznał za analogiczną do dzisiejszego ujęcia teologii fundamentalnej ${ }^{34}$. Wincenty Myszor zaznacza, iż Ireneusz napisał Wyktad dla ludzi wierzących w celu przypomnienia podstawowych prawd wiary i podania ich uzasadnienia, jednak biskup Lugdunum nie dał w swym traktacie pełnego przekazu katechezy II wieku (w traktacie brak większych odniesień do zagadnień eschatologicznych, liturgicznych czy tych związanych z kościelną dyscyplina). Biskup Lyonu sam dokonał prawdopodobnie wyboru zagadnień i form ich przedstawienia (komentarz do katechetycznego nauczania Kościoła w II wieku). Pierwsza część traktatu (rozdziały 1-42a) to synteza nauczania Kościoła II wieku na temat zbawienia człowieka, natomiast druga część traktatu (rozdziały 42b-97) to analiza dowodów z proroctw (testimonia) dotyczących Syna Bożego ${ }^{35}$.

Nieliczne wypowiedzi Ireneusza dotyczące eschatologii, szczególnie te dotyczące teologii eschatologicznego nieba, poruszone są przez autora Wyktadu w kontekście omawiania przez niego powszechnego wymiaru zbawienia dokonującego się przez Boga (rozdziały 4-6), aktywności zbawczej Ducha Świętego (rozdział 7), opisu nieba i aniołów jako części stworzenia (rozdziały 9-10), opisu stworzenia człowieka według charakterystycznej idei wzrostu i dojrzewania (rozdziały 11-15), przepowiadania proroków zapowiadających Wcielenie Syna Bożego (rozdziały 31-33), Chrystusowych zapowiedzi śmierci, zmartwychwstania i wniebowstąpienia (rozdziały 69. 72. 78. 83-85). Najbardziej charakterystycznym wątkiem

30 Por. O. Bardenhewer, Geschichte der altkirchlichen Literatur, vol.1, Freiburg 1913, s. 410.

31 Por. J. Quasten, Initiation aux Pères de l'Église, vol. 1, Paris 1955, s. 335.

32 Por. N. Brox, Einleitung zur Epideixis, w: Irenäus von Lyon, Epideixis. Darlegung der apostolischen Verkündigung-gegen die häresien, Freiburg im Breisgau 1993, s. 26 (FCh 8/1).

33 Por. A. Houssiau, La christologie de Saint Irénée, Louvain 1955, s. 10.

34 Por. S. Weber, Des hl. Irenaeus Schrift zum Erweis der apostolischen Verkündigung..., dz. cyt., Bd. IV, XV; W. Myszor, Wprowadzenie. Kościelne nauczanie w II wieku, w: Ireneusz z Lyonu, Wyktad nauki apostolskiej..., dz. cyt., s. 7-8.

35 Por. W. Myszor, Wprowadzenie. Kościelne nauczanie w II wieku, w: Ireneusz z Lyonu, Wyktad nauki apostolskiej..., dz. cyt., s. 8-13. 
Kształtowanie się nauki o niebie w teologii patrystycznej I-III wieku

Ireneuszowej nauki o niebie w ujęciu katechetycznym jest motyw o niezniszczalności człowieka zbawionego ${ }^{36}$.

\section{Powszechny wymiar zbawienia}

Ireneusz, przeprowadzając wykład nauczania kościelnego na temat zbawienia człowieka (rozdziały 2-42), w rozdziałach 3b-7 przypomniał ówczesne nauczanie katechetyczne ${ }^{37}$. Znajdują się w nim wyraźne wątki teologiczne, które wskazują, że Bóg zamierza obdarować człowieka darem niezniszczalności, czyli nieśmiertelności ${ }^{38}$. Człowiek, opisywany przez Ireneusza jako „istota złożona z duszy i z ciała”39, jest wezwany do życia w pobożności, co dokonuje się poprzez jednoczesny związek zarówno z prawdą (czystość duszy), jak i z moralnością (czystość ciała) ${ }^{40}$. Najprawdopodobniej w odniesieniu do judeochrześcijańskiej nauki o dwóch drogach ${ }^{41}$ Ireneusz mówi o możliwym dla każdego człowieka sposobie słusznego postępowania dzięki wierze, która jest oświetlona przez „światło z (nieba) / a caelesti lumine” 42 , to „droga do (...) królestwa niebieskiego / et illa (quidem) in caelorum ducit regnum"43. Dla chrześcijan pomocą we właściwym trwaniu w pobożności jest przestrzeganie reguł wiary i wypełnianie przyka-

36 Por. Ireneusz z Lyonu, Wyktad nauki apostolskiej 7; 31; 40; 72.

37 Por. W. Myszor, Wprowadzenie. Kościelne nauczanie w II wieku, w: Ireneusz z Lyonu, Wyktad nauki apostolskiej..., dz. cyt., s. 8-13.

38 Por. W. Myszor, Wprowadzenie. Kościelne nauczanie w II wieku, w: Ireneusz z Lyonu, Wyktad nauki apostolskiej..., dz. cyt., s. 9.

39 Ireneusz z Lyonu, Wyktad nauki apostolskiej 2, w: SCh 406, s. 84; „Compositum animal est homo ex anima et corpo", ŹMT 7, s. 22. Myszor zauważa, iż Ireneusz raz określa człowieka jako złożonego z duszy i z ciała, a czasami do tego złożenia dodaje także ducha (np. w Adversus Haereses V,9,1). Więcej na temat antropologii Ireneusza, zob. opracowania A. Orbe, Antropología de San Ireneo, Madrid 1969; A. Rousseau, Appendice I. Anthropologie bipartite ou tripartite?, w: SCh 406, s. 357-364.

40 Por. Ireneusz z Lyonu, Wyktad nauki apostolskiej 2, w: SCh 406, s. 84; „Pobożność

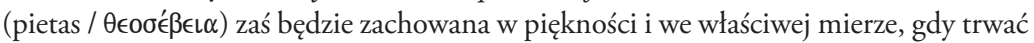
będą jednocześnie prawda w duszy i czystość w ciele", ŹMT 7, s. 7-22.

41 W. Myszor sugeruje (ŹMT 7, s. 22, przypis 8), iż idea drogi światła i ciemności zawarta przez Ireneusza w Wyktadzie 1 (oraz w Adversus Haereses V,20,1-2) może nawiązywać do obrazu dwóch dróg, czyli nauki zawartej tak w Didache, jak w Liście Pseudo-Barnaby.

42 Ireneusz z Lyonu, Wyktad nauki apostolskiej 1, w: SCh 406, s. 82; ŹMT 7, s. 22.

43 Ireneusz z Lyonu, Wyktad nauki apostolskiej 1, w: SCh 406, s. 84; ŹMT 7, s. 22. 
3. Kształtowanie się nauki o niebie w teologii patrystycznej - wiek III

zań Bożych ${ }^{44}$. Chrzest jest, zdaniem Ireneusza, „pieczęcią życia wiecznego «sigillum ( $\sigma \phi \rho \alpha \gamma i \varsigma)$ esse aeternae vitae» i odrodzenia w Bogu tak, że stajemy się dziećmi nie ludzi zmarłych, lecz wiecznego i zawsze istniejącego Boga" 45 . Chrzest odradza wierzących w ich relacji z Ojcem, Synem i Duchem Świętym, dzięki czemu Ojciec udziela im „niezniszczalności /

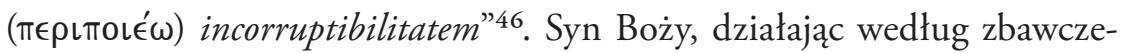
go planu, stał się człowiekiem, aby sprowadzić „wszystko w jedno” (aluzja do Ef 1, 10), „dla zniszczenia śmierci, ukazania życia i zaprowadzenia wspólnoty człowieka z Bogiem” "47. Duch Święty, wraz z przyjściem Syna, „został wylany (effusus est) ... na ludzkość, odnawiając człowieka po całej ziemi dla Boga"48. Wspomniany przez Ireneusza dar niezniszczalności nie jest zatem jakąkolwiek zasługą ludzką, ale wyłącznie konsekwencją odnowionej relacji człowieka wierzącego z Ojcem, Synem Bożym i z Duchem Świętym ${ }^{49}$.

\section{Niebo jako część stworzenia Bożego}

Ireneusz podawał swą naukę o niebie jako objaśnienie wiary, która jest postawą kształtującą chrześcijańskie wyobrażenie „wiecznego i zawsze istniejącego Boga” oraz wszystkiego, co jest przez Niego stworzone i zawsze zależne od Niego ${ }^{50}$. Ireneusz powtarza też inną myśl biblijną, iż niebo jest miejscem

${ }^{44}$ Por. Ireneusz z Lyonu, Wyktad nauki apostolskiej 3, w: SCh 406, s. 86; ŹMT 7, s. 23. Więcej na temat Ireneuszowej koncepcji ortodoksji i ortopraksji, zob. moje opracowanie Kryteria przynależności do wspólnoty wierzacych w I-II wieku, „Analecta Cracoviensia” XL (2008), s. 165-178, szczególnie strony 174-176.

45 Ireneusz z Lyonu, Wyktad nauki apostolskiej 3A, w: SCh 406, s. 88; ŹMT 7, s. 25.

46 Ireneusz z Lyonu, Wyktad nauki apostolskiej 7, w: SCh 406, s. 92; ŹMT 7, s. 29; podobnie Ireneusz wypowiada się o niezniszczalności człowieka w Adversus Haereses $4,20,6$.

47 Ireneusz z Lyonu, Wyktad nauki apostolskiej 6, w: SCh 406, s. 92; ŹMT 7, s. 28.

48 Ireneusz z Lyonu, Wyktad nauki apostolskiej 6, w: SCh 406, s. 92; ŹMT 7, s. 29.

49 Por. Ireneusz z Lyonu, Wyktad nauki apostolskiej 7, w: SCh 406, s. 92; „Ci, którzy noszą Ducha Świętego, kroczą ku Słowu, to jest w kierunku Syna. Syn zaś prowadzi (ich) do Ojca. Ojciec zaś udziela (im) niezniszczalności”, ŹMT 7, s. 29.

50 Por. Ireneusz z Lyonu, Wyktad nauki apostolskiej 3A-4A, w: SCh 406, s. 88; ŹMT 7 , s. 25-26; podobnie Wyktad nauki apostolskiej 4-5, w: SCh 406, s. 88; ŹMT 7, s. 2627. Jak zauważa W. Myszor, ŹMT 7, s. 26, przypis 27, twierdzenie Ireneusza o tym, że „wszystko jest rzeczą Boga i dlatego Bóg jest wszechmocny, a wszystko jest z Boga” (Wyktad nauki apostolskiej 4A) stanowi wyraźną aluzję antygnostycką. 
Kształtowanie się nauki o niebie w teologii patrystycznej I-III wieku

stworzonym przez Boga ${ }^{51}$, specjalnie związanym z Bogiem Ojcem ${ }^{52}$, choć Bóg je przekracza ${ }^{53}$. Ireneusz przywołuje judeochrześcijański topos siedmiu niebios („septem caelis”) ${ }^{54}$ otaczających świat, „w których mieszkają niezliczone moce, aniołowie i archaniołowie, służąc Wszechmogącemu i Stwórcy wszystkich, Bogu, nie jakoby ich potrzebował, ale aby nie byli bezczynni i niepotrzebni”55. Wyłącznie Bóg stworzył cały świat (w tym i niebiosa) przez Logos, wyznaczając całemu światu prawo i jego zakres oraz zakres działalności każdego stworzenia ${ }^{56}$. Żadne dzieło Boże nie jest zatem, według Ireneusza, jakimiś bytem niezależnym od Boga, zaś nadrzędną rolę wobec wszelkich bytów materialnych i duchowych posiada Logos, jako Stwórca.

Siedem niebios jest zdaniem Ireneusza uporządkowanych według siedmiu działań Ducha Bożego (por. Iz 11, 2), które biskup Lyonu wiąże prawdopodobnie z człowieczeństwem Syna Bożego ${ }^{57}$. „Pierwszym niebem, które

51 Ireneusz z Lyonu, Wyktad nauki apostolskiej 43, w: SCh 406, s. 146; „Syn (był) na początku, następnie Bóg stworzył niebo i ziemię (Filius in principio; creavit Deus postea caelum et terram)", ŹMT 7, s. 62 (por. Rdz 1, 1).

52 Ireneusz z Lyonu, Wyktad nauki apostolskiej 44, w: SCh 406, s. 148; „ (...) od Pana z nieba, to znaczy od Ojca, który panuje nad wszystkim (a «Domino» de caelo, (scilicet) a Patre, qui dominatur omnium)", ŹMT 7, s. 63 (por. Rdz 18 - 19).

53 Ireneusz z Lyonu, Wyktad nauki apostolskiej 45, w: SCh 406, s. 148; „Nie ten, który ogarnia ziemię dłonią i ręką niebo", ŹMT 7, s. 64 (por. Iz 40, 12).

54 Por. J. Daniélou, Teologia judeochrześcijańska..., dz. cyt., s. 141-147. Autor ten wskazuje, iż tradycyjny judaizm uznawał trzy niebiosa, natomiast jedynie w judeochrześcijaństwie I-II w. pojawia się idea o siedmiu niebiosach (np. Wniebowstapienie Izajasza; II Księga Henocha), która zanika wraz z nim pod koniec II wieku. Judeochrześcijańska koncepcja siedmiu niebios uznaje je zasadniczo za siedziby hierarchii anielskich. W III wieku odrzuca ją np. Orygenes, Przeciwko Celsusowi VI,21, w: SCh 147, s. 230.232. Koncepcję siedmiu niebios zapożycza od judeochrześcijaństwa literatura gnostycka, która dodaje pod wpływem stoicyzmu niebo ogniste oraz w zależności od systemu gnostyckiego rozmaicie przedstawia zawartość owych niebios (tzn. jako siedziby aniołów i dziedziny zmienności).

55 Ireneusz z Lyonu, Wyktad nauki apostolskiej 9, w: SCh 406, s. 96; ŹMT 7, s. 31.

56 Ireneusz z Lyonu, Wyktad nauki apostolskiej 10, w: SCh 406, s. 96.98; ŹMT 7, s. 3233; podobnie w: Wyktad nauki apostolskiej 43; Adversus haereses 4,20,1; Adversus haereses $5,18,3$.

57 Ireneusz z Lyonu, Wyktad nauki apostolskiej 9, w: SCh 406, s. 96; „A prorok Izajasz wylicza siedem sposobów działań, które znajdują spoczynek na Synu Bożym, to jest na Słowie w jego przyjściu jako człowieka”, ŹMT 7, s. 31 (por. W. Myszor, ŹMT 7 , s. 31, przypis 69). 
jest ponad innymi, jest (niebo) mądrości, drugim po nim niebo rozumu, trzecim rady, czwartym, licząc od góry, niebo męstwa, piąte wiedzy, szóste pobożności, siódme zaś to firmament nad nami, pełne bojaźni tego ducha oświecającego niebiosa" ${ }^{\text {58 }}$. Powtarzany przez Ireneusza motyw siedmioramiennego świecznika Mojżesza jako wzoru niebios oraz kultu Boga potwierdza korzystanie przez Ireneusza z teologii judeochrześcijańskiej, ale także wskazuje na możliwy wpływ Ap 4, $5^{59}$.

\section{Opis stworzenia człowieka według idei dojrzewania}

Człowiek został stworzony przez Boga i wyposażony w Jego właściwości, aby

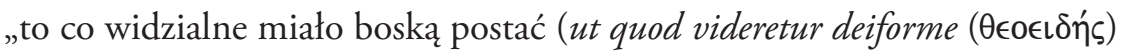
esset)", czyli aby Boży obraz (,ad imaginem enim Dei”) uwidaczniał się także w ciele człowieka ${ }^{60}$. Człowiek został także ukształtowany jako „wolny

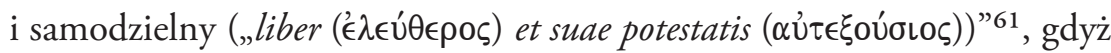
zdaniem Ireneusza właśnie w wolności woli przejawiało się podobieństwo człowieka do Boga. Jak zaznaczają Orbe ${ }^{62}$, Fantino ${ }^{63}$, Rousseau ${ }^{64}$ czy Myszor $^{65}$, według biskupa Lyonu to podobieństwo (similitudo), a nie obraz (imago), było celem wzrastania człowieka. Człowiek, posiadając obraz Boży, miał wzrastać właśnie do podobieństwa do Boga („ita ut ... similis fieret homo Deo") ${ }^{66}$. Stworzony „,złowiek był mały. Był bowiem dzieckiem i trzeba było, aby, wzrastając, doszedł do doskonałości (homo pusillus errat, nam infans errat, et oportebat - et - conveniebat eum crescentem sic ad perfectionem venire)" ${ }^{67}$, czyli do wzoru człowieka doskonałego (bomo perfectus), którym jest Chrystus. Zdaniem Jeana Daniélou koncepcja wzrastania

\footnotetext{
58 Ireneusz z Lyonu, Wyktad nauki apostolskiej 9, w: SCh 406, s. 96; ŹMT 7, s. 31-32.

59 Por. W. Myszor, ŹMT 7, s. 32, przypisy 71 i 72.

${ }^{60}$ Ireneusz z Lyonu, Wyktad nauki apostolskiej 11, w: SCh 406, s. 98; ŹMT 7, s. 33.

61 Ireneusz z Lyonu, Wyktad nauki apostolskiej 11, w: SCh 406, s. 98; ŹMT 7, s. 33 (por. W. Myszor, ŹMT 7, s. 33-34, przypisy 83 i 86).

62 Por. A. Orbe, Antropología de San Ireneo..., dz. cyt., s. 166-173.

63 Por. J. Fantino, L'homme image de Dieu chez saint Irénée de Lyon, Paris 1986.

64 Por. A. Rousseau, Appendice II. Image et ressemblance de Dieu chez Irénée, w: SCh 406, s. $365-371$.

65 Por. W. Myszor, ŹMT 7, s. 33-34, przypis 86.

66 Ireneusz z Lyonu, Wyktad nauki apostolskiej 11, w: SCh 406, s. 98; „Aby w ten sposób (...) człowiek stał się podobny Bogu”, ŹMT 7, s. 33.

67 Ireneusz z Lyonu, Wyktad nauki apostolskiej 12, w: SCh 406, s. 100; ŹMT 7, s. 34-35.
} 
Kształtowanie się nauki o niebie w teologii patrystycznej I-III wieku

człowieka (pełniej opisana w Adversus haereses 4,38,1-268) jawi się jako centralna i najbardziej oryginalna myśl antropologii teologicznej Ireneusza, inspirowana ideą greckiej paidei ${ }^{69}$.

Człowiek miał wzrastać w raju, czyli fizycznie „lepszym miejscu” (melior quam mundus) ... (które) było doskonalsze niż świat (superior)"70, gdzie miał też możliwość bezpośredniego kontaktu z Bogiem, „raj tak oto był piękny i dobry: Słowo Boże (Verbum Dei) przechadzało się stale i rozmawiało z człowiekiem, zapowiadając rzeczy przyszłe, które mają nastąpić, ponieważ będzie zamieszkiwało i rozmawiało z nim i będzie z ludźmi, ucząc ich sprawiedliwości”71. U Ireneusza brak natomiast idei o anielskim życiu pierwszych ludzi ${ }^{72}$. Biskup Lugdunum pośrednio usprawiedliwia upadek Adama, gdyż ten - będąc w swym rozwoju jeszcze dzieckiem - w swej niedojrzałej woli został skuszony przez szatana i upadł w grzech, będąc zarazem winowajcą i ofiarą ${ }^{73}$. Ireneusz rozwijał przy tej okazji, wywodzący się z apokaliptyki żydowskiej ${ }^{74}$, motyw zazdrości szatana, który, zazdroszcząc człowiekowi jego wielu darów, namówił go do nieposłuszeństwa przykazaniu Bożemu ${ }^{75}$.

Człowiek w swym pierwszym grzechu przekroczył niestety prawo nadane mu przez Boga (co stanowi pośrednio polemikę Ireneusza z gnostykami,

68 Syntetycznie oddaje tę ideę W. Myszor, ŹMT 7, s. 34-35, przypis 88, „Tak jak pierwszy człowiek miał się dopiero rozwinąć, aby dopiero na końcu osiągnąć pełnię dojrzałości, tak również ludzkość ma się rozwijać od stanu dziecięctwa do dojrzałości. Tym uzasadniał także przyjęcie przez Chrystusa stanu dziecka (non propter se, sed propter hominis infantiam), który w ten sposób włączył w siebie (recapitulatio) całość człowieka i człowieczeństwa, także w jego okresie dziecięcym”. O wspomnianej tu teorii rekapitulacji, która jest kolejną ważną koncepcją teologiczną Ireneusza, zob. opracowanie T. Dekert, Teoria rekapitulacji w świetle starożytnych koncepcji na temat Adama, Kraków 2007.

69 Por. J. Daniélou, Message évangélique et culture hellénistique aux II et III siècles, Paris 1961, s. 374.

70 Ireneusz z Lyonu, Wyktad nauki apostolskiej 12, w: SCh 406, s. 100; ŹMT 7, s. 35.

71 Ireneusz z Lyonu, Wyktad nauki apostolskiej 12, w: SCh 406, s. 100; ŹMT 7, s. 35.

72 Por. Y. de Andia, Homo vivens. Incorruptibilité et divinisation de l'homme selon Irénée de Lyon, Paris 1986, s. 91-107.

73 Ireneusz z Lyonu, Wyktad nauki apostolskiej 12, w: SCh 406, s. 100; „Człowiek był jeszcze dzieckiem (puer erat) i miał niedojrzałą wolę (nondum perfectum habens consilium (ßou $\lambda \hat{\eta})$ ), dlatego łatwo został zwiedziony przez uwodziciela (a seductore deceptus est)", ŹMT 7, s. 35.

74 Por. J. Daniélou, Teologia judeochrzéscijańska..., dz. cyt., s. 155.

75 Por. Ireneusz z Lyonu, Wyktad nauki apostolskiej 16, ŹMT 7, s. 37. 
3. Kształtowanie się nauki o niebie w teologii patrystycznej - wiek III

odrzucającymi prawo i koncepcję Boga jako prawodawcy), dlatego utracił swą warunkową nieśmiertelność i wrócił z raju na ziemi ${ }^{76}$. Nieśmiertelność (immortalitas) człowieka w raju nie należałaby zatem do natury człowieka, ale była wyłącznym darem Boga. Przez swoje przeciwstawienie się Bogu w grzechu człowiek utracił, zdaniem Ireneusza, swą warunkową nieśmiertelność, „został wyrzucony z raju” i oddalony od Bożego oblicza, jednak „(Bóg), osiedlając go naprzeciw raju (na drodze), raj bowiem nie przyjmuje grzesznika"77, nie oddalił całkowicie Adama od siebie, czyli Adam miał jakiś kontakt $\mathrm{z}$ rajem i mógł do niego wrócićc ${ }^{78}$.

\section{Prorocy zapowiadający Wcielenie Syna Bożego}

Ireneusz wskazuje, iż człowiek dostępuje udziału w „niezniszczalności” („incorruptibilitatis”) jedynie dzięki zjednoczeniu z Bogiem, gdyż sam nie jest $\mathrm{w}$ stanie w niej uczestniczyć ${ }^{79}$. Udział człowieka w niezniszczalności należy rozumieć u Ireneusza w znaczeniu soteriologicznym, jako zjednoczenie Boga z człowiekiem dla jego zbawienia ${ }^{80}$. Także przyszła nieśmiertelność (immortalitas) człowieka jest skutkiem zbawczego działania Chrystusa,

76 Ireneusz z Lyonu, Wyktad nauki apostolskiej 15, w: SCh 406, s. 104; „(Bóg) nałożył

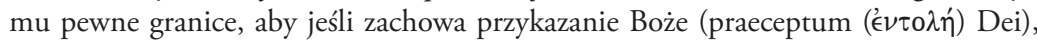
pozostawał zawsze takim, jakim jest, to znaczy nieśmiertelnym (hoc est immortalis), a gdyby zgrzeszył, żeby stał się śmiertelnym (ut mortalis fieret) i wrócił do ziemi, skąd wzięte jest jego ukształtowanie", ŹMT 7, s. 37 (por. W. Myszor, ŹMT 7, s. 37, przypisy 103 i 105).

77 Ireneusz z Lyonu, Wyktad nauki apostolskiej 16, w: SCh 406, s. 104; „transferens-habitare-faciens ( $\mu \in \tau o \iota \kappa i \zeta \omega)$ eum circa paradisum [viae] tunc: peccatorem enim non recipit paradisus", ŹMT 7, s. 38.

78 Por. W. Myszor, ŹMT 7, s. 38, przypis 108. Ireneusz w cytowanym powyżej fragmencie Wyktadu 16 korzystał z tekstu Rdz 3, 24 według LXX: „Wyrzucił Adama i osiedlił go poza tym ogrodem rozkoszy. Postawił tam cheruby i płonący miecz, odwrócony tak, by strzegł dojścia do drzewa życia”, tłum. R. Popowski, PSB 37, s. 10. Tekst

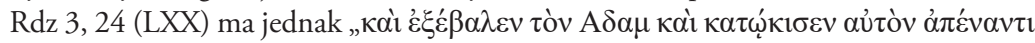

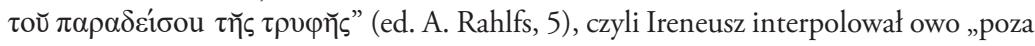
ogrodem" jako naprzeciw ogrodu. W ormiańskim tłumaczeniu tekstu Ireneusza w tekście Rdz 3, 24 dodano także „[viae]”. - „na drodze”, który to zwrot Adelin Rosseau (SCh 406, s. 104) proponowała opuścić.

79 Ireneusz z Lyonu, Wyktad nauki apostolskiej 31, w: SCh 406, s. 126; ŹMT 7, s. 49.

80 Por. Ireneusz z Lyonu, Zdemaskowanie fatszywej gnozy III,18,7; 19,1; Y. de Andia, Homo vivens..., dz. cyt., s. 169; A. Houssiau, La christologie de Saint Irénée..., dz. cyt., s. 201203; W. Myszor, ŹMT 7, s. 49, przypis 183. 
Kształtowanie się nauki o niebie w teologii patrystycznej I-III wieku

który przyjął ludzką naturę i doprowadził w sobie śmiertelność do nieśmiertelności ${ }^{81}$. Wierzący dostępują go po swym zmartwychwstaniu, na skutek zbawienia dokonanego przez Jezusa Chrystusa ${ }^{82}$ w mocy Ducha Świętego ${ }^{83}$.

\section{Chrystusowe zapowiedzi śmierci, zmartwychwstania i wniebowstąpienia}

Wierzący w Chrystusa są uwolnieni od sądu eschatologicznego i nie będą zniszczeni ogniem, gdyż przez ich wybór wiary w Chrystusa dokonało się też ich usprawiedliwienie. Podobnie sam moment przyjęcia sądu jako kary dokonuje się zatem, zdaniem Ireneusza, już w momencie braku zawierzenia Chrystusowi i odrzuceniu jego zbawczej męki ${ }^{84}$. Zmartwychwstanie Chrystusa w konsekwencji niesie Jego ludzką nieśmiertelność i niezniszczalność (immortalitas et incorruptibilitas) ${ }^{85}$. Po swym zmartwychwstaniu Jezus powrócił do nieba: „został wzięty (adsumptus est) i (...) otwarte

81 Ireneusz z Lyonu, Wyktad nauki apostolskiej 33, w: SCh 406, s. 130; „Trzeba było bo-

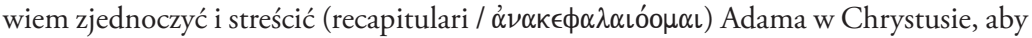
to, co śmiertelne wchłonięte zostało przez nieśmiertelność (ut absorptum-deglutiretur / $\kappa \alpha \tau \alpha \pi i(\nu \omega)$ mortale ab immortalitate)", ŹMT 7, s. 451-52 (por. 1 Kor 15, 54; 2 Kor 5, 4).

82 Ireneusz z Lyonu, Wyktad nauki apostolskiej 41, w: SCh 406, s. 140; „Obiecywali, że Bóg wszechświata da im życie wieczne po zmartwychwstaniu dzięki temu, który umarł i zmartwychwstał, Jezusowi Chrystusowi”, ŹMT, 7, s. 59.

83 Ireneusz z Lyonu, Wyktad nauki apostolskiej 42, w: SCh 406, s. 140.142; „Jego bowiem (działaniem) dokonuje się zmartwychwstanie w tych, którzy uwierzyli, wtedy, gdy ciało na nowo przyjmuje duszę i gdy z tą mocą Ducha Świętego powstaje i wchodzi do Królestwa Bożego", ŹMT 7, s. 59 (por. B. Częsz, Związek Ducha Świętego z Kościotem w ujęciu świętego Ireneusza i w interpretacji montanistycznej, Poznań 1991, s. 121-122).

84 Ireneusz z Lyonu, Wyktad nauki apostolskiej 69, w: SCh 406, s. 182; „Tak i z sądem: na jednych jest przeniesiony, mają go ku śmiertelnej zagładzie, dla innych jest usunięty i dlatego są uwolnieni od niego (a (ஷ்ró) quibus autem sublatum est, et salvati subt ab (ஷُாó) eo). A więc przyjęli sąd na siebie samych ci, którzy go ukrzyżowali, a czyniąc to wskazali, że nie uwierzyli w niego. Tak wskutek sądu, który wzięli na siebie, zostali także ukarani zniszczeniem. Od wierzących w niego sąd został usunięty i już nie podpadają pod niego (sublatum est autem a (’̊mó) credentibus in eum iudicium et iam non suint sub eo). A sądem ma być zniszczenie ogniem niewierzących przy końcu tego świata”, ŹMT 7, s. 81 (por. W. Myszor, ŹMT 7, s. 81, przypis 383).

85 Por. Ireneusz z Lyonu, Wyktad nauki apostolskiej 72, w: SCh 406, s. 186; „A więc wskazuje na jego zmartwychwstanie, ponieważ powstając z martwych jest nieśmiertelny (immortalis est); przyjął życie aby zmartwychwstać oraz dtugie dni na wieki wieków aby być niezniszczalny (incorruptibilis esset)", ŹMT 7, s. 83. 
3. Kształtowanie się nauki o niebie w teologii patrystycznej - wiek III

niebiosa go przyjęły (aperti receperunt eum caeli)” 86 , „wzięty został na prawicę Ojca (adsumptus ad dexteram Patris)" ${ }^{77}$, „wzięty został tam, skąd zstąpił (illuc adsumptus est unde et descendit)" 88 . W Jego imię na końcu mają być zbawieni ci, którzy służyli Bogu ${ }^{89}$. Tym, co z ludzkiej strony ułatwia zbawienie człowieka, to nie wypełnianie prawa, ale prostota wiary i miłoś$\mathrm{ci}^{90}$ oraz służenie Bogu w imię Jezusa ${ }^{91}$.

Motyw niezniszczalności i nieśmiertelności (immortalitas et incorruptibilitas) jest poruszany przez Ireneusza jako jeden z pobocznych wątków, jakich dotyka przy okazji omawiania katechetycznego nauczania Kościoła II wieku w Wyktadzie nauki apostolskiej. Niezniszczalność i nieśmiertelność są przedstawiane jako cechy ludzi zbawionych w niebie. Chrześcijanin w momencie chrztu jest obdarzany zapowiedzią i znakiem życia wiecznego, co dopełni się w wierzących w momencie ich zmartwychwstania (Wyktad3A). Nieśmiertelność jest darem Boga dla wierzących i stanowi jedną z konsekwencji odnowionej relacji z Bogiem (Wyktad 7). Ireneusz przy okazji powtarza biblijną naukę o eschatologicznym niebie (miejsce stworzone przez Boga, specjalnie z Nim powiązane, miejsce przebywania aniołów; Bóg transcendentny wobec nieba - Wyktad 43-45). W tym katechetycznym nauczaniu pojawiają się u Ireneusza także wątki judeochrześcijańskiej nauki o niebie (topos siedmiu niebios, motyw siedmioramiennego świecznika jako wzoru niebios - Wyktad9; motyw zazdrości szatana - Wyktad 16). Mająca się objawić w zbawionych niezniszczalność-nieśmiertelność stanowi, zdaniem Ireneusza, przejaw dojrzewania człowieka od rajskiej warunkowej nieśmiertelności do doskonałej nieśmiertelności według wzoru Chrystusa (Wykład 12). Nieśmiertelność zbawionych jest zatem wyłącznym skutkiem

86 Por. Ireneusz z Lyonu, Wyktad nauki apostolskiej 83, w: SCh 406, s. 196; ŹMT 7, s. 88 (por. Dz 1, 4-12).

87 Por. Ireneusz z Lyonu, Wyktad nauki apostolskiej 85, w: SCh 406, s. 198; ŹMT 7, s. 88.

88 Ireneusz z Lyonu, Wyktad nauki apostolskiej 85, ŹMT 7, s. 89.

89 Por. Ireneusz z Lyonu, Wyktad nauki apostolskiej 88, w: SCh 406, s. 202; ŹMT 7 , s. 90.

90 Ireneusz z Lyonu, Wyktad nauki apostolskiej 87, w: SCh 406, s. 200; „Et quoniam non secundum multiloquium legis, sed secundum brevitatem fidei et dilectionis salvari habebant homines", ŹMT 7, s. 90 (por. Mt 22, 37-40; Rz 13, 10).

91 Por. Ireneusz z Lyonu, Wyktad nauki apostolskiej 88, w: SCh 406, s. 202; „Et quoniam in fine per eius nomen salvari habebant qui serviebant Deo", ŹMT 7, s. 90. 
Kształtowanie się nauki o niebie w teologii patrystycznej I-III wieku

zbawczego działania Chrystusa i mocy Ducha Świętego (Wyktad 41-42). Wierzący w Chrystusa są uwolnieni od eschatologicznego sądu i nie będą, jak niewierzący, zniszczeni ogniem (Wyktad 69).

Nauczanie Ireneusza z Lyonu o eschatologicznym niebie jest zatem kontynuacją teologii biblijnej (niebo miejscem Boga, Jezus zstępujący i wstępujący do nieba, niebo miejscem aniołów i zbawionych, nieśmiertelność zbawionych) oraz apokaliptyki judeochrześcijańskiej (wyniesienie sprawiedliwych do raju; połączenie raju sprawiedliwych z wątkiem królestwa milenijnego; topos o siedmiu niebiosach; motyw siedmioramiennego świecznika jako wzoru niebios; motyw zazdrości szatana).

Ireneuszowy wykład wiary dotyczący eschatologicznego nieba jest uwarunkowany formą przekazu, jaką była polemika z gnostykami czy przekaz katechezy kościelnej. Dlatego wątki o eschatologicznym niebie są tematyką poboczną w stosunku do głównych założeń poszczególnych traktatów biskupa Lyonu. Eschatologiczne niebo opisywane w kategorii motywu przestrzennego (motyw Jerozolimy millenijnej i niebieskiej) było ideą stosowaną przez tego autora w księdze V Zdemaskowania i odparcia fatszywej gnozy. Natomiast aspekty jakościowe zbawionych jak nieśmiertelność i niezniszczalność były wspominane w jego katechetycznym Wykładzie nauki apostolskiej.

\subsection{Klemens Aleksandryjski (150 - około 212$)$ - niebo miejscem deifikacji zbawionych}

Źródła myśli teologicznej Klemensa odnajdujemy w ówczesnej filozofii aleksandryjsko-żydowskiej i platońskiej oraz w jego dialogu z gnostycyzmem, które to kierunki starał się on harmonizować pod przewodnictwem wiary chrześcijańskiej ${ }^{22}$. Centralną postacią jego teologii jest Chrystus, opi-

92 Por. S. C. R. Lilla, Middle Platonism, Neoplatonism and Jewish-Alexandrine Philosophy in the Terminology of Clemens of Alexandria's Ethics, Roma 1961; J. Niemirska- 
3. Kształtowanie się nauki o niebie w teologii patrystycznej - wiek III

sywany jako mistrz i zbawiciel ludzkości. Natomiast człowiek na drodze cnoty powinien stawać się Mu współpodobny ${ }^{93}$. Tematyka eschatologiczna wydaje się być u Klemensa raczej drugoplanowa ${ }^{94}$. Wątki nauczania kościelnego o niebie pojawiają się w trzech głównych dziełach Klemensa, tj. w Zachęcie Greków, Pedagogu i w Kobiercach.

Zachęta Greków ${ }^{95}$, pod względem formy naśladuje analogiczny tekst Arystotelesa, merytorycznie jest natomiast mową misyjną, w której Klemens zachęcał wykształconych Aleksandryjczyków do przyjęcia wiary chrześcijańskiej, gdyż ta prowadzi do szczęścia wiecznego. Klemens najpierw wykazywał niegodziwość kultów pogańskich oraz fałszywość pogaństwa (Zachęta Greków 1-7), by następnie pozytywnie przedstawić wiarę w Chrystusa, jako jedynego i prawdziwego Mistrza, udzielającego ludziom zbawienia (Zachęta Greków 8-12)96. Tematyka eschatologiczna pojawia się w tym utworze okazjonalnie albo w związku z krytyką pogańskiego kultu ciał niebieskich (Zachęta Greków 4,63), albo przy okazji zachęty do nawrócenia na chrześcijaństwo - w celu osiągnięcia odrodzenia w królestwie niebieskim (Zachęta Greków 9,82; 9,86), gdzie otrzymają jako nagrodę - nieśmiertelność (Zachęta Greków 10,96; 10,99; 10,100), której jedynym dawcą jest wieczny Bóg (Zachęta Greków 10,105-107). Niebo stanowi dla wierzących nagrodę i dar za ich posłuszeństwo Bogu (Zachęta Greków 11,111; 11,113-114; 12, 120-121), a sposobem dojścia do nieba jest wiara (Zachęta Greków 11,115-116).

-Pliszczyńska, Pierwsza próba syntezy filozofi greckiej z antyczna doktryna chrześcijańska Klemensa Aleksandryjskiego «Stromata», „Eos” 6 (1977), s. 221-229; J. Grzywaczewski, Obraz gnostyka wedtug „Stromatów” Klemensa Aleksandryjskiego, „Vox Patrum” 11 (1986), s. 543-554; F. Drączkowski, Gnoza w ujęciu Klemensa Aleksandryjskiego, w: Gnostycyzm i wspótczesna gnoza, Warszawa 1996, s. 9-21 (Studia Antiquitatis Christianae 12).

93 Por. L. Rzodkiewicz, Jezus Chrystus w kulturze antycznej. Stanowisko Klemensa Aleksandryjskiego, Legnica 1999; B. Zgraja, Chrystus boski Logos - wzór i mistrz cnoty wedtug Klemensa Aleksandryjskiego, „Studia Warmińskie” 47 (2010), s. 49-70.

94 Por. M. Mees, Clemente di Alessandria (150-215 ca.), NDPAC 1, ed. A. Di Berardino, Genova-Milano 2006², k. 1071-1072.

95 Clemens Alexandrinus, Protrepticus, w: SCh 2. Clément d'Alexandrie, Le Protreptique. Introduction, traduction et notes de C. Mondésert, Paris 1949; przekład polski Klemens Aleksandryjski, Zachęta Greków, w: Apologie, tłum. J. Sołowianiuk, Warszawa 1988, s. 116-201 (Pisma Starochrześcijańskich Pisarzy [dalej: PSP] 44).

96 Por. J. Sołowianiuk, Zachęta Greków - Wstęp, w: Apologie..., dz. cyt., s. 102-103. 
Kształtowanie się nauki o niebie w teologii patrystycznej I-III wieku

Wychowawca ${ }^{97}$, drugie pismo Klemensa, zostało skomponowane w trzech księgach i było prawdopodobnie skierowane do zamożnych chrześcijan aleksandryjskich ${ }^{98}$. Klemens w trzech księgach wskazywał im Chrystusa-Syna Bożego-Logos, kształtującego ich na drodze cnót ${ }^{99}$. Tematyka eschatologiczna, w tym kwestia eschatologicznego nieba, jest w tym traktacie drugorzędna i dosyć rozproszona. W kontekście nauki o eschatologicznym niebie w I księdze autor raczej wskazuje na cechy, jakimi winni odznaczać się chrześcijanie, aby odziedziczyć królestwo niebieskie. Tematyka cnót przewija się także w kolejnych księgach, przy czym w księdze II Klemens podkreśla relacje zbawionych z Chrystusem, a w księdze III uwypukla wartość zasługującą dobrych czynów.

Trzecim traktatem Klemensa są Kobierce ${ }^{100}$, będące wykładem doktryny chrześcijańskiej przełomu II i III wieku. Klemens w formie erudy-

${ }^{97}$ Clemens Alexandrinus, Paedagogus, w: SCh 70. Clément d'Alexandrie, Le Pédagogue. Livre I. Texte grec, introduction et notes de H.-I. Marrou, traduction de M. Harl, Paris 1960; SCh 108. Clément d'Alexandrie, Le Pédagogue. Livre II. Traduction de C. Mondésert, notes de H.-I. Marrou, Paris 1991²; SCh 158. Clément d'Alexandrie, Le Pédagogue. Livre III. Traduction de C. Mondésert et Ch. Matray, notes de notes de H.-I. Marrou, Paris 1970; przekład polski Klemens Aleksandryjski, Wychowawca, tłum. M. Szarmach, Toruń 2012.

98 Por. M. Pujiula, Körper und christliche Lebensweise. Klemens von Alexandria und sein Paidagogos, Berlin-New York 2006, s. 84.

99 Por. F. Drączkowski, Kościót - Agape wedtug Klemensa Aleksandryjskiego, Lublin 1983; F. Drączkowski, Mitość syntezą chrześsijaństwa, Lublin 1991; P. Szczur, Oblicza mitości: „Mitość daje się poznać w sposób wieloraki”: cnoty pokrewne i towarzyszące agape wedtug Klemensa Aleksandryjskiego, Kielce-Lublin 2002; B. J. Zgraja, Semantykà $\alpha \rho \epsilon \tau \dot{~ w ~ p i s-~}$ mach Klemensa Aleksandryjskiego, „Vox Patrum” 28 (2008), t. 52/2, s. 1335-1345.

100 Clemens Alexandrinus, Stromata, w: GCS 52. Clemens Alexandrinus II. Stromata IVI, herausgegeben O. Stählin; $1936^{2}$, Leipzig 1906; SCh 30. Clément d'Alexandrie, Les Stromates. Stromate I. Texte grec, introduction et notes de C. Mondésert, traduction de M. Caster, Paris 1951; SCh 38. Clément d'Alexandrie, Les Stromates. Stromate II. Texte grec, introduction et notes de C. Mondésert, traduction de P. Camelot, Paris 1954; SCh 463. Clément d'Alexandrie, Les Stromates. Stromate IV. Texte grec, introduction et notes de C. Mondésert, traduction de A. van den Hoek, Paris 2001; SCh 278 - 279. Clément d'Alexandrie, Les Stromates. Stromate V. Texte grec, introduction, notes et traduction de A. Le Boulluec, Paris 1981; SCh 446. Clément d'Alexandrie, Les Stromates. Stromate VI. Texte grec, introduction, notes et traduction de P. Descourtieux, Paris 1999; SCh 428. Clément d'Alexandrie, Les Stromates. Stromate VII, Texte grec, introduction, notes et traduction de A. Le Boulluec, Paris 1997; przekład polski Klemens Aleksandryjski, Kobierce zapisków filozoficznych dotyczacych prawdziwej wiedzy, tłum., komentarz i indeksy J. Niemirska-Pliszczyńska, Warszawa 1994, (PAX 33), s. 1-2. 
3. Kształtowanie się nauki o niebie w teologii patrystycznej - wiek III

cyjnego zapisu literackiego prezentuje przeplatające się wątki teologiczne i filozoficzne. Centralnym problemem tego dzieła jest zagadnienie tzw. pozytywnej gnozy, czym ona jest i jak ją uzyskiwać ${ }^{101}$. Przy stałym odwoływaniu się do teologii św. Pawła Apostoła oraz przy użyciu argumentacji Arystotelesa, autor traktatu opisał swoją koncepcję gnostycznej doskonałości chrześcijańskiej. Jest to dążenie do poznawania Boga przez życie moralnie piękne (wpływy platońskie), dążenie do wyrzeczenia się afektów (wpływy stoickie) oraz dążenie do postawy świadomego wyboru decyzji moralnej i do działania jako jedynej weryfikacji postawy chrześcijańskiej (wpływy perypatetyckie) ${ }^{102}$. Miarą tych dążeń jest Chrystus jako ucieleśnienie piękna moralnego ${ }^{103}$. W tej zdecydowanie etycznej syntezie chrześcijaństwa eschatologia wspominana była przez Klemensa sporadycznie: przy okazji modlitwy o dobra prawdziwie chrześcijańskie (Kobierce 4,26,172,2) oraz we fragmentach Kobierca 6.

\section{Antropologia}

Według Klemensa celem, dla którego Bóg stworzył człowieka jest zbawienie człowieka oraz jego ubóstwienie, co dokonuje się dzięki Chrystusowi ${ }^{104}$.

101 Por. S. R. C. Lilla, Clement of Alexandria. A Study in Christian Platonism and Gnosticism, Oxford 1971.

102 Por. A. Swoboda, Stoicka koncepcja cnoty, „Symbolae Philologorum Posnaniensium Graecae et Latinae” 12 (1998), s. 31-41; D. Zagórski, „Miarq wszystkich rzeczy jest Bóg”. Platonska zasada w interpretacji Klemensa Aleksandryjskiego, "Roczniki Teologiczne” L (2003), z. 4, s. 245-255; D. Zagórski, Recepcja arystotelesowskiego ideatu $\mu \in \sigma o ́$ тп $w$ doktrynie Klemensa Aleksandryjskiego, „Roczniki Teologiczne” LI (2004) z. 4, s. $5-42$.

103 Por. J. Niemirska-Pliszczyńska, Wstęp, PAX 33, s. 1, XV-XXXIII; B. Zgraja, Klemensa Aleksandryjskiego koncepcja $\alpha \rho \in \tau \eta$ (cnoty), „Studia Teologiczno-Historyczne Śląska Opolskiego" 29 (2009), s. 211-227.

104 Por. Klemens Aleksandryjski, Zachęta Greków 1,8,4, w: SCh 2, s. 63; „On, który istniejąc w postaci Bożej, nie skorzystał ze sposobności, aby na równi być z Bogiem, lecz wyniszczył samego siebie; miłosierny Bóg, który pragnie zbawienia człowieka. Już samo Słowo wyraźnie mówi do ciebie, aby okryć wstydem twoją niewiarę. Zaprawdę powiadam: Słowo stało się człowiekiem, abyś ty także nauczył się od człowieka, w jaki sposób, będąc człowiekiem, możesz stać się Bogiem”, PSP 44, s. $122-$ 123 (por. Flp 2, 6-7). 
Kształtowanie się nauki o niebie w teologii patrystycznej I-III wieku

Sposobem na wejście człowieka do nieba jest przyjęcie wiary objawionej przez Chrystusa, który jest bramą do nieba ${ }^{105}$.

Tematyka antropologiczna była kontynuowana w Kobiercach. „Bóg stworzył człowieka do niezniszczalności i uczynił go wizerunkiem swej własnej Jedynej odrębności”106. W myśl platońskiego założenia o upodabnianiu się do idei, w miarę możliwości dostępnych ludzkiej naturze ${ }^{107}$, Klemens twierdził, iż gnostyk, upodabniając się do Boga, dzięki działaniu Bożej dobrotliwości, użycza duszy „doglądu-natchnienia-regulującego działania” oraz odblasku, wyciskając na niej pieczęć sprawiedliwości ${ }^{108}$. Klemens, rozwijając naczelną tezę Etyki Nikomachejskiej Arystotelesa, uznawał, że Adam został stworzony jako „uzdolniony do przyswajania sobie cnoty"109. W doczesności wierzący pełni funkcję zbawczą, kiedy upodobnia się do Chrystusa, ${ }^{110}$ jak to jest możliwe dla ludzkiej natury przez swe czyny i poznanie ${ }^{111}$. Odbywa się to na drodze kolejnych stopni doskonalenia. Klemens, wykorzystując platońskie tezy o wstępowaniu ${ }^{112}$, mówił

105 Por. Klemens Aleksandryjski, Zachęta Greków 1,10,2-3, w: SCh 2, s. 66; „2. (...). «Ja jestem bramą» - powiedział - od której powinni się uczyć ci, którzy pragną poznać wolę Boga, i w ten sposób otworzył nam wszystkie bramy nieba. 3. Rozumowe bramy Słowa są bowiem otwierane kluczem wiary. «Boga nikt nie zna, tylko Syn i ten, komu Syn zechce objawić»”, PSP 44, s. 124 (por. J 10, 9; Mt 11, 23; por. też Klemens Aleksandryjski, Zachęta Greków 9,82,4, w: SCh 2, s. 150; PSP 44, s. 178).

106 Klemens Aleksandryjski, Kobierce 6,12,97,1, w: SCh 446, s. 254; PAX 33,2, s. 169170 (por. Mdr 2, 22-23).

107 Por. Platon, Theaetetus 176 A-B.

108 Por. Klemens Aleksandryjski, Kobierce 6,12,104,1-3, w: SCh 446, s. 268.270; PAX 33,2, s. 174.

109 Por. Klemens Aleksandryjski, Kobierce 6,12,96,2, w: SCh 446, s. 252. Por. Arystoteles, Etyka nikomachejska 2,1,1103a,23-26: „Więc cnoty nie stają się udziałem naszym ani dzięki naturze, ani wbrew naturze, lecz z natury jesteśmy tylko zdolni do ich nabywania, a rozwijamy je w sobie dzięki przyzwyczajeniu”, tłum. i oprac. D. Gromska, Warszawa 1956, s. 43 (Biblioteka Klasyków Filozofii [dalej: BKF] 25).

110 Por. B. Zgraja, Chrystus boski Logos..., dz. cyt., s. 49-70.

111 Por. Klemens Aleksandryjski, Kobierce 6,9,77,5, w: SCh 446, s. 216; PAX 33,2, s. 157 (por. Arystoteles, Etyka nikomachejska 6,13,1143b,224-25: „Cnoty są trwałymi dyspozycjami [do pewnego sposobu postępowania - uwaga tłumaczki D. Gromskiej]”, BKF 25, s. 228).

112 Por. Platon, Fajdros 250b, tłum. W. Witwicki, s. 78. Więcej na temat wplywu idei platońskich na tezy Klemensa zob. J. Wytzes, The Twofold Way (I): Platonic Influences in the Work of Clement of Alexandria, „Vigiliae Christianae” 11/4 (1957), s. 226245; J. Wytzes, The Twofold Way (II): Platonic Influences in the Work of Clement of 
3. Kształtowanie się nauki o niebie w teologii patrystycznej - wiek III

zatem o sześciu stopniach modlitewnego wstępowania gnostyckiego (odpuszczenie grzechów; aby nie grzeszył; aby mógł dobrze czynić; aby mógł zrozumieć całe dzieło stworzenia; aby stał się czysty w sercu; aby doznał „twarzą w twarz” wtajemniczenia w „błogosławione widowisko”) ${ }^{113}$.

Odwołując się do 1 Kor 15, 50, Klemens uznawał, że po zmartwychwstaniu człowiek nadal pozostanie złożeniem ciała z duszą ( $\sigma u ́ \nu \theta \epsilon \sigma \iota \varsigma)$, przy czym w ciele nie będzie już zepsucia grzechem ${ }^{114}$. Interpretując w znaczeniu orfickim cielesność człowieka - jako obciążenie i podział, autor ten uznawał najprawdopodobniej, że człowiek po zmartwychwstaniu uwolniłby się od namiętności i przez to zatraciłby płciowość, stawszy się z istoty dwupłciowej - jednopłciową ${ }^{115}$.

Alexandria, „Vigiliae Christianae” 14/3 (1960), s. 129-153; D. Wyrwa, Die christliche Platonaneignung in den Stromateis des Clemens von Alexandrien, Berlin-New York 1983; L. Łesyk, Platon Mojżeszem Greków w ujęciu Klemensa z Aleksandrii, „Littera Antiqua" 7 (2013), s. 66-80.

113 Por. Klemens Aleksandryjski, Kobierce 6,12,102,1, w: SCh 446, s. 264; PAX 33,2, s. 172-173. Szerzej na temat modlitwy według Klemensa, zob. F. Drączkowski, Formy i cele modlitwy doskonatego chrześcijanina (gnostyka)wedtug Klemensa Aleksandryjskiego, w: Homo Meditans I - Medytacja, red. W. Słomka, Lublin 1984, s. 127-132.

114 Por. Klemens Aleksandryjski, Kobierce 3,17,104,5, w: GCS 52, s. 244; PAX 33,1, s. 291. Szerzej o antropologii Klemensa dotyczącej kwestii złożenia ciała i duszy po zmartwychwstaniu (por. S. Łucarz, Grób czy świątynia? Problematyka cielesności w antropologii Klemensa Aleksandryjskiego, Kraków 2007, s. 153-156).

115 Por. Klemens Aleksandryjski, Kobierce 6,12,100,3, w: SCh 446, s. 260.262; „Bo przecież będzie istotnie jego siostrą również po wyzbyciu się ciała, które przez odrębność kształtów dwupłciowych oddala i ogranicza znajomość spraw ducha. Wszak dusze są same przez się sobie równe, bez znamienia płci; nie będzie mężczyzn ani kobiet, gdy już żenić się nie będą ani wychodzić za mąż. I kobieta w równym stopniu przekształci się w mężczyznę, straciwszy znamię kobiecości i stawszy się zarazem męska i kobieca”, PAX 33,2, s. 171-172 (por. Ga 3, 28; Mt 22, 30). S. Łucarz, Grób czy świqtynia?..., dz. cyt., s. 174-175, interpretuje takie stwierdzenie Klemensa alegorycznie i chce tu widzieć postulat pozbycia się przez człowieka, pojmowanego jako dusza, namiętności i wejścia w stan jedności. Natomiast J. B. Bauer, Genitalien, w: Lexikon der christlichen Antike, Hrsg. J. B. Bauer, M. Hutter, Stuttgart 1999, s. 144, uznaje, że zdaniem Klemensa po zmartwychwstaniu zanikną u ludzi wszelkie różnice płciowe. Możliwe, że na cytowaną powyżej opinię Klemensa na temat braku płciowości ludzkiej po zmartwychwstaniu, oprócz sugerowanych wpływów biblijnych, miała także teza gnostycka o przekształceniu tego, co kobiece w to, co męskie - dla porównania np. zakończenie gnostyckiej Ewangelii Tomasza 114. Por. H. Ch. Puech, En quête de la Gnose, vol. II: Sur l'Evangile selon Thomas. Esquisse d'une interprétation systématique, Paris 1978, s. 80 (Collection: „Bibliothèque des Sciences Humaines). 
Kształtowanie się nauki o niebie w teologii patrystycznej I-III wieku

Klemens zakładał także po zmartwychwstaniu moralny rozwój i przenoszenie się zbawionych na wyższe stopnie hierarchii moralnej ${ }^{116}$. Aleksandryjski autor, rozwijając myśl Ez 18, 23, stwierdzał też, że same kary, jakie Bóg zsyła na ludzi, miałyby charakter zbawczy i wychowawczy - „prowadzą dusze do nawrócenia i mają na celu raczej skruchę niż jego śmierć” ${ }^{117}$.

Dzięki wierze człowiek unika kary wiecznej i uzyskuje pożytek jako odpłatę za wiarę ${ }^{118}$. Aktowi wiary muszą jednak towarzyszyć czyny wiary, przez które człowiek wyzbywa się namiętności ${ }^{119}$. Na drodze stopniowalnej pokuty wierzący w doczesności musi dopełnić swego oczyszczenia od każdego uchybienia ${ }^{120}$. Inaczej będzie musiał po śmierci przejść przez jakieś nienazwane „wielkie cierpienie”, aby został uznany ostatecznie za sprawiedliwego ${ }^{121}$.

\section{Chrystus jako sposób osiągnięcia nieba}

Chrystus był opisywany przez Klemensa jako „objawienie odwiecznego Słowa”, gdyż objawił się światu jako odwiecznie istniejący Zbawiciel,

116 Por. Klemens Aleksandryjski, Kobierce 6,6,47,1, w: SCh 446, s. 156; PAX 33,2, s. 138.

117 Klemens Aleksandryjski, Kobierce 6,6,46,3, w: SCh 446, s. 154; PAX 33,2, s. 138 (por. $1 \mathrm{Tm}$ 2, 4). Więcej na temat pedagogicznego charakteru kary według Klemensa, zob. J. Wytzes, "Paideia» e Pronoia in the works of Clement of Alexandria, „Vigiliae Christianae” 9 (1950), s. 150; K. Derkaczewska [E. Fotiju], „Bóg się nie mści, lecz karze ku pożytkowi”: pedagogiczna koncepcja kary w „Kobiercach” Klemensa Aleksandryjskiego, w: Ku duchowej integracji Europy, red. A. Kaim, P. Kantyka, Lublin 2005, s. 211-218.

118 Por. Klemens Aleksandryjski, Kobierce 6,12,98,4, w: SCh 446, s. 258; „(...) wiara ze względu na związane z nią skutki, mianowicie, że dzięki niej unikamy kary i uzyskujemy pożytek jako odpłatę za wiarę", PAX 33,2, s. 170; obszerniej na temat kwestii usprawiedliwienia przez wiarę u Klemensa, zob. w opracowaniu P. Szczur, Miejsce i rola wiary $w$ dążeniu do doskonatości chrześcijańskiej w ujęciu Klemensa Aleksandryjskiego, „Teologia Patrystyczna” 9 (2012), s. 41-55.

119 Por. Klemens Aleksandryjski, Kobierce 6,14,108,4, w: SCh 446, s. 276; PAX 33,2, s. 177; na temat pokuty kanonicznej u Klemensa, zob. opracowanie A. Méhat, "Pénitence Seconde" et "Péché involontaire" chez Clément d'Alexandrie, "Vigiliae Christianae" 8/4 (1954), s. 225-33.

120 Por. Klemens Aleksandryjski, Kobierce 6,14,109,6, w: SCh 446, s. 278; PAX 33,2, s. 177 (por. Rz 8, 30).

121 Por. Klemens Aleksandryjski, Kobierce 6,14,109,6-110,1, w: SCh 446, s. 278; „(..) oczekuje wielkie cierpienie z tego powodu, że nie mogą przebywać razem z uwielbionymi za sprawiedliwość", PAX 33,2, s. 177-178. 
3. Kształtowanie się nauki o niebie w teologii patrystycznej - wiek III

Nauczyciel i Stwórca. W kontekście eschatologii Klemensa szczególnie ważna wydaje się rola Chrystusa jako Nauczyciela, który pouczył ludzi „jak sprawiedliwie żyć, aby jako Bóg poprowadził nas do życia wiecznego"122. Spośród stworzeń śmiertelnych cechą nieśmiertelności, zdaniem Klemensa, mogą być obdarzeni przez Boga tylko ludzie ${ }^{123}$. Klemens zakładał, że poganie mogą dostąpić nieśmiertelności poprzez przyjęcie Chrystusa jako Słowa Bożego ${ }^{124}$. Chrystus i Jego nauka są światłem wewnętrznie oświecającym człowieka w jego drodze do Boga i życia wiecznego. Przyjmując osobę Chrystusa i jego pouczenia, człowiek w akcie wiary uznaje Boga i staje się Jego uczniem ${ }^{125}$. Człowiek będący odwiecznym obrazem Boga ${ }^{126}$ przez upodabnianie się do Słowa Bożego staje się kochającym obrazem Boga, przyjmuje nieśmiertelność i idzie do nieba ${ }^{127}$.

Chrześcijańska wiara jest nazywana przez Klemensa „drogą do nieba”128. Jako chrześcijanin, już po akcie wiary, człowiek zdobywa nieśmiertelność dzięki upodabnianiu się do Chrystusa - upodabnia się do Boga ${ }^{129}$ dzię-

122 Klemens Aleksandryjski, Zachęta Greków 1,7,3, w: SCh 2, s. 61; PSP 44, s. 121.

123 Klemens Aleksandryjski, Zachęta Greków 12,120,3, w: SCh 2, s. 190; „(...) spośród wszystkich istot śmiertelnych tylko wam pozwalam się cieszyć nieśmiertelnością. Chcę zatem, chcę i was obdarzyć taką łaską, dając wam nieskażone dobrodziejstwo - nieśmiertelność ( $\dot{\alpha} \theta \alpha \nu \alpha \sigma i \alpha \nu)$ ", PSP 44, s. 200.

124 Por. Klemens Aleksandryjski, Zachęta Greków 10,106,1-3, w: SCh 2, s. 178; PSP 44, s. 191.

125 Por. Klemens Aleksandryjski, Zachęta Greków 11,113,2-114,2, w: SCh 2, s. 181.182; PSP 44, s. 195-196; Klemens Aleksandryjski, Zachęta Greków 11,115,4, w: SCh 2, s. 184; PSP 44, s. 196-197.

126 Por. Klemens Aleksandryjski, Zachęta Greków 12,120,4, w: SCh 2, s. 190; „O wy, którzy jesteście odwiecznymi obrazami, lecz nie wszystkie wasze obrazy są podobne”, PSP 44, s. 200.

127 Por. Klemens Aleksandryjski, Zachęta Greków 12,121,1, w: SCh 2, s. 191; „Spieszmy się, idźmy naprzód, ludzie, bo jesteśmy obrazami kochającymi Boga i podobnymi do Słowa Bożego. Spieszmy się, postępujmy, weźmy jego jarzmo, przyjmijmy nieśmiertelność, kochajmy Chrystusa jako dobrego woźnicę ludzi. (...) On złączywszy parę ludzi, kieruje wóz ku nieśmiertelności, dążąc wyraźnie do wypełnienia tego, o czym kiedyś tylko wspomniał. Najpiękniejsze odbicie Ojca, wieczny Syn, Zwycięzca, najpierw zmierzał do Jerozolimy, teraz prowadzi do nieba”, PSP 44, s. 200.

128 Klemens Aleksandryjski, Zachęta Greków 11,115,1, w: SCh 2, s. 183; „Stąd pozwolił ci przygotować drogę do nieba. To wielkie dzieła swego stworzenia i wszelkie dobrodziejstwa wypożyczył w zamian za odrobinę wiary”, PSP 44, s. 196.

129 Por. Klemens Aleksandryjski, Zachęta Greków 12,122,4, w: SCh 2, s. 192.194; „Nadszedł więc czas, abyśmy stwierdzili, że tylko chrześcijanin jest bogobojny, bogaty, rozumny, szlachetny i dlatego przez upodabnianie (por. Rdz 1,26) jest obrazem Boga; abyśmy 
Kształtowanie się nauki o niebie w teologii patrystycznej I-III wieku

ki kierowaniu się w życiu Bożym słowem prawdy oraz cnotami, przede wszystkim sprawiedliwości ${ }^{130}$, posłuszeństwa Bogu ${ }^{131}$, miłości i wiary. Gwarantem wiecznego zbawienia wierzących jest Bóg ${ }^{132}$, „wieczny Dawca dóbr"133. Pobożność upodabnia wierzącego do Boga ${ }^{134}$. Inną cechą zalecaną przez Klemensa w celu osiąnięcia nieba jest bogobojność, gdyż człowiek został stworzony jako istota niebiańska, aby poznał Boga ${ }^{135}$.

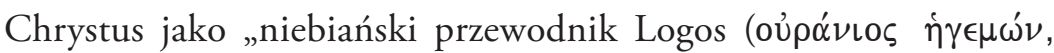
ó $\lambda o ́$ os)"136 nawołuje i zachęca chrześcijan do zbawienia. Zbawienie i osiągnięcie życia wiecznego dokonuje się, zdaniem Klemensa, najpierw na drodze zawierzenia Chrystusowi, a następnie poprzez praktyczne naśladowanie Jezusa w życiu doczesnym.

powiedzieli i uwierzyli, że stał się on «sprawiedliwy i pobożny przy zachowaniu rozsądku» przez Chrystusa, a następnie upodobnił się do samego Boga”, PSP s. 44, s. 201 (por. Platon, Teajet 176B: „U bogów zła nie umocujesz, ono się koniecznie koło natury śmiertelnej plątać musi i po tym świecie chodzić. Dlatego się też starać potrzeba, żeby stąd uciec tam jak najprędzej. Ucieczka - to upodobnienie się do boga, według możności. Upodobnić się do niego to stać się sprawiedliwym i pobożnym, przy zachowaniu rozsądku", tłum. i oprac. W. Witwicki, Warszawa 1959, s. 80).

130 Por. Klemens Aleksandryjski, Zachęta Greków 10,107,1-3, w: SCh 2, s. 175; PSP 44, s. 192.

131 Por. Klemens Aleksandryjski, Zachęta Greków 11,111,3, w: SCh 2, s. 179; PSP 44, s. 194; Klemens Aleksandryjski, Zachęta Greków 11,116,1, w: SCh 2, s. 184; PSP 44, s. 197.

132 Por. Klemens Aleksandryjski, Zachęta Greków 9,86,1, w: SCh 2, s. 153; „Jeśli chcecie, możecie najkosztowniejsze zbawienie kupić przy pomocy skarbu, który posiadacie, czyli miłością i wiarą, jest to bowiem odpowiednia cena za wieczne zbawienie. Tę zapłatę Bóg chętnie przyjmuje", PSP 44, s. 180 (por. 1 Tm 4, 10).

133 Klemens Aleksandryjski, Zachęta Greków 10,104,3, w: SCh 2, s. 172; PSP 44, s. 191 (por. Mt 6, 19. 20).

134 Por. Klemens Aleksandryjski, Zachęta Greków 9,86,2, w: SCh 2, s. 164; „Pobożność bowiem, o ile to jest możliwe, upodabniając człowieka do Boga, bierze Boga za odpowiedniego sobie nauczyciela, który człowieka, o ile jest godny, może uczynić podobnym Bogu”, PSP 44, s. 180.

135 Por. Klemens Aleksandryjski, Zachęta Greków 10,100,2, w: SCh 2, s. 168; „Tak samo nawołujemy człowieka (...) jest bowiem prawdziwie istotą niebiańską - aby poznał Boga, ponieważ jest Jego własnością, wybraną, odróżniającą się od innych istot żywych. Radzimy mu, aby postarał się o bogobojność jako wystarczające na wieczność pożywienie na drogę", PSP 44, s. 188.

136 Klemens Aleksandryjski, Wychowawca 1,1,1, w: SCh 70, s. 110; tłum. M. Szarmach, s. 20. 
3. Kształtowanie się nauki o niebie w teologii patrystycznej - wiek III

Zbawienie ludzkości jest wyłącznym dziełem Boga ${ }^{137}$, a wszyscy ludzie mogą je osiągnąć, w myśl J 6, 40, w Chrystusie ${ }^{138}$, nazywanym przez Klemensa „pierwszym Zarządcą całego świata, który zgodnie z wolą Ojca kieruje zbawieniem wszystkich"139. Klemens, przypominając słowa Jezusa z J 5, 24 („Zaprawdę, zaprawdę, mówi, kto słucha mego słowa i wierzy w tego, który mnie posłał, ma życie wieczne i nie idzie na sąd, lecz z śmierci przeszedł do życia”), wskazuje, że „akt wiary i odrodzenie się daje już doskonałość życia”, dlatego wzywa chrześcijan: „Uczmy się wiecznego zbawienia

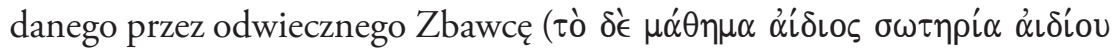
$\left.\sigma \omega \tau \hat{\rho} \rho \varsigma_{)}\right) " 140$. Podobne rozważanie o wierze w Chrystusa, która daje wierzącemu życie wieczne, Klemens przeprowadza nieco dalej: powołując się na J 3, 36 („Kto wierzy w Syna, ma życie wieczne”), stwierdza najpierw, że wiara jest zadatkiem wieczności ${ }^{141}$, co realizuje się poprzez poznanie i oświecenie przez chrzest, a kresem tego poznania jest osiągnięcie wytchnienia w wieczności ${ }^{142}$. Dzięki wierze już w doczesności chrześcijanie podlegają nie prawu strachu, ale Logosowi jako Wychowawcy oraz zostają uznani za dzieci Boże („usynowieni”) w Chrystusie ${ }^{143}$. Klemens, przytaczając teksty

137 Por. Klemens Aleksandryjski, Wychowawca 1,12,100, w: SCh 70, s. 288; „Największym

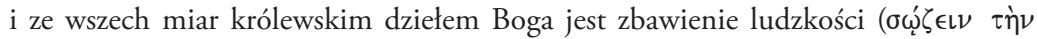

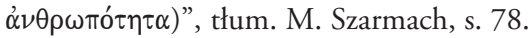

138 Por. Klemens Aleksandryjski, Wychowawca 1,6,28, w: SCh 70, s. 164; „Sam Pan ob-

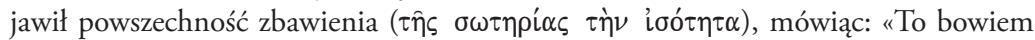
jest wolą Ojca mego, aby każdy, kto widzi Syna i wierzy w Niego, miał życie wieczne. A ja go wskrzeszę w dniu ostatecznym»"; tłum. M. Szarmach, s. 36.

139 Klemens Aleksandryjski, Kobierce 7,2,9,2, w: SCh 428, s. 58; PAX 33,2, s. 223 (por. Hbr 12, 2).

140 Klemens Aleksandryjski, Wychowawca 1,6,27, w: SCh 70, s. 160; tłum. M. Szarmach, s. 35 .

141 Klemens Aleksandryjski, Wychowawca 1,6,29, w: SCh 70, s. 164; „Jeśli przeto wierząc, mamy życie, to czegoż nam nie dostaje, by osiągną́ życie wieczne? (...) Wierzący nie powinni już niczego innego oczekiwać po odejściu stąd, skoro tu otrzymali zadatek na życie wieczne. To przyszłe dobro zapowiadane nam przez wiarę otrzymamy po zmartwychwstaniu jako dobro rzeczywiste i wypełnią się słowa: Według waszej wiary, niech wam się stanie (por. Mt 9, 29)", tłum. M. Szarmach, s. 36.

142 Por. Klemens Aleksandryjski, Wychowawca 1,6,29, w: SCh 70, s. 164.166; tlum. M. Szarmach, s. 36-37.

143 Por. Klemens Aleksandryjski, Wychowawca 1,6,31, w: SCh 70, s. 166.168; tłum. M. Szarmach, s. 37 (por. Ga 3, 26-28). 
Kształtowanie się nauki o niebie w teologii patrystycznej I-III wieku

Pawłowe (Ga 4, 7; 1 Kor 13, 11 i 1 Kor 3, 1-2) uznaje postawę dziecięctwa Bożego w Chrystusie za doskonałość ${ }^{144}$. Logos jako Wychowawca przez

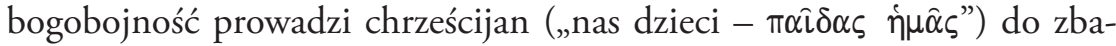
wienia $^{145}$. W Kobiercach zaś doda, iż „zadanie życiowe doskonałego gnostyka (to) obcowanie z Bogiem za pośrednictwem Wielkiego Arcykapłana, stawanie się podobnym Bogu, "w miarę swych możliwości», poprzez całą służbę ku czci Boga"146.

Celem formacyjnym tego wychowania chrześcijan jest upodabnianie się do Chrystusa, gdyż jest to istota życia praktycznego ${ }^{147}$ : unikając złych przykładów i naśladując dobre, wierzący przyjmuje Logos jako prawo, co stanowi „najkrótszą i najszybszą drogę do wieczności”" ${ }^{48}$. Szczególnie zalecane wierzącym jest naśladowanie postawy prostoty dzieci w przyjmowaniu Chrystusa, co umożliwia ludziom wejście do królestwa niebieskiego ${ }^{149}$. Innymi postawami wiary prowadzącymi do nieba są wypełnianie woli Bożej

144 Klemens Aleksandryjski, Wychowawca 1,6,34, w: SCh 70, s. 172; „Doskonałością jest

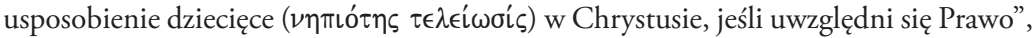
tłum. M. Szarmach, s. 39.

145 Klemens Aleksandryjski, Wychowawca 1,7,53, w: SCh 70, s. 206; tłum. M. Szarmach, s. 49.

146 Klemens Aleksandryjski, Kobierce 7,3,13,2, w: SCh 428, s. 68; PAX 33,2, s. 226-227 (por. Hbr 4, 14; 1 Kor 7, 35). Sformułowanie „w miarę swych możliwości” stanowi odniesienie do zasady Platona, Państwo 10,613b: „Na pewno nigdy bogowie nie opuszczą tego, który by miał dobrą wolę i starał się być sprawiedliwy i chciałby, dzielność objawiając w czynach, stać się do boga podobnym, o ile tylko to człowiek potrafi”, tłum. W. Witwicki, Warszawa 2010, s. 431.

147 Por. Klemens Aleksandryjski, Wychowawca 1,12,100, w: SCh 70, s. 288; „Według nich (tj. przykazań) powinniśmy też upodabniać się do Wychowawcy, troszcząc się o harmonię słów z czynami. To jest istota życia”, tłum. M. Szarmach, s. 78.

148 Klemens Aleksandryjski, Wychowawca 1,3,9, w: SCh 70, s. 126; thum. M. Szarmach, s. 24.

149 Por. Klemens Aleksandryjski, Wychowawca 1,5,12, w: SCh 70, s. 132; tłum. M. Szarmach, s. 27 (por. Mt 18, 3); Klemens Aleksandryjski, Wychowawca 1,5,15-16, w: SCh 70, s. 136.140; tłum. M. Szarmach, s. 29-30; Klemens Aleksandryjski, Wychowawca 1,5,19-20, w: SCh 70, s. 144.146; tłum. M. Szarmach, s. 31-32; Klemens Aleksandryjski, Wychowawca 2,3,38, w: SCh 108, s. 82.84; tłum. M. Szarmach, s. 106; Klemens Aleksandryjski, Wychowawca 3,3,25, w: SCh 158, s. 56.60; thum. M. Szarmach, s. 180. 
3. Kształtowanie się nauki o niebie w teologii patrystycznej - wiek III

w swym życiu ${ }^{150}$ i ubóstwo ducha ${ }^{151}$. Ich odwrotność, czyli grzech w myśl 1 Kor 6, 9-10, uniemożliwia wejście do Królestwa Bożego ${ }^{152}$.

\section{Cechy zbawionych}

Są one darem Bożym dla zbawionych, jako przypisanych Chrystusowi i do Niego upodabniającymi ${ }^{153}$. Są to wyzwolenie od pożądliwości ${ }^{154}$, „wy-

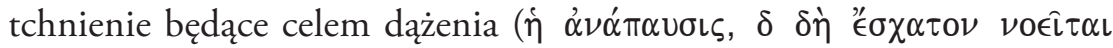

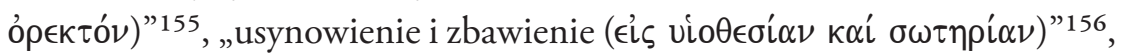
przemiana ziemskiej śmiertelności „w istotę niebieską i świętą (

150 Por. Klemens Aleksandryjski, Wychowawca 1,6,45, w: SCh 70, s. 192; „Odżywianie się mlekiem wiedzie do nieba. (...). Skoro Logos jest «źródłem wody życia» (Ap 21, 6) i został nazwany «rzeką oliwy» (Ez 32, 1-3), Paweł określa go słusznie alegorycznie mlekiem, mówiąc: «dałem ci pić» (por. 1 Kor 3, 1-3). (...) Widzicie więc, że jest jeszcze inny, symboliczny, bliski mleku pokarm - wola Boża”, tłum. M. Szarmach, s. 44-45 (por. Klemens Aleksandryjski, Wychowawca 1,12,98, w: SCh 70, s. 284; „(...) wypełniajmy wolę Ojca, słuchajmy Logosu, naśladujmy prawdziwie w sobie błogosławione życie naszego Zbawiciela”, tłum. M. Szarmach, s. 77).

151 Por. Klemens Aleksandryjski, Wychowawca 2,3,39, w: SCh 108, s. 86; tłum. M. Szarmach, s. 107; Klemens Aleksandryjski, Wychowawca 3,6,34, w: SCh 158, s. 76.78; tłum. M. Szarmach, s. 186 (por. Łk 16, 19); Klemens Aleksandryjski, Wychowawca 3,7,37, w: SCh 158, s. 82.84; tłum. M. Szarmach, s. 189-190.

152 Por. Klemens Aleksandryjski, Wychowawca 3,11,81, w: SCh 158, s. 156.158; tłum. M. Szarmach, s. 213.

153 Por. Klemens Aleksandryjski, Wychowawca 1,12,98, w: SCh 70, s. 284.286; thum. M. Szarmach, s. 77-78.

154 Por. Klemens Aleksandryjski, Wychowawca 1,4,10, w: SCh 70, s. 128; „W tym życiu kobieta różni się od mężczyzny, w przeszłym zaś nie. Tam za życie wspólne i święte zostały przygotowane nagrody nie dla mężczyzn i kobiet, ale dla człowieka wyzwolonego od pożądliwości. To pożądliwość dzieli go na dwie różne istoty. Istnieje przeto wspólne określenie dla mężczyzn i kobiet: człowiek"; tłum. M. Szarmach, s. 25. Klemens kontynuuje tutaj myśl Pawła z Ga 3, 28, obecną także u Justyna Męczennika, Dialog z Żydem Tryfonem 23,5.

155 Klemens Aleksandryjski, Wychowawca 1,6,29, w: SCh 70, s. 164; tłum. M. Szarmach, s. 37.

156 Klemens Aleksandryjski, Wychowawca 1,12,98, w: SCh 70, s. 284; tłum. M. Szarmach, s. 77. 
Kształtowanie się nauki o niebie w teologii patrystycznej I-III wieku

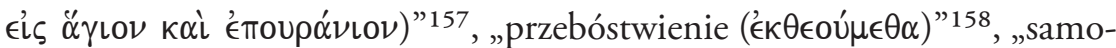

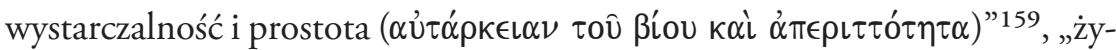

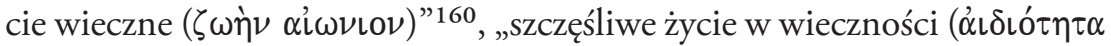

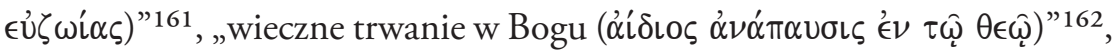
„niezniszczalność $(\dot{\alpha} \phi \theta \alpha \rho \sigma i ́ \varsigma \varsigma)$ "163, udział w prawdziwym pięknie ${ }^{164}$.

157 Klemens Aleksandryjski, Wychowawca 1,12,98, w: SCh 70, s. 284; „ (...) aby zmienić ziemskiego śmiertelnika w istotę niebieską i świętą. Tak wypełniło się Boskie słowo: «Uczyńmy człowieka na Nasz obraz, podobnego nam»", tłum. M. Szarmach, s. 77 (por. Rdz 1, 26).

158 Klemens Aleksandryjski, Wychowawca 1,12,98, w: SCh 70, s. 284; „Dlatego też, dbając o żywot niebiański, dzięki któremu staniemy się przebóstwieni (...), mając jako wyraźny przykład nieśmiertelności życie Pana i krocząc śladami Boga”, tłum. M. Szarmach, s. 77.

159 Klemens Aleksandryjski, Wychowawca 1,12,98, w: SCh 70, s. 286; „On przysposabia nas do samowystarczalności i do prostoty”, tłum. M. Szarmach, s. 77.

160 Klemens Aleksandryjski, Wychowawca 1,29,1, w: SCh 70, s. 164; tłum. M. Szarmach, s. 36.

161 Klemens Aleksandryjski, Wychowawca 1,12,98, w: SCh 70, s. 286; „(On) ... przygotowuje do szczęśliwego życia w wieczności, ucząc, że każdy z nas jest Jego skarbem”, tłum. M. Szarmach, s. 77 (por. Mt 6, 34); podobnie Klemens Aleksandryjski, Wychowawca 1,13,103, w: SCh 70, s. 294; tłum. M. Szarmach, s. 80.

162 Klemens Aleksandryjski, Wychowawca 1,12,102, w: SCh 70, s. 292; „Celem religijności jest wieczne trwanie w Bogu, a koniec naszego życia jest początkiem wiecz-

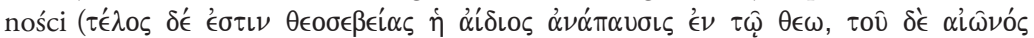

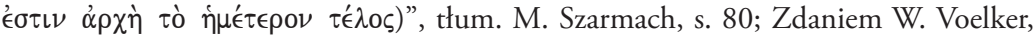
Der wahre Gnostiker nach Clemens Alexandrinus, Berlin 1952, s. 519-520 (Texte und Untersuchungen 57) i H.-I. Marrou, w: SCh 70, s. 292-293, przypis 6, odniesienie do wiecznego odpoczynku, oprócz ewidentnego przesłania kerygmatycznego, mogło u Klemensa definiować także ideał prawdziwego chrześcijańskiego gnostyka.

163 Klemens Aleksandryjski, Wychowawca 2,2,19, w: SCh 108, s. 48; „Na tym polega picie krwi Chrystusa, by uczestniczyć w nieśmiertelności Pana”, tłum. M. Szarmach, s. 95; podobnie Klemens Aleksandryjski, Wychowawca 2,2,20, w: SCh 108, s. 48; „ф$\phi \theta \alpha \rho \sigma i \alpha \nu ”$, tłum. M. Szarmach, s. 95. M. Szarmach oddaje $\dot{\alpha} \phi \theta \alpha \rho \sigma i ́ \alpha$ jako „nieśmiertelność", co jest dopuszczalne, lecz wydaje się, że poprawniejsze jest tłumaczenie tego terminu jako „niezniszczalność”, jako że Klemens stosuje tutaj typowo Pawłową terminologię w kontekście przyjmowania Eucharystii jako pokarmu na niezniszczalność. Por. W. Voelker, Der wahre Gnostiker nach Clemens Alexandrinus..., dz. cyt., s. 598-602; M. Kowalski, Corruptible, Incorruptible and the Kingdom of God. Semantic Background of the Idea of Transformation in 1 Cor 15:50-53, w: Królestwo Boże. Dar i nadzieja, red. K. Mielcarek, Lublin 2009, s. 133-153 (Analecta Biblica Lublinensia 3).

164 Por. Klemens Aleksandryjski, Wychowawca 2,12,129, w: SCh 108, s. 242; „(..) ponieważ Logos ukazuje mu prawdziwe piękno, którego: «ani ucho nie słyszało, ani oko nie widziało»", tłum. M. Szarmach, s. 161 (por. 1 Kor 2, 9). 
3. Kształtowanie się nauki o niebie w teologii patrystycznej - wiek III

\section{Eschatologiczne niebo}

Podstawowymi terminami, jakimi posługiwał się Klemens Aleksandryjski na opisanie eschatologicznego nieba, były: „królestwo niebieskie ( $\dot{\eta}$

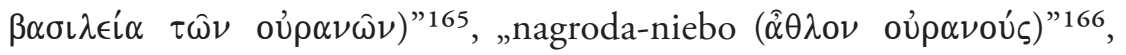

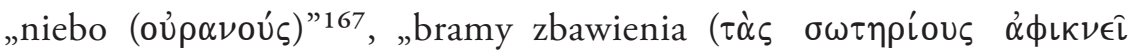
$\sigma \theta \alpha \iota)$ "168, „nagroda-nieśmiertelność ( $\hat{\alpha} \theta \lambda \circ \nu \quad \dot{\alpha} \theta \alpha \nu \alpha \sigma i \alpha){ }^{169}$, „nieśmier-

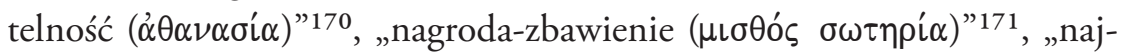
wyższe Dobro-zbawienie (

165 Klemens Aleksandryjski, Zachęta Greków 9,87,3, w: SCh 2, s. 154; „Jego jedynym pragnieniem jest zbawienie człowieka. Dlatego sam przynagla do zbawienia:

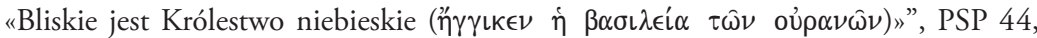
s. 181 (por. Mt 4, 17); Klemens Aleksandryjski, Zachęta Greków 10,99,4, w: SCh 2,

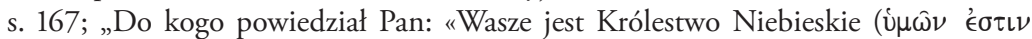
$\dot{\eta} \beta \alpha \sigma \iota \lambda \epsilon^{\prime} \alpha \tau \tau \omega \hat{\omega} \nu$ oủp $\left.\alpha \nu \omega \hat{\omega}\right) »$ )? (por. Mt 5, 3. 10; Łk 6, 20). Wasze jest, jeśli zechcecie, jeśli skierujecie wasze dążenia do Boga; wasze, jeśli tylko zechcecie uwierzyć i w prostocie serca pójdziecie za słowem (Pana)", PSP 44, s. 187.

166 Klemens Aleksandryjski, Zachęta Greków 11,111,3, w: SCh 2, s. 179; „Ten człowiek wypędzony z raju za swe nieposłuszeństwo otrzymuje większą nagrodę - niebo", PSP 44, s. 194.

167 Klemens Aleksandryjski, Zachęta Greków 10,100,1, w: SCh 2, s. 167-168; „Można by

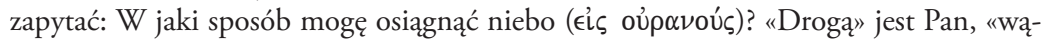
ską" (J 14, 6), lecz «z nieba ( $(\xi \xi$ oủp $\alpha \nu \omega \hat{\omega} \nu)$ ( $(\mathrm{J} 3,13)$, «wąską", lecz prowadzącą do nie-

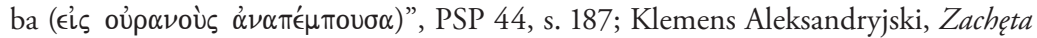
Greków 10,106,3, w: SCh 2, s. 174; „(...) abyście opuścili kryjówki i zamieszkali w nie-

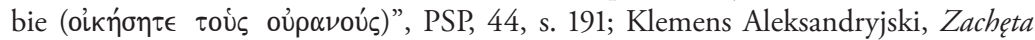
Greków 11,112,1, w: SCh 2, s. 179; „, (...) samo Słowo przyszło do nas z nieba ( $\dot{\omega} \varsigma \dot{\eta} \mu \hat{\alpha} \varsigma$ oủp $\alpha \nu$ ó $\theta \in v$ ò $\lambda$ ó $0 \varsigma$ )", PSP 44, s. 194.

168 Klemens Aleksandryjski, Zachęta Greków 4,63,5, w: SCh 2, s. 127; PSP 44, s. 163.

169 Klemens Aleksandryjski, Zachęta Greków 10,96,3, w: SCh 2, s. 164; „Wyznaczona jest bowiem niemała nagroda - nieśmiertelność", PSP 44, s. 186.

170 Klemens Aleksandryjski, Zachęta Greków 10,106,2, w: SCh 2, 174; „Wspaniały to

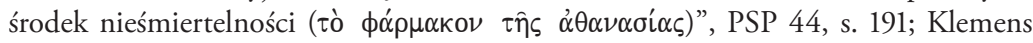
Aleksandryjski, Zachęta Greków 10,107,1, w: SCh 2, s. 175; „Pięknym hymnem

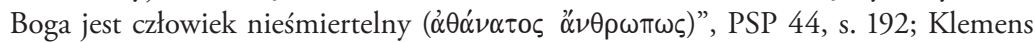
Aleksandryjski, Zachęta Greków 12,120,3, w: SCh 2, s. 190; „Tylko wam pozwalam cieszyć się nieśmiertelnością ( $\alpha \theta \alpha \nu \alpha \sigma i ́ \alpha \nu)$ ", PSP 44, s. 200.

171 Klemens Aleksandryjski, Zachęta Greków 10,106,5, w: SCh 2, s. 175; „Wierzcie, a jako nagrodę otrzymacie zbawienie ( s. 191 (por. Ps 69, 33).

172 Klemens Aleksandryjski, Zachęta Greków 12,123,2, w: SCh 2, s. 193; „(...) zachęcając do osiągnięcia najwyższego Dobra - zbawienia ( 
Kształtowanie się nauki o niebie w teologii patrystycznej I-III wieku

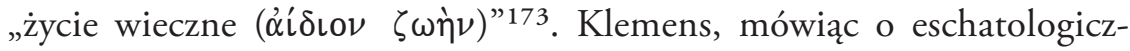
nym niebie przywoływał też obrazy apokaliptycznej „Jerozolimy powy-

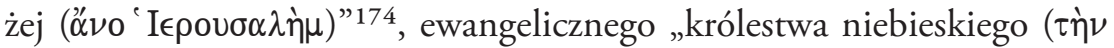

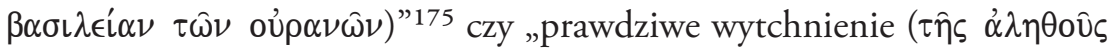

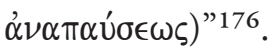

Podczas polemiki z systemami filozofii pogańskiej Klemens wspominał o chrześcijańskiej kosmologii i eschatologii. Odrzucając pogański kult ciał niebieskich („gdyż są one tylko narzędziami do mierzenia czasu”177 i imiennie poglądy Alkmeona z Krotony, który „uważał za bogów gwiazdy obdarzone duszą" ${ }^{178}$ ) oraz idąc za podstawową wykładnią teologii biblijnej, nauczał, iż jedynie Bóg jest stwórcą ${ }^{179}$, Bóg stworzył niebo i ziemię $(\operatorname{Rdz} 1,1)^{180}$, Bóg stworzył niebiosa ${ }^{181}$, także aniołów czy archaniołów

$\sigma \omega \tau \eta \rho i ́ \alpha \nu)$. Nigdy nie zabraknie słów mówiących o życiu, które nie ma końca”, PSP 44, s. 201.

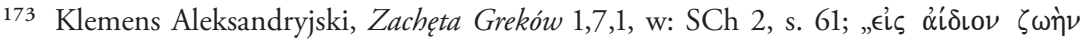
$\pi \alpha \rho \alpha \pi \epsilon \mu \pi \operatorname{s}_{\mu} \in \theta \alpha$ ", w: SCh 2, s. 60; PSP 44, s. 121; Klemens Aleksandryjski, Zachęta

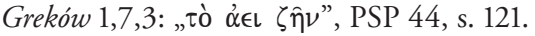

174 Por. Klemens Aleksandryjski, Wychowawca 2,12,119, w: SCh 108, s. 226; „Wiemy z tradycji, że niebieska Jerozolima [dosłownie: „Jerozolima powyżej” - uwaga Autora] została zbudowana ze świętych kamieni, a dwanaście bram tego miasta porównanych do cennych kruszców”, tłum. M. Szarmach, s. 155 (por. Ap 21, 18-21).

175 Klemens Aleksandryjski, Wychowawca 2,12,120, w: SCh 108, s. 228; tłum. M. Szarmach, s. 156 (por. Mt 6, 33).

176 Por. Klemens Aleksandryjski, Wychowawca 3,7,39, w: SCh 158, s. 86 [tłumaczenie własne Autora].

177 Klemens Aleksandryjski, Zachęta Greków 4,63,1, w: SCh 2, s. 126; PSP 44, s. 163 (por. Rdz 1, 14). Cenna jest wzmianka Klemensa o Cyceronie, kiedy, wskazując na grecką czy rzymską dbałość o formę, krytykuje ich jednoczesne zaniedbywanie istoty rzeczy: Klemens Aleksandryjski, Zachęta Greków 4,63,4, w: SCh 2, s. 126-127; „W tej dziedzinie pomyliło się wielu filozofów, którzy wprawdzie przepięknie stwierdzają, że człowiek został stworzony do oglądania nieba (por. Cyceron, $O$ naturze bogów 2,140), jednak czczą zjawiska na niebie dostrzegane oczyma. Chociaż ciała niebieskie nie są uczynione przez ludzi, jednak są stworzone dla ludzi”, PSP 44, s. 163.

178 Klemens Aleksandryjski, Zachęta Greków 5,66,2, w: SCh 2, s. 130; PSP 44, s. 166.

179 Por. Klemens Aleksandryjski, Zachęta Greków 6,67,2, w: SCh 2, s. 132; „Ja zaś pragnę Pana duchów, Pana ognia, Stworzyciela świata, Tego, który słońcu daje światło; szukam Boga, a nie Jego dzieł”, PSP 44, s. 168; podobnie Klemens Aleksandryjski, Zachęta Greków 6,69,1, w: SCh 2, s. 134; PSP 44, s. 169.

180 Por. Klemens Aleksandryjski, Kobierce 6,7,58,1, w: SCh 446, s. 178; PAX 33,2, s. 145.

181 Por. Klemens Aleksandryjski, Zachęta Greków 4,62,4-63,1, w: SCh 2, s. 126; „Jasno i krótko potępia prorok pogańskie zwyczaje: «Bo wszyscy bogowie pogan to ułuda, 
3. Kształtowanie się nauki o niebie w teologii patrystycznej - wiek III

i jest od nich oddzielony niedostępną świętością (Hbr 1, 1) ${ }^{182}$, Bóg stworzył „cały świat”183 i harmonijnie go uporządkował ${ }^{184}$.

Klemens odwoływał się do biblijnej nauki (Ps 8, 4; 2, 4; 4, 10; Mt 6, 9) o niebie (oủp $\alpha \nu$ o) jako miejscu przebywania Boga, stworzonym przez Boga i zależnym od Niego ${ }^{185}$, gdzie przebywa Ojciec, Syn („niebiański przewodnik Logos”186, Logos wstępujący do nieba ${ }^{187}$, patrzący się na chrześcijan „z góry, z okna” ${ }^{188}$ ) i Duch Święty („przychodzący z nieba" ${ }^{189}$, pomagający w zrozumieniu obietnicy stanu zbawionych w przyszłym świecie) ${ }^{190}$.

a Jahwe uczynił niebiosa» i to co na niebie. (...). «Przez słowo Jahwe powstały niebiosa i wszystkie ich zastępy przez tchnienie ust Jego»", PSP 44, s. 163 (por. Ps 95, 5; Ps 33, 6).

182 Por. Klemens Aleksandryjski, Kobierce 6,7,57,5, w: SCh 446, s. 178; PAX 33,2, s. 145.

183 Klemens Aleksandryjski, Zachęta Greków 4,63,2, w: SCh 2, s. 126; „Zatem jak nazwę to wszystko, co czyni Bóg? Popatrz na cały świat, Jego jest dziełem. Niebo i słońce, aniołowie i ludzie są «dziełem Jego palców»", PSP 44, s. 163 (por. Ps 8, 4).

184 Por. Klemens Aleksandryjski, Zachęta Greków 1,5,1, w: SCh 2, s. 57; „Bóg cały wszechświat harmonijnie uporządkował i różne elementy połączył w zgodne współbrzmienie, aby w ten sposób cały świat stał się jedną harmonią”, PSP 44, s. 119 (por. Rdz 4, 21).

185 Por. Klemens Aleksandryjski, Wychowawca 1,7,73, w: SCh 70, s. 238.240; „Ze jest jedynym i tym samym Bogiem wnioskujemy najlepiej ze słów: „Widzę Twoje niebo, dzieło palców Twoich” (Ps 8, 4) i też: „Ten, który mieszka w niebie, je stworzył” (Ps 2, 4) oraz: „Na niebiosach tron Jego” (Ps 4, 10). Tak wyśpiewał Duch Święty. Pan mówi w modlitwie: „Ojcze nasz, który jesteś w niebie” (Mt 6, 9). Niebo należy do

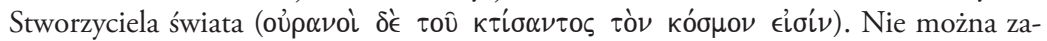
przeczyć, że Pan jest Synem Stwórcy", tłum. M. Szarmach, s. 60.

186 Klemens Aleksandryjski, Wychowawca 1,1,1, w: SCh 70, s. 110; „O yoûv oủpóvıเo

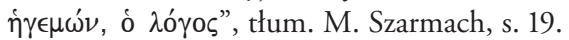

187 Por. Klemens Aleksandryjski, Wychowawca 1,5,13, w: SCh 70, s. 134; „ov̉ó́ $\pi \omega$

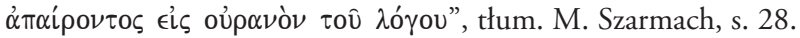

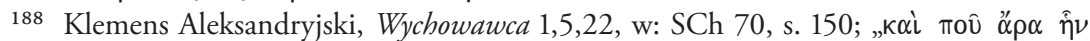

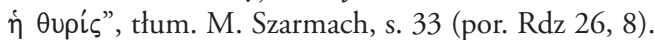

189 Klemens Aleksandryjski, Wychowawca 1,6,28, w: SCh 70, s. 162; „oủp $\alpha \nu$ ó $\theta \in \nu$

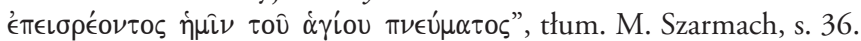

190 Klemens Aleksandryjski, Wychowawca 1,6,37, w: SCh 70, s. 178; „Jeżeli na tam-

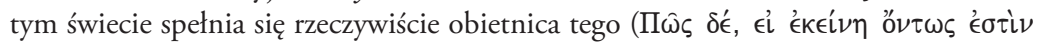

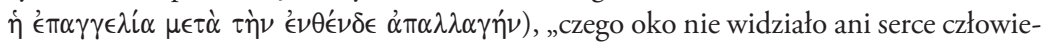
ka nie zdołało pojąc" (1 Kor 2, 9), to jakże mogą poznać już tutaj bez pomocy Ducha, lecz tylko rozumujący umysłem to, „czego ucho nie słyszało”?”, tłum. M. Szarmach, s. 41. 
Kształtowanie się nauki o niebie w teologii patrystycznej I-III wieku

Niebo, za Mt 13, 43 to „święte miejsce pobytu ( gdzie wierzący zdążają za apostołami, którzy okazali się godni swych funkcji i żyli w sposób doskonały według Ewangelii ${ }^{192}$. Również po zmartwychwstaniu Klemens zakładał moralny rozwój i przenoszenie się zbawionych na wyższe stopnie hierarchii moralnej ${ }^{193}$. Miałoby się to dokonywać na zasadzie naśladownictwa wspaniałości anielskiej i ekonomii zbawienia, pojmowanej jako nagroda za pełnienie sprawiedliwości ${ }^{194}$ :

„O nich pisze Apostoł, że ci, uniesieni «na obłokach» (por. 1 Tes 4, 17), będą najpierw diakonami, z kolei zaliczeni zostaną do rady prezbiterów, wedle wyższego stopnia czci (bo między czcią a czcią jest jeszcze różnica), aż urosną do «ideału człowieka w pełni doskonałego» (por. Ef 4, 13)"195.

Zbawieni w niebie byli porównani przez Klemensa do filozofów, którzy dzięki swym dobrym działaniom obcują z Bogiem na najwyższym stopniu poznawania i oddają się „czystej kontemplacji bezustan-

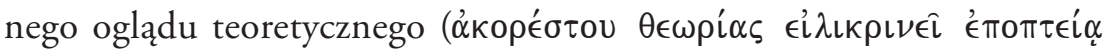
$\left.\pi \rho 0 \sigma \alpha \nu \nu^{\prime} \chi 0 \nu \tau \epsilon \varsigma\right)$ "196. Wyjaśniając za pomocą egzegezy alegorycznej teksty

191 Klemens Aleksandryjski, Kobierce 6,13,105, w: SCh 446, s. 270; PAX 33,2, s. 175.

192 Por. Klemens Aleksandryjski, Kobierce 6,13,106, w: SCh 446, s. 270; PAX 33,2, s. 175.

193 Por. Klemens Aleksandryjski, Kobierce 6,6,47,1, w: SCh 446, s. 156; PAX 33,2, s. 138.

194 Por. Klemens Aleksandryjski, Kobierce 6,13,107,2, w: SCh 446, s. 274; PAX 33,2, s. 176.

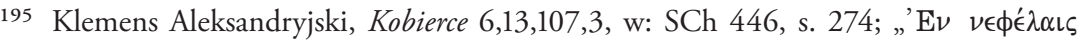

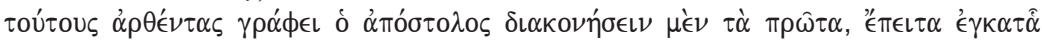

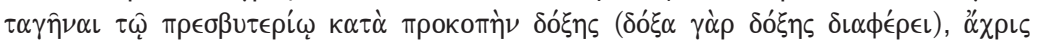

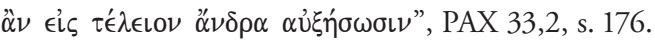

196 Klemens Aleksandryjski, Kobierce 6,14,108,1, w: SCh 446, s. 276; „O tego rodzaju ludziach mówi Dawid, że «spoczną na świętej górze Boga- (por. Ps 14, 1), w najwyższym Kościele, w którym filozofowie obcują z Bogiem, prawdziwi Izraelici (por. J 1, 47), ludzie «czyści sercem» (por. Mt 5, 8), w których «nie ma podstępu» (por. J 1, 47), a zatem ci, którzy nie pozostają na siódmym stopniu pobytu, lecz przez dobroczynny skutek upodobnienia się do Boga dostąpili dziedzictwa dobrego działania, przynależnego ósmemu stopniowi i oddali się czystej kontemplacji bezustannego oglądu teoretycznego", PAX 33,2, s. 176-177. Klemens wcześniej (Kobierce 4,17,109,2, w: SCh 463, s. 236; PAX 33,1, s. 357) wyjaśniał, że dzień siódmy to szabat, w którym nie wykonuje się żadnej pracy, a ósmy to ten, w którym znowu podejmuje się 
3. Kształtowanie się nauki o niebie w teologii patrystycznej - wiek III

z Mdr 3, 9-14 zestawione z Mt 13, 8; Rdz 1, 26; Ef 4, 13, Klemens doszedł do wniosku, iż wierzący w niebie otrzymywaliby, proporcjonalnie do swych wcześniejszych zasług, jedno z trzech miejsc w świątyni niebieskiej (łaska wybrana i miejsce własne, coś milszego Bogu oraz dojście do ideału człowieka doskonałego) ${ }^{197}$. Ostatecznie jako doskonali do-

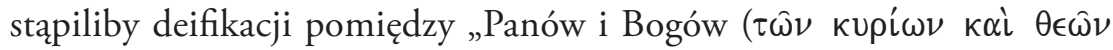
$\gamma^{\prime}(\nu \in \tau \alpha \iota) " 198$. Taka deifikacja człowieka byłaby pewnego rodzaju podobieństwem do Boga, ale nie według kształtu człowieczego czy też cnoty (jako podobieństwo do pierwszej przyczyny), ale według usynowienia przez Boga i przyjaźni z Nim ${ }^{199}$.

pracę (por. J. Grzywaczewski, O kontemplacji w ujęciu św. Klemensa Aleksandryjskiego, Niepokalanów 2010²).

197 Klemens Aleksandryjski, Kobierce 6,14,114,1-5, w: SCh 446, s. 286.288; „Proporcjonalnie ('A $\left.\nu_{\alpha \lambda o ́} \gamma \omega \varsigma\right)$ też różne są, wedle zasług i godności, miejsca zamieszkania

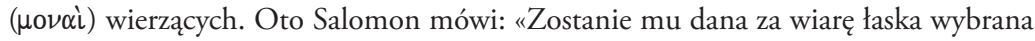
i miejsce własne w świątyni Boga, milsze sercu» (por. Mdr 3, 14). Tu stopień wyższy wskazuje na jakieś miejsce pośledniejsze w świątyni Boga, które zajmuje cały Kościół, pozostaje nadto domyślić się stopnia najwyższego, który zawarłby stan posiadania Pana. Na takie trzy miejsca, które są przeznaczone dla wybranych, zdają się wskazywać trzy liczby w Ewangelii: sześćdziesiąt, trzydzieści, sto (por. Mt 13, 8). Pełne dziedzictwo przypadnie w udziale tym, którzy «na obraz» (por. Rdz 1, 26) Pana dochodzą do «ideału człowieka w pełni doskonałego» (por. Ef 4, 13)", PAX 33,2, s. 180.

198 Klemens Aleksandryjski, Kobierce 6,14,114,6, w: SCh 446, s. 288; „Kto wedle po-

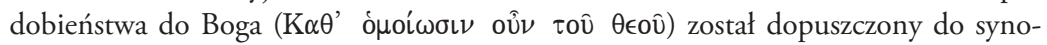

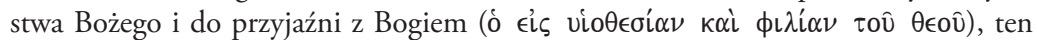
w następstwie swego współudziału w dziedzictwie zaliczony zostanie między Panów i Bogów, jeśli, jak nauczał sam Pan, osiagnnie doskonałość według wymagań Ewangelii”, PAX 33,2, s. 181 (por. Mt 5, 48; Rz 8, 15).

199 Klemens Aleksandryjski, Kobierce 6,14,114,6, w: SCh 446, s. 288; PAX 33,2, s. 181. Komentując powyższe poglądy Klemensa na deifikację. A. Eckmann, Przebóstwienie cztowieka w pismach wczesnochrześcijańskich, Lublin 2003, s. 92-95, podkreśla, iż przebóstwienie dokonywałoby się zdaniem Klemensa przez posłuszeństwo względem Bożych przykazań i stałe poznawanie woli Bożej, a ostatecznie przez odnowienie ludzkiej relacji z Bogiem. Klemens odrzucałby zatem panteistyczną czy stoicką wizję Boga (człowiek jako emanacja bóstwa, ontologiczna jedność bóstwa i człowieczeństwa), a podkreślał, że człowiek, już będąc cząstką Boga i jednej z Nim istoty, staje się Bogu podobnym w sposób ograniczony, przez adopcję - jako dziecko Boże, zawsze na wzór Chrystusa. 
Kształtowanie się nauki o niebie w teologii patrystycznej I-III wieku

Myśl teologiczna Klemensa Aleksandryjskiego dotycząca eschatologicznego nieba nie stanowi tematyki pierwszoplanowej w jego traktatach i jest w dużej mierze uwarunkowana formacyjnym charakterem jego pism. W Zachęcie do Greków niebo stanowi zatem nagrodę nieśmiertelności, a pogan do niego może doprowadzić przyjęcie chrześcijańskiej wiary. W Wychowawcy odziedziczenie królestwa niebieskiego zapewnia chrześcijanom kształtowanie się na wór Chrystusa. W Kobiercach miarą gnostycznej doskonałości chrześcijańskiej jest Chrystus jako ucieleśnienie moralnego piękna.

Te wątki etyczne przeplatają się z antropologią chrześcijańską (człowiek stworzony do zbawienia i ubóstwienia, sposobem na wejście do eschatologicznego nieba jest Chrystus, człowiek wierzący przez upodabnianie się do Niego w doczesności pełni funkcję zbawczą, na drodze kolejnych stopni doskonalenia ostatecznie stanie się „,czysty w sercu” i dojdzie do wtajemniczenia w „błogosławione widowisko” i oglądania Boga „twarzą w twarz”). Elementem charakterystycznym tej antropologii są wątki gnostyckie o człowieku zbawionym jako istocie jednopłciowej.

Klemens rozwija wątki teologii biblijnej dotyczącej osiąnnięcia nieba: gwarantem wiecznego zbawienia jest tylko Bóg, chrześcijańska wiara jest sposobem na osiągniecie nieba - polega ona na zawierzeniu Chrystusowi i naśladowaniu go w doczesności. To upodabnianie się do Chrystusa stanowi istotę życia praktycznego chrześcijan. Stąd cechy zbawionych w niebie są właściwościami osób już przypisanych Chrystusowi i do Niego upodabniającymi. Samo eschatologiczne niebo jest oddawane przez Klemensa terminami biblijnymi, zarówno tymi jakościowymi („nagroda-nieśmiertelność”, „nieśmiertelność”, „nagroda-zbawienie”, „najwyższe Dobro - zbawienie”, „życie wieczne”, „prawdziwe wytchnienie”), jak i obrazowo-miejscowymi („niebo”, „nagroda-niebo”, „królestwo niebieskie”, „bramy zbawienia”, "Jerozolima powyżej - Jerozolima niebieska”). W Kobiercach pojawia się także filozoficzno-gnostycki pogląd o eschatologicznym niebie jako najwyższym stopniu poznawania i oddawania się czystej kontemplacji bezustannego oglądu teoretycznego oraz koncepcja deifikacji zbawionych. 


\subsection{Orygenes (186 - około 253) - w kierunku nowego nieba i nowej ziemi...}

Prawdopodobnie najpłodniejszy pisarz wczesnochrześcijański (o ile można wierzyć Hieronimowi ze Strydonu, który przypisywał mu 2000 dzieł) ${ }^{200}$, prekursor chrześcijańskiej teologii spekulatywnej. Zmarł w Tyrze jako wyznawca, na skutek tortur zadanych podczas antychrześcijańskich prześladowań za czasów cesarza Decjusza. W roku 553, czyli trzysta lat po jego śmierci, Sobór Konstantynopolitański II, z inicjatywy cesarza Justyniana Wielkiego potępił wiele twierdzeń przypisywanych Orygenesowi (w rzeczywistości były one tezami ówczesnych orygenistów) ${ }^{201}$. W celu lepszego zrozumienia twierdzeń Orygenesa o eschatologicznym niebie najpierw dokonam ogólnego wprowadzenia w jego metodologię (korzystanie z filozofii platońskiej, egzegezę alegoryczną, przesłanie wiary chrześcijańskiej) i eschatologię (kosmologia a eschatologia, eschatologia „ludzka” - nieśmiertelność duszy i ciała). Następnie spróbuję podać charakterystykę Orygenesowskiej koncepcji eschatologicznego nieba (terminologia, nowa jakość życia eschatologicznego, powszechna doskonałość stworzeń w eschatonie).

\section{Metodologia Orygenesa}

W swym wykładzie teologii, co dobrze widać np. w traktacie $O$ zasadach, dał oryginalną syntezę filozofii platońskiej, egzegezy alegorycznej oraz przesłania wiary chrześcijańskiej. W tych rozważaniach posługiwał się metodą spekulatywną, poszukując racjonalnego wyjaśnienia wiary, często rozważając kilka możliwych rozwiązań danego problemu. Był w stanie odejść od swych hipotez, jeśli znajdował lepsze rozwiązania, często też pozostawiał swe hipotezy jako nierozstrzygnięte, wnioski stawiał raczej jako pewne

200 Por. Hieronymus Presbyter, Apologia Adversus Libros Rufini 2,22: „(...) et non dico sex millia sed tertiam partem non reperies”, PL 23, k. 467A; zob. też H. Crouzel, Bibliographie critique d'Origène, Turnhout 1971; H. Crouzel, Bibliographie critique d'Origène: Supplément I, Turnhout 1982; H. Crouzel, Bibliographie critique d'Origène: Supplément II, Turnhout 1996.

201 Por. P. Nautin, Origène. Sa vie et son oeuvre, Paris 1977 (Christianisme Antique I). 
Kształtowanie się nauki o niebie w teologii patrystycznej I-III wieku

prawdopodobieństwa, rzadko sugerując ostateczne konkluzje, szczególnie jeśli miałyby przekroczyć granice wyznania wiary ${ }^{202}$. Istotną cechą terminologii Orygenesa jest wieloznaczność stosowanych przezeń pojęć. Stąd połączenie polisemii z egzemplaryzmem nie pozwala w tekstach Orygenesa na dokładne rozróżnienie pomiędzy znaczeniem moralnym a duchowym ${ }^{203}$.

\section{Filozofia Platońska}

Filozofia antyczna była dla Orygenesa pomocnym narzędziem w wyjaśnianiu i uzasadnianiu chrześcijańskiej wiary. Korzystał zeń ostrożnie, choć niektóre jego poglądy są pośrednio uwarunkowane filozofią Platońską i stoicką (preegzystencja dusz, następstwo światów, apokatastaza) ${ }^{204}$. Jego argumentacja filozoficzna była ograniczona regułą wiary ówczesnego Kościoła, których to podstawowych prawd wiary przyjętych przez chrześcijańską wspólnotę od czasów apostolskich nie można odrzucić czy zniekształcić. Gdy reguła wiary nie określała czegoś jednoznacznie, Orygenes podejmował filozoficzne dywagacje, jednak swe hipotetyczne rozważania zawsze proponował jako możliwą formę intelektualnego poszukiwania wspartego wiarą ${ }^{205}$.

Istota bytu w Platońskim rozumieniu świata znajduje się poza materią, realnie istnieją tylko idee, a rzeczy stają się jedynie przelotnymi zjawiskami. Orygenes, podobnie do Platona, uznał istnienie w umyśle Boga inteligibilnego świata idealnego, który stanowił wzorczy plan wobec świata

202 Por. W. Szczerba, Koncepcja wiecznego powrotu w myśli wczesnochrześcijańskiej i jej greckie źródta, Torun $2014^{2}$, s. 208-209.

203 Por. H. Crouzel, Orygenes, tłum. J. Margański, Kraków 2004², s. 113-115.

204 Por. H. Crouzel, Origène et la philosophie, Paris 1962; R. M. Berchman, From Philo to Origen: Middle Platonism in Transition, Chico (California) 1984 (Brown Judaic Studies 69); H. Crouzel, Origène et Plotin, comparaisons doctrinales, Paris 1992.

205 Por. M. Szram, Orygenes, w: Powszechna Encyklopedia Filozofii, red. A. Maryniarczyk, t. 7, Lublin 2006, s. 861-864. M. Szram zaznacza, iż regułą wiary w III wieku były następujące prawdy „wieczne istnienie Jednego Boga - stworzyciela świata z niczego; narodzenie Chrystusa z Ojca przed wszelkim stworzeniem, wcielenie i zmartwychwstanie; zjednoczenie Ducha świętego z Ojcem w chwale i godności; istnienie dobrych i złych aniołów; nagroda lub kara dla ludzkiej duszy po śmierci, stosownie do jej dobrowolnie spełnianych uczynków; zmartwychwstanie ludzkich ciał; przekonanie o natchnieniu Pisma Świętego przez Ducha Świętego", s. 863. 
duchowego - stworzonego z równych sobie bytów duchowych, połączonych z eteryczną materią. Znużone kontemplacją Boga byty duchowe w różnym stopniu oddalały się od Boga, tworząc w ten sposób byty anielskie oraz dusze ludzkie ${ }^{206}$. W antropologicznej konsekwencji w człowieku najważniejsza jest nieśmiertelna i niematerialna dusza, istniejąca przed powstaniem ciała, która będzie trwać także po jego zniszczeniu. Orygenes uwypuklał zatem znaczenie elementu duchowego człowieka i świata kosztem ciała ludzkiego i świata materialnego (co szczególnie widać w jego nauce o Trójcy Świętej, kiedy wykłada o niezrodzonym Ojcu jako monadzie i henadzie, źródle bóstwa; pomniejszaniu znaczenia cielesności i człowieczeństwa wcielonego Logosu, przy podkreślaniu, że pośrednictwo pomiędzy Ojcem a człowiekiem spełnia nie tyle Jezus Chrystus jako Wcielony Bóg, ale bardziej Słowo rozumiane jako zespół licznych dóbr i cnót) ${ }^{207}$. Orygenes, przejmując główne wątki metafizyki i antropologii Platona, starał się jednak nie mieszać wiary chrześcijańskiej z filozofią pogańską, lecz w jego myśleniu każda $\mathrm{z}$ tych dyscyplin miała swoje własne miejsce ${ }^{208}$.

\section{Egzegeza alegoryczna}

Podstawowe normy egzegezy biblijnej Orygenesa zwięźle przedstawił Manlio Simonetti, uwypuklając w nich trzy podstawowe zasady: (1) praktyczną (całe Pismo musi się okazać pożyteczne duchowo dla interpretatora); (2) ideową (treść duchowa Pisma to treść chrystologiczna); (3) strukturalną (wymóg wzniesienia się z poziomu zmysłowego do poziomu inteligibilnego ${ }^{209}$. Z jego podejścia do tekstu biblijnego wynikało, że nigdy nie można ustalić, jakie ma znaczenie słowo Boże, natomiast można się do tego zbliżać, kiedy człowiek będzie chciał i się starał i przebrnie przez język sym-

206 Por. M. Szram, Orygenes, w: Powszechna Encyklopedia..., dz. cyt., s. 865.

207 Por. M. Składanowski, Myśl Orygenesa. Metodologiczne intuicje dla wspótczesnych teologów, „Studia Elbląskie” 14 (2013), s. 155-156.

208 Por. J. Słomka, Teologiczne podstawy egzegezy Orygenesa i jej aktualność, „Śląskie Studia Historyczno-Teologiczne” 36/2 (2003), s. 481.

209 Por. M. Simonetti, Między dostownością a alegorią, tłum. T. Skibiński, Kraków 2000, s. 78. 
Kształtowanie się nauki o niebie w teologii patrystycznej I-III wieku

boliczny i duchowy ${ }^{210}$. Orygenes nigdy nie uznawał własnej interpretacji tekstu biblijnego za ostateczną, choć skutecznie rozpropagował w chrześcijaństwie swój styl egzegezy duchowo-alegorycznej ${ }^{211}$. Proponując ciągłą reinterpretację myśli objawionej, Orygenes stale poszukiwał jej sensu. Dlatego wzbraniał się przed kategorycznym opowiedzeniem się za którąś z alternatywnych wykładni Pisma, nigdy jednak nie podając w wątpliwość samej prawdy chrześcijaństwa ${ }^{212}$. Orygenes zatem chciał dotrzeć do autentycznego tekstu biblijnego i wydobyć zeń sens zamierzony przez Boga nie tylko na drodze metody alegorycznej, żmudnego studium i intelektualnego przygotowania, ale i przez prowadzenie świętego życia ${ }^{213}$.

\section{Przesłanie wiary chrześcijańskiej}

Tematyki teologiczne chrześcijańskiej wiary Orygenes rozwijał w duchu platonizmu, podając je jako hipotezy, zgodnie z przyjętą przez siebie metodą teologii poszukującej. Za Henrykiem Pietrasem można je streścić w następujący sposób. Tylko Ojciec, Syn i Duch są Absolutem: niezmiennym, niewzględnym, wiecznym. Początek stworzenia ma swe miejsce w Logosie Boga. „W początku”, czyli w swoim Synu, Bóg stworzył wszystkie byty rozumne (logikoi): równocześnie, wszystkie jednakowo kochane przez Boga i obdarzone wolnością. Wszystkie stworzenia nie mają w sobie nic absolutnego, są zmienne, względne, a pojęcie „wieczności” jest odnoszone do ich natury i oznacza czas ich trwania. Wszystkie byty rozumne tworzą Kościół preegzystujący. Obdarzone wolną wolą byty rozumne albo pozostają przy Logosie, albo się odeń oddalają. Bóg stale kocha wszystkie swe stworzenia, nawet jeśli się od Niego oddalają, dlatego stwarza dla nich okrągły świat z ziemią w środku. Pierwszym z upadłych bytów rozumnych jest szatan,

210 Por. J. N. D. Kelly, Początki doktryny chrzésiciańskiej, ttum. J. Mrukówna, Warszawa 1988, s. 62; H. Pietras, Orygenes, Kraków 2003, s. 31.

211 Por. J. Słomka, Teologiczne podstawy egzegezy Orygenesa..., dz. cyt., s. 477-489.

212 Por. M. Domaradzki, Między alegoria a typologia. Uwagi o hermeneutyce Orygenesa, „Przegląd Religioznawczy” 1/239 (2011), s. 26.

213 Por. K. J. Torjesen, Hermeneutical Procedure and Theological Method in Origen's Exegesis, Berlin 1986 (Patristische Texte und Studien 28). 
3. Kształtowanie się nauki o niebie w teologii patrystycznej - wiek III

a po nim inni, stając się w zależności od stopnia oddalenia od Boga: demonami, ludźmi, aniołami. Aby zbawić upadłych (umożliwić im powrót do stanu przed upadkiem), Bóg posłał na ziemię jeden logikos, który pozostał zjednoczony z Logosem siłą miłości, ten logikos stał się duszą ludzką Jezusa Chrystusa, jedynym człowiekiem, który był na ziemi nie z własnego upadku, ale z posłuszeństwa Ojcu. Ten logikos zjednoczony z Logosem jest Zbawicielem świata ${ }^{214}$. Dzięki Niemu ludzie mają możliwość naśladowania Jezusa i stania się doskonałymi, co uwiarygadnia się przez ich czyny, a szczególnie przez wyzwolenie się od namiętności i przez miłośćc15. Orygenes dokonuje tu za św. Pawłem rozróżnienia na „człowieka zewnętrznego” (2 Kor 4, 16) i „człowieka wewnętrznego” (Rz 7, 22; Ef 3, 16), który to podział traktuje jak dwa różne aspekty życia człowieka: „cielesno-zmysłowy” i „psychiczno-duchowy”. Obraz Boży tkwi w tym, co określa „człowiekiem wewnętrznym”, który się odnawia i staje się godnym bycia stworzonym na obraz Stwórcy. W „człowieku wewnętrznym” jest siedziba cnót i cała potencjalność piękna człowieka, stąd, według Orygenesa, tylko w „człowieku wewnętrznym” człowiek może realizować ideał człowieczeństwa zgodny z wolą Bożą ${ }^{216}$.

214 Por. H. Pietras, Eschatologia Kościoła pierwszych czterech wieków, Kraków 2007, s. $84-86$.

215 Por. Origenes, Commentarii in Matthaeum 15,18, w: PL 13. Origenis Opera Omnia, tomus tertius, ed. J.-P. Migne, Facsimile of the Paris First Edition, Athens 1999, k. 1305B; przekład polski Orygenes, Komentarz do Ewangelii wedtug Mateusza 15,18: „I nie należy wątpić, że «od razu» staje się doskonatym ten, kto w ten sposób sprzedał wszystko, co posiadat tak, jak przedstawiliśmy, i rozdał ubogim. A jeśli sprzedawanie mienia trwa długi czas i jeśli potrzeba długiego czasu, aby je rozdać tym, których nazwaliśmy «ubogimi», to długotrwałość tego działania nie może przeszkodzić, by ten, kto je wykonuje, stawał się doskonałym w miarę rozdawanych ubogim grzechów. Jasne natomiast jest, że kto tak postąpił, będzie miał skarb w niebie i sam stanie się niebieski, albowiem jaki ów ziemski - jasne, że zły - tacy i ziemscy; jaki Ten niebieski - to jest Chrystus - tacy i niebiescy (1 Kor 15, 48). W części więc swego nieba będzie miał skarb ten, kto chciał być doskonały i sprzedał wszystko, co posiadat i rozdał ubogim", ŹMT 10, tłum. K. Augustyniak, wstęp i oprac. E. Stanula, Kraków 1998, s. 251-252.

216 Por. M. Szram, Ciato zmartwychwstate $w$ myśli patrystycznej przetomu II i III wieku, Lublin 2010, s. 261-263; A. Baron, Swiętość a ideaty cztowieka (Ojcowie apostolscy, Klemens Aleksandryjski, Orygenes). Studium teologiczne na tle modeli filozoficzno-religijnych, Kraków 2013, s. 294-303. 
Kształtowanie się nauki o niebie w teologii patrystycznej I-III wieku

Myśl ta wyraźnie odróżnia soteriologię Orygenesa od idei antropologicznych platonizmu (wyzwolenie duszy z ciała przez poznanie mądrości na drodze filozofii i przez życie etycznie doskonałe) czy gnostycyzmu (zbawienie przez wiedzę). Według Orygenesa dostęp do życia wiecznego jest zatem dla ludzi możliwy dzięki wsparciu i przykładowi Logosu oraz dzięki wyborom wolnej ludzkiej woli ${ }^{217}$.

\section{Kosmologia a eschatologia}

Orygenes pojmował całe stworzenie jako rzeczywistość pomiędzy początkiem a końcem, które mają być do siebie podobne, kiedy całe stworzenie będzie ostatecznie podporządkowane Bogu Ojcu i powróci do pierwotnej doskonałości ${ }^{218}$. Za przyjmowaną przezeń hipotezą apokatastazy, ro-

217 Por. Origenes, Commentarii in Iohannem 19,6, w: PL 14. Origenis Opera Omnia, tomus quartus, ed. J.-P. Migne, Facsimile of the Paris First Edition, Athens 1998, k. 536CD; SCh 290, Origène, Commentaire sur saint Jean. t. 4 (Livres XIX et XX). Text grec, avantpropos, traduction et notes par C. Blanc, Paris 1982, s. 68; przekład polski Orygenes, Komentarz do Ewangelii wedtug św. Jana 19,6: „Nie można bowiem oglądać Boga bez poznania Słowa. (36). A ten, kto widzi Mądrość, którą Bóg stworzył przed wiekami dla dzieł swoich, od poznania Mądrości przechodzi do poznania Jej Ojca. Nie można jednak bez uprzedniego poznania Mądrości poznać Boga Mądrości. (37). To samo powiesz i o Prawdzie, bo przecież nikt nie poznaje i nie ogląda najpierw Boga, a potem Prawdę, lecz najpierw poznaje Prawdę, aby w ten sposób dojść do oglądania bytu lub czegoś więcej niż byt: mianowicie mocy oraz istoty Boga. (38). W świątyni były stopnie, po których można było wstąpić do miejsca najświętszego. Być może tak samo Jednorodzony Boga jest dla nas wszystkimi stopniami. I jak pierwszy stopień jest na dole, drugi wyżej i tak aż do najwyższego, podobnie Zbawiciel to suma wszystkich stopni. Jego człowieczeństwo jest jakby pierwszym stopniem na dole i, wkraczając na niego, przechodzimy po następnych stopniach, przemierzając cała drogę, tak że przechodzimy przez Niego, a On jest Aniołem i innymi Potęgami”, ŹMT 27, tłum. i oprac. S. Kalinkowski, Kraków 2003, s. 371-372. W CZym to jest w Polsce, też ŹMT?

218 Origenes, De principiis 3,6,3, w: SCh 268. Origène, Traité des Principes. t. 3 (Livres III et IV). Introduction, texte critique de la Philocalie et de la version de Rufin, traduction par H. Crouzel et M. Simonetti, Paris 1980, s. 240.242; przekład polski Orygenes, $O$ zasadach 3,6,3: „Ja przynajmniej sadzę, że stwierdzenie: «Bóg będzie wszystkim we wszystkim» (1 Kor 15, 28), oznacza, iż będzie On wszystkim także w poszczególnych istotach, a to w tym sensie, że dla duszy rozumnej, oczyszczonej z błota grzechów i uwolnionej z mgły występku, Bóg będzie wszystkim, co ona może czuć, rozumieć czy myśleć: już tylko Boga będzie słuchać, tylko Boga będzie pojmować, a Bóg będzie stanowił wielkość i miarę wszystkich jej poczynań; i tak Bóg będzie dla 
3. Kształtowanie się nauki o niebie w teologii patrystycznej - wiek III

zumianej jako powszechne zbawienie stworzenia, przemawiałaby zdaniem Orygenesa nieskończona miłość Boga, natomiast paradoksalnie sprzeciwia-

niej wszystkim: nie będzie już ona rozróżniać miedzy dobrem i złem, bo zła już wcale nie będzie; Bóg bowiem jest wszystkim dla tego, kto nie ma już ze złem styczności; ten, kto zawsze tkwi w dobru i dla kogo Bóg jest wszystkim, nie będzie też pragnął jeść z «drzewa wiadomości dobrego i złego» (Rdz 2, 17). Jeśli przeto koniec doprowadzony do początku i kres wszechrzeczy zrównany z ich zaraniem przywróci stan, w którym stworzenie rozumne znajdowało się wówczas, gdy nie potrzebowało jeść z drzewa wiadomości dobrego i złego, po to, aby po usunięciu wszelkiego zła i przywróceniu uczciwości i czystości jedyny dobry Bóg stał się dla niego wszystkim, i to nie w nielicznych, czy nawet w wielu istotach, ale „we wszystkich”, to Bóg naprawdę będzie wszystkim we wszystkim wówczas, gdy już nie będzie nigdzie śmierci ani ościenia śmierci, ani w ogóle żadnego zła. Niektórzy sądzą wszelako, że owa doskonałość i szczęście stworzeń rozumnych trwać będzie w opisanym powyżej stanie - to znaczy w stanie, w którym wszystko mieć będzie Boga, a Bóg będzie dla nich wszystkim aż do czasu, kiedy usunie ich stamtąd jakikolwiek związek z naturą cielesną. W innym wypadku natomiast, jak mniemają, domieszka materialnej substancji stanowić będzie przeszkodę dla chwały najwyższego szczęścia (C). Sprawę tę dokładniej omówiliśmy już poprzednio, tak jak poszczególne zagadnienia przychodziły nam na myśl" (por. Orygenes, $O$ zasadach 2,3,2-3), ŹMT 1, tłum. i oprac. S. Kalinkowski, fragmenty z „Filokalii” tłum. K. Augustyniak, wprowadzenie H. Pietras, Kraków 1996, s. 312.

Fragmenty $i$ świadectwa. C. Hieronim, List 124, 10: „Rozprawiając znowu o różnorodności świata i stwierdzając, że z aniołów powstaną demony, a z demonów aniołowie albo ludzie, oraz z ludzi demony i w ogóle wszystko ze wszystkiego, przedstawia [Orygenes] w końcu takie zdanie: «Nie ulega wątpliwości, że po upływie określonego czasu ponownie powstanie materia i ciała oraz pojawi się różnorodność świata na skutek różnorodnych pragnień rozumnych stworzeń, które po osiągnieciu doskonałego szczęścia, staczając się w dół aż do kresu wszechrzeczy, przyjęły tak wielkie zło, iż przemieniają się we własne przeciwieństwo, skoro nie chcą wytrwać w pierwotnym stanie i mieć nieskażonego szczęścia. Nie wolno jednakże zapominać, że wiele stworzeń rozumnych zachowuje swój stan początkowy jeszcze w drugim, trzecim, czwartym świecie i nie dopuszcza do siebie jakiejkolwiek zmiany; inne stworzenia utracą ze swego pierwotnego stanu tak niewiele, że zdawać się może, iż wcale nic nie utraciły, a niektóre w wielkiej zagładzie muszą się staczać na dno otchłani. Władca wszechrzeczy, Bóg, potrafi przy tworzeniu stanów tak posługiwać się poszczególnymi istotami zgodnie ze słusznością, warunkami i przyczynami, które podtrzymują i zapoczątkowują kierowanie światem, ażeby ten, kto przewyższył wszystkich w występku i całkiem z ziemią się zrównał, w innym, przyszłym świecie był diabłem, początkiem stworzenia Pańskiego, aby wyszydzili go aniołowie, którzy utracili przywileje pierwszeństwa». Cóż w słowach tych próbuje wykazać, jeśli nie to, że grzeszni ludzie tego świata w innym świecie mogą stać się diabłami i demonami, oraz na odwrót, że demony w innym świecie mogą się odrodzić jako aniołowie lub ludzie?”, w: SCh 269. Origène, Traité des Principes. t. 4 (Livres III et IV). Commentaire et Fragments par H. Crouzel et M. Simonetti, Paris 1980, s. 126-131; ŹMT 1, s. 319-320. 
Kształtowanie się nauki o niebie w teologii patrystycznej I-III wieku

łaby się jej wolna wola rozumnych stworzeń. Stąd Orygenes uznawał terapeutyczne i skończone pojmowanie kary Bożej za pedagogiczny i przejściowy środek zaradczy wobec popełnionego zła uczynkowego stworzeń ${ }^{219}$.

Apokatastaza rozumiana jako odnowa czy przywrócenie jest hipotezą, którą Orygenes, zdaniem Henriego Crouzela, wywodził z 1 Kor 15, 23$28^{220}$, a opisywał przy zastosowaniu charakterystycznej dla jego terminologii polisemii. Zdaniem wspomnianego badacza apokatastaza w tekstach Orygenesa może być rozumiana zarówno jako cielesna, jak i bezcielesna, gdyż Aleksandryjczyk rozważa obie hipotezy i za żadną z nich się wyraźnie nie opowiada. Apokatastaza w ujęciu Orygenesa nie ma też, zdaniem Crouzela, charakteru panteistycznego jak u stoików, ale byłoby to zespolenie z Bogiem, które nie likwiduje ludzkich czy anielskich osobowości, gdyż wolność stworzeń rozumnych jest podstawowym elementem ich istnienia. Badacz ten sądzi też, że nie można jednoznacznie rozstrzygnąć, czy Orygenes głosił przekonanie o ostatecznym nawróceniu szatana. Orygenes waha się bowiem przy rozważaniu tezy o wieczności Gehenny, gdyż sam termin „wieczność” w sensie absolutnym odnosi tylko do Boga. Dosyć wieloznacznie mówi on także o możliwości zbawienia diabła. W O zasadach 3,6,5 stwierdza bowiem, że ostatecznie Bóg nawróci wrogą $\mathrm{Mu}$ wolę diabła, ale nie unicestwi jego materiii ${ }^{221}$. Natomiast w innych tekstach mówi

219 Por. M. Szram, Orygenes, w: Powszechna Encyklopedia..., dz. cyt., s. 866.

220 Por. 1 Kor 22 - 28: „22. I jak w Adamie wszyscy umierają, tak też w Chrystusie wszyscy będą ożywieni, 23. lecz każdy według własnej kolejności. Chrystus jako pierwszy, potem ci, co należą do Chrystusa, w czasie Jego przyjścia. 24. Wreszcie nastąpi koniec, gdy przekaże królowanie Bogu i Ojcu i gdy pokona wszelką Zwierzchność, Władzę i Moc. 25. Trzeba bowiem, ażeby królował, aż położy wszystkich nieprzyjaciół pod swoje stopy. 26. Jako ostatni wróg, zostanie pokonana śmierć. 27. Wszystko bowiem rzucił pod stopy Jego. Kiedy się mówi, że wszystko jest poddane, znaczy to, że z wyjątkiem Tego, który mu wszystko poddał. 28. A gdy już wszystko zostanie Mu poddane, wtedy i sam Syn zostanie poddany Temu, który Synowi poddał wszystko, aby Bóg był wszystkim we wszystkich”, Biblia Tysiąclecia Online, Poznań 20034 , http:// www.biblia.deon.pl/rozdzial.php?id=300 (26.11.2016).

221 Por. Orygenes, $O$ zasadach 3,6,5: „Zagłady ostatniego nieprzyjaciela nie należy jednak pojmować w tym sensie, że zginie jego substancja stworzona przez Boga; zginie raczej nieprzyjacielska chęć i wola, która od niego samego, a nie od Boga pochodzi. Wróg więc zostanie zniszczony nie po to, aby go wcale nie było, ale po to, by nie był nieprzyjacielem i śmiercią. Dla Wszechmogącego nie ma rzeczy niemożliwych (por. Hi 42, 2); Stwórca potrafi wszystko uleczyć. Bóg przecież stworzył wszystko, aby istniało, a to, co 
3. Kształtowanie się nauki o niebie w teologii patrystycznej - wiek III

dosyć bezosobowo, że jako ostatni wróg Boga zostanie zniszczona śmierć (utożsamiana z diabłem i grzechem), ale w tych tekstach jest ona rozumiana jako „coś negatywnego”, ,jakiś brak”, a nie jako substancja śmierci. Toteż rozważania Orygenesa dotyczące ewentualnego nawrócenia szatana czy powszechności apokatastazy należy oceniać jako hipotezy tworzone w ramach jego teologii poszukiwania, a nie jakieś kategoryczne stwierdzenia ${ }^{222}$.

Orygenes, rozważając 1 Kor 15, 23-28, wierzył w dobroć Boga wobec Jego stworzeń, choć z drugiej strony dopuszczał możliwość, że zatwardziałe stworzenie w swej wolnej woli będzie tę dobroć stale odrzucało. Ponadto Orygenes żywił nadzieję, że Bóg tak będzie oddziaływał na stworzenie, iż bez łamania jego wolnej woli dobroć Boga przełamie ostatecznie wszelki opór upartego stworzenia. Objaśniany w zachowanych dziełach Orygenesa trzydzieści osiem razy 1 Kor 3, 11-15 w większości tych tekstów utożsamia Boga z ogniem oczyszczającym. On podda próbie każde dzieło i jego budowniczego: jeśli dzieło przetrwa ogień, jego budowniczy otrzyma zapłatę, a jeśli spłonie, to poniesie szkodę, ale zarazem dzięki ogniowi ocaleje. Ogień byłby zatem metaforą sprawiedliwego Boga oczyszczającego grzeszników ze złych czynów, aby ich wpuścić do życia wiecznego. Orygenes w Homiliach do Księgi Kaptańskiej 7,2223 rozwija myśl, iż radość Chrystusa

zostało stworzone dla istnienia, nie może przestać istnieć (por. Mdr 1, 13-15; 2, 23-25). Dlatego też byty stworzone mogą wprawdzie podlegać przekształceniom i zmianom oraz stosownie do swych zasług przebywać w lepszym lub gorszym stanie, jednakże to, co Bóg stworzył, by istniało i trwało, nie może doznać substancjalnej zagłady (D)", w: SCh 253. Origène, Traité des Principes. t. 2..., dz. cyt., s. 244.246; ŹMT 1, s. 314. Fragmenty $i$ świadectwa. D. 1) Teofil z Aleksandrii, List synodalny, u Hieronima, List 92, 2, 1: „W rozprawie $O$ zasadach napisano: «Królestwo Chrystusa kiedyś się skończy; diabeł wyzwolony ze wszystkich plam grzechu zostanie ozdobiony słusznym zaszczytem i będzie poddany wraz z Chrystusem»". 2) Teofil z Aleksandrii, List paschalny I, u Hieronima, List 96, 8, 2: „Orygenes ośmielił się otoczyć wielkim szacunkiem diabła; wypierając się Jezusa stwierdził, że diabeł, uwolniony od wszelkiego grzechu, powróci do pierwotnej czci, natomiast królestwo Chrystusa się skończy, a On sam będzie kiedyś razem z diabłem podlegał władzy Boga”, w: SCh 253. Origène, Traité des Principes. t. 2..., dz. cyt., s. 139-140; ŹMT 1, s. 320.

222 Por. H. Crouzel, Orygenes..., dz. cyt., s. 312-321; W. Szczerba, Koncepcja wiecznego powrotu w myśli wczesnochrześcijańskiej..., dz. cyt., s. 244-254, I. L. E. Ramelli, The Christian Doctrine of Apokatastasis. A Critical Assessment from the New Testament to Eriugena, Leiden-Boston 2013, s. 198-215 (Supplements to Vigiliae Christianae 120).

223 Por. Origenes, In Leviticum homiliae (latine, interprete Rufino) 7,2, w: SCh 286. Origène, Homélies sur le Lévitique. t. 1 (Homélies I-VII). Texte latin, introduction, 
Kształtowanie się nauki o niebie w teologii patrystycznej I-III wieku

i świętych nie będzie pełna, dopóki całe Jego Ciało nie zostanie ponownie ustanowione w niebieskiej Jerozolimie ${ }^{224}$.

Dopełnieniem tez Crouzela o apokatastazie według Orygenesa są badania Panayiotisa Tzamalikosa, profesora filozofii z Uniwersytetu Arystotelesa w Tessalonikach, który twierdzi, iż Orygenes wyprowadza swą hipotezę apokatastazy przede wszystkim z Bożych obietnic o zbawieniu, a jej prefiguracją i egzemplifikacją jest już zmartwychwstanie Jezusa ${ }^{225}$. Ten grecki badacz myśli Aleksandryjczyka zauważa, iż Orygenesowska teoria apokatastazy znaczeniowo jest co prawda w pewnym stopniu zależna od termi-

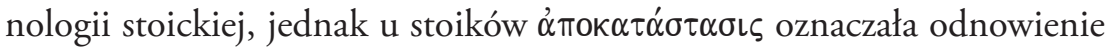
natury i była powrótem do „następnego-identycznego” świata, natomiast u Orygenesa koncepcja apokatastazy nie ma w swym przesłaniu niczego wspólnego z poglądem stoików, oprócz samego terminu. Orygenes, wykorzystując użycie tego terminu w Biblii (por. Dz 3, 19-21226), zastosował go przede wszystkim, komentując tekst Jr 15, $19^{227}$ w swych Homiliach

traduction et notes de M. Borret, Paris 1981, s. 308-322 (głównie wersety: 7,2,148-191, SCh 286, s. 318-322); przekład polski Orygenes, Homilie o Księdze Kaptańskiej 7,2, w: PSP 31,2, tłum. i oprac. S. Kalinkowski, wstęp E. Stanula, Warszawa 1984, s. 86-91.

224 Por. H. Crouzel, Orygenes..., dz. cyt., s. 298-300.

225 Por. P. Tzamalikos, Origen: Philosophy of History and Eschatology, Leiden-Boston 2007, s. 287-290 (Supplements to Vigiliae Christianae 85).

$226 \mathrm{Dz}$ 3, 19-21: „19. Pokutujcie więc i nawróćcie się, aby grzechy wasze zostały zgładzone, 20. aby nadeszły od Pana dni ochłody, aby też posłał wam zapowiedzianego Mesjasza, Jezusa, 21. którego niebo musi zatrzymać aż do czasu odnowienia wszystkich rzeczy ( $\alpha \chi \propto\llcorner\llcorner\chi \rho o ́ \nu \omega \nu ~ \dot{\alpha} \pi о \kappa \alpha \tau \alpha \sigma \tau \alpha \dot{\alpha} \sigma \epsilon \omega \varsigma \pi \dot{\alpha} \nu \tau \omega \nu)$, co od wieków przepowiedział Bóg przez usta swoich świętych proroków”, Biblia Tysiąclecia Online, Poznań 20034, http://www.biblia.deon.pl/rozdzial.php?id=380 (26.11.2016); tekst grecki Dz 3, 21 cytowany za Grecko-polski Nowy Testament. Wydanie interlinearne z kodami gramatycznymi, tłum. R. Popowski, M. Wojciechowski, Warszawa 1995, s. 521 (Prymasowska Seria Biblijna [dalej: PSB] 1).

227 Jr 15, 19 (LXX): „Dlatego tak mówi Pan: «Jeśli wrócisz, znowu cię przyjmę i będziesz stał przede mną. Jeśli będziesz potrafił odróżniać to co wartościowe, od tego, co niegodne, będziesz moimi ustami i to oni zwracać się będą do ciebie, a nie ty do nich»", Septuaginta, czyli Biblia Starego Testamentu wraz z księgami deuterokanonicznymi i apokryfami, tłum. i oprac. R. Popowski, Warszawa 2014, s. 1459 (por. Jr 15, 19 [BT $\left.{ }^{4}\right]$ ): „Dlatego to mówi Pan: «Jeśli się nawrócisz, dozwolę, byś znów stanął przede Mną. Jeśli zaś będziesz wykonywać to, co szlachetne, bez jakiejkolwiek podłości, będziesz jakby moimi ustami. Wtedy oni się zwrócą ku tobie, ty się jednak nie będziesz ku nim zwracał", Biblia Tysiąclecia Online, Poznań 20034, http://www.biblia.deon.pl/rozdzial.php?id=656 http://www.biblia.deon.pl/rozdzial.php?id=656(26.11.2016). 
3. Kształtowanie się nauki o niebie w teologii patrystycznej - wiek III

o Księdze Jeremiasza 14,18, gdzie uznał, iż obecny świat jest dla człowieka jedynie „wygnaniem”228, odkąd Adam został wygnany na „ten świat”229. Dlatego w cytowanych tekstach Orygenes wyprowadza konsekwentnie wnioskowanie o „przywróceniu” człowieka do: „pierwotnego” / „dawnego stanu” / „ojczyzny”, „swej ojczyzny”, co dokonuje się przez Jezusa Chrystusa.

228 Origenes, Homiliae graecae in Ieremiam 14,18, w: SCh 238. Origène, Homélies sur Jérémie. Traduction par P. Husson et P. Nautin. Édition, introduction et notes par P. Nautin. t. 2. Homélies XII-XX et Homélies latines, Paris 1977, s. 108; przekład polski Orygenes, Homilie o Księdze Jeremiasza 14,18: „Dlatego mówi Pan: «Jeśli się nawrócisz, ja cię przywiodę do dawnego stanu». Słowa te kieruje do każdego, kogo Bóg wzywa do nawrócenia się ku niemu; tajemnica zaś, moim zdaniem, zawiera się w zwrocie: «Przywiodę cię do dawnego stanu». Nikogo nie można przywrócić do miejsca, w którym nie był: "przywrócenie» dotyczy tego, co było czyjąś własnością. Na przykład, jeśli zwichnę sobie kończynę, to lekarz usiłuje «przywrócić do dawnego stanu» to, co zostało zwichnięte; jeśli ktoś słusznie czy niesłusznie znalazł się na wygnaniu (ö $\tau \alpha \nu$ ” $€ \xi \omega$

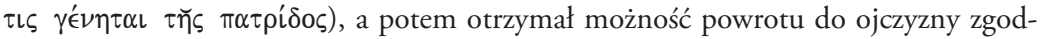
nie z obowiązującymi prawami, to wówczas zostaje «przywrócony» do swej ojczyzny; tak samo możesz myśleć o żołnierzu, który został wyrzucony ze swego szeregu i ponownie został do niego «przywrócony». Bóg zatem powiada tu do nas, którzyśmy się od niego odwrócili, że jeśli się nawrócimy, on nas przywróci do dawnego stanu. Taki jest bowiem cel tej obietnicy, jak napisano w dziejach Apostolskich: «Aż do odnowienia wszystkich rzeczy, o których od wieków mówił Bóg przez usta świętych proroków swoich» (Dz 3, 21) w Chrystusie Jezusie, «któremu chwała i panowanie na wieki wieków, amen (1 P 4, 11)»", w: PSP 30, tłum. i oprac. S. Kalinkowski, wstęp E. Stanula, Warszawa 1983, s. 128.

229 Origenes, Homiliae in Jesu Nave (latine, Rufino interprete) 6,4, w: SCh 71. Origène, Homélies sur Josué. Texte latin, introduction, traduction et notes de A. Jaubert, Paris 1960, s. 188; przekład polski Orygenes, Homilie o Księdze Jozuego 6,4: „Znajdujemy w Piśmie wiele wskazówek, które mówią, iż Jerycho symbolizuje ten świat (por. Orygenes, Komentarz do Ewangelii wedtug Mateusza 16,9). Otóż i ów człowiek, który wedle słów Ewangelii «schodził z Jerozolimy do Jerycha i wpadł w ręce zbójców» (por. Łk 10, 30), bez wątpienia jest symbolem Adama, który z raju został wypędzony na wygnanie w tym świecie (de paradiso in huius mundi exilium trusus est). Także ślepcy z Jerycha, do których przyszedł Jezus, aby przywrócić im wzrok (por. Mt 20, 30), symbolizowali tych, których na tym świecie (in hoc mundo) gnębiła ślepota niewiedzy i do których przyszedł Syn Boży. To Jerycho zatem, czyli ten świat, ma upaść. Od dawna już bowiem święte księgi zapowiadały koniec świata. (...)”, w: PSP 34/1. Orygenes, Homilie o Księgach Liczb, Jozuego, Sędziów, tłum. i oprac. S. Kalinkowski, wstęp E. Stanula, Warszawa 1986, s. 36. 
Kształtowanie się nauki o niebie w teologii patrystycznej I-III wieku

Orygenes zakłada zatem, iż po zmartwychwstaniu, opisywanym np. jako oddzielenie duszy od zła, ${ }^{230}$ człowiek ma powrócić do „swej ojczyzny”, które to wyrażenie należy u Orygenesa odczytywać dosłownie (co np. uczynił Jan Chryzostom; Didym Ślepiec czy Atanazy z Aleksandrii; u Bazylego Wielkiego, Jana Damasceńskiego i Romana Melodosa wyrażenie „starożytna ziemia ojcowska” uległoby natomiast interpolacji). Tzamaliskos polemizuje zatem z poglądem Crouzela, iż koncepcja apokatastazy u Orygenesa zostałaby przez tego wczesnochrześcijańskiego pisarza kościelnego opracowana wyłącznie na bazie tekstu z 1 Kor 15, 22-28, gdyż znaczącymi dla Orygenesa są w tworzeniu tej koncepcji także alegorycznie interpretowane teksty Jr 15, 10-19 (por. Homilia 14 o Księdze Jeremiasza) i Joz 6, 20 (por. Homilia o Księdze Jozuego 6, 4; Komentarz do Ewangelii wedtug Mateusza 16,9).

\section{Eschatologia dotycząca człowieka - nieśmiertelność duszy i ciała}

Orygenes, zakładając hipotezę preegzystencji prekosmicznego upadku, uznawał, iż ciało preegzystujące po upadku w ten grzech utraciło niebiańską nieskazitelność i nieśmiertelność i odziało się w śmiertelność, co symbolizowałoby odzienie ze skór z $\mathrm{Rdz} 3$, 31. Henri Crouzel, komentując Orygenesowe Homilie do Jeremiasza 20(19),7²31; Homilie do Księgi Kaptańskiej 11,2; 14,4a ${ }^{232}$, jak również tegoż Dialog z Heraklidesem 24-27, zauważył, iż Orygenes wyróżniał dwa rodzaje nieśmiertelności:

(1) wobec śmierci fizycznej dusza ludzka miałaby się cieszyć nieśmiertelnością całkowitą (jako przeciwieństwo śmierci powszechnej, co jest częścią samej istoty natury rozumnej, stąd np. dusza ludzka żyje po śmierci

\footnotetext{
230 Por. Origenes, Selecta in Psalmos 74,4, PG 12, k. 1533.

231 Por. Origenes, Homiliae graecae in Ieremiam 20(19),7, w: SCh 238, s. 280-284.

232 Por. Origenes, In Leviticum homiliae 11,2; 14,4, w: SCh 287. t. 2 (Homélies VIII-XVI). Texte latin, introduction, traduction et notes de M. Borret, Paris 1981, s. 150-158, $242-248$.
} 
ciała i wznosi się ku siedzibom czystych i eterycznych bytów (Por. Przeciw Celsusowi 7, 5) ${ }^{233}$;

(2) dusza ludzka może być także nieśmiertelna wobec śmierci z grzechu, jeśli utwierdza się w dobrym. Oba rodzaje nieśmiertelności są darem Boga, wpisanym w stworzenie (tak w człowieka, jak i w aniołów), a związanym z uczestnictwem w obrazie Boga (por. Komentarz do Ewangelii wedtug św. Jana 13,61$)^{234}$. Dopuszczalny w teście $O$ zasadach pogląd o tym, iż błogosławieni w życiu wiecznym mogliby upaść w grzech, byłby jedynie rozważaną hipotezą. Orygenes, wychodząc z platońskiej idei uczestnictwa, dowodził w Dialogu z Heraklidesem 2,11,4; 4,4,9-10, iż dusza ludzka uczestniczyłaby w tych samych dobrach duchowych i boskich rzeczywistościach co aniołowie, gdyż ludzkie dusze i anielskie moce mają tę samą naturę - zarówno aniołowie, jak i dusza ludzka są nieśmiertelne i niezniszczalne. Światło duchowe, w którym uczestniczyłaby dusza ludzka, jako część rozumnego stworzenia, byłoby natomiast naturą trzech Osób boskich. Każda substancja, która uczestniczy w tym boskim-wiecznym świetle jest nieśmiertelna i niezniszczalna, jednak przy założeniu, że stopień owego uczestnictwa nie jest jednakowy. Tak wiec Orygenes wyróżniałby dwa rodzaje nieśmiertelności: tę przyrodzoną oraz tę z łaski ${ }^{235}$.

Śmiertelne i zniszczalne ludzkie ciało po zmartwychwstaniu może stać się nieśmiertelne i niezniszczalne, gdyż dusza przyodzieje ciało wspomnianymi cechami, jakie przynależą do natury duszy. Tym, który udziela człowiekowi nieśmiertelność łaski (jego duszy i ciału), czyli znosi śmierć z grzechu i udziela nowego, wiecznego życia, jest Chrystus, nazywany przez Orygenesa „odzieniem duszy” ${ }^{236}$. Ciała zmartwychwstałych ludzi mają być

233 Por. Origenes, Contra Celsum 7,5, w: SCh 150. Origène, Contre Celse. t. 4 (Livres VII et VIII), Paris 1969, s. 22.24.

234 Por. Origenes, Commentarii in Iohannem 13,61, w: SCh 222. Origène, Commentaire sur saint Jean 13,61. Text grec, avant-propos, traduction et notes par C. Blanc, Paris 1975, s. 64.

235 Por. H. Crouzel, Orygenes..., dz. cyt., s. 291-292.

236 Por. Origenes, De principiis 2,3, w: SCh 268. Origène, Traité des Principes. t. 3 (Livres III et IV). Introduction, texte critique de la Philocalie et de la version de Rufin, traduction par H. Crouzel et M. Simonetti, Paris 1980, s. 250-256. 
Kształtowanie się nauki o niebie w teologii patrystycznej I-III wieku

podobne do ciał aniołów (por. Komentarz do Ewangelii wedtug św. Mateusza 17,30). Substancja ciała pozostanie po zmartwychwstaniu ta sama, eteryczne i niebiańskie staną się natomiast jej jakości, które zmienią się z ziemskich na niebiańskie - oślepiające i eteryczne, nieśmiertelne i niezniszczalne, aseksualne. Zmartwychwstanie ludzi jest tożsame ze zmartwychwstaniem Chrystusa. W konsekwencji także zmiana jakości ludzkich ciał dokona się na wzór tej, jaka miała miejsce w przypadku Jezusa ${ }^{237}$. Analogicznie do Jego przemiany z jakości śmiertelności ciała w jakość eteryczną i boską, nastąpi przemiana ciał zmartwychwstałych ludzi. Zmartwychwstanie ludzi jest wyłącznym dziełem Boga, który ich wskrzesza. Chrześcijanie, którzy po chrzcie nie popełnili grzechu ciężkiego (tzw. „żywi”) mieliby przejść od pierwszego zmartwychwstania (czyli chrztu) do drugiego (tego eschatologicznego), natomiast ci z chrześcijan, którzy popełnili grzechy ciężkie, ale okazali skruchę (tzw. „umarli w Chrystusie”), będą oczyszczeni. Stąd sami zmartwychwstali dzieliliby się na rozmaite kategorie w zależności od swych zasług w życiu doczesnym ${ }^{238}$.

\section{Orygenesowska koncepcja eschatologicznego nieba}

\section{Terminologia}

Przy charakterystyce słownictwa, które Orygenes wykorzystywał w swych hipotezach dotyczących eschatologicznego nieba, natrafiamy na metodologiczną trudność związaną z typową dla tego autora polisemią. Biorąc

237 Origenes, Contra Celsum 3,41-42, w: SCh 136. Origène, Contre Celse. t. 2 (Livres III et IV). Introduction, texte critique, traduction et notes par M. Borret, Paris 1968, s. 96-100.

238 Por. H. Crouzel, Orygenes..., dz. cyt., s. 302-312. Szerzej o koncepcjach Orygenesa dotyczących kwestii zmartwychwstania ciała, zob. studium M. Szram, Ciato zmartwychwstate $w$ myśli patrystycznej..., dz. cyt., terminologia: s. 184-193, s. 201-203; miejsce ciała w strukturze człowieka - ciało w cieniu duszy: s. 255-286; uzasadnienie zmartwychwstania ciała: s. 339-358; zmartwychwstałe ciało Chrystusa - jako mogące dostosować się do ziemskiej i niebiańskiej rzeczywistości: s. 375-397; relacja ciała do duszy w okresie między śmiercią a zmartwychwstaniem: s. 418-434; czas i sposób cielesnego zmartwychwstania - przemiana cech ciała: s. 453-464; tożsamość i integralność ciała po zmartwychwstaniu: s. 501-559; przymioty ciała zmartwychwstałego: s. 583-629. 
3. Kształtowanie się nauki o niebie w teologii patrystycznej - wiek III

pod uwagę, że większość oryginalnych tekstów greckich Orygenesa zaginęła lub została zniszczona jeszcze podczas sporów orygenesowskich (IVVI wiek), w analizie teologicznej jego traktatów odwołujemy się zasadniczo do zachowanych antycznych przekładów łacińskich jego pism. Przy próbie rekonstrukcji oryginalnych znaczeń terminologii Aleksandryjczyka korzystamy dziś w patrologii ze wspomnianych łacińskich tłumaczeń, zestawiając je z zachowanymi fragmentami greckich oryginałów innych pism Orygenesa.

Podstawową terminologię kosmologiczną Orygenesa przeanalizował Jerzy Duda. Zgadzam się z większością jego wniosków, iż kosmologicz-

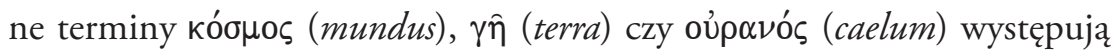
u Orygenesa w znaczeniu charakterystycznym dla świata antycznego i że łacińskie odpowiedniki terminologiczne są zgodne z duchem oryginalnych tekstów Aleksandryjczyka spisanych w języku greckim ${ }^{239}$. Problematyczna wydaje się natomiast jego analiza pojęcia $\alpha \iota \omega$ v (saeculum) oraz wnioskowanie mówiące o tym, jakoby Orygenes miał zerwać z niebem pojmowanym jako miejsce. Odnośnie do pierwszej problematyki Duda zaznacza, że za-

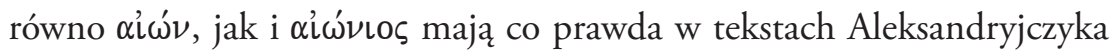
charakter wieloznaczny, ale najczęściej są sprowadzone przez tego badacza myśli Orygenesa do klasycznych wartości semantycznych obecnych w słownikach języka greckiego ${ }^{240}$. Pozwolę sobie nie zgodzić się z tym stwierdzeniem do końca. Prawdą jest, iż termin ten semantycznie odpowiada wszystkim znaczeniom słownikowym klasycznej grecki, ale u Orygenesa jest on

239 Por. J. Duda, Jeden świat czy wiele światów. Kosmologiczne podstawy doktryny Orygenesa, Siedlce 2008, s. 14-23, 31-42.

240 Por. J. Duda, Jeden świat czy wiele światów..., dz. cyt., s. 23-30, gdzie autor ten stwierdza, iż pojęcie $\alpha i \omega ́ v$ - to termin oddający u Orygenesa „rzeczywistość przemijającą”, to oznaczenie „obecnego wieku”, opisanie „wieku przyszłego”, „określonej przestrzeni czasowej, która ma jednak swój koniec” oraz „wieczność” (oddawaną przez łacińskie

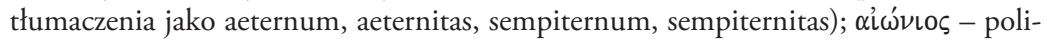
semiczne wykorzystanie terminu, które wskazuje na wieczność (aeternum, aeternitas, przy czym aeternum i sempiternum jako wieczny czy wiekuisty byłoby przez Orygenesa odnoszone ściśle do B). W podsumowaniu (Jeden świat czy wiele światów..., dz. cyt.,

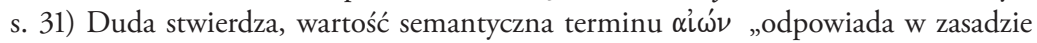
wszystkim tradycyjnym znaczeniom, jakie można znaleźć w słownikach języka greckiego. Pewne różnice zdają się występować w tłumaczeniach tego rzeczownika na język łaciński”. 
Kształtowanie się nauki o niebie w teologii patrystycznej I-III wieku

rozumiany szerzej i inaczej, co postaram się poniżej zaprezentować, wykorzystując wyniki badań Crouzela i Tzamalikosa. Podobnie nie zgadzam się z tezą Dudy, że Orygenes, dokonując komentarza w tekście $O$ modlitwie 23, zrywa z teologicznym pojęciem nieba jako miejsca na rzecz stanu osobowego istoty inteligibilnej, co miałoby się dokonywać na drodze intelektualnego aktu poznawczego zwanego kontemplacją. Orygenes w cytowanym powyżej traktacie idzie bardziej w kierunku twierdzenia, że Boga jako niematerialnego i nieskończonego nie można wiązać z jakąkolwiek wymierną, w tym także w niebie - materialnością czy ograniczonością. Stąd Jego przebywanie w niebie należy rozumieć analogicznie do Jego przebywania pośród świętych ${ }^{241}$. Natomiast uogólnienie tezy o niebie jako stanie pozwala Dudzie na zrównanie hipotezy Orygenesa o niebie ze scholastycznym orzeczeniem Benedykta XII (bulla Benedictus Deus, 1336 roku) o niebie jako stanie szczęśliwości i wizji uszczęśliwiającej udzielonej zbawionymi ${ }^{242}$. W tekstach Orygenesa nie znajdujemy potwierdzenia dla scholastycznego potwierdzenia nieba jako stanu. Moim zdaniem, zasadnicze znaczenie wiążących pojęć eschatologicznych i kosmologicznych jest u Orygenesa teleologiczne i jednoznacznie uwarunkowane jego chrystologiczną egzegezą alegoryczną. Pojęcia eschatologiczne Orygenesa jednoznacznie wskazują na cel zbawionych, jakim jest Chrystus-Logos i Bóg, choć na poziomie przekazu są niejednoznaczne, ponieważ zawsze metaforyczne i polisemicznie. Najważniejszymi z tych pojęć eschatologicznych są zatem:

241 W tym samym dziełku - Orygenes, O modlitwie 26,3, w: PG 11. Origenis Opera Omnia, tomus primus, ed. J.-P. Migne, Facsimile of the Paris First Edition, Athens 2002, k. 500.502.504; przekład polski Odpowiedź na Stowo. Najstarsi mistrzowie chrześcijańskiej modlitwy, tłum. W. Kania, H. Pietras, oprac. H. Pietras, Kraków 1993, s. 184; Orygenes rozwiązuje tę kwestię poprzez alegoryczne utożsamienie nieba z Chrystusem, a ziemi z Kościołem. Takie wyjaśnienie nieba Orygenes stosuje także w innych swoich traktatach, co sam wyjaśniam dalej w tym paragrafie.

242 Por. J. Duda, Jeden świat czy wiele światów..., dz. cyt., s. 196-197. 
3. Kształtowanie się nauki o niebie w teologii patrystycznej - wiek III

(1) utożsamiane z Chrystusem: „przyszłe dziedzictwo” / „ziemia święta” / „królestwo niebieskie”243; „królestwo niebios”244;

(2) „królestwo niebieskie” identyfikowane z dobrami, jakie zbawieni po swoim zmartwychwstaniu otrzymają od Chrystusa ${ }^{245}$;

243 Por. Orygenes, Homilie do Księgi Jozuego 25,4, w: SCh 71, s. 486.488; „Któż może pojąć to wszystko i zrozumieć? Któż zdoła spamiętać i zachować sam układ tajemnic? Jeśli zaś z trudem można wyjaśnić sam tekst opowieści w jego sensie literalnym oraz omówić pomieszanie miejsc i osób, o których opowiada historia, to cóż powiemy o opisanych tam tajemnicach, które zawierają w sobie symboliczny obraz podziału przeszłego dziedzictwa (futurae hereditatis) i wedle których odbędzie się w przyszłości podział ziemi świętej (sanctae terrae), którą w „dziedzictwo otrzymają cisi” (por. Mt 5, 5; Ps 36(37), 11). Któż zdoła wyjaśnić różne miejsca rozmieszczenia obozów, jak po zmartwychwstaniu dokona się ów podział między wszystkich świętych wedle stanu kapłańskiego albo lewickiego, aby, jak mówi apostoł, w zmartwychwstaniu nic nie działo się w sposób zamieszany, lecz żeby każdy przyszedł «wedle własnej kolejności: najpierw Chrystus, potem ci, którzy należą do Chrystusa, którzy uwierzyli w chwili Jego przyjścia, gdy przekaże królowanie Bogu i ojcu, i gdy podda Mu wszelką Zwierzchność i Władzę» (por. 1 Kor 15, 23-24)? Nie ulega wątpliwości, że nastąpi tam tego rodzaju uszeregowanie obozów, rozmieszczenie kapłanów, uporządkowanie wedle stanów oraz znaki będą dawane trąbami. Otóż jak Bóg uszeregował gwiazdy niebieskie i rozmieścił je wedle jakichś cudownych i niewysłowionych zasad, jedne umieścił na osi północnej, inne po stronie wschodniej, inne na sklepieniu południowym, a jeszcze inne na zachodzie, tak samo, sądzę, i tych, którzy po zmartwychwstaniu umarłych będą «jako gwiazdy niebieskie» (por. 1 Kor 15, 41) w liczebności i chwale, bo pochodzą z nasienia Abrahama (por. Rdz 15, 5; Wj 32, 13) być może rozmieści Bóg w królestwie niebieskim (regno coelorum) wedle układu gwiazd i stron świata, i jednym da dział na wschodzie, innym na zachodzie, innym na południu, a jeszcze innym, których zna, wyznaczy miejsce na północy, albowiem "wielu przyjdzie ze wschodu i z zachodu, z czterech stron świata, i zasiądą do stołu z Abrahamem, Izaakiem i Jakubem w królestwie niebieskim» (por. Mt 8, 11), dzięki łasce Pana naszego, Jezusa Chrystusa: «Jemu chwała i władza na wieki wieków, amen» (por. 1 P 4, 11)", PSP 34/2, s. 132-133.

244 Por. Origenes, Commentariorum series in Matthaeum 38, w: PG 12, k. 1652; przekład polski Komentarz do Ewangelii wedtug św. Mateusza. Część druga: Commentariorum series 38 „Kto więc zdąża do tego, by ujrzeć chwałę Chrystusa i jego królestwo, to jest doskonałość Słowa i królestwo, które króluje i panuje, kładąc wszystkie wrogie słowa pod swoje stopy i jako podnóżek swoich stóp (por. Łk 20, 43; Ps 109, 1), w: ŹMT 25, tłum. K. Augustyniak, Kraków 2002, s. 61-62.

245 Por. Orygenes, Komentarz do Ewangelii wedtug św. Mateusza, cz. 2, (Commentariorum series 72): „Zwróć uwagę na to, co powiada, że królestwo zostało przygotowane od założenia świata, nie dla kogo innego, jak tylko dla sprawiedliwych i dlatego odda je im ich Król, Chrystus (por. Mt 25, 34)”, PG 12, k. 1716D; ŹMT 25, s. 131. 
Kształtowanie się nauki o niebie w teologii patrystycznej I-III wieku

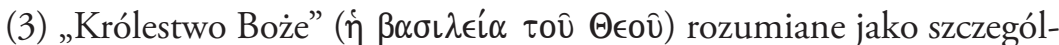
ny świat, gdzie zbawieni indywidualnie doświadczają życia wiecznego ${ }^{246}$, „Królestwo Boże” rozumiane jako „przyszły świat - przyszły czas - przyszłe miejsce - miejsce doskonałe" ( $\alpha$ ‘ $\omega \nu)$, gdzie życie jest całkowicie inne i naprawdę błogosławione, co jest obecnie przedmiotem chrześcijańskiej nadziei; to inny rodzaj życia, które ontologicznie jest rozróżniane od Bożego życia, stąd kiedy Orygenes komentuje w kontekście życia wiecznego biblijne porównania typu „wyżej-niżej” czy „wstępować-zstępować”, to odnosi się nie do jakichś materialnych konotacji czy poziomów geometrycznych, ale do innego rodzaju jakości: tego, co niewidzialne i niecielesne, alegorycznie oznaczających jakości tego drugiego / innego świata ${ }^{247}$;

246 Por. Origenes, Fragmenta in Evangelium Joannis (in catenis) 36: „(komentarz do J 3, 5). Królestwem Bożym nazwać trzeba położenie ludzi żyjących według praw Bożych. Królestwo to ma siedzibę w swym własnym miejscu, to znaczy w niebiosach. Ponieważ jednak tutaj jest mowa o Królestwie Bożym, u Mateusza zaś o królestwie niebieskim (por. Mt 3,2), należy stwierdzić, że Mateusz wywodzi jego nazwę od istot podlegających władzy królewskiej albo od miejsca, w którym te istoty przebywają, natomiast Jan i Łukasz od Boga, który króluje. Tak i my, mówiąc o Cesarstwie Rzymskim, określamy je przydawką wskazującą na ludzi, którzy podlegają władzy cesarskiej, albo nazwę tę wywodzimy od miejsca, gdy określamy je za pomocą nazwy ziemi lub państwa”, w: ŹMT 27, tłum. i oprac. S. Kalinkowski, Kraków 2003, s. 588; Origenes, Selecta in Deuteronomium 8,7, w: PG 12. Origenis Opera Omnia, tomus secundus, ed. J.-P. Migne, Facsimile of the Paris First Edition, Athens 1998, k. 809A-B.

247 Por. Orygenes, Homilie do Ksiegi Jeremiasza 14,17, w: SCh 238, s. 106; przekład polski „Dlaczego ci, którzy mnie nienawidzą, są silniejsi?”. Doznał wielu kłopotów, zaznał cierpień od tych, którzy nie chcieli słuchać prawdy, a oni byli potężniejsi od niego tutaj, w tym świecie, bo Królestwo Boże «nie jest z tego świata», lecz pochodzi z miejsc doskonalszych, zgodnie ze słowami Zbawiciela: «Gdyby królestwo moje było z tego świata, słudzy moi biliby się, abym nie został wydany Żydom» (J 18, 36). Ci, którzy sprawiają prorokowi przykrość, są od niego silniejsi na tym świecie; że są silniejsi popatrzcie na męczenników: sędzia zasiada, sprawując sąd i zażywa zbytku w sądzie; chrześcijanin, w którym Chrystus jest stawiany przed sądem, został nasycony goryczą, został zgnębiony i skazany przez nieprzyjaciela", PSP 30, s. 127-128; Origenes, Commentarii in Iohannem 19,20 (131-135), w: SCh 290. Origène, Commentaire sur saint Jean. t. 4 (Livres XIX et XX). Text grec, avant-propos, traduction et notes par C. Blanc, Paris 1982, s. 126-128; przekład polski Orygenes, Komentarz do Ewangelii wedtug św. Jana 19, 20 (131-135): „(131). (...) «Być w niskości» znaczy tyle, co «znajdować się pod względem nauki i myśli w takim właśnie miejscu». A każdy, kto korzysta z nauk i myśli, które są «z niskości» sam «z niskości» pochodzi. (132) Również ten oto widzialny i materialny świat, ze względu na tych, którzy potrzebują materialnego życia, ma w sobie różne miejsca, a one w zestawieniu z miejscami niematerialnymi, 
3. Kształtowanie się nauki o niebie w teologii patrystycznej - wiek III

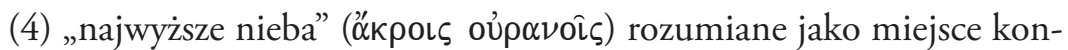
templacji dobrych rzeczy - niewidzialnych rzeczy Bożych, które nie mają nic wspólnego ze światem obecnym, tylko z doskonałością ${ }^{248}$; dlatego Orygenes przyrównuje życie wieczne do „najwyższego szczytu”, symbolizującego „najwyższe szczęście” / „szczyt dóbr”249; wywyższenie zbawio-

niewidzialnymi i niecielesnymi znajdują się w niskości - i to nie tyle ze względu na miejsce, ile z uwagi na porównanie z rzeczywistościami niewidzialnymi. (133). Jeśli natomiast porównać różne miejsca samego świata, to niektóre z nich mogą być nisko, a inne wysoko: okolice ziemskie są nisko, okolice niebieskie są wysoko. Tak więc zgodnie z tym stwierdzeniem ten, kto pochodzi z niskości, pochodzi oczywiście z tego świata, ten zaś, kto pochodzi z tego świata, wcale nie musi pochodzić z niskości. (134). Zauważ bowiem, że mieszkaniec niebios w pewnym sensie pochodzi z tego świata, ale nie pochodzi z niskości | w znaczeniu miejsca. Pochodzi jednak z niskości, jeśli porównać go z istotami duchowymi. A każdy mieszkaniec miejsc widzialnych, przemijających i doczesnych pochodzi z niskości, nawet gdyby ze względu na miejsce wywodził się z wysoka. (135). Ten jednak, kto pochodzi z niskości, z tego świata oraz z ziemi, może się zmienić: pochodzić z wysoka i nie być już z tego świata. Ktoś inny może pozostawać na tym świecie, ale być w przyszłości z nieba”, ŹMT 27, tłum. i oprac. S. Kalinkowski, s. 390.

248 Por. Origenes, Contra Celsum 6,19-20, w: SCh 147. Origène, Contre Celse. t. 3 (Livres V et VI). Introduction, texte critique, traduction et notes par M. Borret, Paris 1968, s. 224-230; przekład polski Orygenes, Przeciw Celsusowi 6,19-20: „19. (...) Także o miejscu nadniebnym Platon wcale nie mówił pierwszy, już dawniej bowiem Dawid, przedstawiając wspaniałość wiedzy o Bogu, którą posiadają ci, co wznoszą się ponad sprawy zmysłowe, powiedział w Księdze Psalmów: «Chwalcie Boga, niebiosa nad niebiosami, i wody, które są nad niebiosami, niech chwalą imię Pańskie” (Ps 148, 4). (...). 20. (...) ... który obiecał skrzętnym uczniom nauki bożej, żyjącym w sposób godny tej nauki, że zaprowadzi ich do miejsca, które jest ponad ziemią; powiedział mianowicie: «Abyście i wy tam byli, gdzie ja jestem» (J 14, 3). Dlatego i my żywimy nadzieję, że po obecnych trudach i utrapieniach znajdziemy się na szczytach nieba i zgodnie z nauką Jezusa otrzymamy źródła wody tryskającej ku życiu wiecznemu (por. J 4, 14), wstąpimy do rzeki poznania i będziemy tam, gdzie, jak powiedziano, «wody, które są ponad niebiosami, chwalą imię Pańskie». Jeśli i my będziemy chwalić imię Pańskie, nie zostaniemy strąceni ze szczytów nieba, lecz zawsze będziemy oglądać niewidzialne przymioty Boga nie będziemy się ich domyślać na podstawie stworzonych rzeczy tego świata, lecz będziemy z nimi, jak powiedział uczeń Jezusa «twarzą w twarz» (1 Kor 13, 12). Albowiem, "gdy przyjdzie to, co jest doskonałe, zniknie to, co jest tylko częściowe»(1 Kor 13, 10)”, PSP 17bis, tłum. i oprac. S. Kalinkowski, Warszawa $1986^{2}$, s. 300-301; Origenes, Selecta in Psalmi 26, w: PG 12, k. 1280BC.

249 Por. Orygenes, Przeciw Celsusowi 6,44, w: SCh 147, s. 288; „(...) uczynił tak po to, aby oczyszczeni ich nieprawością, jak złoto w ogniu, nie dopuszczając zła do natury swego rozumu i okazując się godnymi osiągnięcia rzeczy boskich, byli wynoszeni przez Słowo ku najwyższemu szczęściu i, jeśli tak można powiedzieć, do szczytu dóbr 
Kształtowanie się nauki o niebie w teologii patrystycznej I-III wieku

nego do życia wiecznego to przeniesienie go poza doczesny świat do miej-

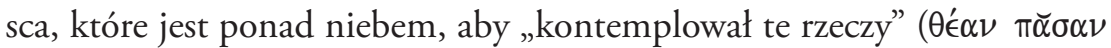
$\left.\pi \epsilon \rho i \sigma \tau \alpha \sigma \iota \nu^{250}\right)$ i aby „kontemplował” ( $\left.\theta \epsilon \omega \rho i ́ \alpha\right)$ żyjący Logos ${ }^{251}$;

(5) „życie wieczne” pojmowane jako „cel-koniec-wypełnienie” ( $\tau \in$ ‘́ $\lambda \circ \varsigma$ ) przynoszący zbawionym ostateczne dobra ( $\tau \in \lambda \iota \kappa o ̀ \nu ~ \alpha ُ \gamma \alpha \theta o ́ \nu)$, przede wszystkim to przebywanie blisko Boga w świętym Jego miejscu ${ }^{252}$, „życie wieczne" rozumiane jako przyjaźń z Bogiem ${ }^{253}$;

(6) „wieczny” ( $\alpha \imath \omega \nu\llcorner o \varsigma)$, aplikowane do stworzeń, wskazuje u Orygenesa nie tyle upływ czasu, co sugeruje nową jakość życia we właściwym miejscu,

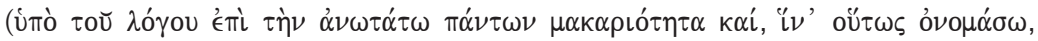

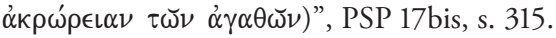

250 Orygenes, Przeciw Celsusowi 6,20, w: SCh 147, s. 228.230; „(...) Doznając zaś utrapień i cierpień, nigdy nie był nimi do tego stopnia zgnębiony, by nie łagodzić ich kontemplacją rzeczy wiecznych (...). Jeśli i my będziemy chwalić imię Pańskie, nie zostaniemy strąceni ze szczytów nieba, lecz zawsze będziemy oglądać niewidzialne przymioty Boga; nie będziemy się ich domyślać na podstawie stworzonych rzeczy tego świata, lecz będziemy z nimi, jak powiedział uczeń Jezusa, "twarzą w twarz» $(1$ Kor 13, 12)", PSP 17bis, s. 300-301; Przeciw Celsusowi 6,59, w: SCh 147, s. 326; „(...) stwierdzit, że ten, kto się wpatrywał w niewidzialne przymioty albo po prostu, jak mówi Pismo, w to, co niewidzialne, wyszedł z tego świata, a wyprowadziło go stąd Słowo i zaniosło w miejsca nadniebne, ażeby oglądał rzeczy piękne”, PSP 17, s. 325 (por. 2 Kor 4, 18; $\mathrm{Rz} 1,20)$

251 Por. Origenes, Exhortatio ad Martyrium 47, w: PG 11, k. 631A; przekład polski Orygenes, Zachęta do męczeństwa 47: „(...) Zróbmy to, byśmy z Jezusem Chrystusem korzystali z własnego szczęśliwego spokoju, byśmy oglądali całe żywe Słowo, byli nim karmieni, rozumieli kunsztowną mądrość w nim zawartą, zostali naznaczeni przez samą prawdę i mieli umysł oświecony przez prawdziwe i nieskończone światło wiedzy i byśmy oczami oświeconymi rozkazem Pana mogli oglądać to, co daje się ujrzeć tej światłości", PSP 24, tłum. S. Kalinkowski, wstęp i oprac. E. Stanula, Warszawa 1980, s. 170; Origenes, Selecta in Psalmos 9, w: PG 12, k. 1196 C.

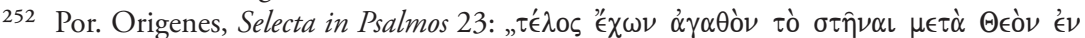

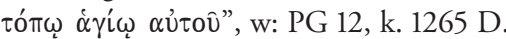

253 Por. Origenes, Commentari in Epistulam ad Romanos (latine, interprete Rufino, libri X) 4,12,2, w: SCh 539. Origène, Commentaire sur l'Épitre aux Romains 4,12,2, Texte critique établi par C. P. Hammond Bammel, Introduction par M. Fédou, Traduction et notes par L. Brésard, Paris 2010, s. 336; przekład polski Orygenes, Komentarz do Listu św. Pawta do Rzymian 4,12,2: „A wierzę, że są jeszcze jacyś bliżsi przyjaciele u Boga w niebie - ci, którzy wciąż oglądają oblicze Boga, albo ci, którzy nieustannie stoją przed obliczem Najwyższego. Bo, jak powiedzieliśmy wyżej, że istnieje jakiś ostatni nieprzyjaciel, tak samo powinni też istnieć jacyśs najwięksi przyjaciele - za zasługi cnót”, PSP 57/1, tłum. S. Kalinkowski, wstęp E. Stanula, oprac. S. Kalinkowski, E. Stanula, Warszawa 1994, s. 241. 
3. Kształtowanie się nauki o niebie w teologii patrystycznej - wiek III

które jest w czasie. Zdaniem Crouzela, komentującego Orygenesowski Komentarz do Listu do Rzymian 6,5254, autor antyczny podaje różne przykłady rozumienia $\alpha \iota \omega ́ v$ w odniesieniu do istot rozumnych: „długie trwanie”, „trwanie które ma kres”, ale także „nieskończenie długie trwanie” - to ostatnie dotyczyłoby życia błogosławionych. Jednak ze względu na typową dla Orygenesowego sposobu myślenia polisemię znaczenia te przenikają się, choć też oddają zakres semantyczny wymienionych trzech sposobów rozumienia $\alpha \iota \omega^{2} \nu^{255}$.

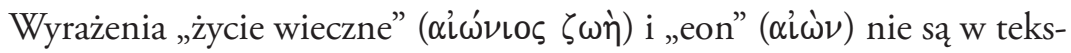
tach Aleksandryjczyka derywatami od „zawsze” ( $\alpha \in i)$ i „być”("o $\nu)$, ale, jak wskazuje Panayiotis Tzamalikos, najprawdopodobniej od terminu „ziemia” ( $\alpha \hat{\imath} \alpha)$, co podkreślałoby przestrzenny charakter ziemi obiecanej. Co więcej, Tzamalikos dowodzi, iż zarówno Crouzel, jak i Simonetti błędnie przetłumaczyli Orygenesowe sformułowanie $\alpha \pi \epsilon \iota \rho \nu \nu \alpha \hat{\imath} \hat{\omega} \nu \alpha$ jako „l'eternitè sans fin” ${ }^{256}$, gdyż właściwy termin „wieczność” nigdy nie był użyty przez Orygenesa, a w jego tekstach $\alpha i \omega ̀ \nu$ oznaczał właśnie „czas”. Rufin w swym tłumaczeniu przełożył $\alpha$ i $\omega \nu$ jako „aeternum”, w znaczeniu „ad perpetuum et aeternum tempus", co według Tzamalikosa jest niezrozumieniem myślenia Orygenesa. Pojęcie $\alpha \pi \epsilon ́ \rho \alpha \nu \tau o \zeta ~ \alpha i \omega \nu$ („,bezgraniczny niewyczerpany” eon) charakteryzuje jakość życia w najwyższym stopniu jego egzystencjalnego statusu $^{257}$, a powiązane z Logosem oznacza trwanie „bez granic”, gdyż odnosi się tylko i wyłącznie do jakości życia wiecznego. Owa „bezgraniczność” nie jest eonem samym w sobie, ale doświadczeniem radości z przebywania w tym samym miejscu. Jest to typowy przykład figury retorycznej zwanej metonimią 258 . Pojęcie $\alpha \iota \omega ́ v ı$ u Orygenesa jest homonimem stosowanym do określania „wiecznego” Boga, „wiecznego życia”, „wiecznej” śmierci i oznaczającym jakiś wymiar transcendencji.

254 Por. Origène, Commentaire sur l'Épître aux Romains 6,5, w: SCh 543. Texte critique établi par C. P. Hammond Bammel, Introduction par M. Fédou, Traduction et notes par L. Brésard et M. Fédou, Index par L. Brésard, Paris 2011, s. 116-126.

255 Por. H. Crouzel, Orygenes..., dz. cyt., s. 297-298.

256 Por. Origène, Traité des principes. t. 3 (Livres III et IV); comment. et fragments par H. Crouzel et M. Simonetti, Paris 1980, w: SCh 268, s. 77.

257 Por. Orygenes, Zachęta do męczeństwa 47, w: PG 11, k. 629.631.

258 Por. Origen, Selecta in Psalmi 22, w: PG 12, k. 1264 AB. 
Kształtowanie się nauki o niebie w teologii patrystycznej I-III wieku

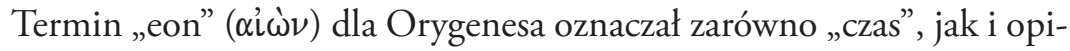
sywał „świat” w znaczeniu czasowo-przestrzennym. Sens przestrzenny wydaje się bardziej uzasadniony w tekstach Aleksandryjczyka, być może takie znaczenie tego pojęcia odczytał on w Biblii. Semantycznie wynikałoby z tego, iż według Orygenesa (w ujęciu Tzamalikosa) w wieczności dla zbawionych istnieje prawdopodobnie tylko perspektywa horyzontalna - ciągle ukierunkowana na przyszłość, brak natomiast perspektywy wertykalnej (rozumianej jako miara zmiany podczas trwania).

Stąd mówienie o koncepcji wieczności w myśli Orygenesa jest, w opinii Tzamalikosa, nieporozumieniem, gdyż nie ma u tego pisarza patrystycznego ogólnej koncepcji wieczności, a określenie rzeczownikowe $\alpha i \omega \nu$ ı̀̀ $\eta \varsigma$ („wieczność”) nie jest używane ani w NT, ani przez Orygenesa. Dlatego kuriozalne wydają się swoiste „odkrycia” koncepcji wieczności u Orygenesa,

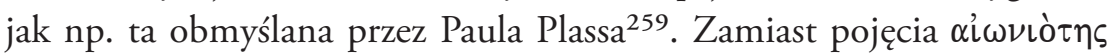
(„wieczność”) Orygenes stosuje metaforę Jerozolimy jako obrazu oddającego: „przyjaźń z Bogiem”, „bycie przyjacielem Boga”. Jerozolimą jest nazwany także Kościół, a określenie „górna Jerozolima” oddaje opisowo społeczny i relacyjny charakter życia wiecznego, rozumianego jako „miasto Boga”, „ojcowizna” czy „matka”. „Jerozolima” może zatem u Orygenesa oznaczać: „życie wieczne" - rozumiane albo jako doświadczenie osobiste, albo jako wyższa forma istnienia, albo jako opatrznościowe stworzenie Boże ${ }^{260}$. Również określenie przymiotnikowe $\alpha \imath \omega \nu \iota \varsigma^{\prime}$ („wieczny”) oznacza u Orygenesa zarówno naturalną, jak i ponadnaturalną rzeczywistość. Pojęcie to może być odnoszone i do świata stworzonego, i do Boga. Natomiast termin „eon” ( $\alpha \iota \omega ่ \nu)$ oznacza w tekstach Aleksandryjczyka odniesienie wyłącznie do świata przestrzenno-czasowego ${ }^{261}$.

259 Por. P. Plass, The concept of eternity in patristic theology, „Studia Theologica - Nordic Journal of Theology" 36/1 (1982), s. 11-25.

260 Por. Origenes, Fragmenta ex Commentariis in Ezechielem 2-12.

261 Por. P. Tzamalikos, Origen: Cosmology and Ontology of Time, Leiden-Boston 2006, s. 245-260 (Supplements to Vigiliae Christianae. Formerly Philosophia Patrum. Texts and Studies of Early Christian Life and Language 77); P. Tzamalikos, Origen: Philosophy of History and Eschatology..., dz. cyt., s. 174-188. 
3. Kształtowanie się nauki o niebie w teologii patrystycznej - wiek III

\section{Nowa jakość życia eschatologicznego}

Orygenes, opisując życie wieczne człowieka w przyszłym wieku, utrzymywał, iż będzie ono nową jakością istnienia w ciele i w duszy, odmienną od tej ziemskiej ${ }^{262}$. Pewne wyobrażenie o rodzaju takiej zmiany z kategorii ziemskiej na niebieską możemy już obecnie odczytać z zapowiedzi Nowego Testamentu. Nawiązując do Hbr 8, 5; 10; $1 \mathrm{Kol}$ 2, 17, Orygenes mówił o Ewangelii, która zawiera figury i cienie niebiańskich rzeczy. Ten figuratywny opis eschatologicznej rzeczywistości nazywał on za Ap 14, 6 „wieczną ewangelią"263. Relacja ewangelii do „wiecznej ewangelii” jest podobna do relacji pomiędzy tajemnicami Starego Testamentu, które są objawione dzięki Nowemu Testamentowi ${ }^{264}$. Analogicznie za Rz 7, 14 „prawo” jest przez niego określone jako „wieczne”, w tym sensie, że jest „duchowe”, czyli „nie podlegające zmianom czasu”, „mistyczne”265. Także głoszenie ewangelii Chrystusa jest $\alpha \delta\llcorner\alpha$ $\delta \circ \chi 0 \nu$ rozumiane jako „wieczne”, gdyż Chrystus jest opisany jako niebo, które nie przeminie i nie zostanie zniszczone ${ }^{266}$.

Komentujący powyższe teksty Panayiotis Tzamalikos stwierdza, iż widać w nich eschatologiczny charakter myśli Orygenesa, który chce opisać charakter „przyszłego czasu”. Wcielenie zmieniło bowiem znaczenie historii aż do końca istnienia czasu. Koniec, pojmowany jako apokatastaza, konstytuuje ostateczną rzeczywistość, która obecnie realizuje się poprzez proroctwa. Dlatego w Orygenesowym znaczeniu eon, potop czy zniszczenie Sodomy były zarówno historycznymi wydarzeniami, ale także mogą być rozumiane

262 Por. Origenes, Selecta in Psalmos 1, w: PG 12, k. 1093 BC.

263 Orygenes, Komentarz do Listu św. Pawta do Rzymian 1,4, w: SCh 532. Origène, Commentaire sur l'Épître aux Romains $(1,6)$, Texte critique établi par C. P. Hammond Bammel, Introduction par M. Fédou, Traduction, notes et index par L. Brésard, Paris 2009, s. 172-176; PSP 57/1, s. 54-55; Origène, Commentaire sur... (1,16)1,14, w: SCh 532, s. 231; PSP 57/1, s. 71; por. także Orygenes, Komentarz do Ewangelii wg św. Jana 1,83-84, w: SCh 120, s. 260; ŹMT 27, s. 42-43; Orygenes, Homilie do Ksiegi Kaptańskiej 4,10, w: SCh 286, s. 196-200; Orygenes, $O$ zasadach 4,3,13, w: SCh 268, s. 390.392.

264 Por. Orygenes, Komentarz do Ewangelii wg św. Jana 1,39-43, ŹMT 27, s. 221-222.

265 Por. Orygenes, Komentarz do Jana 6,44,227, w: SCh 157, s. 302; ŹMT 27, s. 199; Homilie o Księdze Kaptańskiej 13,2, w: SCh 287, s. 200-206; PSP 31/2, s. 169.

266 Por. Orygenes, Komentarz do Ewangelii wedtug św. Mateusza. Częśc druga: Commentariorum series 38,1-2, w: PG 13, k. 1652-1653; ŹMT 25, s. 61-62. 
Kształtowanie się nauki o niebie w teologii patrystycznej I-III wieku

jako figury dokonania się czegoś, wskazując, jak Boża Opatrzność działa wobec grzeszników na większą skalę. Orygenes wierzył, że Bóg objawił się pod postacią człowieka i dlatego stworzenia rozumne mogą Go poznawać do pewnego stopnia. Z tego samego powodu Bóg swoją mądrość objawia człowiekowi pod postacią ludzkich słów. Jest to jednak poznanie ograniczone, gdyż w doczesności, nawet jeśli jako ludzie jesteśmy uzdolnieni do poznawania Boga przez nasz umysł i serce, to nie widzimy go jednak, jakim jest On rzeczywiście. Bóg objawia się nam wyłącznie tak, jak On chce, abyśmy Go widzieli ${ }^{267}$. Tak rozumiana „wieczna ewangelia” stanowi zatem duchową treść, częściowo ukrytą w tekście Pisma Świętego. Zawiera ona mądrość Bożą, owe niewidzialne rzeczy, o których Orygenes tak często mówi, kiedy odnosi się do $\mathrm{Rz} 1,10^{268}$.

Jak zaznacza Tzamalikos, Orygenesowe pojmowanie historii nie będzie zatem jakąś wypadkową pomiędzy grecką cyklicznością a chrześcijańskim teleologicznym widzeniem czasu. To pierwsze odzwierciedlałoby naturalne postrzeganie cykliczności zmian otoczenia jako swoistego koła czasów ${ }^{269}$. Natomiast dla Orygenesa czas ma charakter przede wszystkim teleologiczny i jest umieszczony pomiędzy początkiem i końcem. Przy czym dla Orygenesa niezmiernie ważną jest sama jakość cech czasu, szczególnie jakościowe rozumienie „końca” ( $\tau^{\prime} \lambda \mathrm{o} \varsigma$ ). Stąd wszystkie partykularne jakości czasu i historii nabierałyby teleologicznego charakteru. Myśl Orygenesa jest zaabsorbowana kluczowym rozumieniem historycznych akcji, szczególnie w perspektywie czasu, który ma nadejść. Orygenesowa

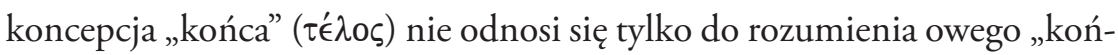
ca”, ale przede wszystkim do rozumienia „wypełnienia” obietnic i realizacji oczekiwania, w sensie wiary i nadziei. Tak pojmowana koncepcja historii byłaby u Orygenesa charakteryzowana przez pojęcia: opatrzność - proroctwo - obietnica - oczekiwanie - realizacja - antycypacja - wiara - nadzieja - wypełnienie - koniec. Rozwój człowieka dokonywałby się zatem

267 Por. Orygenes, Komentarz do Ewangelii wedtug Mateusza 17,19, w: PG 13, k. 1536.1537; ŹMT 10, s. 346-347.

268 Por. P. Tzamalikos, Origen: Philosophy of History and Eschatology..., dz. cyt., s. 96$97,106$.

269 Por. Arystoteles, Fizyka 223b, w: Arystoteles, Zachęta do filozofii. Fizyka, tłum. K. Leśniak, Warszawa 2010, s. 184-185. 
poprzez podejmowanie w wolnej woli moralnych czynów, w kierunku końca rozumianego jako zbawienie ${ }^{270}$.

Życie wieczne, oprócz swego podstawowego i najważniejszego celu, który znajduje dopełnienie w Bogu, byłoby według Orygenesa także rozwojem jakiejś wymiernej materialności stworzeń. Kosmologicznie byłyby to światy i przestrzenie posiadające odmienną jakość od tej, jaką spotykamy w obecnej doczesności ${ }^{271}$, a które Aleksandryjczyk w typowej dla siebie polisemii sprowadza do wyboru pomiędzy trzema możliwymi opiniami:

„Zgodnie przeto z tym, co mogłem pojacć, naszkicowałem trzy opinie na temat kresu wszystkich istot i na temat doskonałej szczęśliwości, a każdy czytelnik niechaj sam staranniej i dokładniej rozważy, czy którąś z nich można zaaprobować i przyjąć. Powiedziano mianowicie tak: (I) Albo trzeba uznać, że można wieść życie w stanie bezcielesnym wtedy, gdy "wszystko zostanie poddane Chrystusowi», a przez Chrystusa Bogu Ojcu, kiedy «Bóg będzie wszystkim we wszystkim» (por. 1 Kor 15, 27-28).

(II) Albo, że kiedy "wszystko będzie poddane Chrystusowi», a przez Chrystusa Bogu, z którym istoty rozumne, będąc duchami, staną się «jednym duchem», wówczas zabłyśnie również substancja cielesna zjednoczona z najlepszymi i najczystszymi duchami oraz przemieniona w stan eteryczny stosownie do wartości i zasług istot, które ją przybiorą, a stanie się to zgodnie ze słowami Apostoła: "I my się odmienimy» (1 Kor 15, 52).

(III) Albo należy z pewnością uznać, że miejsce pobytu istot świętych i błogosławionych mieści się ponad sferą gwiazd stałych niczym w «dobrej ziemi» i w "ziemi świętych», którą otrzymują w dziedzictwie cisi i łagodni; stanie się to po przeminięciu postaci tego, co dostrzegalne, po strząśnięciu i oczyszczeniu wszelkiej zniszczalności oraz po przebyciu

270 P. Tzamalikos, Origen: Philosophy of History and Eschatology..., dz. cyt., s. 143.

271 Orygenes, $O$ zasadach 2,3,6, w: SCh 252. Origène, Traité des Principes. t. 1 (Livres I et II). Introduction, texte critique de la version de Rufin, traduction par H. Crouzel et M. Simonetti, Paris 1978, s. 264-270; ŹMT 1, tłum. i oprac. S. Kalinkowski, fragmenty z Filokalii tłum. K. Augustyniak, wprowadzenie H. Pietras, Kraków 1996, s. $152-155$. 
Kształtowanie się nauki o niebie w teologii patrystycznej I-III wieku

i przekroczeniu całego stanu tego oto świata, w którym, jak powiedziano, zawierają się sfery planet. Niebem dla tamtej ziemi jest to, co ją otacza i obejmuje wspaniałym obwodem, a co nosi prawdziwą i pierwotną nazwę nieba ${ }^{272}$. W owym niebie i owej ziemi w pewnym i bezpiecznym miejscu może istnieć kres wszystkiego i doskonałość: jedni mianowicie po odbyciu kar, które za swe występki ponieśli dla osiągniecia oczyszczania, po dopełnieniu wszystkiego i po odpokutowaniu zasłużą na to, żeby zamieszkać na owej ziemi; inni natomiast, którzy byli posłuszni Słowu Boga i już tutaj okazali się zdolni do przyjęcia Jego mądrości i ulegli wobec Niego, zostaną uznani za takich, którzy «zasłużyli na królestwo niebieskie» (por. Mt 5, 5. 3). W ten sposób godniej dopełni się to, co powiedziano: "Błogosławieni cisi, albowiem oni posiądą w dziedzictwie ziemię", "błogosławieni ubodzy w duchu, albowiem oni otrzymają w dziedzictwie królestwo niebieskie» (Mt 5, 4. 3), oraz spełnią się słowa Psalmu: "On cię wyniesie, abyś posiadł ziemię» (Ps 37(36), 34). Mówimy bowiem, iż na naszą ziemię się zstępuje, do tamtej natomiast, na wysokościach, «jest się wynoszonym». Zdaje mi się zatem, że w ten sposób między ową ziemią i niebiosami otwiera się przed czyniącymi postępy świętymi jak gdyby jakaś droga: otóż wydaje się, że na ziemi tej święci nie tyle pozostają na stałe, ile raczej mieszkają - mianowicie jako ci, którzy po określonym rozwoju przejdą do dziedzictwa królestwa niebieskiego" 273 .

272 Orygenes, $O$ zasadach, Fragmenty $i$ świadectwa 2,3, F: Hieronim ze Strydonu, List 124, 5: I dalej: „Zebrałem więc trzy hipotezy na temat końca świata, a czytelnik niechaj rozstrzygnie, która z nich jest lepsza i prawdziwa. Albowiem albo będziemy żyć bez ciała, gdy podlegając Chrystusowi, będziemy poddani Bogu, a Bóg będzie wszystkim we wszystkim; albo, jak to, co podlega Chrystusowi, wraz z Chrystusem będzie poddane Bogu i zostanie zjednoczone w jednym związku, tak też wszelka substancja będzie doprowadzona do najlepszej wartości i przemieni się w eter, którego natura jest czystsza i prostsza; albo z pewnością tak zwana sfera gwiazd stałych oraz wszystko, co zawiera się w jej okręgu, całkowicie zginie, ta natomiast, która otacza i obejmuje antysferę, będzie się nazywać «dobrą ziemią», a jeszcze inna sfera, która otacza tamtą kręgiem i zwie się niebem, zostanie przeznaczona na mieszkanie świętych", ŹMT 1, s. 158 .

273 Orygenes, $O$ zasadach 2,3,7, w: SCh 252, s. 270-274; „His igitur tribus opinionibus de fine omnium et de summa beatitudine prout sentire potuimus adumbratis, unusquisque legentium apud semetipsum diligentius et scrupulosius iudicet, si potest aliqua darum probari uel eligi. Dictum est enim quod uel incorporea uita agi posse putanda 
3. Kształtowanie się nauki o niebie w teologii patrystycznej - wiek III

We wszystkich trzech możliwych koncepcjach do nieba zbawionych wprowadza Chrystus. Podobnie w innych tekstach Aleksandryjczyka możemy spotkać jego metaforyczne określenia dotyczące życia wiecznego zbawionych, które wskazują, że, czy to kontemplacja Bożych rzeczy ${ }^{274}$, czy stawanie się doskonałym jak Chrystus w miejscu Chrystusa, dokonują się właśnie dzięki Chrystusowi ${ }^{275}$. Życie wieczne we wszystkich trzech proponowanych przez Orygenesa opiniach byłoby też dla człowieka zbawionego nową jakością istnienia: albo w stanie bezcielesnym (I), albo w stanie duchowym - w zjednoczeniu ze wszystkimi bytami rozumnymi (II), albo ponad sferą gwiazd stałych (III). Tę trzecią możliwość Orygenes przyrównuje do przebywania zbawionych gdzieś „powyżej”, na jakiejś „,dobrej ziemi”, w „ziemi świętych”, kiedy ludzie „po oczyszczeniu z doczesności” przyjęli już Mądrość Słowa Bożego. Przebywanie na owej „nowej ziemi” czy w „nowym niebie”, to pobyt $\mathrm{w}$ „pewnym i bezpiecznym miejscu”, gdzie istnieje

sit, posteaquam Christo fuerint, subiecta omnia et per Christum Deo Patri, cum erit omnia et in omnibus Deus; uel cum nihilominus Christo fuerint universa subiecta et per Christum Deo, cum quo et unus spiritus secundum hoc, quod spiritus sunt naturae rationabiles, fiunt, tunc ipsa quoque substantia corporalis optimis ac purissimis spiritibus sociata pro assumentium uel qualitate uel meritis in aetherum statum transmutata, secundum quod apostolus dicit: Et nos inmutabimur, refulgebit; aut certe quod eorum quae uidentur habitu praetereunte omni corruptibilitate decussa atque purgata omnique hoc mundi statu, in quo planetarum dicuntur sphaerae, supergresso atque superato, supra illam, quae $\dot{\alpha} \pi \lambda \alpha \nu$ '́ dicitur, sphaeram piorum ac beatorum statio collocatur, quasi in terra bona et terra uiuorum, quam mansueti et mites haereditate percipient; cuius est caelum illud, quod ambitu magnificentiore ipsam illam circumdat et continet terram, quod uere caelum et principaliter appellatur, in quo caelo uel terra finis omnium atque perfectio tuta ac fidissima possit statione consistere, quo scilicet illi post correptionem castigationum, que quas pro delictis pertulerant purgationis obtentu, expletis omnibus atque depensis, terrae illius habitaculum mereantur, hi uero, qui uerbo Dei obedientes fuerunt ac sapientiae eius iam hinc capaces se obtemperantes praebuerunt, caeli illius uel caelorum regna promereri dicantur, et ita dignius conpleatur illud, quod dictum est: Beati mansueti, quia ipsi hereditate possidebut terram et beati pauperes spiritu, quoniam ipsi hereditatem capient regnum caelorum et quod dicit in psalmo: Exalabit te et hereditate terram. Ad hanc etenim terram descendi dicitur, ad illam autem, quae in alto est, exaltari. Hoc ergo modo uidetur quasi iter quoddam sanctorum profectibus aperiri ab illa terra ad illos coelos, ut non tam permanere in illa terra quam habitare uideantur, transituri scilicet, cum in id quoque profecerint, ad hereditatem regni caelorum", ŹMT 1, s. 156-157.

274 Por. Orygenes, Przeciw Celsusowi 6,23, w: SCh 147, s. 236.238; PSP 17bis, s. 302-303.

275 Por. Orygenes, $O$ zasadach 3,1,19, w: SCh 228, s. 114-124; ŹMT 1, s. 246-248. 
Kształtowanie się nauki o niebie w teologii patrystycznej I-III wieku

„kres wszystkiego i doskonałość”. Co ciekawe, wydaje się, że przebywanie zbawionych powyżej gwiazd stałych, w nowej ziemi i w nowym niebie, nie byłoby czymś ostatecznym. Orygenes zakłada, iż byłby to kolejny stopień rozwoju błogosławionych, po którego zakończeniu przechodziliby oni dalej do „dziedzictwa królestwa niebieskiego”...

Życie wieczne jest opisywane przez Orygenesa jako czynny stan akcji zbawionych, który jest zarazem doskonałą ofiarą i doskonałą pobożnością, a oba te aspekty są dziełami ciągłego błogosławienia Boga ${ }^{276}$. W związku z powyższymi tezami Orygenesa Tzamalikos odrzuca jako błędną opinię Crouzela i Simonettiego, których zdaniem, według Aleksandryjczyka, życie wieczne byłoby jakimś niezmiennym stanem dla zbawionych ${ }^{277}$. Zdaniem Tzamalikosa, kiedy Orygenes komentuje Ps 29, 7 i odnosi pojęcie „odpoczynek” do najwyższego miejsca na świecie ${ }^{278}$, to nie zakłada tym samym jakiejś inercji w idylliczności, ale ma on raczej na myśli wymogi ludzkiego życia w racjonalności. Ciągła zmienność jest fundamentem całego świata. Zatem kiedy Orygenes mówi o „odpoczynku”, to odnosi się do przemiany jakości życia, z poziomu życia na ziemi (istnienie poddane cierpieniom, trudowi) do życia w najwyższym, czyli najdoskonalszym miej-

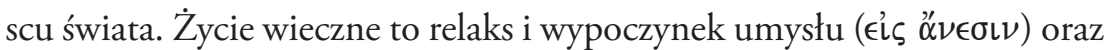

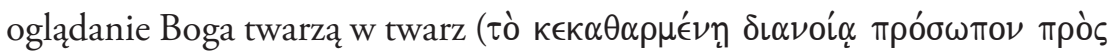

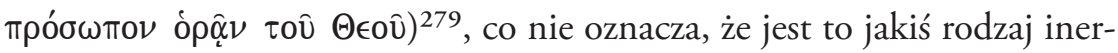
cji. Odpoczynek nie oznacza braku aktywności, jest to rodzaj odpoczynku właściwego świętym (bycie z Jezusem Chrystusem; korzystanie z własnego szczęśliwego spokoju; oglądanie całego żywego Słowa; bycie karmionymi Słowem; rozumienie kunsztownej mądrości zawartej w Słowie; bycie

276 Por. Origenes, Selecta in Deuteronomium 8,7, w: PG 12, k. 809C; Origenes, De oratione 27,13, w: PG 11, k. 519.521; Orygenes, O modlitwie 27,13: „Wobec takiego stanu rzeczy i przy tak wielkiej różnorodności pokarmów jeden i przewyższający wszelkie wyżej wymienione jest "powszedni chleb», o który mamy się modlić, abyśmy się go stali godni i zostali przebóstwieni Bożym Słowem, posilając się tym, co «było na początku u Boga» (J 1, 1). (...) Pismo często wieczność nazywa «dzisiaj» (...) Skoro «dzisiaj» znaczy cały obecny okres, być może "wczoraj» oznacza wiek ubiegły. (...) Nic dziwnego, że dla Boga cały czas tak długo trwa, jak u nas jeden dzień, a uważam, że nawet jeszcze krócej”, w: Odpowiedź na Stowo. Najstarsi mistrzowie..., dz. cyt., s. 198-200.

277 Por. Origène, Traité Des Principes, Paris 1978, w: SCh 252, s. 164.

278 Por. Origenes, Selecta in Psalmos 29, w: PG 12, k. 1293D-1295A.

279 Por. Origenes, Selecta in Psalmos 139, w: PG 12, k. 1664D-1265A. 
3. Kształtowanie się nauki o niebie w teologii patrystycznej - wiek III

naznaczonymi przez samą prawdę; posiadanie umysłu oświeconego przez prawdziwe i nieskończone światło wiedzy; oglądanie oczami oświeconymi rozkazem Pana tego, co daje się ujrzeć tej światłości) ${ }^{280}$.

Życie wieczne pojmowane jako odpoczynek jest zatem czymś czynnym, co wynika zdaniem Orygenesa z dwóch podstawowych przesłanek: jest ono sytuacją czasowo-przestrzenną, jest umiejscowione w szczególnym miejscu świata; gdzie świadome i żywe stworzenia są obdarzone wolną wolą. Tak rozumiane życie wieczne nie oznacza więc jakiegoś niekończącego się trwania, co pozostaje cały czas w zgodzie z koncepcją czasu pojmowanego jako skończony ${ }^{281}$.

Charakterystyczna, na zasadzie swoistego kontrapunktu, jest Orygenesowa koncepcja „wiecznej śmierci”282. Orygenes wyróżniał trzy rodza-

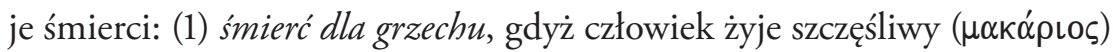
dla Boga. To śmierć duchowa dla grzechu, dlatego też nazywana szczęśliwą, mistyczną. Ten rodzaj śmierci polega na ascezie dnia codziennego i umieszcza wierzącego w misterium śmierci i zmartwychwstania Chrystusa (por. Rz 6, 10-12) ${ }^{283}$; (2) śmierć w grzechu ( umiera dla Boga. Jest to śmierć człowieka, który grzeszy i tego rodzaju śmierci należy się obawiać (por. Ez 18, 4; Mt 8, 22; 10, 28) ${ }^{284}$; (3) śmierć

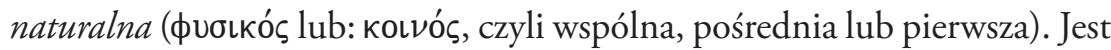
to śmierć fizyczna, która polega na oddzieleniu duszy od ciała i podlegają

280 Por. Orygenes, Zachęta do męczeństwa 47, w: PG 11, k. 629.631; PSP 24, s. 170.

281 Por. P. Tzamalikos, Origen: Philosophy of History and Eschatology..., dz. cyt., s. 217-222.

282 Por. H. Crouzel, Mort et immortalité selon Origène, „Bulletin de Littérature Ecclésiastique" 79 (1978), s. 19-38, 81-96, 181-196; H. Crouzel, Morte e immortalità nel pensiero di Origene, w: Morte e immortalità nella catechesi dei Padri del III-IV secolo, ed. S. Felici, Roma 1985, s. 41-46 (Biblioteca di Scienze Religiose 66)

283 Por. Origenes, Disputatio cum Heracleida 25, w: SCh 67, s. 104; przekład polski Orygenes, Dyskusja z Heraklidesem: „Otóż najpierw - według apostoła - ktoś, żyje dla Boga (por. Rz 6, 10); i inne zdanie: umart dla grzechu (por. Rz 6, 2). Śmierć tego rodzaju jest śmiercią błogosławioną: wszak ktoś umiera dla grzechu. Tą właśnie śmiercią zmarł Pan mój; powiedziano bowiem: umartszy umart dla grzechu (por. Rz 6, 10)", tłum. A. Zajkowski, „Studia Theologica Varsaviensia” 5 (1967) nr 2, s. 175.

284 Por. Orygenes, Disputatio cum Heracleida 25, w: SCh 67, s. 104; przekład polski Dyskusja z Heraklidesem: „Znam też drugi rodzaj śmierci: gdy ktoś umiera dla Boga. O tej śmierci powiedziano: Dusza, która zgrzeszy - sama umrze (por. Ez 18, 4)”, „Studia Theologica Varsaviensia" 5 (1967) nr 2, s. 175. 
Kształtowanie się nauki o niebie w teologii patrystycznej I-III wieku

jej wszyscy ludzie (por. Rdz 5, 6) ${ }^{285}$. W odniesieniu do Gehenny czy miejsca poniżej Hadesu - śmierć w tekstach Orygenesa oznacza koniec ( $\tau \dot{\epsilon} \lambda \mathrm{o} \varsigma$ ) w znaczeniu bycia najbardziej oddalonym od Boga ${ }^{286}$.

Jeśli „życie wieczne” oznacza zatem jakościową bliskość Boga, to „śmierć wieczna” oznacza jakieś miejsce najbardziej oddalone od Boga i całkowicie

285 Por. Orygenes, Disputatio cum Heracleida 25, w: SCh 67, s. 102; przekład polski Dyskusja z Heraklidesem: „Znam również trzeci rodzaj śmierci. Jest to śmierć w powszechnym mniemaniu: ci pomarli, którzy ciała opuścili. W tym właśnie sensie powiedziano: żyt Adam lat dziewię́set, a potem umart (por. Rdz 5, 5)”: „Studia Theologica Varsaviensia" 5 (1967) nr 2, s. 174-175; Orygenes, Commentarii in Epistulam ad Romanos 6,6, w: PG 14, k. 1068A; SCh 543, s. 128-134; przekład polski Komentarz do Listu św. Pawta do Rzymian, PSP 57, tłum. S. Kalinkowski, Warszawa 1994, s. 318-320.

286 Por. Orygenes, Komentarz do Ewangelii wedtug św. Jana 13,37.(244), w: SCh 222, s. 160.162; „Pierwszeństwem nie nazywam tego, co można kojarzyć z potęgą, lecz to, co jest przeciwieństwem końca i bliskie temu, co było na początku. Jak więc dla człowieka pierwszeństwem był pobyt w raju, a końcem - na skutek przestępstwa - pobyt w niskości, w Hadesie albo w jakimś tego rodzaju miejscu, tak też i każdemu bytowi, który upadt, dane było niegdyś jakieś pierwszeństwo", ŹMT 27, s. 323; Orygenes, O zasadach 4,3,10.(23), w: SCh 268, s. 378-382; „Bo może, jak ci, którzy po odejściu z tego świata z powodu wspólnej wszystkim śmierci są umieszczani wedle swych czynów i zasług zgodnie z wydanym na nich wyrokiem - jedni w miejscu, które nazywa się Otchłanią, a inni na «łonie Abrahama» i w różnych miejscach i siedzibach, tak samo ci, którzy, że tak powiem, tam (w niebie) umierają, zstępują z tamtejszych wyżyn w tutejszą otchłań. Wierzę bowiem, że otchłań, do której sprowadzane są stąd dusze umarłych, ze względu na to właśnie rozróżnienie została nazwana przez Pismo "głębszą otchłanią», tak jak powiedziano w Psalmach: «I uwolniłeś duszę moją z głębszej otchłani» (por. Ps 86(85), 13). Każdy więc, kto zstępuje na ziemię wedle swych zasług albo stanowiska, które tam zajmował, na tym świecie jest umieszczany w różnych miejscach, wśród różnych ludów oraz w różnych warunkach, rodzi się w niedostatkach, pochodzi z rodziców bogobojnych albo bezbożnych, tak, że zdarza się niekiedy, że Izraelita zstępuje do Scytów, a nędzarz egipski zostaje wprowadzony do Judei. Jednakże Zbawiciel nasz przyszedł zgromadzić «owce, które poginęły z domu Izraela» (Mt 15, 24), a ponieważ wielu Izraelitów nie poddało się Jego nauce, wezwani zostali ci, którzy pochodzili z pogan. Wydaje się więc, iż proroctwa głoszone na temat poszczególnych ludów należy słusznie odnosić raczej do dusz i do różnorakich ich siedzib niebieskich. Ponieważ jednak rzeczywiste wydarzenia często nie zgadzają się z opisami wypadków historycznych, które miały się przydarzyć ludowi Izraela, Jerozolimie albo Judei podczas najazdów tych czy innych ludów, trzeba przebadać te opisy i zastanowić się, czy nie odnoszą się one raczej do ludów dusz, które mieszkały w owym niebie, o którym powiedziano, że «przeminie» (por. Mt 24, 35), albo, jak wypada sądzić, jeszcze tam zamieszkują", ŹMT 1, s. 361 (por. Hieronim ze Strydonu, List 124,11, ŹMT 1, s. 376). 
nieracjonalne ${ }^{287}$. Gehenna byłaby zatem miejscem kary, które jest usytuowane w tym świecie (eonie), gdyż zużywanie i karanie dotyczy miejsca. Karanie zakłada też osądzanie, a sądzenie zakłada spełnienie w tym eonie. Gehenna byłaby zatem przeniesieniem po sądzie do jakiegoś czasoprzestrzennego wymiaru, gdzie ludzie będą ukarani po osądzeniu całego świata, analogicznie jak po sądzie do „górnego Jeruzalem” będą przeniesieni zbawieni. Dlatego Tzamalikos uznaje za błędną opinię Crouzela, zdaniem którego Orygenes twierdził, iż raj będzie otworzony dla świętych jeszcze przed powszechnym zmartwychwstaniem. Orygenes uznawałby zarówno „życie wieczne”, jak i „śmierć wieczną” za specyficzne jakości życia, a nie jako

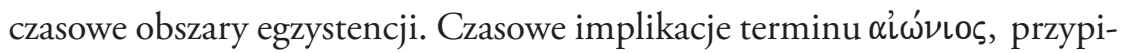
sywane stworzeniom, są zatem mniejszej wagi, gdyż nie mają one powiązania z niebem rozumianym jako najwyższe trwanie z Bogiem ani z piekłem rozumianym jako trwanie najbardziej oddalone od Boga. Wiecznym w pełnym tego słowa znaczeniu, czyli w znaczeniu absolutnym jest tylko aczasowy Bóg. Tam, gdzie Orygenes odnosi termin „wieczny” do bytów stworzonych, jego sformułowania mają wymiar kaznodziejsko-dydaktyczny, ale nie jest to Boża konotacja wieczności. Stąd sformułowanie „życie wieczne” oznacza u Orygenesa jakościowy status życia obiecany przez Boga tym, którzy dążą do zbawienia i mają nadzieję je osiagnąć. To nadzieja jest fundamentem tego oczekiwania wierzacych ${ }^{288}$.

\section{Powszechna doskonałość stworzeń w eschatonie}

Orygenes, komentując 1 Kor 15, 25-28 mówił o doskonałości wszystkich ${ }^{289}$. Nastąpi to, kiedy wszyscy „wrogowie” zostaną podporządkowani Chrys-

287 Por. Orygenes, Komentarz do Ewangelii wedtug Mateusza Mt 17, 16, w: PG 13, k. 1529A; „(...) nie tylko z uczty został wyrzucony, ale także skazany na miejsce pozbawione wszelkiego światła, gdzie głębsza niż w innych ciemnościach panowała ciemność, zwana

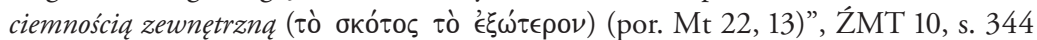
(por. Origenes, Exposita in Proverbia 19, w: PG 17, k. 209º.

288 Por. H. Crouzel, L'Hadès et la Géhenne selon Origène, „Gregoriana” 59 (1978), s. 330 331; P. Tzamalikos, Origen: Philosophy of History and Eschatology..., dz. cyt., s. 223-233.

289 Por. Orygenes, Komentarz do Ewangelii wedtug św. Jana 32,3.(27-39), w: SCh 385, s. 198-204; „(27). (...) Abyśmy jednak mogli lepiej zrozumieć, co znaczy zdanie: "Ojciec dał Mu wszystko w ręce», odwołamy się do następującej wypowiedzi: «Bo jak w Adamie wszyscy umierają, tak w Chrystusie wszyscy będą ożywieni» (1 Kor 15, 22). (28). Chociaż jednak «Ojciec dał Mu wszystko w ręce» oraz «w Chrystusie wszyscy 
Kształtowanie się nauki o niebie w teologii patrystycznej I-III wieku

tusowi, a Ten ostatecznie przyniesie wszystkich Ojcu. Aleksandryjczyk tak pojęty koniec ( $\tau \dot{\epsilon} \lambda$ $\varsigma_{\text {) }}$ rozumie jako życie wieczne stworzeń ${ }^{290}$. Odnosząc do tych tez Orygenesa obietnicę zniesienia zła zapowiedzianą w Ap 3, 12; 21, 11 oraz Orygenesowski komentarz o odbudowie Jerozolimy z Iz 54, 11 14 i Iz 60, 13-20 (LXX) ${ }^{291}$, Crouzel uznał, iż Orygenes rozwija tam koncepcję całkowitego zniesienia zła ${ }^{292}$, którą określa jako „wielką nadzieję”

będą ożywieni» to jednak sprawiedliwość Boża nie ulega naruszeniu, a każdy czyn jest oceniany wedle zasługi. Wynika to stąd, że do zdania: «Tak w Chrystusie wszyscy będą ożywieni», dodano: «Lecz każdy według własnej kolejności» (1 Kor 15, 23). (29). Jeśli zwrócisz uwagę na wypowiedź «Najpierw Chrystus, potem ci, co należą do Chrystusa w czasie Jego przyjścia; wreszcie nastąpi koniec» (1 Kor 15, 23-24), zrozumiesz również, jak różne są kategorie ludzi, którzy zostaną ożywieni w Chrystusie, kiedy wypełnią się słowa: «Ojciec dał Mu wszystko w ręce». Ów koniec nastanie wraz z Chrystusem w czasie Jego przyjścia, kiedy to Zbawiciel «przekaże królowanie Bogu i Ojcu», pokonawszy uprzednio "wszelką Zwierzchność, Władzę i Moc» (1 Kor 15, 24). (30). Sądzę, że to przeciwko nim trwa walka, aby nie były już Zwierzchnością, Władzą i Mocą, z którymi toczy się walka (por. Ef 6, 12). Dlatego też po pokonaniu wszelkiej Zwierzchności, Władzy i Mocy nie będzie już więcej walki. (...). (35). Jezus wyszedł od Boga z przyczyny tych, co odsunęli się od Niego; znalazł się poza Bogiem jako istota, która z natury rzeczy nie chciała opuścić Ojca, czyniąc tak dlatego, aby to, co odsunęło się, powróciło do rąk Bożych przez naukę i polecenie Jezusa, otrzymując nakaz udania się w ślad za Nim do Boga. Ci bowiem, którzy idą za Jezusem, dojdą do Stwórcy. (...). (37). Powinieneś uznać, że coś podobnego, wedle pewnej stosownej analogii, będzie powiedziane do każdego z tych, których Ojciec przekazał w ręce Syna. Do każdego bowiem zostaną powiedziane słowa: «Pójdziesz za mną później» (J 13, 36). (38). Jeśli jednak nie mieli pójść za Nim od razu, to w zdaniu: «Pójdziesz za mną później» słowo «później» nie oznacza tej samej właściwej pory dla każdego z tych, którzy za Nim pójdą. (39). To samo powinieneś myśleć również o wszystkich istotach pokonywanych, o czasie, gdy zwycięży wszelką Zwierzchność, wszelką Władzę czy wszelką Moc, i w ogóle: «Aż położy wszystkich nieprzyjaciół swoich pod swe stopy. Jako ostatni wróg zostanie pokonana śmierć (1 Kor 15, 26-27)»", ŹMT 27, s. 508-510.

290 Por. Orygenes, $O$ zasadach 3,5,6-8, w: SCh 268, s. 228-234; ŹMT 1, s. 305-307; zob. także Origenes, Commentarii in Genesim 3, w: PG 12. Origenis Opera Omnia, tomus secundus..., dz. cyt., k. 89 BC.

291 Por. Orygenes, Komentarz do Ewangelii wedtug św. Jana 10,42.(288-296), w: SCh 157, s. 560-564; ŹMT 27, s. 274-276.

292 Por. Orygenes, Komentarzu do Ewangelii wedtug św. Jana 10,42(295), w: SCh 157, s. 564; „Otóż proroctwo to, skierowane do synów izraelskich przebywających w niewoli,

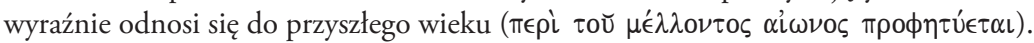
(...) wynika stąd jasno, że jeńcy znajdą się kiedyś w świątyni i powrócą tam, aby ją odbudować, stając się najcenniejszymi jej kamieniami. Albowiem i w Apokalipsie Jana pewien zwycięzca otrzymał obietnicę, że będzie filarem świątyni Bożej i że nie wyjdzie już na zewnątrz (por. Ap 3, 12), ŹMT 27, s. 275-276. 
3. Kształtowanie się nauki o niebie w teologii patrystycznej - wiek III

na totalne zniesienie $\mathrm{zła}^{293}$. W opinii Tzamalikosa Orygenes nie tyle wyrażał nadzieję na zupełne zniesienie zła, co dosyć labilnie opowiadał się za koncepcją „doskonałości wszystkich”. Owo niezdecydowanie wynikałoby z tego, że chodzi o tajemnicę większą i trudniejszą w spekulacji niż inne. Raz owa „doskonałość wszystkich” raz jest ujmowana jako realne i doskonałe zmartwychwstanie ciała Chrystusa ${ }^{294}$, raz jako zmartwychwstanie rozsądnego człowieka ${ }^{295}$, a jeszcze kiedy indziej jako zmartwychwstanie każdego członka ciała Chrystusa, które było zagubione i zostało przywrócone w jego właściwe miejsce ${ }^{296}$. Istotne jest, że zdaniem Orygenesa Jezus doskonali wszelkie stworzone istoty rozumne, przez co wypełnia On wolę Ojca i doprowadza do końca dzieło Ojca ${ }^{297}$.

293 Por. H. Crouzel, L'Hadès et la Géhenne selon Origène..., dz. cyt., s. 331.

294 Por. Orygenes, Komentarz do Ewangelii wedtug św. Jana 10,36(236), w: SCh 157, s. 524; "Skoro więc dokonało się już owo zmartwychwstanie prawdziwego i doskonałego ciała Chrystusowego, to i obecne członki Chrystusa, które w porównaniu z przeszłym ciałem są suchymi kośćmi, zostaną zebrane kość do kości i spojenie do spojenia, a nikt, komu brak spojenia, nie stanie się doskonałym człowiekiem i nie dojdzie do «miary wielkości pełni» ciała Chrystusowego (Ef 4, 13)”, ŹMT 27, s. 264.

295 Por. Orygenes, Przeciw Celsusowi 4,30, w: SCh 136, s. 256; „(...) Albowiem zmartwychwstanie sprawiedliwych, którego istotę potrafią zrozumieć tylko mędrcy, porównuje apostoł ze słońcem, księżycem i gwiazdami: (1 Kor 15, 41-42)”, PSP 17bis, s. 202.

296 Por. Orygenes, Komentarz do Ewangelii wedtug św. Jana 10,36.(237-238), w: SCh 157, s. 524; „Wówczas liczne członki będą jednym ciałem, ponieważ wszystkie członki, chociaż jest ich wiele, stanowią jedno ciało (por. 1 Kor 12,12). Co się zaś tyczy oceny ręki, nogi, oka, ucha, nosa i części, które osobno tworzą głowę i osobno nogi, oraz pozostałych członków, słabszych i godnych mniejszego szacunku, brzydkich i pięknych, to dokonać jej może tylko Bóg, który zwiąże ciało. (238). I wówczas raczej niźli teraz większej udzieli czci temu, któremu jej brakuje, aby nie było już «rozdarcia w ciele, lecz żeby członki dbały jednakowo o siebie nawzajem», i jeśli jeden członek doznaje jakiejś korzyści, żeby korzystały z niej wszystkie członki, a jeśli jeden doznaje poszanowania, żeby wszystkie radowały się wraz z nim" (por. 1 Kor 12, 23-26), ŹMT 27, s. 264; podobnie Orygenes, Homilie o Księdze Kaptańskiej 7,2, PSP 31/2, s. 89-91.

297 Por. Orygenes, Komentarz do Ewangelii wedtug św. Jana 13,37.(245), w: SCh 222, s. 162; „Jezus, doskonaląc dzieło Boże, to znaczy wszelką istotę rozumną, a nie tylko człowieka, udoskonala je w jednakowy sposób. Istoty szczęśliwe, posłuszne Rozumowi i nie potrzebujące cierpienia, są udoskonalane przez sam Rozum, inne zaś byty, nieposłuszne Rozumowi, podlegają cierpieniom, aby zaznawszy ich, mogły być przywiedzione do rozsądku i kiedyś w przyszłości zostać przez Niego udoskonalone. (246). Zresztą obie sprawy: wypełnienie woli tego, który posłał Jezusa, oraz doprowadzenie do końca Jego dzieła, stanowią jedyny pokarm Jezusa”, ŹMT 27, s. 323. 
Kształtowanie się nauki o niebie w teologii patrystycznej I-III wieku

Zdaniem Tzamalikosa opisywane ujęcie Orygenesa to teleologiczna interpretacja historii, a sama historia jest czynnością i oczekiwaniem („dopóki”) w eonie, który nadejdzie (' $\left.\epsilon \nu \tau \hat{\omega} \mu \mu^{\prime} \lambda \lambda \nu \nu \tau \iota \alpha \hat{\imath} \hat{\omega} \nu \iota\right)$. Jest to fraza często powtarzana przez Orygenesa, oznacza ostateczny wymiar rzeczywistości. Stąd w Orygenesowym myśleniu o życiu wiecznym pojawia się też teza tajemniczego „po” życiu wiecznym, gdyż „do” (życia wiecznego) zakłada „po”. Owo „po” ujmowałoby znaczenie ostatecznego końca ( $\tau$ '́ $\lambda$ os), który oznaczałby tę rzeczywistość eschatologiczną, kiedy Chrystus odda wszystkich Ojcu. Stąd nawet „powszechna doskonałość” stworzeń nie byłaby ostatecznym końcem / celem ${ }^{298}$. Treścią chrześcijańskiej nadziei na życie wieczne nie jest bowiem tylko radość czy kontemplacja wizji rzeczy Bożych, ale owo wejście stworzenia do bezczasowego życia Boga. Tak pojmowana nadzieja może być spełniona jedynie przez Chrystusa, co według Orygenesa zostało zapowiedziane przez Chrystusa, kiedy określa się dla wierzących nie tylko „drogą” (J 14, 6), ale i „bramą” do Boga (J 10, 9) ${ }^{299}$. Końcem / celem tej „drogi” człowieka jest wejście przez „bramę Chrystusa” w „szabat Pana”, czyli jedność z Trójcą która na nas czeka ${ }^{300}$.

298 Por. Orygenes, Przeciw Celsusowi 4,17, w: SCh 136, s. 224; (...) dostrzegłby, że Bóg dał szczególny dowód swej dobroci wobec ludzi, gdy zstąpił, aby przywołać do siebie „owce domu izraelskiego, które poginęly” (Mt 15, 24), jak tajemniczo powiada Pismo, owce, które zeszły z gór i do których - zgodnie z tym, co napisano w różnych przypowieściach (por. Mt 18, 12-13; Łk 15, 4) - zstąpił pasterz, pozostawiając na miejscu te, które się nie zbłąkały", PSP 17bis, s. 194.

299 Por. Orygenes, Przeciw Celsusowi 2,9, w: SCh 132, s. 302; PSP 17bis, s. 94. Orygenes, Przeciw Celsusowi 2,64, w: SCh 132, s. 434; PSP 17bis, s. 129. Orygenes, Przeciw Celsusowi 7,16, w: SCh 150, s. 50; PSP 17bis, s. 349. Orygenes, Komentarz do Ewangelii wedtug św. Jana 1,4.22, w: SCh 120, s. 70; ŹMT 27, s. 31. Orygenes, Komentarz do Ewangelii wedtug św. Jana 1,8.51, w: SCh 120, s. 86; ŹMT 27, s. 37. Orygenes, Komentarz do Ewangelii wedtug św. Jana 1,9.54, w: SCh 120, s. 88; ŹMT 27, s. 39. Orygenes, Komentarz do Ewangelii wedtug św. Jana 1,21.126, w: SCh 120, s. 126; ŹMT 27, s. 51. Orygenes, Komentarz do Ewangelii wedtug św. Jana 2,18.125, w: SCh 120, s. 290; ŹMT 27, s. 110. Orygenes, Komentarz do Ewangelii wedtug św. Jana 2,34.209, w: SCh 120, s. 348; ŹMT 27, s. 128. Orygenes, Komentarz do Ewangelii wedtug św. Jana 6, 43.275, w: SCh 157, s. 338; ŹMT 27, s. 198. Orygenes, Komentarz do Ewangelii wedtug św. Jana 10, 30.197, w: SCh 157, s. 498; ŹMT 27, s. 257. Orygenes, Komentarz do Ewangelii wedtug św. Jana 19,6.39, w: SCh 290, s. 70; ŹMT 27, s. 372. P. Tzamalikos, Origen: Philosophy of History and Eschatology..., dz. cyt., s. 250-266.

300 Por. Orygenes, Homilie o Księdze Jozuego 3,2, w: SCh 71, s. 130-136; PSP 34, s. 1619. P. Tzamalikos, Origen: Philosophy of History and Eschatology..., dz. cyt., s. 283-287. 
3. Kształtowanie się nauki o niebie w teologii patrystycznej - wiek III

Stąd stworzenia rozumne, które zamknęły i oddaliły się od Boga, nadal pozostają przyjaciółmi Boga ${ }^{301}$, gdyż Tym, który razem z nimi (tj. z aniołami, duszami i duchami) umniejszałby się, a zarazem zanosił za nie modlitwy do Ojca, jest sam Chrystus ${ }^{302}$.

Wypełnieniem eschatologicznej nadziei stworzeń rozumnych jest Chrystus, a będzie ona zrealizowana przez miłość. Dlatego Orygenes podkreśla, że wszyscy święci mają nadzieję na otrzymanie wszystkiego, ze względu na miłość, która jest w nich ${ }^{303}$. Miłość jest najważniejszą charakterystyką odnowy i doskonałości zmartwychwstania, która nadejdzie, a której prefiguracją i egzemplifikacją jest Jezus ${ }^{304}$. Relację Boga ze swoim stworzeniem rozumnym Orygenes często opisuje przez obrazowanie Boga jako miłości i oddania jego relacji ze stworzeniem przez metaforykę małżeństwa mistycznego ${ }^{305}$.

Życie wieczne zbawionych oznacza u Orygenesa specyficzną jakość życia ludzi, a nie czasowy obszar ich egzystencji. Termin „wieczny”, w odniesieniu do stworzeń, nie konotuje Bożej wieczności, ale sformułowania tego typu posiadają w tekstach Aleksandryjczyka wymiar dydaktyczny. Uznając

301 Por. Orygenes, Przeciw Celsusowi 8,64, w: SCh 150, s. 320; „(...) że jak ruch ciała powoduje poruszenie się cienia, tak samo za życzliwością najwyższego Boga idzie przychylność Jego przyjaciół - aniołów, dusz i duchów”, PSP 17bis, s. 418. Orygenes, Homilie o Księdze Kaptańskiej 7,2, w: SCh 286, s. 314; „(...) zauważ, że skoro wszyscy nazywamy się Jego ciałem i członkami, to dopóki istnieją wśród nas tacy, którzy nie są "poddani» w doskonałym «poddaniu», również i On nie jest «poddany». Kiedy zaś wykona swoje dzieło, kiedy doprowadzi całe swoje stworzenie do pełnej doskonałości, wówczas powiemy o Nim, że jest "poddany» w tych, których poddał Ojcu i w których "wypełnił dzieło wyznaczone Mu przez Ojca», ażeby «Bóg był wszystkim we wszystkich» (1 Kor 15, 28)", PSP 31/2, s. 88. Orygenes, Przeciw Celsusowi 6,36, w: SCh 147, s. 264-268; PSP 17bis, s. 309-310.

302 Orygenes, O Modlitwie 10,2: „Syn Boży bowiem jest Arcykapłanem (Hbr 2, 17; $3,1)$ naszych ofiar i adwokatem u Ojca (J 14, 16-26; 15, 26; 16, 7), modląc się za modlącymi i błagając za błagającymi”, w: PG 11, k. 445D; Odpowiedź na Stowo. Najstarsi mistrzowie..., dz. cyt., s. 131.

303 Por. Origene, Selecta in Psalmos 4, w: PG 12, k. 1168BC.

304 P. Tzamalikos, Origen: Philosophy of History and Eschatology..., dz. cyt., s. 288-290.

305 Por. H. Pietras, L'amore in Origene, Roma 1988, s. 57-70, $79-87$ (Studia Ephemeridis Augustinianum 28). 
Kształtowanie się nauki o niebie w teologii patrystycznej I-III wieku

zasadność tez Tzamalikosa dotyczących Orygenesowych hipotez eschatologicznych, także moim zdaniem są one teleologiczną interpretacją historii, a sama historia jest oczekiwaniem spełnienia w eonie, który nadejdzie. Powszechna doskonałość stworzeń nie jest zatem ostatecznym końcem rozumianym jako cel istnienia. Według Orygenesa owym „końcem-celem” jest wejście stworzenia do bezczasowego życia Boga, co realizuje się dla zbawionych jedynie w Jezusie Chrystusie. Najważniejszą charakterystyką tej odnowy stworzenia jest miłość, a samą relację Boga ze swym stworzeniem rozumnym Orygenes oddaje przez metaforę małżeństwa mistycznego.

\subsection{Autorzy lacińscy III wieku: Tertulian, Cyprian, Wiktoryn z Poetovium, Męczeństwo świętych Perpetuy i Felicyty - motyw Jerozolimy niebieskiej i nagrody}

Motyw Jerozolimy niebieskiej właściwie nie był rozwijany w teologii wschodniej okresu patrystycznego, gdyż sama księga Apokalipsy wg św. Jana nie była uznawana na Wschodzie za kanoniczną ${ }^{306}$. Wyjątkiem były rzadkie odniesienia do tej księgi jedynie pośród pisarzy koptyjskich w Egipcie. Natomiast, co ciekawe, w teologii zachodniej okresu patrystycznego mamy wiele pism komentujących Apokalipse Janową ${ }^{307}$, szczególnie u autorów podzielających idee millenarystyczne. W niniejszym paragrafie chciałbym wskazać na najbardziej charakterystyczne sformułowania zachodnich autorów kościelnych III wieku dotyczące eschatologicznego nieba.

\section{Tertulian}

Według tego kościelnego pisarza (urodzonego w 160, a zmarłym po 220 roku), po zakończeniu ziemskiego królestwa millenijnego, w Jerozolimie

306 Por. J. Delumeau, Alla ricerca del paradiso..., dz. cyt., s. 242.

307 Por. J. Amat, Sognes et visions. L'au-delà dans la littérature latine tardive, Paris 1985; C. Carozzi, Le Voyage de l'âme dans l'au-delà d'après la littérature latine (Ve-XIIe siècle), Roma 1994. 
3. Kształtowanie się nauki o niebie w teologii patrystycznej - wiek III

niebieskiej, która zstąpi z nieba ${ }^{308}$ jako ziemskie wynagrodzenie dla sprawiedliwych ${ }^{309}$, nastąpi zburzenie świata doczesnego, sąd ostateczny i wyznaczenie ludziom ostatecznej nagrody lub kary za ich uczynki ${ }^{310}$. Królestwo Boże (regnum Dei), określane przez Tertuliana także jako „regnum iustorum”, „regnum dominicum”, „regnum caeli”, „regnum caeleste”, „regnum caelorum” lub „vita aeterna”, było pojmowane przez afrykańskiego moralistę jako ostateczna nagroda przyznana ludziom za ich dobre uczynki czynione podczas życia doczesnego. Stąd prawdopodobnie postulował on zróżnicowanie nagrody dla zbawionych - w zależności od stopnia moralnych zasług na ziemi ${ }^{311}$. Pierwsza grupa terminów określających niebo dotyczy

308 Tertulian, Adversus Marcionem 3,24,3, w: SCh 399. Tertullien, Contre Marcion. t. 3 (Livre III). Introduction, texte critique, traduction, notes et index des livres I-III par R. Braun, Paris 1994, s. 204; przekład polski Przeciw Marcjonowi: „Bo i my wyznajemy (nam et confitemur), że na ziemi mamy przyrzeczone królestwo, ale przedtem niebo; ale w innym stanie (regnum repromissum, sed ante caelum, sed alio statu), jako że po zmartwychwstaniu na tysiąc lat, w mieście budowy Boskiej, w Jeruzalem spuszczonym z nieba, które Apostoł nazywa z góry matką naszą. Ale zaznaczając, że ojczyzna nasza, to jest prawo obywatelskie, jest w niebiosach, przeznacza je oczywiście jakiemuś miastu niebieskiemu (et politeuma nostrum, id est municipatum, in caelis esse pronuntians alicui utique caelesti ciuitati eum deputat)", tłum. S. Ryznar, red. W. Myszor, Warszawa 1994, PSP 58, s. 137.

309 Tertulian, Przeciw Marcjonowi 3,24,5, w: SCh 399, s. 206; „A my twierdzimy (dicimus), że dla przyjęcia świętych po zmartwychwstaniu i dla obsypania ich wszelkimi dobrami, oczywiście duchowymi (omnium bonorum utique spiritalium), jako bogactwo na wyrównanie tego (copia in compensationem), czym albo wzgardziliśmy w świecie, albo co traciliśmy (quae in saeculo uel despeximus uel amisimus), Bóg przewidział takie miasto; bo przecież sprawiedliwe to i Boga godne, żeby tam radowali się Jego słudzy, gdzie przedtem byli uciemiężeni w Jego własnym imieniu. Taka jest racja królestwa podniebnego", PSP 58, s. 137.

310 Tertulian, Przeciw Marcjonowi 3,24,6, w: SCh 399, s. 206; „Po tysiącu lat tego królestwa, w którym to czasie dokonuje się zmartwychwstanie świętych, wstających z martwych według zasług wcześniej lub później (pro meritis maturis uel tardius resurgentium), wtedy to, gdy nastąpi zburzenie świata i objawienie palącego sądu. Będziemy odmienieni w każdym atomie na substancję anielską (demutati in atomo in angelicam substantiam), mianowicie przez owo przywdzianie nieskazitelności (scilicet per illud incorruptelae superindumentum), i tak zostaniemy przeniesieni do królestwa niebieskiego (transferemur in caeleste regnum), które teraz jest tak obmawiane, jakby nie było ogłoszone u Stworzyciela i przez to wskazuje na Chrystusa innego Boga, który najpierw i jedynie objawił to królestwo”, PSP 58, s. 137 (por. 1 Kor 15, 52-53).

311 Tertulian, De monogamia 10,6, w: SCh 343, s. 176.178; „Będąc z Bogiem, będziemy razem, ponieważ wszyscy będziemy u jednego Boga - choćby różna była zapłata, chociażby było wiele mieszkań tego samego Ojca (licet merces uaria, licet multuae 
Kształtowanie się nauki o niebie w teologii patrystycznej I-III wieku

miejsca nagrody, a ostatnie określenie „vita aeterna” - czasu jej trwania ${ }^{312}$. Samo niebo charakteryzowałoby się obecnością Boga i oglądaniem Go przez zbawionych ${ }^{313}$, przebywaniem z Chrystusem ${ }^{314}$. Zbawieni w niebie, w ciele i duszy ${ }^{315}$ posiadaliby moc nieskazitelności i nieśmiertelności ${ }^{316}$, byliby obdarzeni dobrami ponadzmysłowymi ${ }^{317}$, upodobniliby się do Boga (restituitur homo deo ad similitudinem eius) ${ }^{318}$, przebywaliby razem we wspólnocie zbawionych ${ }^{319}$. Niebo było też przyrównane przez Tertuliana do uczty („,coena”320) lub opisywane charakterystykami wymiernego raju („paradisum”) 321 .

mansiones penes Patrem eundem) - wypracowaliśmy sobie bowiem za jeden denar jednaką zapłatę - życie wieczne (uno denario eiusdem mercedis operati, id est uitae aeternae), w którym Bóg jeszcze bardziej nie rozdzieli przez siebie złączonych, jako że nie zezwala, by rozdzielać się za życia na ziemi (in qua magis non separabit quos coniunxit Deus, qui in ista minore uita separari ueteat)", PSP 65, s. 72-73. Jak komentuje Marcin Wysocki, Eschatologia okresu prześladowań na podstawie pism Tertuliana i Cypriana, Lublin 2012, s. 176-177, różnorodność jednej nagrody („eiusem merces”), czyli życia wiecznego („,vita aeterna”) zdaniem Tertuliana miałaby posiadać różne warianty („merces varia”), co wynikałoby z różnego stopnia zasług (por. Tertullianus, Adversus Gnosticos Scorpiace 6,6, w: PL 2, k. 133B; CChSL 2, s. 1079-1080; PSP 29, s. 128; Tertullianus, De resurrectione carnis 52, w: PL 2, k. 870C-871A; CChSL 2, s. 1010-1011). Odmiennego zdania jest natomiast Henryk Pietras, Eschatologia Kościota pierwszych czterech wieków..., dz. cyt., s. 81, który nie interpretuje powyższych słów Tertuliana jako odnoszących się do rozróżnień miedzy świętymi w niebie („gdyż zapewne nie czułby się w tym względzie kompetentny"), ale do stopniowego zmartwychwstania w czasie mesjańskiego tysiąclecia - „im kto będzie lepszy, będzie zmartwychwstawać wcześniej”.

312 Por. M. Wysocki, Eschatologia okresu przésladowań..., dz. cyt., s. 165-170.

313 Por. Tertullianus, Adversus Praxeam 23,4, w: PL 2, k. 184CD; CChSL 2, s. 1192; ŹMT 4, s. 73-74.

314 Por. Tertullianus, De resurrectione carnis 63, w: PL 2, k. 885B-886B; CChSL 2, s. 1011.

315 Por. Tertullianus, De resurrectione carnis 51, w: PL 2, k. 868C-869B; CChSL 2, s. 993-995.

316 Por. Tertullianus, De resurrectione carnis 50,5: „incorruptibilitatis et immortalitatis”, w: PL 2, k. 868A; CChSL 2, s. 993.

317 Por. Tertullianus, De resurrectione carnis 26, w: PL 2, k. 831C-833C; CChSL 2, s. 954-966.

318 Por. Tertullianus, De baptismo 5,7, w: PL 1, k. 1206A; CChSL 1, s. 282; PSP 5, s. 139.

319 Por. Tertullianus, De monogamia 10,6, w: SCh 343, s. 176.178; PSP 65, s. 72.

320 Por. Tertullianus, Adversus Marcionem 4,31,2: „inuitari ad caenam”, w: SCh 456, s. 390; PSP 58, s. 221.

321 Tertullianus, Apologeticum 47,13-14, w: CChSL 1Quinti Septimi Florentis Tertulliani Opera. Pars I. Opera catholica, E. Dekkers (cura et studio), Turnholti 1954, s. 165; 
3. Kształtowanie się nauki o niebie w teologii patrystycznej - wiek III

\section{Cyprian z Kartaginy}

Na określenie eschatologicznego nieba ówczesny biskup Kartaginy (urodzony około 200 - zmarły w 258 roku) stosował terminy analogiczne do używanych przez Tertuliana („immortalitas”, „vita aeterna”, „aeternitatis”, "paradiusum”, „regnum”, „regnum aeternum”, "regnum caeleste”, „caelum”). Niebo pojmował jako wymierną nagrodę („praemia divina”, „Christi praemia”, "praemia caelesta”, "praemium vitae”, „coronari", „corona”, „corona militis”, „corona puprura”, „corona caelesta”), jak twierdzili potem autorzy niebędący millenarystami ${ }^{322}$.

Tę pojęciową zbieżność między pisarzami widać jeszcze lepiej, kiedy śledzimy słownictwo tematyczne związane z niebem pojmowanym jako nagroda. Terminologia Cypriana („praemia divina”, „Christi praemia”, "praemium immortalitatis”, "praemia caelesta”, "praemium vitae”, „corona”, ,corona purpura”, „corona caeelesta”) wskazuje, że niebo byłoby nagrodą dla wszystkich wierzących, byłoby bożym wynagrodzeniem za cierpliwość i wytrwanie przy Bożych przykazaniach (pierwsze zmartwychwstanie dokonuje się

przekład polski Tertulian, Apologetyk 47,13-14: „Kiedy znów o raju wspominamy (paradisum nominemus), miejscu boskiej rozkoszy (locum divinae amoenitatis), które jak gdyby murem pasa ognistego odłączone od wiadomości zwykłego świata przeznaczone jest na przyjęcie świętych dusz (recipiendis sanctorum spiritibum destinatum), to wtedy natrafiamy na umysły opanowane wiarą w Elizejskie Pola (Elysii campi fidem occupauerunt)", w: PL 1, k. 587AB; POK 20, s. 189; Tertullianus, Ad martyras 3,3, w: PL 1, k. 624; CChSL 1, s. 5; PSP 5, s. 35.

322 Por. M. Wysocki, Eschatologiczna nagroda w pismach św. Cypriana, „Roczniki historii Kościoła” 1/56 (2009), s. 33-47; M. Wysocki, Eschatologia okresu prześladowań na podstawie pism Tertuliana i Cypriana, Lublin 2012, s. 213-224. Terminologia Cypriana („praemia divina”; „Christi praemia”, „praemium immortalitatis”, „praemia caelesta”; „praemium vitae”, „corona”, „corona purpura”, ,corona caeelesta”), to nagroda wszystkich wierzących, jako nagroda za cierpliwość i wytrwanie przy Bożych przykazaniach (zmartwychwstanie dokonuje się już we chrzcie - Cyprianus Carthaginensis, De mortalitate 21, w: PL 4, k. 619-620; CChSL 3A, s. 28; POK 19, s. 268). Męczennicy natychmiast widzą Boga po śmierci (Cyprianus Carthaginensis, Ad Fortunatum 13, w: PL 4, k. 702CD; CChSL 3, s. 214-216; POK 19, s. 301); dzięki Chrystusowi dostępują przemiany ciała zmartwychwstałego i przebywają na uczcie niebieskiej z Abrahamem, Izaakiem i Jakubem (Cyprianus Carthaginensis, De opere et eleemosynis 24, w: PL 4, k. 643D-644A; CChSL 3A, s. 71; POK 19, s. 345). 
Kształtowanie się nauki o niebie w teologii patrystycznej I-III wieku

już we chrzcie $\left.{ }^{323}\right)$. Męczennicy natychmiast widzieliby Boga po śmier$\mathrm{ci}^{324}$ - dzięki Chrystusowi dostępują przemiany ciała zmartwychwstałego i przebywają na uczcie niebieskiej z Abrahamem, Izaakiem i Jakubem ${ }^{325}$.

\section{Laktancjusz}

O niebie jako nagrodzie mówił także millenarysta Laktancjusz (około 260 około 330). Według niego jedynie sprawiedliwi będą mogli cieszyć się materialnymi radościami królestwa millenijnego, podczas gdy cała reszta będzie musiała czekać na sąd Boga, który nastąpi po drugim zmartwychwstaniu ${ }^{326}$. Przy całej niespójności eschatologicznych koncepcji Laktancjusza, o której wspomina Jerzy Wojtczak ${ }^{327}$, można jednak wywnioskować z VII księgi Divinae Institutiones, że po śmierci wszystkie dusze będą umieszczone pod strażą, aż do czasu ich osądu przez Najwyższego Sędziego. Ten dokona jeszcze przed zmartwychwstaniem oceny ich zasług. Wtedy sprawiedliwi zostaną nagrodzeni nieśmiertelnością, a grzesznicy i bezbożni zostaną zamknięci w ciemnościach na niechybne męki ${ }^{328}$. Po ustaniu królestwa millenijnego dla sprawiedliwych, nastąpi sąd ostateczny. Zdaniem Laktancjusza wyginie wtedy cały ród bezbożnych, a sprawiedliwi wyjdą ze swych kryjówek, gdzie schowali się przed księciem demonów. Później nastąpi okres siedmioletni, w czasie którego zapanuje spokój

323 Por. Cyprianus Carthaginensis, De mortalitate 21, w: PL 4, k. 619-620; CChSL 3A, s. 28; POK 19, s. 268.

324 Por. Cyprianus Carthaginensis, Ad Fortunatum 13, w: PL 4, k. 702CD; CChSL 3, s. 214-216; POK 19, s. 301.

325 Por. Cyprianus Carthaginensis, De opere et eleemosynis 24, w: PL 4, k. 643D-644A; CChSL 3A, s. 71; POK 19, s. 345.

326 Por. V. Loi, Lattanzio. Nella storia del linguaggio e del pensiero teologico pre-niceno, Zürich 1970, s. 247-249.

327 Por. J. Wojtczak, Eschatologiczne koncepcje Laktancjusza w VII księdze «Divinae Institutiones», „Vox Patrum” 10 (1990), z. 19, s. 609-620. Laktancjusz w swej eschatologii, zdaniem Wojtczaka, korzysta zarówno z fantazji ludowych, jak i mitologicznych. Przy omawianiu królestwa millenijnego Laktancjusz cytuje np. całe partie opisu złotego wieku z Owidiusza, Metamorfozy 1,89092 (por. D. I. 7,24,9, w: CSEL 19, s. 660), z IV eklogi Wergilisza oraz cytaty z ksiąg sybillińskich.

328 Por. Laktancjusz, Divinae Institutiones 7,21,7-8, w: CSEL 19, s. 652. 
3. Kształtowanie się nauki o niebie w teologii patrystycznej - wiek III

wieczny („requies sempiterna”) ${ }^{329}$. Po upływie owych siedmiu lat dokładnie minie okres millenium, świat zostanie odnowiony, niebo będzie zwinięte, ziemia odmieniona, prawdopodobnie tylko dobrzy ludzie zostaną przemienieni i uzyskają cechy anielskie; będą oni przebywać w obecności Boga i Mu służyć. Dopiero wtedy nastąpi zmartwychwstanie wszystkich (tj. według Laktancjusza reszty ludzi, czyli tych którzy Boga nie uznali lub się Go wyparli). Ludzie bezbożni wraz z diabłem i jego sługami będą skazani na wieczną karę, stosownie do swych przewinień. Kara ta będzie miała miejsce w ogniu wiecznym ${ }^{330}$.

\section{Wiktoryn z Poetovium}

Podobnie twierdził o niebie także pierwszy znany w patrologii łaciński egzegeta chrześcijański (zmarł około 304 roku), zwolennik alegoryzmu, ale i millenarysta. Co ciekawe, w swoim w komentowaniu Ap $20-$ 21 dał wyjaśnienie bardziej literalne niż alegoryczne ${ }^{331}$. Rozróżniał on dwa zmartwychwstania: pierwsze - millenijne oraz drugie - „ostateczne zmartwychwstanie”332 na koniec królestwa millenijnego ${ }^{333}$. Wybór sprawiedliwych do królestwa millenijnego byłby szczęśliwą zapowiedzią wyłącz-

329 Laktancjusz, Divinae Institutiones 7,26,4, w: CSEL 19, s. 666.

330 Por. Laktancjusz, Divinae Institutiones 7,26,6, CSEL 19, s. 666 (por. J. Wojtczak, Eschatologiczne koncepcje Laktancjusza..., dz. cyt., s. 614-616.

331 Por. D. Kasprzak, Wiktoryn z Poetovium - pierwszy chrześcijański egzegeta taciński, „Analecta Cracoviensia” XLIII (2011), s. 143-157; D. Kasprzak, Drugi millenaryzm w ujęciu Wiktoryna z Poetovium, w: Biblia w kulturze Świata. Między Biblia a kultura II, red. T. Jelonek, Kraków 2011, s. 43-57.

332 Wiktoryn z Poetovium, In Apocalipsin 20,2; „Surgent in novissima tuba post annos mille, id est in novissima resurrectione”: CSEA II, 310.

333 Wiktoryn z Poetovium, In Apocalipsin 20,2; „Ubi esse ergo audivimus novissimam tubam, intellegere debemus et primam: haec autem sunt duae resurrectiones”, CSEA II, s. 310. Millenijne królowanie Chrystusa i chrześcijan miało się dokonać „w mieście przyszłym i pięknym” (Wiktoryn z Poetovium, In Apocalipsin 20,2; „In hac eadem prima resurrectione et civitas futura et speciosa”, CSEA II, s. 310). W świetle dosłownej interpretacji Ap 20 Wiktoryn identyfikuje owo miasto święte, które jest opisane w Ap 21, z ziemską Jerozolimą i antycypuje on zstąpienie na ziemię niebiańskiej Jerozolimy przed sądem ostatecznym (C. Curti, Il regno millenario In Vittorino di Petovio, 1978, s. 427, (Augustinianum 18) 
Kształtowanie się nauki o niebie w teologii patrystycznej I-III wieku

nie ich zbawienia, gdyż cała reszta ludzkości, nie będąc członkami królestwa millenijnego, miałaby zmartwychwstać tylko po potępienie na sądzie ostatecznym i karę w piekle 334 .

Wiktoryn mówił o niebie otwartym (biblijnie oznacza to bliskość Boga) na czas zstąpienia Chrystusa na ziemię. Samo niebo, jak wyjaśnia, jest jednak w tym czasie zamknięte dla wszystkich innych ludzi, aż do czasu wstąpienia doń Jezusa ${ }^{335}$. Ósmy dzień („dies octavus”), czyli eschatologiczne wydarzenie sądu powszechnego, dokona się poza czasem („extra ordinem septimanae dispositionis excessurus est") ${ }^{336}$. Niebo zostało opisane według alegorycznej symboliki apokaliptycznej (trawestacja Ps 33(32), 6) jako stany Ducha Bożego odpowiadające siedmiu dniom stworzenia („septem quoque caeli iliis diebus conveniunt"), które utożsamia także z Chrystusem:

„ «Przez słowo Pana powstały niebiosa, i wszystkie ich zastępy przez tchnienie ust Jego» (Ps 33(32), 6). Jest nimi siedem duchów. Są to imiona tych duchów, które spoczywają nad Chrystusem Bożym, tak jak potwierdził to prorok Izajasz: «I spocznie na nim Duch Pański, duch mądrości i rozumu, duch rady i męstwa, duch wiedzy i miłosierdzia i wypełnia go duch bojaźni Pańskiej» (Iz 11, 2-3, według LXX). Zatem niebem najwyższym jest mądrość, drugim rozumność, trzecim rada, czwartym męstwo, piątym wiedza, szóstym miłosierdzie, siódmym bojaźń Boża. Od tego ostatniego nieba rozbrzmiewają grzmoty, wyładowują się błyskawice, skupiają się kule ognia, objawiają się płomieniste meteory, rozbłyskają gwiazdy, rozświetlają się przerażające komety; czasami przyłączają się także słońce i księżyc: spoglądają na siebie nawzajem i dają to nadzwyczajne światło, które oświeca wzrok tego, kto obserwuje. Autor tego wszystkiego ma na imię Słowo. Tak bowiem mówi Jego Ojciec: «Z mego serca tryska piękne słowo» (Ps 45(44), 2).

334 Wiktoryn z Poetovium, In Apocalipsin 20,2, w: CSEA II, s. 310.312: „Quotquot ergo non anticipaverint surgere in prima risurrectione et regnare cum Christo super orbem super gentes universas - surgent in novissima tuba post annos mille, id est in novissima resurrectione, inter impios et peccatores et varii generis commissores. Merito adiecit dicendo: Beatus et sanctus qui habet partem in prima anastase: ad hunc mors secunda non habet potentatem. Mors autem secunda castigatio est in infernum".

335 Wiktoryn z Poetovium, In Apocalipsin 3,4,1, w: CSEA II, s. 272.

336 Wiktoryn z Poetovium, De fabrica mundi 6, w: CSEA II, s. 332. 
3. Kształtowanie się nauki o niebie w teologii patrystycznej - wiek III

Jan Ewangelista tak mówi: «Na początku było Słowo, a Słowo było u Boga, i Bogiem było Słowo. Ono było na początku u Boga. Wszystko przez Nie się stało, a bez Niego nic się nie stało, co się stało» (J 1, 1-3). Dlatego On po pierwsze uczynił stworzenia, po drugie człowieka lub rodzaj ludzki, jak powiada apostoł. To Słowo, kiedy stworzyło światło jest nazwane mądrością, kiedy stworzyło niebo jest nazwane rozumem, kiedy stworzyło ziemię i morze - radą; kiedy stworzyło słońce, księżyc i inne gwiazdy - mocą; kiedy pozwoliło przynosić owoce ziemi i morzu - wiedzą; kiedy ukształtowało człowieka - miłosierdziem; kiedy błogosławi i uświęca człowieka, nosi imię bojaźni Bożej"337.

W pismach Wiktoryna z Poetovium znajdujemy zatem podwójny opis tajemnicy nieba eschatologicznego: moralistyczny oraz katechetyczno-biblijny. W tym pierwszym, typowym dla ujęć teologii afrykańskiej III wie$\mathrm{ku}$, do nieba, rozumianego jako nagroda, dostawaliby się po zmartwychwstaniu jedynie sprawiedliwi. Natomiast rozwijane wątki apokaliptyczne,

337 Wiktoryn z Poetovium, De fabrica mundi 7, w: CSEA II, s. 334: „Septem quoque caelei illis diebus convenient. Sic enim cautum est: «Verbo Domini caeli firmati sunt et spiritu oris eius omnis virtus eorum». Hi septem spiritus. Nomina sunt eorum spiritus qui supra Christum Dei requieverunt, ut apud Esaiam prophetam cautum est: «Et requiescit super eum spiritus sapientiae et intellectus, spiritus consilii et virtutis, spiritus scientiae et pietatis, et replevit illum spiritus timoris Dei». Summum ergo caelum sapientiae, secundum intellectus, tertium consilii, quartum virtutis, quintum scientiae, sextum pietatis, septimum timoris Dei. Ex hoc ergo tonitrua mugiunt, fulmina extenduntur, ignes conglobantur, trabes ardentes apparent, sidera radiant, comae horribiles coruscant, nonnumquam accedit etiam sol et luna: invicem visitantur atque illa ultra formidabilia lumina, radiantia in acie aspectu eius, efficiunt. Auctori autem totius creaturae iustius verbo cognomen est ei. Sic enim dicit Pater eius: «Eructatum est cor meum verborum bonum». Iohannes evangelista, sic dicit: «In principio erat verbum et verbum erat apud Deum et Deus erat verbum. Hoc erat in principio apud Deum. Omnia per ipsum facta sunt et sine eo factum est nihil». Ergo primus factus creaturae est, secundus hominis <vel $>$ humani generis, ut ait apostolus. Hoc igitur verbum, cum lucem fecit, sapientia vocatur; cum caelum, intellectus; cum terram et mare, consilium; cum solem et lunam ceteraque clara, virus; cum terrae et mari $<\mathrm{fe}$ tus> excitat, scientia; cum hominem finixit, pietas; cum hominem benedicit et sanctificat, timor Dei nomen habet", tłumaczenie własne autora. We fragmencie Iz 11, 2-3 (według LXX) ostatni wyraz hebrajski „bojaźń”, powtórzony w wierszu 3, został oddany tak przez LXX, jak i Veteres Latinae dwoma różnymi słowami: „bojaźń” (wiersz 2) i „miłosierdzie” bądź „pobożność” (wiersz 3). Stąd siedem, a nie sześć duchów / darów ducha. 
Kształtowanie się nauki o niebie w teologii patrystycznej I-III wieku

szczególnie symbolika nieba otwartego na czas zstąpienia Chrystusa oraz nieba opisywanego alegorycznie jako stany Ducha Bożego utożsamianego z Chrystusem wskazują, podobnie jak u innych autorów wczesnochrześcijańskich, iż eschatologiczne niebo jest dostępne dla ludzi jedynie dzięki pośrednictwu Jezusa Chrystusa.

\section{Męczeństwo świętych Perpetuy i Felicyty - wizja Satura}

Wiarę w raj opisywany jako eschatologiczny ogród można spotkać także na początku III wieku w senackiej prowincji Africa Proconsularis, czego dowodem jest np. wizja męczennika Satura zawarta w Męczeństwie świętych Perpetuy i Felicyty (redakcja około roku 203) ${ }^{338}$. W patrologii nie kwestionuje się dziś autentyczności fragmentów zapisanych przez samych męczenników, tj. przez Wibię Perpetuę i Satura ${ }^{339}$. Natomiast odnośnie do możliwego autorstwa wspomnianego passio, to najczęściej przyjmuje się teorię, że redaktorem utworu oraz autorem wstępu i zakończenia był prawdopodobnie Tertulian ${ }^{340}$.

We wspomnianej wizji można przeczytać, że:

338 Por. J. Słomka, Nowe Proroctwo. Historia i doktryna montanizmu, Katowice 2007, s. 116 (Studia Antiquitatis Christianae. Series Nova 4)

339 Por. J. Amat, Introduction, w: Passion de Perpétue et de Félicité suivi des actes, Paris 1996, w: SCh 417, s. 67.

340 Świadczą o tym w Męczeństwie świętych Perpetuy i Felicyty zarówno wątki teologiczne, jak i stylizacja prześladowań jako wypełnienie woli Bożej; męczeństwo ujmowane jako dobro obiektywne; więzienie przedstawiane jako siedziba diabła, ale i miejsce hartowania ducha i ciała; wzmianka o namaszczeniu olejem po wyjściu z wody chrzcielnej, które przynosi owoce duchowe; nazwanie Ducha Świętego kierownikiem walki, a Chrystusa - trenerem; apele do kobiet o męstwo duchowe w chwili męczeństwa. Por. M. Starowieyski, Męczeństwo św. Perpetuy i Felicyty, w: Męczennicy, Kraków 1988, OŻ 9, s. 244. Joyce E. Salisbury, Perpetua's passion. The death of a Young Roman Woman, New York and London 1997, s. 70, traktuje redaktora / narratora passio jako anonimowego świadka męczeństwa, który kieruje swój tekst do wspólnoty, aby przykład męczenników prowadził innych do zbawienia. Natomiast J. Amat, Introduction, SCh 417, s. 69, sugeruje, że redaktorem passio musiał być ktoś z najbliższego otoczenia Perpetui, np. diakon Pomponiusz. 
3. Kształtowanie się nauki o niebie w teologii patrystycznej - wiek III

„Zmarliśmy - powiada [Satur] - i opuściliśmy swoje ciała (exiuimus de carne). Wtedy to czterej aniołowie, nie dotykając nas rękoma, zaczęli nas nieść na wschód. Lecieliśmy, jednak nie leżąc na wznak zwróceni ku górze, ale wznosiliśmy się jakby po jakimś łagodnym stoku (sed quasi molem cliuum ascendentes). Kiedy zaś wydostaliśmy się już poza pierwszy krąg świata, ujrzeliśmy niezmierną światłość (Et liberato primo mundo uidimus lucem immensam). Powiedziałem wówczas do Perpetuy, która znajdowała się obok mnie: «Oto jest to, co Pan nam obiecywał. Otrzymaliśmy to, co obiecał (Hoc est quod nobis Dominus promittebat: percepimus promissionem)». Ale owi czterej aniołowie nieśli nas dalej, aż otworzyła się przed nami ogromna przestrzeń (factum est nobis spatium grande); był to jakby ogród, w którym rosły krzewy różane i wszelkiego rodzaju kwiaty (quod tale fuit quasi uiridiarium, arbores habens rosae et omne genus flores). Krzewy były wysokie jak cyprysy i nieustannie spadały z nich płatki. W ogrodzie znajdowali się inni czterej aniołowie, bardziej jaśniejący od innych (alii quattuor angeli fuerunt clariores ceteris). Skoro tylko ujrzeli nas, oddali nam cześć i zawołali w zachwycie do pozostałych aniołów: "Oto są! Oto są!». A zadrżeli czterej aniołowie, którzy nas nieśli i złożyli nas (deposuerunt nos). Dalej już sami poszliśmy rozległą aleją w stronę otwartej przestrzeni (Et pedibus nostris transiuimus stadium uia lata), gdzie spotkaliśmy Jokunda, Saturnina i Artaksjusza, którzy w tym samym prześladowaniu zostali spaleni żywcem, oraz Kwintusa, który jako męczennik umarł w więzieniu. Zapytaliśmy ich, gdzie byli. Inni aniołowie powiedzieli do nas: «Najpierw chodźcie, wejdźcie i pozdrówcie Pana» (Venite prius, introite, et salutate Dominum). 12. I zbliżyliśmy się do miejsca, które miało ściany zbudowane jakby ze światła (Et uenimus prope locum, cuius loci parietes tales erant quasi de luce aedificati). U bramy wiodącej do środka stali czterej aniołowie, którzy wchodzących ubierali w białe szaty (et ante ostium loci illius angeli quattuor stabant, qui introeuntes uestierunt stolas candidas). My weszliśmy również i usłyszeliśmy chóralny głos wołający bez przerwy: «Święty, święty, święty». Ujrzeliśmy tam siedzącego po środku jakby siwego człowieka; miał on wprawdzie włosy śnieżnobiałe, ale oblicze młodzieńcze (Et uidimus in eodem loco sedentem quasi hominem canum, niueos habentem capillos et uult iuuenili). 
Kształtowanie się nauki o niebie w teologii patrystycznej I-III wieku

Jego nóg nie mogliśmy dojrzeć (cuius pedes non uidimus). Po jego prawej i lewej stronie znajdowało się czterech starców, a z tyłu za nimi stało jeszcze bardzo wielu sędziwych ludzi. Weszliśmy i w pełni zachwytu stanęliśmy przed tronem. Czterech aniołów uniosło nas i pocałowaliśmy owego sędziwego człowieka, on zaś dotknął naszych twarzy ręką. Starcy powiedzieli do nas: "Zatrzymajcie się». Stanęliśmy i przekazaliśmy pocałunek pokoju. Następnie starcy rzekli do nas: «Idźcie i weselcie się». Powiedziałem wówczas do Perpetuy: "Oto osiagnęłaś to, czego pragnęłaś». A ona mi odrzekła: «Bogu niech będą dzięki za to, że już w swym ciele byłam szczęśliwa, zaś teraz stałam się jeszcze szczęśliwsza». 13. Wyszliśmy stamtąd i przy drzwiach spotkaliśmy: po prawej stronie biskupa Optata, a po lewej kapłana naszego i nauczyciela Aspazjusza; stali osobno i byli smutni. Gdy nas zobaczyli, rzucili się nam do nóg i zawołali: «Wprowadźcie pokój miedzy nami, ponieważ odeszliście od nas i pozostawiliście nas samych». My odpowiedzieliśmy im: «Czyż ty nie jesteś naszym biskupem, a czy ty nie jesteś naszym kapłanem? Jak więc możecie padać nam do nóg?» Byliśmy bardzo wzruszeni i uściskaliśmy ich. Perpetua zaczęła z nimi rozmawiać po grecku i oddaliliśmy się w głąb ogrodu, pod krzew różany. Gdy rozmawialiśmy, aniołowie powiedzieli do nich: «Pozwólcie im odpocząć. A jeżeli zaistniały między wami jakieś spory, to odpuśćcie sobie nawzajem». Słowa te bardzo ich zmieszały. Następnie aniołowie zwrócili się do Optata: "Upomnij powierzony ci lud, bo gromadząc się u ciebie zachowują się jak ci, którzy wracają z cyrku kłócąc się na temat stronnictw». I wydało nam się, że jakby chcieli zamknąć bramy (Et sic nobis uisum est quasi uellent claudere portas)" 341 .

Raj, do którego dotarli męczennicy z Kartaginy, byłby zatem „poza pierwszym kręgiem (liberat primo mundo)”, jego zapowiedzią byłaby „niezmierna światłość (lucem immensam)”. Sam „raj” został zobrazowany jako:

341 Passio sanctarum Perpetuae et Felicitas 11-13, w: SCh 417. Passion de Perpétue et de Félicité suivi des Actes, Introduction, texte critique, traduction, commentaire et index par J. Amat, Paris 1996, s. 142-152; Męczeństwo św. Perpetuy i Felicyty 11-13, w: Męczennicy, red. E. Wipszycka, M. Starowieyski, tłum. A. Malinowski, Kraków 1991, OŻ 9, s. 258-261. 
„ogromna przestrzeń (spatium grande)”, „jakby ogród (quasi uiridiarium), w którym rosły krzewy różane i wszelkiego rodzaju kwiaty (arbores habens rosae et omne genus flores). Krzewy były wysokie jak cyprysy i nieustannie spadały z nich płatki (Altitudo arborum erat in modum cypressi, quorum folia canebant sine cessatione)". Przebywali tam aniołowie, różniący się miedzy sobą intensywnością jaśnienia („czterej aniołowie, bardziej jaśniejący od innych (clariores ceteris)"). Aniołowie po raju latali, ludzie zaś chodzili. Raj byłby w jakiś sposób oddzielony od miejsca przebywania Boga („zbliżyliśmy się do miejsca, które miało ściany zbudowane jakby ze światła (cuius loci parietes tales erant quasi de luce aedificati)”), „u jego bram stali czterej aniołowie w białych szatach" (ante ostium loci illius angeli quattuor stabant, qui introeuntes uestierunt stolas candidas)). Poza miejscem przebywania Boga, w opisywanym w passio raju przebywają też inni męczennicy - biskup Optat, kapłan Aspazjusz; co ciekawe, wymienieni męczennicy duchowni „stali osobno i byli smutni”, prosili o wprowadzenie między nich pokoju, którego im w raju dziwnie brakowało („Wprowadźcie pokój miedzy nami, ponieważ odeszliście od nas i pozostawiliście nas samych”. My odpowiedzieliśmy im: «Czyż ty nie jesteś naszym biskupem, a czy ty nie jesteś naszym kapłanem? Jak więc możecie padać nam do nóg?»"). Perpetua rozmawiała z tymi duchownymi w języku greckim, chyba ich uspokajając, co nie było chyba właściwe dla miejsca, skoro duchowni zostali napomniani przez anioła („ «Pozwólcie im odpocząć. A jeżeli zaistniały między wami jakieś spory, to odpuśćcie sobie nawzajem». Słowa te bardzo ich zmieszały. Następnie aniołowie zwrócili się do Optata: «Upomnij powierzony ci lud, bo, gromadząc się u ciebie, zachowują się jak ci, którzy wracają z cyrku, kłócąc się na temat stronnictw». I wydało nam się, że jakby chcieli zamknąć bramy”).

Biorąc pod uwagę następujące przesłanki: raj i osobne miejsce przebywania Boga, smutek i kłótliwość pomiędzy duchownymi a wiernymi już przebywającymi w raju, można dojść do wniosku, że opisywany przez Satura raj nie jest miejscem definitywnej wieczności. W wizji Satura całkowitej szczęśliwości Perpetua doświadcza jedynie w miejscu przebywania Boga $^{342}$, do którego z raju wchodzi i wychodzi. Opisywany raj nie był-

342 Męczeństwo św. Perpetuy i Felicyty 12-13, w: SCh 417, s. 150; „12. Bogu niech będą dzięki za to, że już w swym ciele byłam szczęśliwa, zaś teraz stałam się jeszcze szczęśliwsza 
Kształtowanie się nauki o niebie w teologii patrystycznej I-III wieku

by zatem ostatecznym miejscem zbawionych, choć był już definiowany jako miejsce dla męczenników, miejsce wytchnienia, radości i przebywania z aniołami, choć jeszcze nie z Bogiem.

Podobnie o raju, jako swoistym eschatologicznym stanie pośrednim, przygotowującym do pełnego spotkania z Bogiem, na Wschodzie myśleli: Orygenes ${ }^{343}$, Pseudo-Atanazy ${ }^{344}$, Jan Chryzostom ${ }^{345}$ czy Teodoret z Cyru, a na Zachodzie Izydor z Sewilli czy Beda Wielebny. Sama tematyka otwarcia raju pośredniego przez Jezusa dla dobrego łotra przeszła jako wdzięczny wątek artystyczny do ikonografii bizantyjskiej ${ }^{346}$.

W opisach reprezentatywnych dla III wieku łacińskich pisarzy patrystycznych można spotkać utożsamienie raju pojmowanego jako ogród z terenem wiecznej, definitywnej szczęśliwości. Jak zauważa Jean Delumeau, obraz tego typu zdaje się jakoś sugerować tekst Ap 22, 1-2 $2^{347}$. U Cypriana

(Deo gratias, ut quomodo in carne hilaris fui, hilarior sim et hic modo). 13. Wyszliśmy stamtąd i przy drzwiach spotkaliśmy... (Et exiuimus et uidimus ante fores)”, OŻ 9, s. 260.

343 Por. Orygenes, $O$ zasadach 2,11,7, w: SCh 252, s. 410.412; „Błogosławieni, po ziemskim życiu zostaną w raju ziemskim («wszyscy święci, odchodząc z tego życia, będą przebywać w określonym miejscu na ziemi, w miejscu, które Pismo Święte nazywa rajem»), który będzie dla nich miejscem nauczania («że się tak wyrażę, sala wykładowa i szkoła dusz»). Kiedy staną się czyści sercem i umysłem i żywi inteligencją, wstąpią w powietrze i dotrą do królestwa niebieskiego, przechodząc przez sfery niebieskie, czyli kolejne niebiosa), ŹMT 1, s. 219 (por. też H. Pietras, Eschatologia Kościota pierwszych czterech wieków..., dz. cyt., s. 91-95).

344 Pseudo-Atanazy, Expositio fidei, w: PG 25B, k. 201-203. (Jezus otworzył wejście do raju, skąd Adam został wygoniony i do którego na nowo wszedł w osobie łotra, tak jak to Pan powiedział: „Dziś ze mną będziesz w raju”).

345 Iohannes Chrysostomus, De cruce et latrone homilia I,2, w: PG 49, k. 401-402; przekład polski Jan Chryzostom, Homilia I o krzyżu i totrze, Sinko II, s. 162-175 (Bóg otwiera ci dzisiaj raj zamknięty od pięciu tysięcy lat i więcej. Bóg wprowadza tam łotra tego samego dnia o tej samej porze).

346 J. Delumeau, Alla ricerca del paradiso..., dz. cyt., s. 233-324.

347 Ap 22, 1-2: „Ukazał mi rzekę wody życia, lśniącą jak kryształ, wypływającą z tronu Boga i Baranka. Pomiędzy rynkiem Miasta a rzeką, po obu brzegach, drzewo życia, rodzące dwanaście owoców - wydające swój owoc każdego miesiąca - a liście drzewa [służa] do leczenia narodów". 
3. Kształtowanie się nauki o niebie w teologii patrystycznej - wiek III

z Kartaginy, zwracającego się do rzymskich wyznawców, odnajdujemy w Liście 37 (250 rok) opis raju pojmowanego jako wieczny ogród, który, co więcej, będzie stanowił dla męczenników rekompensatę za poniesione męczeństwo ${ }^{348}$. Jeszcze bardziej rozbudowany opis raju, który stał się niebem, znajdujemy u Pseudo-Cypriana. „Miejsce Chrystusa gdzie spoczywa łaska” (Christi locus, ubi iacet gratia) zostaje opisane jako „ziemia bujna/obfita, której pola wydają owoce i zachowują nietkniętymi pachnące kwiaty". Dalej następuje opis drzew tej ziemi, które są wysokie aż do nieba, dając cień tak głęboki jak ubranie. Ani zimno zimy, ani palący gorąc lat nie niszczy tam wegetacji) ${ }^{349}$.

Komentujący te wyobrażenia rajskie Delumeau zauważa, że od IV wieku swoiste pejzaże rajskie, które mają wyrażać wieczną - niebiańską radość, możemy znaleźć szczególnie u poetów chrześcijańskich opisujących wejście duszy do raju (np. Prudencjusz, IV wiek) ${ }^{350}$, w tekstach passiones z V wieku, oddających radość zbawionych w raju (np. Acta sancti Sebastiani, $\mathrm{V}$ wiek) czy w sztuce mozaikowej (mozaiki w Sant'Apollinare in Classe w Rawennie, VI wiek). Tematyka łąki rajskiej w średniowiecznej sztuce staje się już klasycznym toposem artystycznym (np. mozaiki w absydzie

348 Cyprianus Carthaginensis, Epistula 16,2: „Successit hierni verna temperies rosis, laeta et floribus coronata: sed vobis rossae et flores de paradisi deliciis aderant et caput vestrum serta coelestia coronabant", w: PL 4, k. 266A; Sancti Cypriani, Epistula 37,II.1, w: CChSL 3B, s. 179; przekład polski Cyprian z Kartaginy, List 37,4: „Po zimie nastąpiła wiosna, ciesząca się różami, uwieńczona kwiatami, dla was zaś różami i kwiatami były radości nieba [tłumaczenie własne „flores de paradisi” - „radości raju”] i girlandy [tłumaczenie własne „serta coelestia” - „wieńce niebiańskie”] wieńczyły wasze głowy", tłum. W. Szołdrski, Warszawa 1969, PSP 1, s. 110.

349 PsuedoCyprianus, De laude martyrii 21: „Christi locus, ubi iacet gratia, ubi uirentibus campis terra luxurians alumno se induit gramine et redolenti pascitur flore, ubi altum nemora tolluntur in uerticem et ubi arborum densior coma uestit, quicquid curuantibus ramis scena deiacens inumbrarit. omnia illic non frigoris nec ardoris nec ut autumno arua requiescant aut iterum tellus uere nouo fecunda parturiat", w: CSEL 3.3, CSEL 3.3. Appendix. S. Thasci Caecili Cypriani Opera Spuria cum Indicibus et Praefatione ex Recensione G. Hartelii, Vindobonae 1871, s. 43-44.

350 Aurelius Prudentius Clemens, Hamartigenia 839-859, w: PL 59, k. 1070; przekład polski Prudencjusz, Źródto grzechu, tłum. M. Brożek, PSP 43, s. 133 („ww. s. 839842: Natomiast w dali przeciwnej, gdzie rajska kraina, świadom przyszłości Majestat inne ustanowił nagrody dla dusz w czystości (...) ww. s. 856-859: Tam zaś spoczywa na łożu w purpurowych kwiatach, upajające ich wiecznie wdychając zapachy, I na posłaniu z róż pijąc ambrozyjskie rosy"). 
Kształtowanie się nauki o niebie w teologii patrystycznej I-III wieku

Santa Maria Maggiore w Rzymie, około 1295 roku). Można dostrzec też, że stopniowo biblijny raj pierwotny, czyli ogród Eden, w wyobrażeniach teologów i artystów chrześcijańskich staje się w późnej starożytności ogrodem niebiańskim ${ }^{351}$.

Jak zauważa Antonio Nitrola rozróżnienie pomiędzy rajem rozumianym jako pierwotny ogród Eden a definitywną sytuacją eschatologiczną było niejasne w terminologii chrześcijańskiej aż do średniowiecza. Było to niewątpliwie uwarunkowane podtrzymywaniem idei o miejscu dla sprawiedliwych, które byłoby czymś pośrednim pomiędzy śmiercią a zmartwychwstaniem. Punktem przełomowym na Zachodzie w teologicznej interpretacji raju była wydana w 1336 roku bulla Benedictus Deus papieża Benedykta XII. W dokumencie tym biskup Rzymu definitywnie i kościelnie usankcjonował ekwiwalencję terminów „królestwo niebieskie” / „niebo” / „raj”352. Od tego momentu na Zachodzie obserwuje się też delikatną zmianę semantyczną w terminologii teologicznej. „Raj” będzie oznaczał przede wszystkim „stan niebiański”, natomiast w drugim znaczeniu, z określeniem przymiotnikowym „ziemski”, termin ten zacznie opisywać „ogród Eden”353.

351 Por. J. Delumeau, Alla ricerca del paradiso..., dz. cyt., s. 237-239.

352 DS 1000: „Quod animae puerorum (...) sunt et erunt in caelo, caelorum regno et paradiso caelestis cum Cristo, sanctorum Angelorum consortio congregatae", ed. H. Denzinger, P. Hünermann, Enchiridion Symbolorum, definitionum et declarationum de rebus fidei et morum, Bologna 1996, s. 522; Jak odnotowuje C. Naumowicz, Konstytucja Benedykta XII «Benedictus Deus». Próba nowego spojrzenia na kontrowersję, „Teologia w Polsce” 4,1 (2010), s. 109-123, papież Benedykt XII wprowadza precyzację, iż dusze cieszą się Istotą Bożą (divina essentia perfuuntur) i dlatego są prawdziwie szczęśliwe (sunt vere beatae). Papież oddzielił zatem koncepcję „widzenia Boga” od koncepcji „stanu doskonałego”, pozostawiając, jako otwartą, możliwość, którą sam podzielał, że taki ogląd po sądzie zostanie przewyższony przez ogląd pełniejszy i doskonalszy, w: C. Naumowicz, Konstytucja Benedykta..., dz. cyt., s. 118-119.

353 Por. A. Nitrola, Trattato di escatologia. Vol. 2. Pensare la venuta del Signore, Cinisello Balsamo (Milano) 2010, s. 412. 


\subsection{Podsumowanie nauki o niebie $w$ teologii patrystycznej ojców i pisarzy okresu III wieku}

W tekstach pisarzy i ojców Kościoła z III wieku odnajdujemy bardziej rozbudowane wątki nauki o eschatologicznym niebie. Ich teologia jest już bardziej spekulatywna niż w poprzednich dwóch wiekach, a wątki katechetyczne są tam mniej obecne. $Z$ metodologicznego punktu widzenia najbardziej złożone rozważania o eschatologii końcowej spotykamy u Orygenesa, w którego tekstach dodatkowo mamy do czynienia ze zjawiskiem polisemiczności. W kontekście całej twórczości teologicznej badanych autorów nauka o niebie nadal pozostaje jednak okazjonalna. Nie spotykamy więc do III wieku włącznie chrześcijańskiego traktatu skoncentrowanego wyłącznie na tematyce eschatologicznego nieba.

Dla większości autorów tematyka eschatologii końcowej związanej z niebem jest raczej drugoplanowa (Ireneusz z Lyonu, Klemens Aleksandryjski). Teologowie III wieku rozwijają przede wszystkim wątki teologii biblijnej dotyczącej nieba jako szczególnego miejsca przebywania Boga, obiecanego zbawionym (Klemens Aleksandryjski), którzy będą się tam cieszyli nieśmiertelnością (Ireneusz z Lyonu, Klemens Aleksandryjski, Orygenes). W swej spekulacji teologicznej, uwarunkowanej pośrednio wpływem filozofii greckiej, pisarze ci dochodzą również do postawienia hipotez, że zbawieni w niebie będą doświadczali najwyższego stopnia poznawania Boga (Klemens Aleksandryjski, Orygenes), dostąpią deifikacji (Klemens Aleksandryjski), a nawet stopniowego przechodzenia w życiu wiecznym do przebywania w aczasowości Boga (Orygenes).

\section{Opisy nieba}

Autorzy patrystyczni III wieku rozważają rzeczywistość nieba, kontynuując główne wątki biblijnego przekazu na ten temat. Klucz ich rozważań jest zasadniczo soteriologiczny. Eschatologiczne niebo jest częścią Bożego stworzenia jako miejsce specjalnie wybrane przez Boga, choć Bóg je przekracza $^{354}$, jest zależne od Boga ${ }^{355}$ i uporządkowane według siedmiu działań

354 Por. Ireneusz z Lyonu, Wyktad nauki apostolskiej 3A-4A; 43; 45.

355 Por. Ireneusz z Lyonu, Wyktad nauki apostolskiej 3A-4A; 4-5. 
Kształtowanie się nauki o niebie w teologii patrystycznej I-III wieku

Ducha Bożego wiązanych z człowieczeństwem Syna Bożego ${ }^{356}$; stąd życie rozumiane jako „wieczne” oznacza „nowy rodzaj życia-duchowy-mistyczny”, nie podlegający zmianom czasu, gdyż gwarancją takiego życia zbawionych jest Chrystus. W ten sposób zostaje zrealizowany najważniejszy cel bytów stworzonych, ponieważ człowiek zbawiony znajduje swoje dopełnienie w Bogu ${ }^{357}$. W rozważaniach autorów greckojęzycznych widać podkreślanie nowej jakości życia opisywanej jako duchowa; natomiast autorzy łacińskojęzyczni w swych opisach uwypuklają wymierność nieba jako miejsca nagrody za życie moralne w doczesności, stąd częste metafory nieba jako uczty czy opisy niebiańskiego raju.

\section{Stosowana terminologia}

W tekstach autorów chrześcijańskich III wieku powtarzają się zarówno motywy przestrzenno-rzeczowe jak i motywy jakościowe:

(1) określenia związane z motywami przestrzenno-rzeczowymi: Jerozolima okresu millenium ${ }^{358}$, Jerozolima niebieska ${ }^{359}$, Jerozolima powyżej ${ }^{360}$, raj ${ }^{361}$, królestwo niebieskie ${ }^{362}$, Królestwo Boże ${ }^{363}$, nagroda-niebo ${ }^{364}$, nagroda-miasto ${ }^{365}$, niebo ${ }^{366}$, bramy zbawienia ${ }^{367}$, święte miejsce poby$\mathrm{tu}^{368}, \mathrm{uczta}^{369}, \mathrm{raj}^{370}$;

356 Por. Ireneusz z Lyonu, Wyktad nauki apostolskiej 9; Wiktoryn z Poetovium, De fabrica mundi 7.

357 Por. Orygenes, Komentarz do Ewangelii wedtug św. Jana 6,44,227; Komentarz do Ewangelii wedtug św. Mateusza cz. 2. C.S. 38,1-2.

358 Por. Ireneusz z Lyonu, Adversus haereses 5,35.2.

359 Por. Ireneusz z Lyonu, Adversus haereses 5,36.1-36.2; Tertulian, Przeciw Marcjonowi 3,24 .

360 Por. Klemens Aleksandryjski, Wychowawca 2,12,119.

361 Por. Ireneusz z Lyonu, Adversus haereses 5,36.2.

362 Por. Klemens Aleksandryjski, Zachęta Greków 9,87,3.

363 Por. Origenes, Fragmenta in Evangelium Joannis (in catenis) 36.

364 Por. Klemens Aleksandryjski, Zachęta Greków 11,111,3.

365 Por. Tertulian, Przeciw Marcjonowi 3,24,5.

366 Por. Klemens Aleksandryjski, Zachęta Greków 10,100,1.

367 Por. Klemens Aleksandryjski, Zachęta Greków 4,63,5.

368 Por. Klemens Aleksandryjski, Kobierce 6,13,105.

369 Por. Tertulian, Przeciw Marcjonowi 4,31,2.

370 Por. Tertulian, Apologetyk 67,12, Tertulian, Do męczenników 3,3; Męczeństwo św. Perpetuy i Felicyty 11-13. 
3. Kształtowanie się nauki o niebie w teologii patrystycznej - wiek III

(2) określenia związane z motywami jakościowymi: cechy anielskie ${ }^{371}$, obraz i podobieństwo Boga ${ }^{372}$, niezniszczalność i nieśmiertelnośćc ${ }^{373}$, życie wieczne ${ }^{374}$; nagroda-nieśmiertelność ${ }^{375}$, nagroda-zbawienie ${ }^{376}$, najwyższe Dobro-zbawienie ${ }^{377}$, życie wieczne ${ }^{378}$, prawdziwe wytchnienie ${ }^{379}$, Chrystus - opisywany jako: przyszłe dziedzictwo / ziemia święta / królestwo niebieskie / Królestwo Boże ${ }^{380}$, najwyższe nieba / doskonałość / najwyższe szczęście / szczyt dóbr ${ }^{381}$, życie wieczne jako cel-koniec-wypełnienie-przebywanie blisko Boga-przyjaźń z Bogiem ${ }^{382}$, wieczność - jako nowa jakość życia we właściwym miejscu, które jest w czasie błogosławionych dzięki powiązaniu zbawionych z Logosem to też trwanie bez granic (doświadczenie radości z przebywania w tym samym miejscu z Logosem) ${ }^{383}$; Jerozolima - jako metafora przyjaźni z Bogiem, bycia przyjacielem Boga ${ }^{384}$; obecność Boga i oglądanie Go przez zbawionych ${ }^{385}$.

Jak widać z powyższego zestawienia określeń eschatologicznego nieba w tekstach autorów chrześcijańskich III wieku przeważają te związane z motywami jakościowymi.

371 Por. Ireneusz z Lyonu, Adversus haereses 5,35,1.

372 Por. Ireneusz z Lyonu, Adversus haereses 5,36,2-3.

373 Por. Ireneusz z Lyonu, Wyktad nauki apostolskiej 7; 31; 40; 72; Klemens Aleksandryjski Zachęta Greków 10,106,2; Tertullianus, De resurrectione carnis 52,10.

374 Por. Klemens Aleksandryjski, Zachęta Greków 1,7,3.

375 Por. Klemens Aleksandryjski, Zachęta Greków 10,96,3.

376 Por. Klemens Aleksandryjski, Zachęta Greków 10,106,5; Cyprian z Kartaginy, De mortalitate 21; Cyprian z Kartaginy, Ad Fortunatum 13; Cyprian z Kartaginy, De opere et eleemosynis 24; Lactantius, Divinae Institutiones 7.

377 Por. Klemens Aleksandryjski, Zachęta Greków 12,123,2.

378 Por. Klemens Aleksandryjski, Zachęta Greków 1,7,1.

379 Por. Klemens Aleksandryjski, Wychowawca 3,7,39.

380 Por. Orygenes, Homilie do Ksiegi Jozuego 25,4; Orygenes, Komentarz do Ewangelii wedtug św. Mateusza. Cz. 2. Commentariorum series 72; Tertullianus, De resurrectione carnis 67,7.

381 Orygenes, Przeciw Celsusowi 6,19-20; Tamże 6,44.

382 Por. Origenes, Selecta in Psalmos 23; Orygenes, Komentarz do Listu św. Pawta do Rzymian 4,12,2; Tertullianus, De baptismo 5,7.

383 Por. Orygenes, Zachęta do męczeństwa 47; Origenes, Selecta in Psalmi 22.

384 Por. Origenes, Fragmenta ex Commentariis in Ezechielem 2-12.

385 Por. Tertulian, Przeciwko Prakseaszowi 23,4. 
Kształtowanie się nauki o niebie w teologii patrystycznej I-III wieku

\section{Najważniejszy przekaz teologiczny dotyczący nieba}

Myśl przewodnia odnosząca się do eschatologicznego nieba jest w analizowanych tekstach patrystycznych spójna z nauczaniem nowotestamentalnym i stale wskazuje na Jezusa Chrystusa jako na sposób wejścia i przebywania w eschatologicznym niebie. Człowiek stworzony przez Boga jako dziecko, wzrastając, ma dojść do doskonałości ${ }^{386}$, którą osiąga przez zjednoczenie z Bogiem ${ }^{387}$. Metodą osiągnięcia nieba przez człowieka jest przyjęcie przezeń wiary objawionej przez Chrystusa ${ }^{388}$ i formowanie się w życiu doczesnym na wzór Chrystusa ${ }^{389}$. Prefiguracją i egzemplifikacją odnowienia stworzeń jest już zmartwychwstanie Jezusa ${ }^{390}$.

\section{Cechy zbawionych w niebie}

Cechy zbawionych są konsekwencją ich wiary w Jezusa i wynikają ostatecznie z odnowienia ich relacji z Bogiem. Wynikają one z przyjęcia przez omawianych autorów perspektywy soteriologicznej - dzięki wierze w Chrystusa dokonało się już usprawiedliwienie wierzących i ich uwolnienie od sądu rozumianego jako kara ${ }^{391}$, a zmartwychwstanie Jezusa, przynosząc Jego nieśmiertelność i niezniszczalność, jest zapowiedzią tego samego dla wierzących w Jezusa ${ }^{392}$. Nieśmiertelność i niezniszczalność człowieka zbawionego jest możliwa dla ludzi jedynie dzięki ich zjednoczeniu z Bogiem ${ }^{393}$.

Autorzy aleksandryjscy podkreślają, że po zmartwychwstaniu nastąpi uwolnienie się zbawionych od namiętności, utrata płciowości połączona $\mathrm{z}$ przejściem w formę istoty jednopłciowej ${ }^{394}$ czy aseksualnej ${ }^{395}$. Cechy zbawionych w niebie upodabniają ich do Chrystusa ${ }^{396}$, dlatego są

\footnotetext{
386 Por. Ireneusz z Lyonu, Wyktad nauki apostolskiej 12; Klemens Aleksandryjski, Zachęta Greków 12,120,3.

387 Por. Ireneusz z Lyonu, Wyktad nauki apostolskiej 31.

388 Por. Klemens Aleksandryjski, Zachęta Greków 1,10,2-3.

389 Klemens Aleksandryjski, Wychowawca 1,12,100.

390 Por. Orygenes, $O$ zasadach 3,6,3 i Orygenes, Homilie o Księdze Jeremiasza 14,18.

391 Por. Ireneusz z Lyonu, Wyktad nauki apostolskiej 69.

392 Por. Ireneusz z Lyonu, Wyktad nauki apostolskiej 72; 88.

393 Por. Ireneusz z Lyonu, Wyktad nauki apostolskiej 31.

394 Por. Klemens Aleksandryjski, Kobierce 6,12,100,3.

395 Por. Orygenes, Przeciw Celsusowi 3,41-42.

396 Por. Klemens Aleksandryjski Wychowawca 1,12,98; Orygenes, Przeciw Celsusowi $3,41-42$.
} 
oni wolni od pożądliwości ${ }^{397}$, doświadczają wytchnienia ${ }^{398}$ i życia wiecznego $^{399}$, są usynowieni i zbawieni ${ }^{400}$, przemienieni w istoty niebiańskie i święte ${ }^{401}$, przebóstwieni ${ }^{402}$, samowystarczalni i prości ${ }^{403}$, wiecznie szczęśliwi ${ }^{404}$, wiecznie trwający w Bogu ${ }^{405}$, niezniszczalni ${ }^{406}$ i doświadczający udziału w prawdziwym pięknie ${ }^{407}$.

Eschatologiczne niebo byłoby też dla zbawionych dalszym postępowaniem w rozwoju moralnym ${ }^{408}$ oraz rozwojem w jakiejś wymiernej, choć odnowionej jakościowo materialności ${ }^{409}$. Szczególnie, według Orygenesa, życie wieczne nie będzie inercją, ale rodzajem czynnego odpoczynku właściwego świętym (bycie z Jezusem Chrystusem, relaks, wypoczynek umysłu, oglądanie Boga twarzą w twarz). Tak rozumiana „czasowość” w życiu wiecznym byłaby zatem jakościowo skończona. Stąd Orygenes rozważa, iż w jakościowym rozumieniu „końca” tego, co ma nadejść w niebie, będzie jakieś kolejne przejście do „dziedzictwa królestwa niebieskiego”, czyli pojawia się teza o wejściu przygotowanych do tego zbawionych stworzeń do bezczasowego życia Boga. Wypełnieniem wszystkich tych eschatologicznych nadziei jest Chrystus, a ich realizacja dokonuje się przez miłość.

Natomiast u autorów łacińskich III wieku zauważamy, że ich opisy życia wiecznego są skoncentrowane na wymierności nagrody przyszłego życia i swoistej rajskości, która jednak nie stanowi pełni zbawienia, gdyż np. Tertulian, niezależnie od swoich opisów uczty niebieskiej i wymiernego raju, mówi także o upodabnianiu się zbawionych do Boga. Podobnie w wizji męczennika Satura znajdujemy wzmiankę o wchodzeniu i wychodzeniu z raju do tajemniczego miejsca przebywania Boga.

\footnotetext{
397 Por. Klemens Aleksandryjski Wychowawca 1,4,10.

398 Por. Klemens Aleksandryjski Wychowawca 1,6,29.

399 Por. Klemens Aleksandryjski Wychowawca 1,29,1.

400 Por. Klemens Aleksandryjski Wychowawca 1,12,98.

401 Por. Klemens Aleksandryjski Wychowawca 1,12,98.

402 Por. Klemens Aleksandryjski Wychowawca 1,12,98.

403 Por. Klemens Aleksandryjski Wychowawca 1,12,98.

404 Por. Klemens Aleksandryjski Wychowawca 1,13,103.

405 Por. Klemens Aleksandryjski Wychowawca 1,12,102.

406 Por. Klemens Aleksandryjski Wychowawca 2,2,19.20.

407 Por. Klemens Aleksandryjski Wychowawca 2,12,129.

408 Por. Klemens Aleksandryjski, Kobierce 6,6,47,1.

409 Por. Orygenes, $O$ zasadach 2,3,7.
} 
Kształtowanie się nauki o niebie w teologii patrystycznej I-III wieku

\section{Przygotowanie do osiągniecia nieba}

Autorzy III wieku powtarzają nowotestamentalną parenezę chrześcijańską o życiu według wiary. W doczesności postawami wskazanymi dla wierzących w Chrystusa są zatem: przestrzeganie reguł wiary i wypełnianie przykazań Bożych ${ }^{410}$, przyjęcie chrztu ${ }^{411}$, prostota wiary i miłość ${ }^{412}$, służenie Bogu w imię Jezusa ${ }^{413}$, życie w sprawiedliwości ${ }^{414}$ i w cierpliwości ${ }^{415}$.

Zarówno dla chrześcijańskich autorów greckojęzycznych III wieku, jak i dla autorów łacińskojęzycznych tego okresu, nauczanie o eschatologicznym niebie nie było podstawową tematyką rozważań. Ich przekazy na powyższy temat nadal pozostają fragmentaryczne, choć zwiększa się ilość relatywnych wzmianek eschatologicznych oraz niewątpliwie pogłębia się poziom samej spekulacji teologicznej. Eschatologiczne niebo pozostaje „stworzonym-wybranym-szczególnym” przez Boga miejscem Jego przebywania ze stworzeniami, które Go kochają. Przeważają w tym okresie jakościowe opisy niebiańskiej rzeczywistości eschatologicznej, ujęte w ramach chrześcijańskiej soteriologii. Charakterystyczny jest opis nieba jako rzeczywistości progresywnej, zmierzającej do coraz pełniejszego stopnia zjednoczenia zbawionych z Bogiem. Najważniejszym przesłaniem chrześcijańskim dotyczącym eschatologicznego nieba nadal pozostaje idea, iż drogą i bramą do życia wiecznego jest Jezus Chrystus.

\footnotetext{
410 Por. Ireneusz z Lyonu, Wyktad nauki apostolskiej 3.

411 Por. Ireneusz z Lyonu, Wyktad nauki apostolskiej 3A.

412 Por. Ireneusz z Lyonu, Wyktad nauki apostolskiej 87.

413 Por. Ireneusz z Lyonu, Wyktad nauki apostolskiej 88.

414 Por. Tertulian, Przeciw Marcjonowi 3,24,5.

415 Por. Cyprian z Kartaginy, De mortalitate 21.
} 


\section{Zakończenie}

Opis tematyki eschatologicznego nieba i życia wiecznego w teologicznym ujęciu autorów patrystycznych I-III wieku wydaje się być progresywny, a zarazem spójny. Analizowani autorzy prowadzili bowiem swe refleksje teologiczne, odnosząc się do tego samego Objawienia, jakim jest Pismo Święte i pierwotna Tradycja apostolska, a w niej przede wszystkim przekaz prawdy wiary o zbawieniu już dokonanym w Jezusie Chrystusie. Refleksja teologów pierwszych trzech wieków różnicowała się natomiast na poziomie stosowanych przez nich środków przekazu literackiego oraz osobowości każdego z nich.

Spójność przekazu dotyczącego eschatologicznego nieba dostrzegam u autorów patrystycznych I-III wieku przede wszystkim w powtarzaniu najważniejszej prawdy teologicznej wynikającej z orędzia NT, iż jedynym sposobem na osiągnięcie nieba jest dla chrześcijanina wiara, chrzest i zaufanie do Jezusa Chrystusa. Kluczem do zrozumienia eschatologicznego przekazu autorów wczesnochrześcijańskich pozostaje zatem bezwzględnie nowotestamentalna soteriologia, co nie powinno specjalnie dziwić.

Autorzy I wieku powtarzają podstawowy kerygmat NT dotyczący zbawienia i życia wiecznego. Sposób przekazu tej prawdy pozostaje zasadniczo katechetyczny. Apologeci greccy II wieku, ze względu na swój dialog prowadzony ze światem pogańskim, zaczynają harmonizować orędzie soteriologii 
Kształtowanie się nauki o niebie w teologii patrystycznej I-III wieku

nowotestamentalnej z etycznymi kategoriami filozofii greckiej (stoicki prymat cnoty, platoński idealizm etyczny), co w przekazie wiary skutkuje pośrednio wypracowaniem swoistej teologii eschatologicznej zasługi i moralistycznym uzależnianiem osiągnięcia nieba przez wierzącego od zgodności jego wyborów moralnych (analogiczną narrację o niebie jako nagrodzie za wybory etyczne spotykamy u afrykańskich moralistów III wieku). Tak silne powiązanie orędzia ewangelicznego z grecką antropologią i etyką filozoficzną skutkuje też pośrednio początkiem chrześcijańskiej refleksji nad hipotetycznym stanem pośrednim. Jednak podstawowy przekaz teologiczny pozostaje w swym wymiarze katechetyczny i zgodny z soteriologią NT.

Autorzy chrześcijańscy w III wieku są niewątpliwie bardziej zróżnicowani zarówno pod względem form przekazu, jak i rozwijanych koncepcji eschatologicznych. Obok klasycznego przekazu katechetycznego pojawiają się bowiem w ich dziełach pierwsze spekulacje eschatologiczne, z których na czoło wybijają się eschatologiczne hipotezy Orygenesa o rozwoju moralnym i materialnym zbawionych w niebie, aż do osiągnięcia nowego nieba i nowej ziemi i wejścia zbawionych do tajemniczej aczasowosci Boga. W tym czasie afrykańscy moraliści III wieku rozważają wątek nieba „wymiernego” jako nagrody za dobre wybory etyczne. Obie tendencje teologiczne (aleksandryjska i afrykańska) wykazują jednak swoiste podobieństwo w tezie o ostatecznym losie zbawionych: jest to osiagnięcie życia Bożego / upodobnianie życia zbawionych do życia Boga. Pomimo odnotowanych różnic podstawowy przekaz wiary pozostaje ten sam: jedynym sposobem na osiągnięcie przez człowieka wierzącego eschatologicznego nieba - rozumianego jako wspólnota zbawionego z Bogiem i innymi zbawionymi - jest realna więź człowieka wewnętrznego z Jezusem Chrystusem. Gwarancją obietnicy eschatologicznego nieba dla wierzącego jest zawsze wiara w prawdomówność i łaskawość Boga.

Uderza fragmentaryczność przekazu ojców i pisarzy Kościoła I-III wieku na temat eschatologicznego nieba / życia wiecznego zbawionych. Tematyka ta nigdy nie jest pierwszoplanowa, najczęściej jest wpisana w kontekst szerszego nauczania soteriologicznego. Terminologia, jaką stosują omawiani autorzy, stanowi kontynuację eschatologicznego słownictwa nowotestamentalnego, czasami są to również zbitki semantyczne terminów biblijnych, wyjątkowo spotykamy w analizowanych tekstach słownictwo mityczne 
świata pogańskiego (motyw Arkadii). W I wieku przeważają motywy przestrzenne, w dwóch kolejnych jakościowe. Wszystkie opisy eschatologiczne nieba są przekazem archetypów pozytywnych. Niebo eschatologiczne pozostaje w warstwie przekazu - stworzonym, wybranym i uprzywilejowanym przez Boga, szczęśliwym miejscem, gdzie Bóg jest z człowiekiem zbawionym w przyjaźni. W tak pojmowanym niebie cechy Chrystusa stają się też definitywnie cechami zbawionych. W ten sposób zostaje również zrealizowany najważniejszy cel bytów stworzonych, gdyż człowiek zbawiony znajduje swoje ostateczne dopełnienie w Bogu. 



\section{Bibliografia}

\section{Teksty źródłowe}

\subsection{Edycje Biblii}

Grecko-polski Nowy Testament. Wydanie interlinearne $z$ kodami gramatycznymi, przekł. R. Popowski, M. Wojciechowski, (Prymasowska Seria Biblijna 1), Warszawa 1995.

Hebrajsko-polski Stary Testament. Ksiega Rodzaju. Wydanie interlinearne z kodami gramatycznymi, transkrypcją oraz indeksem rdzeni, tłum. i oprac. A. Kuśmirek, (Pymasowska Seria Biblijna 14), Warszawa 2000.

Pismo Święte Starego i Nowego Testamentu w przektadzie z jezyków oryginalnych ze wstępami i komentarzami, red. M. Peter i M. Wolniewicz, t. 2, Poznań 1997. Pismo Święte Starego i Nowego Testamentu w przektadzie z jezyków oryginalnych. Biblia tysiąclecia. Opracował zespół biblistów polskich z inicjatywy benedyktynów tynieckich, Poznań 20024.

Septuaginta. Id est Vetus Testamentum graece iuxta LXX interpretes edidit Alfred Rahlfs. Duo volumina in uno, Stuttgart 1979; przekład polski Septuaginta czyli Biblia Starego Testamentu wraz z ksiegami deuterokanonicznymi i apo- 
Kształtowanie się nauki o niebie w teologii patrystycznej I-III wieku

kryfami, tłum. i oprac. R. Popowski SDB, (Pymasowska Seria Biblijna 37), Warszawa $2014^{2}$.

\subsection{Edycje apokryfów}

Apocalypsis Pauli (Apokalipsa Pawta), w: Apokryfy Nowego Testamentu. Listy i apokalipsy chrześcijańskie, tłum. M. Starowieyski, Kraków 2001, s. 241-279. Apocalypsis Petri (Apokalipsa Piotra), w: Apokryfy Nowego Testamentu. Listy i apokalipsy chrześcijańskie, tłum. S. Kur (etiopski), M. Starowieyski (grecki), Kraków 2001, s. 225-241.

Evangelium Aegyptiorum (Ewangelia wedtug Egipcjan), w: Apokryfy Nowego Testamentu. Ewangelie apokryficzne, cz. 1, red. M. Starowieyski, tłum. M. Starowieyski, Kraków 2003, s. 122-122.

Evangelium Thomae (Ewangelia Tomasza), w: Apokryfy Nowego Testamentu. Ewangelie apokryficzne. Cz. 1. Fragmenty, Narodzenie i Dzieciństwo Maryi i Jezusa, tłum. W. Myszor, A. Dembska, oprac. M. Starowieyski, Kraków 2003, s. 180-202.

Pseudo-Clemens Romanus (Pseudo-Klemens Rzymski), Agrapha 8, w: Apokryfy Nowego Testamentu. Ewangelie apokryficzne, cz. 1, red. M. Starowieyski, tłum. M. Starowieyski, Kraków 2003, s. 93.

\subsection{Edycje tekstów patrystycznych (wydania krytyczne $\mathrm{i}$ istniejące polskie tłumaczenia)}

Anonymus ad Diognetum, w: SCh 33bis. A Diognète. Introduction, édition critique, traduction et commentaire de H. I. Marrou, Paris 1997; przekład polski List do Diogneta, w: BOK 10. Pierwsi świadkowie. Pisma Ojców Apostolskich, tłum. A. Świderkówna, wstęp, komentarz i oprac. M. Starowieyski, Kraków $1998^{2}$, s. 339-348.

Aristides, Apologia, w: SCh 470, Aristide, Apologie. Introduction, textes critiques, traductions et commentaire par B. Pouderon, M.-J. Pierre, B. Quttier, M. Guiorgadzé, Paris 2003; przekład polski Arystydes z Aten, Apologia, w: BOK 24. Pierwsi apologeci greccy. Kwadratus, Arystydes z Aten, Aryston 
z Pelli, Justyn Męczennik, Tacjan Syryjczyk, Milcjades, Apolinary z Hierapolis, Teofil z Antiochii, Hermiasz, tłum., wstępy i komentarze L. Misiarczyk, oprac. J. Naumowicz, Kraków 2004, s. 111-133 [wstęp], s. 135-150 [tekst wersja grecka].

Athenagoras Philosophus, De resurrection mortuorum, w: SCh 379. Athénagore, Supplique au sujet des chrétiens et Sur la resurrection des morts. Introduction, texte critique, traduction et notes par B. Pouderon, Paris 1992, s. 214317; przekład polski Atenagoras z Aten, O zmartwychwstaniu umartych, w: PAX 24, tłum., wstęp, komentarz i oprac. S. Kalinkowski, Warszawa 1985, s. 83-115.

Athenagoras Philosophus, Suplicatio pro Christianis, w: SCh 379. Athénagore, Supplique au sujet des chrétiens et Sur la resurrection des morts. Introduction, texte critique, traduction et notes par B. Pouderon, Paris 1992, s. 70-209; przekład polski Atenagoras z Aten, Prośba za chrześcijanami, w: PAX 24, tłum., wstęp, komentarz i oprac. S. Kalinkowski, Warszawa 1985, s. 27-80.

Aurelius Prudentius Clemens, Hamartigenia, w: PL 59. M. Aurelii Clmentis Prudenti Carmina, ed. J.-P. Migne, Paris 1862, k. 1007-1078; przekład polski Prudencjusz, Źródto grzechu, w: PSP 43, Aureliusz Prudencjusz Klemens, Poezje, tłum., wstęp i oprac. M. Brożek, Warszawa 1987, s. 112-136.

Clemens Alexandrinus, Excerpta ex Theodoto, w: SCh 23. Clément d'Alexandrie. Extraits de Théodote, Introduction, textes critiques, traductions et commentaire par F. Sagnard, Paris 1948; przekład polski Klemens Aleksandryjski, Wypisy z Theodota, w: ŹMT 22, tłum. i oprac. P. Siejkowski Kraków 2001.

Clemens Alexandrinus, Paedagogus, w: SCh 70. Clément d'Alexandrie, Le Pédagogue. Livre I. Texte grec, introduction et notes de H.-I. Marrou, traduction de M. Harl, Paris 1960; SCh 108. Clément d'Alexandrie, Le Pédagogue. Livre II. Traduction de C. Mondésert, notes de H.-I. Marrou, Paris 1991²; SCh 158. Clément d'Alexandrie, Le Pédagogue. Livre III. Traduction de C. Mondésert et Ch. Matray, notes de notes de H.-I. Marrou, Paris 1970; przekład polski Klemens Aleksandryjski, Wychowawca, tłum. M. Szarmach, Toruń 2012.

Clemens Alexandrinus, Protrepticus, w: SCh 2. Clément d'Alexandrie, Le Protreptique. Introduction, traduction et notes de C. Mondésert, Paris 1949; przekład polski Klemens Aleksandryjski, Zachęta Greków, w: PSP 44. Apologie, tłum. J. Sołowianiuk, Warszawa 1988, s. 116-201. 
Kształtowanie się nauki o niebie w teologii patrystycznej I-III wieku

Clemens Alexandrinus, Stromata, w: GCS 52. Clemens Alexandrinus II. Stromata I-VI, herausgegeben O. Stählin; 1936², Leipzig 1906; SCh 30. Clément d'Alexandrie, Les Stromates. Stromate I. Texte grec, introduction et notes de C. Mondésert, traduction de M. Caster, Paris 1951; SCh 38. Clément d'Alexandrie, Les Stromates. Stromate II. Texte grec, introduction et notes de C. Mondésert, traduction de P. Camelot, Paris 1954; SCh 463. Clément d'Alexandrie, Les Stromates. Stromate IV. Texte grec, introduction et notes de C. Mondésert, traduction de A. van den Hoek, Paris 2001; SCh 278 279. Clément d'Alexandrie, Les Stromates. Stromate V. Texte grec, introduction, notes et traduction de A. Le Boulluec, Paris 1981; SCh 446. Clément d'Alexandrie, Les Stromates. Stromate VI. Texte grec, introduction, notes et traduction de P. Descourtieux, Paris 1999; SCh 428. Clément d'Alexandrie, Les Stromates. Stromate VII, Texte grec, introduction, notes et traduction de A. Le Boulluec, Paris 1997; przekład polski Klemens Aleksandryjski, Kobierce zapisków filozoficznych dotyczących prawdziwej wiedzy, tłum., komentarz i indeksy J. Niemirska-Pliszczyńska, PAX 33, s. 1-2, Warszawa 1994.

Clemens Romanus, Epistola ad Corinthios, w: FCh 15. Clemens von Rom, Epistola ad Corinthios. Brief an die Korinther, übersetzt und eingeleitet von G. Schneider, Freiburg im Breisgau 1994; przekład polski Klemens Rzymski, List do Kościota w Koryncie, w: BOK 10. Pierwsi świadkowie. Pisma Ojców Apostolskich, tłum. A. Świderkówna, wstęp, komentarz i oprac. M. Starowieyski, Kraków $1998^{2}$, s. 51-87.

Cyprianus Carthaginensis, De Opere et Eleemosynis, w: PL 4. Cypriani Episcopi Carthaginensis et Martyris Opera Omnia. Tomus unicus, ed. J.-P. Migne, Paris 1844, k. 625-646; Sancti Cypriani, De opere et eleemosynis, w: CChSL 3A. Sancti Cypriani Episcopi Opera. Pars II, ed. M. Simonetti, Turnholti 1976, s. 55-72; przekład polski Cyprian z Kartaginy, O uczynku i jatmużnach, w: POK 19. Św. Cyprian, Pisma. I. Traktaty, tłum. i oprac. J. Czuj, Poznań 1937, s. 324-348.

Cyprianus Carthaginensis, Epistola ad Fortunatum de Exhortatione Martyrii, w: PL 4. Cypriani Episcopi Carthaginensis et Martyris Opera Omnia. Tomus unicus, ed. J.-P. Migne, Paris 1844, k. 681-702; Sancti Cypriani, Ad Fortunatum, w: CChSL 3A. Sancti Cypriani Episcopi Opera. Pars I, ed. R. Weber, Turnholti 1976, s. 183-216; przekład polski Cyprian z Karta- 
giny, Do Fortunata, w: POK 19. Św. Cyprian, Pisma. I. Traktaty, tłum. i oprac. J. Czuj, Poznań 1937, s. 272-301.

Cyprianus Carthaginensis, Epistolae, w: PL 4. Cypriani Episcopi Carthaginensis et Martyris Opera Omnia. Tomus unicus, ed. J.-P. Migne, Paris 1844, k. 191-438C; CChSL 3B, Sancti Cypriani Episcopi Epistolarium. Pars 3,1 (Epistulae 1-57), ed. G. F. Diercks, Turnholti 1994; przekład polski Cyprian z Kartaginy, Listy, w: PSP 1. Św. Cyprian, Listy, tłum. W. Szołdrski, wstęp M. Michalski, oprac. E. Stanula, Warszawa 1969.

Cyprianus Carthaginensis, Liber de Mortalitate, w: PL 4. Cypriani Episcopi Carthaginensis et Martyris Opera Omnia. Tomus unicus, ed. J.-P. Migne, Paris 1844, k. 603-624; Sancti Cypriani, De mortalitate, w: CChSL 3A. Sancti Cypriani Episcopi Opera. Pars II, ed. M. Simonetti, Turnholti 1976, s. 17-32; przekład polski Cyprian z Kartaginy, O śmiertelności, w: POK 19. Św. Cyprian, Pisma. I. Traktaty, tłum. i oprac. J. Czuj, Poznań 1937, s. $252-271$.

Didache, w: FCh 1. Didache. Zwölf-Apostel-Lehre, übersetzt und eingeleitet von G. Schöllgen, Freiburg im Breisgau 1991, s. 23-139; przekład polski Nauka Dwunastu Apostotów, w: BOK 10. Pierwsi świadkowie. Pisma Ojców Apostolskich, tłum. A. Świderkówna, wstęp, komentarz i oprac. M. Starowieyski, Kraków $1998^{2}$, s. 33-44.

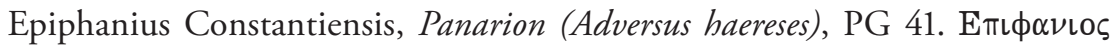

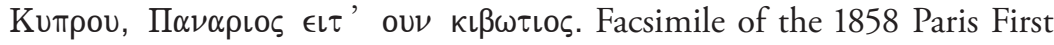
Edition, Athens 1992.

Hermas, Pastor, w: SU 3. Papiasfragmente. Hirt des Hermas, eingeleitet, herausgegeben, übertragen und erläutert von M. Leutzsch, Darmstadt 1998, s. 107-497; przekład polski Hermas,, Pasterz, w: BOK 10. Pierwsi świadkowie. Pisma Ojców Apostolskich, tłum. A. Świderkówna, wstęp, komentarz i oprac. M. Starowieyski, Kraków 1998², s. 205-299.

Hieronymus Presbyter, Apologia Adversus Libros Rufini, w: PL 23. Sancti Eusebii Hieronymi Stridonensis Opera Omnia, tomus secundus, ed. J.-P. Migne, Paris 1883, k. 445-514.

Ignatius Antiochenus, Epistula ad Ephesios, w: SU 1. Die Apostolischen Väter, eingeleitet, herausgegeben, übertragen und erläutert von J. A. Fischer, Darmstadt $1998^{10}$, s. 142-161; przekład polski Ignacy Antiocheński, List do Kościota w Efezie, w: BOK 10. Pierwsi świadkowie. Pisma Ojców Apostolskich, 
Kształtowanie się nauki o niebie w teologii patrystycznej I-III wieku

tłum. A. Świderkówna, wstęp, komentarz i oprac. M. Starowieyski, Kraków $1998^{2}$, s. 113-119.

Ignatius Antiochenus, Epistula ad Magnesios, w: SU 1. Die Apostolischen Väter, eingeleitet, herausgegeben, übertragen und erläutert von J. A. Fischer, Darmstadt $1998^{10}$, s. 162-171; przekład polski Ignacy Antiocheński, List do Kościoła w Magnezji, w: BOK 10. Pierwsi świadkowie. Pisma Ojców Apostolskich, tłum. A. Świderkówna, wstęp, komentarz i oprac. M. Starowieyski, Kraków $1998^{2}$, s. $120-123$.

Ignatius Antiochenus, Epistula ad Philadelphos, w: SU 1. Die Apostolischen Väter, eingeleitet, herausgegeben, übertragen und erläutert von J. A. Fischer, Darmstadt $1998^{10}$, s. 194-203; przekład polski Ignacy Antiocheński, List do Kościoła w Filadelfi, w: BOK 10. Pierwsi świadkowie. Pisma Ojców Apostolskich, tłum. A. Świderkówna, wstęp, komentarz i oprac. M. Starowieyski, Kraków $1998^{2}$, s. $132-135$.

Ignatius Antiochenus, Epistula ad Polycarpos, w: SU 1. Die Apostolischen Väter, eingeleitet, herausgegeben, übertragen und erläutert von J. A. Fischer, Darmstadt $1998^{10}$, s. 246-265; przekład polski Ignacy Antiocheński, List do Polikarpa, w: BOK 10. Pierwsi świadkowie. Pisma Ojców Apostolskich, tłum. A. Świderkówna, wstęp, komentarz i oprac. M. Starowieyski, Kraków $1998^{2}$, s. $140-142$.

Ignatius Antiochenus, Epistula ad Smyrnesios, w: SU 1. Die Apostolischen Väter, eingeleitet, herausgegeben, übertragen und erläutert von J. A. Fischer, Darmstadt $1998^{10}$, s. 204-215; przekład polski Ignacy Antiocheński, List do Kościota w Smyrnie, w: BOK 10. Pierwsi świadkowie. Pisma Ojców Apostolskich, tłum. A. Świderkówna, wstęp, komentarz i oprac. M. Starowieyski, Kraków $1998^{2}$, s. 136-139.

Ignatius Antiochenus, Epistula ad Trallianos, w: SU 1. Die Apostolischen Väter, eingeleitet, herausgegeben, übertragen und erläutert von J. A. Fischer, Darmstadt $1998^{10}$, s. 172-181; przekład polski Ignacy Antiocheński, List do Kościota w Tralleis, w: BOK 10. Pierwsi świadkowie. Pisma Ojców Apostolskich, tłum. A. Świderkówna, wstęp, komentarz i oprac. M. Starowieyski, Kraków $1998^{2}$, s. 124-127.

Irenaeus Lugdunensis, Adversus haereses V. Ubersetzt und eingeleitet von N. Brox, Freiburg im Breisgau 2001 (Fontes Christiani 8/5); częściowy przekład polski W. Myszor, Tysiąc lat panowania Chrystusa na ziemi. Millenaryzm 
w ujęciu Ireneusza z Lyonu ( Adversus Haereses» V,30,4-36,3), „Śląskie Studia Historyczno-Teologiczne" 33 (2000), s. 5-24.

Irenaeus Lugdunensis, Demonstratio praedicationis apostolicae (Epideixis), w: SCh 406. Irénée de Lyon, Démonstration de la prédication apostolique. Introduction, traduction et notes par A. Rousseau, Paris 1995; przekład polski Ireneusz z Lyonu, Wyktad nauki apostolskiej, w: ŹMT 7, tłum., wstęp, i oprac. W. Myszor, Kraków 1997.

Iohannes Chrysostomus, De cruce et latrone homilia I, w: PG 49. S. P. N. Joannis Chrysostomi Opera Omnia quae exstant. Voluminis secundi. Pars prior, ed. J.-P. Migne, Facsimile of the 1859 Paris First Edition, Athens 1996, k. 399-408; przekład polski Jan Chryzostom, Homilia I o krzyżu i totrze, Sinko II. Św. Jan Złotousty, Dwadzieścia homilij i mów, tłum. T. Sinko, Kraków 1947, s. 162-175.

Iustinus martyr, Apologia, w: SCh 507. Justin, Apologie pour les chrétiens. Introduction, texte critique, traduction et notes par Ch. Munier, Paris 2006; przekład polski Justyn Męczennik, 1 i 2 Apologia, tłum. i oprac. L. Misiarczyk, Warszawa 2012, s. 7-114.

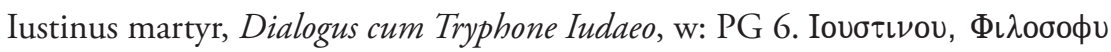

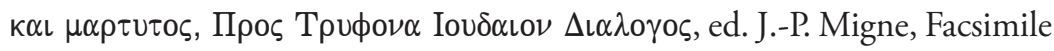
of the 1857 Paris Edition, Athens 2001, k. 471-800; przekład polski Justyn Męczennik, Dialog z Żydem Tryfonem, tłum. i oprac. L. Misiarczyk, Warszawa 2012, s. 119-318.

Lactantius, Divinae Institutiones, w: CSEL 19. Lucius Caeli Firmiani Lactanti Opera Omnia. Pars prima. Divinae Institutiones et Epitome Divinarum Institutionum, recensuit S. Brand, Pragae-Vindobonae-Lipsiae 1890, s. 1-672. Martyrio Sancti Polycarpi. Epistola Circularis, w: PG 5. AA.VV., ed. J.-P. Migne, Paris 1857, k. 1029-1046; przekład polski Męczeństwo świętego Polikarpa, biskupa Smyrny, w: BOK 10. Pierwsi świadkowie. Pisma Ojców Apostolskich, tłum. A. Świderkówna, wstęp, komentarz i oprac. M. Starowieyski, Kraków $1998^{2}$, s. 162-169.

Melito Sardensis, De Pascha, w: SCh 123. Méliton de Sardes, Sur la Pâque et fragments. Introduction, texte critique, traduction et notes par O. Perler, Paris 1966; przekład polski Meliton z Sardes, Homilia paschalna, w: BOK 10. Pierwsi świadkowie. Pisma Ojców Apostolskich, tłum. A. Świderkówna, wstęp, komentarz i oprac. M. Starowieyski, Kraków $1998^{2}$, s. 308-333. 
Kształtowanie się nauki o niebie w teologii patrystycznej I-III wieku

Origenes, Commentarii in Epistulam ad Romanos (latine, intreprete Rufin, libri X), w: SCh 532. Origène, Commentaire sur l'Épître aux Romains. T. I (Livres I-II). Texte critique établi par C.P. Hammond Bammel, Introduction par M. Fédou, Traduction, notes et index par L. Brésard, Paris 2009; SCh 539. Origène, Commentaire sur l'Épître aux Romains. T. II (Livres III-V). Texte critique établi par C.P. Hammond Bammel, Introduction par M. Fédou, Traduction et notes par L. Brésard, Paris 2010; SCh 543. Origène, Commentaire sur l'Épître aux Romains. T. III (Livres VI-VIII). Texte critique établi par C. P. Hammond Bammel, Introduction par M. Fédou, Traduction et notes par L. Brésard et M. Fédou, Index par L. Brésard, Paris 2011; przekład polski Orygenes, Komentarz do Listu św. Pawta do Rzymian, w: PSP 57/1-2, tłum. i oprac. S. Kalinkowski, wstęp E. Stanula, Warszawa 1994.

Origenes, Commentarii in Genesim, w: PG 12. Origenis Opera Omnia, tomus secundus, Facsimile of the 1857 Paris First Edition, Athens 1998, k. 45-146.

Origenes, Commentarii in Iohannem, w: SCh 120. Origène, Commentaire sur saint Jean. T. I (Livres I-V). Text grec, avant-propos, traduction et notes par C. Blanc, Paris 1966; SCh 157. Origène, Commentaire sur saint Jean. T. II (Livres VI et X). Text grec, avant-propos, traduction et notes par C. Blanc, Paris 1970; SCh 222. Origène, Commentaire sur saint Jean. T. III (Livre XIII). Text grec, avant-propos, traduction et notes par C. Blanc, Paris 1975; SCh 290. Origène, Commentaire sur saint Jean. T. IV (Livres XIX et XX). Text grec, avant-propos, traduction et notes par C. Blanc, Paris 1982; SCh 385. Origène, Commentaire sur saint Jean. T. V (Livres XXVIII et XXXII). Text grec, avant-propos, traduction et notes par C. Blanc, Paris 1992; przekład polski Orygenes, Komentarz do Ewangelii wedtug św. Jana, w: ŹMT 27, tłum. i oprac. S. Kalinkowski, Kraków 2003.

Origenes, Commentarii in Iohannem, w: PG 14. Origenis Opera Omnia, tomus quartus, Facsimile of the Paris First Edition, Athens 1998, k. 21-830; przekład polski Orygenes, Komentarz do Ewangelii wedtug św. Jana, w: ŹMT 27, tłum. i oprac. S. Kalinkowski, Kraków 2003, s. 371-372.

Origenes, Commentarii in Matthaeum, w: PG 13. Origenis Opera Omnia, tomus tertius, Facsimile of the Paris First Edition, Athens 1999, k. 835-1599; przekład polski Orygenes, Komentarz do Ewangelii wedtug Mateusza, w: ŹMT 10, tłum. K. Augustyniak, wstęp i oprac. E. Stanula, Kraków 1998. 
Origenes, Contra Celsum, w: SCh 132. Origène, Contre Celse. T. I (Livres I et II). Introduction, texte critique, traduction et notes par M. Borret, Paris 1967; SCh 136. Origène, Contre Celse. T. II (Livres III et IV). Introduction, texte critique, traduction et notes par M. Borret, Paris 1968; SCh 147. Origène, Contre Celse. T. III (Livres V et VI). Introduction, texte critique, traduction et notes par M. Borret, Paris 1968; SCh 150. Origène, Contre Celse. T. IV (Livres VII et VIII). Introduction, texte critique, traduction et notes par M. Borret, Paris 1969; SCh 227. Origène, Contre Celse. T. V. Introduction générale, tables et index par M. Borret, Paris 1976; przekład polski Orygenes, Przeciw Celsusowi, w: PSP 17bis, tłum. i oprac. S. Kalinkowski, Warszawa $1986^{2}$.

Origenes, De oratione, w: PG 11. Origenis Opera Omnia, tomus primus, ed. J.-P. Migne, Facsimile of the 1857 Paris Edition, Athens 2002, k. 415561; przekład polski Odpowiedź na Stowo. Najstarsi mistrzowie chrześcijańskiej modlitwy, tłum. W. Kania, H. Pietras, oprac. H. Pietras, Kraków 1993, s. 101-240.

Origenes, Deprincipiis, w: SCh 252. Origène, Traité des Principes. T. I (Livres I et II). Introduction, texte critique de la version de Rufin, traduction par H. Crouzel et M. Simonetti, Paris 1978; SCh 253. Origène, Traité des Principes. T. II (Livres I et II). Commentaire et Fragments par H. Crouzel et M. Simonetti, Paris 1978; SCh 268. Origène, Traité des Principes. T. III (Livres III et IV). Introduction, texte critique de la Philocalie et de la version de Rufin, traduction par H. Crouzel et M. Simonetti, Paris 1980; SCh 269. Origène, Traité des Principes. T. IV (Livres III et IV). Commentaire et Fragments par H. Crouzel et M. Simonetti, Paris 1980; SCh 312. Origène, Traité des Principes. T. V. Compléments et index par H. Crouzel et M. Simonetti, Paris 1984; przekład polski Orygenes, $O$ zasadach, tłum. i oprac. S. Kalinkowski, fragmenty z „Filokalii” tłum. K. Augustyniak, wprowadzenie H. Pietras, Kraków 1996.

Origenes, Disputatio cum Heracleida, w: SCh 67. Origèn, Entretien avec Héraclide, Introduction, texte, traduction et notes par J. Scherer, Paris 1960; przekład polski Orygenes, Dyskusja z Heraklidesem, tłum A. Zajkowski, „Studia Theologica Varsaviensia" 5 (1967) nr 2, s. 129-180.

Origenes, Exhortatio ad Martyrium, w: PG 11. Origenis Opera Omnia, tomus primus, ed. J.-P. Migne, Facsimile of the 1857 Paris Edition, Athens 2002, 
Kształtowanie się nauki o niebie w teologii patrystycznej I-III wieku

k. 563-638; przekład polski Orygenes, Zachęta do męczeństwa, w: PSP 24, tłum. S. Kalinkowski, wstęp i oprac. E. Stanula, Warszawa 1980, s. 138-173.

Origenes, Expositione in Proverbia, w: PG 17. Origenis Opera Omnia, tomus septimus, Facsimile of the 1857 Paris Edition, Athens 2000, k. 161-252.

Origenes, Homiliae (graecae) in Ieremiam, w: SCh 238. Origène, Homélies sur Jérémie. Traduction par P. Husson et P. Nautin. Édition, introduction et notes par P. Nautin. T. II. Homélies XII-XX et Homélies latines, Paris 1977; przekład polski Orygenes, Homilie 1-20 o Księdze Jeremiasza, w: PSP 30. Orygenes, Homilie o Księdze Jeremiasza; Komentarz do Lamentacji Jeremiasza; Homilie o Księgach Samuela i Ksiegach Królewskich, tłum. i oprac. S. Kalinkowski, wstęp E. Stanula, Warszawa 1983, s. 23-190.

Origenes, Homiliae XXVI in Jesu Nave (latine, Rufino interprete), w: SCh 71. Origène, Homélies sur Josué. Texte latin, introduction, traduction et notes de A. Jaubert, Paris 1960; przekład polski Orygenes, Homilie o księdze Jozuego, w: PSP 34/2. Orygenes, Homilie o księgach Liczb, Jozuego, Sędziów, tłum. i oprac. S. Kalinkowski, wstęp E. Stanula, Warszawa 1986, s. 3-137.

Origenes, In Leviticum homiliae XVI (latine, interprete Rufuno), w: SCh 286. Origène, Homélies sur le Lévitique. T. I (Homélies I-VII). Texte latin, introduction, traduction et notes de M. Borret, Paris 1981; SCh 287. Origène, Homélies sur le Lévitique. T. II (Homélies VIII-XVI). Texte latin, introduction, traduction et notes de M. Borret, Paris 1981; przekład polski Orygenes, Homilie o księdze Kaptańskiej, w: PSP 31/2. Orygenes, Homilie o księgach Rodzaju, Wyjścia, Kaptańskiej, tłum. S. Kalinkowski, wstęp E. Stanula, Warszawa 1985, s. 3-203.

Origenes, Selecta in Deuteronomium, w: PG 12. Origenis Opera Omnia, tomus secundus, Facsimile of the Paris First Edition, Athens 1998, k. 805-818.

Origenis, Selecta in Psalmos, w: PG 12. Origenis Opera Omnia, tomus secundus, Facsimile of the Paris First Edition, Athens 1998, k. 1053-1686.

Pseudo-Barnaba, Epistula (Barnabae), w: SU 2. Didache (Apostellehre), Barnabasbrief, Zweiter Klemensbrief, Schrift an Diognet. Eingeleitet, herausgegeben, übertragen und erläutert von K. Wengst, Darmstadt 1998, s. 103-202; SC 172, Épître de Barnabé. Introduction, traduction et notes par P. Prigent. Texte grec établi et présenté par R. A. Kraft, Paris 1971; przekład polski List Barnaby, w: BOK 10. Pierwsi świadkowie. Pisma Ojców Apostolskich, 
tłum. A. Świderkówna, wstęp, komentarz i oprac. M. Starowieyski, Kraków $1998^{2}$, s. 174-204.

Passio sanctarum Perpetuae et Felicitatis, w: SCh 417. Passion de Perpétue et de Félicité suivi des Actes, Introduction, texte critique, traduction, commentaire et index par J. Amat, Paris 1996; przekład polski Męczeństwo św. Perpetuy i Felicyty, w: OŻ 9, Męczennicy, red. E. Wipszycka, M. Starowieyski, tłum. A. Malinowski, Kraków 1991, s. 258-261.

Pseudo-Clemens Romanus, Epistula altera od Corynthios, w: SU 2. Didache (Apostellehre), Barnabasbrief, Zweiter Klemensbrief, Schrift an Diognet. Eingeleitet, herausgegeben, übertragen und erläutert von K. Wengst, Darmstadt 1998, s. 205-280; przekład polski Pseudo-Klemens Rzymski, Homilia z II wieku (zwana dawniej „Drugim listem do Koryntian św. Klemensa”), w: BOK 10. Pierwsi świadkowie. Pisma Ojców Apostolskich, tłum. A. Świderkówna, wstęp, komentarz i oprac. M. Starowieyski, Kraków 1998², s. 88-101.

Pseudo-Cyprianus, De laude martyrii, w: CSEL 3.3. Appendix. S. Thasci Caecili Cypriani Opera Spuria cum Indicibus et Praefatione ex Recensione G. Hartelii, Vindobonae 1871, s. 26-52.

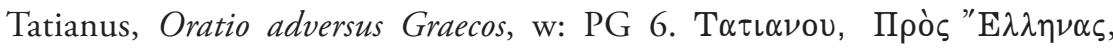
ed. J.-P. Migne, Facsimile of the 1857 Paris Edition, Athens 2001, k. 804888; przekład polski Tacjan Syryjczyk, Mowa do Greków, w: BOK 24. Pierwsi apologeci greccy. Kwadratus, Arystydes z Aten, Aryston z Pelli, Justyn Męczennik, Tacjan Syryjczyk, Milcjades, Apolinary z Hierapolis, Teofil z Antiochii, Hermiasz, tłum., wstępy i komentarze L. Misiarczyk, oprac. J. Naumowicz, Kraków 2004, s. 301-310 [wstęp], s. 311-355 [tekst].

Tertullianus, Ad martyres, w: PL 1. Quinti Septimii Florentis Tertulliani [Presbyteri] Carthaginiensis Opera Omnia. Pars prima, ed. J.-P. Migne, Paris 1844, k. 619-628A; Q. S. Fl. Tertulianus, Ad martyras, w: CChSL 1. Quinti Septimi Florentis Tertulliani Opera. Pars I. Opera catholica, E. Dekkers (cura et studio), Turnholti 1954, s. 3-8.

Tertullianus, Adversus Gnosticos Scorpiace, w: PL 2. Quinti Septimii Florentis Tertulliani [Presbyteri] Carthaginiensis Opera Omnia. Pars secunda, ed. J.-P. Migne, Paris 1844, k. 121-154; Q. S. Fl. Tertulliani, Scorpiace, w: CChSL 2. Quinti Septimi Florentis Tertulliani Opera. Pars II. Opera montanistica, A. Reifferscheid et G. Wissowa (cura et studio), Turnholti 1954, s. 1069-1097. 
Kształtowanie się nauki o niebie w teologii patrystycznej I-III wieku

Tertullianus, Adversus Marcionem III, w: SCh 399. Tertullien, Contre Marcion. T. III (Livre III). Introduction, texte critique, traduction, notes et index des livres I-III par R. Braun, Paris 1994; przekład polski Tertulian, Przeciw Marcjonowi, w: PSP 58, tłum. S. Ryzner, wstęp i oprac. W. Myszor, Warszawa 1994, s. 103-139; Tertullianus, Adversus Marcionem IV, w: SCh 456. Tertullien, Contre Marcion. T. IV (Livre IV). Texte critique par C. Moreschini. Introduction, traduction et commentaire par R. Braun, Paris 2001; przekład polski, w: PSP 58, s. 141-251.

Tertullianus, Adversus Praxeam, w: PL 2. Quinti Septimii Florentis Tertulliani [Presbyteri] Carthaginiensis Opera Omnia. Pars secunda, ed. J.-P. Migne, Paris 1844, k. 153-196; Q. S. Fl. Tertulliani, Adversus Praxean, w: CChSL 2. Quinti Septimi Florentis Tertulliani Opera. Pars II. Opera montanistica, Aem. Kroymann et Ern. Evans (cura et studio), Turnholti 1954, s. 1159-1205; przekład polski Tertulian, Przeciw Prakseaszowi, w: ŹMT 4. Trójca Święta (Tertulian, Przeciw Prakseaszowi; Hipolit, Przeciw Noetosowi), tłum. E. Buszewicz, wprowadzenie i oprac. H. Pietras, Kraków 1997, s. 35-86.

Tertullianus, Apologeticus Adversus gentes pro Christianis, w: PL 1. Quinti Septimii Florentis Tertulliani [Presbyteri] Carthaginiensis Opera Omnia. Pars prima, ed. J.-P. Migne, Paris 1844, k. 305-604; Q. S. Fl. Tertullianus, Apologeticum, w: CChSL 1. Quinti Septimi Florentis Tertulliani Opera. Pars I. Opera catholica, E. Dekkers (cura et studio), Turnholti 1954, s. 85-171; przekład polski Tertulian, Apologetyk, w: POK 20, tłum. i oprac. J. Sajdak, Poznań 1947. Tertullianus, De baptismo Adversus Quintillam, w: PL 1. Quinti Septimii Florentis Tertulliani [Presbyteri] Carthaginiensis Opera Omnia. Pars prima, ed. J.-P. Migne, Paris 1844, k. 1197-1224; Q. S. Fl. Tertulliani, De baptismo, w: CChSL 1. Quinti Septimi Florentis Tertulliani Opera. Pars I. Opera catholica, J. G. Ph. Borleffs (cura et studio), Turnholti 1954, s. 227-295.

Tertullianus, De monogamia, w: SCh 343. Tertullien, Le mariage unique (De monogamia). Introduction, texte critique, traduction et commentaire de P. Mattei, Paris 1988; przekład polski Tertulian, O jednożeństwie, w: PSP 65. Tertulian. Wybór pism III, tłum. E. Stanula, oprac. T. Kołosowski, I. SalamonowiczGórska, Warszawa 2007, s. 59-82.

Tertullianus, De resurrectione carnis, w: PL 2. Quinti Septimii Florentis Tertulliani [Presbyteri] Carthaginiensis Opera Omnia. Pars secunda, ed. J.-P. Migne, Paris 1844, k. 791-886; Q. S. Fl. Tertulliani, De resurrectione mortuorum, 
w: CChSL 2. Quinti Septimi Florentis Tertulliani Opera. Pars II. Opera montanistica, J. G. Ph. Borleffs (cura et studio), Turnholti 1954, s. 921-1012. Theophilus Antiochenus, Ad Autolycum libri III, w: SCh 20. Théophile d'Antioche, Trois livres a Autolycus, texte grec, introduction et notes de G. Bardy, traduction de J. Sender, Paris 1948; przekład polski Teofil z Antiochii, Do Autolika, w: BOK 24. Pierwsi apologeci greccy. Kwadratus, Arystydes z Aten, Aryston z Pelli, Justyn Męczennik, Tacjan Syryjczyk, Milcjades, Apolinary $z$ Hierapolis, Teofil z Antiochii, Hermiasz, tłum., wstępy i komentarze L. Misiarczyk, oprac. J. Naumowicz, Kraków 2004, s. 373-384 [wstęp], s. 385464 [tekst].

\subsection{Przekłady traktatów filozofii antycznej i tekstów klasycznych}

Artstoteles, Etyka nikomachejska, tłum. i oprac. D. Gromska, Warszawa 1956 (Biblioteka Klasyków Filozofii [BFK] 25).

Arystoteles, Fizyka, w: Arystoteles, Zachęta do filozofii. Fizyka, tłum. K. Leśniak, Warszawa 2010.

Arystoteles, Metafizyka TA META TA $\Phi$ Y $2 I K A$ METAPHYSICA, w: Arystoteles, Dzieła wszystkie, t. 2, tłum., wstęp i komentarz K. Leśniak, Warszawa 1990, s. 601-857.

Arystoteles, O niebie ПEPI OYPANOY DE CAELO, w: Arystoteles, Dzieta wszystkie, t. 2, tłum., wstęp i komentarz P. Siwek, Warszawa 1990, s. 232-338.

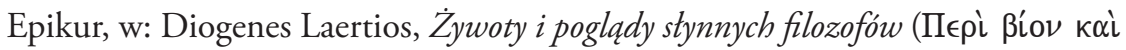
$\gamma \nu \omega \mu \omega \nu \nu)-$ Księga X, tłum. K. Leśniak, Warszawa 1982, s. 585-658.

Homer, Iliada, tłum. i oprac. I. Wieniewski, ilustracje S. Wyspiański, KrakówWrocław 1984.

Homer, Odysjea, tłum. i oprac. J. Parandowski, Warszawa 1998 (Biblioteka Antyczna 1$)$.

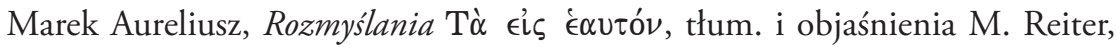
wstęp T. Sinko, Łódź 1948.

Platon, Fajdros $\Phi \alpha i ̂ \delta \rho \varsigma$, tłum., wstęp, objaśnienia i ilustracje W. Witwicki, Warszawa 1958.

Platon, Fedon $\Phi \alpha i \delta \omega \nu$, tłum., wstęp, objaśnienia i ilustracje W. Witwicki, Warszawa 1958. 
Kształtowanie się nauki o niebie w teologii patrystycznej I-III wieku

Platon, Gorgiasz Гopүías, tłum., wstęp, objaśnienia i ilustracje W. Witwicki, Warszawa 1958.

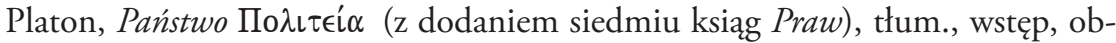
jaśnienia i ilustracje W. Witwicki, t. 1-2, Warszawa 1958', Warszawa $2010^{2}$.

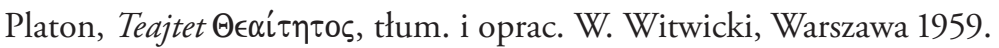

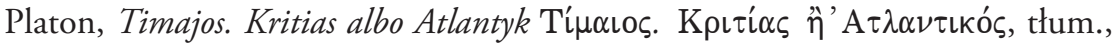
wstęp, komentarz i skorowidz P. Siwek, Warszawa 1986 (BKF 153).

Plotyn, Enneady I-III, tłum. i wstęp A. Krokiewicz, Warszawa 2000 (BFK 6); Enneady IV-V, tłum. i wstęp A. Krokiewicz, Warszawa 2001(BFK 7); Enneady VI, tłum. i wstęp A. Krokiewicz, Warszawa 2003 (BFK 9).

Seneka [Młodszy], Listy moralne do Lucyliusza (Epistolae morales ad Lucilium), tłum. W. Kornatowski, Warszawa 2010.

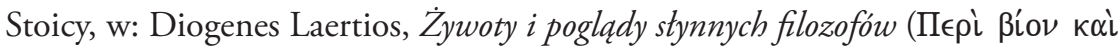
$\gamma \nu \omega \mu \omega \hat{\nu})$ - Księga VII, tłum. K. Leśniak, Warszawa 1982, s. 369-468.

\section{Opracowania naukowe}

\subsection{Opracowania biblijne}

Alfrink B., L'expression šamaim ou šemei haššamaim dans l'AT, w: Mélanges Eugène Tisserant, vol. 1, ed. P. Hennequin, Città del Vaticano 1964, s. 231-237 (Studi e Testi 231).

Barr J., Biblical Words for Time, London $1962^{2}$ (Studies in Biblical Theology 33). Bator W., Hathor, w: Bogowie, demony, herosi. Leksykon, red. Z. Pasek, Kraków 1997, s. 164.

Beasley-Murray G. R., Word Biblical Commentary 36. John, Waco (Texas) 1987.

Benveniste E., Il vocabolario delle istituzioni inodoeuropee, vol. 2. Potere, diritto, religione, Torino 1981.

Biały, w: Stownik obrazów i symboli biblijnych, red. M. Lurker, tłum. K. Romaniuk, Poznań 1989, s. 25-26.

Bietenhard H., ’̊vo, w: Dizionario dei concetti biblici del Nuovo Testamento, ed. L. Coenen, E. Beyreuther, H. Bietenhard, ed. italiana, Bologna $1980^{2}$, s. $282-283$ (EDB). 
Bietenhard H., oủpavós, w: Dizionario dei concetti biblici del Nuovo Testamento, ed. L. Coenen, E. Beyreuther, H. Bietenhard, ed. italiana, Bologna $1980^{2}$, s. 283-291 (EDB).

Binger T., Asherah: goddesses in Ugarit, Israel and the Old Testament, Sheffield 1997.

Chrostowski W., Czy Adam i Ewa mieli się nie starzeć i nie umierać? Egzegetyczny przyczynek do nauczania o nieśmiertelności pierwszych ludzi, w: Verbum caro factum est. Ksiega pamiatkowa dla ks. prof. Tomasza Jelonka w 70. Rocznice urodzin, red. R. Bogacz, W. Chrostowski, Warszawa 2007, s. 151-179.

Chrostowski W., Ogród Eden. Zapoznane świadectwo asyryjskiej diaspory, Warszawa 1996 (Studia i Rozprawy Biblijne 1).

Cielo, w: Dizionario dei concetti biblici del Nuovo Testamento, ed. L. Coenen, E. Beyreuther, H. Bietenhard, ed. italiana, Bologna $1980^{2}$, s. 280-281 (EDB).

Cornelius I., עִדר, wew International Dictionary of Old Testament Theology \& Exegesis, vol. 3, ed. W. A. VanGemeren, Grand Rapids (Michigan) 1997, s. 331-332.

Cornelius I., Eden, w: New International Dictionary of Old Testament Theology \& Exegesis, vol. 4, ed. W. A. VanGemeren, Grand Rapids (Michigan) 1997, s. 555-556.

de Silva D. A., niebo, nowe niebo, w: Stownik późnych ksiag Nowego Testamentu ipism Ojców Apostolskich, ed. R. P. Martin, P. H. Davids, [red. nauk. wyd. pol. J. Kręcidło], Warszawa 2014, s. 645-648 (Prymasowska Seria Biblijna 39).

Dubarle A.-M., Oczekiwanie nieśmiertelności w Starym Testamencie i w judaizmie, „Concilium” 6-7 (1970), s. 214-222.

eden עיע, wi Wielki stownik hebrajsko-polski i aramejsko-polski Starego Testamentu, t. 1, ed. L. Koehler, W. Baumgartner, J. J. Stamm, [red. nauk. wyd. pol. P. Dec], Warszawa 2008, s. 741 (Prymasowska Seria Biblijna 30).

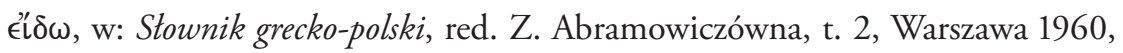
s. $28-30$.

€î̉ov, w: W. Bauer, A Greek English Lexicon of the New Testament, Chicago 1957, s. 220.

Eissfeldt O., Ba 'alšamèm und Yahweh, „Zeitschrift für die Alttestamentliche Wissenschaft" 57 (1939), s. 1-31.

Evans C. A., Mark 8:27-16:20, Word Biblical Commentary, vol. 34B, Nashville 2001. 
Kształtowanie się nauki o niebie w teologii patrystycznej I-III wieku

Fuhs H. F., rāâa, w: Theological Dictionary of the Old Testament, vol. 13, ed. G. J. Botterweck, H. Ringgren, H.-J. Fabry, Grand Rapids (Michigan) 2004, s. $208-242$.

Gnilka J., Marco, trad. G. Poletti, Assisi $1987^{2}$ (Commenti e Studi Biblici).

Gould E. P., Critical and Exegetical Commentary on the Gospel according to St. Mark, Edinburgh 1982 (The International Critical Commentary on the Holy Scriptures of the Old and New Testament).

Hanson P. D., Rebellion in Heaven, Azazel, and Euhemeristic Heroes in 1 Enoch 6-11, „Journal of Biblical Literature” 96/2 (1977), s. 195-233.

Iwański D., Mieszkanie Boga w niebie wedtug Księgi Czuwających (1 Henoch 14,823), „Collectanea Theologica” 79 (2009) nr 2, s. 101-112.

Jacobs-Horning B., ำ (gan), w: Theologisches Wörterbuch zum Alten Testament, vol. 2, ed. G. J. Botterweck, H. Ringgren, H.-J. Fabry, Stuttgart 1977, s. $35-41$.

Jankowski A., Eschatologia Nowego Testamentu, Kraków 2007.

Jasiński A. S., Chrześcijanin a życie wieczne (Mt 19, 16. 19), w: Szukajcie zawsze oblicza Jahwe. Personalistyczne perspektywy orędzia biblijnego, red. A. S. Jasiński, Opole 1999, s. 189-196.

Jasiński A. S., Osoba arcykaptana a zbawienie wieczne w Liście do Hebrajczyków, w: Szukajcie zawsze oblicza Jahwe. Personalistyczne perspektywy orędzia biblijnego, red. A. S. Jasiński, Opole 1999, s. 197-205.

Jasiński A. S., Wedtug postanowienia wiecznego Boga. Aionios w Nowym Testamencie, Opole 1991.

Jelonek T., Biblia a mity. O Raju i ztotym wieku, Kraków 2010.

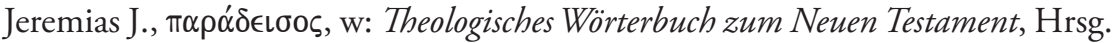
G. Kittel, G. Friedrich, Bd V, Stuttgart-Berlin-Köln 1990, s. 763-771.

Johnston P. S., Cienie Szeolu. Śmierć i zaświaty w biblijnej tradycji żydowskiej, tłum. P. Sajdek, Kraków 2010.

Koester C. R., Hearing, Seeing, and Believing in The Gospel of John, „Biblica” 70 (1989), s. 327-348.

Kowalski M., Corruptible, Incorruptible and the Kingdom of God. Semantic Background of the Idea of Transformation in 1 Cor 15:50-53, w: Królestwo Boże. Dar i nadzieja, red. K. Mielcarek, Lublin 2009, s. 133-153 (Analecta Biblica Lublinensia 3).

Kudasiewicz J., Ewangelie synoptyczne dzisiaj, Ząbki 1999. 
Lane W. L., The Gospel of Mark. The English Text with Introduction, Exposition, and Notes, The New International Commentary on the New Testament, Grand Rapids 1974.

Langkammer H., Życie po śmierci. Eschatologia Starego i Nowego Testamentu, Lublin 2004.

Lemański J., Księga Rodzaju rozdziały 1-11. Wstęp, przekład z oryginału, komentarz, t. I, cz. 1, Częstochowa 2013 (Nowy Komentarz Biblijny - Stary Testament).

Matysiak B. W., Niebo w hebrajskim obrazie świata, „Studia Theologica Varsaviensia” 38 (2000) nr 1, s. 295-304.

Mędala S., Tradycja o wieczności Mesjasza i redakcja J 12,34, „Ruch Biblijny i Liturgiczny” 28 (1975) nr 4-5, s. 199-216.

Michaelis W., ó $\alpha \alpha \omega$, w: Theologisches Wörterbuch zum Neuen Testament, Hrsg. G. Kittel, G. Friedrich, Bd. V, Stuttgart-Berlin-Köln 1990, s. 315-381.

Mickiewicz F., Ewangelia wedtug św. Eukasza rozdziaty 1-11. Wstęp, przektad z oryginatu, komentarz, Częstochowa 2011 (Nowy Komentarz Biblijny - Nowy Testament III/1).

Mickiewicz F., Wizja nowego nieba i nowej ziemi w Ap 21, 1-22, 5, „Communio” 20 (2000) nr 4, s. 20-39.

Morris L., The Gospel according to John. Revised Edition, Grand Rapids (Michigan) 1995 (The New International Commentary on the New Testament).

Münnich M., Niesiołowski-Spanò Ł., Muchowski P., Zachować tożsamość. Starozytny Izrael w obliczu obcych religii i kultur, Warszawa 2009 (Rozprawy i Studia Biblijne 31).

Naumczyk A., Ważniejsze bóstwa panteonu kananejskiego w świetle tekstów z Ugarit, „Rocznik Teologiczny Chrześcijańskiej Akademii Teologicznej 1960”, Warszawa 1961, s. 133-177.

Niebo, w: Stownik symboliki biblijnej. Obrazy, symbole, motywy, metafory, figury stylistyczne i gatunki literackie w Piśmie Świętym, L. Ryken, J. C. Wilhoit, T. Longman III, tłum. Z. Kościuk, [red. nauk. wyd. pol. W. Chrostowski], Warszawa 2003, s. 579-581 (Prymasowska Seria Biblijna 20).

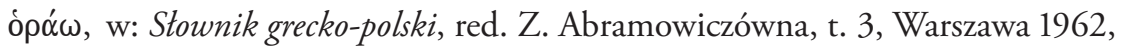
s. 307-308.

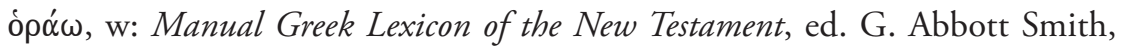
Edinburgh $1999^{3}$, s. 322. 
Kształtowanie się nauki o niebie w teologii patrystycznej I-III wieku

ogród, w: Stownik symboliki biblijnej. Obrazy, symbole, motywy, metafory, figury stylistyczne i gatunki literackie w Piśmie Świętym, L. Ryken, J. C. Wilhoit, T. Longman III, tłum. Z. Kościuk, [red. nauk. wyd. pol. W. Chrostowski], Warszawa 2003, s. 638-641 (Prymasowska Seria Biblijna 20).

'ôlām עוֹ עו Wielki stownik hebrajsko-polski i aramejsko-polski Starego Testamentu, t. 1, L. Koehler, W. Baumgartner, J. J. Stamm, [red. nauk. wyd. pol. P. Dec], Warszawa 2008, s. 747-748 (Prymasowska Seria Biblijna 30).

Olson D. T., Ogród w Edenie, w: Stownik wiedzy biblijnej, B. M. Metzger, M. D. Coogan, [konsult. wyd. pol. W. Chrostowski], Warszawa 1996, s. 576 (Prymasowska Seria Biblijna 5).

Paciorek A., Ewangelia wedtug świętego Mateusza rozdziaty $14-28$. Wstęp, przektad z oryginatu, komentarz, cz. 2, Częstochowa 2008 (Nowy Komentarz Biblijny - Nowy Testament I/2).

$\pi \alpha \rho \alpha ́ \delta \epsilon \iota \sigma o \varsigma$, ó, -ov, w: R. Popowicz, Wielki Stownik Grecko-Polski Nowego Testamentu. Wydanie z petna lokalizacja greckich haset, kluczem polsko-greckim oraz indeksem form czasownikowych, Warszawa 1995, s. 462 (Prymasowska Seria Biblijna 3).

Parchem M., Teologiczne znaczenie terminu „niebiosa” jako zastępczego określenia Boga $w$ tradycji biblijnej oraz $w$ literaturze rabinicznej, w: Gloriam praecedit humilitas (Prz 15, 33). Księga pamiatkowa dla księdza profesora Antoniego Troniny w 70. rocznicę urodzin, red. M. Szmajdziński, Częstochowa 2015, s. $513-533$.

Parchem M., Zmartwychwstanie, odptata po śmierci i życie wieczne w literaturze międzytestamentalnej, „Verbum Vitae” 15 (2009), s. 99-142.

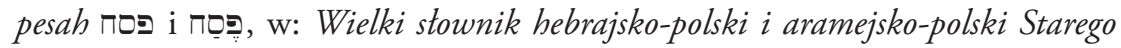
Testamentu, t. 2, L. Koehler, W. Baumgartner, J. J. Stamm, [red. nauk. wyd. pol. P. Dec], Warszawa 2008, s. 35-36 (Prymasowska Seria Biblijna 30).

Pesch R., Il vangelo di Maerco. Parte seconda. Testo e traduzione. Commento ai capp. 8, $27-16,20$, ed. italiana: ed. O. Soffritti, trad. M. Soffritti, Brescia 1982 (Commentario teologico del Nuovo Testamento II/2).

Porter S. E., wieczność, wieczny, w: R. P. Martin, P. H. Davids, Stownik późnych ksiag Nowego Testamentu i pism Ojców apostolskich, [red. nauk. wyd. pol. J. Kręcidło], Warszawa 2014, s. 1064-1066 (Prymasowska Seria Biblijna 39). 
Preuß H. D., עָלָם ('álam), w: Theologisches Wörterbuch zum Alten Testament, Hrsg. G. J. Botterweck, H. Ringgren, H.-J. Fabry, vol. 5, Stuttgart 1986, s. 1144-1159.

Price J. D., עדו, w: New International Dictionary of Old Testament Theology \& Exegesis, vol. 3, ed. W. A. VanGemeren, Grand Rapids (Michigan) 1997, s. 329-330.

Raj, w: F. Rienecker, G. Maier, Leksykon biblijny, tłum. D. Irmińska, J. Kruczyńska, [red. nauk. wyd. pol. W. Chrostowski], Warszawa 2001, s. 685 (Prymasowska Seria Biblijna 18).

Schnackenburg R., The Gospel according to St John. Volume I. Introduction and Commentary on Chapters 1-4, transl. by K. Smyth, New York 1967 (Herder's Theological Commentary on the New Testament).

Schnackenburg R., The Gospel according to St John. Volume II. Introduction and Commentary on Chapters 5-12, transl. by C. Hastings, M. McDonagh, D. Smith, R. Foley, New York 1980 (Herder's Theological Commentary on the New Testament).

Schnackenburg R., The Gospel according to St John. Volume III. Introduction and Commentary on Chapters 13-21, transl. by D. Smith, A. G. Kon, New York 1982 (Herder's Theological Commentary on the New Testament).

Seely P. H., The Firmament and the Water above, „The Westminster Theological Journal” 53 (1991), s. 227-240.

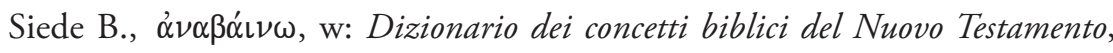
ed. L. Coenen, E. Beyreuther, H. Bietenhard, Bologna $1980^{2}$, s. 281-282 (EDB).

Söding T., Mieszkanie Boga dla ludzi. Nowotestamentowa nowina, „Communio” 25 (2005) nr 3, s. 42-51

Soggin J. A., שָמֵ (saamájim) cielo, w: E. Jenni, C. Westermann, Dizionario teologico dell'Antico Testamento, vol. 2, ed. italiana G. L. Prato, Casale Monferrato 1982, s. 871-875.

Stanek T., Jahwe a bogowie ludów. Religia Izraela na tle religii ludów Egiptu, Kanaanu i Mezopotamii, Poznań 2002.

Stock K., Il cammino di Gesù verso Gerusalemme. Marco 8, 27 - 10, 52, Roma $2002^{2}$ (Pontificio Instituto Biblico).

Strack H. L., Billerbeck P., Kommentar zum Neuen Testament aus Talmud und Midrasch, vol. 2, München 1961³ , München 1961. 
Kształtowanie się nauki o niebie w teologii patrystycznej I-III wieku

Strack H. L., Billerbeck P., Kommentar zum Neuen Testament aus Talmud und Midrasch, vol. 3. Die Briefe des Neuen Testaments und die Offenbarung Johannis, München 1961.

Strack H. L., Billerbeck P., Kommentar zum Neuen Testament aus Talmud und Midrasch, vol. 4, 1-2. Exkurse zu einzelnen Stellen des Neuen Testaments: Abhandlungen zur Neutestamentlichen Theologie und Archäologie, München $1961^{3}$

Tomasino A., עורלָ ('ôläm), w: New International Dictionary of Old Testament Theology \& Exegesis, vol. 3, ed. W. A. VanGemeren, Grand Rapids (Michigan) 1997, s. 345-351.

Traub H., є̇тора́ G. Kittel, G. Friedrich, Bd. V, Stuttgart-Berlin-Köln 1990, s. 538-542.

Traub H., oủpóvıos, w: Theologisches Wörterbuch zum Neuen Testament, Hrsg. G. Kittel, G. Friedrich, Bd. V, Stuttgart-Berlin-Köln 1990, s. 536-538.

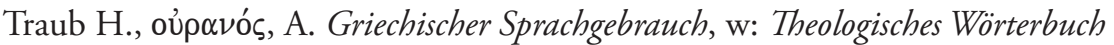
zum Neuen Testament, Hrsg. G. Kittel, G. Friedrich, Bd. V, Stuttgart-BerlinKöln 1990, s. 496-501.

Traub H., oủpavós, C. Septuaginta und Judentum, w: Theologisches Wörterbuch zum Neuen Testament, Hrsg. G. Kittel, G. Friedrich, Bd. V, Stuttgart-BerlinKöln 1990, s. 509-512.

Traub H., oủpavós, D. Neues Testament, w: Theologisches Wörterbuch zum Neuen

Testament, Hrsg. G. Kittel, G. Friedrich, Bd. V, Stuttgart-Berlin-Köln 1990, s. $512-535$.

Traub H., oủpavós, E. Apostolische Väter, w: Theologisches Wörterbuch zum Neuen Testament, Hrsg. G. Kittel, G. Friedrich, Bd. V, Stuttgart-Berlin-Köln 1990, s. $535-536$.

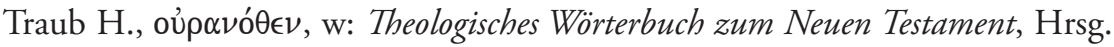
G. Kittel, G. Friedrich, Bd. V, Stuttgart-Berlin-Köln 1990, s. 542-543.

Trwatość, w: Stownik symboliki biblijnej. Obrazy, symbole, motywy, metafory, figury stylistyczne i gatunki literackie w Piśmie Świętym, L. Ryken, J. C. Wilhoit, T. Longman III, tłum. Z. Kościuk, [red. nauk. wyd. pol. W. Chrostowski], Warszawa 2003, s. 1024 (Prymasowska Seria Biblijna 20).

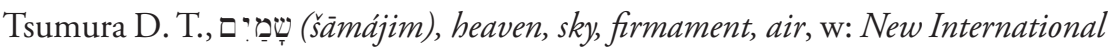
Dictionary of Old Testament Theology \& Exegesis, vol. 4, ed. W. A. VanGemeren, Grand Rapids (Michigan) 1997, s. 160-166. 
Tsumura D. T., The Earth and the Waters in Genesis 1 and 2: A Linguistic Analysis, "Journal for the Study of the Old Testament”, Sheffield 1989 (Supplement Series 83).

Tułodziecki T., Widzenie Boga w świetle księgi Psalmów, „Verbum Vitae” 16 (2009), s. 107-122.

Viard A.-A., Guillet J., życie, w: Stownik teologii biblijnej, ed. X. L. Dufour, tłum. i oprac. K. Romaniuk, Poznań 1994, s. 1156-1161.

von Rad G., oủpavós, B. Altes Testament, w: Theologisches Wörterbuch zum Neuen Testament, Hrsg. G. Kittel, G. Friedrich, Bd. V, Stuttgart-Berlin-Köln 1990, s. 501-509.

Wallace H. N., Eden, Garden of, w: The Anchor Bible Dictionary, ed. D. N. Freedman, vol. 2, New York 1992, s. 281-283.

Wallace H. N., Garden of God, w: The Anchor Bible Dictionary, ed. D. N. Freedman, vol. 2, New York 1992, s. 906-907.

White S. A., Życie pośmiertne i nieśmiertelność-Judaizm drugiej świątyni i wczesne chrześcijaństwo, w: Stownik wiedzy biblijnej, ed. B. M. Metzger, M. D. Coogan, [konsult. wyd. pol. W. Chrostowski], Warszawa 1996, s. 835-836 (Prymasowska Seria Biblijna 5).

Wolkstein D., Kramer S. N., Inanna, Queen of Heaven and Earth, Her Stories \& Hymns from Sumer, New York 1983.

Wprowadzenie, w: Stownik symboliki biblijnej. Obrazy, symbole, motywy, metafory, figury stylistyczne i gatunki literackie w Piśmie Świętym, L. Ryken, J. C. Wilhoit, T. Longman III, tłum. Z. Kościuk, [red. nauk. wyd. pol. W. Chrostowski], Warszawa 2003, XV-XXIII (Prymasowska Seria Biblijna 20).

życie pośmiertne, w: Stownik symboliki biblijnej. Obrazy, symbole, motywy, metafory, figury stylistyczne i gatunki literackie w Piśmie Świętym, L. Ryken, J. C. Wilhoit, T. Longman III, tłum. Z. Kościuk, [red. nauk. wyd. pol. W. Chrostowski], Warszawa 2003, s. 1215-1218 (Prymasowska Seria Biblijna 20).

\subsection{Opracowania filozoficzne}

Bańka J., Plotyn i odwieczne pytania metafizyki, t. 2. O rzeczywistości prawdziwej, pozornej i stanach mistycznych, Katowice 1996. 
Kształtowanie się nauki o niebie w teologii patrystycznej I-III wieku

Bańka J., Plotyn i odwieczne pytania metafizyki. t. 1. Monada pryncypialna, Katowice 1995.

Barnes J., La doctrine du retour éternel, w: Les stö̈ciens et leur logique. Actes du Colloque de Chantilly (18-22 septembre 1976), ed. J. Brunschwig, Paris 1978, s. 3-20 (Bibliothèque d'Histoire de la Philosophie).

Bibik B., Wyobrażenia Platona o życiu pozagrobowym, „Nowy Filomata” 6 (2002) nr 1, s. 13-26.

Burkert W., Lore and Science in Ancient Pythagoreanism, Harvard 1972.

Dodds E. R., Grecy i irracjonalność, tłum. J. Partyka, Bydgoszcz 2002.

Drozdek A., Anaksagoras: kosmos i nieskończoność, „Przegląd Filozoficzny” 4 (2000), s. 5-16.

Drozdek A., Bóg Platona, „Studia Philosophiae Christianae” 34 (1998) nr 2, s. $87-102$.

Drozdek A., In the Beginning Was the Apeiron: Infinity in Greek Philosophy, Stuttgart 2008.

Drozdek A., Infinity in Plato, „Eos” 87 (2000) nr 1, s. 53-62.

Gaiser K., Il paragone della caverna: variazioni da Platone a oggi, Memorie dell'Istituto italiano per gli studi filosofici 13, Napoli 1985.

Hoven R., Stoïcisme et stö̈ciens face au problème de l'au-delà, Paris 1971.

Izdebska A., Pitagoreizm. Jedno jako "Arche» $w$ metafizyce, antropologii i polityce, Warszawa 2012.

Kirk G. S., Raven J. E., Schofield M., Filozofia przedsoktarejska. Studium krytyczne z wybranymi tekstami, tłum. J. Lang, Poznań 1999.

Krämer H. J., Platone e i fondamenti della metafisica. Saggio sulla teoria dei principi e sulle dottrine non scritte di Platone,trad. G. Reale, Milano $2001^{6}$.

Ksieniewicz M., Funkcja mitu w filozofii Platona, „Philosophon Agora” 1 (1999), s. 32-38.

Legutko R., Sokrates. Filozofia męża sprawiedliwego, Poznań 2013.

Long A. A., Soul and Body in Stoicism, „Phronesis” 27 (1982), s. 34-57.

Long A. A., The stoics on world-conflagration and everlasting recurrence, „Southern Journal of Philosophy" 23 (1985, Suppl. 1), s. 13-37.

Łojek S., O tryumfie (platońsko-chrześcijańskiej) wieczności nad (presokratejska) nieśmiertelnością, „Edukacja filozoficzna” 45 (2008), s. 135-152.

Mohr R. D., Plato on Time and Eternity, „Ancient Philosophy” 6 (1986), s. 36-46. 
Pohlenz M., La Stoa. Storia di un movimento spirituale. Vol. 1, trad. O. De Gregorio, B. Proto, Firenze 1978.

Pokulniewicz A., Problem wieczności świata $w$ traktacie Arystotelesa „O niebie”, „Edukacja filozoficzna” 44 (2007), s. 217-229.

Pokulniewicz A., Zagadnienie pierwszych przyczyn skończoności świata w traktacie Arystotelesa „O niebie”, Warszawa 2010.

Reale G., Historia filozofii starożytnej, t. V. Stownik, Indeksy i bibliografia. tłum. E. I. Zieliński, Lublin 2005.

Reale G., Historia filozofii starożytnej. t. 1. Odpoczątków do Sokratesa, tłum. I. Zieliński, Lublin 2005.

Reale G., Historia filozofii starożytnej. t. 2. Platon i Arystoteles, tłum. I. Zieliński, Lublin 2005.

Reale G., Historia filozofii starożytnej. t. 3. Systemy epoki hellenistycznej, tłum. I. Zieliński, Lublin 2004.

Reale G., Historia filozofii starożytnej. t. 4. Szkoty epoki cesarstwa, tłum. I. Zieliński, Lublin 1999.

Repellini F. F., Cielo - cieli, w: Enciclopedia filozofica, vol. 2 ed. V. Melchiore Milano 2006, s. 1890-1903 (Fondazione Centro Studi Filozofici di Gallarate).

Siwek P., Wstęp ttumacza. O niebie ПEPI OYPANOY DE CAELO, w: Arystoteles, Dzieta wszystkie, t. 2. Fizyka, O niebie, O powstawaniu i niszczeniu, Meteorologika, O świecie, Metafizyka, tłum., wstępy i komentarze K. Leśniak, A. Paciorek, L. Regner, P. Siwek, Warszawa 1990, s. 206-321.

Swoboda A., Stoicka koncepcja cnoty, „Symbolae Philologorum Posnaniensium Graecae et Latinae” 12 (1998), s. 31-41.

Ślipko T., Historia etyki, Kraków 2010.

Voegelin E., Platon, tłum. A. Legutko-Dybowska, Warszawa 2009.

von Leyden W., Time, Number, and Eternity in Plato and Aristotle, "The Philosophical Quarterly” 14/54 (Jan. 1964), s. 35-52.

Wojtczak J., Pośmiertne losy duszy $w$ dialogach Platona, „Studia Philosophiae Christianae" 29 (1993) nr 1, s. 73-86.

Wolicka E., Mimetyka i mitologia Platona. U poczatków hermeneutyki filozoficznej, Lublin 1994. 
Kształtowanie się nauki o niebie w teologii patrystycznej I-III wieku

\subsection{Opracowania patrystyczne}

Alpigiano C., Aristide di Atene, Apologia, Firenze 1988.

Ancient Christian Doctrine. Vol. V. We Beleve in One Holy Catholic and Apostolic

Church, ed. A. Di Berardino, T. C. Oden, Dovners Grove (Illinois) 2010.

Audet J.-P., La Didachè. Instructions des apôtres, Paris 1958.

Baasland E., Der 2. Klemensbrief und frühchristliche Rhetorik: "Die erste christliche Predigt» im Licht der neueren Forschung, Aufstieg und Niedergang der römischen Welt II.27.1, Berlin-New York 1993.

Bardenhewer O., Geschichte der altkirchlichen Literatur, vol. 1, Freiburg 1913.

Bardy G., St. Justin et la filosophie stö̈cienne, „Recherches de Science Religieuse” 13 (1923), s. 491-510.

Barnard L. W., Athenagoras. A Study in Second Century Christian Apologetic, Paris 1972 (Théologie Historique 18).

Barnard L. W., Justin Martyr: His Life and Thought, Cambridge 1967.

Barnard L. W., Justin Martyr's Eschatology, „Vigiliae Christianae” 19 (1965), s. 86-98.

Baron A., Świętość a ideaty cztowieka (Ojcowie apostolscy, Klemens Aleksandryjski,

Orygenes). Studium teologiczne na tle modeli filozoficzno-religijnych, Kraków 2013.

Bauer J. B., Genitalien, w: Lexikon der christlichen Antike, Hrsg. J. B. Bauer, M. Hutter, Stuttgart 1999, s. 144.

Beatrice P. F., Clemente Romano (Lettere di), NDPAC, vol. 1, Genova-Milano $2006^{2}$, s. 1073-1077.

Bellinzoni A., The Sayings of Jesus in the Writings of Justin Martyr, Leiden 1967.

Berchman R. M., From Philo to Origen: Middle Platonism in Transition, Brown Chico (California) 1984 (Judaic Studies 69).

Blinzler J., Justinus Apol. 1, 15, 4 und Matthàus 19, 11-12, w: Mélanges Bibliques en hommage au R. P. Béda Rigaux, ed. A. Descamps, A. de Halleux, Gembloux 1970, s. 45-55.

Bolgiani F., Encratismo, w: NDPAC I, ed. A. Di Berardino, Genova-Milano $2006^{2}$, s. $1653-1655$.

Bolgiani F., Taziano, w: NDPAC 3, Genova-Milano 2008², s. 5205-5209.

Brock S. P., Studies in Syriac Christianity: History, Literature and Theology, Aldershot 1992. 
Bruni C., Atenagora, Introduzione, w: Gli apologeti greci. Traduzione, introduzioni e note a cura di Clara Bruni, Roma 1986, s. 235-248 (Collana di testi patristici 59).

Cantalamessa R., I più antichi testi pasquali della Chiesa. Le omelie di Melitone di Sardi e dell'Anonimo Quartodecimano e altri testi del II secolo, Introduzione, traduzione e commento di R. Cantalamessa, Roma 1991.

Cantalamessa R., Méliton de Sardes. Une christologie antignostique du II siècle, w: R. Cantalamessa, Dal kerygma al dogma. Studi sulla cristologia dei Padri, Milano 2006, s. 241-263 (Studia Patristica Mediolanensia 26).

Carleton Paget J., The Epistle of Barnabas, „The Expository Times” 117 (2006), s. 441-446.

Carleton Paget J., The Epistle of Barnabas: Outlook and Background, Wissenschaftliche Untersuchungen zum Neuen Testament II.64, Tübingen 1994.

Ciccarese M. P. (ed.), Visioni dell'Aldilà. Fonti, modelli, testi, Firenze 1987 (Biblioteca Patristica 8).

Comby J., Singles D., św. Ireneusz z Lyonu, Chwata Boga żyjący człowiek, tłum. W. Myszor, Kraków 1999.

Crouzel H., Bibliographie critique d'Origène, Turnhout 1971.

Crouzel H., Bibliographie critique d'Origène: Supplément I, Turnhout 1982.

Crouzel H., Bibliographie critique d'Origène: Supplément II, Turnhout 1996.

Crouzel H., L'Hadès et la Géhenne selon Origène, „Gregoriana” 59 (1978), s. $291-331$.

Crouzel H., Mort et immortalité selon Origène, „Bulletin de Littérature Ecclésiastique" 79 (1978)" s. 19-38, 81-96, 181-196.

Crouzel H., Morte e immortalità nel pensiero di Origene, w: Morte e immortalità nella catechesi dei Padri del III-IV secolo ed. S. Felici, Roma 1985, s. 41-46 (Biblioteca di Scienze Religiose 66).

Crouzel H., Origène et la philosophie, Paris 1962.

Crouzel H., Origène et Plotin, comparaisons doctrinales, Paris 1992.

Crouzel H., Orygenes, tłum. J. Margański, Kraków 2004².

Częsz B., Związek Ducha Świętego z Kościotem w ujęciu świętego Ireneusza i w interpretacji montanistycznej, Poznań 1991.

dal Covolo E., "Regno di Dio» nel Dialogo di Giustino con Trifone Giudeo, „Augustinianum" 28 (1988), s. 111-123. 
Kształtowanie się nauki o niebie w teologii patrystycznej I-III wieku

Daniélou J., Message évangelique et culture hellenistique aux II et III siècles, Paris 1990.

Daniélou J., Teologia judeochrześcijańska. Historia doktryn przed Soborem Nicejskim, tłum. S. Basista, Kraków 2002 (MT 39).

Daniélou J., Terre et paradis chez le Pères de l'Église, „Eranos Jahrbuch” 22 (1953), s. 433-472.

de Andia Y., Homo vivens. Incorruptibilité et divinisation de l'homme selon Irénée de Lyon, Paris 1986.

Dekert T., Teoria rekapitulacji $w$ świetle starożytnych koncepcji na temat Adama, Kraków 2007.

Delumeau J., Alla ricerca del paradiso, Cinisello Balsamo (Milano) 2012.

Delumeau J., Une histoire du Paradis. Le Jardin des délices, Paris 1992.

Derkaczewska K. [E. Fotiju], „Bóg się nie mści, lecz karze ku pożytkowi”: pedagogiczna koncepcja kary w „Kobiercach” Klemensa Aleksandryjskiego, w: Ku duchowej integracji Europy, red. A. Kaim, P. Kantyka, Lublin 2005, s. 211-218.

Domaradzki M., Między alegoria a typologią. Uwagi o hermeneutyce Orygenesa, „Przegląd Religioznawczy” 1/239 (2011), s. 17-27.

Drączkowski F., Formy i cele modlitwy doskonatego chrześcijanina (gnostyka)wedtug Klemensa Aleksandryjskiego, w: Homo Meditans I-Medytacja, red. W. Słomka, Lublin 1984, s. 127-132.

Drączkowski F., Gnoza w ujęciu Klemensa Aleksandryjskiego, w: Gnostycyzm i wspótczesna gnoza, Warszawa 1996, s. 9-21 (Studia Antiquitatis Christianae 12).

Drączkowski F., Kościót-Agape wedtug Klemensa Aleksandryjskiego, Lublin 1983.

Drączkowski F., Mitość synteza chrześcijanstwa, Lublin 1991.

Drews P., Der literarische Charakter der neuentdeckten Schrift des Irenäus «Zum Erweise der apostolischen Verkündigung”, „Zeitschrift für Neutestamentliche Wissenschaft“ 8 (1907), s. 226-233.

Drobner H. R., Patrologia, Casale Monferrato 1998.

Duda J., Jeden świat czy wiele światów. Kosmologiczne podstawy doktryny Orygenesa, Siedlce 2008.

Eckmann A., Przebóstwienie człowieka w pismach wczesnochrześcijańskich, Lublin 2003.

Edwards J. M., On the Platonic Schooling of Justin Martyr, „The Journal of Theological Studies" 42 (1991), s. 17-34.

Fantino J., L’homme image de Dieu chez saint Irénée de Lyon, Paris 1986. 
Filoramo G., L'escatologia e la retribuzione negli scritti dei Padri (dai Padri Apostolici ad Agostino), w: Dizionario di Spiritualità Biblico Patristica. Vol. 16. Escatologia, Roma 1997, s. 195-316.

Filoramo G., Ramelli I., Ermetismo, w: NDPAC, vol. 1, ed. A. Di Berardino, Genova-Milano $2006^{2}$, s. 1728-1739.

Fuchs G., Weikmann H. M., Das Exsultet. Geschichte, Theologie und Gestaltung der österlichen Lichtdanksagung, Regensburg $2005^{2}$.

Gaine S. F., 'Will there be Free will in Heaven?' Freedom, Impeccability and Beatitude, London-New York 2003.

Gavrilyuk P. L., Coakley S., Zmysty duchowe. Percepcja Boga w zachodnim chrześcijaństwie, tłum. A. Gomola, Kraków 2014.

Giardini F., Il desiderio del paradiso nella vita cristiana, Roma 2003; J. Delumeau, Alla ricerca del paradiso, Cinisello Balsamo (Milano) 2012.

Giet S., L'énigme de la Didachè, Paris 1970 (Publications de la Faculté des Lettres de l'Université de Strasbourg)

Goodenought E. R., Theology of Justin Martyr, Jena 1923, s. 279-291.

Grant R. M., Athenagoras or Pseudo-Athenagoras?, „Harvard Theological Review” 47 (1954), s. 121-129.

Grant R. M., The heresy of Tatian, „Journal of Theological Studies (New Series)” 5 (1954), s. 62-68.

Grigenti G., Giustino Martire. Il primo Cristiano platonico, Milano 1995.

Grigenti G., Teologia, cosmologia e antropologia di Giustino Martire, „Rivista di Filosofia Neo-Scolastica” 83 (1991), s. 51-89.

Grzywaczewski J., Obraz gnostyka wedtug „Stromatów” Klemensa Aleksandryjskiego, „Vox Patrum” 11 (1986), s. 543-554.

Henne Ph., Le pénitence et la rédaction du Pasteur d'Hermas, „Revue Biblique International" 98 (1991), s. 358-397.

Houssiau A., La christologie de Saint Irénée, Louvain 1955.

Hunt E. J., Christianity in the Second Century. The Case of Tatian, London-New York 2003.

I novissimi negli scritti dei Padri della Chiesa, ed. V. Brosco, Napoli 2008.

Kasprzak D., Kryteria przynależności do wspólnoty wierzacych w I-II wieku, „Analecta Cracoviensia” XL (2008), s. 165-178. 
Kształtowanie się nauki o niebie w teologii patrystycznej I-III wieku

Kasprzak D., Milenaryzm: „ziemski raj” tylko dla wybranych sprawiedliwych okres patrystyczny, w: Woczekiwaniu na Królestwo. Nadzieje i obawy zwiąane z końcem tysiąclecia, red. P. J. Śliwiński, Kraków 2000, s. 89-124.

Kasprzak D., Sens duchowy Pisma Świętego i doktryna o pięciu zmystach duchowych jako przyktad interpretacji stowa przez świętych, w: Hermeneutyka Pisma Świętego w Kościele, red. R. Pindel, S. Jędrzejewski, Kraków 2013, s. 67-97 (Hermeneutica et Judaica 6).

Kasprzak D., Teologia natchnienia biblijnego wokresie patrystycznym, w: Gwiazda z Jakuba - demony - Niewiasta Apokalipsy, red. T. Jelonek, Kraków 2007, s. 93-129 (Z badań nad Biblią 12).

Kelly J. N. D., Początki doktryny chrześcijańskiej, tłum. J. Mrukówna, Warszawa 1988.

Köster H., Septuaginta und Synoptischer Erzählungsstoff im Schriftbeweis Justins des Märtyrers, Heidelberg; 1956.

Köster H., The Text of the Synoptic Gospels in the Second Century, w: W. L. Petersen, Gospel Traditions in the Second Century, Notre Dame 1990, s. 19-38.

Kraft R. A., Barnabas and the Didache. The Apostolic Fathers. A New Translation and Commentary, vol. 3, New York 1965.

Lazzati G., Ellenismo e cristianesimo. Il primo capitolo dell'Apologia di Aristide, „Scuola Cattolica“ 66 (1968), s. 35-51.

Łesyk L., Platon Mojżeszem Greków w ujęciu Klemensa z Aleksandrii, „Littera Antiqua” 7 (2013), s. 66-80.

Lilla S. C. R., Middle Platonism, Neoplatonism and Jewish - Alexandrine Philosophy in the Terminology of Clemens of Alexandria's Ethics, Roma 1961.

Lilla S. R. C. Clement of Alexandria. A Study in Christian Platonism and Gnosticism, Oxford 1971.

Löhr H., Studien zum frühchristlichen und frühjüdischen Gebet. Untersuchungen zu 1 Clem 59 bis 61 in seinem literarischen, historischen und theologischen Kontext, Tübingen 2003.

Lona H. E., Der erste Clemensbrief, Bd. 2, Göttingen 1998 Kommentar zu den Apostolischen Vätern.

Łucarz S., Grób czy świątynia? Problematyka cielesności w antropologii Klemensa Aleksandryjskiego, Kraków 2007. 
Luttikhuizen G. P., Paradise interpreted: representations of biblical paradise in Judaism and Christianity, Leiden-Boston-Köln 1999 (Themes in Biblical Narrative 2).

McDannell C., Lang B., Heaven. A History, New Haven-London 1988.

Mees M., Clemente di Alessandria (150-215 ca.), NDPAC 1, ed. A. Di Berardino, Genova-Milano 2006², s. 1066-1073.

Méhat A., "Pénitence Seconde" et "Péché involontaire" chez Clément d'Alexandrie, „Vigiliae Christianae” 8/4 (1954), s. 225-33.

Milavec A., The Didache: Faith, Hope, and Life of Earliest Christianity 50-70 C.E., New York 2003.

Misiarczyk L., Teologia wcielenia u apologetów greckich II wieku, „Vox Patrum” 20 (2000), t. 38-39, s. 41-70.

Misiarczyk L., Wstęp - Apologetyka wczesnochrześcijańska, w: BOK 24. Pierwsi apologeci greccy. Kwadratus, Arystydes z Aten, Aryston z Pelli, Justyn Męczennik, Tacjan Syryjczyk, Milcjades, Apolinary z Hierapolis, Teofil z Antiochii, Hermiasz, tłum., wstępy i komentarze L. Misiarczyk, oprac. J. Naumowicz, Kraków 2004, s. 11-91.

Munier Ch., La méthode apologéthique de Justin le Martyr, „Revue des Sciences Religieuses" 62 (1988), s. 90-100; 227-239.

Myszor W., Kierunki rozwoju chrześcijaństwa w okresie poapostolskim, w: PSP 45.

Ojcowie apostolscy, tłum. A. Świderkówna, wstęp i oprac. W. Myszor, Warszawa 1990, s. 5-22.

Myszor W., Tysiąc lat panowania Chrystusa na ziemi. Millenaryzm w ujęciu Ireneusza z Lyonu ("Adversus Haereses» V,30,4-36,3), „Śląskie Studia Historyczno-Teologiczne” 33 (2000), s. 5-24.

Myszor W., Wersja koptyjska "Ewangelii Tomasza», w: Apokryfy Nowego Testamentu. Ewangelie apokryficzne, cz. 1, red. M. Starowieyski, Kraków 2003, s, 180-182. Myszor W., Wprowadzenie. Kościelne nauczanie w II wieku, w: Ireneusz z Lyonu, Wyktad nauki apostolskiej, tłum., wstęp, i opracowanie W. Myszor, Kraków 1997, s. 5-13 (ŹMT 7).

Nautin P., Ignazio di Antiochia, w: NDPAC, vol. 2, Genova-Milano 2007², s. 2514-2016.

Nautin P., Origène. Sa vie et son oeuvre, Paris 1977 (Christianisme Antique I).

Niederwimmer K., Die Didachè, Göttingen $1993^{3}$. 
Kształtowanie się nauki o niebie w teologii patrystycznej I-III wieku

Niemirska-Pliszczyńska J., Pierwsza próba syntezy filozofii greckiej z antyczną doktryna chrześcijańska - Klemensa Aleksandryjskiego «Stromata», „Eos” 6 (1977), s. $221-229$.

Niemirska-Pliszczyńska J., Wstęp, w: Klemens Aleksandryjski, Kobierce zapisków flozoficznych dotyczacych prawdziwej wiedzy, Warszawa 1994, XV-XXXIII (PAX 33,1).

Norelli E., A Diogneto, Milano 1991 (Letture Cristiane del Primo Millennio 11).

O'Ceallaig G. C., „Marcianus” Aristides on the Worship of God, „The Harvard Theological Review” 51 (1958), s. 227-254.

Orbe A., Antropología de San Ireneo, Madrid 1969.

Orbe A., Introducción a la teología de los siglos II y III, Roma 1987.

Orbe A., La teologia dei secoli II e III. Il confronto della Grande Chiesa con lo gnosticismo. Vol. 2. Temi neotestamentarii, Roma 1995.

Orbe A., Teologia de San Ireneo. Comentario al Libro V del "Adversus haereses", 3 vol. vol. 3, Madrid 1985-1988.

Pietras H., Eschatologia Kościota pierwszych czterech wieków, Kraków 2007.

Pietras H., L'amore in Origene, Roma 1988 (Studia Ephemeridis Augustinianum 280.

Pietras H., Orygenes, Kraków 2003.

Plass P., The concept of eternity in patristic theology, „Studia Theologica - Nordic Journal of Theology" 36/1 (1982), s. 11-25.

Pouderon B., L'autenticité du "De resurrectione», w: B. Pouderon, D'Athènes à Alexandrie. Etudes sur Athènagore et les origines de la philosophie chrétienne, Québec 1997, s. 71-144.

Prostmeier F. R., Der Barnabasbrief. Übersetzt und erklärt, Göttingen 1999 (Kommentar zu den Apostolischen Vätern, Bd. 8).

Prostmeier F. R., Der Logos im Paradies. Theophilos von Antiochia und der Diskurs über eine zutreffende theologische Sprache, w: Logos der Vernunft - Logos des Glaubens, Millennium Studies in the culture and history of the first millennium C.E., ed. F. R. Prostmeier, H. E. Lon, Berlin-New York 2010, s. 207-228.

Prostmeier F. R., Gen 1-3 in Theophilos von Antiochia „An Autolykos“. Beobachtungen zu Text und Textgeschichte der Septuagintagenesis, w: Textgeschichte und Schriftrezeption im frühen Christentum / Textual History and the Reception of Scripture in Early Christianity (SBL.SCS 60), ed. J. de Vries, M. Karrer, Missoula (Mont) 2013, s. 359-393. 
Puech H. Ch., En quête de la Gnose, vol. 2: Sur l'Evangile selon Thomas. Esquisse d'une interprétation systématique, Paris 1978 (Collection: „Bibliothèque des Sciences Humaines").

Pujiula M., Körper und christliche Lebensweise. Klemens von Alexandria und sein Paidagogos, Berlin-New York 2006.

Pycke N., Connaissaince rationnelle et conaissance de grace chez saint Justin, „Ephemeredies Theologicae Lovaniensis" 17 (1961), s. 52-85.

Quasten J., Initiation aux Pères de l'Église, vol. 1, Paris 1955.

Ramelli I. L. E., The Christian Doctrine of Apokatastasis. A Critical Assessment from the New Testament to Eriugena, Leiden-Boston 2013 (Supplements to Vigiliae Christianae 120).

Rankin D. I., Athenagoras: Philosopher and Theologian, Farnham (GB)-Burlington (USA) 2009.

Rendel Harris J., The Apology of Aristides: on Behalf of the Christians, Cambridge 1891.

Rordorf W., A. Tuilier W., La doctrine des douze Apôtres (Didachè), SCh 248 bis, Paris $1998^{2}$.

Rousseau A., Appendice I. Anthropologie bipartite ou tripartite?, SCh 406, Paris 1995, s. 357-364.

Rousseau A., Appendice II. Image et ressemblance de Dieu chez Irénée, SCh 406, Paris 1995, s. 365-371.

Rzodkiewicz L., Jezus Chrystus w kulturze antycznej. Stanowisko Klemensa Aleksandryjskiego, Legnica 1999.

Salisbury J. E., Perpetua's passion. The death of a Young Roman Woman, New York and London 1997.

Schmaus M., Das Paradies, München 1965 (Münchener Universitätsreden. Neue Folge Heft 38).

Schoedel W. R., Athenagoras. "Legatio» and «De resurrectione», Oxford 1972.

Scorza Barcellona F., Epistola di Barnaba, Torino 1975 (Corona Patrum 1).

Sfameni Gasparro G., Enkrateia e antropologia. Le motivazioni protologiche della continenza e della verginità nel cristianesimo dei primi secoli e nello gnosticismo, Roma 1984 (SEA 20).

Sheppard H. J., Kehl A., McL. Wilson R., Hermetik, w: Reallexikon für Antike und Christentum (RAC), Hrsg. E. Dassmann, Bd. 14, Stuttgart 1988, s. 780-808.

Simonetti M., Między dostownościq a alegorią, tłum. T. Skibiński, Kraków 2000. 
Kształtowanie się nauki o niebie w teologii patrystycznej I-III wieku

Składanowski M., Myśl Orygenesa. Metodologiczne intuicje dla wspótczesnych teologów, „Studia Elbląskie” 14 (2013), s. 151-164.

Słomka J., Nowe Proroctwo. Historia i doktryna montanizmu, Katowice 2007 (Studia Antiquitatis Christianae. Series Nova 4).

Słomka J., Teologiczne podstawy egzegezy Orygenesa i jej aktualność, „Śląskie Studia Historyczno-Teologiczne” 36/2 (2003), s. 477-489.

Sołowianiuk J., Zachęta Greków - Wstęp, Warszawa 1988, s. 99-115 (PSP 44).

Starowieyski M., [Wstęp do] h. Ewangelia wedtug Egipcjan (EwEg), w: Apokryfy Nowego Testamentu. Ewangelie apokryficzne, cz. 1, red. M. Starowieyski, Kraków 2003, s. 121.

Studi sull'escatologia. VI Incontro di studiosi dell'antichità cristiana, Roma maggio 1977, Roma 1978 (Studia Ephemeridis Augustinianum 15).

Szczerba W., Koncepcja wiecznego powrotu $w$ myśli wczesnochrześcijańskiej i jej greckie źródta, Toruń $2014^{2}$.

Szczur P., Miejsce i rola wiary $w$ dążeniu do doskonatości chrześcijańskiej $w$ ujęciu Klemensa Aleksandryjskiego, „Teologia Patrystyczna” 9 (2012), s. 41-55.

Szczur P., Oblicza mitości: „Mitość daje się poznać w sposób wieloraki”: cnoty pokrewne i towarzyszace agape wedtug Klemensa Aleksandryjskiego, Kielce-Lublin 2002.

Szram M., Ciato zmartwychwstate w myśli patrystycznej przetomu II i III wieku, Lublin 2010.

Szram M., Orygenes, w: Powszechna Encyklopedia Filozofii, red. A. Maryniarczyk, t. 7, Lublin 2006, s. 860-869.

The Bobbio Missal: Liturgy and Religious Culture in Merovingian Gaul, ed. Y. Hen, R. Meen, Cambridge 2004.

Torjesen K. J., Hermeneutical Procedure and Theological Method in Origen's Exegesis, Berlin 1986 (Patristische Texte und Studien 28).

Trottmann Ch., La vision béatifique des disputes scolastiques à sa définition par Benoît XII, Roma 1995 (Bibliothèque des Écoles Françaises d'Athènes et de Rome 229).

Tzamalikos P., Origen: Cosmology and Ontology of Time, Leiden-Boston 2006 (Supplements to Vigiliae Christianae. Formerly Philosophia Patrum. Texts and Studies of Early Christian Life and Language 77).

Tzamalikos P., Origen: Philosophy of History and Eschatology, Leiden-Boston 2007 (Supplements to Vigiliae Christianae 85). 
Bibliografia

Ullmann W., The Cosmic Theme of the Prima Clementis and Its Significance for the Concept of Roman Rulership, „Studia Patristica” 11/2 (1972), Berlin 1972), s. 85-91 (TU 108).

van Unnik W. C., Die Gotteslehre bei Aristides und in Gnostischen Schriften, „Theologische Zeitschrift“ 17 (1961), s. 166-174.

Vanni U., Il millenarismo. Parametri per un discernimento cristiano alla luce di Apocalisse 20,1-10, „Sette e religioni” 1 (1991), s. 110-147.

Verheyden J., Justin's text of the Gospels: another look at the citations in 1 Apol. 15, 1-8, w: The early text of the New Testament, ed. Ch. E. Hill, M. J. Kruger, New York-Oxford 2012, s. 313-335.

Vielhauer P., Geschichte der urchristlichen Literatur: Einleitung in das Neue Testament, die Apokryphen und die Apostolischen Väter, Berlin-New York 1975.

Visonà G., Didachè. Insegnamento degli Apostoli, Milano 2000.

von Harnack A., Nachwort und Anmerkungen, w: K. Ter-Mekerttschian, E. TerMinassianz, Des hl. Irenäus Schrift „Zum Erweise der apostolischen Verkündigung" in armenischer Version entdeckt, Leipzig 1907, s. 53-66 (Texte und Untersuchungen 31).

Vorgrimler H., Geschichte des Paradieses und des Himmels. Mit einem Exkurs über Utopie, München-Paderborn 2008

Weber S., Des hl. Irenaeus Schrift zum Erweis der apostolischen Verkündigung, Bd. IV, Kempten 1912, s. 583-650 (Bibliothek der Kirchenväter).

Weisse W., Reich Gottes. Hoffnung gegen Hoffnungslosigkeit, Berlin 1997 (Ökumenische Studienhefte 6).

Wright J. E., The Early History of Heaven, New York-Oxford 2000; B. E. Daley, The Hope of the Early Church. A Handbook of Patristic Eschatology, Peabody (Massachusetts) 2003.

Wyrwa D., Die christliche Platonaneignung in den Stromateis des Clemens von Alexandrien, Berlin-New York 1983.

Wysocki M., Eschatologia okresu prześladowań na podstawie pism Tertuliana i Cypriana, Lublin 2010, s. 153-182.

Wytzes J., "Paideia» e Pronoia in the works of Clement of Alexandria, „Vigiliae Christianae" 9 (1950), s. 148-158.

Wytzes J., The Twofold Way (I): Platonic Influences in the Work of Clement of Alexandria, „Vigiliae Christianae” 11/4 (1957), s. 226-245. 
Kształtowanie się nauki o niebie w teologii patrystycznej I-III wieku

Wytzes J., The Twofold Way (II): Platonic Influences in the Work of Clement of Alexandria, „Vigiliae Christianae” 14/3 (1960), s. 129-153.

Zagórski D., "Miara wszystkich rzeczy jest Bóg”. Platońska zasada w interpretacji

Klemensa Aleksandryjskiego, „Roczniki Teologiczne” L (2003) z. 4, s. 245-255.

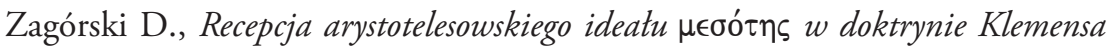
Aleksandryjskiego, „Roczniki Teologiczne” LI (2004) z. 4, s. 5-42.

Zeegers N., Les trois cultures de Théophile d'Antioche, w: Les apologistes chrétiens et la culture grecque, J. Doré, B. Pouderon, Paris 1998, s. 135-176.

Zeegers-Vander Vorst N., Adversaires et destinataires $d u$ "De resurrectione» attribué à Athénagore d'Athènes, „Salesianum” 57 (1995), s. 75-122, 199-250, 415-442, 611-656.

Zgraja B. J., Semantyka' $\alpha € \epsilon \tau$ $w$ pismach Klemensa Aleksandryjskiego, „Vox Patrum” 28 (2008), t. 52/2, s. 1335-1345.

Zgraja B., Chrystus boski Logos - wzór i mistrz cnoty wedtug Klemensa Aleksandryjskiego, „Studia Warmińskie” 47 (2010), s. 49-70.

Zgraja B., Klemensa Aleksandryjskiego koncepcja $\alpha \rho \epsilon \tau \eta$ (cnoty), „Studia Teologiczno-Historyczne Śląska Opolskiego” 29 (2009), s. 211-227.

Zincone S., Diogneto (A), w: NDPAC I, Genova-Milano 2006², s. 1428-1430.

\subsection{Literatura pomocnicza}

A Patristic Greek Lexicon, ed. G. W. H. Lampe, Oxford $1991^{10}$.

Ancona G., Escatologia cristiana, Brescia 2003, s. 169-173 (Nuovo Corso di Teologia Sistematica, vol. 13).

Beri G., I mondi ultraterreni, Milano 1998.

Bordoni M., Ciola N., Gesù nostra speranza. Saggio di escatologia, Bologna 1988.

Buksiński T., Zasady i metody interpretacji tekstów źródtowych, Poznań 1991.

Cohn N., Kosmos, chaos i świat przyszty. Starożytne źródta wierzeń apokaliptycznych, tłum. A. Kurowska-Mitas, Kraków 2006.

Daley B., Drittes Kapitel: Patristische Eschatologie, w: Handbuch der Dogmengeschichte, Hrsg. M. Schmaus, A. Grillmeier, L. Scheffczyk, M. Seybold Band IV. Faszikel 7a: Eschatologie. In der Schrift und Patristik, ed. B. Daley, J. Schreiner, H. E. Loina, Freiburg-Basel-Wien 1986, s. 84-140. 
Drewnowska-Rymarz O., Wygnańska Z., Mitologie świata - Ludy Mezopotamii, Warszawa 2007.

Fantazzi Ch., Golden Age in Arcadia, „Latomus” 33 (1974), s. 280-305.

Fedalto G., Verso la Gerusalemme nuova. Considerazioni sulla vita eterna, Verona 2013.

Grobler A., Metodologia nauk, Kraków 2006.

Hryniewicz W., Oczekuje życia w przysztym świecie, Poznań 2013.

Jachmann G., L'Arcadia di Virgilio come passaggio bucolico, „Maia” 5 (1952), s. 161-74.

Jenkyns R., Virgil and Arcadia, „Journal of Roman Studies” 79 (1989), s. 26-39.

Kasprzak D., Wykorzystanie myśli patrystycznej w dokumencie Międzynarodowej Komisji Teologicznej „Teologia dzisiaj: perspektywy, zasady i kryteria”, w: Koncepcje teologii katolickiej, red. M. Chojnacki, J. Morawa, A. A. Napiórkowski, Kraków 2013, s. 253-269.

Kijas Z. J., Niebo w domu Ojca, czyściec dla kogo, piekto w oddaleniu, Kraków 2010.

Kobielus S., Cztowiek i ogród rajski w kulturze religijnej średniowiecza, Warszawa 1997.

Kobielus S., Niebiańska Jerozolima. Od sacrum miejsca do sacrum modelu, Ząbki 2004.

Krąpiec M. A., Zdybicka Z. J., Świętość spetnieniem osoby, w: M. A. Krąpiec, Cztowiek - kultura - uniwersytet, Lublin 1982, s. 59-74.

Kubiak Z., Mitologia Greków i Rzymian, t. 1-2, Warszawa 1998².

Lee M. O., Death and Rebirth in Virgil's Arcadia. Albany (NY) 1989 (SUNY Series in Classical Studies); E. Anagnostou-Laoutides, Ancient Ritual and the Search for Arcadia: from Vergil to Poussin, „Transcultural Studies” 2-3 (2006-2007), s. 19-53.

Looser G., Dokąd podąża dusza? Wizje i wyobrażenia w różnych religiach świata, tłum. E. Łukaszyk, Kraków 2015.

Łukaszuk T. D., Ostateczny los czlowieka i świata w świetle wiary katolickiej, Kraków 2006.

Majdecki L., Historia ogrodów, t. 1. Od starożytności po barok, Warszawa 2010².

Międzynarodowa Komisja Teologiczna, Teologia dzisiaj: perspektywy, zasady i kryteria, tłum. K. Stopa, Kraków 2012.

Miśkiewicz B., Wstęp do badań historycznych, Warszawa-Poznań $1988^{5}$. 
Kształtowanie się nauki o niebie w teologii patrystycznej I-III wieku

Nagórny J., Historiozbawczy fundament moralności chrześcijańskiej, w: Teologia moralna u kresu II tysiąclecia, red. Nagórny, K. Jeżyna, Lublin 1998, s. 153-170.

Nitriola A., Trattato di escatologia. Vol. 2. Pensare la venuta del Signore, Ciniselli Balsamo (Milano) 2010.

Niwiński A., Egiptu starożytnego religia, w: Religia. Encyklopedia PWN, t. 3, red. T. Gadacz, B. Milerski, Warszawa 2001, s. 368-373.

Pawłowski S., Hierarchia prawd wiary, w: Leksykon teologii fundamentalnej, red. R. Rusecki, Lublin-Kraków 2002, s. 488-490.

Rahner K., Considerazioni dogmatiche sulla scienza e autocoscienza di Cristo, w: K. Rahner, Saggi di cristologia e mariologia, Roma 1965, s. 225-230.

Rahner K., Visio beatifica, w: K. Rahner, Enciclopedia teologica. Sacramentum mundi, vol.8, Brescia 1977, s. 637-642.

Ruiz de la Peňa J. L., L'altra dimensione, Roma 1981.

Salij J., Przekleństwo śmierci i śmierć w Chrystusie, „Zeszyty formacji duchowej” 24 (2004), s. 10-21.

Scafi A., Il paradiso in terra. Mappe del giardino dell'Eden, Bologna 2007.

Segal Ch. P., Tamen cantabitis, Arcades: Exile and Arcadia in Eclogues 1 and 9, „Arion” 4 (1965), s. 237-66.

Stownik grecko-polski, red. Z. Abramowiczówna, t. 3-4, Warszawa 1958-1965.

Snell B., Arcadia: The Discovery of a Spiritual Landscape, w: B. Snell, The Discovery of the Mind: The Greek Origins of European Thought, Oxford 1953, s. 281-309.

Sołtysiak A., Mezopotamii starożytnej religie w: Religia. Encyklopedia PWN, t. 6, red. T. Gadacz, B. Milerski, Warszawa 2002, s. 511-518.

Sołtysiak. A., Bogowie nocy. Motywy astralne $w$ religiach starożytnej Mezopotamii, Kraków 2003.

Taubes J., Zachodnia eschatologia, tłum. A. Serafin, Warszawa 2016.

Wicks J., Wprowadzenie do metody teologicznej, tłum. J. Ożóg, Kraków 1995 (MT 3).

Zalewska-Lorkiewicz K., Czas apokalipsy. Wizje dni ostatecznych w kulturze europejskiej od starożytności do wieku XVII, Warszawa 2013.

Zdybicka Z. J., Religia i religioznawstwo, Lublin 1988. 


\title{
Stosowane skróty
}

\author{
BFK - Biblioteka Filozofii Klasycznej, wyd. AKME, Warszawa $1990 \rightarrow$ \\ BKF - Biblioteka Klasyków Filozofi, PWN, Warszawa $1952 \rightarrow$ \\ BOK - Biblioteka Ojców Kościota, Kraków $1992 \rightarrow$ \\ BT $^{4}$ - Biblia Tysiąclecia, Poznań $1983^{4}$. \\ CSEL - Corpus Scriptorum Ecclesiasticorum Latinorum, Wien $1866 \rightarrow$ \\ NDPAC - Nuovo Dizionario Patristico e di Antichità Christiane, vol. 1-4, \\ Genova-Milano $2010^{2}$. \\ FCh - Fontes Christiani. Zweisprachige Neuausgabe christlicher Quel- \\ lentexte aus Altertum und Mittelalter, Herder, Freiburg im \\ Breisgau $1988 \rightarrow$ \\ GCS - Die griechischen christlischen Schriftsteller der ersten drei Jahr- \\ hunderte, Leipzig-Berlin $1897 \rightarrow$ \\ LXX - Septuaginta (różne wydania, podane w tekście). \\ NDPAC - Nuovo Dizionario Patristico e di Antichità Cristiane, diretto da \\ Angelo Di Berardino, Genova-Milano 2006²-2008². \\ PG - Patrologiae cursus completus. Series Graeca, 1-161, Paris \\ 1857-1866. \\ PL - Patrologiae cursus completus. Series Latina, 1-222, Paris \\ 1878-1890. \\ POK - Pisma Ojców Kościota, Poznań 1924-1970.
}


Kształtowanie się nauki o niebie w teologii patrystycznej I-III wieku

PSP $\quad$ - Pisma Starochrzéscijańskich Pisarzy, Warszawa $1969 \rightarrow$

SCh - Sources Chrétiennes, Institut des Sources Chrétiennes, Lyon I Paris 1943, Paris $1946 \rightarrow$

SU - Schriften des Urchristentums, Wissenschaftliche Buchgesellschaft, Darmstadt $1956 \rightarrow$

ŹMT - Źródta Myśli Teologicznej, Kraków $1996 \rightarrow$ 


\section{Indeks biblijny}

\begin{tabular}{|c|c|c|c|}
\hline \multicolumn{2}{|c|}{ Księga Rodzaju (Rdz) } & \multirow{2}{*}{$\begin{array}{l}\operatorname{Rdz} 2,5 \\
\operatorname{Rdz} 2,5-6\end{array}$} & \multirow{2}{*}{$\begin{array}{l}: 21 / 24 / \\
: 18 /\end{array}$} \\
\hline $\mathrm{Rdz}$ & $: 23 /$ & & \\
\hline Rdz 1 & :19/207/ & $\mathrm{Rdz} 2,7$ & $: 63 /$ \\
\hline $\operatorname{Rdz} 1,1$ & :65/207/240/260 & $\mathrm{Rdz} 2,8$ & $: 16 / 17 / 18 / 22 / 31 /$ \\
\hline $\operatorname{Rdz} 1,1 b$ & :207/ & & $40 / 42 / 109 / 192 /$ \\
\hline $\operatorname{Rdz} 1,2$ & :192/ & & $212 / 218 /$ \\
\hline $\operatorname{Rdz} 1,5$ & $: 120 /$ & $\mathrm{Rdz} 2,8-15$ & $: 191 /$ \\
\hline $\mathrm{Rdz} 1,6-8$ & $: 25 /$ & $\operatorname{Rdz} 2,8-25$ & $: 217 /$ \\
\hline $\operatorname{Rdz} 1,6-20$ & $: 23 /$ & $\mathrm{Rdz} 2,9$ & $: 18 /$ \\
\hline $\operatorname{Rdz} 1,8$ & :67/ & $\mathrm{Rdz} 2,10$ & $: 16 / 17 / 18 / 42 /$ \\
\hline $\operatorname{Rdz} 1,14$ & $: 68 / 206 /$ & $\mathrm{Rdz} 2,10-14$ & $: 17 / 20 /$ \\
\hline $\mathrm{Rdz} 1,21-22$ & $: 62 /$ & $\operatorname{Rdz} 2,15$ & $: 16 / 17 / 20 /$ \\
\hline $\operatorname{Rdz} 1,24$ & $: 62 /$ & & $40 / 212 /$ \\
\hline \multirow[t]{2}{*}{$\mathrm{Rdz} 1,26$} & :68/201/253/ & $\mathrm{Rdz} 2,16$ & :18/ 192/ \\
\hline & $258 / 263 /$ & $\operatorname{Rdz} 2,17$ & $: 19 / 171 /$ \\
\hline $\mathrm{Rdz} 1,28$ & $: 62 /$ & $\mathrm{Rdz} 2,23$ & $: 16 /$ \\
\hline $\mathrm{Rdz} 2$ & $: 19 / 40 / 83 /$ & $\mathrm{Rdz} 3$ & $: 40 / 193 /$ \\
\hline $\mathrm{Rdz} 2,1$ & $: 68 /$ & $\mathrm{Rdz} 3,1-3$ & $: 18 /$ \\
\hline $\mathrm{Rdz} 2,4$ & :192/ 207/ & $\mathrm{Rdz} 3,7$ & $: 218 /$ \\
\hline $\mathrm{Rdz} 2,4 \mathrm{~b}$ & $: 20 / 21 / 25 /$ & $\mathrm{Rdz} 3,8$ & $: 18 /$ \\
\hline
\end{tabular}


Kształtowanie się nauki o niebie w teologii patrystycznej I-III wieku

\begin{tabular}{|c|c|c|c|}
\hline $\operatorname{Rdz} 3,10$ & $: 18 /$ & $\operatorname{Rdz} 17,3$ & $: 30 /$ \\
\hline $\operatorname{Rdz} 3,16$ & $: 19 /$ & $\operatorname{Rdz} 17,7$ & $: 30 /$ \\
\hline $\operatorname{Rdz} 3,19$ & $: 19 /$ & $\operatorname{Rdz} 17,13$ & $: 30 /$ \\
\hline $\mathrm{Rdz} 3,22$ & $: 63 /$ & $\operatorname{Rdz} 17,19$ & $: 30 /$ \\
\hline $\mathrm{Rdz} 3,22-24$ & $: 21 /$ & $\mathrm{Rdz} 18$ & $: 240 /$ \\
\hline $\operatorname{Rdz} 3,23$ & $: 17 / 40 /$ & Rdz 19 & $: 240 /$ \\
\hline $\mathrm{Rdz} 3,23-24$ & $: 41 /$ & $\operatorname{Rdz} 19,24$ & $: 24 /$ \\
\hline $\mathrm{Rdz} 3,24$ & $: 16 / 17 / 18 / 21 / 243 /$ & $\mathrm{Rdz} 21,17$ & $: 26 /$ \\
\hline $\operatorname{Rdz} 3,31$ & $: 276 /$ & $\operatorname{Rdz} 21,33$ & $: 28 /$ \\
\hline $\mathrm{Rdz} 3,34$ & $: 20 /$ & $\mathrm{Rdz} 22,11$ & $: 26 /$ \\
\hline $\operatorname{Rdz} 4,11-15$ & $: 63 /$ & $\mathrm{Rdz} 22,15$ & $: 26 /$ \\
\hline $\mathrm{Rdz} 4,16$ & $: 16 / 17 / 42 /$ & $\operatorname{Rdz} 24,3$ & $: 26 / 66 /$ \\
\hline $\mathrm{Rdz} 4,21$ & $: 261 /$ & $\operatorname{Rdz} 24,7$ & $: 26 / 83 /$ \\
\hline $\operatorname{Rdz} 5,5$ & $: 294 /$ & $\mathrm{Rdz} 25,8$ & $: 63 /$ \\
\hline $\operatorname{Rdz} 5,6$ & :294/ & $\operatorname{Rdz} 26,2$ & $: 50 /$ \\
\hline $\mathrm{Rdz} 5,24$ & $: 67 / 86 / 121 /$ & $\operatorname{Rdz} 26,8$ & $: 261 /$ \\
\hline $\operatorname{Rdz} 6,1-6$ & $: 200 /$ & Rdz 26, 24 & $: 50 /$ \\
\hline $\operatorname{Rdz} 6,3$ & $: 63 /$ & $\mathrm{Rdz} 28,12$ & $: 26 / 33 / 34 /$ \\
\hline $\operatorname{Rdz} 6,7$ & $: 68 /$ & & $77 / 83 /$ \\
\hline $\mathrm{Rdz} 7$ & $: 24 /$ & $\mathrm{Rdz} 28,13$ & :84/ \\
\hline $\operatorname{Rdz} 7,11$ & :67/ & $\mathrm{Rdz} 28,17$ & $: 138 /$ \\
\hline $\operatorname{Rdz} 8,2$ & $: 21 / 24 /$ & $\mathrm{Rdz} 35,9-10$ & $: 50 /$ \\
\hline $\operatorname{Rdz} 9,4-5$ & $: 63 /$ & Rdz 35, 29 & $: 63 /$ \\
\hline $\operatorname{Rdz} 9,12$ & $: 30 /$ & $\mathrm{Rdz} 41,5$ & $: 33 /$ \\
\hline $\operatorname{Rdz} 9,16$ & $: 30 /$ & $\operatorname{Rdz} 47,8$ & $: 63 /$ \\
\hline $\mathrm{Rdz} 11$ & $: 24 /$ & $\mathrm{Rdz} 49,20$ & $: 17$ \\
\hline $\operatorname{Rdz} 11,4$ & $: 26 / 68 /$ & Rdz 49, 26 & $: 28 /$ \\
\hline $\operatorname{Rdz} 11,5$ & $: 26 / 66 /$ & & \\
\hline $\operatorname{Rdz} 12,7$ & $: 50 /$ & \multicolumn{2}{|c|}{ Księga Wyjścia (Wj) } \\
\hline $\mathrm{Rdz} 13,10$ & $: 17 / 21 / 40 / 41 /$ & $W_{j}$ & $: 23 /$ \\
\hline $\mathrm{Rdz} 14,19$ & $: 25 /$ & Wj 3, 6 & $: 50 /$ \\
\hline Rdz 14, 22 & $: 25 /$ & Wj 9, 29 & $: 67 /$ \\
\hline Rdz 15, 1-6 & $: 63 /$ & Wj 9, 33 & $: 67 /$ \\
\hline $\operatorname{Rdz} 15,5$ & $: 281 /$ & Wj 12, 14 & $: 30 /$ \\
\hline $\mathrm{Rdz} 17,1$ & $: 50 /$ & Wj 12, 17 & $: 30 /$ \\
\hline
\end{tabular}


Indeks biblijny

\begin{tabular}{|c|c|c|c|}
\hline Wj 12, 24 & $: 30 /$ & Kpł 3, 17 & $: 30 /$ \\
\hline Wj 15, 18 & $: 27 /$ & $\mathrm{Kpł} \mathrm{6,18}$ & $: 30 /$ \\
\hline Wj 15, 26 & $: 63 /$ & $\operatorname{Kpł~7,34~}$ & $: 30 /$ \\
\hline Wj 16, 4 & $: 25 /$ & $\operatorname{Kpł~7,36~}$ & $: 30 /$ \\
\hline Wj 16, 15 & $: 25 /$ & Kpł 10, 9 & $: 30 /$ \\
\hline Wj 16, 31 & $: 25 /$ & Kpł 10, 15 & $: 30 /$ \\
\hline Wj 16, 33 & $: 25 /$ & Kpł 16, 2 & $: 50 /$ \\
\hline Wj 16, 35 & $: 25 /$ & Kpł 16, 29 & $: 30 /$ \\
\hline Wj 19, 9 & $: 28 /$ & Kpł 16, 34 & $: 30 /$ \\
\hline Wj 19, 18 & $: 66 /$ & Kpł 17, 11 & $: 63 /$ \\
\hline Wj 19, 21 & $: 50 / 164 /$ & Kpł 18, 5 & $: 63 /$ \\
\hline Wj 20, 4 & $: 67 /$ & $\mathrm{Kpł} 20,10$ & $: 128 /$ \\
\hline Wj 20, 7 & :71/ 72/ & Kpł 23, 14 & $: 30 /$ \\
\hline Wj 20, 13 & $: 63 /$ & Kpł 23, 21 & $: 30 /$ \\
\hline Wj 20, 22 & $: 26 /$ & Kpł 23, 41 & $: 30 /$ \\
\hline Wj 21, 6 & $: 27 / 28 /$ & Kpł 24, 8 & $: 30 /$ \\
\hline Wj 23, 26 & $: 63 /$ & & \\
\hline Wj 24, 9 & $: 66 /$ & \multicolumn{2}{|c|}{ Księga Liczb (Lb) } \\
\hline Wj 24, 9-11 & $: 49 /$ & $\mathrm{Lb} 4,20$ & $: 50 /$ \\
\hline Wj 24, 12 & $: 49 /$ & $\mathrm{Lb} 10,8$ & $: 30 /$ \\
\hline Wj 25, 9 & $: 70 /$ & Lb 11, 6 & $: 25 /$ \\
\hline Wj 25, 40 & $: 70 /$ & $\mathrm{Lb} 11,7$ & $: 25 /$ \\
\hline Wj 27, 21 & $: 30 /$ & Lb 11, 9 & $: 25 /$ \\
\hline Wj 28, 43 & $: 30 /$ & Lb 15,15 & $: 30 /$ \\
\hline Wj 29, 9 & $: 30 /$ & Lb 18, 8 & $: 30 /$ \\
\hline Wj 29, 28 & $: 30 /$ & $\mathrm{Lb} 18,11$ & $: 30 /$ \\
\hline Wj 30, 21 & $: 30 /$ & $\mathrm{Lb} 18,19$ & $: 30 /$ \\
\hline Wj 31, 16-17 & $: 30 /$ & $\mathrm{Lb} 18,23$ & $: 30 /$ \\
\hline Wj 32, 13 & $: 281 /$ & $\mathrm{Lb} 25,13$ & $: 30 /$ \\
\hline Wj 33, 20 & $: 50 /$ & & \\
\hline Wj 33, 20b & $: 49 /$ & \multicolumn{2}{|c|}{ Księga Powtórzonego Prawa (Pwt) } \\
\hline Wj 34, 4 & $: 33 /$ & Pwt & $: 23 /$ \\
\hline & & Pwt 4, 1 & $: 63 /$ \\
\hline \multicolumn{2}{|c|}{ Księga Kapłańska (Kpł) } & Pwt 4, 40 & $: 63 /$ \\
\hline Kpł & $: 23 /$ & Pwt 10, 14 & $: 24 / 25 / 66 / 67 /$ \\
\hline
\end{tabular}


Kształtowanie się nauki o niebie w teologii patrystycznej I-III wieku

\begin{tabular}{|c|c|c|c|}
\hline Pwt 11, 11 & $: 24 /$ & Joz 5,14 & $: 68 /$ \\
\hline Pwt 11, 21 & $: 25 / 68 /$ & Joz 6,20 & $: 276 /$ \\
\hline Pwt 12,5 & $: 66 /$ & & \\
\hline Pwt 12, 11 & $: 66 /$ & \multicolumn{2}{|c|}{ Księga Sędziów (Sdz) } \\
\hline Pwt 12, 21 & $: 66 /$ & $\mathrm{Sdz} 2,1$ & $: 30 /$ \\
\hline Pwt 15, 17 & $: 28 /$ & $\mathrm{Sdz} 5,20$ & $: 68 /$ \\
\hline Pwt 18, 9 & $: 70 /$ & $\mathrm{Sdz} 5,4$ & $: 66 /$ \\
\hline Pwt 23, 4 & $: 30 /$ & Sdz 8, 19 & $: 62 /$ \\
\hline \multirow[t]{2}{*}{ Pwt 26, 15} & $: 25 / 26 / 66 /$ & $\mathrm{Sdz} 9,12$ & $: 38 /$ \\
\hline & $67 / 83 /$ & Sdz 13,18 & $: 38 /$ \\
\hline Pwt 28, 12 & $: 25 /$ & Sdz 13, 22 & $: 50 /$ \\
\hline Pwt 28, 24 & $: 24 /$ & & \\
\hline Pwt 30, 12 & $: 68 / 84 /$ & \multicolumn{2}{|c|}{1 Księga Samuela (1 Sm) } \\
\hline Pwt 30, 15 & $: 129 /$ & $1 \mathrm{Sm}$ & $: 23 /$ \\
\hline Pwt 32, 7 & $: 28 /$ & $1 \mathrm{Sm} 1,3$ & $: 33 /$ \\
\hline Pwt 32, 34 & $: 25 /$ & $1 \mathrm{Sm} \mathrm{1,} 22$ & $: 28 /$ \\
\hline Pwt 32, 39 & $: 63 /$ & $1 \mathrm{Sm} \mathrm{19,6}$ & $: 621$ \\
\hline Pwt 32, 40 & $: 67 /$ & $1 \mathrm{Sm} \mathrm{20,15}$ & $: 28 /$ \\
\hline Pwt 33, 2 & $: 66 /$ & $1 \mathrm{Sm} 27,12$ & $: 28 /$ \\
\hline Pwt 33, 15 & $: 28 / 86 /$ & $1 \mathrm{Sm} 28,1-24$ & $: 86 /$ \\
\hline Pwt 33, 26 & $: 23 / 26 / 66 /$ & & \\
\hline Pwt 4, 17 & $: 24 /$ & \multicolumn{2}{|c|}{2 Księga Samuela (2 Sm) } \\
\hline Pwt 4, 19 & $: 68 /$ & $2 \mathrm{Sm}$ & $: 23 /$ \\
\hline Pwt 4, 32 & $: 77 /$ & $2 \mathrm{Sm} 3,28$ & $: 29 /$ \\
\hline Pwt 4, 36 & $: 66 /$ & $2 \operatorname{Sm} 7,13$ & $: 30 /$ \\
\hline Pwt 4, 39 & $: 25 / 66 /$ & $2 \operatorname{Sm} 7,16$ & $: 30 /$ \\
\hline Pwt 8, 3 & $: 25 /$ & $2 \operatorname{Sm} 7,24$ & $: 30 /$ \\
\hline \multirow[t]{2}{*}{ Pwt 8, 16} & $: 25 /$ & $2 \operatorname{Sm~7,25}$ & $: 30 /$ \\
\hline & & $2 \operatorname{Sm} 7,29$ & $: 30 /$ \\
\hline \multicolumn{2}{|c|}{ Księga Jozuego (Joz) } & $2 \operatorname{Sm} 18,9$ & $: 24 /$ \\
\hline Joz & $: 23 /$ & $2 \operatorname{Sm~22,8}$ & $: 24 / 68 /$ \\
\hline Joz 10, 11 & $: 24 /$ & $2 \operatorname{Sm} 22,10$ & $: 26 /$ \\
\hline Joz 3, 10 & $: 62 /$ & $2 \operatorname{Sm} 22,51$ & $: 30 /$ \\
\hline Joz 4,7 & $: 29 /$ & $2 \operatorname{Sm} 23,5$ & $: 30 /$ \\
\hline Joz 5, 12 & $: 25 /$ & & \\
\hline
\end{tabular}


1 Księga Królewska (1 Krl)

$1 \mathrm{Krl}$

$: 23 /$

$1 \mathrm{Krl} 1,31$

$: 28 /$

$1 \mathrm{Krl} 2,33$

$: 30 /$

$1 \mathrm{Krl} 2,45$

$: 30 /$

$1 \mathrm{Krl} \mathrm{8,13}$

$: 29 / 66 /$

$1 \mathrm{Krl} 8,23$

$: 25 /$

$1 \mathrm{Krl} 8,27$

:24/ 26/66/ 67/

$1 \mathrm{Krl} 8,30$

$: 67 /$

$1 \mathrm{Krl}$ 9, 5

$: 30 /$

$1 \mathrm{Krl} 19,18$

$: 166 /$

$1 \mathrm{Krl} 22,19$
$2 \operatorname{Krn~1,7\quad :50/~}$

2 Krn 2, 5 :24/26/

2 Krn 6, 18 :24/ 26/

$2 \operatorname{Krn~7,12}: 50 /$

2 Krn 13, 15 :30/

2 Krn 18, 18 :83/

2 Krn 36, 23 :26/ 83/

Księga Ezdrasza (Ezd)

Ezd :23/

Ezd 1, 2 :26/

Ezd 9, 1 :30/

Ezd 9, 12 :30/

Księga Nehemiasza (Ne)

$\mathrm{Ne} 1,4$

$: 26 /$

Ne 2, 3

$: 28 /$

Ne 2, 4

$: 83 /$

Ne 2, 8

:40/ 42/

$\mathrm{Ne} 9,6$

$: 24 /$

Ne 9, 13 :26/

$\mathrm{Ne} 9,20$

$: 25 /$

Księga Tobiasza (Tb)

Tb 8, 5 :38/ 71

Księga Jydyty (Jdt)

Jdt

$: 23 /$

1 Księga Machabejska (1 Mch)

1 Mch 3, 18 :71/

1 Mch 4, 10 :71/

2 Księga Machabejska (2 Mch)

2 Mch 7, 23 :63/ 
Kształtowanie się nauki o niebie w teologii patrystycznej I-III wieku

$\begin{array}{ll}2 \text { Mch 7, 28 } & : 206 / \\ 2 \text { Mch 7, 34 } & : 72 / \\ 2 \text { Mch 15, 23 } & : 71 / \\ 2 \text { Mch 36 } & : 63 /\end{array}$

Księga Hioba (Hi)

$\mathrm{Hi}$

Hi 1,1

Hi 1, 6

Hi 3, 13-19

Hi 9, 8

Hi 10, 21-22

Hi 14,1

Hi 14,12

Hi 15, 15

Hi 19, 24-27

Hi 19, 26

Hi 20, 6

Hi 22, 15

Hi 23, 9

Hi 26, 10

Hi 26, 11

Hi 34, 14

Hi 34, 29

Hi 35,5

Hi 36, 27

Hi 37, 9

Hi 38, 8-11

Hi 38, 11

Hi 38, 22

Hi 38, 28-29

Hi 38, 37

Hi 42, 2

Hi 42, 5

Hi 42, 17
:23/

$: 73 /$

:66/ 68/

$: 86 /$

$: 24 /$

$: 86 /$

$: 63 /$

$: 25 /$

$: 118 /$

$: 86 /$

:50/ 121/

$: 26 /$

$: 28 /$

$: 50 /$

:215/ 216/

:24/ 68/

$: 631$

$: 50 /$

$: 23 /$

$: 68 /$

$: 68 /$

:215/ 216/

$: 120 /$

:25/ 68/

$: 241$

$: 68 /$

$: 272 /$

$: 50 /$

:63/
Księga Psalmów (Ps)

Ps 1, 1-50 :50/

Ps $1,3 \quad: 85 / 86 /$

Ps 2, $4 \quad: 25 / 261 /$

Ps 2, $7 \quad: 124 /$

Ps 3, 6 :121/

Ps 4, 10 :261/

Ps 6, $6 \quad: 86 /$

Ps $8,4 \quad: 25 / 261 /$

Ps 8, $9: 24 /$

Ps $9,8 \quad: 53 /$

Ps 11, 4 :25/

Ps 11, $7 \quad: 50 /$

Ps 12, 28 :86/

Ps 14, 1 :262/

Ps 14, 2 :84/

Ps 15, 15 :29/

Ps 16, 10 :86/

Ps 16, 10-11 : :86/

Ps 16, $11 \quad: 50 / 63 /$

Ps 17, 14 :192/

Ps 17, 15 :50/

Ps 18, 10 :26/

Ps 18, 51 :30/

Ps 19, 2 :65/

Ps 20,7 :25/

Ps 21, 5 :28/

Ps 21, $7 \quad: 50 /$

Ps 22, 4 :121/

Ps 23, 7-8 : :165/

Ps 24, $7 \quad: 28 /$

Ps 24, 9 :28/

Ps 25, 6 :28/

Ps 27, $7 \quad: 121 /$

Ps 27, 13 :50/ 63/ 
Indeks biblijny

\begin{tabular}{|c|c|c|c|}
\hline Ps 29,7 & $: 292 /$ & Ps 67,9 & :78/ \\
\hline Ps 29,9 & $: 65 /$ & Ps 68,5 & $: 66 /$ \\
\hline Ps 29,10 & $: 66 /$ & Ps 69,33 & :259/ \\
\hline Ps 30,7 & $: 29 /$ & Ps 73,24 & :67/ 86/ \\
\hline Ps 30,10 & $: 86 /$ & Ps 75,10 & $: 29 /$ \\
\hline Ps 30,13 & $: 29 /$ & Ps 77,5 & $: 27 /$ \\
\hline Ps 31,18 & $: 86 /$ & Ps 77,6 & $: 28 /$ \\
\hline Ps 33(32), 6 & :306/ & Ps 78,24 & $: 25 /$ \\
\hline Ps 33,6 & $: 25 / 65 / 261$ & Ps 78,69 & $: 29 /$ \\
\hline Ps 33,7 & $: 25 / 68 /$ & Ps 79,13 & $: 29 /$ \\
\hline Ps 36,6 & $: 23 /$ & Ps 80,15 & $: 84 /$ \\
\hline Ps 36,7 & $: 86 /$ & Ps 82,1 & $: 66 /$ \\
\hline Ps 36,8 & $: 17 /$ & Ps $82,1-8$ & :178/ \\
\hline Ps 36,10 & $: 50 / 63 /$ & Ps 84,11 & $: 63 /$ \\
\hline Ps $36(37), 11$ & $: 281 /$ & Ps 85,6 & $: 29 /$ \\
\hline Ps $37(36), 34$ & :290/ & Ps $86(85), 13$ & :294/ \\
\hline Ps 37,36 & $: 63 /$ & Ps 86,13 & $: 86 /$ \\
\hline Ps 39, 6 & $: 63 /$ & Ps 87,11 & :121/ \\
\hline Ps 41,13 & $: 29 /$ & Ps $89(90), 2$ & $: 53 /$ \\
\hline Ps 41,14 & $: 30$ / & Ps 89,2 & $: 29 /$ \\
\hline Ps 42,3 & $: 50 / 62 /$ & Ps 89,3 & $: 66 /$ \\
\hline Ps 45(44), 2 & $: 306 /$ & Ps 89,5 & $: 30 /$ \\
\hline Ps 45,15 & $: 25 /$ & Ps 89,12 & $: 25 /$ \\
\hline Ps 48,9 & $: 29 /$ & Ps 89,30 & :25/68/ \\
\hline Ps 49,16 & $: 86 /$ & Ps 90,2 & $: 30 /$ \\
\hline Ps 52,10 & $: 29 /$ & Ps 90,4 & $: 171 /$ \\
\hline Ps 52,11 & $: 29 /$ & Ps 90,10 & $: 63 /$ \\
\hline Ps 55,23 & $: 29 /$ & Ps $91(92), 9$ & $: 53 /$ \\
\hline Ps 57,11 & $: 23 /$ & Ps 93,1 & $: 86 /$ \\
\hline Ps 58,6 & $: 135 /$ & Ps 93,2 & $: 28 /$ \\
\hline Ps 61,5 & $: 29 /$ & Ps 94,4 & $: 206 /$ \\
\hline Ps 61,8 & $: 28 /$ & Ps 95,5 & $: 261 /$ \\
\hline Ps 61,13 & $: 121 /$ & Ps $96(95), 5$ & :164/ \\
\hline Ps 63,3 & $: 50 /$ & Ps 96,6 & $: 49 /$ \\
\hline Ps 63,4 & $: 63 /$ & Ps 96,10 & $: 86 /$ \\
\hline
\end{tabular}


Kształtowanie się nauki o niebie w teologii patrystycznej I-III wieku

\begin{tabular}{|c|c|c|c|}
\hline Ps 101(102), 13 & $: 53 /$ & Ps 140,14 & $: 50 /$ \\
\hline Ps 102,20 & $: 25 / 84 /$ & Ps $144(145), 1$ & $: 53 /$ \\
\hline Ps 102,27 & $: 86 /$ & Ps 144,4 & $: 63 /$ \\
\hline Ps 103,9 & $: 215 / 216 /$ & Ps 144,5 & $: 26 /$ \\
\hline Ps 103,14 & $: 206 /$ & Ps 145,1 & $: 29 /$ \\
\hline Ps $103,15-18$ & $: 86 /$ & Ps 145,6 & $: 216 /$ \\
\hline Ps 103,17 & $: 30 /$ & Ps 146,8 & $: 206 /$ \\
\hline Ps 104,2 & $: 24 / 68 /$ & Ps 148,4 & $: 24 / 67 / 283 /$ \\
\hline Ps 104,3 & $: 66 / 68 /$ & Ps $148,4-6$ & $: 67 /$ \\
\hline Ps 104,5 & $: 29 /$ & Ps 148,6 & $: 29 /$ \\
\hline Ps 104,28 & $: 63 /$ & & \\
\hline Ps 105,10 & $: 30 /$ & \multicolumn{2}{|c|}{ Księga Przysłów (Prz) } \\
\hline Ps 105,40 & $: 25 /$ & $\operatorname{Prz}$ & $: 23 /$ \\
\hline Ps 108,5 & $: 23 /$ & $\operatorname{Prz} 2,19$ & $: 63 /$ \\
\hline Ps 109,1 & $: 124 / 281 /$ & $\operatorname{Prz} 3,6$ & $: 58 /$ \\
\hline Ps $110(109), 1$ & $: 36 /$ & Prz 3, 19 & $: 25 /$ \\
\hline Ps 110,1 & $: 77 /$ & $\operatorname{Prz} 8,23$ & $: 28 /$ \\
\hline Ps 110,13 & :167/ & $\operatorname{Prz} 8,27$ & $: 25 /$ \\
\hline Ps 111,8 & $: 29 /$ & Prz 8, 27-29 & $: 25 / 215 / 216$ \\
\hline Ps 113,5 & $: 66 /$ & Prz 10, 25 & $: 28 /$ \\
\hline Ps 115,3 & $: 25 /$ & $\operatorname{Prz} 10,30$ & $: 29 /$ \\
\hline Ps $115,15-17$ & :67/ & $\operatorname{Prz} 11,19$ & $: 63 /$ \\
\hline Ps 115,16 & $: 25 /$ & $\operatorname{Prz} 14,27$ & $: 63 /$ \\
\hline Ps 119,89 & $: 29 / 66 /$ & $\operatorname{Prz} 15,33$ & $: 71 / 342 /$ \\
\hline Ps 119,152 & $: 29 /$ & Prz 22, 28 & $: 28 /$ \\
\hline Ps 121,8 & $: 86 /$ & $\operatorname{Prz} 23,10$ & $: 28 /$ \\
\hline Ps 127 & $: 63 /$ & $\operatorname{Prz} 24,12$ & $: 121 /$ \\
\hline Ps 128 & $: 63 /$ & $\operatorname{Prz} 30,4$ & $: 26 / 68 /$ \\
\hline Ps 135,6 & $: 135 /$ & & \\
\hline Ps 135,7 & $: 25 / 68 /$ & \multicolumn{2}{|c|}{ Księga Koheleta [Eklezjastesa] } \\
\hline Ps 136 & $: 86 /$ & (Koh) & \\
\hline Ps 136,6 & $: 23 /$ & Koh 1, 2 & $: 24 /$ \\
\hline Ps 136,26 & $: 26 /$ & Koh 1, 4-7 & $: 86 /$ \\
\hline Ps 139,8 & $: 26 /$ & Koh 2, 5 & $: 40 / 42 /$ \\
\hline Ps 139,24 & $: 86 /$ & Koh 3, 11 & $: 30 /$ \\
\hline
\end{tabular}


Indeks biblijny

\begin{tabular}{|c|c|c|c|}
\hline Koh 3, 19 & $: 63 /$ & Iz 6,3 & $: 66 /$ \\
\hline Koh 5, 1 & $: 84 / 85 /$ & Iz 6,5 & $: 50 /$ \\
\hline Koh 11, 8 & $: 62 /$ & Iz 6,11 & $: 233 /$ \\
\hline \multirow[t]{2}{*}{ Koh 12, 7} & $: 63 / 86 /$ & Iz 6,12 & $: 233 /$ \\
\hline & & Iz 8,18 & $: 66 /$ \\
\hline \multicolumn{2}{|c|}{ Pieśń nad pieśniami (Pnp) } & Iz 11,2 & $: 240 /$ \\
\hline Pnp 1,1 & $: 24 /$ & Iz $11,2-3$ & $: 306 / 307 /$ \\
\hline \multirow[t]{2}{*}{ Pnp 4, 13} & $: 40 / 42$ & Iz 13,9 & $: 233 /$ \\
\hline & & Iz 14,11 & $: 86 /$ \\
\hline \multicolumn{2}{|c|}{ Księga Mądrości (Mdr) } & Iz 19,1 & $: 66 /$ \\
\hline Mdr 1, 13 & $: 63 /$ & Iz 24,18 & $: 24 /$ \\
\hline Mdr 1, 13-15 & $: 63 / 273 /$ & Iz 26, 10 & $: 49 / 233 /$ \\
\hline $\operatorname{Mdr} 2,2$ & $: 63 /$ & Iz 26, 19 & $: 87 /$ \\
\hline $\operatorname{Mdr} 2,22-23$ & $: 250 /$ & Iz 30,8 & $: 29 /$ \\
\hline Mdr 2, 23-25 & $: 273 /$ & Iz 34, 4 & $: 24 / 25 / 68 / 142 /$ \\
\hline Mdr 3, 9-14 & $: 263 /$ & Iz 34,5 & $: 70 /$ \\
\hline $\operatorname{Mdr} 3,14$ & $: 263 /$ & Iz $35,1-10$ & $: 40 /$ \\
\hline Mdr 9, 10 & $: 38 /$ & Iz 35,2 & $: 49 /$ \\
\hline Mdr 9, 10 & $: 71 /$ & Iz 35,5 & $: 45 /$ \\
\hline \multirow[t]{2}{*}{ Mdr 15, 11} & $: 63 /$ & Iz 37,12 & $: 18 /$ \\
\hline & & Iz 38, 18-19 & $: 86 /$ \\
\hline \multirow{2}{*}{\multicolumn{2}{|c|}{$\begin{array}{l}\text { Mądrość Syracha [Eklezjastyk] } \\
\text { (Syr) }\end{array}$}} & Iz 40 & $: 22$ \\
\hline & & Iz 40,8 & $: 29 /$ \\
\hline Syr & $: 23 /$ & Iz 40,10 & $: 121 /$ \\
\hline Syr 1,4 & $: 29 /$ & Iz 40,12 & $: 240 /$ \\
\hline Syr 15,17 & :129/ & Iz 40, 22 & :24/ 68/ 208/ \\
\hline Syr 16, 18 & $: 24 /$ & $\mathrm{Iz} 40,28$ & $: 28 / 62 /$ \\
\hline Syr 18, 1 & $: 53 /$ & $\mathrm{Iz} 40,40$ & $: 131 /$ \\
\hline \multirow[t]{2}{*}{ Syr 18, 9} & $: 63 /$ & Iz 41, 18 & $: 40 /$ \\
\hline & & Iz 42, 1-9 & $: 115 /$ \\
\hline \multicolumn{2}{|c|}{ Księga Izajasza (Iz) } & Iz 42,5 & $: 23 / 24 / 25 / 63 /$ \\
\hline $\mathrm{Iz}$ & $: 23 / 40 /$ & & $65 / 135 /$ \\
\hline $\mathrm{Iz} 2,2$ & $: 40 /$ & Iz 44,23 & $: 38 /$ \\
\hline Iz 5 & $: 115 /$ & Iz 44, 24 & $: 23 / 24 / 68 /$ \\
\hline Iz 6,1 & $: 73 / 83 / 84 /$ & $\mathrm{Iz} 45,8$ & $: 23 /$ \\
\hline
\end{tabular}


Kształtowanie się nauki o niebie w teologii patrystycznej I-III wieku

\begin{tabular}{|c|c|c|c|}
\hline Iz 45,12 & $: 24 /$ & Iz 66, 18 & $: 49 /$ \\
\hline Iz 45,18 & $: 25 /$ & Iz 66,22 & $: 25 / 68 / 235 /$ \\
\hline Iz 45, 21 & $: 62 /$ & Iz 66, 24 & $: 145 /$ \\
\hline Iz 45,23 & $: 165 /$ & & \\
\hline Iz 47,13 & $: 38 / 70 / 75 /$ & \multicolumn{2}{|c|}{ Księga Jeremiasza (Jr) } \\
\hline Iz 49, 1-6 & $: 115 /$ & $\mathrm{Jr}$ & $: 23 /$ \\
\hline Iz 49, 16 & $: 231 /$ & Jr 2, 13 & $: 63 /$ \\
\hline Iz 50, 4-11 & $: 115 /$ & $\mathrm{Jr} 3,5$ & $: 29 /$ \\
\hline \multirow[t]{2}{*}{ Iz 51, 3} & $: 16 / 21 / 22 / 31 / 40 /$ & $\operatorname{Jr} 4,23-26$ & :68/ \\
\hline & $41 / 83 / 109 /$ & $\operatorname{Jr} 5,15$ & $: 28 /$ \\
\hline Iz 51, 6 & $: 25 / 68 /$ & $\mathrm{Jr} 7,13$ & $: 63 /$ \\
\hline Iz 51, 13 & $: 24 /$ & $\mathrm{Jr} 7,18$ & $: 27 /$ \\
\hline Iz 52,13 & $: 115 /$ & Jr 8, 7 & $: 24 /$ \\
\hline Iz 53, 7 & $: 196 /$ & Jr 10, 2 & $: 70 /$ \\
\hline Iz 53, 8 & $: 63 /$ & Jr 10, 10 & $: 62 /$ \\
\hline Iz 53,10 & $: 63 /$ & Jr 10,12 & $: 24 /$ \\
\hline Iz 53, 12 & $: 115 /$ & Jr 10,13 & $: 24 / 25 /$ \\
\hline Iz 54,10 & $: 86 /$ & Jr 13, 13 & $: 68 /$ \\
\hline Iz 54, 11-14 & $: 296 /$ & Jr 14,22 & $: 24 /$ \\
\hline Iz 55 & $: 22 /$ & Jr 15, 10-19 & $: 276 /$ \\
\hline Iz 55, 2-13 & $: 166 /$ & Jr 15,19 & $: 274 /$ \\
\hline Iz 55, 10 & $: 24 / 68 /$ & $\operatorname{Jr} 17,4$ & $: 29 /$ \\
\hline Iz 58, 12 & $: 28 /$ & Jr 18,15 & $: 28 /$ \\
\hline Iz $60,13-20$ & $: 296 /$ & Jr 20, 11 & $: 28 /$ \\
\hline Iz 60, 19 & $: 29 /$ & Jr 20, 17 & $: 28 /$ \\
\hline Iz 61, 4 & $: 28 /$ & Jr 21, 8 & $: 63 /$ \\
\hline Iz 62,11 & $: 121 /$ & Jr 23, 24 & $: 26 / 78 /$ \\
\hline Iz 63,15 & $: 25 / 83 /$ & Jr 34, 4 & $: 68 /$ \\
\hline Iz 63, 19 & $: 24 / 67 / 68 /$ & Jr 44, 17 & $: 27 /$ \\
\hline Iz 65 & $: 32$ & $\mathrm{Jr} 49,36$ & $: 68 /$ \\
\hline Iz 65,17 & $: 25 / 68 / 164 /$ & $\operatorname{Jr} 50,3$ & $: 68 /$ \\
\hline Iz $65,17-25$ & $: 83 / 171 /$ & Jr 51, 9 & $: 23 /$ \\
\hline Iz 65,21 & $: 233 /$ & Jr 51, 13 & $: 25 /$ \\
\hline Iz 66 & $: 32 /$ & $\mathrm{Jr} 51,15$ & $: 24 /$ \\
\hline Iz 66,1 & $: 25 / 75 / 206 /$ & Jr 51, 16 & $: 24 /$ \\
\hline
\end{tabular}


Indeks biblijny

\begin{tabular}{|c|c|c|c|}
\hline Jr 51, 34 & $: 17 /$ & $\mathrm{Ez} 28,13$ & $\begin{array}{l}: 16 / 21 / 22 / 31 / 40 / \\
41 / 109 /\end{array}$ \\
\hline Lamentacje & & $\mathrm{Ez} 28,14$ & $: 21 /$ \\
\hline $\mathrm{Lm}$ & $: 23 /$ & $\mathrm{Ez} 28,16$ & $: 21 /$ \\
\hline $\operatorname{Lm} 3,41$ & $: 25 /$ & $\mathrm{Ez} 31,8$ & $: 83 /$ \\
\hline $\operatorname{Lm~3,44}$ & :67/ & $\mathrm{Ez} 31,9$ & $: 16 / 21 / 41 / 83 /$ \\
\hline $\operatorname{Lm} 4,5$ & $: 17 /$ & $\mathrm{Ez} 31,16$ & :16/21/22/41/83/ \\
\hline $\operatorname{Lm} 4,19$ & $: 24 /$ & Ez 31, 18 & :16/21/22/41/83/ \\
\hline & & $\mathrm{Ez} 32,1-3$ & $: 257 /$ \\
\hline Księga Baru & $\mathbf{a}(\mathbf{B a})$ & Ez 33, 11-14 & $: 63 /$ \\
\hline Ba 3,14 & $: 63 /$ & $\mathrm{Ez} 35$ & $: 30 /$ \\
\hline $\mathrm{Ba} 5,3$ & $: 231 /$ & $\mathrm{Ez} 36,35$ & $\begin{array}{l}: 16 / 21 / 22 / \\
40 / 83 /\end{array}$ \\
\hline Księga Ezec & la $(\mathrm{Ez})$ & Ez 37, 7-8 & $: 165 /$ \\
\hline $\mathrm{Ez}$ & $: 21 / 23 / 40 /$ & Ez 37, 11-14 & $: 63 /$ \\
\hline Ez 1 & $: 84 / 86 /$ & $\mathrm{Ez} 37,12$ & $: 87 /$ \\
\hline $\mathrm{Ez} 1,1$ & $: 73 /$ & Ez 37, 12-14 & $: 171 /$ \\
\hline $\mathrm{Ez} 1,13$ & $: 84 /$ & $\mathrm{Ez} 46,14$ & $: 30 /$ \\
\hline Ez 1, 15 & $: 84 /$ & Ez 47, 1-12 & $: 40 /$ \\
\hline $\mathrm{Ez} 1,18$ & :84/ & $\mathrm{Ez} 47,12$ & $: 85 /$ \\
\hline Ez 1, 21 & $: 84 /$ & & \\
\hline Ez 1, 22-26 & $: 23 /$ & Księga Dani & (Dn) \\
\hline Ez 1, 26-28 & $: 83 /$ & Dn & $: 23 /$ \\
\hline Ez 2, 1 & $: 70 /$ & Dn 2,18 & $: 26 /$ \\
\hline $\mathrm{Ez} 8,3$ & $: 24 /$ & Dn 4, 23 & $: 71 /$ \\
\hline $\mathrm{Ez} 10,1$ & $: 23 /$ & Dn 4,26 B & :72/ \\
\hline Ez 18, 4 & $: 293 /$ & Dn 6, 21 & $: 62 /$ \\
\hline $\mathrm{Ez} 18,23$ & $: 252 /$ & Dn 7,2 & :68/ \\
\hline $\mathrm{Ez} 18,32$ & $: 63 /$ & Dn 7,9 & $: 66 / 73 /$ \\
\hline $\mathrm{Ez} 20,11$ & $: 216 /$ & Dn 7, 9-28 & :168/ \\
\hline Ez 24, 9-11 & $: 73 /$ & Dn 7,13 & $: 25 / 32 / 71 /$ \\
\hline $\mathrm{Ez} 24,10$ & $: 26 /$ & & $77 / 166 /$ \\
\hline $\mathrm{Ez} 25,12$ & $: 30 /$ & Dn $7,13-14$ & $: 165 /$ \\
\hline $\mathrm{Ez} 25,35$ & $: 30 /$ & Dn 12,1 & :57/ \\
\hline Ez 28, 11-19 & $: 83 /$ & Dn $12,1-3$ & $: 51 /$ \\
\hline
\end{tabular}


Kształtowanie się nauki o niebie w teologii patrystycznej I-III wieku

$\begin{array}{ll}\text { Dn 12, 1-4 } & : 87 / \\ \text { Dn 12, } 2 & : 54 / 63 / \\ \text { Dn 12, } 3 & : 85 /\end{array}$

Księga Ozeasza $(\mathrm{Oz})$

$\mathrm{Oz}$ $: 23 /$

$\mathrm{Oz} 2,24$ $: 40 /$

$\mathrm{Oz}$ 6, 1 $: 63 /$

\section{Księga Joela (J1)}

$\mathrm{Jl}$

J1 2, 2 $: 23 /$

J1 2, 3 $: 28 /$

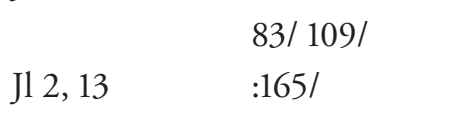

Księga Amosa (Am)

Am $: 23 /$

Am 1, 2 $: 661$

Am 1, 5 $: 18 /$

Am 5, 4 $: 63 /$

Am 8, 9 $: 68 /$

Am 9, 6 $: 23 / 68 /$

Am 9, 11-12 $: 621$

Am 9, 13 $: 40 /$

Księga Abdiasza (Ab)

$\mathrm{Ab}$ $: 23 /$

Ab 3, 3 :66/

\section{Księga Jonasza (Jon)}

Jon $: 23 /$

Jon 1,9 $: 26 /$

Jon 2, 7 $: 33 /$
Księga Micheasza (Mi)

$\begin{array}{ll}\text { Mi 4, } 1 & : 40 / \\ \text { Mi 4, } 2 & : 40 / \\ \text { Mi 7, 14 } & : 28 /\end{array}$

Księga Habakuka (Ha)

Ha 2, 4 :63/

Ha 3, 6 :28/

Księga Sofoniasza (So)

So :23/

Księga Aggeusza (Ag)

Ag :23/

Księga Zachariasza (Za)

$\mathrm{Za} \quad: 23 /$

Za 1, $8 \quad: 25 / 32 /$

$\mathrm{Za} 2 \quad: 70 /$

Za 2, $10 \quad: 68 / 77 /$

Za 5, 9 :24/

$\mathrm{Za} \mathrm{6,1 \quad :25/}$

Za 6, $5 \quad: 68 /$

Za 8, $4 \quad: 63 /$

Za 12, $1 \quad: 24 /$

Za 12, $10 \quad: 164 / 166 /$

Za 12, 10-12 :165/

Za 14, $5 \quad: 165 /$

Za 14, 8 :40/

Księga Malachiasza (M1)

$\mathrm{Ml}$

$: 23 /$

Ml 3, 10 :24/

Ml 3, $19 \quad: 142 /$ 
Indeks biblijny

\begin{tabular}{|c|c|c|c|}
\hline \multirow{2}{*}{\multicolumn{2}{|c|}{$\begin{array}{l}\text { Ewangelia według św. Mateusza } \\
\text { (Mt) }\end{array}$}} & \multirow{3}{*}{$\begin{array}{l}\text { Mt 6, } 20 \\
\text { Mt 6, } 25 \\
\text { Mt 6, 26 }\end{array}$} & \multirow{2}{*}{$\begin{array}{l}: 39 / 75 / 76 / 254 / \\
: 63 /\end{array}$} \\
\hline & & & \\
\hline Mt & $: 74 / 75 / 174 /$ & & $: 80 /$ \\
\hline Mt 1, 20 & $: 52 /$ & Mt 6, 32 & :74/ \\
\hline Mt 1, 22 & $: 156 /$ & Mt 6, 33 & $: 260 /$ \\
\hline Mt 2, 13 & $: 52 /$ & Mt 6, 34 & $: 258 /$ \\
\hline Mt 2, 15 & $: 156 /$ & Mt 7, 11 & $: 75 /$ \\
\hline Mt 2, 19 & $: 52 /$ & Mt 7, 13 & $: 138 /$ \\
\hline Mt 3, 2 & :75/ 282/ & Mt 7, 14 & $: 63 /$ \\
\hline Mt 3, 12 & $: 87 /$ & Mt 7, 15 & $: 179 /$ \\
\hline Mt 3, 16 & $: 33 / 76 /$ & Mt 7, 16 & $: 179 /$ \\
\hline Mt 3, 17 & $: 216 /$ & Mt 7, 19 & $: 179 /$ \\
\hline Mt 4, 14 & $: 156 /$ & $\mathrm{Mt} 7,21$ & :75/ 143/178/ \\
\hline Mt 4, 17 & :75/ 259/ & Mt 7, 22-23 & $: 178 /$ \\
\hline Mt 5, 1 & $: 33 /$ & Mt 7, 24 & $: 178 /$ \\
\hline Mt 5, 3 & :259/290/ & Mt 8, 11 & $: 281 /$ \\
\hline Mt 5, 4 & $: 290 /$ & Mt 8, 11-12 & $: 168 / 178 /$ \\
\hline Mt 5, 5 & $: 281 / 290 /$ & Mt 8, 20 & $: 80 /$ \\
\hline Mt 5, 8 & $: 52 / 262 /$ & Mt 8, 22 & $: 293 /$ \\
\hline Mt 5, 10 & :75/ 259/ & Mt 9, 6 & $: 63 /$ \\
\hline Mt 5, 12 & $: 39 / 76 /$ & Mt 9, 29 & $: 173 / 255 /$ \\
\hline Mt 5, 16 & :38/ 75/ & Mt 10, 28 & :59/172/ 293/ \\
\hline Mt 5, 18 & :79/86/ & Mt 10, 32 & $: 75 /$ \\
\hline Mt 5, 29 & $: 173 /$ & Mt 10, 40 & $: 178 /$ \\
\hline Mt 5, 32 & $: 173 /$ & Mt 11, 5 & $: 45 /$ \\
\hline Mt 5, 34 & :38/75/79/ & Mt 11, 12-15 & $: 168 /$ \\
\hline Mt 5, 35 & $: 38 /$ & Mt 11, 23 & $: 250 /$ \\
\hline Mt 5, 45 & $: 75 /$ & Mt 11, 25 & $: 75 / 79$ \\
\hline Mt 5, 48 & :74/ 263/ & Mt 11, 27 & $: 76 /$ \\
\hline Mt 6, 1 & $: 75 /$ & Mt 12,50 & $: 75 /$ \\
\hline Mt 6, 9 & :75/261/ & Mt 13, 7 & $: 33 /$ \\
\hline Mt 6, 10 & $: 77 /$ & Mt 13, 8 & $: 263 /$ \\
\hline Mt 6, 14 & $: 74 /$ & Mt 13, 22 & $: 187 /$ \\
\hline Mt 6, 16 & :74/ & Mt 13, 24-30 & :193/ \\
\hline Mt 6, 19 & $: 254 /$ & Mt 13, 39 & :57/ \\
\hline
\end{tabular}


Kształtowanie się nauki o niebie w teologii patrystycznej I-III wieku

\begin{tabular}{|c|c|c|c|}
\hline Mt 13, 40 & :57/ & Mt 22, 37-40 & $: 245 /$ \\
\hline Mt 13, 42-43 & $: 178 /$ & Mt 23, 9 & :74/ \\
\hline Mt 13, 43 & $: 262 /$ & Mt 23, 22 & $: 38 /$ \\
\hline Mt 13, 49 & :57/ & Mt 24, 4 & :127/ 128/ \\
\hline Mt 14, 19 & $: 216 /$ & Mt 24, 30 & :77/ 166/ \\
\hline Mt 14, 23 & $: 33 /$ & Mt 24, 31 & $: 77 /$ \\
\hline Mt 15, 13 & :74/ & Mt 24, 35 & :79/294/ \\
\hline Mt 15, 24 & :294/ 298/ & Mt 25, 10 & $: 138 /$ \\
\hline Mt 15, 29 & $: 33 /$ & Mt 25, 21 & $: 85 / 87 /$ \\
\hline Mt 16,2 & $: 80 /$ & Mt 25, 23 & $: 85 / 87 /$ \\
\hline Mt 16, 18 & $: 138 /$ & Mt 25, 31-45 & $: 203 /$ \\
\hline Mt 16, 19 & :38/77/ 138/ & Mt 25, 34 & $: 281 /$ \\
\hline Mt 16, 25 & $: 63 /$ & Mt 25, 41 & :87/ 172/ \\
\hline Mt 17, 5 & $: 216 /$ & Mt 26, 64 & $: 39 /$ \\
\hline Mt 17, 16 & $: 295 /$ & Mt 27, 9 & $: 156 /$ \\
\hline Mt 17, 23 & $: 156 /$ & Mt 28, 2 & $: 39 / 74 /$ \\
\hline Mt 18, 3 & :176/ 256/ & & \\
\hline Mt 18,8 & $: 63 /$ & \multirow{2}{*}{\multicolumn{2}{|c|}{$\begin{array}{l}\text { Ewangelia według św. Marka } \\
\text { (Mk) }\end{array}$}} \\
\hline Mt 18, 9 & $: 173 /$ & & \\
\hline Mt 18,10 & :39/74/ 77/ & Mk 1, 1 & $: 38 /$ \\
\hline Mt 18, 12-13 & $: 298 /$ & $\mathrm{Mk} 1,10$ & :38/39/76/ \\
\hline Mt 18, 18 & :38/ 77/ & Mk 1, 11 & $: 76 /$ \\
\hline Mt 18, 19 & $: 74 /$ & Mk 3, 4 & $: 63 /$ \\
\hline Mt 18, 35 & :74/ & $\mathrm{Mk} 3,13$ & $: 33 /$ \\
\hline Mt 19, 8 & $: 45 /$ & Mk 4, 19 & :57/ 187/ \\
\hline Mt 19, 11-12 & $: 174 / 348 /$ & Mk 4, 32 & $: 80 /$ \\
\hline Mt 19, 12 & $: 174 /$ & Mk 6, 41 & $: 38 / 80 / 216 /$ \\
\hline Mt 19, 16 & $: 57 / 63 / 340 /$ & $\mathrm{Mk} 7,27-29$ & $: 46 /$ \\
\hline Mt 19, 16-22 & $: 156 /$ & $\mathrm{Mk} 7,34$ & $: 38 / 80 / 216 /$ \\
\hline Mt 19, 19 & $: 63 / 340 /$ & Mk 8, 11 & $: 80 /$ \\
\hline Mt 19, 29 & $: 57 / 63 /$ & Mk 8, 14 & $: 46 /$ \\
\hline Mt 20, 30 & $: 275 /$ & Mk 8, 27 & $: 57 / 343 /$ \\
\hline Mt 21, 4 & $: 156 /$ & Mk 8, 33 & $: 39 /$ \\
\hline Mt 22, 13 & $: 295 /$ & Mk 9, 44-48 & $: 145 /$ \\
\hline Mt 22, 30 & :39/251/ & Mk 10, 2-12 & $: 45 /$ \\
\hline
\end{tabular}


Indeks biblijny

\begin{tabular}{|c|c|c|c|}
\hline Mk 10, 17 & :57/ & Łk 9, 28 & $: 33 /$ \\
\hline Mk 10, 17-22 & $: 156 /$ & Łk 9, 54 & $: 76 /$ \\
\hline $\mathrm{Mk} 10,17-30$ & $: 60 /$ & Łk 10,18 & :39/75/ 200/ \\
\hline Mk 10, 21 & $: 39 /$ & Łk 10, 20 & :39/75/ 76/ \\
\hline Mk 10, 27-31 & $: 57 /$ & Łk 10, 22 & $: 215 /$ \\
\hline Mk 10, 30 & :57/ & Łk 10, 25 & $: 58 /$ \\
\hline Mk 10, 52 & :57/ 343/ & Łk 10, 30 & $: 275 /$ \\
\hline Mk 11, 25 & $: 38 /$ & Łk 11, 13 & $: 38 /$ \\
\hline Mk 11, 30 & $: 75 /$ & Łk 12, 4-5 & $: 172 /$ \\
\hline Mk 12, 25 & :39/74/ & Łk 12, 32 & $: 216 /$ \\
\hline $\mathrm{Mk} 12,27$ & $: 63 /$ & Łk 12, 33 & $: 39 /$ \\
\hline Mk 13 & $: 74 /$ & Łk 12, 56 & :79/ \\
\hline Mk 13, 5 & :127/ 128/ & Łk 13, 24 & :138/ \\
\hline Mk 13, 25 & $: 80 /$ & Łk 13, 25 & :138/ \\
\hline Mk 13, 27 & :77/ & Łk 13, 26-27 & $: 178 /$ \\
\hline Mk 13, 31 & $: 75 /$ & Łk 14, 15-24 & $: 85 /$ \\
\hline Mk 13, 32 & $: 39 /$ & Łk 15, 4 & $: 298 /$ \\
\hline Mk 13, 36 & $: 39 /$ & Łk 15,18 & $: 75 /$ \\
\hline Mk 14, 62 & :39/77/ & Łk 15, 21 & $: 75 /$ \\
\hline Mk 16, 19 & :36/39/192/ & Łk 16, 8 & :57/ 187/ \\
\hline \multirow[t]{2}{*}{ Mk 16, 20} & :58/339/ & Łk 16, 16 & $: 168 /$ \\
\hline & & Łk 16, 17-31 & $: 87 /$ \\
\hline \multicolumn{2}{|c|}{ Ewangelia według św. Łukasza } & Łk 16, 19 & $: 257 /$ \\
\hline$(\mathbf{E k})$ & & $\operatorname{~Łk~16,~} 23$ & $: 44 / 87 /$ \\
\hline$€ \mathrm{k}$ & $: 74 /$ & Łk 16, 26 & $: 84 /$ \\
\hline Łk 1, 35 & $: 158 /$ & Łk 17, 29 & $: 76 /$ \\
\hline Łk 2, 4 & $: 33 /$ & Łk 18, 10 & $: 33 /$ \\
\hline Łk 2, 13 & $: 72 /$ & Łk 18, 13 & :38/ 80/ 84/ \\
\hline Łk 2, 15 & :74/ & Łk 18,18 & $: 58 /$ \\
\hline Łk 4, 25 & $: 80 /$ & Łk 18, 18-23 & $: 156 /$ \\
\hline Łk 6, 20 & $: 259 /$ & Łk 18, 30 & $: 58 /$ \\
\hline Łk 6, 23 & :39/76/ & Łk 19, 3 & $: 52 /$ \\
\hline Łk 7, 22 & $: 45 /$ & Łk 20, 35-36 & $: 168 /$ \\
\hline Łk 8, 5 & $: 80 /$ & Łk 20, 43 & $: 281 /$ \\
\hline Łk 9, 16 & $: 216 /$ & Łk 21, 8 & :127/ 128/ \\
\hline
\end{tabular}


Kształtowanie się nauki o niebie w teologii patrystycznej I-III wieku

\begin{tabular}{|c|c|c|c|}
\hline Łk 21, 27-28 & $: 77 /$ & $\mathrm{J}$ 6, 41 & $: 34 / 158 /$ \\
\hline Łk 22, 43 & $: 39 / 74 /$ & $\mathrm{J} 6,41-50$ & $: 77 /$ \\
\hline Łk 23, 43 & $: 39 / 43 / 44 / 229 /$ & $\mathrm{J} 6,42$ & $: 84 /$ \\
\hline Łk 24, 37 & $: 127 /$ & $\mathrm{J} 6,46$ & $: 52 /$ \\
\hline Łk 24, 38 & $: 33 /$ & $\mathrm{J} 6,50$ & $: 35 /$ \\
\hline $\operatorname{Ek} 24,39$ & $: 87 /$ & $\mathrm{J} 6,51$ & $: 131 /$ \\
\hline \multirow[t]{2}{*}{ Łk 24, 51} & $: 131 / 156 /$ & $\mathrm{J} 6,54$ & $: 59 /$ \\
\hline & & $\mathrm{J} 6,58$ & $: 131 /$ \\
\hline \multicolumn{2}{|c|}{ Ewangelia według św. Jana (J) } & $\mathrm{J} 6,60$ & $: 35 /$ \\
\hline $\mathrm{J}$ & $: 74 /$ & J 6,62 & $: 34 /$ \\
\hline $\mathrm{J} 1,1$ & $: 63 / 215 / 292 / 307 /$ & $\mathrm{J} 7,8$ & $: 33 /$ \\
\hline $\mathrm{J} 1,1-3$ & $: 307 /$ & $\mathrm{J} 8,5$ & $: 128 /$ \\
\hline $\mathrm{J} 1,4$ & $: 63 /$ & $\mathrm{J} 8,23$ & $: 36 /$ \\
\hline $\mathrm{J} 1,7$ & $: 139 /$ & $\mathrm{J} 10,9$ & :127/ 138/250/ 298 \\
\hline $\mathrm{J} 1,18$ & $: 215 /$ & $\mathrm{J} 10,7$ & $: 127 /$ \\
\hline $\mathrm{J} 1,47$ & $: 262 /$ & $\mathrm{J} 10,10$ & $: 63 /$ \\
\hline $\mathrm{J} 1,51$ & :34/ 77/ 138/ & $\mathrm{J} 10,11$ & $: 63 /$ \\
\hline $\mathrm{J} 3,3-5$ & $: 176 /$ & $\mathrm{J} 10,14$ & $: 63 /$ \\
\hline $\mathrm{J} 3,5$ & $: 139 / 141 / 216 / 282 /$ & $\mathrm{J} 10,15$ & $: 63 /$ \\
\hline $\mathrm{J} 3,13$ & $: 34 / 158 / 259 /$ & $\mathrm{J} 10,17$ & $: 63 /$ \\
\hline $\mathrm{J} 3,15$ & $: 59 /$ & $\mathrm{J} 10,30$ & :127/ \\
\hline $\mathrm{J} 3,16$ & :59/63/ 156/ & $\mathrm{J} 11,15$ & $: 63 /$ \\
\hline $\mathrm{J} 3,27$ & $: 75 /$ & $\mathrm{J} 11,21$ & $: 631$ \\
\hline $\mathrm{J} 3,36$ & :59/127/ 255/ & $\mathrm{J} 11,25$ & $: 63 /$ \\
\hline J 4, 10-14 & $: 46 /$ & $\mathrm{J} 11,34$ & :59/341 \\
\hline $\mathrm{J} 4,14$ & $: 283 /$ & $\mathrm{J} 11,41$ & $: 36 /$ \\
\hline J 5,24 & $: 34 / 63 / 255 /$ & $\mathrm{J} 12,1$ & $: 36 /$ \\
\hline J 5,26 & $: 63 /$ & $\mathrm{J} 12,25$ & $: 59 /$ \\
\hline J 6 & $: 46 /$ & $\mathrm{J} 12,26$ & $: 44 /$ \\
\hline J 6, 27 & $: 59 /$ & $\mathrm{J} 12,28$ & $: 76 /$ \\
\hline J $6,31-38$ & $: 77 /$ & $\mathrm{J} 12,31$ & $: 75 /$ \\
\hline J 6,33 & :34/ 84/ 156/ 158/ & $\mathrm{J} 12,34$ & $: 59 / 341$ \\
\hline $\mathrm{J} 6,35$ & $: 131 /$ & J 12, 44-45 & $: 52 /$ \\
\hline J 6, 38 & :34/ 84/ 158/ & $\mathrm{J} 13,1$ & $: 34 /$ \\
\hline $\mathrm{J} 6,40$ & :53/131/ 255/ & $\mathrm{J} 13,36$ & $: 296 /$ \\
\hline
\end{tabular}


Indeks biblijny

\begin{tabular}{|c|c|c|c|}
\hline $\mathrm{J} 14,1-3$ & $: 84 / 87 /$ & $\mathrm{Dz} 1,16$ & $: 84 /$ \\
\hline $\mathrm{J} 14,2$ & $: 44 / 84 / 216 / 235$ & Dz 1,22 & :192/ \\
\hline $\mathrm{J} 14,2-3$ & $: 84 /$ & $\mathrm{Dz} 1,25$ & :129/ \\
\hline $\mathrm{J} 14,3$ & $: 283 /$ & $\mathrm{Dz} 2,2$ & $: 76 /$ \\
\hline \multirow[t]{2}{*}{ J 14, 6} & :127/ 214/ & Dz 2, 17-21 & :77/ \\
\hline & $259 / 298 /$ & $\mathrm{Dz} 2,19$ & $: 36 /$ \\
\hline $\mathrm{J} 14,9$ & $: 52 /$ & $\mathrm{Dz} 2,34$ & $: 33 /$ \\
\hline $\mathrm{J} 14,16$ & $: 39 /$ & Dz 3, 1 & $: 33 /$ \\
\hline J 14, 16-26 & :299/ & Dz 3, 15 & $: 63 /$ \\
\hline J 14, 23 & :216 & Dz 3, 19-21 & $: 274 /$ \\
\hline $\mathrm{J} 14,26$ & $: 39 /$ & $\mathrm{Dz} 3,21$ & 61/77/274/275/ \\
\hline $\mathrm{J} 15,26$ & :39/299/ & $\mathrm{Dz} 4,24$ & $: 75 / 79 / 216 /$ \\
\hline $\mathrm{J} 16,7$ & :39/299/ & $\mathrm{Dz} 5,20$ & $: 63 /$ \\
\hline $\mathrm{J} 17,1$ & $: 38 / 80 /$ & $\mathrm{Dz} 7,2$ & $: 52 /$ \\
\hline $\mathrm{J} 17,2$ & $: 59 /$ & $\mathrm{Dz} 7,42$ & $: 75 /$ \\
\hline J 17, 3 & :58/59/63/ & $\mathrm{Dz} 7,49$ & $: 75 /$ \\
\hline J 18, 36 & $: 282$ & $\mathrm{Dz} 7,55$ & $: 38 / 80 /$ \\
\hline J 19, 37 & $: 164 / 165 / 166 /$ & $\mathrm{Dz} 7,59$ & $: 44 /$ \\
\hline J 20, 17 & $: 34 / 131 /$ & $\mathrm{Dz} 8,32$ & $: 196 /$ \\
\hline $\mathrm{J} 20,20$ & :127/ & Dz 8, 32-35 & $: 115 /$ \\
\hline $\mathrm{J} 20,23$ & $: 77 /$ & $\mathrm{Dz} 10,12$ & $: 80 /$ \\
\hline J 20, 27 & $: 127 /$ & Dz 10, 42 & $: 143 /$ \\
\hline \multirow[t]{2}{*}{$\mathrm{J} 20,31$} & :127/ & Dz 11, 6 & $: 80 /$ \\
\hline & & $\mathrm{Dz} 13,46$ & $: 62 /$ \\
\hline \multicolumn{2}{|c|}{ Dzieje Apostolskie (Dz) } & Dz 13, 48 & $: 62 /$ \\
\hline $\mathrm{Dz}$ & :74/ 196/ & Dz 14,15 & :75/ 79/ 217/ \\
\hline $\mathrm{Dz} 1,2$ & $: 84 / 192 /$ & $\mathrm{Dz} 14,17$ & $: 80 /$ \\
\hline Dz 1, 4-12 & $: 245 /$ & $\mathrm{Dz} 14,27$ & $: 138 /$ \\
\hline Dz 1,8 & $: 39 /$ & Dz 15,18 & $: 61 /$ \\
\hline $\mathrm{Dz} 1,9$ & $: 85 / 156 / 166 /$ & Dz 17, 24 & $: 75 /$ \\
\hline Dz 1, 9-11 & $: 39 /$ & Dz 17, 30 & $: 217 /$ \\
\hline $\mathrm{Dz} 1,10$ & $: 84 /$ & Dz 20, 9 & $: 76 /$ \\
\hline \multirow[t]{2}{*}{ Dz 1,11} & $: 77 / 80 / 84 /$ & $\mathrm{Dz} 24,26$ & $: 121 /$ \\
\hline & $192 / 216 /$ & Dz 32-36 & $: 77 /$ \\
\hline
\end{tabular}


Kształtowanie się nauki o niebie w teologii patrystycznej I-III wieku

\begin{tabular}{|c|c|c|c|}
\hline \multicolumn{2}{|c|}{ Św. Pawła List do Rzymian (Rz) } & \multicolumn{2}{|c|}{ Św. Pawła 1 List do Koryntian } \\
\hline Rz 1, 3-4 & $: 158 /$ & (1 Kor) & \\
\hline $\mathrm{Rz} 1,10$ & $: 288 /$ & 1 Kor 1,20 & $: 57 /$ \\
\hline Rz 1, 18 & $: 76 /$ & 1 Kor 1,23 & :127/ \\
\hline $\mathrm{Rz} 1,23$ & $: 85 /$ & 1 Kor 1,24 & $: 206 /$ \\
\hline $\mathrm{Rz} 2,4$ & $: 216 /$ & 1 Kor 2, 6 & :57/ \\
\hline $\mathrm{Rz} 2,6$ & $: 121 /$ & 1 Kor 2,9 & $: 33 / 84 / 118 / 121 /$ \\
\hline $\mathrm{Rz} 3,23$ & $: 45 /$ & & $134 / 145 / 258 / 261 /$ \\
\hline $\mathrm{Rz} 3,25$ & $: 215 / 217 /$ & 1 Kor 3, 1 & $: 126 /$ \\
\hline $\mathrm{Rz} 3,28$ & $: 122 /$ & 1 Kor 3, 1-2 & $: 256 /$ \\
\hline $\mathrm{Rz} 3,30$ & $: 122 /$ & 1 Kor $3,1-3$ & $: 257 /$ \\
\hline $\mathrm{Rz} 5,12$ & $: 45 /$ & 1 Kor $3,11-15$ & $: 273 /$ \\
\hline $\mathrm{Rz} 6,2$ & :293/ & 1 Kor 3, 14 & $: 87 /$ \\
\hline $\mathrm{Rz} 6,3$ & $: 63 /$ & 1 Kor 6, 9 & $: 127 / 128 /$ \\
\hline $\mathrm{Rz} 6,4$ & $: 127 / 200 /$ & 1 Kor 6, 9-10 & $: 257 /$ \\
\hline $\mathrm{Rz} 6,5$ & $: 87 /$ & 1 Kor 7,35 & $: 256 /$ \\
\hline $\mathrm{Rz} 6,8$ & $: 156 /$ & 1 Kor 8, 6 & :78/ \\
\hline $\mathrm{Rz}_{\mathrm{z}} 6,10$ & :63/ 293/ & 1 Kor 9,17 & $: 128 /$ \\
\hline Rz 6, 10-12 & $: 293 /$ & 1 Kor 9, 25 & $: 85 / 87 /$ \\
\hline $\mathrm{Rz}_{\mathrm{z}} 6,13$ & $: 63 /$ & 1 Kor 10,11 & $: 57 /$ \\
\hline $\mathrm{Rz} 7,14$ & :287/ & 1 Kor 12,12 & :297/ \\
\hline $\mathrm{Rz} 7,22$ & $: 269 /$ & 1 Kor $12,23-26$ & $: 297 /$ \\
\hline $\mathrm{Rz} 8,10$ & $: 63 / 173 /$ & 1 Kor 13,8 & $: 86 /$ \\
\hline Rz 8, 15 & $: 263 /$ & 1 Kor 13,10 & :283/ \\
\hline $\mathrm{Rz} 8,18$ & :84/ & 1 Kor 13, 11 & $: 256 /$ \\
\hline $\mathrm{Rz} 8,20$ & $: 45 /$ & 1 Kor 13,12 & :52/ 63/ 84/ \\
\hline $\mathrm{Rz} 8,30$ & $: 252 /$ & & $283 / 284 /$ \\
\hline $\mathrm{Rz} 8,32$ & $: 216 /$ & 1 Kor 13,13 & $: 85 /$ \\
\hline $\mathrm{Rz} 9,5$ & :78/ & 1 Kor 14,2 & $: 217 /$ \\
\hline Rz 10, 6 & $: 33 / 35 /$ & 1 Kor 15 & $: 87 /$ \\
\hline $\mathrm{Rz} 12,2$ & :57/ 187/ & 1 Kor 15,4 & $: 156 /$ \\
\hline Rz 13, 10 & $: 245 /$ & 1 Kor 15,22 & $: 295 /$ \\
\hline $\mathrm{Rz} 15,24$ & $: 120 /$ & 1 Kor $15,22-28$ & $: 276 /$ \\
\hline $\mathrm{Rz} 15,28$ & $: 120 /$ & 1 Kor 15, 23 & $: 296 /$ \\
\hline
\end{tabular}


Indeks biblijny

1 Kor 15, 23-24 :281/296/

2 Kor 5, 1

1 Kor 15, 23-28:272/ 273/

2 Kor 5, 2-4 : :188/

1 Kor 15, $24 \quad: 85 / 296 /$

2 Kor 5, $4 \quad: 63 / 244 /$

1 Kor 15, 25-28:295/

2 Kor 5, 8 :39/44/63

1 Kor 15, 26-27 :296/

2 Kor 6, 16 :63/

1 Kor 15, 27-28 :289/

1 Kor 15, 28 :63/270/299/

2 Kor 10, 1 :215/

1 Kor 15, 33 :128/

2 Kor 11, $24 \quad: 120 /$

1 Kor 15, 35 :173/

2 Kor 12, 3 :79/

1 Kor 15, 35-38:85/

1 Kor 15, 35-55:63/

1 Kor 15, 40 :79

1 Kor 15, 41 :281/

2 Kor 12, 4 :43/44/

1 Kor 15, 41-42 :297/

1 Kor 15, 42-57:87/

1 Kor 15, $45 \quad: 63 /$

1 Kor 15, 48 :269/

1 Kor 15, 48-53:79/

1 Kor 15, $50 \quad: 211 / 216 / 217 / 251$

1 Kor 15, 50-53:228/340/

1 Kor 15, 52 :167/ 289/

1 Kor 15, 52-53:301/

1 Kor 15, 53 :212/

1 Kor 15, 53-54:190/

1 Kor 15, 54 :244/

1 Kor $22: 272 /$

1 Kor $28 \quad: 272 /$

\section{Św. Pawła 2 List do Koryntian}

(2 Kor)

2 Kor 2, 14 :144/

2 Kor 4, 4 :187/

2 Kor 4, $10 \quad: 63 /$

2 Kor 4, 16 :269/

2 Kor 4, 18 :284/

Św. Pawła List do Galatów (Ga)

$\begin{array}{ll}\text { Ga } 1,5 & : 57 / \\ \text { Ga } 1,8 & : 74 / \\ \text { Ga 1, 12 } & : 214 / \\ \text { Ga 2, 1 } & : 33 / \\ \text { Ga 2, 16 } & : 122 / \\ \text { Ga 3, 8-11 } & : 122 / \\ \text { Ga 3, 26-28 } & : 255 / \\ \text { Ga 3, 28 } & : 251 / 257 / \\ \text { Ga 4, 4-5 } & : 216 / \\ \text { Ga 4, 7 } & : 256 / \\ \text { Ga 4, 24-25 } & : 36 / \\ \text { Ga 4, 26 } & : 36 / 76 / 192 / 231 / \\ \text { Ga 6, 2 } & : 217 / \\ \text { Ga 6, 7 } & : 127 / 128 /\end{array}$

Św. Pawła List do Efezjan (Ef)

Ef 1, $3 \quad: 79 /$

Ef $1,4 \quad: 144 /$

Ef $1,10 \quad: 78 / 239 /$

Ef $1,20 \quad: 79 / 158 / 192 /$

Ef $1,21 \quad: 57 / 128 /$

Ef 1, $23 \quad: 78 /$

Ef 2, $2 \quad: 75 / 187 /$

Ef 2, $6 \quad: 79 / 87 /$ 
Kształtowanie się nauki o niebie w teologii patrystycznej I-III wieku

\begin{tabular}{|c|c|c|c|}
\hline Ef 2,8 & $: 122 /$ & Kol 1, 16 & :78/ 128/ \\
\hline Ef 2,18 & :138/ & Kol 1, 20 & $: 78 /$ \\
\hline Ef 3,9 & $: 216 /$ & Kol 2, 10 & $: 128 /$ \\
\hline Ef 3,10 & :75/ 128/ & Kol 2, 17 & $: 287 /$ \\
\hline Ef 3,12 & $: 138 /$ & Kol 2, 18 & $: 87 /$ \\
\hline Ef 3,15 & $: 74 / 78 /$ & $\mathrm{Kol} 2,20$ & $: 78 /$ \\
\hline Ef 3,16 & $: 269 /$ & $\operatorname{Kol} 3,1$ & $: 36 /$ \\
\hline Ef 3, 21 & :57/ & Kol 3, 3 & $: 63 /$ \\
\hline Ef 4,4 & :139/ & $\operatorname{Kol} 3,4$ & $: 63 / 127 /$ \\
\hline Ef $4,7-13$ & $: 34 /$ & & \\
\hline Ef 4,8 & $: 33 /$ & \multirow{2}{*}{\multicolumn{2}{|c|}{$\begin{array}{l}\text { Św. Pawła } 1 \text { List do Tesaloniczan } \\
(1 \text { Tes })\end{array}$}} \\
\hline Ef $4,8-10$ & :192/ & & \\
\hline Ef 4,9 & $: 78 /$ & 1 Tes 4,16 & $: 35 /$ \\
\hline Ef $4,9-10$ & $: 34 / 158 /$ & 1 Tes 4,17 & $: 262 /$ \\
\hline Ef 4,10 & :78/ & & \\
\hline Ef 4,13 & /262/263/297: & \multirow{2}{*}{\multicolumn{2}{|c|}{$\begin{array}{l}\text { Św. Pawła } 2 \text { List do Tesaloniczan } \\
(2 \text { Tes) }\end{array}$}} \\
\hline Ef 4,18 & $: 63 /$ & & \\
\hline Ef 5,1 & $: 217 /$ & 2 Tes 1,9 & $: 87 /$ \\
\hline Ef 6,12 & :75/ 296/ & & \\
\hline
\end{tabular}

Św. Pawła List do Filipian (Flp)

Św. Pawła 1 List do Tymoteusza

Flp 1, 6

$: 83 /$

(1 Tm)

Flp 1, 21

$: 63 / 127 /$

Flp 1, 23

$: 39 / 44 / 63 /$

$1 \operatorname{Tm} 1,1$

$: 129 /$

$1 \operatorname{Tm} 1,17$

:52/ 57/ 85/ 164/

Flp 2, 5-11

$: 158 /$

$1 \operatorname{Tm} 1,18$

$: 128 /$

$1 \operatorname{Tm} 2,4$

$: 252 /$

Flp 2, 6-7 : :249/

$1 \operatorname{Tm} 3,16$

$: 192 /$

Flp 2, 9

$: 78 /$

$1 \operatorname{Tm} 4,10$

:254/

Flp 2, $10 \quad: 77 /$

Flp 3, 14 :36/78/

$1 \operatorname{Tm}$ 6, 16

$: 52 /$

$1 \operatorname{Tm} 6,17$

$: 187 /$

Flp 3, $20 \quad: 39 / 76 /$

Flp 4, 20 :57/

Św. Pawła 2 List do Tymoteusza

(2 Tm)

Św. Pawła List do Kolosan (Kol)

$2 \operatorname{Tm} 2,5$

$: 87 /$

Kol 1, 15-20 :158/

$2 \operatorname{Tm} 2,12 \quad: 167 /$

Kol 1, 15-23 : :78/

$2 \operatorname{Tm} 3,16$ :207/ 
$2 \operatorname{Tm} 4,1 \quad: 143 /$

$2 \operatorname{Tm} 4,7-8 \quad: 85 /$

$2 \operatorname{Tm} 4,8 \quad: 87 /$

$2 \operatorname{Tm} 4,10 \quad: 187 /$

$2 \operatorname{Tm} 4,18$ :44/57/

Św. Pawła List do Tytusa (Tt)

Tt 2, 12

:187/

Tt 3, 3

$: 217 /$

List do Hebrajczyków (Hbr)

$\mathrm{Hbr}$

:74/78/

Hbr 1, 1

$: 261 /$

Hbr 1, 3

$: 78 / 124 /$

Hbr 1,8

$: 57 / 61 /$

Hbr 1, 13

Hbr 2, 5

:124/

Hbr 2, 17

$: 156 /$

Hbr 3, 1

$: 299 /$

Hbr 4, 9-11

$: 78 / 299 /$

Hbr 4, 14

Hbr 5, 9

Hbr 6, 4

Hbr 6, 5

$\mathrm{Hbr} 7,26$

Hbr 8,1

Hbr 8, 1-6

Hbr 8, 5

Hbr 9, 11

Hbr 9, 15

Hbr 9, 23

Hbr 9, 28

Hbr 10

Hbr 10, 19

Hbr 10, 19-39
$: 287 /$

$: 138 /$

$: 85 /$

$: 39 / 78 / 256 /$

$: 621$

$: 78 /$

$: 57 /$

$: 78 /$

$: 75 / 78 /$

$: 39 /$

$: 77 / 287 /$

$: 39 / 78 /$

$: 621$

$: 77 / 78 /$

$: 78 /$

:156/
Hbr 10, 23 :145/

Hbr $11 \quad$ :136/

Hbr 11, 3 :187/

Hbr 11, 10 :215/

Hbr 11, 13-14 :85/

Hbr 11, 16 :78/ 84/

Hbr 12, 2 :255/

Hbr 12, 14 :52/

Hbr 12, 22 :44/ 76/ 192/

Hbr 12, 22-23 :78/

Hbr 12, 22-24 :39/

Hbr 12, 23 :76/

Hbr 12, 25 :76/

Hbr 12, 26 :75/

Hbr 13, 8 :62/

Hbr 13, 20 :61/

Hbr 13, 21 :61/

List św. Jakuba (Jk)

Jk 1, 12 :87/

Jk $1,17: 35 /$

Jk 5, 18 :80/

List 1 św. Piotra (1 P)

1 P $1,4 \quad$ :76/ 85/87/

$1 \mathrm{P} 1,12$ :76/

$1 \mathrm{P} 1,24-25 \quad$ :86/

1 P $1,25 \quad: 61 / 86 /$

$1 \mathrm{P} 2,17 \quad: 87 /$

1 P 2, 21 :121/

$1 \mathrm{P} 3,18$ :35/

$1 \mathrm{P} 4,5 \quad: 35 / 143 /$

$1 \mathrm{P} 4,11 \quad: 57 / 61 / 275 / 281 /$

$1 \mathrm{P} 5,4 \quad: 85 / 87 /$

$1 \mathrm{P} 5,10$ :62/ 
Kształtowanie się nauki o niebie w teologii patrystycznej I-III wieku

$1 \mathrm{P} 5,11 \quad$ :61/ Jud 21

List 2 św. Piotra (2 P)

2 P 1,4

$: 63 /$

2 P 1,11

$: 61 /$

2 P 1,13

$: 214 /$

2 P 3, 7

$: 75 /$

2 P 3,10

$: 75 /$

2 P 3, 10-12

$: 142 /$

2 P 3,12

$: 75 /$

2 P 3, 13

$: 75 / 76 / 83 /$

2 P 3,18

$: 62 /$

List 1 św. Jana (1 J)

$1 \mathrm{~J} 1,1$

:63/

$1 \mathrm{~J} 1,2$

$: 62 /$

$1 \mathrm{~J} 2,17$

$: 621$

$1 \mathrm{~J} 2,25$

$: 58 / 62 /$

$1 \mathrm{~J} 3,2$

$: 53 / 63 /$

$1 \mathrm{~J} 3,14$

$: 34 /$

$1 \mathrm{~J} 3,15$

$: 62 /$

$1 \mathrm{~J} \mathrm{3,16}$

$: 63 /$

1 J 4, 12

$: 53 /$

$1 \mathrm{~J} 4,19$

$: 217 /$

$1 \mathrm{~J} 5,10$

$: 59 /$

$1 \mathrm{~J} 5,11$

$: 59 / 62 /$

1 J 5,13

$: 59 / 62 /$

1 J 5,20

$: 62 /$

List 2 św. Jana (2 J)

2 J 2

:62/

List św. Judy (Jud)

Jud 7

:87/

Jud 13

$: 87 /$

\section{Apokalipsa św. Jana (Ap)}

Ap :74/79/

Ap 1, 7

$: 164 /$

Ap 1, 18

:35/ 138/

Ap 2, 7

:43/ 84/

Ap 2, 7b

$: 441$

Ap 2, 17

$: 87 /$

Ap 2, 26-27 :87/

Ap 2, 28

$: 85 /$

Ap 3, 5

$: 85 /$

Ap 3, 7

:138/214/

Ap 3, 11

$: 87 /$

Ap 3, 12

:35/ 76/ 84/ 85/

192/ 296/

Ap 3, 18 :85/

Ap 3, $21 \quad: 87 /$

Ap 4

:75/ 84/ 88/

Ap 4, 1

$: 85 /$

Ap 4, 4

$: 85 /$

Ap 4, 5

$: 241 /$

Ap 4, 6-8 : :84/

Ap 4, 8-11 : :39/

Ap 4, 9 :61/

Ap 4, 10 :61/

Ap 5 :84/

Ap 5, 1-5 :77/

Ap 5, 11-14 :77/

Ap 5, 13

$: 61 /$

Ap 6, 2

$: 87 /$

Ap 6, 9

$: 63 /$

Ap 6, $11 \quad: 85 /$

Ap 6, $13 \quad: 80 /$

Ap 7,9

$: 85 /$

384 


\begin{tabular}{|c|c|c|c|}
\hline Ap 7, 9-12 & :84/ & Ap 18, 4 & $: 76 /$ \\
\hline Ap 7, 12 & :61/ & Ap 18, 20 & $: 75 /$ \\
\hline Ap 7, 13 & $: 85 /$ & Ap 19, 1 & $: 74 /$ \\
\hline Ap 7, 14 & $: 75 / 85 /$ & Ap 19, 1-9 & $: 85 / 88 /$ \\
\hline Ap 7, 16 & $: 85 /$ & Ap 19, 8 & $: 85 /$ \\
\hline Ap 7, 17 & $: 85 /$ & Ap 19, 11 & $: 85 /$ \\
\hline Ap 8, 10 & $: 80 /$ & Ap 20 & $: 84 / 305 /$ \\
\hline Ap 9, 1 & $: 80 /$ & Ap 20, 1-10 & :132/357/ \\
\hline Ap 10, 1 & $: 75 /$ & Ap 20, 2 & $: 45 /$ \\
\hline Ap 10, 4 & $: 76 /$ & Ap 20, 4 & $: 171 /$ \\
\hline Ap 10, 5 & $: 80 /$ & Ap 20,10 & $: 45 /$ \\
\hline Ap 10, 6 & :61/ 75/ & Ap 20, 11 & :75/ \\
\hline Ap 10,8 & $: 76 /$ & Ap 20, 14 & $: 63 /$ \\
\hline Ap 11, 6 & $: 80 /$ & Ap 21 & $: 83 / 191 / 220 /$ \\
\hline Ap 11,12 & $: 75 / 76 /$ & & $221 / 305 /$ \\
\hline Ap 11,13 & $: 75 /$ & Ap 21, 1 & :75/ 76/ 84/ \\
\hline Ap 11, 19 & :76/ 84/ & & $165 / 341 /$ \\
\hline Ap 12,1 & $: 80 /$ & Ap 21, 1-4 & $: 234 /$ \\
\hline Ap 12, 3 & $: 80 /$ & Ap 21, 2 & :35/ 76/ 84/ \\
\hline Ap 12, 4 & $: 80 /$ & Ap 21, 2-5 & $: 192 /$ \\
\hline Ap 12,7 & :74/ & Ap 21, 3 & $: 45 / 63 / 76 / 84 /$ \\
\hline Ap 12,12 & $: 75 /$ & Ap 21, 4 & $: 45 / 63 / 85 /$ \\
\hline Ap 13, 13 & $: 80 /$ & Ap 21, 6 & $: 85 / 257 /$ \\
\hline Ap 14, 4 & :84/ & Ap 21, 10 & $: 35 / 76 /$ \\
\hline Ap 14, 4-5 & $: 85 /$ & Ap $21,10-27$ & $: 45 /$ \\
\hline Ap 14, 6 & $: 287 /$ & Ap 21, 11 & $: 84 / 296 /$ \\
\hline Ap 14,7 & :75/ 79/ & Ap 21, 12-27 & $: 138 /$ \\
\hline Ap 14, 11 & $: 87 /$ & Ap 21,15 & $: 83 /$ \\
\hline Ap 14,13 & $: 76 / 85 /$ & Ap 21, 18-21 & $: 84 / 260 /$ \\
\hline Ap 15 & $: 80 /$ & Ap 21, 22 & :84/ 192/ \\
\hline Ap 15,2 & $: 39 /$ & Ap 21, 23-24 & $: 84 /$ \\
\hline Ap 15,5 & $: 84 / 85 /$ & Ap 21,25 & $: 85 /$ \\
\hline Ap 15, 7 & $: 61 /$ & Ap 21, 26 & $: 83 /$ \\
\hline Ap 16, 11 & $: 75 /$ & Ap 22 & $: 84 /$ \\
\hline Ap 18,1 & $: 75 /$ & Ap 22, 1 & $: 45 / 63 /$ \\
\hline
\end{tabular}


Kształtowanie się nauki o niebie w teologii patrystycznej I-III wieku

$\begin{array}{llll}\text { Ap 22, 1-2 } & : 83 / 84 / 312 / & \text { Ap 22, } 4 & : 52 / \\ \text { Ap 22, 1-6 } & : 87 / & \text { Ap 22, 5 } & : 62 / 76 / 84 / 341 / \\ \text { Ap 22, 1-10 } & : 45 / & \text { Ap 22, 12 } & : 87 / \text { 121/ } \\ \text { Ap 22, 2 } & : 45 / & \text { Ap 22, 14 } & : 63 / \\ \text { Ap 22, 2-3 } & : 83 / & \text { Ap 22, 14-15 } & : 138 / \\ \text { Ap 22, 3-5 } & : 45 / & \text { Ap 22, 19 } & : 63 /\end{array}$




\section{Indeks rzeczowy}

Aczasowość Boga 295, 315, 322

Adad / Addu 21, 69

Androgyniczne niebo 146

wątki 147

zrównanie 146

Antycypacja nieba (Pasterz 78) 134,

136, 141

u Orygenesa 288

w Apokalipsie 146

Architekt i Budowniczy wszech-

świata 215, 218

budowniczy (bóg) 273

budowniczy (u Platona) 91

władca i budowniczy 216

Arkadia 135, 136, 138, 141, 149, 150,323

Baal 21, 66

Bit-Adini (kraina) 18

Bóg a niebo

Stary Testament 65, 66, 67, 68, 69, 70, 71, 72, 73, 74, 80, 81
Nowy Testament 74, 75, 76, 77, $78,79,80,81$

Bóg transcendentny wobec nieba i raju 205, 206, 213, 245, 285 transcendencja objawienia 213

Być z Chrystusem 44, 64, 109

być z Bogiem 249

Cechy anielskie 234, 305, 317

Cechy zbawionych w niebie 7,44 , $85,123,146,150,152,154,216$, 228, 278

Cel 5, 6, 10, 12, 33, 34, 40, 50, 78, $82,85,86,90,91,92,93,94$, $96,100,101,107,155,157,161$, 166, 173, 181, 183, 187, 198, 202, 203, 223, 230, 236, 237, 241, 247, 249, 251, 252, 254, 256, 257, 258, 265, 275, 280, 284, 289, 298, 300, 316, 323

$\mathrm{Cel} / \mathrm{Koniec} / \mathrm{wypełnienie} 285$, 300, 317 
Kształtowanie się nauki o niebie w teologii patrystycznej I-III wieku

Chmury 23, 38

Chrystus 19, 34, 35, 36, 39, 44, $52,58,59,61,62,63,64,65$, $75,76,77,78,79,80,81,84$, $87,108,109,115,116,117,118$, $119,120,122,123,124,125,127$, $129,130,131,132,139,142,143$, $144,145,150,151,153,154,155$, $156,158,159,160,162,164,165$, $166,167,168,169,172,173,175$, $176,177,178,179,180,181,186$, 191, 192, 193, 194, 195, 196, 197 , $207,212,215,218,219,220$, $222,223,224,225,230,231$, 232, 233, 234, 235, 237, 241, 243, 244, 245, 246, 247, 248, 249, 250, 252, 253, 254, 255, 256, 257, 258, 263, 264, 266, 267, 269, 272, 273, 275, 277, 278, 280, 281, 282, 284, 287, 289, 290, 291, 292, 293, 295, 296, 297, 298, 299, 300, 301, 302, 303, 304, 305, 306, 308, $312,313,316,317,318,319$, 320, 321, 322, 323, 330, 332, $353,355,358,360$

Cnoty 96, 102, 105, 107, 141, 174, $175,177,179,180,181,182,223$, 225, 247, 248, 249, 250,254, $322,347,356,358$

Czyny / Postawy umożliwiające osiągnięcie zbawienia 139

Deifikacja 26, 246, 263, 264, 315

Didachè 114, 115

Didache 61, 62, 114, 115, 116,
$117,118,130,142,149,150$, 151,238

Dilmum (kraina) 20, 70

Długi czas, trwanie, na wieki, na zawsze 16, 27

Długi czas 16, 27, 53, 142, 269

Na wieki 27, 28, 29, 30, 45, 53, $57,60,115,116,120,122$, 131, 140, 144, 194, 211, 244, 275,281

Na zawsze 27, 28, 29, 30, 53,187

Trwałość 25, 32, 53, 58, 62, 64, $65,68,69,84,85,86,88$, $109,110,269$

Trwanie 5, 16, 27, 28, 31, 32, $53,56,57,64,65,87,94$, $95,109,110,120,121,140$, 152, 201, 202, 210, 219, 238, $258,268,285,293,295$, $302,303,317$

Wieczność 8, 16, 19, 27, 30, $31,32,52,53,55,56,57$, 58, 59, 60, 61, 62, 63, 64, $65,69,88,94,97,99,100$, 105, 109, 110, 134, 136, 140, $144,145,149,152,160,172$, 189, 198, 200, 203, 210, 219, $222,223,235,236,254$, 255, 256, 258, 268, 272, 279, 285, 286, 292, 295, 299, 311, 317

Do Diogneta 61, 153, 213, 214, 215, 216, 217, 218, 220, 221, 222,326 
Dobre czyny 54,73, 96, 117, 118, 119, 121, 122, 123, 128, 129, 131, $133,134,135,140,141,142,143$, $145146,147,148,149,151,152$, $167,173,176,177,178,179,180$, 181, 184, 189, 200, 201, 203, 204, 223, 225, 248, 250, 251, 266, 289, 294, 301

Doczesność 52, 59, 65, 69, 78, 86, $113,115,116,117,118,124,128$, 134, 139, 140, 141, 145, 147, 149, $151,152,163,171,173,179,182$, 184, 185, 193, 200, 203, 211, 212, 217, 235, 250, 252, 254, 255, 264, 278, 283, 284, 288, 289, 291, 301, 316, 318, 320 doczesny świat spłonie w ogniu 171,173

Doskonałość stworzeń 241, 265, 270, 271, 281, 283, 295, 297 , 298, 299, 300

Droga do nieba 96, 123, 128, 129, $131,133,140,144,145,152,159$, $166,238,253,254,256,259$, $270,290,298,320$

Drugi millenaryzm 8, 130, 132, 133, 134, 152, 163, 170, 171, 182, 188, $222,223,225,228,230,231$, $232,234,236,305,316$

Drzewo życia 18, 19, 20, 21, 42, 43, $45,63,83,209,218,243,321$

Dualizm ontologiczny 214

Dusza 10, 19, 20, 43, 44, 54, 59, 69, 73, 90, 91, 92, 94, 95, 96, 97, $98,100,102,103,104,105,106$,
$107,108,109,118,121,146,169$, $170,172,173,182,183,185,186$, 187, 188, 190, 191, 193, 198, 200, 201, 202, 203, 212, 213, 214 , $218,221,222,223,228,229$, 230, 236, 238, 244, 250, 251, 252, 260, 265, 266, 267, 269, 270, 276, 277, 278, 287, 293, 294, 299, 302, 303, 304, 312, $313,314,347,359$

Dziedzictwo 5, 60, 122, 124, 128, 149, 194, 232, 233, 262, 263, $282,289,290,292,317,319$ Eden / ogród (w) Eden 10, 16, 17, $18,19,20,21,22,31,40,41$, $42,43,51,65,82,83,84,87$, $88,109,110,120,188,191,192$, 208, 209, 210, 218, 220, 221, 228,314

Egzegeza 17, 19, 58, 188, 262, 265, $267,268,280$

Element enkratycki 182, 183, 184, 185,223

Eon $54,59,187,231,285,286$, $287,295,298,300$

Eschatologia 5, 6, 7, 8, 9, 11, 12, 13, $39,40,42,43,45,50,51,53$, $57,60,64,65,70,71,72,78$, $82,83,88,90,91,92,95,98$, $108,109,110,111,113,114,116$, $117,118,129,130,132,133,134$, $135,138,141,143,145,148,153$, $154,155,156,157,160,161,162$, $163,164,168,169,170,173$, $177,178,179,180,181,182,183$, 
Kształtowanie się nauki o niebie w teologii patrystycznej I-III wieku

$187,188,189,191,192,197,199$, 201, 203, 208, 212, 213, 218, 219, 220, 222, 223, 224, 225 , 227, 228, 229, 230, 231, 232, 235, 237, 244, 245, 246, 247 , 248, 249, 253, 259, 260, 264, $265,169,270,274,276,278$, 280, 286, 287, 288, 289, 293, 295, 298, 299, 300, 302, 303, 304, 305, 307, 308, 312, 314, $315,317,318,319,320,321$, 322,323

Eschatologiczne niebo 5, 6, 9, 11, $12,13,39,40,42$

Firmament 23, 24, 32, 36, 37, $65,66,67,68,75,80,208$, 220,241

Gehenna 59, 73, 272, 294, 295, 297

Hadad / Haddu 21

Hadda / Adda 21

Hades 43, 54, 95, 97, 98, 108, 294, 295, 297

Hesperidion (ogród) 20

Homilia z II wieku 61, 62, 114, 142, $143,144,145,146,148,149,150$, 151,152

Idea dojrzewania 237, 241, 245

Irinini (las cedrowy) 20

Jakby ogród 41, 309, 311

Jakość 31, 55, 62, 64, 89, 96, 102, $109,110,111,116,117,127,130$, $141,143,148,149,150,151,154$, $182,188,189,190,199,201,212$, 216, 217, 218, 220, 221, 224,
225, 236, 246, 265, 278, 282, 284, 285, 287, 288, 289, 291, 292, 294, 295, 299, 316, 317, $319,320,323$

Jerozolima 10, 22, 29, 33, 35, 36, $42,45,60,63,66,73,76,83$, 132, 170, 192, 194, 195, 197, 221, 228, 229, 230, 231, 232, 234, 235, 236, 246, 253, 260, 264, 274, 275, 286, 294, 296, 300, $305,316,317$

Jezus 12 , 32, 33, 34, 35, 36, 43, 44, $45,46,52,57,58,59,63,65$, $75,76,77,78,79,80,81,87$, 108, 110, 114, 115, 116, 117, 120, $122,123,124,126,127,128,129$, $130,131,138,139,142,143,145$, $147,150,151,153,154,158,159$, $162,163,164,165,166,167,168$, $169,173,175,176,180,181,182$, 189, 194, 195, 197, 204, 222, 224, 225, 229, 244, 245, 246, $247,254,255,267,269,273$, 274, 275, 278, 281, 283, 284, 292, 296, 297, 299, 300, 306, $308,312,318,319,320,321,322$ Kary 29, 50, 54, 68, 69, 86, 87, $90,91,95,96,97,98,106,145$. $160,168,170,172,173,174,175$, $176,177,179,180,183,184$, $186,203,211,218,244,252$, 266, 272, 290, 295, 301, 305, 306,318

Koniec 18, 22, 24, 25, 28, 32, 39, $40,51,52,54,58,61,64,80$, 
$89,90,106,110,117,128,129$, $132,138,140,141,149,163,171$, $186,188,213,230,235,240$, $258,260,270,271,272,275$, 279, 285, 287, 288, 289, 290, 294, 296, 297, 298, 300, 305, 317,319

Kosmologia 23, 33, 34, 35, 36, 37, $38,65,67,70,72,75,78,79$, $80,88,89,90,91,92,104,107$, $108,118,120,148,152,155,156$, $157,187,188,206,208,212$, $213,214,215,216,220,224$, 260, 265, 270, 279, 280, 289

Królestwo Boga 25, 31, 32, 45, 61, 65, 110, 137

Królestwo Boże 7, 39, 44, 57, 65, 116, 117, 127, 128, 131, 133, 134, 135, 136, 137, 138, 139, 141, 144, $146,148,150,168,181,213,216$, 217, 218, 220, 244, 257, 258, 282, 301, 316, 317

Królestwo niebieskie 44, 64, 74, 75, 109, 126, 154, 156, 159, 160, 168, $169,173,176,178,216,217,218$, 220, 222, 238, 247, 248, 256, 259, 260, 264, 281, 282, 290, $301,312,314,316,317,319$

Królestwo Syna 114 115, 116, 117, 119, 132, 145, 147, 150, 168, 231, $232,233,234,273,281,282$

Księga żywych 136, 140, 149

Los duszy 108

Łaska 28, 29, 33, 86, 107, 111, 116, 117, 124, 143, 149, 151, 181, 186,
189, 194, 195, 196, 212, 217, 218, $223,229,253,263,277,313,322$

Łono Abrahama 44, 64, 87, 109, 229, 294

Marduk 21

Masa wód 23

Metempsychoza 90, 91, 95, 96, 106, 108, 198

Metodologia 5, 9, 10, 11, 153, 181, $265,267,278,315$

Miasto ojczyste 136, 140, 149

Miejsce 10, 16, 23, 25, 26, 29, 30, $32,33,38,39,40,41,42,43$, $44,57,59,60,64,65,66,67$, $69,71,73,74,82,83,84,85$, $87,88,90,91,93,94,96,97$, 98, 99, 104, 105, 107, 109, 110, 111, 119, 120, 121, 129, 130, 135, 137, 140, 147, 149, 163, 164, 167, 169, 170, 172, 182, 187, 190, 192, 193, 194, 196, 206, 208, 209, $212,213,218,219,220,222$, 224, 228, 229, 242, 245, 246, 252, 261, 262, 263, 264, 267, $268,270,275,278,279,280$, 281, 282, 283, 284, 285, 289, 290, 291, 292, 293, 249, 295, 297, 298, 302, 303, 305, 308, $309,311,312,313,314,315,316$, 317, 319, 320, 323

Miejsce Boga 32, 163, 164, 182, 220, 246

Miejsce szczęśliwości 16, 43, 64, 65,110

Miejsce wytchnienia 312 
Kształtowanie się nauki o niebie w teologii patrystycznej I-III wieku

Miejsce zbawionych 163, 167, $182,219,312$

Moralizm eschatologiczny 161, 163, $173,178,180,181,182,223$, 224, 225

Moralne zasługi 73, 123, 130, 133, $135,140,141,145,166,176$, $177,180,182,189,200,223$, 232, 239, 248, 263, 273, 278, 284, 289, 294, 296, 301, 302, 304,322

Motyw Jerozolimy millenijnej 29, $36,170,228,229,230,231$, 232, 234, 246, 316

Motyw Jerozolimy niebieskiej 10, $35,45,63,73,76,83,132$, 192, 194, 197, 221, 228, 229, 231, 232, 234, 235, 236, 246, 260, 274, 286, 296, 300, 305, 316,317

Motyw miasta (Jerozolima) 22, 33, 42, 60, 66, 194, 195, 228, 231, 236, 253, 275, 294, 305

Motyw nieśmiertelności i niezniszczalności 244, 246, 318, 228

Motywy jakościowe $64,109,148$, $149,150,221,316,317$

Motywy przestrzenno-rzeczowe 148 , $150,220,316$

Na wieki wieków 45, 53, 57, 120, 122, 244, 275, 281

Nadejście łaski 116, 149

Nagroda 36, 50, 54, 57, 60, 70, $76,85,87,95,96,97,109,117$, $120,128,143,144,145,148,152$,
$163,174,176,177,180,184,189$, 203, 211, 223, 247, 257, 259, 262, 264, 266, 300, 301, 302, 303, 304, 307, 313, 316, 317, 319,322

Nagroda i wzór 120

Nagroda za dobre życie 96, 189

Nagroda za uczynki 117, 148

Najważniejszy przekaz teologiczny $150,222,318$

Najwyższe nieba 283, 317

Niebieskie Jeruzalem 44, 64, 82, $84,88,109$

Niebiosa niebios 24, 67

Niebo passim

niebo jako część stworzenia 239 niebo jako nagroda 117,152

Niebo w LXX i w późnym judaizmie LXX 17, 31, 32, 33, 38, 40, 41, $42,49,53,71,72,75,78$, 109, 162, 171, 193, 204, 207, $209,216,233,243,274$, 269, 306, 307 późny judaizm 40, 45, 51, 71, 75,79

Nieśmiertelna dusza 54, 201, 202, 213, 214, 218

Nieśmiertelność 19, 20, 21, 31, 54, 55, 63, 70, 105, 110, 1160, 117, $123,124,127,129,130,143,145$, $149,150,151,165,166,167,168$, 169, 170, 174, 179, 182, 186, 188, 189, 190, 191, 201, 203, 204, 210, 211, 212, 219, 220, 221, $222,225,228,236,238,243$, 
244, 245, 246, 247, 253, 258, 259, 264, 265, 276, 277, 302, $304,315,317,318$

Nieśmiertelność z radością 182, 189, 221

Niezniszczalność 79, 85, 99, 100, $145,156,157,160,166,167,168$, 169, 174, 196, 197, 201, 202, 211, 212, 213, 214, 216, 217, 218, 220, 221, 222, 223, 225, 228, 230, 236, 238, 239, 243, 244, $245,246,250,258,277,278$, $317,318,319$

Nowe niebo 25, 31, 32, 65, 68, , 76, 80, 83, 84, 110, 165, 219, $235,265,291,292,322$

Nowa ziemia 45, 76, 84, 235, 265, 291, 292, 322

Obrazy nieba 12, 15, 81, 83, 109

Ocean niebiański 23, 66

Odpoczynek 82, 85, 133, 142, 143, 144, 145, 206, 258, 292, 293, 319

Ogród 10, 16, 17, 18, 19, 20, 21, 22, $31,39,40,41,42,43,65,82$, 83, 84, 87, 88, 109, 110, 188, 191, 208, 209, 210, 212, 216, 217, 218, 220, 221, 229, 243, 308, 309, 310, 311, 312, 313, 314

Ogród / raj Boży 41

Ogród / raj rozkoszy 41

Ogród Boga 21, 22, 31, 41, 65, 109

Ogród Boży 40, 82

Ogród, park, raj 22, 39, 208
Park 22, 39, 40, 208

Opisy nieba

ST 67, 68, 69, 70, 71, 72, 73

NT 74, 75, 76, 80, 110, 148, 219, 224, 315

Orfizm 37 90, 91, 92, 108, 251

Otwarte niebo 32

Ósmy dzień 306

Pascha Chrystusa 193, 195, 196, 197, 222

Patrzeć, widzieć - „wizja Boga” 47, 48, 50, 51, 53, 123, 151, 219, 220,263

Piekło 8, 67, 73, 87, 105, 163, 172, $182,194,295,306$

Pitagorejczycy 89, 90, 91, 92, 108

Podobieństwo Boga 185, 208, 234, 317

Postawy sprzyjające odziedziczeniu nieba 129

Postawy uniemożliwiające odziedziczenie nieba 128

Powrót do raju 204, 212

Powszechny wymiar zbawienia 237, 238

Powyżej, na wysokości, ponad 35, 64, 65, 109, 290

Przesłanie wiary 265, 268

Przygotowanie do osiagnięcia nieba $151,225,320$

Przyszłe dziedzictwo 281317

Przyszłość 27, 28, 32, 53, 55, 57, 62, 65, 94, 133, 134, 135, 141, 149, 169, 195, 222, 259, 281, $283,286,297,313$ 
Kształtowanie się nauki o niebie w teologii patrystycznej I-III wieku

Przyszły świat 9, 70, 134, 136, 140, $141,149,152,156,159,219,221$, $261,271,282,358,359$

Rzeczy niebiańskie 10, 13, 23, 34, $36,37,38,39,45,50,64,65$, $66,67,70,72,73,74,77,78$, $79,88,91,92,109,113,116$, $126,132,134,149,155,156,160$, $185,200,201,219,221,228$, $234,254,258,261,276,278$, $287,305,313,314,316,319$, 320,359

Rzeczy niebieskie 24, 25, 35, 37, 44, 63, 64, 66, 68, 69, 70, 72, 74, $75,76,77,79,82,83,84,85$, $88,91,94,99,105,109,117,118$, $124,126,127,129,131,138,143$, $144,149,154,155,156,157,159$, $160,165,168,169,173,174,176$, $178,190,191,192,193,194,195$, 196, 197, 200, 216, 217, 218, 220 , 221, 222, 228, 229, 231, 232, 235, 236, 238, 246, 247, 248, 256, 257, 258, 259, 260, 263, 264, 269, 274, 281, 282, 283, 287, 290, 291, 294, 300, 301, 303, 304, 312, 314, 316, 317, 319

Rzeczy przyszłe 131, 149, 242

Sąd z uczynków 54, 142

Sferyczność nieba 89, 91, 93

Sfera gwiazd stałych $89,98,99$, 100, 103, 289, 290, 291

Sfera niebiańska 37, 67, 70, 78, 91,312

Siduri (ogród) 20
Sklepienie 23, 25, 83, 199, 208, 220, 281

„Stać w obliczu Pana” 44, 64, 109

Stan przejściowy? 170

Stan przejściowy 170, 222, 225

Szkoła stoicka 37, 102, 103, 104, $105,108,114,153,171,175$, $176,179,180,181,183,187$, $188,215,223,225,240,249$, 263, 266, 274, 322, 338, 346, 347,348

Śmierć $8,12,19,20,29,32,33,34$, 36, 39, 41, 43, 44, 45, 50, 51, $54,59,63,64,67,70,73,85$, $86,87,90,95,96,97,104,105$, $108,110,113,120,125,127,128$, $129,130,138,141,158,168,170$, $172,175,178,180,183,186,190$, 191, 194, 197, 198, 204, 210, 211, $222,229,237,239,244,252$, $255,265,266,271,272,273$, 276, 277, 278, 285, 293, 294, 295, 296, 303, 304, 314, 340, $341,342,360$

Święte miejsce pobytu 262, 316

Ubóstwienie 249, 264

Uczynki „zasługujące” na niebo 133, 140,145

Uczynki zasługujące 133, 140, 145

Upodabnianie się do Chrystusa 253, 256, 264, 319

W domu Ojca mego 44, 64, 109 Wartość uczynków 121, 122, 248 Widzenie Boga 47, 50, 58, 64, 65, $109,212,314,345$ 
Wieczny 8, 10, 11, 12, 19, 20, 28, 55, $56,57,58,59,60,61,62,64$, $77,81,82,85,87,88,93,94,99$, $100,109,110,117,127,139,140$, $143,145,148,152,153,156,160$, $165,172,173,174,177,178,179$, 189, 194, 196, 197, 198, 201, 202, 203, 210, 218, 222, 236, 239, 245, 247, 252, 253, 254, 255, 258, 264, 266, 268, 270, 273, $277,279,282,283,284,285$, 286, 291, 295, 298, 299, 302, $305,313,315,319,320,321,342$ Wstąpił do nieba $77,131,156,158$, 159, 166, 167, 220

Wstępować, wchodzić 33, 165, 282 Wstępowanie - zstępowanie 33, 34, $64,109,165,282$

Wszechświat $85,86,98,99,101$, 103, 104, 107, 118, 119, 120, 121, $133,155,157,160,186,188,189$, 201, 205, 206, 215, 216, 218, 219, 244, 261

Wyżyny niebieskie 118, 124, 192, 193, 194, 195, 196, 197, 220, 222 Wzór 5, 24, 40, 55, 66, 70, 93, 95, 105, 107, 120, 121, 126, 141, 147, 191, 231, 241, 245, 246, 247 , $263,266,278,318$

Zapłata 39, 65, 87, 120, 131, 133, $134,145,152,254,273,301,302$
Zbawienie 12, 51, 54, 58, 59, 60, $62,63,64,67,78,107,110$, $123,127,139,140,143,145,146$, $147,150,158,159,160,168,175$, 176, 177, 178, 180, 181, 193, 194, 195, 196, 197, 200, 211, 213, 216, 223, 225, 229, 231, 237 , 238, 243, 244, 245, 247, 249, 254, 255, 256, 257, 259, 262, 264, 270, 271, 272, 274, 289, 295, 306, 308, 316, 317, 319, 321,340

Ziemia święta 281, 317

Zstąpił z nieba 156, 158, 159, 165,220

Życie pośmiertne zbawionych 64, $67,69,86,115$

Życie wieczne 5, 8, 10, 11, 12, 19, $20,28,51,57,58,59,60,61$, $62,63,64,77,81,87,88,109$, $110,116,117,127,128,129,136$, 139, 140, 142, 143, 144, 146, 148, $149,150,154,156,160,169,177$, 189, 197, 198, 200, 221, 222, 223, 236, 239, 244, 245, 253, 254, 255, 258, 260, 264, 270, 273, 277, 282, 283, 284, 285, 286, 287, 289, 291, 292, 293, 294, 295, 296, 298, 299, 302, $315,317,319,320,321,322$, 340,342 



\section{Indeks osobowy}

A

Abbott Smith G. 53, 341

Abramowiczówna Z. 46, 210, 339, 341,360

Alfrink B. 24, 338

Alpigiano C. 158, 348

Ancona G. 8, 358

Andia Y. de 242-243, 350

Arystoteles 37, 56, 89, 98-101,

104, 108, 247, 249-250, 288, 337,347

Arystydes z Aten 153-160, 219223, 326

Atenagoras z Aten 153, 197-203, 219, 221, 223, 327

Audet J.-P. 114-115, 348

Aureliusz Prudencjusz Klemens 327

B

Baasland E. 142, 348
Bańka J. 105, 107, 345-346

Bardenhewer O. 237, 348

Bardy G. 176, 204, 337, 348

Barnard L. W. 163, 188, 198, 348

Barnes J. 104, 346

Baron A. 139, 269, 348

Barr J. 61, 338

Bator W. 26, 338

Bauer J. B. 251, 348

Bauer W. 53, 171, 339

Baumgartner W. 18, 193, 339, 342

Beasley-Murray G. R. 58, 338

Beatrice P. F. 117, 142, 348

Bellinzoni A. 162, 348

Benveniste E. 48, 54, 57, 338

Berchman R. M. 266, 348

Beri G. 10, 358

Beyreuther E. 32, 338-339, 343

Bibik B. 95, 346 
Kształtowanie się nauki o niebie w teologii patrystycznej I-III wieku

Bietenhard H. 32, 35-37, 66-68, 71, 73-80, 338-339, 343

Billerbeck P. 43-44, 343-344

Binger T. 27, 339

Blinzler J. 174, 348

Bolgiani F. 182-183, 348

Bordoni M. 9, 358

Botterweck G. J. 18, 27, 49, 340, 343

Brock S. P. 188, 348

Bruni C. 197-198, 349

Buksiński T. 11, 358

Burkert W. 92, 346

C

Cantalamessa R. 191, 193, 195, 349

Carleton Paget J. 130, 349

Chrostowski W. 17-22, 54, 81-82, 339, 341-345

Ciccarese M. P. 7, 349

Ciola N. 9, 358

Coakley S. 124, 351

Coenen L. 32, 338-339, 343

Cohn N. 70, 358

Comby J. 230, 349

Coogan M. D. 54, 82, 342, 345

Cornelius I. 16, 22, 339

Covolo E. dal 168, 349

Crouzel H. 265-266, 270-274, 276-278, 280, 285, 289, 292293, 295-297, 333, 349

Cyprian z Kartaginy 8, 12, 227 , 300, 303, 313, 317, 320, 328-329

Częsz B. 244, 349
D

Daley B. 7, 9, 357-358

Daniélou J. 132, 170-171, 206, 228, $235,240-242,350$

Davids P. H. 61-62, 83, 339, 342

Dec P. 18, 193, 339, 342

Dekert T. 242, 350

Delumeau J. 7, 228-229, 300, 312314, 350-351

Derkaczewska K. [E. Fotiju] 252, 350

Diogenes Laertios 89, 101-105, 337-338

Dodds E. R. 92, 346

Domaradzki M. 268, 350

Drączkowski F. 247-248, 251, 350

Drewnowska-Rymarz O. 70, 359

Drews P. 236, 350

Drobner H. R. 125-126, 130, 134, 213,350

Drozdek A. 89, 92-93, 101, 103,346

Dubarle A.-M. 63, 339

Duda J. 279-280, 350

E

Eckmann A. 263, 350

Edwards J. M. 176, 350

Eissfeldt O. 26, 339

Epifaniusz z Salaminy 182

Epikur 101-102, 108, 337

Evans C. A. 58, 336, 339

F

Fabry H.-J. 18, 27, 49, 340, 343

Fantazzi Ch. 138, 359 
Fantino J. 241, 350

Fedalto G. 9, 359

Filoramo G. 7, 134, 351

Friedrich G. 25, 228, 340-341, 344-345

Fuchs G. 191, 351

Fuhs H. F. 49, 340

G

Gaine S. F. 7, 351

Gaiser K. 94, 346

Gavrilyuk P. L. 124, 351

Giardini F. 7, 351

Giet S. 114, 351

Gnilka J. 60, 340

Goodenought E. R. 162-163, 351

Gould E. P. 58, 340

Grant R. M. 187, 198, 351

Grigenti G. 176, 179, 351

Grobler A. 11, 359

Grzywaczewski J. 247, 263, 351

Guillet J. 63, 345

\section{H}

Hanson P. D. 172, 340

Harnack A. von 236, 357

Henne Ph. 134, 351

Heraklides z Pontu 90, 98, 108

Hermas 62, 134-141, 148-152, 329

Hieronymus Presbyter (Hieronim ze Strydonu) 130, 154, 206, 265, 290, 294, 329

Homer 33, 37, 41, 46-47, 54, 90, 169, 337

Houssiau A. 237, 243, 351
Hoven R. 105, 346

Hryniewicz W. 9, 359

Hunt E. J. 187-188, 351

\section{I}

Ignacy Antiocheński 62, 125-129, 144, 148-152, 158, 329-330

Ireneusz z Lyonu 7-8, 12, 227-246, 315-318, 320, 331, 353

Iwański D. 72, 340

Izdebska A. 92, 346

J

Jachmann G. 138, 359

Jacobs-Horning B. 18, 340

Jan Chryzostom 58, 276, 312, 331

Jankowski A. 39, 340

Jasiński A. S. 56-57, 59, 63, 340

Jelonek T. 20, 207, 305, 340, 352

Jenkyns R. 138, 359

Jeremias J. 40, 42-46, 228, 340

Johnston P. S. 67, 340

Justyn Męczennik 153, 161-182, 184, 188-190, 203, 219-223, $225,257,331$

K

Kasprzak D. 5, 124, 132, 207, 305, 351-352, 359

Kehl A. 134, 355

Kelly J. N. D. 268, 352

Kijas Z. J. 8, 359

Kirk G. S. 90, 346

Kittel G. 25, 228, 340-341, 344-345 
Kształtowanie się nauki o niebie w teologii patrystycznej I-III wieku

Klemens Aleksandryjski 12, 188, 227, 246-264, 315-319, 327328,354

Klemens Rzymski 61, 114, 117-124, $148-152,215,328$

Kobielus S. 10, 359

Koehler L. 18, 193, 339, 342

Koester C. R. 53, 340

Köster H. 162, 175, 352

Kościuk Z. 81, 341-342, 344-345

Kowalski M. 258, 340

Kraft R. A. 114, 131, 334, 352

Krämer H. J. 94, 346

Kramer S. N. 26, 345

Krąpiec M. A. 48, 359

Kręcidło J. 61, 339, 342

Ksieniewicz M. 92, 346

Kubiak Z. 41, 359

Kudasiewicz J. 44, 340

\section{L}

Lactantius (Laktancjusz) 12, 227, 304-305, 317, 331

Lampe G. W. H. 193, 210, 358

Lane W. L. 60, 341

Lang B. 7, 353

Langkammer H. 39, 341

Lazzati G. 157, 352

Lee M. O. 138, 359

Legutko R. 346

Lemański J. 17, 21, 341

Leyden W. von 56, 347

Lilla S. C. R. 246, 249, 352

Löhr H. 117, 352

Lona H. E. 117, 352
Long A. A. 104-105, 346

Longman III T. 81, 341-342, 344-345

Looser G. 10, 359

Lurker M. 139, 338

Luttikhuizen G. P. 7, 353

$\mathbf{E}$

Łesyk L. 251, 352

Łojek S. 55, 346

Łucarz S. 251, 352

Łukaszuk T. D. 9, 359

M

Majdecki L. 10, 359

Marek Aureliusz 161, 202, 204, 337

Martin R. P. 61-62, 83, 339, 342

Matysiak B. W. 67, 341

McDannell C. 7, 353

Mees M. 247, 353

Méhat A. 252, 353

Meliton z Sardes 153, 191-197, 219222,331

Metzger B. M. 54, 82, 342, 345

Mędala S. 59, 341

Michaelis W. 46-48, 50-53, 341

Mickiewicz F. 58, 76, 341

Milavec A. 114-115, 353

Misiarczyk L. 153-155, 157-158, 160-162, 167, 176, 181, 183-184, 205-207, 327, 331, 335, 337, 353

Miśkiewicz B. 11, 359

Mohr R. D. 55, 346

Morris L. 59, 341

Muchowski P. 26, 341 
Munier Ch. 161-162, 165, 172, 331, 353

Münnich M. 26, 341

Myszor W. 114, 147, 230-244, 301, 326, 330-331, 336, 349, 353

$\mathbf{N}$

Nagórny J. 181, 360

Naumczyk A. 27, 341

Nautin P. 125, 265, 275, 353

Niederwimmer K. 114-115, 353

Niemirska-Pliszczyńska J. 246, 248-249, 328, 354

Niesiołowski-Spanò Ł. 26, 341

Nitriola A. 360

Niwiński A. 48, 69, 360

Norelli E. 213, 354

O

O’Ceallaig G. C. 158, 354

Olson D. T. 82-83, 342

Orbe A. 230, 232, 234-235, 238, 241, 354

Orygenes $12,17,124,193,227,240$, 265-300, 312, 315-319, 322, 332-334

$\mathbf{P}$

Paciorek A. 57, 99, 342, 347

Parchem M. 51, 71, 342

Pawłowski S. 12, 360

Pesch R. 59-60, 342

Pietras H. 7-8, 132, 170, 268-269, 271, 280, 289, 299, 302, 312, $333,336,354$
Plass P. 286, 354

Platon 37, 47, 55-56, 89, 92-99, 101-102, 105, 108, 169, 171$173,175,177,179,185,202$, 250, 254, 256, 266-267, 283, 337-338

Plotyn 90, 105-108, 338

Pohlenz M. 103-104, 347

Pokulniewicz A. 100, 347

Popowicz R. 43, 342

Porter S. E. 61-62, 342

Pouderon B. 154, 197-198, 200, 202-204, 326-327, 354, 358

Preuß H. D. 27-29, 31, 343

Price J. D. 16, 343

Prostmeier F. R. 131, 204, 207, 354

Pseudo-Barnaba 130, 334

Pseudo-Clemens Romanus (Pseudo-Klemens Rzymski) 142, 147, 326, 335

Pseudo-Cyprianus (Pseudo-Cyprian) 313, 335

Puech H. Ch. 251, 355

Pujiula M. 248, 355

Pycke N. 181, 355

Q

Quasten J. 237, 355

R

Rad G. von 25, 66-68, 71, 345

Rahner K. 48-49, 360

Ramelli I. 134, 351

Ramelli I. L. E. 273, 355

Rankin D. I. 198, 355 
Kształtowanie się nauki o niebie w teologii patrystycznej I-III wieku

Raven J. E. 90, 346

Reale G. 90-96, 98-107, 346-347

Rendel Harris J. 158, 355

Repellini F. F. 90-91, 347

Ringgren H. 18, 27, 49, 340, 343

Romaniuk K. 63, 138-139, 338,345

Rordorf W. 114-115, 355

Rousseau A. 236, 238, 241, 331, 355

Ruiz de la Peňa J. L. 48, 360

Ryken L. 81, 341-342, 344-345

Rzodkiewicz L. 247, 355

$S$

Salij J. 19, 360

Salisbury J. E. 308, 355

Scafi A. 10, 360

Schmaus M. 7, 9, 355, 358

Schnackenburg R. 58-59, 343

Schoedel W. R. 198, 355

Schofield M. 90, 346

Scorza Barcellona F. 131, 355

Seely P. H. 23, 343

Segal Ch. P. 138, 360

Seneka [Młodszy] 102-103, 338

Sfameni Gasparro G. 184, 355

Sheppard H. J. 134, 355

Siede B. 34-35, 343

Silva D. A. de 83, 339

Simonetti M. 267, 270-271, 277, 285, 289, 292, 328-329, 333,355

Singles D. 230, 349

Siwek P. 55, 92-94, 98-100, 337338,347
Składanowski M. 267, 356

Słomka J. 267-268, 308, 356

Snell B. 138, 360

Söding T. 76, 343

Soggin J. A. 23-26, 343

Sołowianiuk J. 247, 327, 356

Sołtysiak A. 69-70, 360

Stamm J. J. 18, 193, 339, 342

Stanek T. 26, 343

Starowieyski M. 115, 128, 147, 229, 308, 310, 326, 328, 329-331, $335,353,356$

Stock K. 57, 343

Strack H. L. 43-44, 343-344

Swoboda A. 249, 347

Szczerba W. 266, 273, 356

Szczur P. 248, 252, 356

Szram M. 266-267, 269, 272, 278,356

$\hat{s}$

Ślipko T. 179, 347

$\mathbf{T}$

Tacjan Syryjczyk 153, 182-191, 203, 219-223, 225, 335

Taubes J. 9, 360

Teofil z Antiochii 19, 153, 204-212, 219-221, 337

Tertulian 8, 12, 227, 300-303, 308, 316-317, 319-320, 336

Tomasino A. 27-31, 344

Torjesen K. J. 268, 356

Traub H. 36-39, 71-72, 74, 76-77, 79-80, 344 
Trottmann Ch. 7, 356

Tsumura D. T. 23-26, 38, 65-67, $71,79,344-345$

Tuilier W. A. 114-115, 355

Tułodziecki T. 50, 345

Tzamalikos P. 274, 280, 285-289, 292-293, 295, 297-300, 356

\section{$\mathbf{U}$}

Ullmann W. 118, 357

Unnik W. C. van 157, 357

V

VanGemeren W. A. 16, 339, 343-344

Vanni U. 132, 357

Verheyden J. 175, 357

Viard A.-A. 63, 345

Vielhauer P. 134, 357

Visonà G. 114-115, 357

Voegelin E. 89, 347

Vorgrimler H. 7, 357

W

Wallace H. N. 16-17, 21-22, 345
Weber S. 236-237, 328, 357

Weikmann H. M. 191, 351

Weisse W. 7, 357

White S. A. 54, 345

Wicks J. 11, 360

Wilhoit J. C. 81, 341-342, 344-345

Wilson R. 134, 355

Wojtczak J. 95, 304-305, 347

Wolicka E. 92, 347

Wolkstein D. 26, 345

Wright J. E. 7, 357

Wygnańska Z. 70, 359

Wyrwa D. 251, 357

Wysocki M. 8, 302-303, 357

Wytzes J. 250, 252, 357-358

\section{Z}

Zagórski D. 249, 358

Zalewska-Lorkiewicz K. 10, 360

Zdybicka Z. J. 48, 359-360

Zeegers-Vander Vorst N. 198, 204, 208, 358

Zgraja B. 247-250, 358

Zincone S. 213, 358 



\section{Spis treści}

1. Biblijne terminy, koncepcje i obrazy dotyczące nieba . . . . . 15

1.1. Biblijne terminy i koncepcje hebrajskie dotyczące nieba . . . . . . . . . . . 15

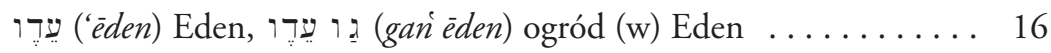

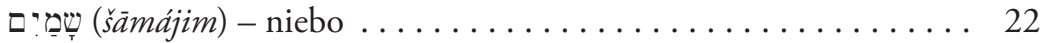

עוֹלָם ('ôlàm) - długi czas, trwanie ................ 27

1.2. Biblijne terminy i koncepcje greckie dotyczące nieba $\ldots \ldots \ldots 32$

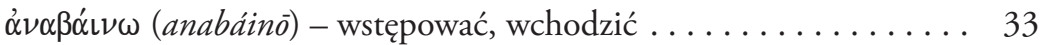

$\nsim \omega \omega($ anō $)$ - powyżej, na wysokości, ponad ............ 35

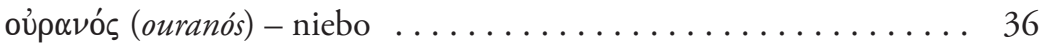

$\pi \alpha \rho \alpha ́ \delta \in \iota \sigma o \varsigma$ (parádeisos) - ogród, park, raj . . . . . . . . . 39

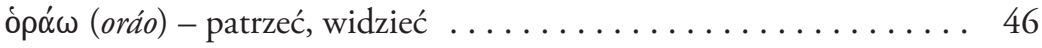

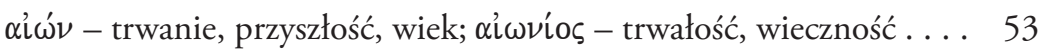

1.3. Rozwój biblijnej koncepcji nieba ............... 64

Znaczenia nieba w Starym Testamencie . . . . . . . . . . . . 65

Znaczenia nieba w Septuagincie i w późnym judaizmie . . . . . . 71

Znaczenia nieba w Nowym Testamencie . . . . . . . . . . . . . . 74

1.4. Biblijne obrazy nieba $\ldots \ldots \ldots \ldots \ldots \ldots \ldots \ldots \ldots \ldots \ldots \ldots \ldots$ 
Kształtowanie się nauki o niebie w teologii patrystycznej I-III wieku

„Ogród Eden” / „ogród Boży” / „raj” / „ogród niebieski” / „eschatologiczne miasto - niebieskie Jeruzalem” . . . . . . . . . 82

1.5. Niebo w koncepcjach filozofii starożytnej a ujęcie biblijne . . . . . . 88

1.6. Podsumowanie pierwszego rozdziału . . . . . . . . . . . . . . 109

\section{Kształtowanie się nauki o niebie w teologii patrystycznej -} wiek I-II . . . . . . . . . . . . . . . . . . . . . . . . . 113

2.1. Kształtowanie się nauki o niebie w teologii ojców i pisarzy

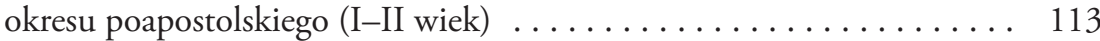

2.1.1. Didache - niebo jako „Królestwo Jezusa” . . . . . . . . . . 114

2.1.2. Klemens Rzymski, List do Kościota $w$ Koryncie - niebo jako realizacja obietnicy Jezusa i nagroda za uczynki . . . . . . 117

2.1.3. Ignacy Antiocheński - „Chrystus - bramą Ojca” . . . . . . . 125

2.1.4. List Psedo-Barnaby - moralność zasługi, przez „drugie millenium" do nieba . . . . . . . . . . . . . . . . . . . . . . . 130

2.1.5. Hermas Pasterz - Królestwo Boże osiągalne przez chrzest

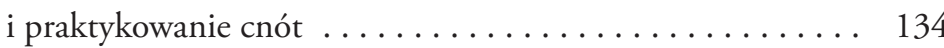

2.1.6. Homilia z II wieku - niebo jako życie wieczne /

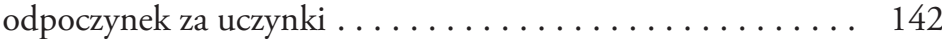

2.1.7. Podsumowanie nauki o niebie w teologii patrystycznej ojców i pisarzy okresu poapostolskiego (I-II wiek) . . . . . 148

2.2. Kształtowanie się nauki o niebie w teologii apologetów greckich II wieku . . . . . . . . . . . . . . . . . . . . . . . . . . . . 153

2.2.1. Arystydes z Aten - życie wieczne w królestwie niebieskim przez Jezusa Chrystusa . . . . . . . . . . . . . . . . . 154

2.2.2. Justyn Męczennik - nauka o niebie jako kontynuacja kerygmatu i próba syntezy Biblii, nauk rabinackich i filozofii antycznej (moralizm eschatologiczny)

2.2.3. Tacjan Syryjczyk, Mowa do Greków - niebo jako „nieśmiertelność z radością”, osiągnięte dzięki dobrym wyborom duszy

2.2.4. Meliton z Sardes, Homilia Paschalna - Chrystus wprowadza

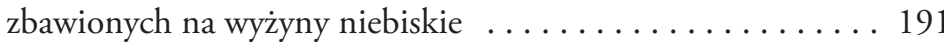

2.4.5. Atenagoras z Aten - życie wieczne za dobre czyny . . . . . . 197 
2.2.6. Teofil z Antiochii - Do Autolika - powrót do raju w nieśmiertelności, w perspektywie nieba? . . . . . . . . 204

2.2.7. List do Diogneta - nieśmiertelna dusza mieszkająca w namiocie śmiertelnym oczekuje niezniszczalności człowieka w niebie

2.2.8. Podsumowanie nauki o niebie w teologii patrystycznej apologetów greckich II wieku

2.2.9. Podsumowanie nauki o niebie w teologii patrystycznej ojców i pisarzy okresu poapostolskiego i apologetów greckich II wieku

\section{Kształtowanie się nauki o niebie w teologii patrystycznej -} wiek III

3.1. Ireneusz z Lugdunum (130/140 - około 200) - nieśmiertelni i niezniszczalni zbawieni w niebiańskiej Jerozolimie

3.2. Klemens Aleksandryjski (150 - około 212) - niebo miejscem

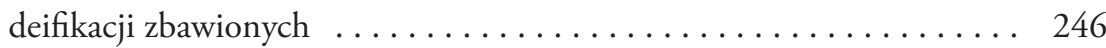

Antropologia ............................... 249

Chrystus jako sposób osiągnięcia nieba . . . . . . . . . . 252

Cechy zbawionych . . . . . . . . . . . . . . . . 257

Eschatologiczne niebo . . . . . . . . . . . . . . . . . 259

3.3. Orygenes (186 - około 253) - w kierunku nowego nieba i nowej ziemi........................... 265

Metodologia Orygenesa ... . . . . . . . . . . . . . . . . . 265

Filozofia Platońska . . . . . . . . . . . . . . . . . . . . 266

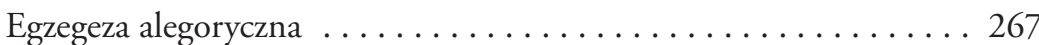

Przesłanie wiary chrześcijańskiej . . . . . . . . . . . . . . 268

Kosmologia a eschatologia . . . . . . . . . . . . . . . . . 270

Eschatologia dotycząca człowieka - nieśmiertelność duszy i ciała . . 276

Orygenesowska koncepcja eschatologicznego nieba . . . . . . . 278

3.4. Autorzy łacińscy III wieku: Tertulian, Cyprian, Wiktoryn

z Poetovium, Męczeństwo świętych Perpetuy i Felicyty - motyw

Jerozolimy niebieskiej i nagrody $\ldots \ldots \ldots \ldots \ldots \ldots \ldots \ldots \ldots \ldots \ldots \ldots$

Tertulian ............................ 300 
Kształtowanie się nauki o niebie w teologii patrystycznej I-III wieku

Cyprian z Kartaginy . . . . . . . . . . . . . . . . . . . . 303

Laktancjusz ........................... 304

Wiktoryn z Poetovium . . . . . . . . . . . . . . . . . 305

Męczeństwo świętych Perpetuy i Felicyty - wizja Satura . . . . . . . . . 308

2.5. Podsumowanie nauki o niebie w teologii patrystycznej ojców i pisarzy okresu III wieku $\ldots \ldots \ldots \ldots \ldots \ldots \ldots \ldots \ldots$

Zakończenie ........................ 321

Bibliografia .......................... 325

1. Teksty źródłowe . . . . . . . . . . . . . . . . . 325

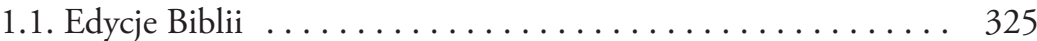

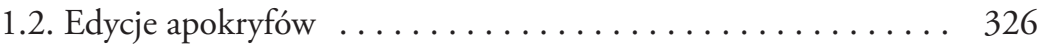

1.3. Edycje tekstów patrystycznych (wydania krytyczne

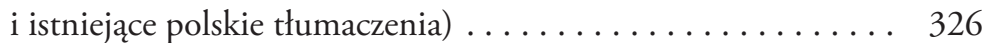

1.4. Przekłady traktatów filozofii antycznej i tekstów klasycznych . . 337

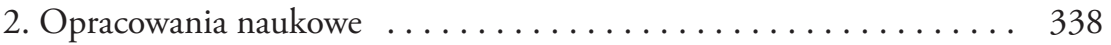

2.1. Opracowania biblijne ... . . . . . . . . . . . . . . 338

2.2. Opracowania filozoficzne ................. 345

2.3. Opracowania patrystyczne . . . . . . . . . . . . . 348

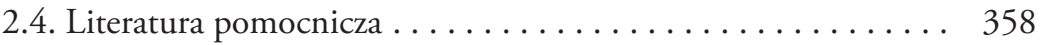

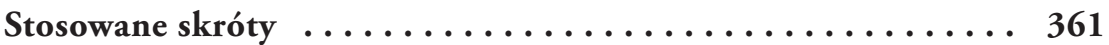

Indeks biblijny $\ldots \ldots \ldots \ldots \ldots \ldots \ldots \ldots \ldots \ldots \ldots \ldots \ldots \ldots \ldots$

Indeks rzeczowy $\ldots \ldots \ldots \ldots \ldots \ldots \ldots \ldots \ldots \ldots \ldots \ldots$

Indeks osobowy $\ldots \ldots \ldots \ldots \ldots \ldots \ldots \ldots \ldots \ldots \ldots \ldots$

Summary ......................... 409

Table of contents ......................413 


\section{Summary}

The topic of the following study "Emergence of study of eschatological heaven in patristic theology of the 1st - 3rd century" describes the main research goal of my work, which is an attempt to rationally categorise the patristic message of the first three centuries on the topic of hope for eschatological heaven - eternal life and its theological explanations. As such the main research goal of the work is to present patristic study of eschatological heaven in the ante-nicene period. Subject to analysis are texts of representative theologians of the discussed period, who represent Asian and Alexandrian traditions. The presented work would be an analytical study of texts of ancient Christian writers from the 1st - 3rd century, which were devoted to the topics of terminal eschatology related to eschatological heaven and the life of the eternally saved. This approach in my study is an attempt of sorts to fill the gap in patristic studies thus far. The topic of this work in itself describes what its goal is.

The following chapters are an answer to specific research goals. Therefore thorough clarification was needed in the case of topics I discuss in the following chapters and subchapters. The work consists of an introduction, three chapters: 1 . Biblical terms, concepts and portrayals of heaven; 2. Emergence of study of heaven in patristic theology - 1st - 3rd century; 3. Emergence of study of heaven in patristic theology - 3rd century; 
Kształtowanie się nauki o niebie w teologii patrystycznej I-III wieku

closure and bibliography. The layout itself as well as specific topics are determined by source material contained in the analysed texts of Church fathers and writers of the 1st - 3rd century. Discussion of biblical naming, concepts and imagery of the Hebrew and Greek languages relating to the topic of heaven was meant to indicate coherency of the message, as well as describing basic motives of biblical eschatology of heaven. Eschatological thought contained in the Holy Bible was a base for deliberations of early Christian writers, therefore it should be compared to eschatological concepts of classical philosophy in order to point out ideological differences as well as possible borrowings. Describing the emergence of study of eschatological heaven in the theology of fathers and writers of the post-apostolic period of the 1st - 2nd century (apostolic fathers and Greek apologists) was intended to indicate the development of early Christian terminal eschatology in respect to heaven. Similarly, description of the development of the study of heaven in patristic theology in the 3rd century was meant to indicate the progressive character of theological speculation in the analysed period.

Description of the subject of eschatological heaven and eternal life in theological perspective of 1st - 3rd century patristic authors appears to be progressive as well as consistent, because the analysed authors conducted their theological deliberations on the basis of the same revelation which is the Holy Bible and the original apostolic Tradition, including above all the message of the truth of faith of salvation already accomplished in Jesus Christ. The thoughts of theologians of the first three centuries varied however on the level of means of literary communication they used and their personalities.

I notice consistency in 1st - 3rd century patristic authors' message on eschatological heaven above all in their repeating of the most theological truth arising from the New Testament message, which is that the only way to reach heaven is for a Christian to believe and to trust Jesus Christ. The key to understanding the eschatological message of early Christian authors therefore is still strictly New Testament soteriology, which shouldn't be particularly surprising.

1st century authors repeat the basic kerygma of the New Testament about salvation and eternal life. The method of conveying this message 
remains fundamentally catechetical. 2nd century Greek apologists because of their dialogue with the pagan world begin to harmonise the message of New Testament soteriology with ethical categories of Greek philosophy (stoical primacy of virtue, platonic ethical idealism), which in message of faith results indirectly in emergence of a kind of theology of eschatological merit and moralistic dependence of reaching heaven by the believer on compatibility of their moral choices (an analogous narrative about heaven as a reward for ethical choices can be seen in 3rd century African moralists). Such a strong connection of evangelic message with Greek anthropology and philosophical ethics also results indirectly in a beginning of Christian reflection on the topic of hypothetical intermediate state. However the basic theological message remains catechetical and compatible with New Testament soteriology.

3rd century Christian authors are doubtlessly the most varied in terms of their forms of communication as well as developed eschatological concepts. Apart from traditional forms of catechetical message we can observe in their works first eschatological speculations, from which doubtlessly the most outstanding are Origen's eschatological hypotheses about moral and material development of the saved in heaven until they can reach new heaven and new land and enter the mysterious atemporality of God. On the other hand 3rd century African moralists consider the idea of "tangible" heaven as a reward for good ethical choices. Both theological trends (Alexandrian and African) however display a sort of similarity when it comes to their claim on the topic of the final fate of the saved: attainment of God's life/transformation of the saved life to the life of God. Despite the noted differences the basic message of faith remains the same: the only way for a believer to attain eschatological heaven - understood as union with God and other saved - is a real bond with Jesus Christ. The guarantee of the promise of eschatological heaven for a believer is always belief in honesty and mercy of God.

What's striking is the fragmentariness of the 1st - 3rd century Church fathers and writers' message on eschatological heaven/eternal life of the saved. This topic has never been at the front, it's usually been contained in the wider context of soteriological teaching. Terminology used by the authors discussed here is a continuation of New Testament eschatological 
Kształtowanie się nauki o niebie w teologii patrystycznej I-III wieku

vocabulary as well as occasionally semantic clusters of biblical terms. Rarely we can encounter in the analysed texts mythical vocabulary of the pagan world (theme of Arcadia). In the 1st century spatial themes dominate, in the two subsequent ones - those of quality. All eschatological descriptions of heaven are a message of positive archetypes. Eschatological heaven remains at the level of the message a happy place that's created, chosen and privileged by God, where a saved person lives in friendship with God. In a heaven so understood Christ's traits definitely also become traits of the saved. In this way the most import goal of created beings is realised, for a saved person finds their final fulfillment in God. 


\section{Table of contents}

1. Biblical terms, concepts and portrayals of heaven ........ 15

1.1. Biblical terms and Hebrew concepts of heaven ... . . . . . . 15

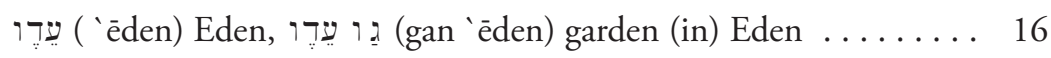

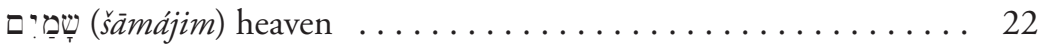

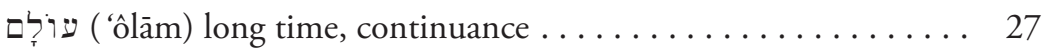

1.2. Biblical Greek terms and concepts of heaven ... . . . . . . 32

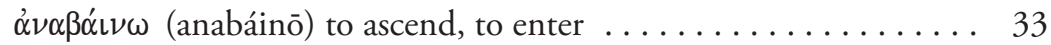

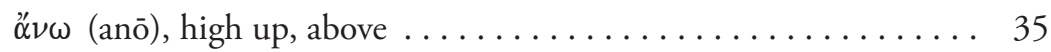

oủpavós (ouranós) heaven .................. 36

$\pi \alpha \rho \alpha ́ \delta \epsilon \iota \sigma o \varsigma$ (parádeisos), garden, park, paradise .......... 39

óó́ (oráo) to look, to see ................. 46

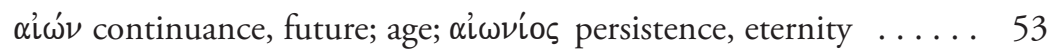

1.3. Development of the biblical concepts of heaven . . . . . . . . . 64

Meaning of heaven in the Old Testament . . . . . . . . . 65

Meaning of heaven in Septuaginta and in later Judaism . . . . . . . 71

Meaning of heaven in the New Testament ............ 74

1.4. Biblical portrayals of heaven $\ldots \ldots \ldots \ldots \ldots \ldots \ldots \ldots \ldots \ldots$ 
Kształtowanie się nauki o niebie w teologii patrystycznej I-III wieku

"Garden of Eden"/"God's garden"/"paradise"/"heavenly garden"/"eschatological city/heavenly Jerusalem" .......... 82

1.5. Heaven in ancient philosophy in relation to the Bible . . . . . . 88

1.6. First chapter summary . . . . . . . . . . . . . . . . . . . . 109

\section{Emergence of the study of heaven in patristic theology -}

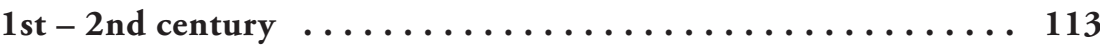

2.1. Emergence of the study of heaven in theology of Fathers and writers of the post-apostolic period (1st -2 nd century) $\ldots \ldots \ldots 113$

2.1.1. Didache - heaven as a "Kingdom of Jesus" . . . . . . . . . . 114

2.1.2. Clement of Rome, Letter to the church at Corinth - heaven as a realisation of Jesus's promise and a reward for deeds . . . 117

2.1.3. Ignatius of Antioch - "Christ - gate of the Father" . . . . . 125

2.1.4. Epistle of Pseudo-Barnabas - morality of merit, through a "second millennium" to heaven ................. 130

2.1.5. Hermas, Shepherd - Kingdom of God achievable through baptism and virtue .............. 134

2.1.6. Homily of the 2nd century - heaven as eternal life/rest

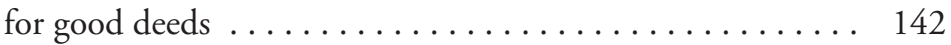

2.1.7. Summary of the study of heaven in patristic theology of Fathers and writers of the post-apostolic period

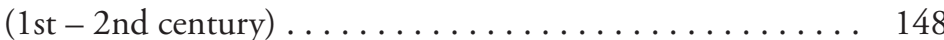

2.2. Development of the study of heaven in theology of Greek apologists of the 2 nd century $\ldots \ldots \ldots \ldots \ldots \ldots \ldots \ldots \ldots \ldots \ldots \ldots \ldots \ldots$

2.2.1. Aristides of Athens - eternal life in the heavenly kingdom through Jesus Christ . . . . . . . . . . . . . .

2.2.2. Justin Martyr - study of heaven as a continuation of kerygma and an attempt to synthesise the Bible, rabbinical teachings and ancient philosophy (eschatological moralism) ........

2.2.3. Tatian the Syrian, Address to the Greeks - heaven as "immortality with joy", achieved through good decisions of the soul $\ldots \ldots \ldots \ldots \ldots \ldots \ldots \ldots \ldots \ldots \ldots \ldots \ldots$

2.2.4. Melito of Sardis, Peri Pascha-Christ introduces the saved to heaven . . . . . . . . . . . . . . . . . . . . . . . . 191

2.4.5. Athenagoras of Athens - eternal life for good deeds . . . . . 197 
2.2.6. Theophilus of Antioch, Apology to Autolycus - return to paradise in immortality, with the prospect of heaven? . . . 204

2.2.7. Epistle to Diognetus - immortal soul living in a mortal tent awaits human invincibility in heaven . . . . . . . . 213

2.2.8. Summary of the study of heaven in patristic theology

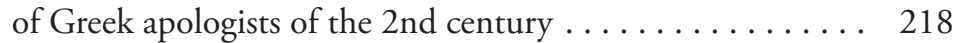

2.2.9. Summary of the study of heaven in patristic theology of the Fathers and writers of the post-apostolic period and Greek apologists of the 2nd century .......... 224

\section{Development of the study of heaven in patristic theology -}

3rd century . . . . . . . . . . . . . . . . . . 227

3.1. Saint Irenaeus (early 2nd century - c. 202) - the immortal and invincible saved in heavenly Jerusalem . . . . . . . . . . . . 228

3.2. Clement of Alexandria (150 - c. 212) — heaven as a place of deification of the saved $\ldots \ldots \ldots \ldots \ldots \ldots \ldots \ldots \ldots \ldots$

Anthropology .......................... 249

Christ as a way to achieve heaven . . . . . . . . . . . . . 252

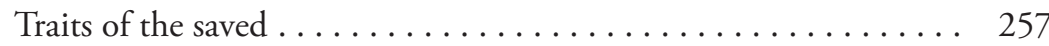

Eschatological heaven . . . . . . . . . . . . . . . . . . . . 259

3.3. Origen $(186$ - c. 253$)$ — towards new heaven and new earth . . . . 265

Origen's methodology ...................... 265

Plato's philosophy ........................ 266

Allegorical exegesis . . . . . . . . . . . . . . . . 267

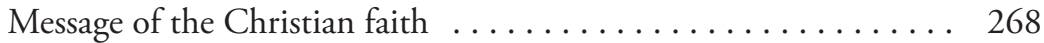

Cosmology and eschatology . . . . . . . . . . . . . . 270

Human related eschatology - immortality of the soul

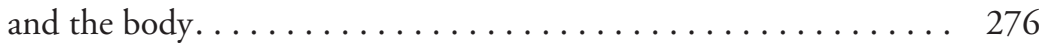

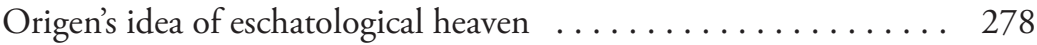

3.4. Latin authors of the 3rd century: Tertullian, Cyprian, Victorinus of Pettau, Passion of St. Perpetua and St. Felicitas - the motive of heavenly Jerusalem and reward . . . . . . . . . . . 300

Tertullian ......................... 300

Cyprian............................... 303

Lactantius . . . . . . . . . . . . . . . . . . . . . . . . . . . . 304 
Kształtowanie się nauki o niebie w teologii patrystycznej I-III wieku

Victorinus of Pettau . . . . . . . . . . . . . . . . . . . . . 305

Passion of St. Perpetua and St. Felicitas . . . . . . . . . . . . 308

3.5. Summary of the study of heaven in patristic theology

of the Fathers and writers of the 3 rd century . . . . . . . . 315

End $\ldots \ldots \ldots \ldots \ldots \ldots \ldots \ldots \ldots \ldots \ldots \ldots \ldots \ldots \ldots \ldots \ldots \ldots \ldots \ldots, 321$

Bibliography .......................... 325

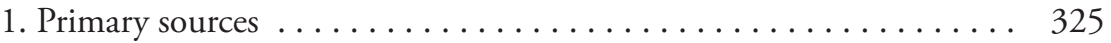

1.1. Editions of the Bible .................. 325

1.2. Editions of apocrypha .............. 326

1.3. Editions of patristic texts (critical editions and existing

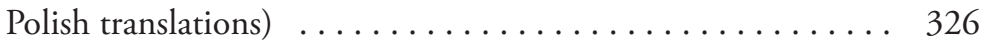

1.4. Translations of treatises of ancient philosophy and classical texts . . . . . . . . . . . . . . . . . . . . . . . . 337

2. Scientific elaboration $\ldots \ldots \ldots \ldots \ldots \ldots \ldots \ldots \ldots \ldots \ldots \ldots \ldots$

2.1. Biblical elaboration .................... 338

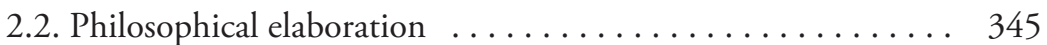

2.3. Patristic elaboration . . . . . . . . . . . . . . . . . . 348

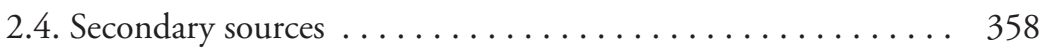

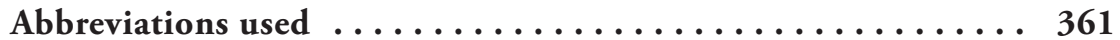

Biblical index ....................... 363

Subject index $\ldots \ldots \ldots \ldots \ldots \ldots \ldots \ldots \ldots \ldots \ldots \ldots \ldots$

Name index ......................... 397

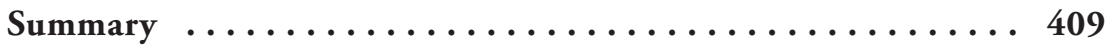

